\title{
SALMON RIVERS
}

- AND loCHS

OF SCOTLAND 

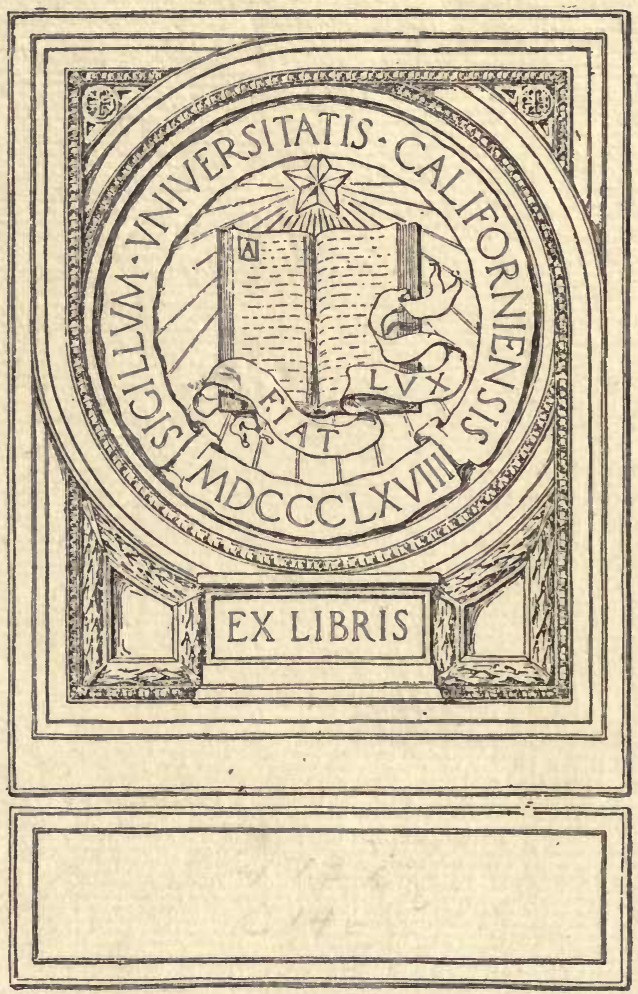




THE SALMON RIVERS

AND LOCHS

OF SCOTLAND 

म and 
$\because$\begin{tabular}{c}
0 \\
\hdashline
\end{tabular}

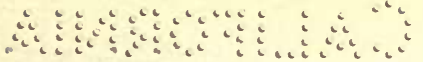

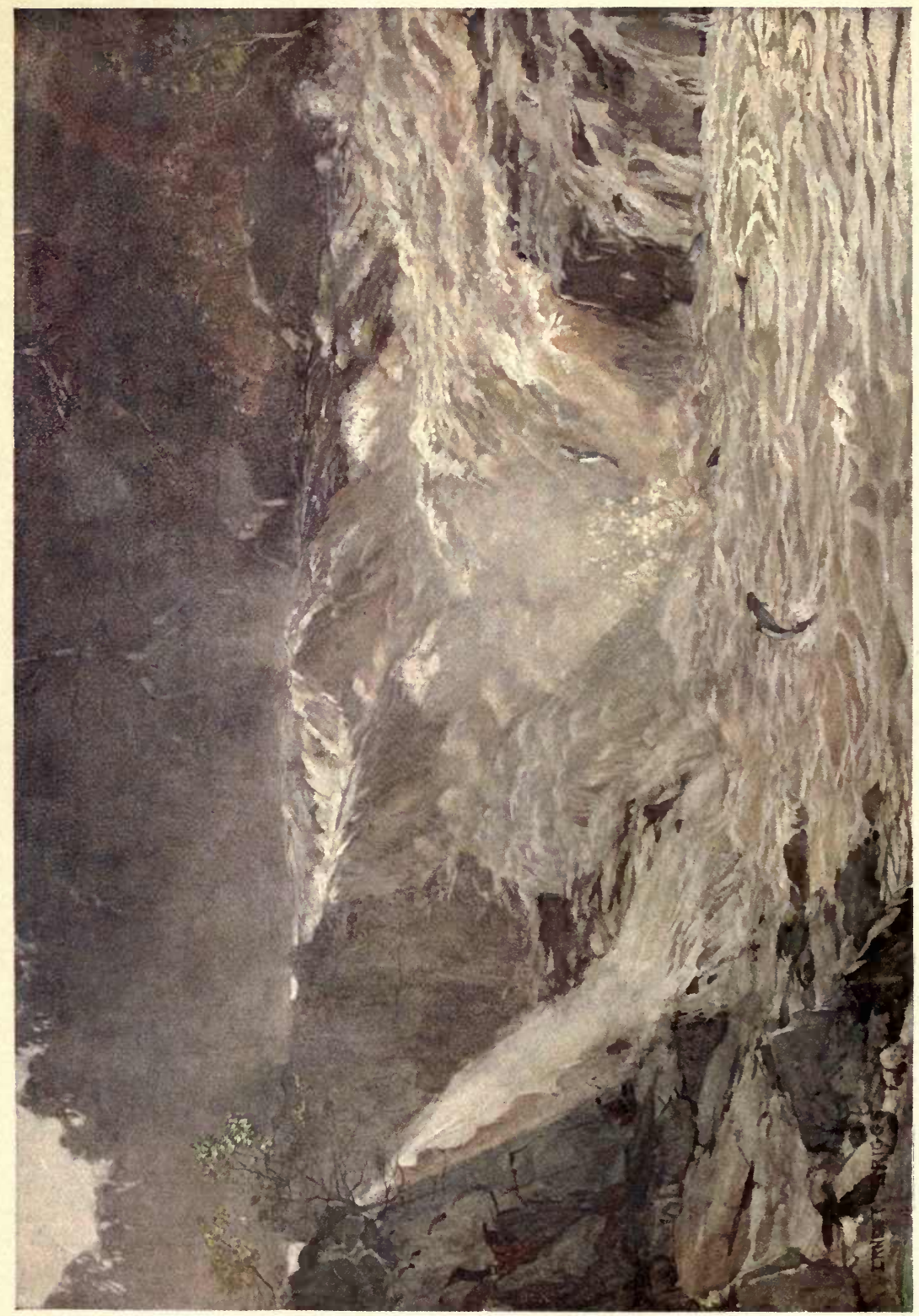

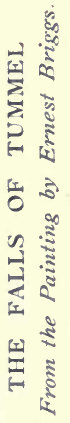




\section{THE SALMON RIVERS}

\section{AND LOCHS}

\section{OF SCOTLAND}

BY

W. L. CALDERWOOD, F.R.S.E.

AUTHOR OF "THE LIFE OF THE SALMON"

“ MUSSEl CUlTURE AND bait SUPPly," etc.

ILLUSTRATED

LONDON

EDWARD ARNOLD

I 909

[All rights reserved] 
$\mathrm{SH}^{347}$
$\mathrm{C}^{3}$

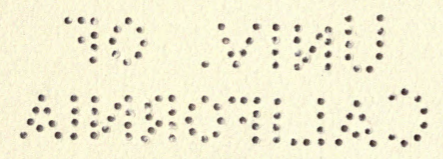




\section{PREFACE}

In preparing this volume, my desire has been, not merely to describe the various rivers and lochs of Scotland in which the salmon angler may cast his line, but also, as far as circumstances seem to permit, to refer to points connected with the conservation or improvement of the salmon fisheries.

I know full well that suggestions given officially in blue books do not generally reach the notice of those to whom one fancies they will be of interest, so I take this opportunity of offering a few opinions and pointing a few morals based upon what I conceive to be the broad lines of salmon fishery regulation. In doing so I may seem to deal, unasked, with the rights and property of others, but I would plead in excuse that my business is really to study the general interests of our salmon fisheries.

In preparing the maps of the leading rivers, I have received much assistance in the delimitation of the various fisheries. I desire to express my thanks to Mr. H. W. Johnston for marking off the Tay map, to Mr. Grant of Elchies for the Spey map, and to Mr. Alex. Duffus, Aberdeen, for the Dee map. For certain of the photographs also I am indebted. The views of Loch Quoich and of the Dog Pool on the Garry were taken by Mr. R. C. Malcolm. The Deveron view is by Mr. Milne of Ardmiddle. The small pictures of Lochs Clare and Coulin (which lose much in reproduction) were taken by Mrs. Boas, Edinburgh, while for the snap-shots of leaping salmon I am indebted to Rev. Horace Bonar.

Very many have assisted me with detailed information respecting certain fisheries, and by kindly giving me records of annual catches. References will be found in the appropriate chapters.

Since writing the account of the Tweed, I have learned, while fishing with Major Hunter in Norway, confirmed by letter from Lord Dunglass, that the record Tweed fish is not the $57 \frac{1}{2} \mathrm{lb}$. 
monster figured and referred to, but that in the early "thirties" the Earl of Home, grandfather of the present peer, killed by rod a fish of $69 \frac{3}{4} \mathrm{lb}$. A letter on the subject of Tweed fish and referring to this great example, written by Lord Dunglass' great grandfather, and shown to me, is dated 1835 .

W. L. C.

South Bank,

Edinburan, September, 1909. 


\section{CONTENTS}

CHAPTER

PAGE

INTRODUCTION

I. The TweEn - $\quad$ - $\quad$ - $\quad$ -

II. The Forth -

III. THE TAY AND EARN - $\quad$ - $\quad$ - $\quad$ - $\quad$ - 53

IV. North EsK AND South EsK - $\quad$ - $\quad$ - $\quad$ - 97

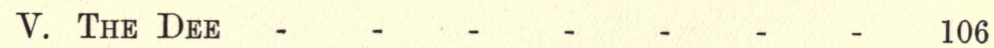

VI. THE DON

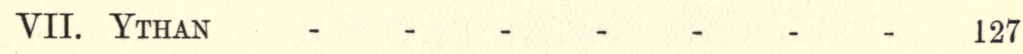

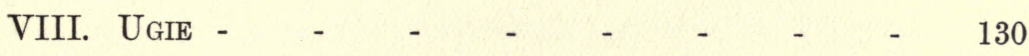

IX. DEVERON

X. SPEY - $\quad$ - $\quad$ - $\quad$ - $\quad$ - $\quad$ - $\quad$ -

XI. FINDHORN

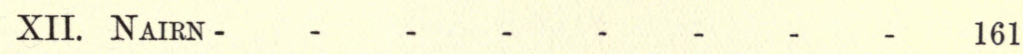

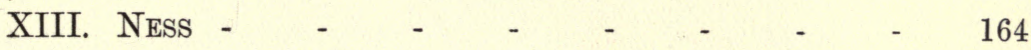

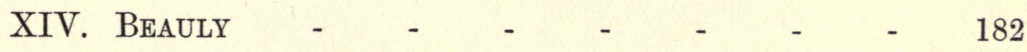

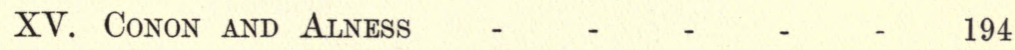

XVI. Kyle of Sutherland : Carron, Oykell, Cassley,

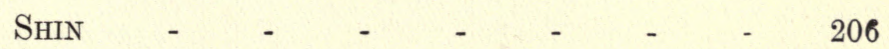

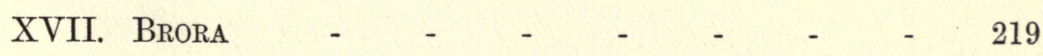

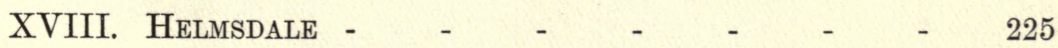


CHAPTER

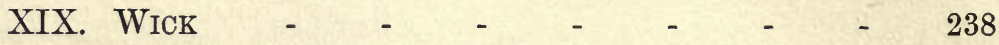

XX. Thurso - $\quad$ - $\quad$ - $\quad$ - $\quad$ - $\quad$ - 241

XXI. Forss, Halladale, Naver, Borgie - $\quad 250$

XXII. Hope, Dionard, Kinloch, AND Polla - - 261

XXIII. The Rivers of West Sutherland and Ross:

Inchard, Laxford, Inver, Kirkaig, Polly, Kanaird, Ullapool, Broom - $\quad$ - $\quad$ - $\quad 266$

XXIV. Gruinard, Dundonnell, Ewe, and Carron - 286

XXV. Streams of the Outer Isles and of Skye - 298

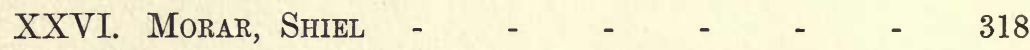

XXVII. Lochy, Spean, Roy, AND ARKaIg - - $\quad$ - 329

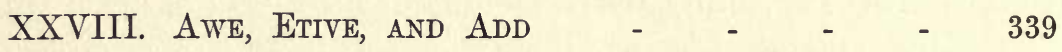

XXIX. Rivers of Clyde Area: Leven and Loch Lomond, Echaig, aNd Loch Eck, Ruel $\quad$ - 359

XXX. Ayr, Doon, Girvan, and Stinchar - $\quad 372$

XXXI. The Solway Rivers: Luce, Bladenoch, Cree,

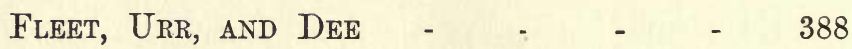

XXXII. Nith AND ANNAN - $\quad$ - $\quad$ - $\quad$ - $\quad$ - 405

Appendix A. The Right of Salmon Fishing and the Scottish Salmon ACtS $\quad$ - $\quad$ - $\quad$ - 419

B. Croys on Salmon Rivers - $\quad$ - $\quad$ - 431

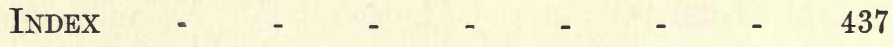




\section{LIST OF ILLUSTRATIONS}

\section{PLATES IN COLOUR}

The Falls of Tummkit. From the painting by Ernest Briggs

TO FACE PAGE

Frontispiece

('The picture is the property of J. B. TAYLOR, Esq., Salzeraggie Lodge)

The Tweed looking towards Melrose. From the water-colour painting by Thomas SсотT, R.S.A. - _ _ - $\quad 16$

(The picture is the property of T. J. S. RoBERTs, Esq., of Drygrange)

The Dee, Lochnagar in the Distance. From the watercolour painting by JAMES CADENHEAD, A.R.S.A. - - 118

(The pieture is the property of A. J. Sмiтн, Esq., J.P., Aberdeen)

The Helmsdale. From the water-colour painting by Percy Dixon -

(The picture is the property of J. B. TAYLOR, Esq., Salzcraggie Lodge)

\section{OTHER PLATES}

Salmon weighing $57 \frac{1}{2} \mathrm{lb}$. CaUght by Rod in Floors Water 10

Sprouston Dub (November) - $\quad$ - $\quad$ - $\quad$ - $\quad$ - $\quad$ - $\quad$ - 22

The Tweed at Coldstream

The Tweed at Galafoot - $\quad$ - $\quad$ - $\quad$ - $\quad$ - 30

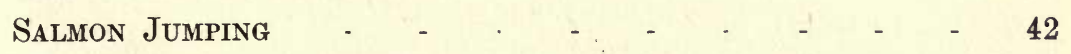

The Croy Pool, UpPer TAY - - -

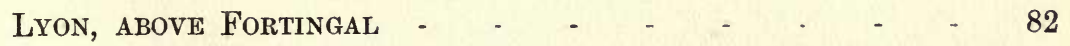

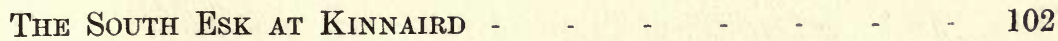

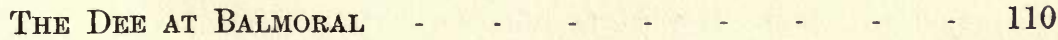

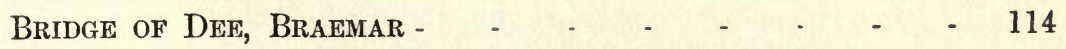


The Deveron at Ardmiddle - $\quad$ - $\quad$ - $\quad$ - $\quad$ - $\quad$ - 138

The Spey at Arndilly - $\quad$ - $\quad$ - $\quad$ - $\quad$ - $\quad$ - $\quad$ - $\quad 146$

Bacterial Filter and Hatchery, Coleburn Distillery - 152

The Findhorn at Darnaway - $\quad$ - $\quad$ - $\quad$ - $\quad$ - 156

The InVermoriston Pass, From bottom of cutting (WATer TURNED OFF) - - - - - - - $\quad$ - -170

Plan of the Fish Pass on the River Moriston - - - 172

The Big and Little Crooked Pools, Inverness-shire Garry 176

The Dog Pool, Inverness-shire Garry - - - - - 178

Loch Quoich, Head Waters of Ness District - - $\quad 180$

The Beauly below Eilean Aigas - - $\quad$ - $\quad$ - $\quad$ - 186

The Cruive Dyke of the Beauly - $\quad$ - $\quad$ - $\quad$ - $\quad$ - $\quad$ - 190

A Cruive in Fishing Order, River Conon - - - $\quad 200$

Kilfeddar Pool, Helmsdale, looking down to Salzcraggie 230

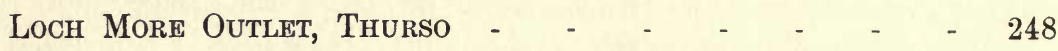

The EWe, LOOKING UP THe "NARrows" - _ _ _ $\quad$ - 290

Loch Clare; and Loch Coulin, head waters of Ewe District 294

The Record Day's Catch for one Rod, Grimersta - - 306

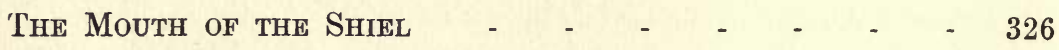

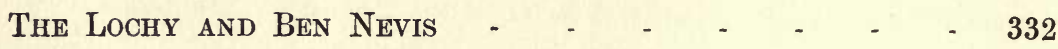

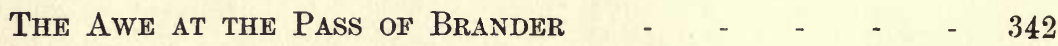

Awe, at Inverawe Cruive - $\quad$ - $\quad$ - $\quad$ - $\quad$ - $\quad$ - 346

The Ayr at Achincruive - $\quad$ - $\quad$ - $\quad$ - $\quad$ - $\quad$ - $\quad 374$

A Yair Net in Estuary of Solway Dee, low tide - - 402

The Nith at Drumlanrig -

MAPS

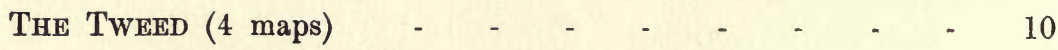

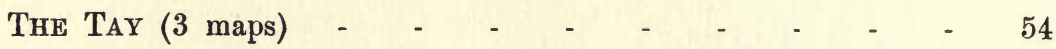

The Dee (5 maps) - - - - - - - - - 108

The Deveron (2 maps) - $\quad$ - $\quad$ - $\quad$ - $\quad$ - $\quad$ - $\quad$ - $\quad$ - 134

The Spey (3 maps) - - - - - - - - - - 142

The Awe (1 map) - $-\quad$ - $\quad$ - $\quad$ - $\quad$ - $\quad 340$ 


\section{THE SALMON RIVERS AND LOCHS OF SCOTLAND}

\section{INTRODUCTORY}

IT is difficult at first to realise that our mountains have been made by our rivers, yet such seems to be the literal truth. When the geologist restores the country, in imagination, to its earliest condition, he sees it as a great plateau of more or less uniform height. He finds the main axis lies in a north-east and south-west direction, and from this the water has run off chiefly in transverse courses. Through process of time, in which "a thousand years are but as yesterday," the erosion eats back from the mouths of the water channels towards the main divide, and rivers begin to show the characters we now recognise; the lower courses through the wide open valleys, the upper courses still descending from considerable heights.

All our Scottish mountains of any importance are of more or less similar height. We have no towering peaks as in Switzerland. Our hill-tops represent, in a somewhat modified degree, the surface of our old plateau. Our rivers and glaciers have scooped out the valleys so as to form the hills, and have sculptured the face of our beautiful country.

On top of the old rocks lie, or at one time lay, great depths of sandstones, which have evidently filled up our early valleys. To account for this and other features it is necessary, geologists tell us, to understand that the old and already much eroded plateau sank beneath the waves, and that the sand was thus laid down, so that when the country again emerged from the waters the plateau 
formation was practically restored. Twice, therefore, have the rivers become formed and twice have our hills and valleys come into being. The more recent valleys did not necessarily follow the former courses; water did not always eat down into the old channels or keep to more than parts of the old channels. Ice carried great masses of boulders and debris, made huge banks here and overturned obstacles there. Those causes are responsible for the fact that the main watershed of the country frequently shows no connection with the geological structure, wanders about, as it were, in total disregard of it.

The most northerly portion of the watershed, viz. that part which is found between Cape Wrath and Knoydart," "coincides pretty closely with the geological strike. It then turns sharply eastward to the line of the Great Glen between Lochs Lochy and Oich. The other portion of the watershed shows a contrasted disregard for geological structure. Sweeping round the head of the Spey valley, and crossing the hills above the head of Loch Laggan, it follows a curving southerly course past the west end of the Moor of Rannoch and the Brae Lyon mountains to Crianlarich, thence across Ben Lomond, until it traverses the great fault and enters the Midland Valley. The farther course of the general watershed of the country may be traced on the map over the Campsie Fells into the wide Lowland Valley, whence, after skirting the south-western parts of Linlithgow and Midlothian, and striking across the Pentland Hills, it runs into the southern uplands between the valleys of the Clyde and Tweed, crossing the Hartfell heights, from which it sweeps across to the Cheviot Hills."

A glance at the map of the watershed shows how near to the Atlantic seaboard the line keeps in the north of Scotland, and how impossible it is therefore that the rivers in that region can be of any great size. With the first sweep eastwards of the line we have the presence of the largest rivers of the Western Central Highlands, the Lochy, the Spean, and the Awe. With the passage of the line into the Lowlands we have the large river Clyde, still, alas, barred to salmon by the pollutions of Glasgow, pollutions which, under the enlightened modern treatment now in course of development, are steadily diminishing.

The eastern side of the watershed line contains the great majority of the leading salmon rivers of the country, since the courses of the rivers are longer, and in great measure free from natural obstruc-

${ }^{1}$ Sir Archibald Geikie, Scenery of Scotland, p. 169. 
tions in the shape of waterfalls. The Spey and the Tay are each a hundred miles long. The Dee and Tweed are almost that length, while the Findhorn, Deveron, Don, and Forth follow closely. In the last mentioned the requirements of man have to a considerable extent interfered with the arrangements of nature, for Glasgow has carried off an enormous quantity of water which under normal conditions should have found its way to the eastern seaboard. A proposal for a similar transference of water to the west coast, in the interests of a commercial undertaking, was frustrated by the salmon fishing interests of the Tay.

This question of water supply, either for domestic and industrial purposes or for power, is one which is bound to bulk more largely as our population increases and our enterprise extends. Projects of considerable magnitude are constantly being laid in the industrial incubator. The huge operations at Kinlochleven are just completed, other schemes will take definite shape before long. The very high value of salmon fisheries is often growled against by angling tenants, but this very factor is the one of all others which safeguards our stock of fish in certain districts. If the fishings were not of very great value, water rights would more easily be obtained, and, as a Scotsman is reported to have said in evidence before a Salmon Fisheries Commission, "It's a weel kent fac' in oor country that where there's nae water there can be nae fush."

Pollution is another danger which threatens salmon fisheries. In the thinly populated country districts, notably in the Highlands, this question does not trouble, and is not likely to trouble. In the Lowlands, however, and wherever the modern tendency of our population to congregate in towns obtains, the danger of pollution becomes greater every day. The various reports of the Sewage Disposal Commission are most illuminating reading as to the complex character of many of the effluents which have to be combated. As a Scotsman dealing only with Scottish salmon rivers, I am devoutly thankful that we have nothing approaching what is reported as characteristic of many rivers in the Midlands of England. The chemists of the Commission just referred to have, however, produced most substantial arguments and demonstrations in favour of bacterial methods of purification. In Scotland the methods have been applied to the extremely toxic bye-products of whisky making with marked success. In the account of the Spey a description will be found of a severe test made upon salmon eggs and fry with the purified pot ale from the Commission's bacterial filter at Coleburn Distillery. 
In the following pages the salmon angler's interests are those chiefly kept in view. A descriptive account of each river of importance being attempted, and the various physical features, the conditions which have been brought about by the action of man, as injurious or as helpful to the fisheries, are touched upon. As far as possible, without introducing matter of a private nature, particulars are given to show the productiveness of the various fishings, and I would here express my indebtedness to very many proprietors who have consented to my publishing the records of their waters.

In no sense is an attempt here made to criticise in any exhaustive way the various factors which crop up as adverse to the best interests of the salmon fisheries. A book such as this is clearly not the place where more or less delicate matter of this kind can be fully dealt with. Most valuable interests are frequently involved, and although my chief desire is to support and improve our salmon fisheries, I do not go so far as to say that all other interests must be regarded as subservient to them. But, at the same time, I feel that to deal in a really useful way with the particular features of each salmon river, it is necessary to notice features which I conceive to be adverse to the best interests of the rivers, many of which have already for the most part been dealt with by me in a series of reports bound in blue paper covers, and therefore only to be regarded, I presume, as ordinary waste paper.

The broad lines of salmon fishery improvement have been of late years pretty generally recognised. The service rendered to the country by the Elgin Commission on Salmon Fisheries is far greater than most people suppose. Never was there so enlightened and so complete a review of the whole situation, so definite and so thorough a grasp of what is most needed for the conservation and improvement of the salmon interests. Unhappily as yet no practical result has been attained therefrom, but I venture to think it is very certain that when legislation does come about, it is bound to follow the general lines laid down by the Royal Commission Report referred to. The reduction of netting in narrow waters where fish congregate before ascending to their natural spawning grounds; the opening up of barriers to ascent; the adjusting of the weekly close time; the purification of pollutions; the fuller control of District Fishery Boards and of the Supervising Central Authority; and a considerable number of lesser points dependent therefrom, are all necessities which the experience of forty years of our present salmon 
acts and the changed conditions of our salmon fisheries have clearly enough demonstrated.

In writing of the various rivers it will, I think, be found that I do not hesitate to point out the unfortunate conditions which exist here and there; or, on the other hand, the great improvements which have here and there been effected or are in contemplation. In all cases my views of what seems best for the general interest are based on the broad principles which have been so clearly laid down by the Elgin Commission, and which, I may add, are in entire harmony with the results of my own experience. I do not desire to labour this point in any way, but it happens that the subject of Salmon Fisheries is one about which people are apt to become strangely dogmatic, and to forget that the conditions present in one part of the country are quite different from those in other parts. It is a common experience to find that a man who has a salmon fishery in the West Highlands, or on the East Coast, or in the Solway, regards all Scottish Salmon Fisheries as exactly like his own, or as differing only in degree. Indeed it is not altogether uncommon to come upon a man who, though he owns rights of salmon fishing, has no personal knowledge of fishing at all, but who is none the less ready to pose as a first-class authority on the subject, thanks to his capacity for picking other people's brains. Some writers also, and here I desire to speak with all deference, since I myself may be regarded as guilty, have ventured to give to the world what in my humble opinion are rather ill-digested theories, and to denounce in rather wholesale fashion this or that particular kind of netting or poaching practice, or to attach perhaps very undue importance to some system of improvement, coupling their statements with the assurance that if their particular views were acted upon-usually regardless of cost-wonderful results would follow in a few years. I have watched salmon fisheries long enough to observe that even when the most carefully matured operations are put into practice recovery of a depleted fishery is extremely slow. It is easy to destroy a river; it is difficult, and costly, and requires a deal of patience to restore it again.

United action along a definite line of policy is generally necessary on the part of a number of people. Bad seasons will come now and again, and some men are apt to break away. The personal factor is usually a danger. By continuance only will it gradually appear that the bad seasons are not quite so bad as formerly, and that the good seasons are becoming better. The operation is not wholly 
under human control. Floods and frosts come to destroy spawn. The young salmon's natural enemies in the sea become numerous and aggressive, and the grilse fail. Such difficulties cannot wholly be combated. In old days when the stock of salmon was abundant, these things did not so much matter. Temporary loss was soon repaired. Now, much effort is required to seize every opportunity of improving various conditions which could formerly be disregarded. The value of salmon is great, competition in the salmon's extinction is keen, and indirect agencies of an adverse kind are far more numerous than formerly. In many parts of the Highlands the conditions are still more or less ideal, and much more complete concentration in the interests of salmon fishing is possible. Yet even in such districts complaints of decline are not infrequent, and recovery is slow in cases where the depleted condition has been allowed to continue for any length of time. The more we learn of the life history of the salmon, the more we need to realise how seldom many fish spawn. In a period of depression which lasts only for a year or two, there are probably sufficient salmon remaining in the sea of the locality, and which would not naturally have spawned during the period, to replenish the stock. If, let us say, close netting continues at the mouths of the rivers till these fish are also caught, the stock can be supported only by the fish which manage to ascend when the nets are off. Under these circumstances the stock has small chance of recovery till the netting conditions are altered. Further than that, it may happen, although more definite evidence is sorely needed on this particular point, that the undue netting of grilse as compared with salmon in a locality at present regarded by many as harmless, produces a marked result on the fisheries.

The great desire for salmon angling which is at present so evident amongst sportsmen acts as a most important force in the best interests of salmon fishing in all its branches. Associations of anglers are springing up in various parts of the country, and so long as the effort to reduce netting is not carried out in a purely selfish spirit, but in order to secure the increase of the salmon by allowing a proportion of every run of fish into fresh waters where they may naturally propagate their species, the benefit gained is shared by all eventually. It may be noticed, for instance, that in the Aberdeenshire Dee the action of reducing fresh water netting by the Dee Angling Improvement Association is supported financially by the Aberdeen Harbour Commissioners (who net the coast and estuary), because their fishings benefit from the increased number of salmon 
in the district. I am fully aware that not a few anglers exist who wish only to get the best sport which their money can procure, and who regard the netsmen as their antagonists and natural enemies. Long-line fishermen would rejoice to see all the trawlers sunk for the same selfish reason. But the salmon must be supplied to the market, and the best marketable fish comes from the sea. Until trawling was introduced the sole was scarcely seen on the British breakfast table.

I have no hesitation in saying that salmon netting and salmon angling can exist satisfactorily side by side; the question is one of regulation. There are immense difficulties to be overcome in some districts before proper regulations can be brought about. If from the pages that follow some appreciation of what these particular difficulties are can be secured, we are a step nearer proper regulation.

The order in which the various river-districts are arranged is geographical, from the Tweed northwards round the coast, along the Pentland Firth, and south on the west side of the country to the Solway. 


\section{CHAPTER I.}

\section{THE TWEED.}

Anglivg Season: February 1st to November 30th.

After 14th September fly is the only lure allowed, and this lure must alone be used at the beginning of the season till 15th February.

Netting Season: February 14th to September 13th.

This District is under the management of the Tweed Commissioners, whose Executive body meet at Kelso. D. W. B. Tait, Esq., W.S., Kelso, acts as Clerk.

Romance of Border feud, poetry, and legend seem to fill the air when Tweed is thought of, and many have written, and sung, and painted its many charms. To deal with its salmon fisheries may be a less extensive work than to write of the complex history of the district, yet it is verily sufficiently difficult. Sir Herbert Maxwell has filled a large and beautiful book with the history and romance of Tweed, and I am glad of it, for were it necessary for me to deal chiefly with this aspect, I should be tempted at once to lay down my pen.

Yet the Tweed is a wonderful river when we view it solely from its salmon fishery standpoint. No other river in Scotland is asked to maintain a salmon fishery, and at the same time to support so many industrial centres largely acting adversely to the interests of the salmon. The Clyde gave up the attempt long ago. But for the magnificent natural spawning grounds in the upper river and its tributaries and the absence of serious obstructions, the Tweed long ere this would have followed suit, or would have deteriorated to a second class fishery.

As a Border river, for long the scene of hot feuds, where, when folk were not busy cracking one another's crowns, Scotsmen and Englishmen alike were not disposed to conserve fisheries for the benefit of their opposite enemies, the salmon ran but a poor chance of attention. The very intensity of the feuds, however, may have acted as a partial shield to the salmon. The leister and the cairn net were no doubt busy at times, but men had more absorbing 
slaughter on hand. When more peaceful times supervened, special legislation was brought into existence, dealing first with "the mouth" of the river in 1771, and afterwards to give both sides a general interest in protecting the fisheries, and now, for sixty years, the special legislation still in force has held sway.

From time to time loud outcries have been raised against those Tweed Acts, and at intervals efforts have been made to end them. Without doubt we are now nearer the realisation of those efforts. No section of the community on Tweedside seems particularly anxious to maintain the Acts.

The river forms the boundary between England and Scotland for some fourteen miles, from Carham down to a point between four and five miles out of Berwick. For the remainder of its course the river is wholly in England, as also is the whole of the Till, an important tributary. In other respects the Tweed is purely Scottish, and since this means 75 miles out of 97 miles of its main channel, and a drainage area of nearly 1000 square miles out of 1500 square miles, there is every reason for the generally accepted view that if the Tweed Acts are to be repealed, Scotland rather than England may be fairly expected to accept the responsibility.

The basin of the Tweed is well defined, and extends from the extreme south-west of the county of Peebles, where the river takes its rise 1500 feet above sea-level, by the line of the Moorfoot Hills and Lammermuirs on the north, and the Cheviots on the south. The mouth is, as everyone knows, at Berwick-upon-Tweed, a town not only famed in history, but specially identified with the salmon, where annually-at least I hope the custom is still kept up-the Mayor and Magistrates open the season in a practical and gastronomic fashion by having an al fresco feast, the chief dish at which is salmon à la Berwick-upon-Tweed. There is no method of preparing salmon equal to the Berwick method, and I am glad it is practised in Scotland as well as in Berwick.

In the highest part of its course the river flows in a northerly direction, as the Clyde, which is across the hill to the west, also does. At Tweedsmuir the Talla enters, or one may say what is left of Talla water enters, for the city of Edinburgh has tapped this beautiful little stream and has constructed a large reservoir on what was previously a marshy meadow. A certain number of spawning fish used to enter Talla, and the loss of spawning ground, and loss of water, was the subject of arbitration between the Tweed Commissioners and Edinburgh. Fish are seen up in this neighbourhood 
only just before the spawning season. One may further say, I think, that the fish are not generally seen for long; they vanish from sight with singular regularity. I recollect getting a leister from a quaint old man of Tweedsmuir. It was, or is, for I have it still, a rude and heavy weapon of four prongs, probably made by a local blacksmith. I remembered that the prong points were much blunted on the stones of Tweed. "Richt or wrang I dinna ken Mr. Calderwood," was the reply, "but its ta'en oot many a dozen." The farm hands in the neighbourhood, and indeed the farmers themselves in some cases, do not consider their winter complete if they have not a night or two at " burning the water." The signs by which the movements of the water bailiffs are made known to the initiated are very interesting, but I am not going to tell how much I know on that point. At Broughton the Biggar water enters. For a few miles it is little but a deep broad ditch, but a good many salmon go up it at " the back end." In times of flood they penetrate into Coulter Burn, which flows from a flat divide, and occasionally when the water is high flows to the Clyde at one end and to Biggar Water at the other. Hence it sometimes happens that Tweed salmon find themselves above the Falls of Clyde, and parr are subsequently caught where no parr ought to be.

An early writer, one Dr. Pennecuick, writes of the head water of the river as follows: "Tweed runneth for the most part with a soft, yet trotting stream, towards the north-east, the whole length of the country, in several meanders, passing first through the Paroch of Tweed's moor, the place of its birth, then running Eastward, it watereth the parishes of Glenholm, Drumelzear, Broughton, Dawick, Stobo, Lyne, Manor, Peebles, Traquair, Innerleithen, and from thence in its course to the March at Galehope-burn, where, leaving Tweedale, it beginneth to water the Forest on both sides, a little above Elibank." A soft yet trotting stream may be said to be the character the whole way to the sea, yet with increase of volume comes the dignity of the large river, and the powerful glide and swirl.

Tweed has not gone far before an old Peel Tower is passed, for in the old days a line of signals could be flashed "from Berwick to the Bield," and those towers are characteristic of the Tweed to this day.

Many of them are not now to be readily identified. The highest of all, for instance, Old Oliver Castle, which was in touch with Drumelzier, is now no longer visible. The most famous in those upper waters is Neidpath Castle, a short distance above Peebles. Like Oliver it originally seems to have belonged to the Frasers. It 


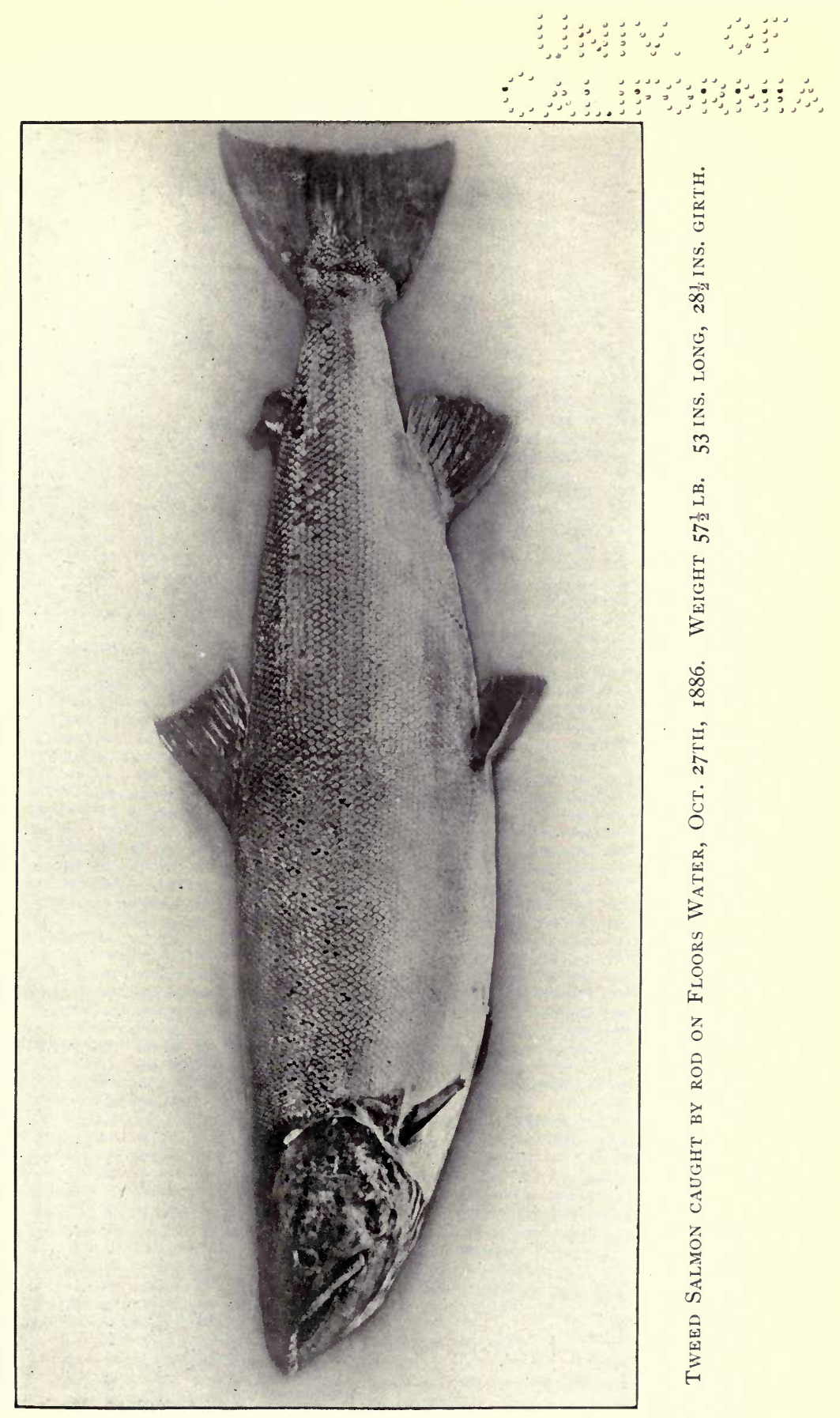


舟

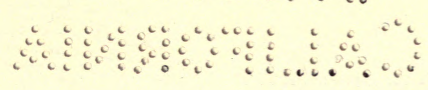




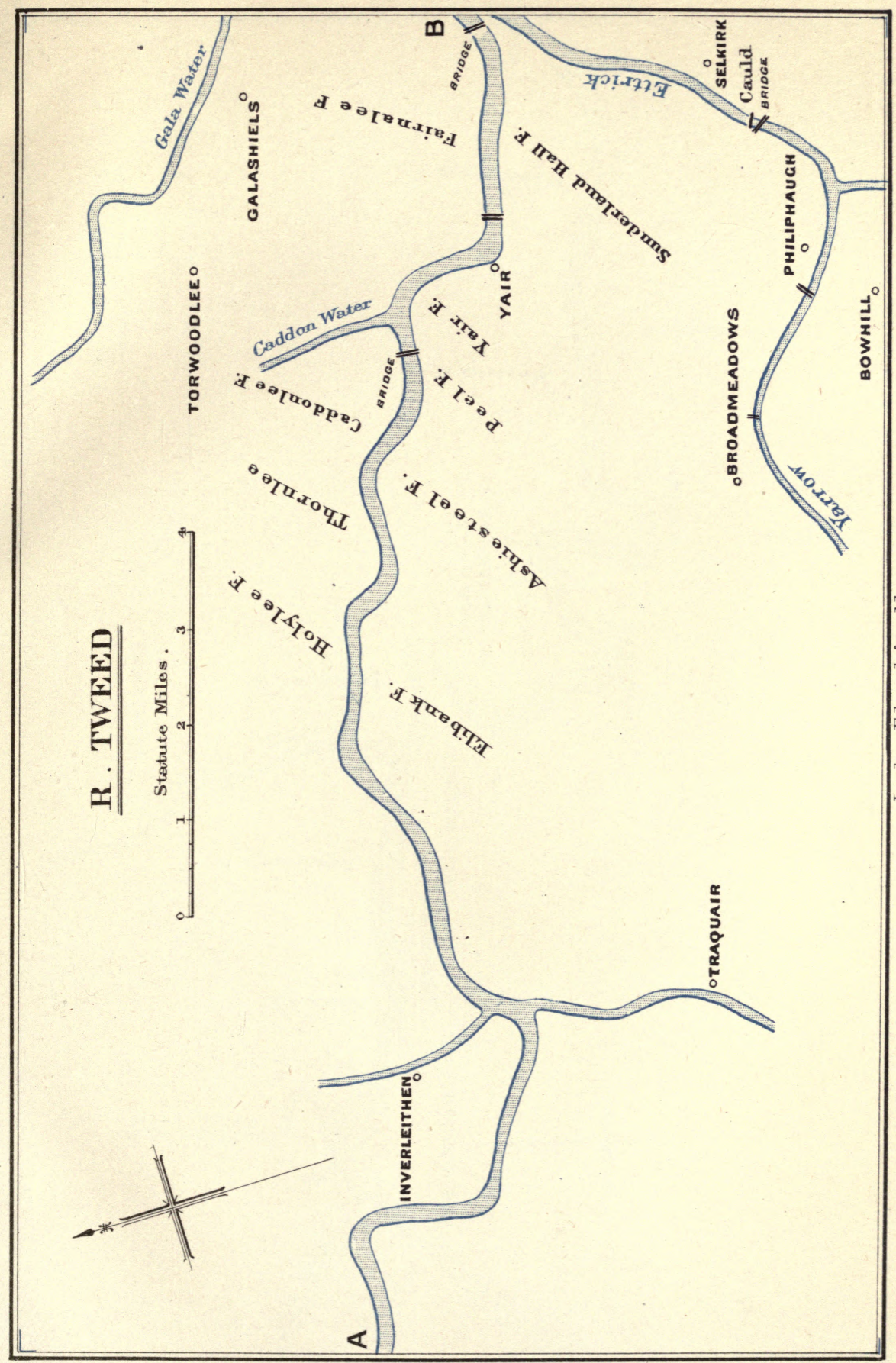




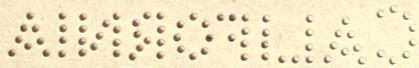




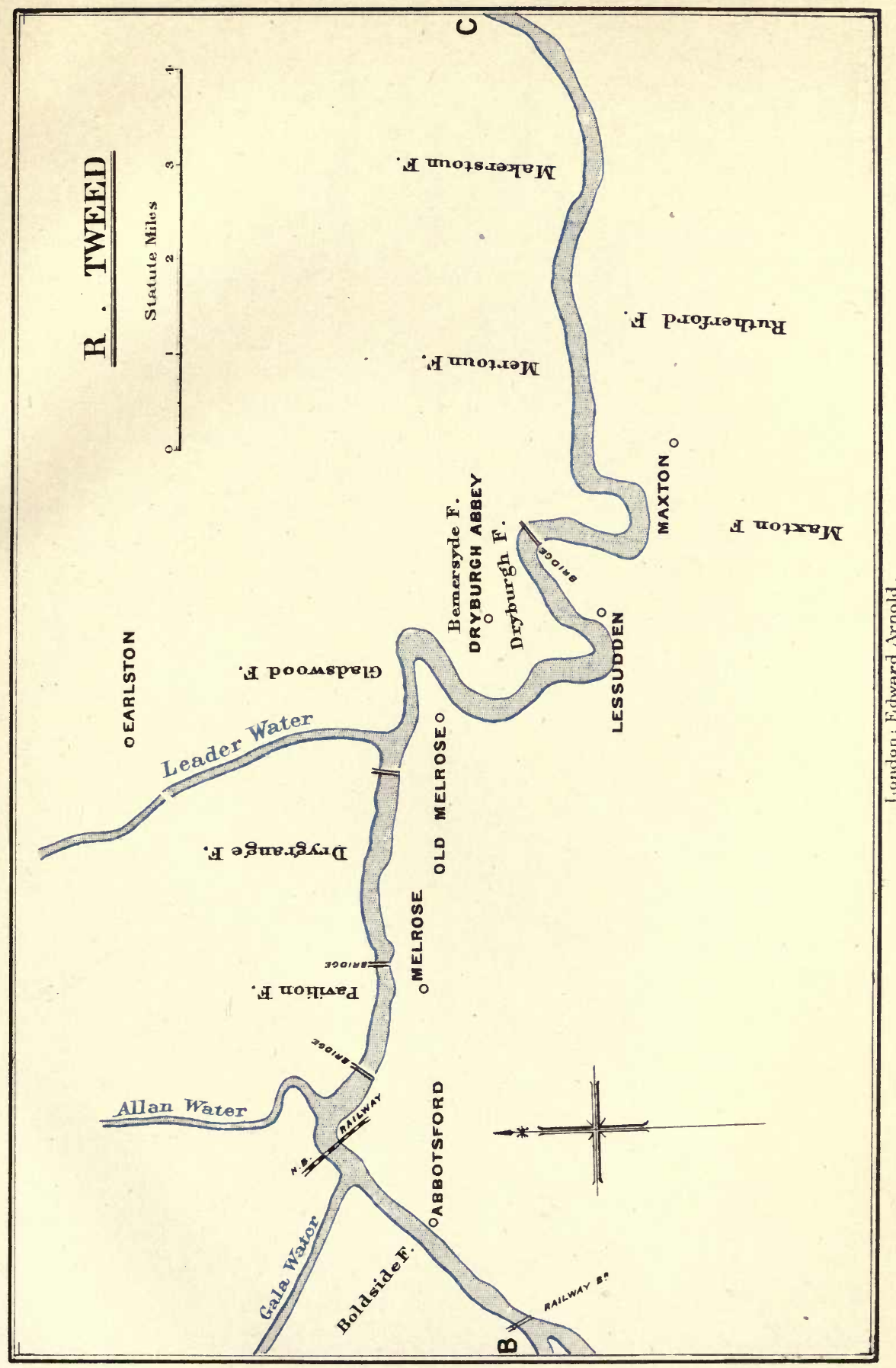


a 


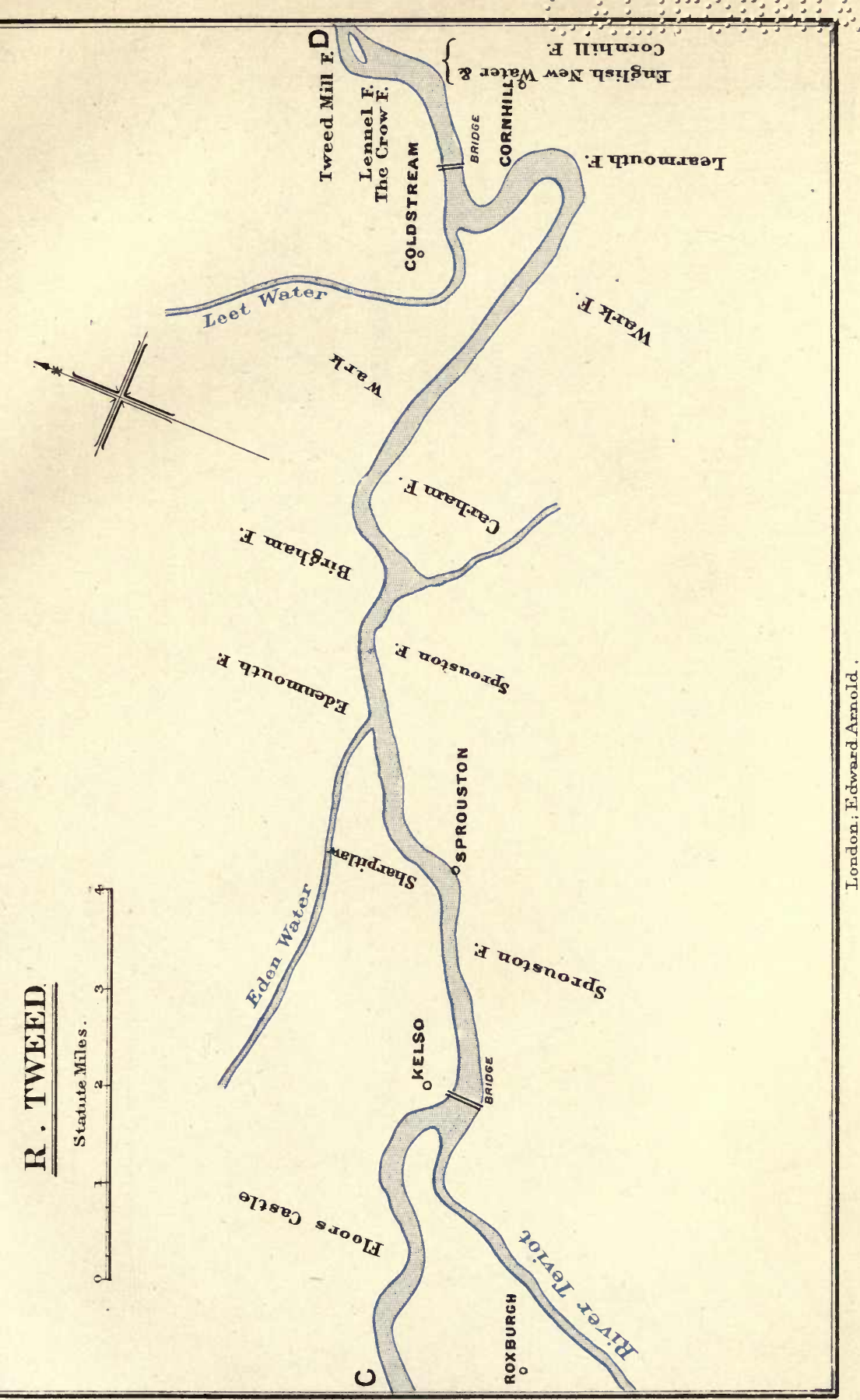


ํ.

a.d. 


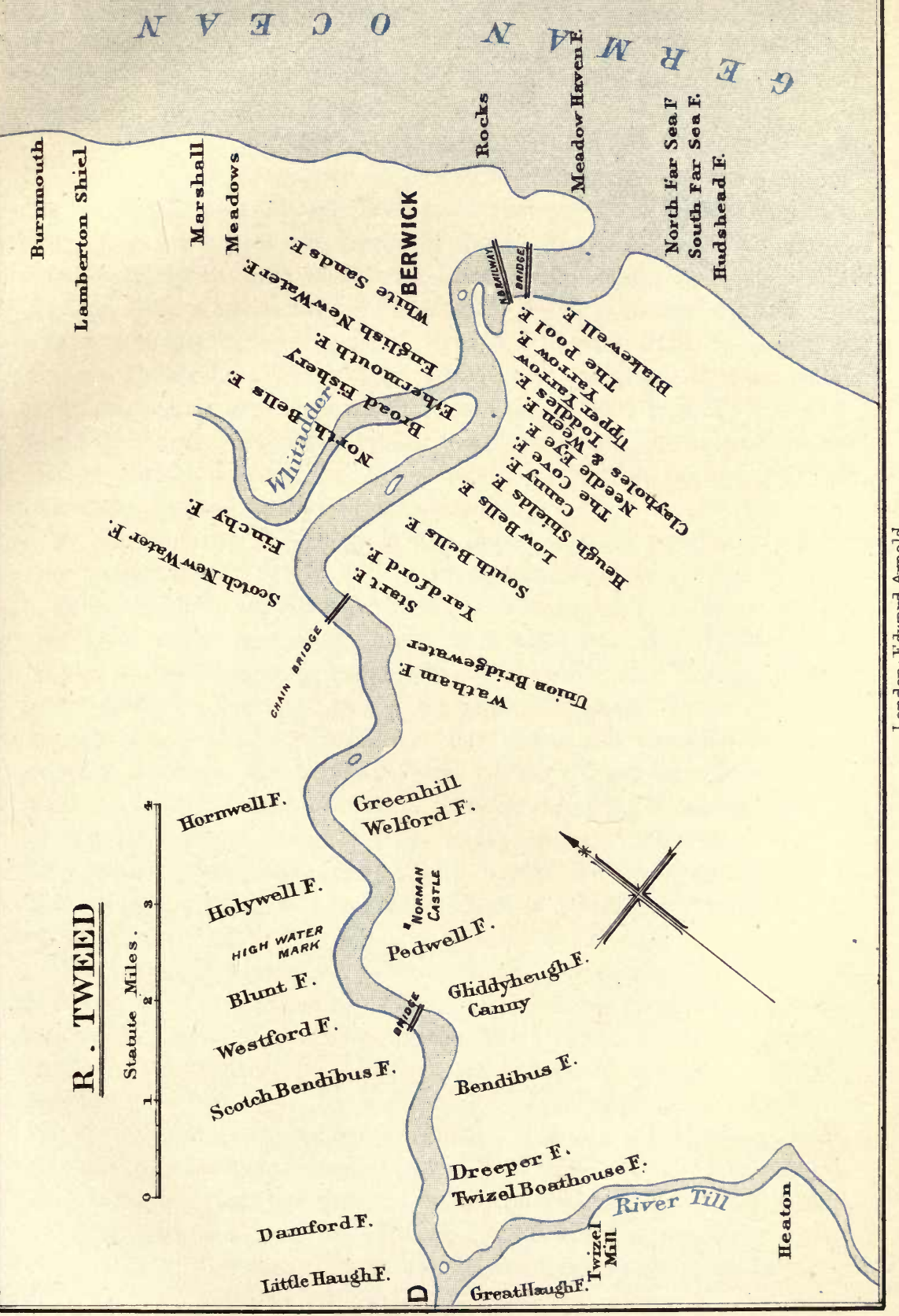




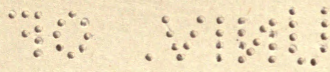

$\therefore$ 
stands picturesquely on a rocky bluff, where the river makes a couple of bends through a wooded defile. On the slope above, on a small flat eminence amongst the trees, a splendid view both up and down the valley used to be obtained. I am not aware if the trees have yet obscured it, but thirty years ago it was known to me as "Mount Pizgah."

The trend of the river eastward begins about Broughton, and before Neidpath is reached the tributary of Lyne has come in on the left bank and Manor Water on the right. The former rises away to the north on the slopes of the Pentland Hills. The latter, remarkable for its fine water and lusty trout, comes, in many small streams, from a half circle of hills which lie close to one another, the remnant of an old land surface; Scrape, Pykeston Hill, Long Green Knowe, Dollar Law, Black Law, Blackhouse Heights-how Lowland Scots the names are; the hills are all above 2200 feet, Dollar Law being 2680 feet. By Manor banks David Ritchie, the original of Sir Walter's Black Dwarf, had his cottage-a ghoulish person with an extremely twisted nature by all accounts.

At Peebles the Eddleston Water enters-at its mouth called by true gutterbluids "The Cuddy." Immediately below, the first weir or "cauld" of the river exists. The tweed mills of Peebles make full use of the water, and do not leave it as they find it. Peebles may be said to be the first of many sources of pollution. Sewage fungus grows freely in the river below the town. A Royal Burgh since the days of David II., son of Bruce, the clean and peaceful town lies sweetly amongst the pastoral hills. King's Moor across the river used to be the scene of many "weaponschawings" at an annual tournament. The hackbut, the arquebuss, and the bow had to be practised, and that this might better be done James II. in 1557 prohibited golf and football. Here is a hint for the supporters of rifle clubs.

The Peebles motto is Contra nando incrementum, and this is perhaps more to the point. The burgh arms represent three salmon, one swimming to the right as against the stream, and two swimming in the opposite direction. This is the sermon of the salmon on the benefits of adversity. By swimming against contending forces the salmon ultimately multiplies its kind. This is a fitting enough commentary on the "stout heart to the stie brae," which characterises the Scotsman; but the flippant, who know the ways of Tweedside, consider that the order of the salmon should be reversed, for, say they, "for two salmon that go up, only one comes down again." 
Before the Tweed leaves Peeblesshire, the town of Innerleithen is reached, and the obstruction of Walkerburn Dyke is passed. The dyke is generally believed to be the worst barrier to salmon in the river. The Leithen in ordinary weather conditions is entirely absorbed by the local mills, and finds its way to Tweed through a lade. In its upper reaches it is still a good trouting stream, but salmon are entirely barred. Sir Thomas Dick Lauder ${ }^{1}$ describes the joys of wandering up the valley, "guided by the thread of the little streams only, and dropping as you move onwards, a shortened line over its banks, finding yourself ever and anon yalked to a fish that compels you in prudence to give him somewhat of his own way and a little indulgence in the music of the reel, before you begin to think of drawing him gently near you, in order to lay your hands upon him. How agreeably does the lid of your willow basket utter its peculiar, gently creaking sound in welcome to the panting captive."

A rather violent contrast to this echo of the gentle art is found when we turn to the Report on the Pollution of the River Tweed, prepared by Dr. Wheaton and Mr. Curphey. ${ }^{2}$ "Occasionally, in time of heavy rainfall severe floods occur on the Leithen; when these occur a large amount of water flows down the bed of the stream, which is usually dry, and flushes it out, carrying all the rubbish and filth to the Tweed. . . . The mills are supplied with water from the milllade, and one of them obtains water from the Tweed when necessary. The people of the town are entirely engaged in the woollen industry, wool scouring, weaving, and dyeing are all carried on here. The town is sewered. All the sewage is collected in an outfall sewer, which discharges into the mill lade below the lowermost mill, and about 300 yards from the Tweed; there is no attempt at purification of the sewage. The liquid refuse from the mills is discharged into the lade. The water of the lade where it discharges to the Tweed is very foul with sewage and dye water. . . Below the point at which the lade discharges to the Tweed the water of this river is greatly fouled, the bottom of the river is covered with sewage deposit and the stones coated with sewage fungus. The river here contains also a large amount of refuse of all kinds, such as pots and pans, old linoleum, old ironwork, and such like. Although there is a daily collection of rubbish in the town a great deal of large-sized rubbish is thrown into the bed of the Leithen, and the tip to which all refuse is taken, together with offal from the slaughter-houses, is situate just where the Leithen falls into the Tweed. In times of 
flood the water of the Leithen excavates this refuse tip and carries the refuse into the Tweed. Some of the mill owners here have tanks for settling the spent liquids after dyeing, and in this way some of the solid refuse is retained, but the coloured liquid is allowed to enter the river."

This serves to show how "the silver Tweed" is treated while it is yet sixty miles from the sea.

The river now passes through the north-east portion of Selkirkshire by famous Ashiestiel, where Scott spent seven of perhaps the happiest years of his life. It is one of the most beautiful parts of Tweed. Abbotsford was bought by Sir Walter in 1811. I will not attempt to do more than mention it, so many able pens have already been busy with everything which pertains to the sacred place.

Opposite Abbotsford, the Boldside fishings are situated, and from a return furnished to Lord Elgin's Salmon Fisheries Commission by the proprietor, Mr. Scott of Gala, it is possible to make an estimate of their productiveness. The return is for the years 1880-1900, excepting 1891, and deals with results obtained only between 15th September and 30th November each year. The average take for the eleven years is 70 fish, the extreme of variation being from 31 to 103 fish. The return is of interest since it refers to a fishery of the upper waters.

Through the heart of Selkirkshire flow the tributaries of the Ettrick and Yarrow which unite at Philiphaugh two miles above the county town. Below the junction, the river is called Ettrick, since Ettrick is 27 miles long and Yarrow only 20. But if the Meggat Water, which flows into St. Mary's Loch at the head of Yarrow, is taken count of, the waterways would be practically the same length. At the Meggat Water, which passes the south side of Dollar Law, we are only across the divide from the source of Manor Water already referred to.

There are four caulds or weirs on Ettrick; the Selkirk cauld, which is about eight feet high, and which in spite of a fish-pass, so called, salmon can only ascend with difficulty or when the river is in flood; Philiphaugh cauld, about six feet high and of a steep gradient, now being provided with a new pass by which fairly easy ascent is expected; Oakwoodmill cauld and Collins Bridge cauld, both of which are not very formidable structures, and which do not appear to offer much difficulty to fish except when the water is low.

Away up at Ettrick Church lie the remains of Hogg and of “Tibbie Shiels." From St. Mary's Loch, where Tibbie many a time 
ministered to the "Ettrick Shepherd" and "Christopher North," the Yarrow descends by its " dowie dens" to

"The shatter'd front of Newark's Tower, Renowned in Border story."

At Bowhill hangs the full-length portrait of Scott by Raeburn. The house was a favourite residence of the Earl of Dalkeith, to whom Scott inscribed his Lay of the Last Minstrel.

The north-east boundary of the county of Selkirk is formed by the Gala tributary, which rises in the Moorfoot Hills of Midlothian. From those hills much of Edinburgh's water supply is taken, and the Gala flows clear and limpid over its gravel bed till suddenly, at Galashiels, its waters are turned as if to ink. Galashiels has over 14,000 inhabitants, covers an area of 862 acres, and has a rateable value of $£ 63,172$. There are many large woollen mills, a tannery, a gas-liquor work, and a chemical manure work, besides the numerous sources of pollution more or less inseparable from the requirements of a town. "It would be impossible to find a river more grossly polluted than the Gala as it passes through Galashiels," say the writers of the report of 1906 already quoted.

Proceedings have been taken successfully, in the past, against Galashiels and its pollutions, and certain undertakings were entered into. Now at length the municipal authorities are laying down a new system both of drainage and purification. Without doubt the system of purification will be watched as carefully as the demands of the situation require.

It is convenient here, when touching upon this matter of pollution, to refer to the efforts which are now being made for the general and systematic combating of the evil. In the report of Messrs. Wheaton and Curphey, already referred to, a short review of the situation is given, and from this I will quote. "In the year 1897 the County Council of Roxburgh, having had their attention called to the serious and increasing pollution of the river Tweed by liquid refuse of domestic origin as well as by the products of manufacturing processes, decided to endeavour to form a Joint-Cornmittee of Sanitary Authorities interested in the condition of the river, with a view to taking action for its purification. With this object the County Council approached the County Council of Northumberland and the County Councils in the Tweed basin in Scotland, proposing a conference of the authorities interested, and through whose districts the river passed, for the purpose of deciding upon an application to the 
Secretary for Scotland for the formation of a Joint-Committee to enforce the Rivers Pollution Prevention Act of 1876. It was then found that it was doubtful if the County Council of Northumberland or other authority in England could combine with authorities in Scotland for this purpose; . . . Under these circumstances the Rivers Pollution Prevention (Border Councils) Act, 1898 (61 and 62 Vict., ch. 34) was passed in 1898. This Act provides that where a river or any tributary thereof is situate partly in England and partly in Scotland, the Local Government Board for England and the Secretary for Scotland, by Provisional Order made on the application of the Council of any of the counties concerned, may together constitute a Joint-Committee or other body representing all or any of the counties through or by which such river or any specified portion or tributary thereof passes, and may confer on such committee or body all the powers of a sanitary authority under the Rivers Pollution Prevention Act, 1876. . . .

"In 1905 the Commissioners of the river Tweed made representations to several County Authorities drawing their attention to the polluted state of the river, and expressing the hope that the councils would take up the question of river purification at an early date, and would proceed to exercise the powers in that direction which were at their command."

As a result of this, the County Council of Roxburgh took action, and applied to the Local Government Board of England and the Secretary for Scotland to constitute a joint committee. The two departments named then ordered an investigation and report on the actual pollutions which exist, and Messrs. Wheaton and Curphey were instructed in this matter, and furnished the report from which quotations are here made.

All those interested in the purification of this noble river should realise the value of the action taken by Roxburgh County Council and the Tweed Commissioners in this matter.

If I might venture to go a little further in this matter, I would say that what is ultimately needed is the establishment of a standard of purity, and the creation of an official authority capable of testing and controlling the manner in which the standard is maintained. In their last report the Royal Commission on Sewage Disposal state that they are satisfied with regard to the basis upon which such a standard should be made; that it must take cognizance of two points: 1st, the amount of suspended solid matter in the water, which provisionally they suggest should not be greater than 3 parts in 100,000: and 
2nd, the amount of dissolved oxygen capable of being taken up by the fluid after the removal of the suspended solids. At the same time it is provided that a certain amount of elasticity is possible to suit local conditions.

I find that Stoddart, in The Angler's Companion, says: "It is not until it reaches Ashiestiel that Tweed is looked on by salmon-fishers with much regard. Higher up the fish killed by the rod are comparatively few, and these, most of them, in execrable condition." It is in this neighbourhood that the Edinburgh Angling Club have for over sixty years had their headquarters. "The Nest," a cottage on the Fernielee property, close to Yair Bridge, was the time-honoured base, as it is lovingly referred to in many a song of the club. Ultimately a change had to be made, and a new home was found two or three miles away,

"Where Ashiestiel looks on the Tweed, And Tweed rolls broad by Caddonlee."

The water rented is fished from the north or left bank both above and below Ashiestiel Bridge, but salmon are not expected before October, unless the summer has been an unusually wet one.

The river Tweed and the various tributaries above this point, with the exception of the Leithen, must therefore be regarded at the present time as spawning ground. Fortunately it is spawning ground of exceptionally high quality. It is unnecessary, and indeed it would be well-nigh confusing, to describe in detail the positions of the various fisheries from this point downwards. These will be found marked in the maps of the river.

The Tweed now passes into Roxburghshire, where in the Boldside Water good results are obtained "at the back end," if conditions have been favourable. The 1908 season was poor with only 47 fish. From Abbotsford the distance is not far to Melrose, with its famous twelfth century abbey. The entrance of the Gala from the north between those two points has already been touched upon. We must be thankful that Melrose does not stand on a tributary, else no doubt the woollen industry would have taken root here also, and the beautiful old pile would have been frowned upon by such monsters of utility as we see at Galashiels, and blackened by the smoke of belching chimneys. It is sadly jostled already by crowding houses, but the old town remains unchanging. At Melrose there is a cauld which is none too easy for ascending fish, in spite of its pass near the left bank. It checked many fish in 1908. 

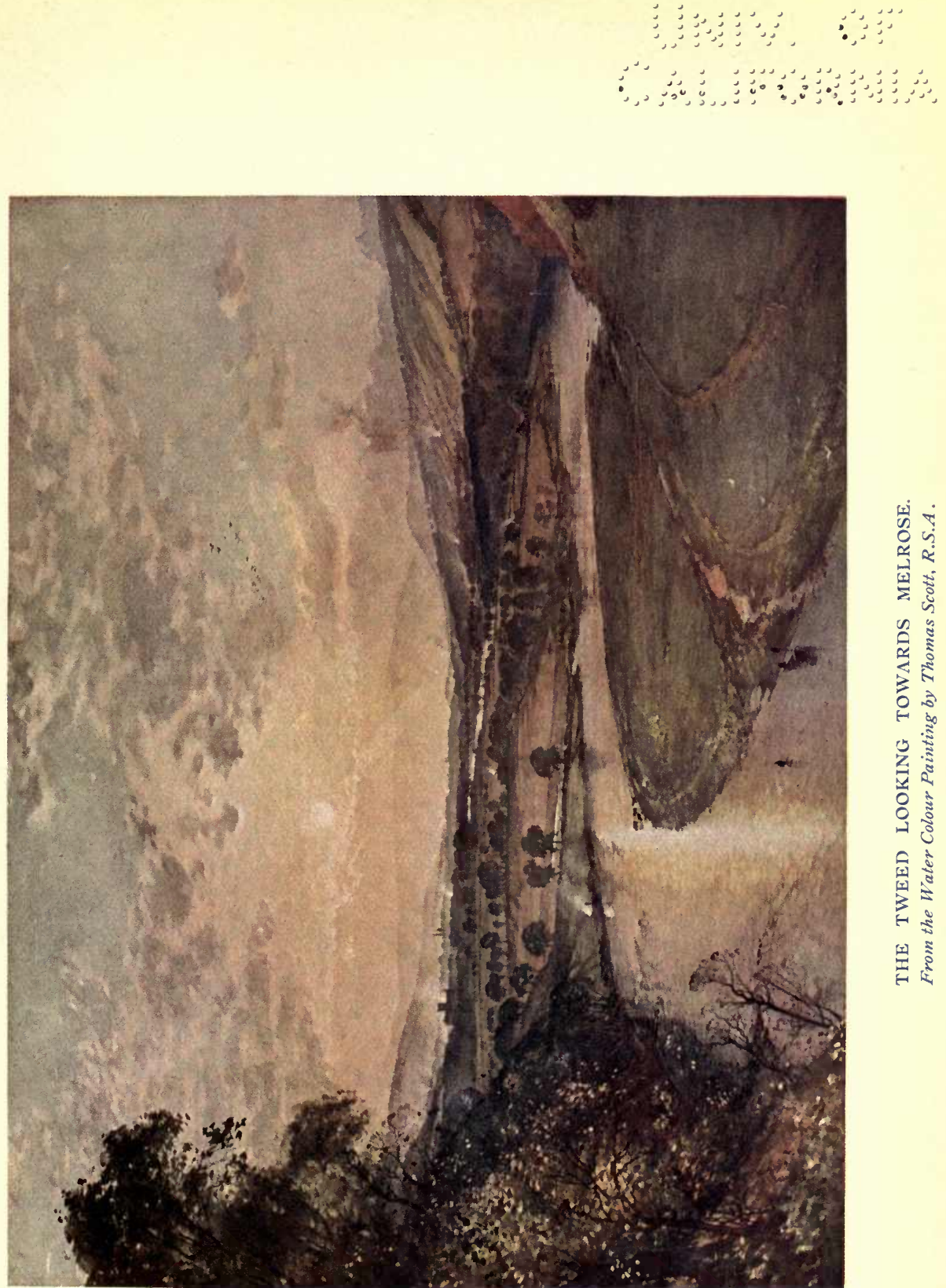

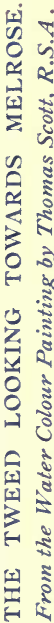




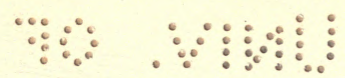

$\therefore$ 
A beautiful run of river now goes on to Leaderfoot, spanned by the high bridge which takes one from Melrose to Earlston. The Leader, or Lauder, rises in the Lammermoors, and flows through its dale with many a beautiful bend amidst woods and pastures. It is obstructed near its mouth, but the trout are finer than those of Tweed. A considerable discussion recently arose as to the benefit of erecting a suitable pass in the Leader foot cauld. The view upstream from Newstead, with its now famous Roman Camp, is typical of Tweed. The fishings go with Pavillion and Drygrange. The best season at Drygrange was 1908, curiously enough, when Mr. Roberts scored 112 fish.

The Tweed now takes a series of quick bends. Between Gladswood and Bemerside it turns back in a south-westerly direction, then getting a little to the east of south it passes Dryburgh Abbey, embowered in its trees, where in Sept. 1832 Sir Walter Scott was buried. Then a great $\mathbf{S}$-shaped bend, and the river reaches the beautiful stretch at Mertoun. It then flows steadily in an easterly direction, but gradually trending slightly northwards.

The nine upper pools of Mertoun have the right of fishing on each bank. Lord Polwarth then continues on the left bank, the Maxton Water being opposite, and then again Mertoun fishes seven remaining pools from both banks. There are twenty-two pools in all. In forty-three days' fishing in the autumn of 1908, from reports in The Field, it appears that the middle stretch of Mertoun produced 116 salmon and 10 grilse.

Rutherford Water then comes in with two miles and a half of both banks. In the appendices to Part III. Section 2 of the report of Lord Elgin's Commission a return is given for Rutherford Water between 1887 and 1900. The average take for the fourteen years is 97 ; the range of variation being from 32 to 191 fish.

At Makerston, next below, the channel narrows somewhat, has a rocky bed, and the current becomes much more rapid. This is practically the only part of the Tweed which is rough and broken in character. Soon again the river assumes its more usual features and sweeps past stately Floors Castle, the seat of the Duke of Roxburghe, to the weir at Kelso.

Out of Makerston Water, in 1873, a single rod is reported to have killed in one week the exceptional number of 73 fish. This is, I think, the second best week's score in the river. It is very remarkable in certain seasons, with a good stock of fish in the water, how many big scores may occur in a single week of favourable 
weather. There was a wonderful week in November, 1903, for instance, when

$\begin{array}{lcccccc}\text { Upper Floors produced } & - & - & - & - & - & 65 \\ \text { Lower Floors } & " & - & - & - & - & - \\ \text { Ednam } & " & - & - & - & - & - \\ \text { Hendersyde } & " & - & - & - & - & - \\ \text { Birgham } & " & - & - & - & - & - \\ \end{array}$

The total for Lower Floors is, I think, the highest week's score for the river. The average weight of the 78 fish was $19 \mathrm{lb}$.

The late Colonel Malcolm of Poltalloch had some great fishing on Makerston Water. A good four days' catch is reported in the Fur, Feather, and Fin Series (Salmon, p. 135). It occurred in October 1873. Colonel Malcolm had 12,14, and 15 fish on three consecutive days, and on the fourth day his neighbour, Mr. Dennison (of Ness fame), fished his rod, and had 16, i.e. 57 fish in four days. With regard to Makerston totals for the season, I am able to give the catches of Mr. Cockburn, who fished in 1882, 1883, 1884, and 1885. These were, salmon and grilse taken together, 157, 209, 131, and 214. In 1891, Mr. Justice Madden had 91 fish in three weeks.

Floors Water has the distinction of having yielded the heaviest rod-caught Tweed fish. It weighed $57 \frac{1}{2} \mathrm{lb}$., and was caught on 27th October, 1886. Through the kindness of Sir Richard Waldie Griffith, who has one of the three full-size photographs of it in his smoking-room, I am able to give the measurements.

$\begin{array}{llllll}\text { Length - } & - & - & - & - & 53 \text { inches } \\ \text { Girth at back fin } & - & - & - & - & 28 \frac{1}{2} ", \\ \text { Girth behind head } & - & - & - & - & 26\end{array}$

The fish was a male, as all those extra big salmon are, and is reported to have been firm in the flesh, of a very good colour on the back, and a little red on the belly. I am able, through the kindness of Mr. W. R. Plummer, to give a small representation of the full-size photograph which hangs in Kelso. The third photograph, I understand, hangs in Floors Castle, where the fish was carried and weighed at the end of the day, by its captor, Mr. Pryor.

While referring to big fish, I may mention that, in Mertoun Water in December, 1907, a fish was found dead which weighed $60 \mathrm{lb}$. Is it possible that some lucky man may yet beat $\mathrm{Mr}$. Pryor's monster? From an examination of its scales, made by Mr. H. W. Johnston, it appears that the fish was nearly eight years 
old, and had spawned twice in its life-time, once as a grilse in 1903, and again in 1905.

With regard to the catch of salmon in Floors Water, the Duke of Roxburghe has very kindly let me have the perusal of the Floors Fishing Books, which date back to 1839 . In the early years it has been customary to enter the kelts and baggots landed, as well as the clean fish, and also as one goes through the records it is noticeable that angling was apparently not carried on in late autumn to the same extent as now. Not infrequently no fishing is recorded in November; occasionally there is no record in October, or only three or four days' catches are mentioned. This makes those early records scarcely comparable with the carefully kept records of more recent years, which are complete up to the 30 th November, 1908. I therefore propose to deal in detail only with the period from 1890 onwards. In passing, however, I should like to mention the year 1846 , on account of the number of clean fish which appears to have been taken at a fairly early date. In seventeen days' fishing in April of that year 37 clean fish are recorded, and in eight days' fishing in May, 20 clean fish. The earliest date in which a clean fish is noted is 20th March, 1868. In later years, notably in 1903, Upper Floors produced 2 clean fish in February, and 2 in March, while Lower Floors produced 5 clean fish in February and 4 in March. This was a marvellous year in many ways, and will be referred to later.

In the Floors Records, the Upper and Lower Water is first divided in 1890; in 1903, Sprouston and Ednam House Water is added. The following is the record of Upper and Lower Floors Water alone.

\begin{tabular}{|c|c|c|c|c|c|c|c|c|c|}
\hline $\begin{array}{l}\text { Year. } \\
1890\end{array}$ & $\begin{array}{c}\text { Upper. } \\
-\quad 58\end{array}$ & $\begin{array}{c}\text { Lower. } \\
143\end{array}$ & $\begin{array}{c}\text { Total. } \\
201\end{array}$ & Averages. & $\begin{array}{l}\text { Year. } \\
1900\end{array}$ & $\begin{array}{l}\text { Upper. } \\
-\quad 245\end{array}$ & $\begin{array}{c}\text { Lower. } \\
1066\end{array}$ & $\begin{array}{r}\text { Total. } \\
351\end{array}$ & Averages. \\
\hline 1891 & - 253 & 194 & 447 & & 1901 & -156 & 95 & 251 & \\
\hline 1892 & - 195 & 189 & 384 & & 1902 & 91 & 120 & 211 & 356 \\
\hline 1893 & 30 & 73 & 103 & 183 & 1903 & - 293 & 321 & 614) & \\
\hline 1894 & 44 & 56 & 100 & 100 & 1904 & 29 & - & 一 & \\
\hline 1895 & 99 & 46 & 145 & & 1905 & 55 & 40 & $95)$ & \\
\hline 1896 & - 264 & 148 & $412)$ & & 1906 & - 139 & 105 & 244 & 145 \\
\hline 897 & 109 & 47 & 156 & 910 & 1907 & 83 & 61 & 144 & 140 \\
\hline 1898 & 89 & 68 & 157 & 219 & 1908 & 63 & 35 & 98 & \\
\hline 99 & 91 & 71 & 152J & & & & & & \\
\hline
\end{tabular}

The very large fish was taken in 1886, and 15 seem to have been taken by Mr. Pryor in Upper Floors that day. The Fishing Book simply adds: "Heaviest $57 \frac{1}{2}$ lb." I believe brevity must be the soul of more things than wit. 
No record of Lower Floors, as it is now called, occurs for that year, but it has been reported that two rods had three most remarkable days on 25th, 26th, and 27th October, killing 91 fish. On October 22nd, 1900, the Duke of Roxburghe himself killed 16 fish. The late Mr. George M'Culloch had Lower Floors for three years from 1901, and during that period made some very considerable scores. On 8th November, 1901, he had 18 fish averaging just over $18 \mathrm{lb}$. On the last day of that season he had 11. 1903 was, however, his great year. His scores on seven consecutive days' fishing from October 15, were : 13,11, 11, 12, 7, 15, and 13 . In November he had five consecutive days of $12,17,16,15$, and 10. Then on 20th November came his greatest day, when he killed 19 fish, in the Garden Wall and Peat Pools, averaging $20 \frac{1}{2} \mathrm{lb}$. The weights were : 39 lb., 28 lb., 24 lb., 24 lb., 24 lb., 23 lb., 21 lb., 20 lb., 20 lb., 20 lb., 19 lb., 19 lb., 18 lb., 17 lb., 17 lb., 16 lb., 16 lb. 15 lb., and $14 \mathrm{lb}$. Next day he had $11 \mathrm{fish}$, and the day after that 18 fish. In this couple of months his total was 285 salmon and 21 grilse. For the accompanying photograph of $\mathbf{M r}$. M'Culloch and his 19 fish on the 20th November I am indebted to the kindness of Mr. W. R. Plummer.

Taking now the totals for Upper and Lower Floors, Sprouston, and Ednam House Water, since 1903, we have these great totals:

\begin{tabular}{|c|c|c|c|c|c|}
\hline Year. & Upper Floors. & Lower Floors. & Sprouston. & Ednam. & Total. \\
\hline 1903 & - 293 & $\begin{array}{r}321 \\
99\end{array}$ & 262 & $\begin{array}{r}149 \\
15\end{array}$ & $\begin{array}{r}1025 \\
156\end{array}$ \\
\hline $\begin{array}{l}1904 \\
1905\end{array}$ & $\overline{55}$ & 40 & 138 & 48 & 281 \\
\hline 1906 & 139 & 105 & 268 & 104 & 616 \\
\hline 1907 & 83 & 61 & 116 & 39 & 299 \\
\hline 1908 & 63 & 35 & 158 & 47 & 30 \\
\hline
\end{tabular}

It is of great interest to notice also the number of fish taken in Sprouston Water in the three first months of the season, showing very clearly, what I state elsewhere, that the Tweed has the making of a first-class spring river if only the fish were allowed to ascend in sufficient numbers. Take the three last springs at Sprouston, the numbers are:

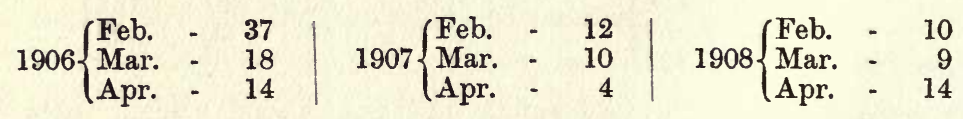

A curious coincidence was reported by Mr. Alex. Scott as having happened in the Floors Water in October, 1908. Lord Herbert, fishing on the 19th, lost a fish and with it a small silver Wilkinson. 
On 23rd, Hon. Mr. Ward hooked and landed a fish on a silver Wilkinson and found Lord Herbert's fly in its mouth.

Below Kelso Weir, on the opposite side from the town, the Teviot enters from the south-west. It is the largest tributary of Tweed being about 39 miles long. A recent writer has copied an error of a well-known angler's book of reference in stating that the Teviot is 60 miles long. Sixty miles in the same direction would be away across both the Esk and the Annan. It rises, however, near the borders of Dumfriesshire. The chief feeders are the Ale, Jed, Oxnam, and Kale. Numbers of fish ascend the Teviot, and, in the autumn, the water bailiffs are usually busy in this district, for the poaching fraternity are numerous and over bold.

Hawick, Denholm, Ancrum, and Jedburgh, are towns in Teviotdale-or Tividale if one must adopt an ugly abbreviation. On the Teviot and the feeders named there are no fewer than 32 weirs. In the case of not a few, fish can ascend without much difficulty, and this in some cases in spite of the fact that no passes exist. Some of the caulds are, however, much more serious affairs, notably at the Bongate Mill cauld at Jedburgh, and at Millheugh on the Oxnam. The latter is formed of natural rock, and both are almost wholly obstructive to the ascent of fish.

Though several of the feeders are rocky-the Rule Water indeed which enters at Denholm means, I believe, the rumbling soundthe lower Teviot, owing no doubt to the prolonged action of denudation, becomes quiet and rather sluggish, so that attempts have ere now been made to increase the current by concentration, and so, if possible, improve the fishing. Early Tweed fish, if they are lucky, get up to Kelso, where their progress is checked by the cauld. The quiet Teviot then offers itself as a further channel. Hence it follows that not a few fish are sometimes caught in lower Teviot in the months of March and April. Bull-trout, by which I mean the round tail ( $S$. trutta variety eriox), also ascend, but, as usual, are little use to anyone.

The Tweed after receiving the Teviot, is a river of such proportions that boatwork becomes more or less necessary in fishing. In following the river downwards from Kelso we have now the most productive water in front of us. Leaving out of count the bends of the river, the general direction is now north-east to Berwick, about five-and-twenty miles. Hendersyde or Sharpitlaw of Sir Richard Waldie Griffith, Bart., the present chairman of the Tweed Commissioners is on the left, and Sprouston, of the Duke of Roxburghe, on 
the right. There are some twenty pools and streams in about three miles of this famous stretch. Sprouston Dub is the pick, and perhaps may be fairly regarded as the most productive pool in Tweed. It is smooth still water, as its name seems to imply, has a bottom of flat shelving rock, and an average depth of about nine feet, which is maintained by the weir at the foot of the pool. Owing to the raising of water-level in two lower pools, the Dub weir is no obstruction to fish entering the pool. In fishing the Dub, each proprietor fishes his own side, the understood rule being that with his back to his own bank each may cast across the middle line as he chooses. All fishing is from boats. The upper and lower sections of the Sprouston water are fished alternately by each side, the Dub only, which is in the centre, being fished by both. The Dub requires a breeze to fish really well, and fairly light tackle is often advisable. The record is, I believe, 33 fish, on November 21st, 1873, and on two other days of November that year the Hendersyde score was 23. Days of 13 or 14, with sometimes an average weight of about $18 \mathrm{lb}$. are not uncommon; the fame of the Dub being largely because of the large number of fish almost always present, and given suitable weather conditions, the steadiness of the good results obtained. This may be better understood when it is said that of the fish taken from the whole of this water, the Dub yields more than half.

From Hendersyde the fishing is perhaps not so heavy as in other waters, or as is usual with so much good water. Only two rods are as a rule fishing at a time, and frequently the angling is intermittent. If the weather conditions are not good the water is rested. For instance, in 1888 the river was constantly low in the early part of the season, and flooded at the end. It was almost the poorest year in result, for only 64 fish were killed in all; but it has to be noted that fishing was practised on only nineteen days, and that of the 64 fish, 44 were taken in one week. It is contended that by the policy of resting the water in this way, the high average of Hendersyde has been maintained in recent years.

Sir Richard has kindly allowed me to give the results of his autumn fishing which date from 1873 , i.e. the angling from the commencement of the close time for nets to the end of the rod-fishing season-14th September to 30th November. In this period, be it noted, there are sixty-four fishing days, and I find that on an average Sir Richard appears to fish about thirty-eight days:

[Year. 

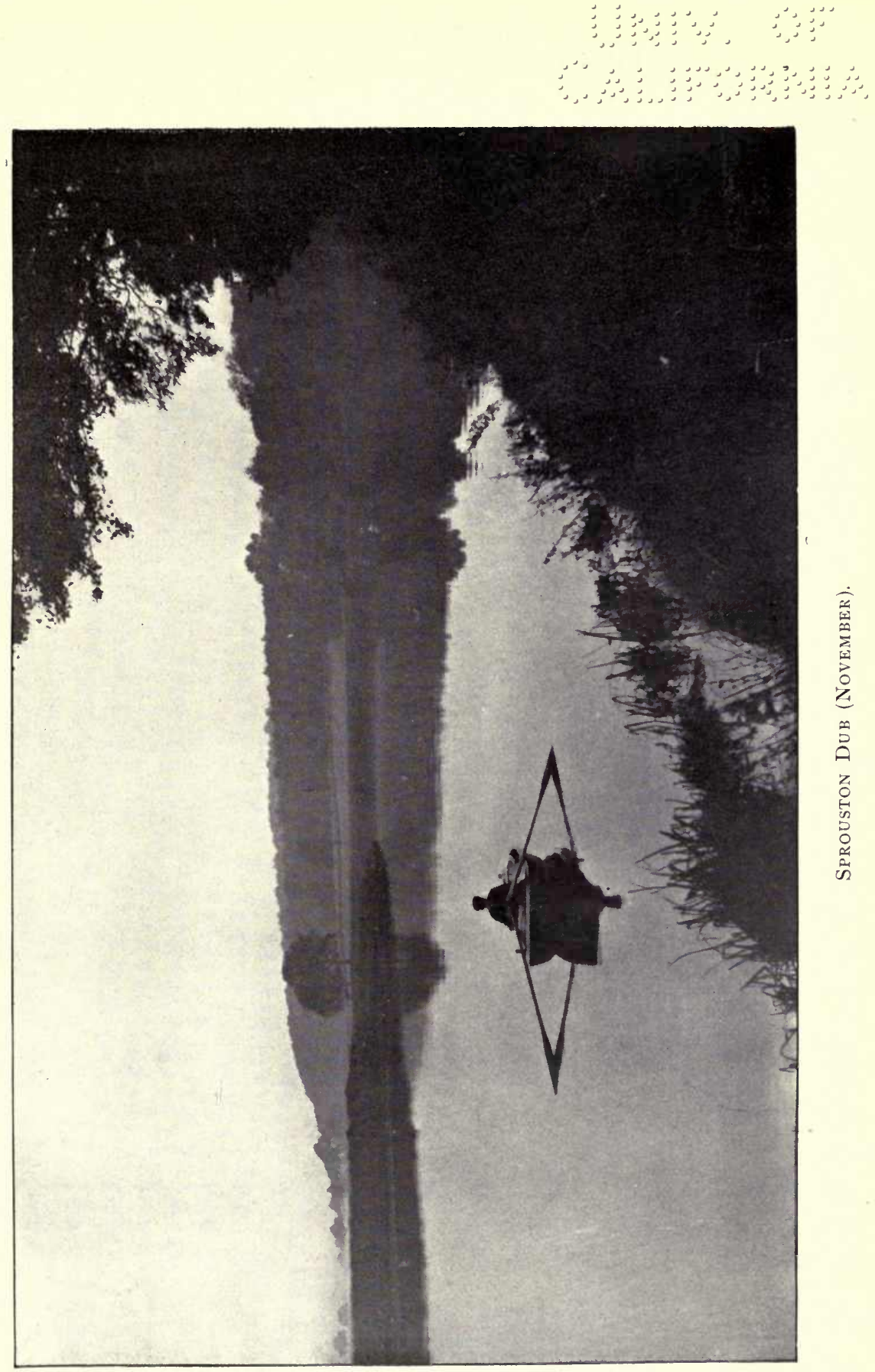
等

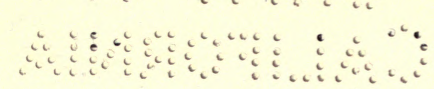




\begin{tabular}{|c|c|c|c|c|c|c|c|}
\hline Year. & Salmon. & Grilse. & Total. & Year. & Salmon. & Grilse. & Total. \\
\hline 1873 & 208 & 140 & 348 & 1891 & 132 & 55 & 187 \\
\hline 1874 & 82 & 44 & 126 & 1892 & 131 & 28 & 159 \\
\hline 1875 & 80 & 23 & 103 & 1893 & 50 & 16 & 66 \\
\hline 1876 & 79 & 39 & 118 & 1894 & 41 & 10 & 51 \\
\hline 1877 & 83 & 60 & 143 & 1895 & 61 & 174 & 235 \\
\hline 1878 & 57 & 12 & 69 & 1896 & 102 & 26 & 128 \\
\hline 1879 & 57 & 58 & 115 & 1897 & 29 & 22 & 51 \\
\hline 1880 & 69 & 15 & 84 & 1898 & 111 & 18 & 129 \\
\hline 1881 & 81 & 73 & 154 & 1899 & 29 & 105 & 134 \\
\hline 1882 & 80 & 15 & 95 & 1900 & 80 & 32 & 112 \\
\hline 1883 & 59 & 61 & 120 & 1901 & 123 & 29 & 152 \\
\hline 1884 & 140 & 58 & 198 & 1902 & 96 & 57 & 153 \\
\hline 1885 & 141 & 142 & 283 & 1903 & 276 & 64 & 330 \\
\hline 1886 & 167 & 45 & 212 & 1904 & 76 & 46 & 122 \\
\hline 1887 & 231 & 91 & 322 & 1905 & 70 & 50 & 120 \\
\hline 1888 & 41 & 23 & 64 & 1906 & 108 & 126 & 234 \\
\hline 1889 & - $\quad 100$ & 54 & 154 & 1907 & 76 & 6 & 82 \\
\hline 1890 & 46 & 35 & 81 & & & & \\
\hline
\end{tabular}

The average for this period of 35 years is 118 . The average for the 28 years down to 1900 is 145 . The most extreme fluctuation is noticeable in the grilse column: from 126 in 1906 to only 6 in the year 1907, or from 174 in 1895 to 26 in 1896 . If we take the salmon column alone, the average is almost 97 .

If we isolate the two best years giving the weight, we have:

1873.

\begin{tabular}{|c|c|c|c|}
\hline $\begin{array}{l}213 \text { salmon } \\
142 \text { grilse }\end{array}$ & - & $\begin{array}{l}-\quad 4518 \mathrm{lb} . \\
\text { - } \quad 1150 \mathrm{lb} .\end{array}$ & $\begin{array}{l}\text { Average, } \\
\text { Average, }\end{array}$ \\
\hline 276 sa & - & $\begin{array}{r}1903 . \\
-\quad 5383 \frac{1}{2} \mathrm{lb} .\end{array}$ & Ave \\
\hline 64 grilse & . & - $\quad 481 \mathrm{lb}$. & Averag \\
\hline
\end{tabular}

The record for the Sprouston water is, I believe, 36 fish killed by Lord Home in April 1875. That this should have been done in a spring month is specially interesting. And as a record showing the number of fish which may be in the Dub at one time, I may add that in the old times when leistering was regarded as legitimate sport, Lord John Scott and party killed in one night by this means 84 fish.

The angling season of 1908 was not very profitable in the majority of the upper fishings, but a large number of fish seemed present in the lower waters. The river ran low and the atmospheric conditions were very frequently unfavourable, but Sprouston is reported to have yielded 120 fish. Major Gerald Trotter was conspicuously successful in that he made the season's record of 13 fish in one day (27th October) from Sprouston Dub, the aggregate weight being 
$260 \mathrm{lb}$., and in his 13 fish included the heaviest Tweed fish of the year-a 43 pounder.

To show what Sprouston Water alone has produced in recent years we have to add the results obtained from the Floors Fishing Book to those from Hendersyde Park:

\begin{tabular}{l|l|l|l}
$1903-592$ & $1905-258$ & $1907-198$ \\
$1904-234$ & $1906-502$ & $1908-278$
\end{tabular}

Below Hendersyde water comes Birgham, the property of the Earl of Home. Here at the top of the water we have another famous dub - the Birgham Dub, followed by twenty-eight good pools. In the south bank, Carham shares the water, and Carham Burn is the boundary between Scotland and England on this side.

Many fishings in Scotland, especially in the Lowlands, have remarkable names for some of the casts. The Birgham fishings are, I think, as peculiar in this way as any I have come across. Here is a selection: Corbie-nest, Jean-my-lady, Long-ship-end, Flummery, Dritten-ass, Glitters, Bloody-breeks, Mark's-shilling-head, Shaw's mare.

The field of Flodden is only about six miles from Coldstream, and the spot where the Scottish king fell only some three miles. It is reported that at a Cistercian nunnery which used to exist at Coldstream, many of the "Flowers of the Forest" were quietly interred. Another matter of interest to which we may refer in passing, is that Coldstream was formerly the Gretna Green of the Tweedside Border. I do not know if it was a blacksmith who here married the runaway couples, but I have no doubt the place was the cause of sorrow to many an Englishman. Carham Burn, which enters Tweed opposite the Birgham fishing about half-a-dozen miles above Coldstream Bridge, is the boundary of England and Scotland on the south bank, so that to cross Coldstream Bridge is to cross from England into Scotland. I doubt if Coldstream ever had the fullblown reputation of Gretna, yet the bridge must have been a useful place to hold up the enraged parent who followed. The ford previous to the building of the bridge was, however, a dangerous source of delay, and Gretna, no doubt, had the preference then.

About two miles and a half below Coldstream Bridge, the wholly English tributary of Till enters opposite Tweed mill fishings. The Till is a sluggish river of many windings, and is reported to hold a lot of pike, eels, and perch, base fishes one does not care for in a salmon river. A considerable number of salmon and sea-trout (including a lot of whitling) enter the river, however, and the salmon 
may be fished for in spring as in the case of Teviot mouth. The sluggish nature of the stream is in strong contrast to the swinging force of Tweed at the junction.

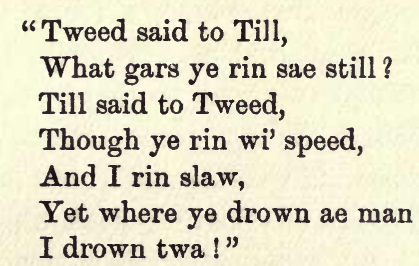

There are four weirs in Till, the first at Twizel being of little moment. At Heaton Mill, which is not now worked, there is a heavy rush of water from a bye-wash which has formed a basin below the weir, and fish find difficulty in ascending the rush. At Etal, which is about six miles and a half up the river, there is a still more obstructive weir. It is reported that few salmon are taken in the upper Till because of this weir. Sea-trout seem to find less difficulty in ascending, and penetrate to the river Glen and the Bowmont and College waters above, which drain the eastern slopes of the Cheviots. From Wooler to the mouth of Till is about 17 miles. The entire length of Till is about 30 miles.

Below Till mouth the two Bendibus fishings are passed before old Norham Castle is reached. This picturesque and massive old pile was founded as early as 1121, and seems originally to have been attached to the See of Durham. It played a conspicuous part in most of the frays and battles of this region, but although James IV. of Scotland used it, the battle of Flodden was independent of it. At a survey of the castle nine years after Flodden, in 1522, the inner keep was considered quite impregnable. The great square tower rises 70 feet, and the view as one looks down the river, over masses of trees, from the Scottish side, is peculiarly striking.

Three miles and a half by the river below Norham, at Horncliffe, is the Union Bridge, a suspension bridge constructed by a Captain Samuel Brown, R.N. This bridge practically marks the top of tide reach in Tweed, and has before now been spoken of as the point at which netting might end. I will have occasion to refer to it again, when dealing with the future of the salmon fisheries.

The netting stations are now very numerous, as the map will show, for the value is considerable. Rather more than half way to the mouth, the Whitadder tributary enters on the left side. It rises away in East Lothian on the slopes of the Lammermoors and has a 
course of about 38 miles. The last two miles are in England, for the Tweed before the junction is reached has passed wholly out of Scotland. The line of the Whitadder, and its erosion of the old land surface, forms a natural passage from the Borders towards Edinburgh, and a chain of castles formerly guarded this line as similar structures already referred to kept watch over Tweedside. The river does not become of any great size till Abbey St. Bathans is reached, a former Cistercian settlement now no longer in existence. The county is typical of Berwickshire, with its undulating stretches of highly farmed land interspersed with woods and fertile meadows. Cockburn's Law, close to the river is a well-marked feature and is interesting to geologists as a granite cone resting on the greywacke of the surrounding country.

At Chirnside the Whitadder is joined by the Blackadder, another stream of considerable length-some 16 miles-wholly in Berwickshire. It rises in the parish of Westruther on the southern slopes of the Lammermoors, which divide the head streams from Lauderdale. It flows east by Greenlaw in a direction almost parallel to Tweed, and thus joining the south-coming Whitadder at a fully abrupt angle. Sir Thomas Dick Lauder, ${ }^{1}$ speaking of Westruther parish, quotes an interesting passage from the Statistical Account which in explaining that the name was originally Wolfstruther, or Wolf's Swamp, speaks of it "as a place of old which had great woods, with wild beasts, fra quhilk the dwellings and hills were designed as Wolfstruther, Roecleugh, Hindside, Hartlaw, and Harelaw."

There are nine weirs on the Whitadder and two on the Blackadder, but none of them need be regarded as very serious obstacles to ascending fish, in spite of the fact that only one, at Chirnside, has a pass. The paper works at Chirnside are provided with nine settling tanks and a filter of ashes, so that a great part of the deleterious matter is kept from the effluent. At Cumledge, on the river above Chirnside, the woollen mills have also tanks, where the effluent is treated with sulphuric acid and neutralised. At Greenlaw, on the Blackadder, chemical refuse from dyeing and scouring wool was run into the river untreated before the local mill was burnt down. Greenlaw is a long way upstream, however, and the water is small.

The Whitadder is the great tributary for sea-trout, and at times large numbers of these fish ascend. The sea-trout of the Tweed is now almost exclusively the bull-trout or round-tail $S$. trutta var. eriox, the same fish as ascends the Coquet. It is a bad rising fish,

${ }^{1}$ Scottish Rivers, 1890, p. 254. 

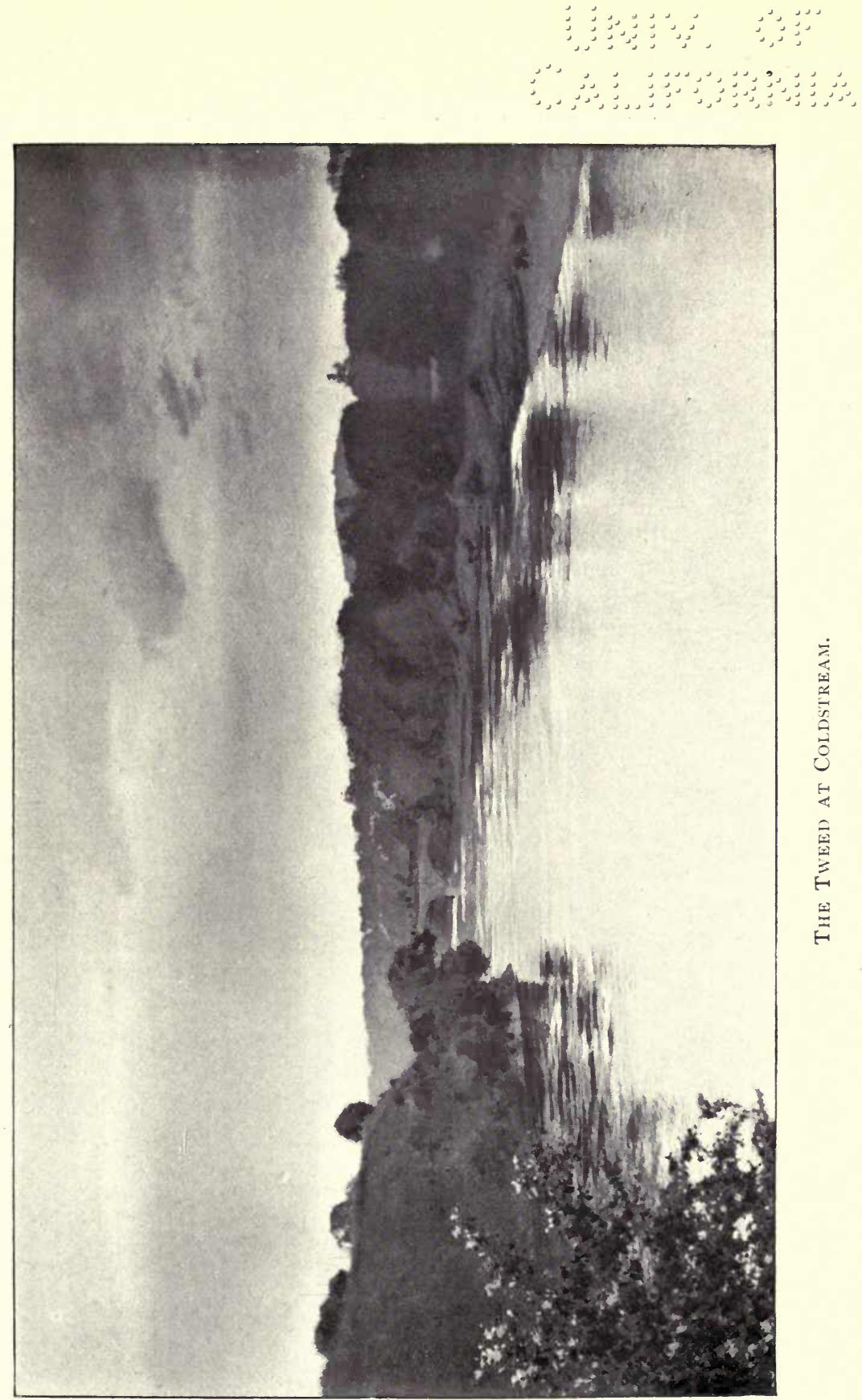


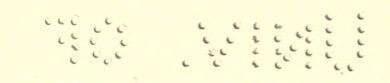

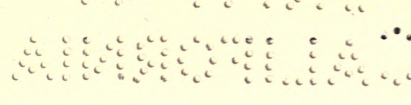


however, and a source of much vexation to the angler. So greatly did it multiply in the Coquet that an attempt to reduce the number was made at one time, by removing restrictions for its capture during the spawning season, the object being to increase salmon at the expense of the migratory trout. The round-tail sea-trout is a robust variety, however, and the attempt was abandoned. In the returns of the Tweed commercial fisheries, which have been published in blue books, the trout table seems to maintain its level more steadily than either the salmon or the grilse columns.

Below the mouth of the Whitadder, the Tweed is not of great use as an angling river. It is the scene of constant netting in the season, and is within tide reach. Within a distance of two miles is Berwick, and thereafter at the end of the pier we see the last of the river. Before the railway viaduct was built the view up Tweed from the old many arched road bridge must have been very fine. I have read somewhere that it gave the traveller an adequate conception of the importance of the river, but was apt to give an undue sense of the beauties of the town of Berwick. It is a little difficult to understand what this means if it is not uncomplimentary to Berwick. To one whose chief interest is the river, however, it might be said that if Berwick were as grand a place as London, or even as Edinburgh, the beauties of the river would still hold first place. Yet venerable old Berwick deserves everyone's regard. What a place of battles it was! One can still walk round the remains of its worn battlements and realise in some faint measure the factors which created as tough a set of fighters as were to be found in a long day's march in the fighting times. I believe this characteristic has not yet wholly departed from the lieges of the Burgh, or from the folk just north and south of them.

The Tweed has no natural estuary, but an equivalent has been created by statute in what is termed "the mouth" of the river. The limits of this mouth have been extended beyond the area as at first described. By 22 and 23 Vict. c. 70, par. 4 (the Tweed Act of 1859), " the limits of the mouth or entrance of the river Tweed shall be deemed to extend, and shall extend, from the pier called Queen Elizabeth's pier along the sea-coast, on the south side of the said pier, to a point at high water mark, on the said sea-coast, on the south side, distant seven miles measured in a straight line from the lighthouse on the said pier, and along the sea-coast on the north side of the said pier, to the point of boundary at high water mark, between the borough of Berwick-on-Tweed and the kingdom of 
Scotland, and shall also extend five miles in front of the mouth of the said river, and of the whole line of sea-coast within the boundary points hereinbefore mentioned into the sea-such distance towards the sea to be computed by lines drawn at right angles to a line drawn between the said northern and southern extremities; and the said limit on the south shall be deemed to include, and shall include, the fishery now known as the Holy Island Station of the Goswick Fisheries."

By the General Scottish Act 26 and 27 Vict. c. 50, par. 4, power was given to extend these limits northwards, and a bye-law was accordingly issued in 1863 determining "That the limits of the mouth or entrance of the said river Tweed shall extend northwards, from the limits thereof, as defined in the said 'Tweed Fisheries Amendment Act, 1859,' along the sea-coast to the boundaries between the counties of Haddington and of Berwick, and shall also extend into the sea five miles in front of that portion of the coast hereby added to the limits of the said river Tweed, the distance to be measured at right angles with the coast."

Under the general Acts for Scotland the chief factor determined by the limits of an estuary is the point at which fixed engines must cease in their approach to a river mouth. In the case of the Tweed the definition of the "mouth" last quoted does not, however, carry this significance. The result of the last definition to the Haddingtonshire boundary is to extend the Commissioners' jurisdiction seaward for five miles in pursuance of the early definitions relating to the mouth, i.e. beyond what is technically known as the territorial limit of three miles usual in the rest of the country. In so far as fishing by means of fixed net is concerned the limits defined in the 1859 Tweed Act, first quoted, are the limits which determine the proximity of such nets to the river.

We may now consider the past and present condition of Tweed fisheries, and the influences which seem to be at work in modifying the results. A good many tables of statistics of the fisheries have been published from time to time, and these are arranged in two ways: 1st, the Estimated Annual Produce of the river fisheries apart from the coast fisheries; and 2nd, the Produce disposed of by the Berwick Salmon Fisheries Company, Limited, a company which certainly represent the largest proportion of netting results. The former were prepared. by Mr. Paulin, for many years Secretary of the Berwick Company; but it appears that owing to an error in the figures on which his estimates were based, which occurred about the 
year 1880 , the figures for the whole produce of the river have to be discarded after that date. The latter have the advantage of being actual results instead of estimates. The former commence in 1808, while the latter in any readily available form commence only in 1842. The one is therefore not quite comparable with the other.

I therefore propose to abide exclusively by the actual returns of the Berwick Company, although by so doing I sacrifice giving a statement of the great years of plenty in the early part of last century. I will, however, mention the record year as a matter of general interest,

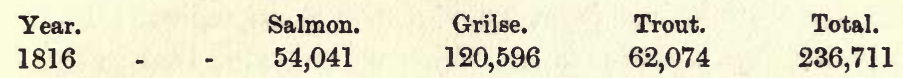

and add that the salmon column consistently shows five figures till the year 1829, when from 13,511 fish the previous year there is a sudden drop to 5350. The grilse column does not suffer in this way for other forty years, when from 23,448 fish in 1867 there is a sudden drop to 4078.

Taking now the returns of the Berwick Salmon Fisheries Company - the descendant of the old Berwick Shipping Company-I will condense matters by giving quinquennial averages from 1845 to 1899 , i.e. fifty-four years. The figures from 1860 onwards were given to Lord Elgin's Commission by the late Sir William Crossman.

\begin{tabular}{|c|c|c|c|c|}
\hline Years. & & Salmon. & Grilse. & Trout. \\
\hline 1845 to 1849 & - & 8,909 & 39,409 & 35,641 \\
\hline 1850 to 1854 & - & 7,590 & 18,898 & 27,931 \\
\hline 1855 to 1859 & - & 7,489 & 18,756 & 23,861 \\
\hline 1860 to 1864 & - & 6,131 & 15,118 & 20,145 \\
\hline 1865 to 1869 & - & 6,214 & 5,681 & 24,485 \\
\hline 1870 to 1874 & - & 8,266 & 10,603 & 1,72 \\
\hline 1875 to 1879 & - & 5,733 & 7,341 & 17,10 \\
\hline 1880 to 1884 & - & 7,262 & 8,427 & 18,35 \\
\hline 1885 to 1889 & - & 7,267 & 9,359 & 22,261 \\
\hline 1890 to 1894 & - & 6,440 & 11,432 & 21,776 \\
\hline 1895 to 1899 & - & 7,366 & 8,458 & 23,74 \\
\hline
\end{tabular}

The salmon column is wonderfully steady, but the grilse column shows a marked decline. In the early days of plenty, the netting, although no doubt less perfect in its working, was more extensive in amount than it is now. Stell nets and cairn nets, the fixed engines which used to be employed in the fresh waters of Tweed, were only abolished (without compensation) at the passing of the 1857 Tweed Act. On the other hand, polutions were not so serious as now : the Land Drainage Acts came into operation only in 1846, and before that date the floods lasted long, so that fish could secure 
better facilities for ascending to their spawning grounds at an earlier date; and salmon disease had not broken out.

I am inclined to think that we are hardly able in these days to estimate the change which must have taken place in the Tweed since the rapid drainage from the land came into operation. The change has been gradual and therefore never striking, but it has been very complete. The whole district of Tweedside is like one huge farm, run on the most perfect modern principles. The average rainfall is not heavy, and varies apparently from 27 to $38 \frac{1}{2}$ inches. Water is quickly carried off not only the high land of the upper basins, but the rich undulating farm land of the main valley. Floods rise suddenly and last a short time. When we consider that in the Tweed and its tributaries there are no fewer than eighty-three weirs, and that very many of these are unprovided with fish-passes but accompanied by polluted water, the effect of a smaller normal water-level and of more sudden and extreme fluctuations, is more clearly understood. With regard to salmon disease it may be explained that while it only became epidemic as late as 1878 and 1879, it was present in the river long before that time. In the Severn, salmon disease was epidemic about the year 1856, and the trouble seems to have been recognised, and to have become more or less well known as early as 1836 .

Saprolegnia of course exists in a sporadic form in ordinary water, and is found to a greater or less degree in pure waters. The tissue attacked by the vegetable fungus has previously been affected by the action of Bacillus salmonis pestis, and unless the bacillus has been at work, the fungus does not grow upon the fish. It is, therefore, the life of the bacillus which has to be studied, and which $\mathrm{Mr}$. Hume Paterson, the discoverer of the bacillus, has now been studying for some time in Tweed. The presence of disease in fish inhabiting pure water is never, it seems to me, so marked as in water where the fish have been subjected to the health impoverishing action of pollutions. Between 1880 and 1884 the Tweed police removed from the water 37,969 diseased fish. In 1907 the number was 4426 . Certain pollutions are no doubt much more suitable for the cultivation of the bacillus than others; this aspect of the question is being worked out. That salmon disease can occur, however, in water believed to be perfectly pure is believed to have been shown by a most marked epidemic which broke out amongst coarse fish in ponds supplied with spring water at Ightham in Kent. ${ }^{1}$ As

1 Official Report, by Buckland, Walpole, \& Young, 1880. 

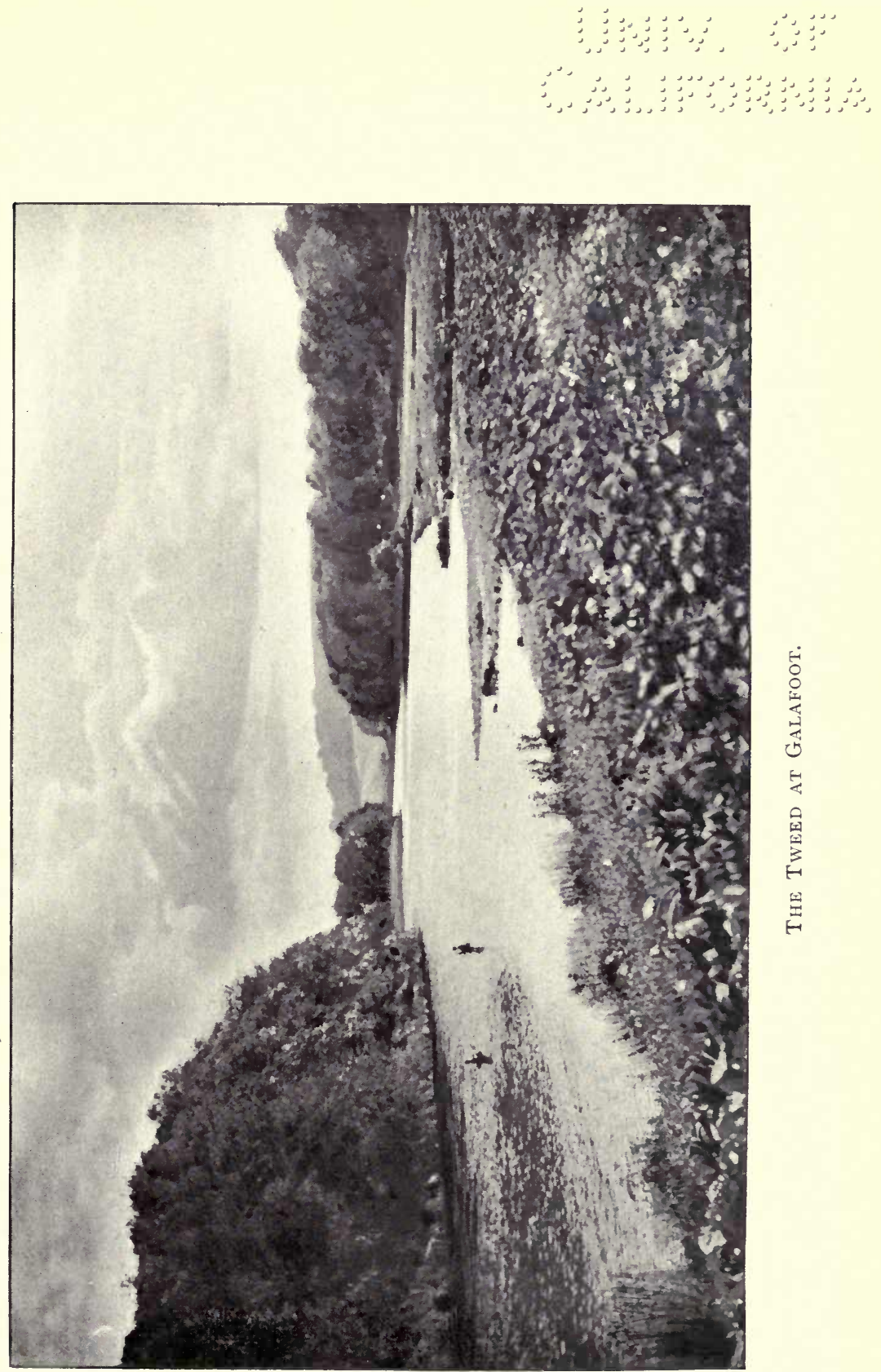
“

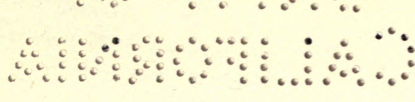


in the case of grouse disease, the state of nutrition and health of the fish has probably much to do with it. That fish enter from the sea in some seasons in a poorly nourished condition seems sufficiently clear. In the present season, 1908, the grilse were in many cases remarkably thin and poor. The influence of polluted water on such fish is likely to be much more deleterious than on strong wellnourished fish.

In addition to this there is the statement made by those who have much more Tweed experience than I, that the ova of spring fish frequently dies before spawning time; that in spring fish caught dropping back in summer the ovaries are white and dead, and the silvery hue of the fish has turned to a greenish tinge. I have rot seen this myself, but if it is proved to be the case, I should certainly be further disposed to blame the health-destroying pollutions.

Russel, of The Scotsman, wrote at considerable length on the Decay of Salmon. ${ }^{1}$ He necessarily dealt with returns of an early date, 1811 to 1855 , and he wrote chiefly concerning the Tweed. $\mathrm{He}$ found strong evidence of decline amongst salmon, and also adduces arguments, in which I can scarcely follow him, of decline amongst grilse. The most marked decline of grilse occurred later than the dates mentioned by Russel. The various combining factors of the time are rather lost sight of, it seems to me, in Russel's antipathy to the coast net. Every argument is turned directly against the expansion of coast netting. With regard to this I would only say here that we have ample proof to show that the coast net, if kept at a suitable distance from the river mouth and otherwise regulated, is quite compatible with the upkeep of an ample stock of fish, and that the coast net is not so deadly as the river net, which catches fish already congregated in narrow waters and on their way to their natural spawning grounds.

A director of the Berwick Salmon Fisheries Co. gave evidence, in 1895, before the Tweed and Solway Commission, and dealing with the take of fish in the whole district, which was accepted as sufficiently reliable, produced figures showing a decline in results equal to 20 per cent.

The removal of the cairn nets and stell nets was no doubt a step in the right direction, but in all probability with the conditions of sweep netting which remained, very little was done for the benefit of the stock of fish. When floods used to last long a greater proportion of fish probably got past all nets, and although a vast

1 The Salmon, 1864, p. 88. 
number of fish were caught, and especially a vast number of grilse, the actual number of spawning fish must have been much greater than it is now. We are always quite dependent on the number of spawning fish. But conditions of capture plus other contributing conditions did reduce the stock.

After the introduction of the 1857 and 1859 Tweed Acts, the conditions of the river have remained more constant than previously, but sweep netting is still carried on to such an extent as to make the weekly close time inoperative except in times of flood. The stock reduced from its old abundance seems to be fairly maintained at its lower level. There does not, at any rate, appear to be any great falling off in the total produce of the net fisheries during the last forty years, so far as the figures available go to show. What seems to be happening is that the greatest number of fish enter the river at a later date than formerly.

Between 1842 and 1856, the third week of July was the time, as the returns show, when the greatest catches of the season were made. From 1860 to 1894 , the best catches were made in the last week of August. In more recent reports, indications are not absent that the two last weeks of the season (which ends on 13th September), are more important than they used to be. "The Autumn Net Fishing of 1907 was steady till the end of the season," runs the Tweed Commissioners' Report and the newspaper accounts of the Annual Meeting of the Berwick Salmon Fisheries Co.), "the last few weeks especially giving excellent results." This is, no doubt, satisfactory for those shareholders who in that year got their 15 per cent., but in the general interests of the river I venture to think the result unfortunate.

Netting in the river is at present carried on, and has from time immemorial been carried on, from Berwick to Coldstream, a distance of 16 miles. About 62 nets are used at 39 stations. No part of the water which can be netted is unworked. A weekly close time from 6 o'clock on Saturday evening to 6 o'clock on Monday morning exists, but as already stated, the length of river netted is so great that no material benefit is secured to the spawning stock of fish in the river. The fish which pass through the lowest fishings on Sunday are caught by the upper nets on Monday. There is simply a transference of profit once a week. When the river is in flood some fish get through the gauntlet of nets, but under ordinary conditions no great head of fish available for spawning purposes reach water above Kelso while the nets are at work. The fish 
which form the breeding stock are the late-running fish. Rod fishing in Tweed is an autumn sport. Spring fish are removed by the nets; and spring fish, be it recollected, have been removed in this way for a very very long time.

Spring fish are the earliest spawners, and both for commercial purposes and for sport are the most highly prized of any. It has repeatedly been noticed in our country that when a river is overnetted the first result is shown in the decline of the spring runs. There can be no manner of doubt that the spring runs in Tweed have had no sort of chance for many a long day. As I have already stated, statistics show that the river is steadily becoming later and later. Netting goes on till 13th September, and rod fishing to the end of November. I have been informed from a most credible source that of late years, at the opening of the netting season, a number of unspawned fish are taken. One is always told that the Tweed is naturally a late river. I firmly believe that as a matter of fact it has been made a late river by the action of man. Under present conditions one would scarcely be surprised to hear that a movement was on foot to make the commencement of the Annual Close Time later, so that netting profits may be maintained. This process of following up the already unduly late season has only to be continued, and in course of time, the best period for fishing in Tweed will be at the natural spawning time of the fish, when all other Scottish rivers are closed. Rod fishing already continues till after fish have begun to spawn, not only in many of the tributaries, but in the main river. The spawning season really commences in Tweed in the middle of October, as it does in other rivers, and salmon have been noticed spawning as early as 7 th October.

The statement that the Tweed is naturally a late river, that is to say, is a river in which spring runs of fish are not naturally to be expected, is, I consider, perfect nonsense. No salmon river in Scotland, especially on the East Coast, having a water-flow such as the Tweed, or, for that matter, a water-flow equal to half that of Tweed, is naturally a late river. Is there any characteristic of the Tweed which peculiarly marks it out as distinct from the Dee in Aberdeenshire, for instance, on the North or South Esks? In 1872 the Dee had so declined that the rental was only about $£ 9000$. The Dee was then netted for 16 miles, as the Tweed now is. An Association began taking off the nets from above downwards. Now only 2 miles of the river mouth are netted, and the rental is over $£ 20,000$. No doubt this sum has been attained to a considerable extent 
through the great increase in sporting value, but if the nets had not been removed there would have been no spring angling in the Dee.

The Tweed still retains, however, what one may describe as a remnant of its spring run. A comparatively small percentage of the annual netted produce of the river is distributed over the early months of the year. ${ }^{1}$ A limited amount of spring angling is to be obtained in the lower reaches of the river. I have also notes of 5 clean fish having been taken at Wark, 12 miles from the mouth, and one clean fish taken at Mertoun, 32 miles from the mouth, in December, 1901, during ova fishing; and it is not uncommonly the case that a few are taken by rod before the close of the autumn angling. In this way, in 1908, I noticed in The Field, that on 30th November, Lady Nina Balfour had 3 clean fish at the Willow Bush, $15 \mathrm{lb}$., $15 \mathrm{lb}$, and $13 \mathrm{lb}$. This occurrence of a few clean run fish at various points in the river, is due to the divided migration of the salmon; and if the stock of fish in Tweed were further reduced, the spring run would still further fall off.

Conversely, if the stock of fish in Tweed were allowed to increase, if a due proportion of each run of fish which enter the river were allowed to ascend to the upper waters and there to reproduce their species, the spring run of fish would improve, and with this improvement would also come a more natural and more defined spawning season. The process could only be brought about by degrees, else dislocation of existing conditions of fishing would result.

A proposal has been brought forward once or twice to arrange for the removal of the nets from Coldstream to the Union Bridge, which, as already explained, marks the top of tide reach. There are, I believe, twenty-one nets worked in this stretch of river, giving employment to between eighty and ninety men. The fishings represent a considerable annual value, and we may assume that at this date no proposal of this kind would be brought forward without allowing for adequate compensation. In my view the project is by no means impracticable. Similar action has been taken elsewhere, and all experience shows that the best interests of the fisheries as a whole are served thereby. It is not only merely a proposal which will benefit the rod fishers of the upper waters, who will be the first to reap the benefit of an additional and an earlier supply of fish. The increase in the stock of fish will presently tell also upon the nets which remain. So much is this recognised on the Dee that the

1 Vide Appendix X., Report of Tweed and Solway Commission, Part I., 1896. 
Aberdeen Harbour Commissioners, who have valuable salmon fishings on the coast and in the river mouth, analogous to those of the Berwick Salmon Fisheries Company, voluntarily subscribe to the funds of the Association who have carried out the negotiations, and who lease the nets for the purpose of removal. The success of the operations is undoubted. No one in the Upper Dee would now dream of again putting in a net, There is no reason to suppose that a similar and gradual action in Tweed would bring about any dissimilar result. Fishings which are now valuable in autumn would become valuable also in spring, and the proposals already on foot for the purification of the river, which I have already referred to, would go hand in hand with the increase of Tweed salmon. 


\section{CHAPTER II.}

\section{FORTH DISTRICT.}

RIVERS : FORTH, TEITH, LENY, AND ALLAN.

LOCHS : VENNACHER, ACHRAY, LUBNAIG, VOIL, AND DOINE.

Angling Season: January 15th to October 15th.

Netring Season : February 11th to August 26th.

District Fishery Board sits in Stirling. Patrick Welsh, Esq., Procurator-Fiscal, Stirling, acts as Clerk.

THIS district is peculiar in that it is of very extensive area, has an exceptionally large sea firth, and a comparatively short fresh water area. It extends from Fife Ness, at the mouth of the Firth of Forth, on the north, through part of Fife, Kinross, Clackmannan, Perthshire, Stirlingshire, and the three Lothian counties, to the boundary between Haddington and Berwickshire on the south, where it "marches" with the Tweed District. The shores of the Firth of Forth are for the most part sandy, the eastern portion of Fife and the coast of Haddington being steep and rocky. On the sandy shores fly nets and bag nets are fished in considerable numbers, those on the Fife coast being the most productive. On this stretch a marked fish from the Deveron was taken in 1907. It was marked 18 months before recapture and had gained $7 \frac{1}{4} \mathrm{lb}$. The rocky section is fished by bag nets alone.

From a salmon fishing point of view the estuary of the Forth is fixed a short distance to the east of the Forth Bridge, by an imaginary line drawn from the Hound Point on the south shore to St. David's Point on the north. From the town of Stirling this estuary measures $31 \frac{1}{2}$ miles, and has on it such towns as Alloa, Kincardine, Grangemouth, where the Forth and Clyde Canal enters, Bo'ness, and Queensferry, not to mention the prospective town and naval station of Rosyth. The "Links of Forth," in their extraordinary windings between Stirling and Alloa, give the river course a length of $12 \frac{1}{2}$ miles in a point to point distance of $5 \frac{1}{2}$ miles. This long estuary, 
like that of the Tay, was formerly much fished by hang net, now, by House of Lords decision, declared to be an illegal method of fishing for salmon within the limits of an estuary. Perhaps it is a little premature to speak of this hang netting as quite discontinued in the Forth District, since the Board have had continual trouble in checking it, and cases of breach of interdict have only recently been settled. As in the Tay estuary also a considerable winter fishing for sparlings or smelts is carried on.

The landward section of the district includes the Trossachs and the celebrated scenery of Lochs Achray and Katrine, the Pass of Leny, Loch Lubnaig, and Strathyre; places better known to the tourist than I suppose almost any other in Scotland; sung of by Sir Walter Scott, and ever now linked with the romantic memories of Fitz James and Roderick Dhu, of Rob Roy and Helen M'Gregor. The famous outlaw and his two sons lie buried at Balquhidder by Loch Voil. But one must resist the temptation to follow the train of recollections associated with so bold, so wild, and withal so strong a character.

To gain an adequate idea of the geography of the Forth District it is necessary to understand that there are three main lines of waterflow; one coming from Loch Katrine through Loch Achray and Loch Vennacher, the central line; one on the north coming from Loch Voil through Loch Lubnaig and uniting with the central line at Callander; lastly, one coming from Loch Chon through Loch Ard, and continuing separate from the others till a couple of miles out of Stirling. This last is the line of the River Forth. The river formed by the confluence of the two others at Callander, and flowing from Callander to the junction with the Forth near Stirling is the River Teith. The Forth is considered the main river, since by reason of its extraordinary windings it is certainly the longest, but the Teith is the more important river from a salmon fishing point of view.

There seems to be little doubt that the central line, that coming through the Trossachs, formed originally the principle source of water supply to the Forth. The great misfortune of the district is that these head waters of so much value to the salmon have been found to be necessary for the more important use of man. The City of Glasgow takes its chief water supply from Loch Katrine. Sixty to seventy million gallons of water are taken every twenty-four hours, and only a little over five million gallons are allowed to flow down the stream to Loch Achray by way of compensation. It is useless to mourn over this. Glasgow has got her water supply for 
all time, and-although the cry is ever for more-she has done her duty in building most substantial salmon passes where these were required.

In the old days, Loch Vennacher must have been the spring fishing loch of this district, the Loch Tay or Loch Ness of the Forth. I have been informed by one who has had long experience of fishing in this neighbourhood that he has known a rod take nine salmon in a day in Loch Vennacher. This main source of the Teith is much reduced in an absolutely permanent and irrevocable manner, and the potential value of the salmon fisheries impaired in proportion. The Leny water on the north and the Forth on the south are as yet untouched, although I believe the former is not absolutely free from danger. In the meantime, however, "the Second City in the Empire" is laying hands upon Loch Arklet, a high loch beyond Loch Chon, which naturally drains into Loch Lomond at Inversnaid, but will in future add a sixth to Glasgow's water through Loch Katrine.

The united river as one sees it at Stirling or at Craigforth is still in appearance a stream of important size, and pleasure steamers and small craft find their way up to Stirling, but the attraction to ascending fish must be sensibly less than it used to be. The influence of the tide extends above Stirling to Craigforth where the Craigforth Cruive Dyke, which is a natural barrier of rock with stone building superadded, practically marks the limit, although in high spring tides the flow of water is affected above this point.

From Craigforth to Alloa the tidal water is regularly fished by sweep net. At the height of the season there are 37 shots fished, although considerable variation seems to exist as to the particular hailing grounds used, there being some 63 of these available in the whole stretch of water. Above Craigforth also, three stations are fished at the junction of Teith and Forth, and a few shots are annually taken in the upper Teith, in the Campbell Pool at Callander. The number of fish netted annually appears to vary from about 500 in a dry year to about 1100 in a year when better water-flow allows freer ascent and clears the river of pollution. Until not very long ago even more netting than this was practised. The banks of the tidal area of the river are very muddy, and therefore from Stirling downwards the water is constantly much discoloured. This alluvial matter in suspension is not, however, injurious to the fish, although it naturally allows nets to work with more effect than in clear water. Much pollution is, however, allowed to enter from the town of Stirling, where, I believe, nothing is done by way of purification, 
and about half-way down to Alloa the river Devon enters from the left, which in the past has more than once done serious damage in destroying salmon. The Devon is used by distilleries, and on one occasion some 347 fish were found dead. The Carron, which enters the estuary at Grangemouth after flowing through a region of iron works, and which in early days was a salmon river, is now reduced to a state beyond description.

It was at the mouth of the Devon that, during the winter of 1901 or 1902, three fishermen, who were not particularly anxious to have their movements observed, are reported to have caught a salmon of $103 \mathrm{lb}$. No visible record of this monster was retained, so that no actual proof can be produced. On this account it is not surprising that many decline to believe in the fish's existence. I had, however, an opportunity of putting questions to one of the men, and as a result $I$ accepted the statement he made, viz. that the fish weighed $103 \mathrm{lb}$. and a few ounces. My informant said it was without exception the ugliest fish he had ever seen, was black in colour and covered with sea lice in the region of the pectoral fins, a male fish with the hook of the lower jaw penetrating the upper jaw. The record of a very large male fish taken in winter time in tidal water is not out of harmony with what many other indications show to be possible. I take the man's word as to the weight, because he is a quiet self-reliant man, and because he has no reason to give false information. Of course, we all know how large fish grow after death, but my informant isn't even an angler, I believe.

Richard Franck, writing about the Forth at Stirling two hundred and fifty years ago, says that "the price of a salmon formerly exceeded the value of sixpence sterling, which I suppose no Englishman will grudge, nor think it unreasonable to give at any time," and goes on to describe how people get ill by eating over much. ${ }^{1}$

The Craigforth Cruive was long complained against as hindering the ascent of fish. The dyke is a large and substantial structure, there being one large opening for the cruive box, the only passage by which fish could ascend to the upper waters. It was pointed out some years ago that this cruive was situated where "the sea fillis and ebbis," and where, therefore, by the early statutes governing these matters, no cruive should remain. The angling proprietors in the Teith, after some prolonged negotiations, at last succeeded in 1904 in purchasing this engine for the purpose of leaving it unfished. They at the same time purchased certain net and coble fishings

${ }^{1}$ Northern Memoirs, Edition 1821, p. 133. 
which were associated with the cruive. Since the year mentioned, therefore, the criticism as to the destructive action of the cruive has been removed, and as the flow through the cruive-box is of easy gradient, fish experience no difficulty in making the ascent.

\section{RIVER FORTH.}

The Forth is formed by two head streams, the Duchray Water and the Avondhu, which rise barely three miles from one another and unite a mile west of "the clachan of Aberfoyle." Each branch rises at a very high altitude, and each is remarkable for the rapidity with which a quite low level is reached. The denudation of this region has been extreme. Ben Lomond is 3192 feet, and the source of the Duchray is about the 3000 feet level on the north side of the mountain, and only about a mile and three-quarters from the shores of Loch Lomond. The course of this stream is so broken by falls that it is not possible for salmon to ascend. The length of its channel is only $13 \frac{3}{4}$ miles, and the junction is only 80 feet above sea-level. The Avondhu, i.e. the black water, rises at an altitude of about 1900 feet, and after 9 miles of rapid descent passes into Loch Chon, a mile and three-quarters long and 290 feet above sealevel. Continuing its descent, it next enters Loch Ard, two miles. and a quarter long and 103 feet above the sea, from which Aberfoyle is not far distant.

The great, low, transverse valley which stretches across Scotland between Forth and Clyde has its ill-defined divide running also in a transverse direction for a considerable distance, as will be seen by reference to the watershed map, south of the Forth, and the insignificant tributary, Kelty tributary. It is a flat alluvial region in which a river can make but little headway, and hence the Forth in working to the eastward describes the most extraordinary succession of windings. It has $18 \frac{1}{2}$ miles to go to Stirling and only 80 feet of a fall. The result is that with its many "links" or "crooks" it actually travels 39 miles. There is much sameness in the course, each part looking very much like the other, yet this expanse of flat country and varied woodland, with the mountainous region of the Trossachs in the distance has a charm of its own, and, when well lit, conveys a splendid sense of space and freedom; a landscape that looks best with great white clouds in a high sky. It is through this flat expanse from below Stirling to Loch Lomond that the proposed ship canal across Scotland is planned out.

As a salmon fishing river the Forth above the junction with the 
Teith is really of very little account. A certain number of fish ascend it annually, but the river is too like a uniform winding canal in actual character to admit of good fishing, and in summer time the growth of weeds in its sluggish waters is excessive.

\section{RIVER TEITH.}

The head waters of the Teith are in Loch Katrine, and more particularly in the neighbourhood of the place, composed of a hotel, which vies with any other in Scotland for the strength of its name -Stronachlacher. The burn called Glen Gyle Water is the actual head stream. The loch is about 8 miles long, and is so deep that although its surface is 364 feet above sea-level, 645 acres of its floor are below sea-level. It needs no description from me. Who has not passed through the Trossachs to Loch Katrine, seen Ellen's Isle, and read The Lady of the Lake? The water-level has been raised by the barrage of the Glasgow Water Works (and the erstwhile famous "silver strand" covered like the foundations of Philae). The outlet is furnished with nine sluices of different levels and a byewash. A very solid salmon pass is built behind and parallel to the weir, and to this each sluice has an opening opposite which is a pool $10^{\prime} \times 6^{\prime} \times 2^{\prime} 3^{\prime \prime}$. Inasmuch, however, as all the sluices except the lowest open by being lowered instead of being raised-this arrangement suiting the purposes of the Water Trustees-a waterfall is apt to be formed into each pool. As a matter of fact, however, I am not sure that salmon often make a serious attempt to enter the loch, although on rare occasions they have been noticed in the pass. Their spawning ground beyond Loch Katrine would be confined to the Glen Gyle Burn in any case, and they would be no use for sport. Trout, char, and pike are the inhabitants of this famous sheet of water.

The Achray Water flows from here to Loch Achray, and, although small in volume under ordinary weather conditions, has some nice gravelly beds for spawning fish. Salmon which do not penetrate as far as Loch Achray ascend the Finglas, which flows into the Blackwater between Lochs Achray and Vennacher, at the Brig o' Turk. Unfortunately the Finglas is obstructed by impassable falls when only three-quarters of a mile up, but this short space, during recent years is reported to hold many more fish than formerly. There are four cascades at these falls, which descend over perpendicular ledges in a narrow and deep gorge, and the lowest fall is a sheer drop of some seven or eight feet. No salmon pass is practicable except at very 
great cost. It sometimes happens that when the Finglas is in spate, Loch Achray has not risen to flood level, and, the Blackwater being at this point very flat, has its current reversed for a time, and owing to the flood of the Finglas flows into Loch Achray instead of out of it.

Loch Achray is still more of a trouting loch than a place where the capture of salmon can be relied upon. Boats are supplied from the Trossachs Hotel, and the loch is open to the public; but fish are rather late in reaching the locality, and none were reported as having been taken in 1908. The beauties of the loch are to many, perhaps, more attractive than any fishing. The "bosky thickets" of birch and rowan which closely fringe the water's edge seem to allow the little loch to nestle in their embrace.
"Aloft, the ash and warrior oak
Cast anchor in the rifted rock :
And, higher yet, the pine tree hung
His shatter'd trunk, and frequent flung,
Where seemed the cliffs to meet on high,
His bows athwart the narrow'd sky,
Highest of all, where white peaks glanced,
Where glist'ning streamers waved and danced,
The wanderer's eye could barely view
The summer heaven's delicious blue ;
So wondrous wild, the whole might seem
The scenery of a fairy dream."

The loch is about one and a quarter miles long, and a maximum width of nearly one-third of a mile. The waters cover an area of 205 acres, and the mean depth has been found to be $36 \frac{1}{2}$ feet, and the maximum depth 97 feet. It is a simple basin, having one central area of deep water, two-thirds of a mile being under the 50-feet line. There are shallows off the mouth of the Achray Water and between the mouth and the Trossachs Hotel. At the eastern end of the loch there is a depression of 27 feet surrounded by shallow water, and at another place there is what the members of the Bathymetrical Survey considered to be a submerged crannog covered by only one or two feet of water.

Loch Vennacher, which is the last loch in this the central chain, is about 4 miles long and has a mean breadth of two-fifths of a mile. It is 270 feet above sea-level and has an average depth of 41 feet, and a maximum depth of 111 feet, or eight fathoms and a half. It is therefore comparatively shallow.

Only a few years ago it was as barren of salmon in the fishing 


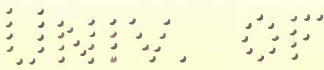

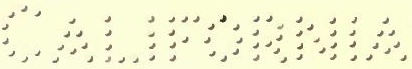
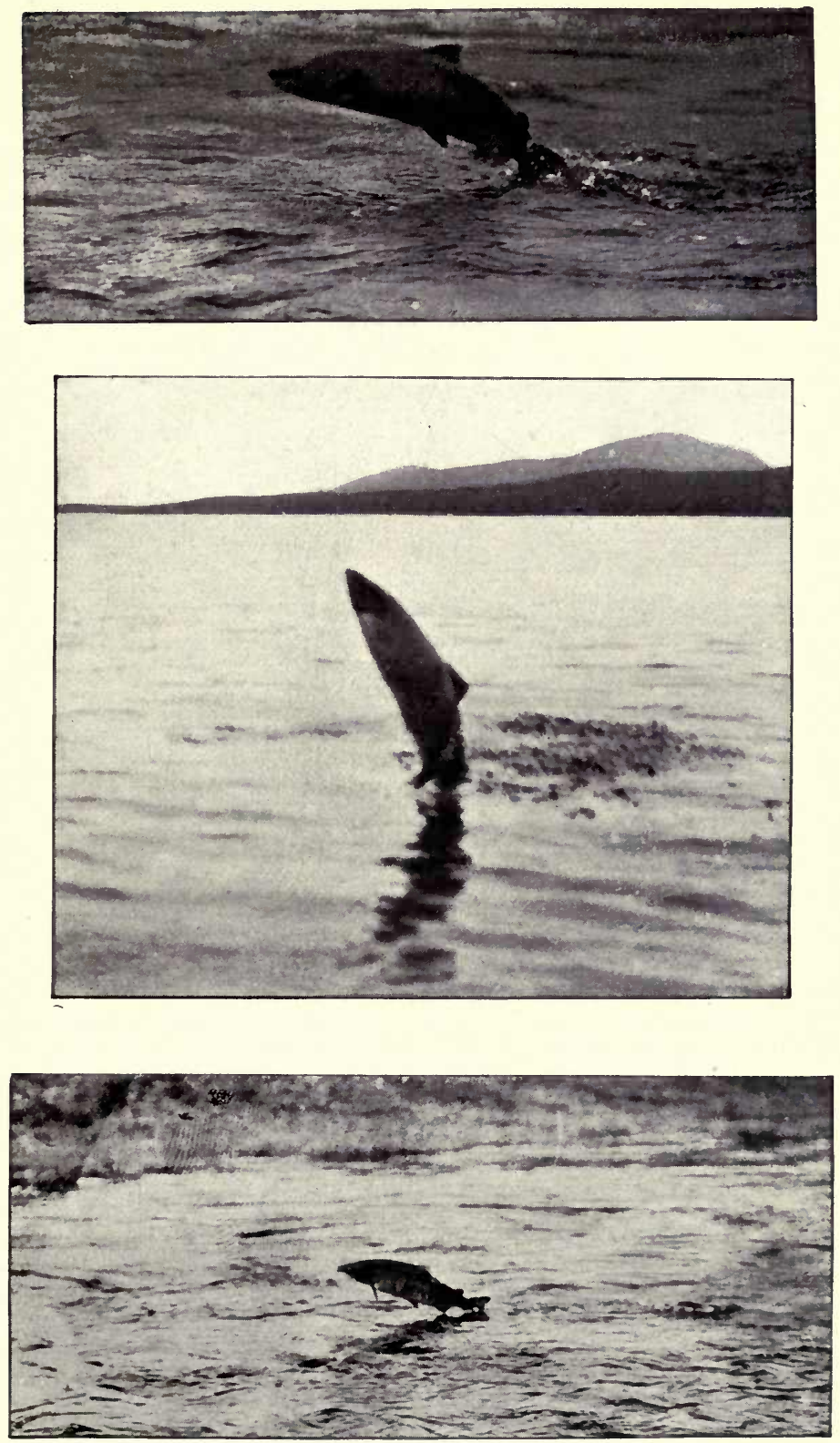

JUMPFi: SALMON. 
$9 \mathrm{~s}$ wint

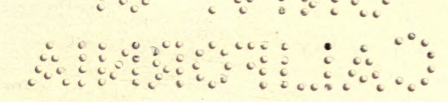


season as Loch Achray, but now it may be said to be undergoing a period of observation because of a new fish-pass which has recently been erected by the Glasgow Water Commissioners to satisfy the demands of the Forth District Board, who rightly condemned the old passes which existed at the gauge house of the Commissioners situated at the loch outlet. A natural river outlet has always been maintained here, and has been modified in various ways to facilitate the ascent of fish, but a large stone building with numerous sluices was erected at the commencement of the Glasgow Commissioners' operations, above what is still called "the new cut," an artificial channel parallel to the natural outlet.

The sluices here, like those at Loch Katrine, are unfortunately made to open by being lowered, so that surface water is alone allowed to escape. This makes the arrangement of a pass a matter of some difficulty, since the level at which water enters is a varying one. The new pass now constructed is adapted so that water may enter from one or other of two sluices, there being two branches to the upper section of the pass. Those two branches are built along the side of the "new cut," and unite at a level section, from which the water is then carried in the opposite direction, at a gradient of one in twenty, towards the foot of the gauge house. The total length of the pass is 194 feet, and the breadth 7 feet.

It appears to be certain that fish are ascending the new pass much more freely than the old one, and that they have been noticed passing through the sluices into the loch, although this operation is accomplished with some difficulty to gravid fish. The future history of the salmon fishing of Loch Vennacher will be the surest guide to the success of this pass from a sporting point of view. The distribution of fish over the upper spawning grounds is perhaps the most valuable result.

In early days, before Glasgow commandeered the water, Loch Vennacher often yielded good spring fishing, as Loch Lubnaig also did, although the latter was perhaps not so much fished. I believe that some thirty or forty years ago as many as 60 salmon have been taken from the two lochs in a season, and it was frequently observed that according as the water-flow favoured one or other channel, so one loch or the other yielded better results. Referring to the Loch Vennacher outlet, the official report of an inspecter says : " "The best fishing above these works is said to have been obtained in 1887, when the river had been in flood from the 19th January to the 9th

1 Eleventh Report Fishery Board for Scotland, Part ii., p. 5. 
February, and when 37 salmon were taken in Loch Vennacher and 5 in Loch Achray." In 1906, 3 salmon were taken, I believe, and in the present season (1900) I have heard of only one.

The Report of the Bathymetrical Survey of this $\operatorname{loch}^{1}$ states that "The loch is deeper in the eastern than in the western portion, the western end being shallow and covered with weeds, so that one must proceed nearly a mile from the west end of the loch before encountering depths of 50 feet, and this is merely a small patch separated from the principal 50-feet depression by a distance of nearly twothirds of a mile. In August the water in the loch is at its lowest, and the weeds at the west end most abundant. The principal 50feet depression is about two miles in length, with a mean breadth of about one-third of a mile, and a maximum breadth of nearly half a mile. It includes two 100-feet depressions; the first one is very irregular in shape, situated approximately in the centre of the loch, and contains the greatest observed length [? depth] (111 feet), which lies towards the northern shore; the second one occupies the central portion of the large 50-feet depression, the greatest depth observed therein being 106 feet. Towards the eastern end of the large 50feet depression is a small shallow patch in the centre of the loch opposite Portnellan, in which a depth of 36 feet was found."

The Vennacher Water, or Teith, as it may now be called, flows from the loch for a distance of about two miles before it joins with the Leny Water above Callander. The stream is of pleasant character, but somewhat small for salmon angling.

The general character of the Teith below Callander is that of a pleasantly running stream with a fairly direct course of about 13 miles to the junction with the Forth above Stirling. It is much fringed with trees, and is sometimes rather uniform in its rippling flow, there being rather a lack of holding pools such as might perhaps be artificially induced by the introduction of low weirs or croys. About two and three-quarter miles below Callander, the Kelty enters from the north. It is, except in its lowest part, a rather brawling stream, and 3 miles up its course is completely barred to salmon by the picturesque falls of Bracklinn, which form the objective of many summer excursions from Callander. Any opening up of these falls is a hopeless task, not only on account of their precipitous nature, but on account of the steep character of the stream further up.

There is one weir on the Teith at Deanston, near Doune. This ${ }^{1}$ Scottish Geographical Magazine, xvi., No. 4, p. 207. 
weir would block the river but for two fish-passes, built one at each bank. The first of these was erected by Smith of Deanston-a remarkable man in many ways - in 1840 , and is, I think, the first successful pass in Scotland. Three men-Brachett, Foster, and Brewer-had already suggested passes of an open rectangular form, and Smith's plan follows Foster's idea most nearly. A considerable quantity of water is taken into the built pass of comparatively easy gradient, and alternating breaks to check the water-flow are built out at right angles to the sides of the pass, so that the descending water takes a zig-zag course. This system was adopted with equal success at Galway and Balisodare in Ireland, and was then recommended as the best type in a bye-law attached to the Salmon Fishery (Scotland) Act, 1868, governing these matters. In the experience which has been gained subsequently, however, it is, I think, evident that one particular form of pass is not suitable to all the varying conditions which are met with, and that a certain amount of elasticity is desirable in order to secure the most suitable pass at any one obstruction.

With regard to the rod fishing results in the Teith great complaints have been made within recent years that the glory has departed. The pollutions, the overnetting, and the obstruction of water are certainly three factors of most ominous portent, forming collectively a powerful force in antagonism to all salmon fishing interests. In attempting to secure evidence from actual figures, I have been favoured with the record since 1876 of the late Mr. Baillie Hamilton of Cambusmore. He was a very steady fisherman on the Teith, and his water is perhaps better than any other as a test of changed conditions, since it may be fished at any season. Occasionally it happened that absence from home, or continued heavy water, made a difference in the amount of fishing, but as a rule Mr. Baillie Hamilton fished steadily through the spring, and either let his water or gave leave to others to fish in the autumn. I prefer, therefore, to deal solely with the spring fish caught in February, March, April, and May.

\begin{tabular}{|c|c|c|c|c|c|}
\hline Year. & Fish. & Remarks. & r. & Fish. & arks. \\
\hline 1876 & 15 & & 1881 & 11 & Hard frost all Feb. \\
\hline 187 & 14 & Feb., March, and April & & & No fish. \\
\hline 187 & 14 & only & 1882 & 21 & $\begin{array}{l}\text { About a score were } \\
\text { diseased and not fit }\end{array}$ \\
\hline 37 & 6 & $\begin{array}{l}\text { Only fished a few days } \\
\text { in Feb., Mar., ard }\end{array}$ & & & to take \\
\hline 80 & 20 & Apr. & 1884 & 24 & $\begin{array}{l}\text { Very heavy } \\
\text { Feb. } 12 \text { fish }\end{array}$ \\
\hline
\end{tabular}




\begin{tabular}{lrl|rrl} 
Year. & Fish. & Remarks. & Year. & Fish. & Remarks. \\
1885 & 9 & Feb. and March alone. & 1897 & 3 & Heavy water all March. \\
1880 & 6 & No fishing most of Feb. & 1898 & 3 & \\
1887 & 13 & No mention of May. & 1899 & 4 & \\
1888 & 14 & No mention of May. & 1900 & 3 & \\
1889 & 7 & March and April alone. & 1901 & 3 & \\
1890 & 6 & & 1902 & 6 & \\
1891 & 3 & & 1903 & 2 & In April. \\
1892 & 7 & & 1904 & 0 & \\
1893 & 13 & & 1905 & 4 & \\
1894 & 11 & & 1906 & 3 & \\
1895 & 6 & & & 3 & \\
1896 & 4 & & & &
\end{tabular}

This is a rather melancholy record of decline. If we separate the quinquennial periods the result is, $14,15,9,8,4,3$. With regard to the weight of fish taken in the spring the average usually works out at $17 \mathrm{lb}$. Fish from $14 \mathrm{lb}$. to $22 \mathrm{lb}$. are most common; but a few small springers of 9 and $10 \frac{1}{2}$ occur and the heaviest fish is $30 \mathrm{lb}$.

With regard to autumn fishing a few records are available, although since 1896 this fishing was let to a shooting tenant. In 1885 there is a note, "Gave leave to many to fish. 3 or 4 fish were killed daily during the last 3 weeks." In 1891, the weights of 27 fish caught during the last 10 days of the season are recorded. In 1892 there were 34 autumn fish; in 1893 there were 26 , one of them being $32 \mathrm{lb}$., the heaviest weight. Later years give 30,20 , and 13 , and then no records are given till 1908, when 9 autumn fish and 2 spring fish make the season's total, this result being only mitigated by the note "More fish seen than for many years. These results are pretty plain reading and need no comment.

I have also been favoured with a return of the fish caught at Lanrick, just above. The figures are for the years 1895 to 1904 inclusive, and show a similar decline.

\begin{tabular}{rrrr|rrrr}
1895 & - & - & 41 & 1900 & - & - & 13 \\
1896 & - & - & 26 & 1901 & - & - & 11 \\
1897 & - & - & 19 & 1902 & - & - & 9 \\
1898 & - & - & 10 & 1903 & - & - & 13 \\
1899 & - & - & 13 & 1904 & - & - & 10
\end{tabular}

These returns do not include the fish caught by persons to whom leave to fish was granted.

\section{LENY WATER.}

The rise of the Leny Water, the most northerly of the three lines of water-flow in the Forth district, is the Lochlarig Water which flows into Loch Doine. This stream has its origin on the eastern 
side of the high pass (about 1800 feet), which separates the Lochlarig glen from the mouth of Glen Falloch at the head of Loch Lomond. Lochs Doine, Voil, and Lubnaig, were, no doubt, at one time a continuous sheet of water, and even at the present day the separations which exist are slight, being stretches of alluvium washed down by the hill streams, which all enter the valley of the lochs at right angles. The burn in the Monaclyle glen is chiefly responsible for the delta which now separates Loch Doine from Loch Voil. Both lochs are still of the same level, and similar depths are found on either side of the mass of detritus which separates them. The height above the sea is 414 feet, which is 50 feet above the level of Loch Katrine, and the suggestion has been made before now that Glasgow Water Commissioners could add to their supply in Loch Katrine by tapping Loch Voil. If this came about it would be another serious menace to the salmon fishery interests of the Forth district. The two lochs drain an area of 24,600 acres, or $38 \frac{1}{2}$ square miles. Loch Voil is $3 \frac{1}{2}$ miles long and has a mean breadth of a quarter of a mile. The average depth is about 40 feet, and the maximum depth 98 feet. The deep water is at the western end and the water then gradually shallows in the Balquhidder direction. Loch Doine is a simple basin, deepening centrally to 65 feet.

Both lochs are set amongst magnificent mountains of varied outline, and, lying as they do in an east and west direction, offer views, especially at sunset, which cannot easily be excelled in Scotland. This is the centre of the Rob Roy country; his house stood at the head of Loch Doine, and he was hunted hard on the Braes of Balquhidder and on Loch Lomond side. He lies buried in Balquhidder kirkyard.

Salmon penetrate to both lochs, although they are not caught in great numbers; but they manage to reach these waters fairly early in the season, so that the chance of catching the fish that are present is greater than otherwise would be the case. Fish which enter a loch late are never of any sporting value. The opening of the season is generally the best. I noticed that, in 1908, between 15 th and 31st January, the capture of 4 salmon were reported, and later I saw notice of a few fish taken in Loch Voil.

The distance from Loch Voil to Loch Lubnaig is 5 miles, and the river Balvag meanders with many windings along this flat Strathyre. The fall from the one loch to the other is only 9 feet, so that naturally the flow of the river is very slow. The Kirkton Burn, behind Balquhidder, and the Caladir Burn directly opposite 
are no doubt responsible for the termination of Loch Voil, while several lesser burns further down account for the rest of the alluvial stretch. The Balvag is of little use as a salmon stream.

Loch Lubnaig is 4 miles long and has an average depth of about 43 feet. It is not a simple rock basin as the two lochs above are, but has a floor composed of three separate depressions. The greatest depth was found by the Bathymetrical Survey to be 146 feet, or $24 \frac{1}{3}$ fathoms, but nearly two-thirds of the loch is of less than 50 feet in depth. The western end, as might be expected, is slow in deepening, and geologists consider that at one time the loch reached about three-quarters of a mile past the present eastern end into the Pass of Leny.

This loch contains salmon from the opening day of the season, in spite of the marked fall which occurs in the Pass of Leny, due, apparently, to one of the faults which strike through this region in a north-easterly and south-westerly direction. It has sometimes occurred to me that there are considerable possibilities of salmon fishing in Loch Lubnaig, if the run of fish to the loch could be improved.

The Leny has some most interesting casts below the Falls which yield a very fair number of spring fish. Three, for instance, were caught on the opening day (15th January), this season. The lower part of the river is boulder-strewn and comparatively shallow, while above the Falls some good spawning ground exists till the sluggish runs below the loch outlet are reached. The rise and fall of Loch Lubnaig appears to be about 6 feet, and in spite of the unfortunately low ground in Strathyre at the head of the loch, it is, I think, worthy of consideration whether or not some impounding of water could not be accomplished. The outlet is very narrow opposite St. Bride's Signal Box on the Callander and Oban line, which traverses the Pass and western side of the loch, and the banks and substructure might with advantage be tested to see if a weir and easy pass could be erected.

If, as I believe to be the case, the fishing value of Loch Vennacher, and the Vennacher water is for ever impaired by the abstraction of water to Glasgow, and the value of the Teith also impaired by the lack of water from a former important source, it may still be possible to restore the Teith to its former value by increasing the water supply from Loch Lubnaig, and in so doing to improve also the fishing of the Leny and Loch Lubnaig and the higher lochs. Not only would sporting capabilities and values be certainly increased, 
but improved facilities for the distribution of spawning fish brought about.

An increase to the Leny water would increase to some extent the drawing power of the river as compared with the stream from Loch Vennacher, and might, therefore, be regarded as to some extent a condition adverse to the latter, but the ascent and the rising properties of the fish in the whole of the Teith would be improved.

In this connection it might be necessary to deal to some extent with the Falls of Leny. These falls have two channels separated by a rocky island. The channel at the right bank is quite precipitous, but the channel by the left bank, although rocky and broken, is not impassable to fish. In cold winters, or perhaps more accurately after cold autumns, fish will not ascend the fall with any freedom. To reduce the gradient of the left channel and to blast or remove two or three of the worst rocks would result in fish ascending at an earlier date and at more frequent periods; but before any alterations were decided upon it would be well to study carefully the effects of increased water flow.

There is no doubt that in favourable winters a very considerable number of fish pass through the Leny into the loch. It is probable that with easier ascent and an increased stock of fish brought about by the various means adopted in other parts of the district, and let us hope by the reduction of both netting and pollution in the lower Forth, Loch Lubnaig would come to be a spring fishing loch of some repute, instead of a rather second-rate loch as at present. The success attained by impounding water in the upper Helmsdale is an example of what can be done by the operation suggested, and reference to this will be found in the chapter dealing with that river (p. 226).

The catchment basin of Lochs Doine, Voil, and Lubnaig is calculated as 73.39 square miles by the officers of the Bathymetrical Survey, reference to whose reports has already been made, and in dealing with the rainfall and water of the area it is stated," "The usual practice among engineers is to add $2 \frac{1}{2}$ per cent. of rainfall for each 100 feet of height above rain-gauges. . . A Applying this rule to Loch Lubnaig catchment basin, where we have an observed rainfall of 76.25 inches at an average height of 538 feet, we must add 20 per cent. for the additional 809 feet of mean height, making an average annual rainfall over the entire catchment basin of 91.5 inches." In the same valuable paper, from information supplied by the late Dr.

${ }^{1}$ Scottish Geographical Magazine, xvi., No. 4, p. 221. 
Buchan, it appears that the total catchment basin of Lochs Vennacher, Achray, Katrine, and Drunkie is about 75.29 square miles, and the mean height above sea-level $1035 \cdot 185$ feet. The rainfall is reduced to cubic feet in each case, and the totals given according to three methods of estimating rainfall described by Dr. Buchan. In comparing in this way the Vennacher catchment with the Lubnaig catchment, the following figures are arrived at:

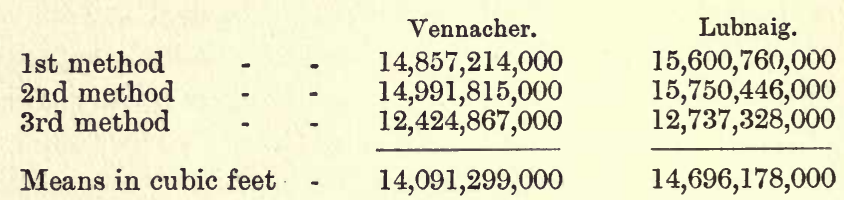

From these calculations, which are no doubt as accurate as can possibly be obtained, it appears that there is rather more water in the Lubnaig than in the Vennacher system, and this in spite of the fact that Loch Katrine is the largest loch in either chain.

From a table given on p. 213 of the paper already quoted, I extract the following particulars as to the lochs in each chain. It should be noted that Lochs Vennacher and Lubnaig correspond very closely, and that the difference in level between Loch Voil, with its continuation Loch Doine, and Loch Lubnaig is apparently only 9 feet.

\begin{tabular}{|c|c|c|c|c|c|c|c|}
\hline \multicolumn{3}{|c|}{ Lochs. } & \multirow{2}{*}{$\begin{array}{c}\begin{array}{c}\text { Elevation } \\
\text { of Surface } \\
\text { above Sea. }\end{array} \\
\text { Feet. }\end{array}$} & \multirow{2}{*}{$\begin{array}{l}\text { Length. } \\
\text { Miles. }\end{array}$} & \multirow{2}{*}{$\begin{array}{c}\text { Mean } \\
\text { Breadth } \\
\text { per cent. } \\
\text { of Length. }\end{array}$} & \multirow{2}{*}{$\begin{array}{c}\begin{array}{c}\text { Mean } \\
\text { Depth. }\end{array} \\
\text { Feet. }\end{array}$} & \multirow{2}{*}{$\begin{array}{c}\text { Volume } \\
\text { in Million } \\
\text { of Cubic } \\
\text { Feet. }\end{array}$} \\
\hline & & & & & & & \\
\hline Katrine & - & - & 364 & $8 \cdot 00$ & $7 \cdot 5$ & $199 \cdot 189$ & 27,274 \\
\hline Achray - & - & - & 276 & $1 \cdot 25$ & $20 \cdot 8$ & $36 \cdot 009$ & 321 \\
\hline Vennacher & - & - & 270 & $4 \cdot 00$ & $10 \cdot 0$ & $42 \cdot 410$ & 1,903 \\
\hline Voil & . & - & 414 & $3 \cdot 50$ & $6 \cdot 9$ & $40 \cdot 936$ & 1,000 \\
\hline Doine - & - & - & 414 & $1 \cdot 00$ & $21 \cdot 0$ & $33 \cdot 130$ & 196 \\
\hline Lubnaig & - & - & 405 & 4.00 & $6 \cdot 0$ & $42 \cdot 773$ & 1,144 \\
\hline
\end{tabular}

This result clearly supports the view that, if no practical difficulties are found to exist, the opening of the Leny Falls and the storing of the great amount of water which at present runs to waste from Loch Lubnaig, would yield a most hopeful future for the fisheries of the Teith and Leny and the northern chain of lochs.

With regard to the actual fishing results in recent years it is encouraging to learn that a considerable improvement is noticeable. The best time may be said to be from the opening day (15th January) to the end of April, but much naturally depends on the beneficial 
mildness of the season and the amount of water. The fish usually run from $12 \mathrm{lb}$. to $22 \mathrm{lb}$. in weight, the average being about $17 \mathrm{lb}$. I am able to give the approximate results for the last five springs:

$\begin{array}{lllll}1905 & - & - & - & 14 \\ 1906 & - & - & - & 16, \text { including } 2 \text { in June. } \\ 1907 & - & - & - & 12 \\ 1908 & - & - & - & 30 \text { and } 7 \text { or } 8 \text { in Loch Voil. }\end{array}$

In 1909 Loch Voil seems to have done unusually well. The total for the two lochs was reported as about 50 by the middle of March.

There are now about a score of boats available on Loch Lubnaig. About forty years ago there were only some two or three. The day may not be far distant when some systematic regulation of the fishing on the loch will be quite necessary.

\section{ALLAN WATER.}

One tributary of the Forth remains to be referred to, viz. the Allan Water, which enters the left bank of the main river a short distance above Stirling, and which flows in a south-westerly direction from the neighbourhood of Blackford, past Dunblane and Bridge of Allan. It drains an area of about 77 square miles, and not long after the junction of its small head streams, which rise on the northern slopes of Sheriff Muir close to the source of the Devon, it is used in winter time to supply water for the safety curling pond at Carsbreck, upon which "The Grand Match," North against South, is annually played-when there is ice. This Carsbreck Pond is at the present time being turned into a trout-fishing lake of apparently a more permanent character. Presumably the Caledonian Curling Club has satisfied itself as to the "safety" character and as to the possible growth of weeds which may arise in a permanent but shallow sheet of water.

The Allan Water is obstructed by no fewer than ten dam dykes, and although it is not a large river, frequented by salmon in the early part of the year, it attracts a large number of late fish, and is a most useful spawning stream. With a considerable population on its banks, it appears that the fish, which are checked by the various weirs, are subjected to a rather serious amount of stroke-hauling and poaching in other forms. It is therefore highly desirable that the weirs should be provided with gaps and passes, and the lades provided with hecks.

An Angling Association of those chiefly interested in the Allan Water fishings is now, however, in course of formation, from which 
it is hoped much good may arise. At the same time the Forth District Fishery Board have powers to require that the owners of the various obstructions comply with the requirements of the Salmon Fishery Acts.

On ascending the river, the first weir is that of Keirfield at Bridge of Allan. The lade and mill are on the right bank. A short distance above is the Bridge of Allan meal mill dam, a low structure and not very serious in itself, but unprovided with any gap, and so arranged as to lade that the water carried off is not returned to the river above the Keirfield dam met below, but runs into the lade of the Keirfield mill. The next dam dyke is one of the most serious in the river, viz. the Airthrie Dyke, which supplies a paper mill. The weir is 167 feet long and 9 ft. 6 ins. high. The downstream face has a gradient of 1 in 5. A pass has been planned for this weir so as to take advantage of some rock ledges which project into the river from the right bank.

At Kippenross a cruive used to exist, and although this has long been cleared away the rocks still check fish, and are reported to afford a point of vantage for fish-snatchers. Above this is the Lower Keir Mill, which has an exemplary form of dyke running off to a vanishing point. Then comes the Upper Keir Mill, with its dyke below the railway viaduct, where a gap is needed. The Dunblane Dam Dyke next above is another bad barrier unprovided with either gap, fish pass, or hecks, and where, moreover, much water is wasted which might, with advantage to the salmon and little inconvenience to any one, be sent over the dyke. A short distance above this is a curious feature. A dyke exists intended for some sort of mill which never was built. It is not a very serious dyke, but is a quite needless obstruction, rather typical of the kind of treatment Allan Water has been subjected to. Springbank Wool Mill Dyke, Ashfield Dyke, and Kinbuck Dyke are the remaining obstacles to the ascent of fish, and as Kinbuck is only six miles from the mouth of the river, it will be seen that the spawning fish which attempt to ascend the Allan have a pretty series of obstacles to contend with before they have gone very far. Gravid fish have but a poor chance of getting beyond the Airthrie Dyke as it at present exists. We may hope, however, that better days are in store for Allan Water. 


\section{CHAPTER III.}

\section{TAY DISTRICT.}

RIVERS : TAY, TUMMEL, GARRY, TILT, LYON, ISLA, ALMOND, EARN. LOCHS : TAY, TUMMEL, RANNOCH GARRY, EARN.

Angling Season: January 15th to October 15 th.

Netting Season : February 5th to August 20 th.

(For special fishing seasons of Earn see under that river.)

District Fishery Board sits in Perth.

Clerks : Messrs. Condie \& Mackenzie, Solicitors, Perth.

THERE is a certain amount of rivalry between the Tay, the Dee, and the Tweed as to which is the greatest or most important salmon river in Scotland, or it may be in Britain. I have been blamed for describing the Tay as the premier river of Scotland, so I will not make the statement again. I confess to a feeling of diffidence in commencing to write of the river at all; it is such a big thing. I suppose our American cousins, who are accustomed to big things, would regard the river as a mere brook. It is over a hundred miles long. The Spey, by the way, is the same length. On the authority of Sir Archibald Geikie, however, the Tay has the greatest volume of water in Great Britain. I leave Londoners to make the best of that statement. The drainage area is nearly 2000 square miles. ${ }^{1}$ The Fillan Water is the real source of the Tay. It rises from a high corrie on Ben Laoigh on the borders of Argyllshire and at an elevation of about 3000 feet. This corrie forms the upper end of a highly eroded basin of great extent, and touches the main water parting of the country. An idea of the extent of erosion may be obtained when it is realised that, from its high source, the Fillan has in 11 miles reached the comparatively low level of 500 feet. Loch Dochart and Loch Jubhair are 512 feet, and from the latter

1 The Geology and Scenery of the Grampians. Peter Macnair, F.R.S.E., F.G.S. Vol. i. p. 69. MacLehose \& Sons, Glasgow, 1908. 
the stream now known as the Dochart flows $14 \frac{1}{2}$ miles to Loch Tay at Killin.

In June, July, and August; a fair number of salmon may be caught in the Dochart by visitors staying at the Luib Hotel, and the pools in the immediate neighbourhood of Luib are the best. The lowest section of the river is fished from Killin, but falls exist a short distance above Killin, and when salmon leave Loch Tay, as they commonly do from about the third week of May onwards, and ascend the falls, they appear to travel onwards pretty steadily till the Luib pools are reached. The fish are of the heavy Loch Tay class, which have ascended to the loch in the early months of the year, and now average perhaps $16 \mathrm{lb}$. to $17 \mathrm{lb}$. This ascent at the Killin Falls is governed by the temperature of the water, and is comparable to the conditions found in the Inverness-shire Garry, or the Helmsdale at Kildonan, where also fish do not ascend till the wintry conditions of the water have given way at the approach of summer.

Glen Dochart is a wide and, for the most part, rather bare glen. From the railway line, which traverses it from Killin Junction to Crianlarich, the river is seen from one end to the other, and, it may be, the tiny-looking train which puffs its way up from Loch Tay to the junction. But the hills on either side rise over three thousand feet, Ben More, on the south side, being 3843 feet.

Loch Tay, to which more detailed reference will presently be made, is practically 350 feet above sea-level, and from its eastern or Kenmore end the river Tay takes its rise in considerable volume. Here the lower slopes are beautifully wooded, and the extensive parks round Taymouth Castle, the seat of the Marquis of Breadalbane, introduce that sense of the value and care of the surrounding lands which seem to me to distinguish the Tay throughout its course. It is not a river in wild open Highland scenery. The banks and the lower hills are richly wooded with a variety of trees; beeches, oaks, limes, and conifers are mingled in profusion. The more rugged features of the landscape appear only in the hill tops beyond and above the woods, and from the time the large river leaves its loch at Kenmore to the time when its waters mingle with the tide below Perth, the country is rich in wood, and at more than one spot is peculiarly rich in wood.

In the upper Tay, and more especially in the defiles through which the Tummel and Garry pass, the grander elements of the country assert themselves and demand admiration; the wooding 


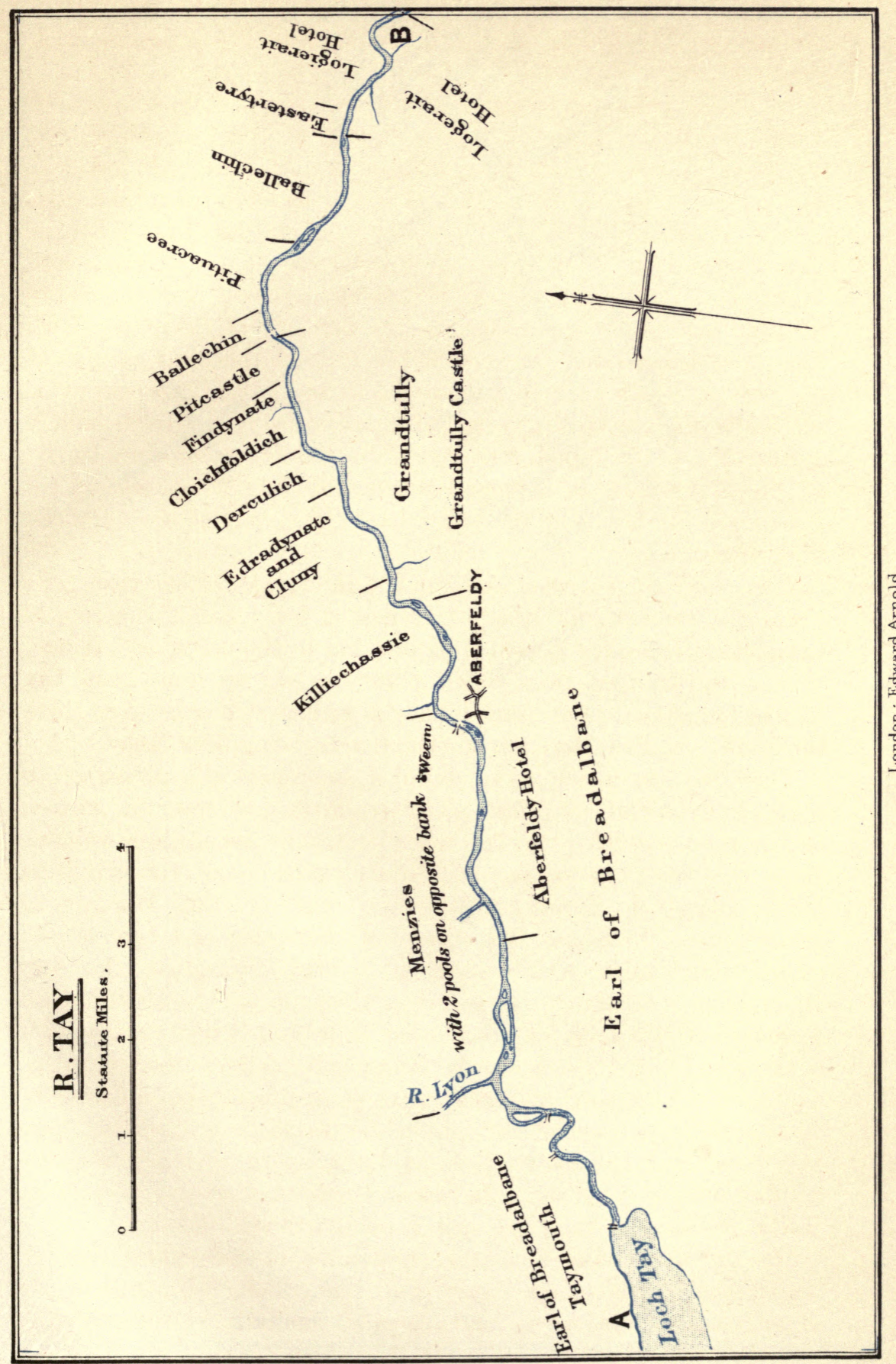





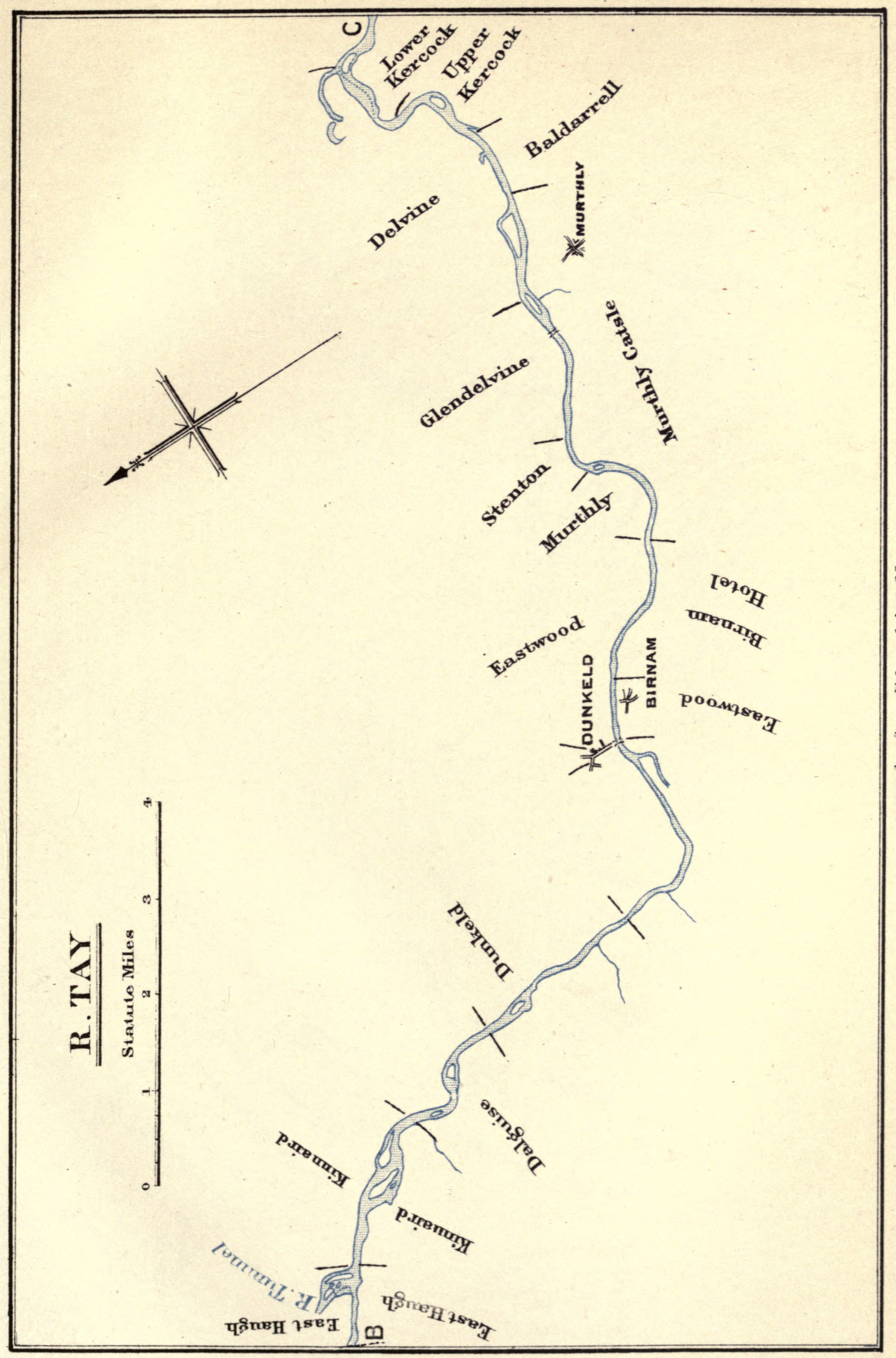





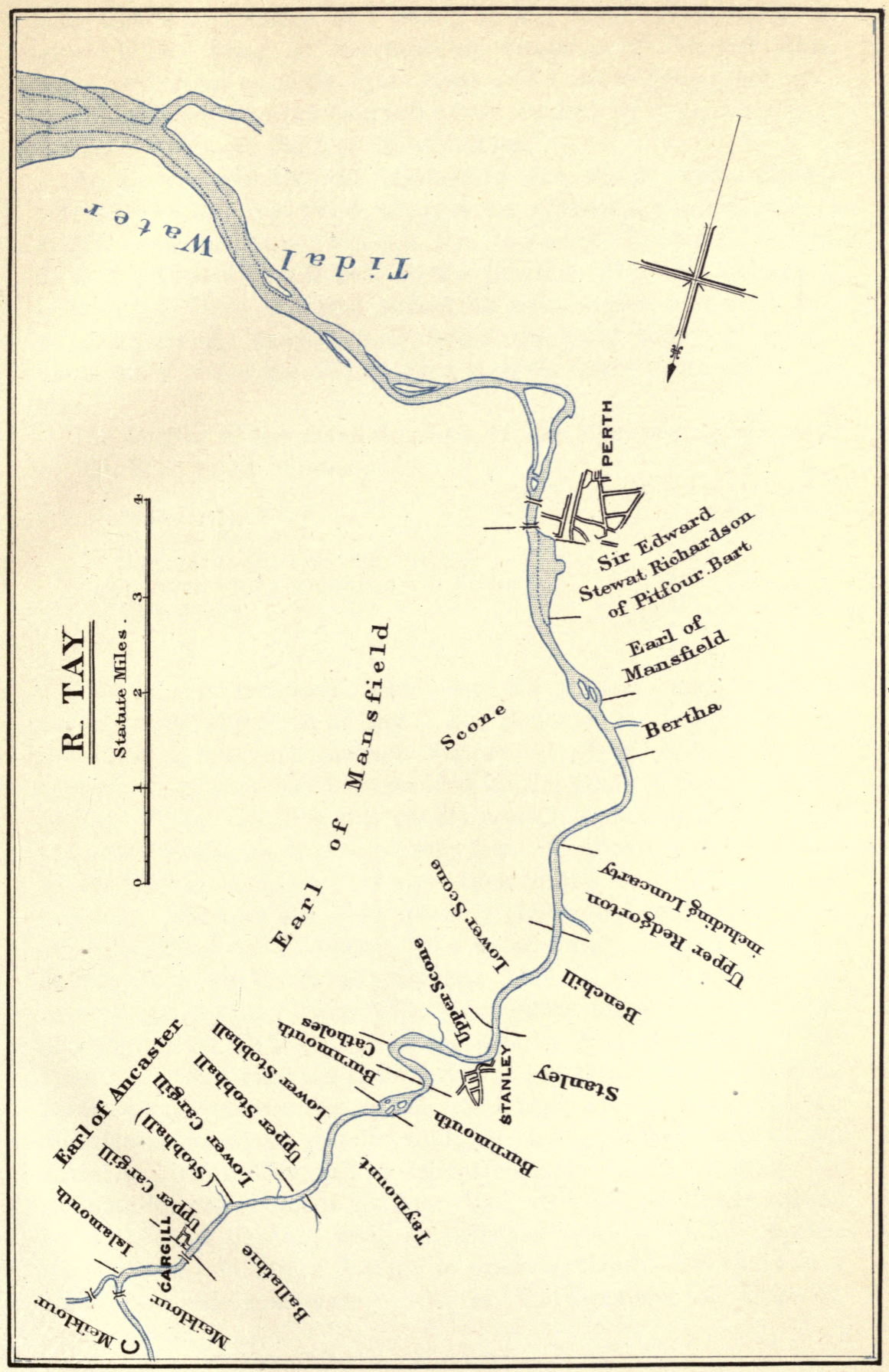



only adds a refinement and beauty to the robust strength of the great hills. Away in the heathery stretches of Rannoch Moor again, one does not look upon trees and narrow gorges, but upon great expanses of wind-swept heather, backed by distant peaks of serried outline and the free lift of heaven.

As pointed out by Mr. Macnair in the recent work already referred to, the Tay twice changes its direction and describes a rough parabolic curve through the centre of Perthshire. From Loch Tay it flows north-east to the junction with the Tummel at Ballinluig. Here it turns almost at right angles, and flows in a direction mainly south-easterly across the wide valley of Strathmore until it reaches Perth, when it again turns sharp off to the east.

The lengths of the main divisions of the river system are given by Mr. Macnair as follows :

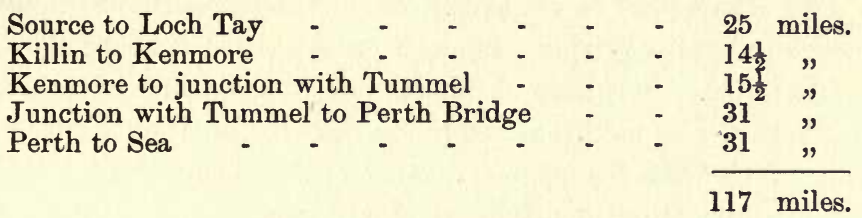

The last measurement comprises the estuary, being what is usually called the Firth of Tay. The limits of the estuary are not scheduled in the 1868 Salmon Fishery Act, because early in last century the matter had been decided by the Court of Session. The finding of the Court is not readily accessible, and for this reason the actual limits are known to very few. The matter was appealed to the House of Lords, but sent back to the Scottish Courts for decision. The case was John, Duke of Athole and others v. the Hon. William Maule of Panmure. The interlocutor was finally issued on 8th July, 1817. It is somewhat lengthy, and deals with the removal of "yairs, stake nets, and other machinery," but the passage dealing with the line of the estuary runs as follows: "The Lords . . . find that the eastern end of the Drumley or Draumlaw Sands is the eastern end of the sand bank denominated Abertay on some of the charts referred to, lying on the southern side of the River or Firth of Tay, and as delineated and marked 'Abertay' on the plan in process made by John Bell, and referred to and signed by Mr. James Jardine, civil engineer, as relative to his report; remit to the said James Jardine to draw a straight line south and north from the said eastern end of the Drumlaw or Drumley 
sands, now called Abertay, as delineated on the aforesaid plan, and mark the points where the said line intersects the northern and southern shores. Find that the River, Firth, or Water of Tay extends as far down as the line so to be drawn."

In drawing the line, Mr. Jardine ascertained by observation the meridian of Buddon Ness on 29th July, 1817, the first day after full moon, and at time of low water drew the line from the eastern end of Abertay Sands. At the same time he caused "the hewn Kingoody Sandstones," referred to in his report, to be taken up and placed at the point where the line intersected the shores. These proceedings were formally approved by the Court.

The Kingoody Sandstone on the north side came to be known as "The Chancellor's Stone," but it cannot now be seen, the supposition being that it is buried deep in drifted sand. The stone on the south shore was known as "The Sea Stone." It was or is in a field nearly two miles east of St. Andrews. A local farmer not knowing it served any useful purpose made a gate-post of it after removing it a short distance. I rather think its use is still that of a gate-post, and since the Chancellor's Stone is not to be found the accurate replacing of the Sea Stone is a matter of some importance which the District Fishery Board might well see to. If it cannot now be conveniently replaced some other mark should be erected.

Seaweed grows in the estuary as far up as Newbury, which is a short distance below the mouth of the Earn. For a few miles above this the water is brackish. Between Kinfauns and Perth the effect of the tide acts more in damming back the fresh water than in actually mingling with it. The influence of the tide reaches to the Woody Island above the North Inch of Perth.

A battle of modern times took place one dark night a short distance above Newburgh. It is still spoken of as the battle of the Gutter Hole, and it may be mentioned here because it was of great moment, I believe, in bringing about the end of estuary poaching on anything like an extensive scale. The Gutter Hole is the name of a fishing station, and was the scene of the encounter. Gangs of men had for some time been working nets in spite of the watchers, and ernboldened by success, and with steady additions to their numbers, were beginning to openly defy the river watchers even in daylight. The watchers finding themselves in a powerless minority quickly sought help from Mr. Lumsden's force up the river, and, on a night appointed, two boat crews, floated silently down the river. A large body of poachers were discovered with two boats busily at 
work. A skirmish, or perhaps more properly a reconnaissance, accompanied with a deal of stone throwing on the poachers' part, enabled the party of water bailiffs to estimate the force they had to deal with. Mr. Lumsden then drew off his men, landed, and deployed till he was able, unseen, to approach from the land within striking distance. After waiting till the law-breakers were busily engaged in hauling their net the signal for attack was given, and a determined little battle immediately ensued. Many crowns were cracked, and a good deal of damage was done on both sides, but the discomfiture of the poachers was complete, and many prisoners were secured. Two men who tried to swim to Mugdrum Island were drowned. Feeling ran high in Newburgh, and the police scented manslaughter to follow. Fortunately, however, the well-planned attack at the Gutter Hole had produced sufficient impression, and the Courts wound up the proceedings without any additional charges. The result in all conscience was serious enough. Doctors were busy as well as lawyers; but open poaching was crushed.

Such adventures are still possible in Ireland, where cattle rather than salmon seem recently to have been the game, but it is well-nigh incredible that in peaceful Scotland such things should have taken place not so very long ago. On the Borders, matters are at times perhaps not dissimilar, and in Aberdeenshire there are also some hardy rascals to deal with, but no organised poaching on a large scale has now to be tackled as this Tay affair was.

The estuary has been a famous centre of salmon fishing since netting was first practised. It is a famous centre still, although most of the netting is now concentrated in the narrow tidal waters a few miles below Perth, all fishings in this section and below being in the hands of the Tay Salmon Fisheries Company, so that all elements of competition are eliminated, and the complement of fish taken by only the necessary number of nets and men. The "hailing grounds" or hauling beaches have a venerable aspect, smooth from long use, and here the windlasses are at work night and day during the season. The bothies for the men are low stone houses with slated roofs, with frequently a store attached for the gear; sweep nets of extraordinary lengths are in use in some of the wide shots. The crews who carry on the fishing have also a certain hereditary interest in the work, and Maxwells and Pantons, Thomases and Haggarts are always to be found in the water or in the boats, at the windlasses or in the bothies.

In the old days the whole estuary was netted by toot and haul, 
hang net, and the sweep net, and the last-named style was carried on right up the river, and even in the upper tributaries where the water was suitable. It is of some interest to know what was then netted in the Tay, and through the kindness of the Hon. Morton Stewart Gray, who has a detailed return of catches at Kinfauns Castle for the period between 1830 and 1846, I am able to give the following totals, representing the produce of thirty-four netted fisheries from the mouth of the estuary up to well above Dunkeld, thus including all the important waters of the river. The return distinguishes between salmon and grilse, and I have added the quinquennial averages after adding the salmon and grilse of each year together :

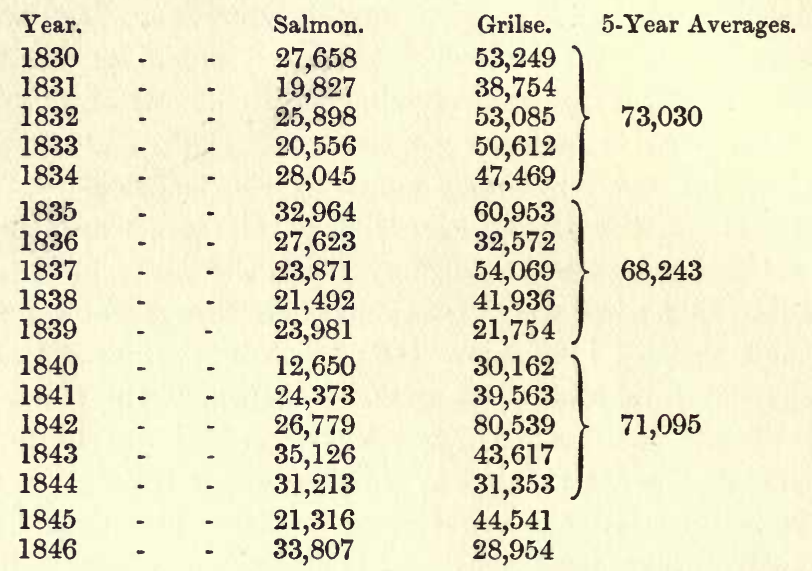

The year 1842 is the record in this series, the total catch being no fewer than 107,318 fish; but for this wonderful run of grilse the last quinquennial average would have shown a considerable decline. If, for instance, one or other of the two last years had been in place of the 1842 figures, the average would have been 62,762 or 62,163 .

As is noted in the case of early figures given for the Tweed District, there is more fluctuation in the grilse than in the salmon column; but the grilse return here given for the Tay does not show that violent fluctuation which the Tweed does at, however, a rather later period. It is not possible, at the present day, to compare modern returns with those given, even if one had full returns from the Tay Salmon Fisheries Company, because the amount of netting is now so completely altered; but one thing is very certain, viz. that grilse never now come in such numbers as are represented in the above column. The growth of bag net fishing in the sea must be 
recollected in this connection; but even then, a feature of our presentday fishing is that good years are not so good as of old, and bad years are much worse and more frequent. For the last couple of years, indeed, it might be said that grilse have almost utterly failed in many parts. From this it must not by any means be inferred that the Tay Salmon Fisheries Company is not a prosperous concern. Prices are high.

In the history of the Tay, litigation has arisen from time to time. The Bermoney Boat Case is historical. The toot and haul fishing and drift net cases went to the House of Lords, and resulted in the decision, given as recently as 1900, that in Scotland those forms of fishing cannot now be practised in any estuary, since they are to be regarded as fixed engine fishing. This decision is largely responsible for freeing the lower reaches of the estuary of nets, and has resulted in the suppression of drift net or hang net fishing in several other estuaries where it could be and was practised. The only district which is not affected by it, so far as the question has yet been tested, is the Solway, the clauses of the Scottish Acts regulating fixed net fishing being there excepted and the English regulations being substituted, with the result that considerable confusion and difficulty follows. Netting by means of sweep or draught net-net and coble fishing-is practised during the whole season between Perth Bridge and the mouth of the Earn. Above the Bridge of Perth, since 1906, a reduction in the netting has been agreed to by the Tay Fisheries Company. Between the Linn of Campsie, which is the one partial barrier in the whole of the main river (a dyke of dolerite rock through which the current has worn a great gap), and the Bridge of Perth, a distance of about 9 miles, netting is now carried on only till 31st May in each year, and in addition to this a sixty hours weekly close time is allowed. This means much for the passage of fish to the upper waters, although between four and five thousand are probably accounted for before 31st May.

By agreement of all proprietors of fishings no netting is now carried on above the Linn.

The names of some of the netting stations above Perth are interesting. One, for instance, is called "Rome." A large Roman camp once existed in the haugh land now forming part of the policies of Scone Palace, and the name of the netting station is believed to be derived in consequence. The river Almond enters on the opposite side, and from it the Perth Lade is carried 4 miles to the Fair City. This lade is believed to have been constructed by the Romans. It 
serves a multitude of purposes nowadays, and enters the Tay in two branches, one close to the Bridge of Perth, the other about the centre of the South Inch. This lower branch is the source of much gross pollution to the Tay, and unhappily it is not the only source of this growing trouble to salmon interests in the immediate neighbourhood of Perth. The particular nature of the various pollutions which enter the river has lately received the careful attention of the District Fishery Board. The desire for the purification of our rivers is becoming keenly felt and expressed on all hands, and without doubt the interest of the valuable fishings will be well served when steps are taken to remedy the evil. The fact that the annual rental of Tay salmon fishings is at present fully $£ 23,000$ is sufficient to show the interests involved. Since 1900 the Tay rental has never been below $£ 22,500$.

A little distance above "Rome" the Stormontfield Ponds are situated. These ponds, constructed with the encouragement of the then Lord Mansfield, and on his ground, were closely associated with the early experiments to prove that the parr is the young of the salmon, and to elucidate the migratory habits of the fish. Here, from 1853, salmon fry were hatched out in artificially constructed channels resembling natural redds, the young fish being afterwards transferred to ponds. A little book written by Brown the superintendent, and a pioneer of salmon hatching in Scotland, along with Shaw of Drumlanrig, describes the formation of the original establishment and the various experiments conducted by "Peter of the Pools," the keeper of the ponds. The deductions drawn from the early experiments were to a considerable extent erroneous, but were none the less of great value as giving stimulus to this branch of natural history, and inducing other observers to work at the problems suggested. At a later date the hatching place at Stormontfield was cleared of its artificial redds and converted into a rearing pond, while the operation of hatching was transferred to a more modern hatchery situated at Dupplin on the Earn. The ordinary method of hatching on glass grilles was here adopted and carried on with varying results. No great number of ova was at any time laid down in the hatchery, and it is not surprising to find that no certain advantage has been secured from the operations. The following numbers represent the ova treated in six years:

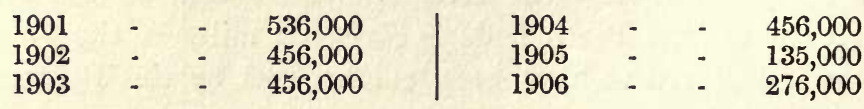


or only $2,315,000$ in the six years. I understand that the Tay District Fishery Board, who have for some years borne the cost of the operations, have now decided to discontinue hatching. The historical associations of Stormontfield Ponds make it almost inevitable that the step brings with it a certain amount of regret, but to many it has seemed for several years that the value of the establishment was slight; that the mere hatching was productive of little or no practical benefit and that the real benefit of Stormontfield ceased when the famous experiments ceased in the middle of last century.

The migration of the smolt has since been determined with much more accuracy by means of marking wild smolts caught in the lower Tay at Kinfauns. In $1905 \mathrm{Mr}$. M'Nicol, under the supervision of Mr. Malloch as Manager of the Tay Salmon Fisheries Company, attached a small loop of silver wire to the dorsal fins of 5500 smolts. The recapture of the marked fish as grilse proved first, that these fish do not return in the year of their descent as smolts, as was supposed to have been proved by the Stormontfield experiments, but in the year succeeding that of their descent; secondly, that a number do not return as grilse at all, but as small spring fish, and summer fish in their fourth year, and also that some of them do not even return then, but at a still later period. An account of these results has been given elsewhere, ${ }^{1}$ but I may here add that in 1908 further recaptures of the smolts of 1905 were made.

\section{RIVER TAY.}

The general characteristics of the water are really rather like the characteristics of the Tweed. In both rivers one sees large and often somewhat deep pools, long stretches of beautiful running water, and, at comparatively rare intervals, rocky corners or rapids. Both rivers also have at times fine stretches of gravel banks, at times long stretches of grass-grown, rather earthy banks, with a wealth of trees. In each river there is magnificent spawning accommodation for salmon, and often surprisingly coarse gravel with many stones the size of coconuts seem to be preferred by the fish. The Tweed is without natural obstruction and has several obstructions supplied by man. The Tay has only some two or three insignificant weirs, and the natural obstruction of the Linn of Campsie. Each river, is now, as it were, enjoying the fruits of advanced erosion.

${ }^{1}$ Auctor, The Life of the Salmon, chap. ii. Edward Arnold, 1907. 
The Tay is so big that in practically its whole course much fishing has to be done by boat. The common practice is to "harl" the large pools, this operation being carried out in greatest completeness in the wide stretches of the lower river. Two men commonly row the boat, each rowing a pair of oars, and two anglers sit facing the stern with two, or it may be three, rods out. One rod may perhaps have a fly, another a gudgeon, and the third a phantom minnow, or in early spring or late in the season three flies may be on. When the lines are paid out the boatmen begin to row with the bow pointing upstream, but so as to allow the current to force the boat slowly across the river. When sufficiently far across, the bow is turned towards the first bank again and the current is made to impinge mostly on the other bow, i.e. the boat's head is slightly pointed for the return journey. At the same time the current works the boat down-stream as far as the rowers allow. In this manner a zig-zag course down the pool is taken. When a fish is hooked the angler generally lands and the other lines are reeled up. Cases sometimes occur of two fish being hooked almost simultaneously, and then very naturally the fun is fast and furious. I have been told a story of two rods being fast in the same fish, fly being the lure, and that on the fish being landed the two flies were found in the mouth. I may add that my informant, who was one of the fishermen, assured me he knew I wouldn't believe him but that the story was perfectly true.

It is this system of harling which, I believe, is largely responsible for the practice common in the Tay of opposite proprietors fishing the whole water on alternate days, rather than each attempting to fish his own section of the water as in Tweed. To harl properly one must go from bank to bank.

The strength of the current in the Tay is often very great and the effort of rowing a heavy coble correspondingly hard. It is not surprising therefore that the more easily handled Norwegian boat is now becoming more common, as in the Spey. The boat introduced is not, however, the Norwegian "pram," but the "faering" which is not so commonly used for angling in Norway. In all ordinary conditions of water one man can easily manage a faering.

In harling, the man or men at the oars really do the fishing, the man or men at the rods do the landing. At the same time, a good deal of casting is done from the boat as well as from the bank, and I understand that, on some of the waters, bank fishing is rather on the increase. 
Below the Bridge of Perth, in the tidal water, the public are allowed to fish by rod. This is only taken advantage of in the autumn when the nets are off. The banks are in places rather muddy and sedge grown, and wading or bank work is quite necessary. Some heavy fish are taken at times. It was here that in the back end of 1907 a citizen of Perth took, by what method I have never heard, a salmon of $61 \frac{1}{2} \mathrm{lb}$. The head of this immense fish is now in the Perth Museum.

Above the Bridge of Perth and still within tide reach a limited number of permits are commonly granted either by Lord Mansfield or Sir G. Stewart Richardson of Pitfour for angling in autumn on the Woody Island and Inch waters respectively. The Inch Water is not however particularly good, although fish are got. It is a long, uniform and rather shallow stream along the North Inch. A good pool exists below the Woody Island, and the stream abreast of the island is the top of tide reach.

Immediately beyond this is Bertha fishing and Almondmouth Pool, and here at the end of the season great numbers of fish accumulate. I recollect going to mark salmon here one November day. I had intended to net and mark from Almondmouth to Perth, but when daylight failed I was still busy where I had started and had not got to the end of the fish that were in the pool. I have known of the Tay Board's men, when ova fishing, land 430 salmon in one haul from this pool, and not a few clean run fish are then taken. Mr. Lumsden, the Superintendent, has also told me that at times fish are so thick below the first dam dyke on the Almond as to make it impossible for any one to miss hooking a fish at some part of its body if minnow tackle. were used, and that quite a Pacific Coast salmon story could be manufactured by a person of suitable imagination.

It is on the whole rather unfortunate that so many breeding fish insist, as it were, upon running up the Almond, because this tributary is in great part rocky and unsuited for spawning, and moreover is obstructed by five dam dykes, and finally by the impassable Falls of Buchanty. The first or lowest obstruction was only recently added to the river. The course of the river was utilised for the formation of a loch, and a new channel was cut for the ascent of fish. The retaining wall of the loch itself was a high perpendicular structure with no outlet except for flood water. I never heard that the loch was of much use as a fishing, and I fear it sometimes held up a good many kelts. The huge flood which took place on 16th 
and 17th January, 1909, owing to a rapid thaw after a heavy snow storm, carried away the retaining wall and flooded a considerable stretch of country. Some unfortunate people in neighbouring cottages had to make a hurried flitting in the middle of the night. The Tay at Dunkeld had risen 15 feet, and the Inches at Perth were already covered. The Almond was in very high flood, and the sudden bursting of the dam carried the water over the high banks which protect the fields on the right side, filled up the fields, and poured along the Perth road till the dip at the railway bridge had about 6 feet of water. Some anxiety was felt for the railway embankment, but the water poured through a narrow archway uniting fields on either side, and eventually broke down the river banks to find its way back to the Almond and Tay. Some 5 feet of water stood in one of the streets of Perth.

When the flood subsided the new river channel lay dry and bare, and the proprietor decided not to rebuild the dam. The perpendicular concrete wall across the old river channel was therefore taken down entirely, so that the Almond has now reverted to its old bed along the bottom of the erstwhile loch.

The next dyke is also a comparatively recent addition. It is not a very formidable structure, however, although it supplies water to another fishing loch (trout). It is situated about half a mile or so below Huntingtower, and is faced with cement, but is provided with a serviceable fish pass at the left bank, so constructed that the fish enter close to the foot of the weir, are led in a down-stream direction and then turned upstream to the pool above.

The two dykes above this are used by Almondbank and Huntingtower bleach works. The dyke, usually termed Low's Dyke, acts in conjunction with Perth Lade already referred to. The dyke next above sends water to a large bleach work on the left bank. The lade passing through this work re-enters the Almond immediately above Low's Dyke, and so much at an abrupt angle to the river that the water during ordinary levels passes across the Almond above the sill of the dyke and continues its course into the intake of the Perth Lade on the opposite bank.

Low's Dyke itself has an unusually long slope but no fish pass. Indeed the passage of fish is considerably impeded by a beam which has been placed on top of the sill for the purpose of sending more water into Perth Lade. I have watched fish running this dyke, and many of them seem tired out before they reach the last third of the down-stream face, when, if they succeed in struggling further, they 
are met by the abrupt beam on top of the sill and immediately fall back and are carried to the foot of the weir again. When the water is suitable, however, large numbers of fish ascend, and after spawning the kelts accumulate in the deep pool above Low's Dyke, and until recently were very apt to be drawn into the Perth Lade. Now, after a good deal of negotiation, a heck has been placed here, but it can be raised, and not infrequently, even when the leaves are not coming down so as to choke the bars, I have found it raised. The water from the Almond which is carried down Perth Lade is lost to this tributary, since the mouth of the lade enters the Tay at Perth.

Continuing upstream in the Tay above Almondmouth we have the Scone Water on the right hand, and Lower Redgorton, Luncarty, Upper Redgorton, Benchill, Stanley (where the first of the two weirs of the main river occurs, a not very serious obstacle), and Burnmouth, on the left hand before The Linn of Campsie is reached. As in other cases, the particular fishings will not be catalogued, but will be found indicated on the maps which accompany the chapter. Both the Redgorton beats go with Battleby House, and are sometimes described as the Battleby Water. The water below the Linn is very good in spring, as well as from the time the grilse appear onwards. It is, of course, big water, and is for the most part harled. The famous Black Crag Pool of the Upper Redgorton beat offers good casting from either bank. The Stormontfield Rearing Ponds are just below on the left bank, receiving water from the Stormontfield Lade.

Above the Linn, including water for several miles, is generally considered the very best of the Tay for angling.

Stobhall on the left bank has about six miles of water. It belongs to Lord Ancaster, but is let to Mr. Malloch, who sublets rods upon it. Opposite Stobhall is Taymount and Ballathie. Taymount House overlooks the Linn of Campsie from the right bank. The gliding plunge of the water over the Linn is fascinating to watch, for the surface, when at all high, is unbroken in the central flow till it meets the lower level of the pool below. If one is near this flow in a boat or on the rocks of the left bank, the sense of force given by the mass of water is tremendous. Yet during an exceptionally dry summer, Peter Thomas, the manager of the fisheries here, once managed to row a coble up the Linn. The pool below is not very deep, but is wide and smooth till a reef of rock, utilised for netting, breaks it about two-thirds of the way across. I know of 
no more spirited place to see a sweep net worked than this Linn Pool when the water is about a foot too high. I have seen Peter Thomas send his boat out here in great style, and I have seen him have the windlass whirling net and boat back again when the latter had been taken a trifle too far to pay out with safety, the boat coming in stern first and rearing up under the pressure of the net till one thought it would be dragged under. Then when the shot is properly rowed in high water it has to be rowed with speed, and as the coble charges the beach, the men leap out and the line is run along to the windlass, the smartness of the whole operation reminds one of bluejackets at their gun drill.

Stobhall now commands a large total rental, something, I suppose, over $£ 1000$. I was informed lately by Sir John Graham that in his early sporting days he and two friends rented this water-from Islamouth to Lady Mansfield's cottage-for $£ 80$ a year. I should say they got their money's worth.

Here are some results of the fishings to which reference has just been made, which have already been published. ${ }^{1}$ They refer to the autumn angling after the close of the netting, and for four years, three days a week, the habit on the Tay being for each tenant to fish both banks on alternate days.

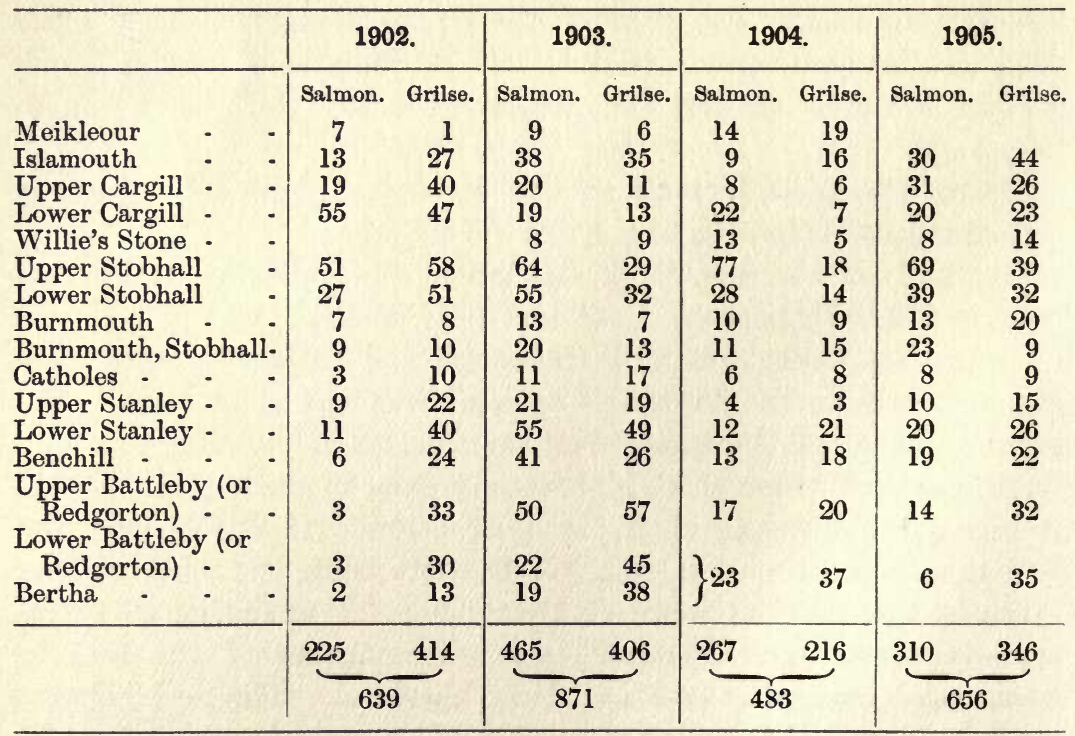

1 The Fishing Gazette at the close of the seasons referred to. 
From reports published as to season 1908, it appears that Upper and Lower Stobhall and Redgorton produced 215 salmon in the autumn, and Taymount about 100 . In the previous autumn, which was an average one with a goodish finish, the results as published in the Fishing Gazette, ${ }^{1}$ show that in the last seven days' fishing those lower waters produced 99 fish as under:

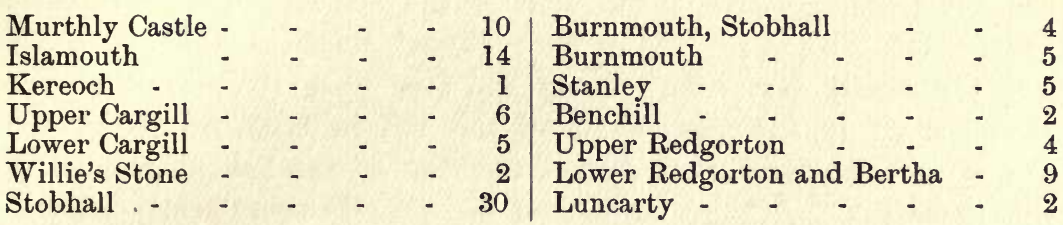

With regard to the Taymount autumn fishing, Mr. Charles Murray, who has been associated with this water for so long, has kindly informed me that his best year showed a total of 275 fish. This is only the fishing of alternate days after the nets are off. The best score in spring was obtained in 1908, the total being 74 . On two occasions 20 fish have been caught by one rod in a day. $\mathrm{Mr}$. Murray himself took, on the lower beat on a day when the upper beat was unfortunately not being fished, 16 salmon and 4 grilse weighing $355 \mathrm{lb}$. On the other great day, curiously enough, the numbers of grilse and salmon were exactly reversed. Rev. the Hon. Robert Liddle took 16 grilse and 4 salmon. "On both days the fish were rising hard all day and would have taken anything," Mr. Murray writes. Perhaps other people might have landed fewer however. Figuratively, I take off my hat to any one who can kill a $48 \mathrm{lb}$. fish in fifteen minutes as Mr. Murray has done. The heaviest fish taken out of the Taymount Water was a 54 pounder killed by Lord Ruthven several years ago.

The heaviest rod-caught fish from this lower part of the Tay for the last eight years are as follow:

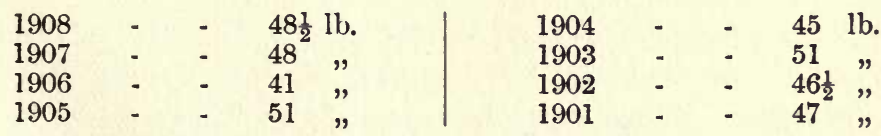

Some heavier fish, as already stated, have been taken in the tidal reaches during this period. This supports the impression which has been pretty strongly borne in upon me during recent years, that a few quite exceptionally heavy salmon, males, which do not enter 
fresh waters during the fishing season, or apparently to any great extent even at the spawning time, come cruising into the estuarial waters at " the back end," and at long intervals are happened upon by some chance. As already stated, a $61 \frac{1}{2} \mathrm{lb}$. fish was caught in the tidal water in 1907, and an 84 pounder was captured by one Willie Walker, a native of Newburgh, in a sparling net some miles above the Tay Bridge, on the north side of the estuary, in the winter of 1869. The Bishop of Bristol once played a fish here for 10 hours and eventually lost him. From the free water below Moncreiffe Island a $51 \mathrm{lb}$. fish was taken on the rod in 1905, this being the second for the river that season, the first is the fish mentioned in the above list. A large number of fish usually come pretty near to the record. In other words, the Tay yields a very considerable number of fish over $40 \mathrm{lb}$. each year. The $70 \mathrm{lb}$. fish which Frank Buckland stuffed and had in his museum was caught at Newburgh, below Moncreiffe Island.

Important fishings, such for instance as Murthly and Ballathie, are not infrequently let to tenants who are unable to be on the water a great deal, or are not disposed to fish the water very regularly. It follows, of course, that the total catch is commonly less than would be the case were the water fully fished, and that to give the annual catches would yield no indication of the real sporting value.

Murthly is in the rather exceptional position, for the Tay, of having both banks for such distance as will give a boat a whole day's fishing. On this water, therefore, Murthly may fish every legal day. Below this water Murthly fishes from one bank, and therefore on alternate days. Mr. Steuart Fotheringham kindly informs me that the average for the water during the last twentysix years is $128 \mathrm{fish}$. The average weight of fish is $16 \mathrm{lb}$, although salmon of $46 \mathrm{lb}$. and $44 \mathrm{lb}$. have been taken. The best season in the period referred to yielded 229 fish with an average of $17 \mathrm{lb}$. The experience at Murthly, as at other lower Tay fishings, is that of late years the spring results have improved and the autumn results have declined. It happened, however, that 1908, in autumn, was a season of remarkably poor fishing weather, dull, muggy, hazy, windless; the sort of autumn when gnats play over every white stone, and cobwebs float across one's face. Fish flop about in the oilylooking pools, and sometimes splash so close to one that the silent fisher is startled, and presently realises that the salmon either ignores his presence or regards him with contempt. Let him fish never so 
wisely, his flies and his minnows are allowed to pass through pool after pool, or are merely played with, nipped at, or what is worse, carried down and fastened on to the bottom after deferred hopes have been at last raised by a brief run.

At Murthly the usual method of fishing employed is casting from a boat, but some of the pools may be fished from the bank or by wading.

With regard to the catch on Delvine and Glendelvine waters I am indebted to Mr. Lyle for permission to give the following record of recent years, separating spring from autumn fish :

\begin{tabular}{lcccc|ccccc} 
Year. & & Spring. & Autumn. & Total. & Year. & & Spring. & Autumn. & Total. \\
1904 & - & 34 & 36 & 70 & 1907 & - & 72 & 33 & 105 \\
1905 & - & 30 & 43 & 73 & 1908 & - & 101 & 44 & 145 \\
1906 & - & 81 & 19 & 100 & & & & &
\end{tabular}

This shows the recent increase in spring fishing, which is remarked in most of the lower Tay fishings.

In the whole Tay district there are ninety-five separate fishings assessed each year, some of which, however, are net fisheries pure and simple. There is a marked contrast in the Tay district as compared with the Tweed as to the amount of money necessary for carrying on the business of protection and regulation. The Tay, with its rental of over $£ 23,000$, has a rate of 6 per cent., yielding $£ 1392$. The Tweed, with its rental of $£ 15,732$, has an assessment of 20 per cent., yielding $£ 3146$. This signifies inter alia the difficulties to be encountered in one district as compared with another.

Above the Bridge of Perth, exclusive of tributaries, there are thirty proprietors who hold rights of salmon fisheries qualifying for assessment. For an understanding of the relative positions of the various fishings reference must be made to the accompanying sketchmaps of the river.

I have been favoured with a record for the last nine years as to the Dalguise fishing, which extends to about $1 \frac{1}{4}$ miles. The Duke of Atholl has the left bank, and in accordance with the usual custom, both banks are fished on alternate days by one estate. The Duke's section is generally let with Dunkeld. Mr. Evan MacGregor kindly informs me that the Dalguise estate takes were:

\begin{tabular}{ccccc|ccccc} 
Year. & & Spring. & Autumn. & Total. & Year. & & Spring. & Autumn. & Total. \\
1900 & - & 8 & 4 & 12 & 1905 & - & 31 & 2 & 33 \\
1901 & - & 16 & 4 & 20 & 1906 & - & 60 & - & 60 \\
1902 & - & 11 & 2 & 13 & 1907 & - & 36 & - & 39 \\
1903 & - & 19 & 2 & 21 & 1908 & - & 51 & 2 & 53 \\
1904 & - & 30 & 5 & 35 & & & & &
\end{tabular}


So far as I understand from other sources the marked variation shown in this list may be accounted for by a varying amount of fishing and by a varying kind of fisherman.

The fishings in the Tay above the junction of the Tummel at Logierait are, like the Dalguise fishings just referred to, chiefly productive in the spring. The autumn fish which yield so much sport in the lower waters do not ascend so far before the season finishes. Some of the water between Logierait and Grandtully is even-flowing and rather sluggish. Just above Grandtully Bridge a considerable rapid occurs as the river descends amongst rocks below a partial weir. Above this, beautiful streams and pools exist in Findynate, Killiechassie, Grandtully, and Edradynate, and again further up at Weem, where, however, the water does not yield very many salmon. At Edradynate the system of croy-building has been carefully developed by Mr. H. W. Johnston, so that in one large pool alonerepresented in the photograph with $\mathrm{Mr}$. Johnston in his Norwegian boat-there are eleven croys. It is well named the Croy Pool. As the proper method of erecting those structures is as little known in some localities as the benefit to be derived from them, and as I have repeatedly referred to the probable benefit of erecting croys in other rivers, I have given an extract from a valuable article on the subject which appeared in Baily's Magazine for May 1908, in an appendix.

The spring fish taken in this topmost stretch of the river between Aberfeldy and Grandtully Bridge during recent years are:

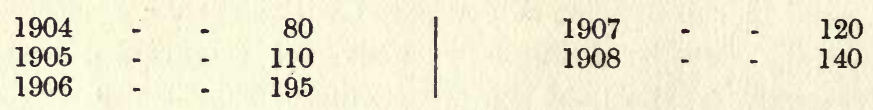

\section{RIVER ISLA.}

The Isla tributary enters immediately below Meikleour on the left bank, a short distance below the handsome new road bridge which now crosses the Tay to Kinclaven, Murthly, and Stanley. The mouth of the Isla is peculiarly sluggish, and since the Tay sweeps round the bend below the bridge with a merry current, the water of the Isla seems to produce little or no effect upon it, and the lead in for fish is poor in consequence. Plans for improving the mouth of the river have been suggested more than once, but so far nothing has been done. For some miles the Isla is deep and sluggish and infested by pike, though a finer character is found in the Ericht, which flows into it from the north through Blairgowrie, where, at the Keith, serious obstructions exist in the form of cascades, and 


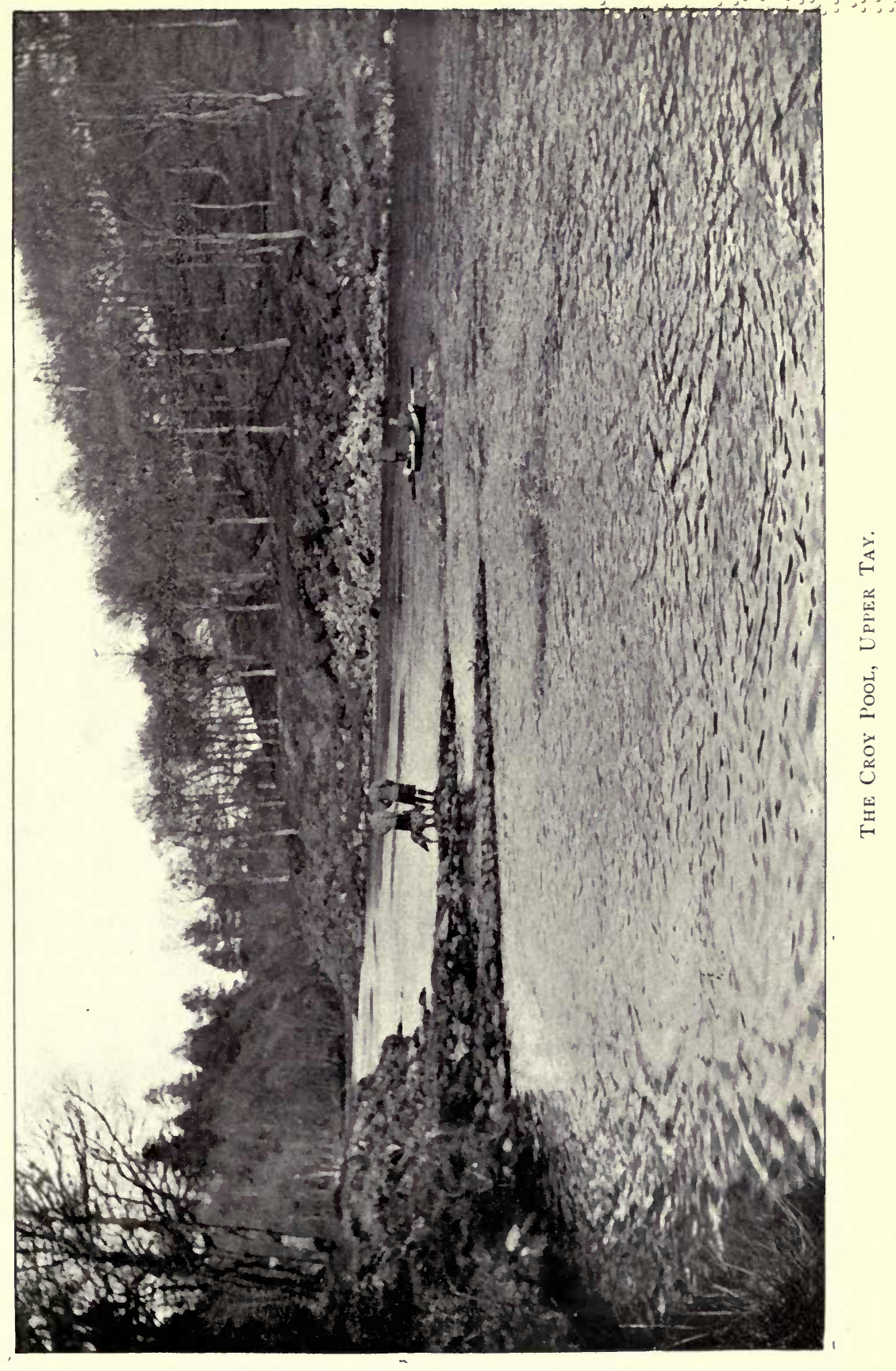


ar

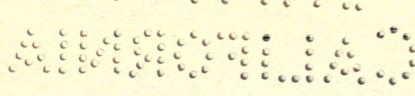


eventually a perpendicular weir of great height. An attempt was made here many years ago to allow salmon to ascend by the erection of an American fish-way of the Macdonald type. The floods, however, soon choked up the side channels of the pass with gravel, so that the steep descent of water was practically unchecked. I believe no salmon ever negotiated the difficulty.

The Isla is a long stream, its source being actually only a little over six miles south-west of Lochnagar and one and a half miles north-east of the point where the shires of Aberdeen, Forfar, and Perth meet. The source is at an altitude of 3100 feet, in the Canlochan and the Cannes glens, two steep corries south of Carn-naGlasha. The length of the river is about forty-six miles. The scenery of the upper part is remarkably fine. At the Reekie Linn, $3 \frac{1}{4}$ miles west of Alyth, the river has cut a gorge fully 100 feet deep, and descends by two falls of 60 feet and 20 feet, presenting during times of flood a beautiful spectacle. Salmon do not reach as far as this, however, being stopped by a double cascade in another deep and narrow defile called the Slugs of Achrannie, about two miles below the Reekie Linn. Taking it all over the Isla is more famous for its trout than for its salmon, but at the "back end" of the year a fair number of fish are sometimes got in the lower reaches. At the "Bonnie House of Airlie" the river, which to this point has been running south, is deflected gradually to the west; but there is not any very marked separation between the Isla at this point and the South Esk river which, in Glen Clova a short distance to the east, has been running parallel to the Isla, but which is carried now to the eastward, while the Isla begins its tortuous and sluggish course through the alluvial plain between Meigle and the Tay.

The Ericht is as long as the Isla above Meigle, and like the upper division of that river, flows south from the hills on the northern limits of Perthshire. Two streams, the Ardle and the Blackwater, which is the lower Shee, join at Strone, 5 miles north of Blairgowrie, to form the Ericht. The head streams of the Ardle drain the southern and western slopes of Ben Vrackie, Ben Vuroch, and Ben-y-Gloe. The Shee rises from high streams on either side of Glas Thulachan, 3445 feet. The Spital of Glen Shee road from Braemar to Blairgowrie follows the course of the river.

The Isla has not, unfortunately, the making of a really good salmon river. The physical conditions are against it; yet if salmon had a better lead into it, there is no reason why they should not enter fairly early in the season. When one looks at the fine running water 
of the Tay at Meikleour, however, one realises that, even with a greatly improved mouth, the Isla must always take a very subordinate place. At present the Isla is so uniform and canal-like in character that the creation of a more attractive mouth is a matter of some difficulty. If a contraction of the mouth were resorted to in order to concentrate the current, some precaution would also have to be taken to prevent this simply resulting in a further deepening of the river and an ultimate return to the present sluggish character.

\section{RIVER TUMMEL.}

If a glance be taken at the catchment basin of the Tay, and the disposition of the chief lines of water-flow noted, the central line will be seen to be that of Glen Garry and the lower Tummel to the Tay at Ballinluig-the line traversed by the Highland Railway. The direction of this central line is rather singular, being south-east, for the main axis of the mountains are at right angles to it. The composition of the hills plus the glacial erosion are no doubt responsible for the existing conditions, the rocks of the region being of very different consistency and capable of resisting the action of ice or of water to very different extents. The erosion of the Loch Tay and Glen Dochart area is more advanced, however, than that of the Tummel or Garry, and the main line of the Grampians cuts off Loch Ericht from the source of the Garry, and still forms a high and hard ridge. The Tummel, and to a greater extent the Dochart and Loch Tay, secure much greater length by having been forced, as it were, to flow to the central line from a west and south-west direction.

The direction of the Tummel is to the east throughout almost its whole course. It rises from a number of small lochs lying in glacial moraines in the Black Mount, south-west of the Moor of Rannoch, and not far from the head waters of the Orchy. The furthest back source is the stream called the $\mathrm{Ba}$, which rises about three miles west of the road from Loch Tulla to Kingshouse at the head of Glen Coe, and flows into Loch $\mathrm{Ba}$, thence into Loch Laidon, and so on to Loch Rannoch. This region, at the glacial period, seems to have been a sort of cap or ice-shed from which the ice moved in various directions. Geological maps indicating glacial drift show that ice moved, in the time of confluent glaciers, after the climax of the Ice Age, down the line of the Tummel, down the Lyon, into the Loch Tay region, and also down upon Loch Tulla and Glen 
Orchy, all radiating from the Moor of Rannoch. Not only do ice markings show this, but boulders of diorite and hornblendic granite from the same source, are peppered about in the regions named, and even carried apparently as far as Glen Almond across the water-shed.

The Tummel, from its source above Loch $\mathrm{Ba}$ to its junction with the Tay at Ballinluig, measures 58 miles, the outlet of Loch Rannoch, which may be regarded as the real commencement of the river section, being as far from the source of the $\mathrm{Ba}$ as it is from the junction with the Tay.

Loch Rannoch is a glacial rock basin, which was at one time perhaps rather longer than now. It scarcely merits special notice in connection with salmon fisheries, for I do not anticipate that even were salmon allowed freely to enter Loch Tummel and to ascend to Loch Rannoch, they would ever be of great sporting value. The loch is $9 \frac{3}{4}$ miles in length, and 668 feet above sea-level. Close to its upper end it receives the water from Loch Ericht. The lower end of the original rock basin is now filled up for a distance of about three miles with alluvial débris washed down from the high land on either side. The end of the basin is believed by geologists to be now seen in the rocky barrier which constitutes the Dunalastair Falls, reference to which will be made later.

Some fine fishing pools occur above the falls, where the river winds about in a narrow and thickly-wooded gorge immediately below Dunalastair House. Below the falls the country gradually opens out, and the course of the river flattens till Loch Tummel is reached, where the alluvium is spread out widely, and must be steadily reducing the loch at this end. A short distance before Loch Tummel is reached, an old weir connected with a small mill at Dalcroy is thrown across the river. The mill is very little used, and the weir of river stones has not been kept in very good repair, so that a great quantity of water finds its way through the interstices of the down-stream face, and by this means loses all concentration in flow, for no gap of any kind exists.

Loch Tummel is a typical rock basin, is $2 \frac{1}{2}$ miles long and about half a mile broad. It is a loch of great beauty and famed for its trout. The bays and headlines are often richly wooded, and here and there cultivated slopes add a pleasant variety of colour and outline. Schiehallion (3547 feet) ever rises dominant in the high land to the left as one looks up the loch, while the hills behind Dunalastair are of a finely-chiselled outline and fill in the picture 
with great balance and charm. From the highest point on the road which skirts the north side of the loch the view is peculiarly fine, and since 1866, when Queen Victoria visited it and wrote of its beauty, has been styled "The Queen's View."

Geologists identify the end of the rock basin of the loch at the rocks which appear in the Tummel about a mile below the loch and in the hill slopes at Allean House. "For several miles downstream, as far as Faskally, the Tummel cuts through solid rock, composed mainly of the Perthshire quartzite, with bands of black schist. This loch has had originally a greater extension westwards, for it has been silted up by alluvial matter deposited by the streams. It is about $2 \frac{1}{2}$ miles long, and the soundings show that it forms three separate basins of no great depth, the deepest sounding of the western basin being 128 feet; of the central, 119 feet; of the eastern, 99 feet. Where these slopes and barriers appear, streams enter the lake from the south, which have given rise to cones projecting for some distance into the loch." 1

The rocky defile spoken of here as forming this section of the Tummel culminates at the famous Falls of Tummel, where the river, considerably contracted, plunges over a broken barrier of rock 15 to 16 feet high.

A photograph gives (as usual in my view) a poor conception of what really charms the eye. The Tummel water is somewhat peaty, and the crest of the fall breaks in fine ale colour, the sultry eddies of "The Pot" below showing echoes of the colour. The movement of the water in the fine S-shaped rapid which forms the Bonskeid side of the fall, is a constant joy to watch, and the harmony of colour in the rocks and trees beyond finds no response in a black-and-white representation. Under the overhanging rock, which forms a sort of island in the centre of the fall, the dipper commonly builds a secure nest. On one of my many visits to the fall, the little fledglings happened to make their first essay at flight. The mother bird flitted about through the falling spray as if to show how safely it could be done, and one or two youngsters presently made some successful short circles over the eddy below, bobbing in the most approved and grown-up manner as they found themselves again safely on the familiar rock. Then one started off boldly for the Bonskeid shore, but apparently losing nerve above the swinging rapid, fell headlong therein, and was imme-

\footnotetext{
'Messrs. Peach and Horne, "Notes on the Geology of the Tay Basin," Scottish Geographical Magazine, xx., No. 1, p. 40.
} 
diately swallowed up and swept over the fall. I watched anxiously the deep-eddying "Pot," where no human swimmer would have much chance, and in a few seconds saw the little bird pop up like a guillemot and paddle its way to a tiny ledge, up which it clambered with difficulty, but apparently with unconcern.

Below "The Pot " comes "The Long Cast," fished principally from a short wooden platform on each bank, and then the Garry runs in from the Pass of Killiecrankie, and the Tummel turns to the right into the main south-easterly direction for its run of 9 miles to the junction with the Tay.

The river swings from side to side of the deep-wooded glen, leaving beautiful banks of clean shingle at each turn. Faskally House, with its fine museum of African and other big game trophies, stands in a wide park on the left, at the foot of the prehistoric river bank now covered with tall trees.

Both Faskally and Bonskeid will probably soon have additions to their extent of fishing, but of this later; as it is, they share the water between the falls to the junction, and then Faskally fishes both banks to Cluny Bridge, a short distance above Pitlochry, and two miles from the Garry junction, where the river becomes more sluggish and deep between high rocky banks, and below which the remaining pools of Faskally Water are let. There are good pools below the junction, all fished from the bank except the Boat Pool, just below the junction. The total capture varies a good deal, but the best season of recent years resulted in about 100 fishabout 80 is said to be the average. On several occasions 7 fish have been taken in a day. The beauty of the scenery and the fine running character of the water must make Faskally a delightful fishing even if the score be small.

From Cluny Bridge, Fisher's Hotel, Pitlochry, has the right of fishing for about a mile and a half, the right bank in part being fished by Finab and Dunfallandy. This water is not so good as Faskally, nor is it so interesting to fish, but fair sport is sometimes had.

The remainder of the Tummel goes with Easthaugh, one of the Duke of Atholl's properties which is let on lease, and which holds also the fishing rights on the Tay for some little distance above the junction at Ballinluig. The Tummel section of this fishing is about five miles in length, and has this advantage over the other Tummel fishings, that a certain number of early fish enter and remain in the deep pools till the rising thermal conditions of the rivers allows of 
their further ascent. In this way both the Tay and Tummel sections of Easthaugh fishing are available for early fishing. By the month of March, however, the Tummel fish are moving up to the Falls, and in April they usually begin to enter the Garry, although in mild springs fish are up as far as the Pass of Killiecrankie before March is out, or even sometimes by the end of February.

Early fish moving up to the Falls of Tummel are of course stopped in any further ascent. The weight of water which pours over this barrier is such that no fish will attempt to make the ascent in spring, or when the water is at or above normal level at any season. In the height of summer, however, when the water is low, fish not only attempt but accomplish the ascent. They leap on the Bonskeid side from the deep water below into the foot of the S-shaped rapid already referred to. This necessitates a perpendicular leap of about seven feet, and is as high a leap as any I know of in Scotland. If accomplished, the fish finds itself in a kind of natural trough where there is below the surface a "water cushion" of easy water in which the fish commonly remains for some time before the next attempt is made. The surprising slackness of the water in this trough can be easily tested by any one who knows the place to test. From this vantage point further ascent is made by a most vigorous swim in zig-zag fashion up the S-shaped rapid, successful fish ultimately passing over the crest of the rapid close to the Bonskeid side. A wrong turn means that the fish is at once swept down to the depths below. Only strong fish can overcome the difficulties, but in favourable seasons a considerable number of fish at times manage to succeed in these attempts. A number fail in the first leap, either through not springing high enough or springing in the wrong direction, and in old days this was taken advantage of for the capture of many a plucky fish. A widemouthed basket was hung by a chain from the rock close to where the leap is made, and the unsuccessful fish as often as not fell into the basket, and so suffered the last penalty. The sockets where the attachment of the chain was pinned to the rock are still clearly visible, but the basket, as an illegal trap, has been cleared away many years ago.

One or two other falls in Scotland were also fished in this curious manner, the acme being reached in the case of a basket hung at the fall of the Arkaig, close to Achnacarry House, where, it is reported, matters were so arranged that the salmon not only 
fell into the basket, but in doing so rang a bell in the kitchen to announce its arrival, and, as it were, advise the cook to put the water on to boil.

When the water is at all heavy at the Falls of Tummel fish cannot get to the foot of the fall, and if they could, they would be quite unable to make the ascent. They commonly lie back a little where the water is not too highly aerated, in one or other of two little rocky bays on either side of the lower division of the "Pot." The proposal to erect a salmon pass at this fall must therefore take advantage of this fact, and, if it is to be at all successful, have its mouth close to the lie of the fish, for the best salmon pass in the world is useless if the salmon don't find their way into it.

I may add that the plans for this pass are drawn and accepted, that an engineer has made a careful survey of the ground, and that before this writing is published the actual formation of the pass on the Bonskeid side will either be well in hand or already an accomplished fact. Proposals for the erection of a pass at this fall have been made intermittently for the last forty years, so that the consummation of the undertaking, owing to the agreement between Mr. Barbour of Bonskeid and the Duke of Atholl in the matter of title to fishings, and the action of the Tay District Fishery Board in providing the pass, is now matter of general satisfaction.

In the general description of the river I have referred to the two other obstructions of Dalcroy Dam and Dunalastair Fall. A very considerable extent of water exists between the Falls of Tummel and Dalcroy, which, if the falls are opened successfully, will be regularly peopled by salmon; but to complete the benefit to the district at large in the distribution of spawning fish, the modification of those two barriers is also advisable.

Dalcroy Dam Dyke is by no means a difficulty. At present it is only a partial or temporary barrier. Without much loss it could be entirely removed, or, if this were considered undesirable, might be rendered watertight and a proper gap in the down-stream face provided; the dyke is about 6 feet high. The mill at present is very seldom used and is of no very great value. In any case, with the presence of salmon recognised in the water, it will become a statutory duty to provide for the ascent of the fish. Fish at present reach here in June.

Dunalastair Fall is a much more serious affair, for the difficulty to ascending fish is not much less than that at the Falls of Tummel 
and indeed there is a considerable resemblance between the falls, since there is here an S-shaped rapid of great force, followed by a precipitous drop of the water. Dunalastair Fall is, in fact, a replica of the negotiable part by the Falls of Tummel, but without the higher and more abrupt section of the fall on the right side. The difference of level in the total obstruction is not less than 18 or 19 feet, but the abrupt part of the fall into the pool below is not so high as in the case of the Tummel Fall. From the centre of the rapid to the pool below is about $13 \frac{1}{2}$ feet. A great part of the rock barrier could be removed by blasting, or alternatively a pool-pass could be constructed round a great part of the fall on the left bank.

Even in its present state, however, fish manage to negotiate it. They have been watched making the ascent, and they have been caught in the pools above. Some extremely nice water exists in those upper waters, and I have known of 4 fish being hooked within an hour in the large pool below Dunalastair House. Some excellent spawning ground also exists between Dunalastair and the foot of Loch Rannoch.

\section{RIVER GARRY.}

This river flows out of the loch of the same name, situated within a short distance of Dalnaspidal Railway Station, and flows through Struan, Blair Atholl, and Killiecrankie, to join the Tummel at Faskally, a distance of 22 miles. Loch Garry is fully $2 \frac{1}{2}$ miles long, and has an average breadth of less than quarter of a mile. It is, for its size, a rather deep loch basin with two depressions, one 113 feet, which is the maximum depth of the loch situated towards the northern end, and the other and larger depression yielding a sounding of 105 feet. The loch is about 1320 feet above sealevel and drains an area of fully 22 square miles of steep hill country.

The river from the time it emerges through alluvial deposits close to the outlet from the loch-deposits which cause a shallow area for about half a mile in the loch itself-rattles along over a long succession of schist ledges which dip south-east in the direction of the river. Before Struan is reached (12 miles) one or two abrupt little cascades have been passed, and in all this rocky bed no great amount of gravel is allowed to settle, hence a great part of the upper Garry is of little use as spawning ground. At Struan a double fall occurs in the gorge immediately below the railway station. This double 
obstruction has always been regarded as a serious obstacle to ascending fish, but in 1907 the Duke of Atholl, who owns almost all the Garry, agreed to the modification of both falls, and operations were commenced at the expense of the Tay District Board to facilitate the ascent of fish. Owing to the scarcity of good spawning ground above-for beyond Loch Garry a comparatively short and small stream exists-no attempt was made to entirely open up the falls, but rather, by gradual removal of certain pieces of rock to allow a limited number of fish to ascend. At the spawning time now, as a result of this careful alteration, from 90 to 100 fish may be seen, a sufficient number to occupy all the available spawning ground. The Errichdie, a small tributary which enters on the right bank a short distance below the falls, offers several miles of spawning ground to fish which are unable to make the ascent, but since the blasting operations referred to, it is reported that fewer spawnings are in the Errichdie than formerly.

Passing out of the gorge at Struan, the Garry assumes again for a time an open and rather uniform character, and passes round the wide haugh now occupied in the summer by the training camp of the Scottish Horse; all this water is, however, not of very much account to the anglers either for trout or salmon. At Blair Atholl, the Tilt enters on the left bank. This river drains two of the Duke's deer forests to the north, and until recently was much obstructed. The worst fall was about two miles above Blair Castle, but this has now been entirely removed by blasting, so that fish have a long stretch of spawning ground open to them. In view of the rocky nature of the Garry, the opening of the Tilt cannot fail to be of great value, and from reports as to the result it appears that a good number of fish are already taking advantage of the river during the summer months of the angling season and have been caught by rod. The Tilt enters the Garry with a brisk-running stream which offers a good lead for fish.

In the Garry below this point some attractive casts occur before Killiecrankie is reached, then the channel narrows and has broken rocky banks. "The Soldier's Leap" is a well-known object of local interest, and the large and deep pool below, which can be well seen from the passing train, forms the head of the Pass of Killiecrankie. The famous battle was fought in 1689 in the immediate vicinity of Urrard House, not far from where the railway station now stands. It was perhaps the shortest battle on record, for, from all accounts, the charge of the Highlanders was so impetuous, and the defence of 
General Mackay's royal forces so weak-kneed, that the whole thing was over in two minutes of hard slaying. Mackay himself galloped right through the Highland force and, finding himself clear, turned round to find, as he himself expressed it, that "in the twinkling of an eye in a manner, our men, as well as the enemy, were out of sight, being got down pell-mell to the river where our baggage stood." "All was over; and the mingled torrent of red-coats and tartans went raving down the valley to the gorge of Killiecrankie."

The angler's battle with his fish is generally a longer struggle than that just referred to, unless the fish is a wild one and goes down stream where the angler cannot follow. The usual practice is to hold him very hard, because in this rocky and steep gorge one's movements are necessarily restricted. In moving from pool to pool one has to clamber up to the path above, move along, and then slide down again. One gets a lot of exercise.

I recollect a friend of mine recounting how he took out a man just invalided home from India. It was the Fast Day, and the people going to church saw the invalid hooked to a sulking fish. His tackle was of the lightest, and the fish kept deep down. Some folk did not go on to the church, and some who did, found the man still fast to the sulking fish when they came out. A long-handled gaff could only reach the fish's tail. Eventually victory was secured by suddenly releasing all strain. Whereupon the fish immediately assumed the horizontal position, which just brought it above the gaff point.

The water runs rapidly over a stony bottom where, on occasion, salmon can be seen like ghosts, for so well disguised are they that one almost seems to see the stones through them. A short distance below Garry Bridge, where pools are again deep and rocky, the river sweeps round in a shallow stretch to the junction with the Tummel at Faskally.

The fish which are recognised as Garry fish are really a detachment of the summer fish of the district, although a certain number of the heavier spring fish do penetrate to the deep pools in March. The Garry fish are, however, not expected till May, and are then found to average about $11 \mathrm{lb}$. in weight. Grilse also reach these waters, and although the Pass of Killiecrankie is some 30 miles from Perth, and 50 from the open sea, summer fish have been taken here with sea-lice still upon them, showing apparently that the ascent has not occupied more than four or five days. 


\section{RIVER LYON.}

This river rises from Loch Lyon and the streams above, which have their source on the divide to the east of the Orchy, and flows a distance of 30 miles to the Tay, about 2 miles below the Loch Tay outlet, where it forms the northern boundary of the Taymouth Castle grounds. The Lyon has the distinction amongst Tay tributaries of holding spring fish at as early a date as Loch Tay. Some most attractive water exists in the Lyon, and some of it, moreover, is open to the public who stay at Fortingal Hotel or the Breadalbane Hotel at Kenmore. The best spring fishing is in the 6 miles of water nearest the mouth of the river. Above this, the river descends through a steep defile where one or two cascades occur, and early fish do not pass these for some little time.

The central section of the river, below the Bridge of Balgie, and especially in the neighbourhood of Slatich, is flat and sluggish, being in all probability the site of a prehistoric loch, the waters of which were released when the defile above Fortingal was pierced by ice at the yielding of the glacial period. Some trout of large size are said to be found in this sluggish section, and indeed the whole river has a good reputation for trouting. The scenery below this point is specially fine and perhaps equal to anything in Perthshire, which is saying a good deal when it is recollected that the Trossachs are in the same county.

From Loch Lyon downwards for 12 miles or so, the fishing rights go with the Meggernie estate, and from May onwards this is understood to be a very fine fishing. Any one who has seen the ascent of fish at the Gallan Falls, or Falls of Meggernie, has at anyrate been able to realise the great number of fish which the river holds. These falls are extraordinary, in that the river is divided into many courses owing to the high angle at which the rocks are pitched and the manner in which they fracture. Fish cannot get up during low levels of water, and indeed a more than moderate rise is necessary before they go up in numbers. At such times they pop here and pop there at all sorts of different places, each, as it were, finding the best way for itself; no great number of them impelled to follow one line by the natural conditions of water-flow, yet each having to make quite a series of ascents by means of leaping. When a really high flood is on, the falls must be turned into a long sloping cataract. The falls are 3 miles above Balgie Bridge, and a mile above Meggernie Castle. The water between these two points may be styled 
the best in the river. When the summer fish are up, the Gallan Pool is full of fish and continues so till the end of the season. M'Farlane's Pool, the Neck, and the Fir Pool are also reputed excellent.

Immediately above the Bridge of Balgie there are a series of rapids, at the bridge itself a low fall of between 3 and 4 feet, and round the first corner at the head of the rapids another fall of about the same height. Innerwick Water, which also belongs to Meggernie, but is let, commences at the bridge and goes down for about 5 miles. The lower section of this water consists of the sluggish stretch in the broad part of the glen already referred to as in all probability the site of an old lake. The upper part of the water is, however, of fine character, and at times offers good results, although the total for Innerwick is always far short of that for Meggernie.

At Chesthill, next below, the beauties of Glen Lyon are seen at their best. The central portion is in the thickly-wooded defile illustrated in the photograph, where often the water is deep and rather still in rocky pools, but here also one or two small cascades occur. Emerging from the defile the river opens out in fine streamy character with beautiful gravel bottom at Fortingal, and broken with rocky ledges lower down.

At Chesthill, on the left bank, the fishing, till recently, went with Meggernie, but has now been bought by Mr. Stewart Menzies of Chesthill, although a mile and a half of the land belongs to the trustees of the late Sir Donald Currie. On the right bank the fishings are let to Fortingal Hotel. This section forms beats 3 and 4 of the hotel water. Below this, on the right bank, the rights belong to Lord Breadalbane, down to the mouth of the river. Two fishings are comprised in this stretch, first the Duneaves Water, rented by the late Sir Donald Currie, and let to Fortingal Hotel, forming beats 5 and 6 of the hotel fishings; next, the last 3 miles of this bank is let by Lord Breadalbane to the Kenmore Hotel, and, along with part of the Loch Tay fishings, is kept for hotel visitors.

On the left bank, below Chesthill, comes the Glenlyon Water, which forms beat 2 of Fortingal Hotel. Below this the Garth Water, which goes down to the Keltny Burn and forms beat 1 of the Fortingal Hotel. Below this, Sir Neil Menzies' comes in and follows down the Tay.

Fortingal Hotel has thus six beats in about $6 \frac{3}{4}$ miles of water, 


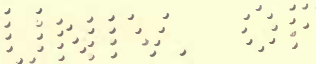

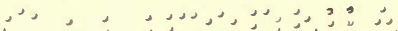

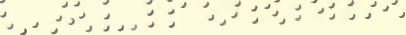

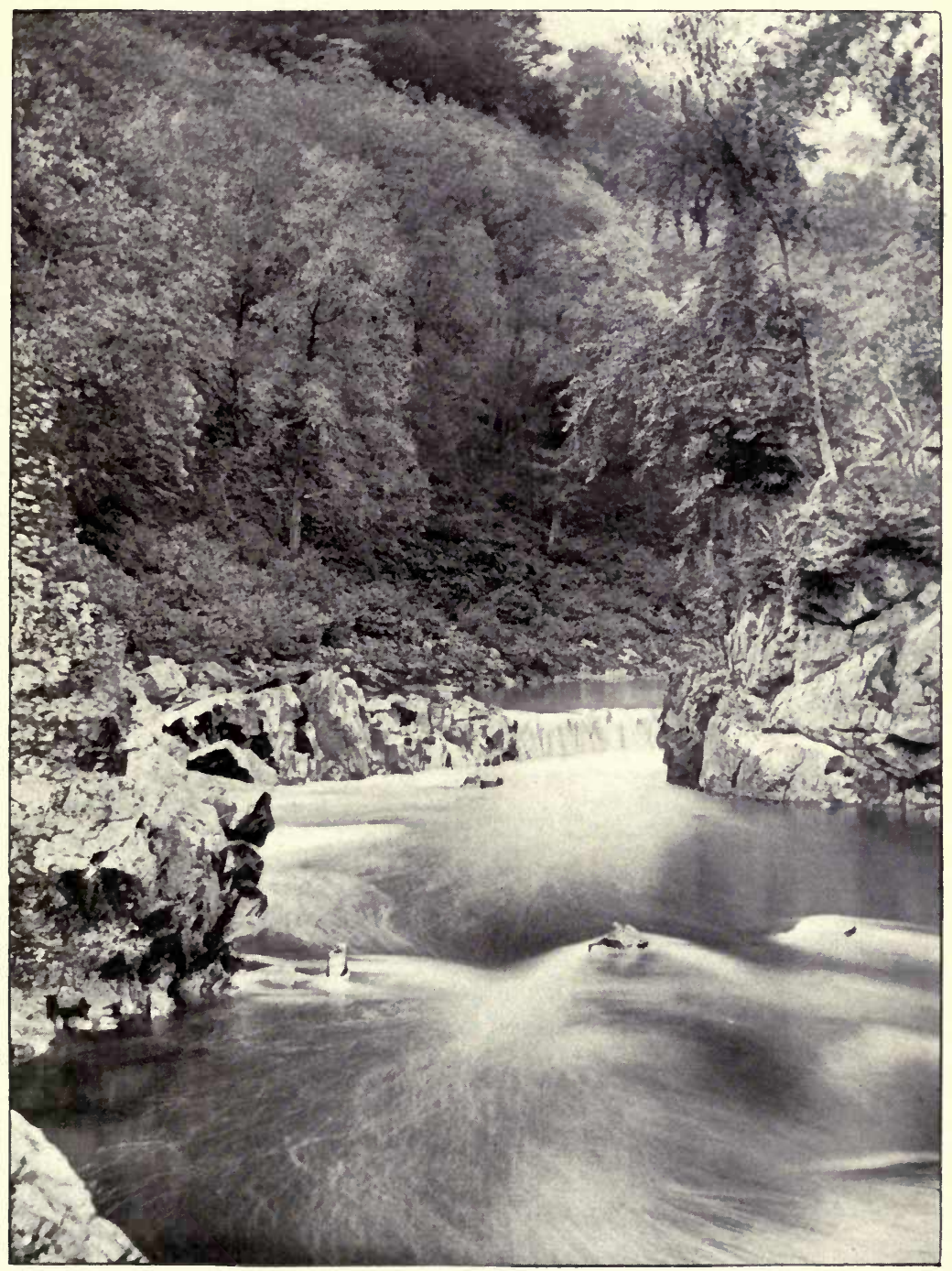

Lyon, Above Fortingal. 

counting both banks. The charge is 10 s. per day per rod. The five lowest beats are fished from 15th January. The furthest up beat is not fished till March. One rod goes with each beat, and spinning baits are largely used till about April, when the fly seems to come into greater favour. Mr. Stewart, the hotelkeeper, has kindly given me the catches for the last four years.

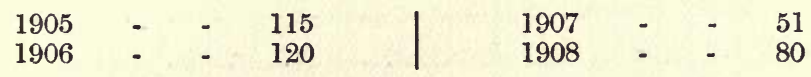

Mr. Geen had 7 fish one day here at the opening of season 1909.

Visitors fishing from the Kenmore Hotel are charged 10s. per fish caught.

In referring to the upper tributaries of the Tay, the Tummel and Garry and the Lyon, mention has at the same time been made of the times at which fish may be first expected in each, and it may be noticed that these times are different. The Lyon has fish as early as Loch Tay, the Tummel receives fish rather later, and the Garry is the latest of the three. Some three years ago I was able to compare thermometric readings from each river, when it became evident that in early spring the Lyon had a temperature practically equal to that of the Tay as it comes from the loch, the Tummel was slightly colder, and the Garry was colder still; in other words, the order in which fish enter these tributaries corresponded with the times at which the temperature of each approached that of the main river.

No doubt the Lyon varies considerably in temperature from year to year, according as the snow lies in the early spring months. If January and February pass without much severe weather, any difference of temperature between the Lyon and the Upper Tay is insignificant, so that, except for the greater volume of water in the main river, there is practically as much inducement for fish to ascend the Lyon as the Tay. Further also, it is found that in extra warm springs fish not only enter the mouth of the Tummel early but ascend that river, and that they are also found up in the Garry at an earlier date than usual.

Subjoined is a chart of curves which shows means of actual readings in the Tay at Grandtully (above the Tummel Junction), the Tay at Perth (after receiving the cold Almond), the Lyon, and the Garry. It will be at once noticed that the Garry curve is constantly lower than the Tay and the Lyon. In January the 
Lyon is seen to be colder than the Upper Tay by $3^{\circ}$, and in February by $2^{\circ}$, after which the two Tay curves and the Lyon

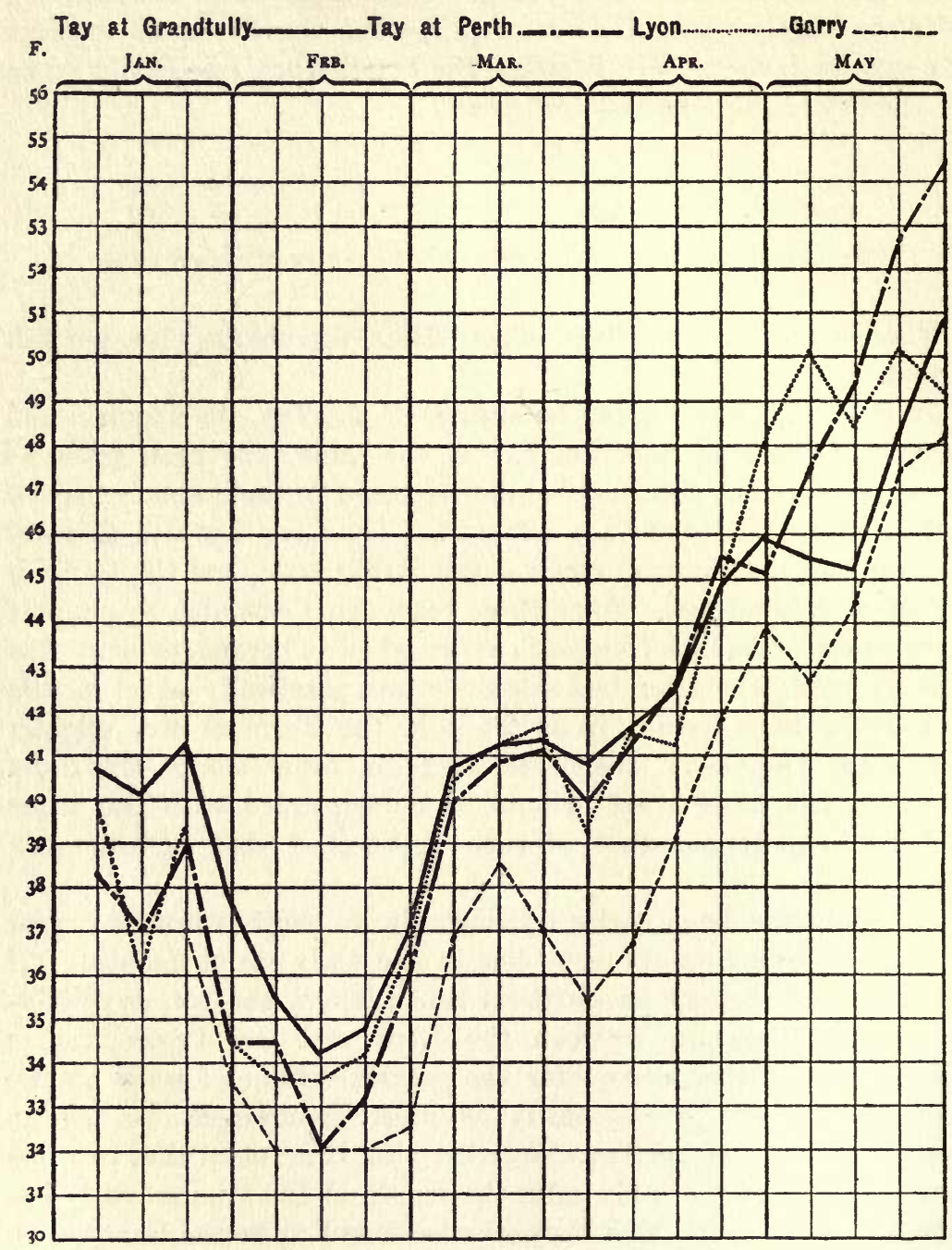

Weekly Mean Temperature of the River Tay, Upper and Lower Water, and Tributaries of Lyon and Garry, 1902.

curve are in close conjunction till the end of April, when, with a mean temperature ranging from $40^{\circ}$ to $45^{\circ}$, spring fishing may be expected to be at its best. 
In seeking to elucidate the bearing which temperature has upon the salmon's ascent of tributaries, it seems clear that we are dealing with quite different conditions from those which govern the ascent of salmon from the sea to fresh water. Once the salmon has entered fresh water, the question of temperature seems to play an important part. The steady ascent of the main river is continued, though early fish certainly pause for considerable periods, and not infrequently descend again, when met by exceptionally cold conditions of water. Tributaries entering the lower portions of large rivers are as a rule passed, by all early-running salmon, but upper tributaries if supplied with good flows of water are entered when their temperatures become approximate to the temperature of the main river, or when their thermal conditions are already relatively high. But it is clear that temperature must be treated in close association with water-flow, and it may be with certain peculiarities of water. Hence it follows that if the cause prompting fish to enter any particular tributary at a particular time is sought (and we are dealing exclusively with fish in which the spawning instinct is still absent), we must study the temperature plus the conditions of waterHow. We find salmon in large tributaries when the temperature is that generally associated with winter and spring; we find fish in smaller tributaries only when the water has lost its wintry character. A certain ratio between temperature and volume would therefore seem to exist, which must be determined in every case; and, given the infinite varieties of the infinite number of tributaries in Scotland, we are not surprised that different localities should present such different results in times and seasons of successful fishing.

This deduction has a most important application with regard to the results which may be expected to follow the opening up of natural and artificial obstructions, since such operations influence neither temperature nor volume. On comparatively small tributaries, while most valuable to enable fish to be more widely distributed over suitable spawning grounds towards the spawning season, such works would not influence the ascent of early fish. Also, in large tributaries, such, for instance, as the Tummel, it seems to follow that if any early fish are to ascend to the upper waters, the pass on the falls must be of extremely easy gradient, since even a comparatively slight obstruction, when the water is cold, is sufficient to check early fish. 


\section{LOCH TAY.}

As everyone knows, Loch Tay has ever been famous as a place for spring fishing where the fish run heavy. The usual weights of fish are or were from 18 to $22 \mathrm{lb}$, and fish from 30 to $35 \mathrm{lb}$. have frequently been taken. A $39 \mathrm{lb}$. fish was got in 1900 at Killin. The fish are caught by trolling and the line is sunk deep, for the loch is deep. The same class of fish are taken in Loch Ness, which, in recent years, has become a serious rival of time-honoured Loch Tay.

In length the loch is fully $14 \frac{1}{2}$ miles; the mean breadth being 0.70 mile. The superficial area is 10.19 square miles, the maximum depth 508 feet, and the mean depth 199.076 feet. $^{1}$

The loch lies in a north-east and south-west direction, and is therefore an example of a valley running along the main axes of the country's formation. It is of extremely simple conformation, the bottom sloping gradually without any pronounced irregularities. The slope is rather steeper at the south-west or Killin end than at the outflow end. "The 50 -feet basin approaches to within less than 400 feet from the south-west end and less than 800 feet from the north-east end, and is $14 \frac{1}{3}$ miles in length." The 100 -feet basin is very nearly 14 miles in length, while the 200 feet basin is about 11 miles in length. The deepest part of the loch is about $5 \frac{1}{2}$ miles from the north-east end of the loch, being between Skiag and Cragganruar, and here there is a small basin 500 feet in depth.

The officers of the Ordnance Survey found the level above the sea to be 347.9 feet on 12th August, 1899. The staff of the Bathymetrical Survey determined the level, by levelling from bench marks, as being $349 \cdot 1$ feet in 1902 . In great part the loch has been hollowed out by ice erosion, although geologists appear to agree that it is not entirely so, since a well-marked fault slants across the north-eastern end and, continuing along the southern side of the loch, is traced through Loch Earn and on to the shores of Loch Vennacher.

A section of water at each end of the loch is preserved by Lord Breadalbane, who owns the right of fishing, but by staying at any of the neighbouring hotels angling can be obtained. Kenmore Hotel has six boats and about 8 miles of water. Killin Hotel has also six boats and 8 miles of water. Those two hotels are situated,

${ }^{1}$ Bathymetrical Survey of Fresh Water Lochs of Scotland, under the direction of Sir John Murray and Laurence Pullar. Scottish Geographical Magazine, vol. xix., No. 11. 
the first at the north-east and the other at the south-west end of the loch. Bridge of Lochy Hotel has three boats and fishes the same water as Killin Hotel. Ardeonaig Hotel has two boats. It is situated about half-way along the loch. Lawers Hotel, opposite Ardeonaig, has two boats and fishes the Kenmore Hotel water. Tighanloan Hotel has two boats and fishes from Tearnan to Ardeonaig.

Provision is also made for a few boats to be fished by those in the neighbourhood who do not reside at one of the hotels, and the reserved water at each end may be fished privately or may be let, so that fully two dozen boats may be calculated as likely to be on the water each fishing day in spring.

A good deal of variation may of course appear in the results of any individual. The hooking of the fish is practically outside the control of the angler. A novice has just as good a chance as a past master. Since also the fishing is entirely done by artificial minnow -a lure which does not readily allow a hooked fish to escapecomparatively few fish are lost if the tackle is good and the reel has plenty of line. There is, of course, any amount of room for a fish to move in, and from all accounts some desperate rushes are to be expected. An average fish of about $19 \mathrm{lb}$. may be a very lively fellow, but a 35 pounder with open water all round him must certainly take some stopping. I have small experience of loch fishing myself, but I can well understand the accounts one hears. Fish up to $40 \mathrm{lb}$. have been taken here, and as to big days, we have records of 10,11, and even 12 having been got on rare occasions. The best week's fishing is, I believe, that scored by the late Colonel Murray of Polmaise on the Kenmore reserved water. $\mathrm{He}$ is reported to have caught $31 \mathrm{fish}$ weighing $600 \mathrm{lb}$., the average weight thus being $19 \frac{1}{2} \mathrm{lb}$.

The charge made for salmon fishing on Loch Tay is identical from whichever hotel the angler puts out. Instead of as formerly making a charge per day, the charge is now made per fish. An angler fishing two rods is charged $£ 1$ per fish, and a maximum charge for a week's fishing is $£ 5$ if more than 5 fish are taken. This arrangement prevents the grumble of the man who fishes steadily for some time without getting fish. Formerly he was paying for the time. The new system is found, I understand, to give general satisfaction. For the reserved water a charge of $£ 8$ per week is made from the opening to 15th April, when the charge is reduced to £5. The best sport is usually obtained at the commencement of the season, and 
by the third week of May the chances are practically past, as by that time the salmon are making their next move, their ascent of the Dochart. As in many other localities mentioned in this volume, the water of the Dochart is, in the early months of the year, not only colder than Loch Tay, but also descends a rocky fall immediately above Killin-a very picturesque fall it is-and this combination is sufficient to stop all spring fish till such time as the wintry thermal conditions have responded to the rising air temperature.

The fishing of twenty-five boats for the first month in 1908 yielded 2.6 fish per boat per day, 56 salmon having been taken. Since the average weight was about $19 \mathrm{lb}$, this is no mean result, and is a better total for this first month of the season than was obtained either in 1907 or 1906.

Through the kindness of Lord Breadalbane, and his factor, Mr. Glen, I am able to give the totals since 1882 to 1907 . The figures for 1891 and 1892 may not be absolutely accurate, since complete returns from every hotel were not available; but Mr. Glen, taking the available totals, has struck an average which no doubt is not far out:

\begin{tabular}{|c|c|c|c|c|c|c|c|}
\hline Year. & $\begin{array}{c}\text { Fish } \\
\text { Caught. }\end{array}$ & $\begin{array}{c}\text { Lbs. } \\
\text { Weight. }\end{array}$ & $\begin{array}{l}\text { Average } \\
\text { Weight. }\end{array}$ & Year. & $\begin{array}{c}\text { Fish } \\
\text { Caught. }\end{array}$ & $\begin{array}{c}\text { Lbs. } \\
\text { Weight. }\end{array}$ & $\begin{array}{l}\text { Average } \\
\text { Weight. }\end{array}$ \\
\hline 1882 & - $\quad 139$ & 2674 & $19 \cdot 25$ & 1895 & - 214 & 3765 & $17 \cdot 9$ \\
\hline 1883 & - 491 & 9679 & $19 \cdot 75$ & 1896 & - 236 & 4513 & $20 \cdot 1$ \\
\hline 1884 & - 240 & 4710 & $19 \cdot 50$ & 1897 & - $\quad 373$ & 7074 & $18 \cdot 4$ \\
\hline 1885 & - 398 & 8167 & $20 \cdot 8$ & 1898 & - $\quad 178$ & 3207 & $17 \cdot 5$ \\
\hline 1886 & - $\quad 379$ & 7652 & $20 \cdot 3$ & 1899 & - 247 & 4629 & 18 \\
\hline 1887 & - 227 & 4385 & $19 \cdot 5$ & 1900 & 79 & $1471 \frac{1}{2}$ & $15 \cdot 9$ \\
\hline 1888 & $-\quad 378$ & 7006 & $18 \cdot 8$ & 1901 & - 153 & $2750 \frac{1}{2}$ & $17 \cdot 5$ \\
\hline 1889 & - 261 & 4925 & $18 \cdot 14$ & 1902 & - 233 & 4252 & $19 \cdot 13$ \\
\hline 1890 & - $\quad 347$ & 6766 & $19 \cdot 5$ & 1903 & -100 & 1683 & 16.95 \\
\hline 1891 & - 381 & 7239 & 19 & 1904 & - $\quad 199$ & 3622 & $17 \cdot 5$ \\
\hline 1892 & $-\quad 351$ & 6318 & 18 & 1905 & - 186 & 3239 & 18 \\
\hline 1893 & - 396 & 8018 & $20 \cdot 3$ & 1906 & - 268 & 5005 & $18 \cdot 9$ \\
\hline 1894 & - 283 & 5439 & $19 \cdot 3$ & 1907 & - 223 & $4003 \frac{1}{2}$ & $17 \cdot 8$ \\
\hline
\end{tabular}

If, for the convenience of securing quinquennial averages, we miss out the first year, the averages are, in chronological order: 345,343 , 300,178 , and 195 . The drop from the third to the fourth average is most marked, and the greatest depth is reached in the year 1900 . This was the year the House of Lords decision put an end to driftnet fishing, and to toot and haul fishing in the estuary; and at the same time the keen competition in net and coble fishing was then largely diminished by the active policy of The Tay Fisheries Company. At the same time 1900 was very cold, and a very low river tem- 
perature seemed to prevent fish ascending as quickly as usual. It was quite a good year in the lower reaches of the river.

It would appear that the stock of spring fish has improved within recent years; and, without actually expressing a definite opinion that the reduction of netting has resulted in the rise shown in the last quinquennial period, the reflection is allowable that the first class of fish affected by over-netting is the spring run.

In the figures it is also noticeable that almost in every year in which the total is poor, the average weight is also poor. The lowest total of 79 in 1900 has also the lowest average weight, and, with one exception, every year yielding less than 200 fish has an average weight of $18 \mathrm{lb}$. or under, so that we have this result:

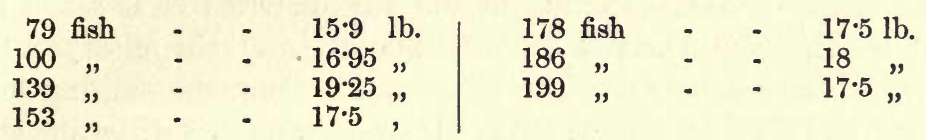

Mr. Augustus Grimble, in his account of Loch Tay, ${ }^{1}$ written in 1900-the worst year-says that the total catch for the loch was 89. I am, of course, not in a position to say if the estate record is incomplete, but even if 89 be the total instead of 79 , the season is still the worst on record.

I expect that the figure 139 , which breaks the sequence, was capable of some explanation, for after 1882, the year when it occurred, no similar total appears for sixteen years. This appearance of few fish and at the same time light fish, is quite in accordance with netsmen's experience in catching grilse. If when grilse begin to appear the weights are light, old fishermen generally prophesy a short year, and this is one of the few fishermen's prophecies I have never seen fail. Further, if the stock of grilse is deficient the next season's stock of small spring fish is also deficient, and no doubt the following years are affected in the same way from the same cause, although, thanks to the divided migration of the salmon, results are often not quite so obvious. Only slowly, however, do bad years become a little less bad and good years a little better, if we review a number of years at a time. The proportion of breeding salmon in any year is not perhaps very great compared to the stock of fish in the sea, so a reduction of actual breeders is a serious factor, recovery from which is not rapidly secured.

1 The Salmon Rivers of Scotland, vol. iv. p. 164. 


\section{THE EARN.}

Angling Season: 1st February to 31st October. Netring Season: 5 th February to 20th August.

It has been contended that the Earn is a quite separate river from the Tay, since it has a separate close time, being recognised as a late river and because it has a separate entrance, coming into the Tay estuary at a point where that estuary is 2 miles broad at high water. There is something wrong about the geography of the Tay estuary if this last statement is true. As a matter of fact one has to go about half way to Dundee, about seven miles below the mouth of the Earn, before the Tay estuary is 2 miles wide.

The Earn is most certainly in the Tay district; it is also supervised by the Tay District Fishery Board; and the close time for netting is the same as the Tay close time. Only the angling season is later, and that by a fortnight. It is a large river, entering the tidal area of the Tay at what may be described as the foot of the upper, narrow, and river-like section of the estuary. It is itself affected by the tide for quite 10 miles. It is netted by net and coble about three miles up from the mouth to a bend of the river called the Carey Hole, and very occasionally, I believe, at Elliothead, which is 5 miles up. The quiet, even character of the lowest stretch of the river is well seen as the North British train to Perth crosses the flat ground beyond Bridge of Earn before reaching the Perth tunnel.

The river rises from Loch Earn, a sheet of water fed by several comparatively small streams, none of which, owing to their steepness can be regarded as salmon head waters except for spawning purposes. It flows down the wide Strath Earn past Comrie and Crieff to Dupplin and the tidal reaches already referred to, a distance, includ the many windings, of 46 miles.

Loch Earn is nearly $6 \frac{1}{2}$ miles in length and over half a mile in mean breadth. It is a beautiful loch as one looks from the St. Fillans end to Ben Vorlich on the left, or as one looks across it and up Glen Ogle at Lochearnhead. The style of scenery is that of a large loch. One always seems to understand that Loch Earn must be quite 12 miles long. There is nothing trivial or detailed in the landscape. The whole is composed in broad masses, with simplicity and not a little sweetness, and yet with grandeur. We have here a large loch in miniature.

In formation it is a simple basin, having its greatest depth 
approximately in the centre and shallowing gradually in all directions. The greatest sounding found in Sir John Murray's survey was 287 feet. Previous to this, I believe, its depth was believed to be 600 feet "in many places." The floor of the loch is below 250 feet in depth for a distance of nearly two miles, and the 200 area is $4 \frac{1}{2}$ miles long.

The very regular nature of the basin is shown by the fact that " of the entire lake-floor 39 per cent. is covered by less than 100 feet of water, 31 per cent. is covered by water with depths between 100 and 200 feet, and 30 per cent. by water exceeding 200 feet in depth." 1 It cannot be said to be much of a loch for salmon, although a fish is occasionally taken. I have seen newspaper accounts of salmon being taken quite early in the season, but I have a suspicion that the fish must have been very lean, and with a good many maggots in their gills.

There is no doubt that a number of fish enter the loch, but they do not do so as a rule till late in the season, when salmon lochfishing is useless. I recollect on one occasion I essayed from Lochearnhead to catch something on a good-sized phantom minnow. In the hotel before starting I got one of the hooks of the tail triangle up to the bend in my forefinger. One cannot pass the hook of a triangle right through, so I just had to harden my heart and cut it out. When I did get the thing going in the loch, I caught one small trout about half as big again as the phantomsmelt my blood on the tail hook I suppose. I have cut out more than one hook from the fingers of other people. I prefer that operation.

The river issues from the loch at a level of 306 feet above the sea, or practically 50 feet lower than Loch Tay. It is for several miles a beautiful if rather small gravelly stream, flowing largely through varied woods as far as Comrie. Here it is joined by the Ruchill Water, an important tributary, which flows in a north-easterly direction through Glen Artney. Four miles up, the Ruchill becomes extremely rocky, and is deeply cut in a gorge. Serious falls for long obstructed the further passage of fish, but of recent years these have been modified with considerable ingenuity and made passable, so that a fair number of salmon are now taken above, and a valuable extent of spawning ground opened up. About 50 fish were taken above the falls the first season after the operations (1901). Other tributaries

1 “The Survey of British Lakes," Scottish Geographical Magazine, vol. xviii., No. 8, p. 416. 
of the Earn are the Lednock and Turret on the north, the latter having impassable falls, and the Machany, Ruthven, and May on the south, but none of these is of any account for salmon fishing. Drummond Castle, Dunira, and Aberuchil hold the highest stretches, although trouting below Loch Earn may be enjoyed by stopping at St. Fillans Hotel.

Below Comrie come the Lawers and Strowan estates, on the left and right banks respectively, then on the left bank Ochtertyre and Ferntower, still opposite Strowan Water.

Below Crieff Bridge, on the right, the Drummond Castle private water extends down to Colquhalzie (pronounced Cohiley), about four miles, while on the opposite bank Lord Ancaster also holds the rights for 2 miles, this portion being let. ${ }^{1}$ Below the bridge on this bank and above Lord Ancaster's water there are two short stretches of about 200 and 440 yards held by separate proprietors, and below the water referred to another small stretch of about 300 yards comes in before Strathallan water is reached, after which Auchterarder and Gleneagles take us to Dalreoch Bridge. On the right bank, below the Drummond Castle water, we have Colquhalzie, Strathallan (there being a bridge here at Millearn), and Trinity Gask.

Below Dalreoch, on the left bank, the fishings are Duncrub, Invermay, and Upper Dupplin, till Dupplin Dyke is reached, the waters on the right bank are Gask and Upper Dupplin. Below this all too-important dyke Dupplin fishes both banks for some little distance, that next the dyke being styled the Reserve Water-the most productive water on the river-the other being called the Lower Water. Below this, Freeland fishes both banks, and then Dunbarnie and Moncrieffe face each other above Bridge of Earn. Below the Bridge of Earn the Earl of Wemyss has the fishing to the mouth, with the exception of a quarter of a mile just below the bridge, which goes with Kinmouth. On the left bank, Kilgraston and Moncrieffe, Carey and Cordon, share the fishing with Lord Wemyss.

There is much fine water in the Earn, but, unlike the larger Tay, fish have not facilities for reaching it. Quite a series of bad dykes exist to prevent fish becoming distributed throughout the water till comparatively late in the season. The lower reaches of the river are such as would naturally induce a fair proportion of spring fish to enter, but with conditions as they are at present, they cannot be said

${ }^{1}$ Tickets for the season or shorter periods can be had at the Drummond Arms Hotel, Crieff, and elsewhere. 
to do so. The tacksmen of the netting stations find that their fishing does not pay wages till about the end of June, and as a consequence the river may be said to be clear of nets in spring. The Earn actual period of regular netting is therefore practically July, and the three available weeks of August. Two or three spring fish are generally got on the rod in the middle reaches of the river, showing, as it seems to me, the possibility of better things, but such fish must undoubtedly ascend very early before the temperature of the river water has fallen sufficiently to make the various and serious obstructions of the river act as checks.

It is believed by many that the reason why spring fish do not ascend the Earn at all freely is that the temperature of the river water is lower than that of the Tay. I know of only one paper which gives actual thermometric readings, ${ }^{1}$ and these are somewhat limited, being monthly means for 1888 , as compared with the Tay and Almond. It is interesting to note the figures for the five first months of the year :

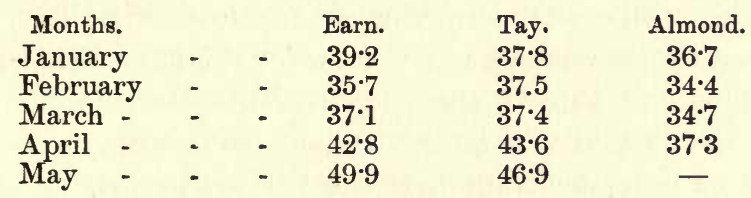

From these it would appear that during the early months of this particular year, the Earn has greater fluctuations than the Tay. As compared with the Tay, the Earn temperatures are $1.4^{\circ}$ higher in January, and $3^{\circ}$ higher in May, but slightly lower in the three other months mentioned. The Almond, it will be noticed, is consistently lower in temperature than either the Tay or Earn. In this connection it is necessary to state that the Earn readings were taken at Bridge of Earn, which, as already seen, is within the tidal area; so that it is just possible that some influence of the Tay may have been allowed to affect the results. But certainly from the limited amount of data to go upon, there does not appear to be any sufficient distinction in temperature to account for the absence of Earn spring fish. A more important factor is perhaps the predominating volume of Tay water, which acts as an inducement to incoming fish to pass the mouth of the sluggish Earn.

Tributaries entering the lower portions of large rivers are, as a rule, passed by all early-running salmon; but upper tributaries, if supplied with good volumes of water, are entered when their tem-

${ }^{1}$ H. R. Mill, British Association Report, 1891. 
peratures become approximated to the temperature of the main river, or when their thermal conditions are already relatively high. Temperature in this connection must be treated in close association with volume of water. The volume of the Earn is greater than that of many spring rivers, and its temperature does not appear to be unduly low; but it has the Tay to compete with at its mouth, and for reasons to be described it has an insufficient stock of fish. Between Dupplin and Earn mouth the river winds about like the Forth. At one point, near Forgandenny, a great loop has been cut off, and in course of time other loops will no doubt be cut off. As the crow flies, the distance to Dupplin is 9 miles, but by the course of the river it is 14 miles.

At Dupplin the first dyke occurs. This is a cruive dyke which not many years ago was fished to the great detriment of the river in general. The cruive box habitually had a rush of water through it so heavy that it was seldom, even when the heck was off, that fish could freely pass. I have seen fish lying so closely packed at the sides of the white water rushing from the cruive box, that their back-fins and tails were out of the water. I have lifted fish out by the tail here and thrown them up over the obstruction. Needless to say, at such times the river-watchers have always to be on the spot. By an agreement amongst the various proprietors, this cruive is now disused, and a pass has been constructed round the right-bank end of the dyke. I am told that numbers of fish go through the pass, and also that numbers of fish go over the dyke as they used to do whenever the water-level is suitable for them to do so. It is the presence of this dyke which is still responsible for the great collection of fish at the end of the season in the Dupplin Reserved Water, and for the great value of this fishing. Hence the very material difficulty of regulating the fisheries of the Earn in the general interest.

And even if Dupplin Dyke were totally removed it would at once become necessary to deal with the somewhat similar structures further up. Strathallan, Millearn, Colquhalzie, and Bridgend or Cook's Dykes have still to be negotiated, and there is not a pass at any one of them. Another dyke formerly existed at Dornock, below Crieff, but the two mills which derived water therefrom practically fell into disuse, and a merciful flood managing to make a breach in the structure, Lord Ancaster, to whom it belonged, allowed the natural gap to remain, and to be enlarged by subsequent floods. Strathallan, like Dupplin, is a cruive dyke, the others supply water to 
mills. Below each obstruction fish have to stop till the condition of water-flow permits them to continue the ascent. This is a serious thing when the great majority of the fish become fairly heavy with spawn. Carefully considered suggestions have been made from time to time for the modification of all those dykes, but up to the present these have not been acted upon, and the salmon fishing suffers in consequence.

As a result of the many obstructions, and, I think, as a result of nothing else, fishing in the upper reaches is practically confined to September and October. Without any doubt all this beautiful river would fish well throughout the greater part of the season if it only had a chance, and I should imagine that with rents as they now are, salmon angling might very easily be more remunerative than the small mills or the cruive fishing. It is noteworthy that wherever in Scotland the owner of cruive fishing rights has also the whole interest in the angling above, the cruive dyke has been abolished or rendered harmless. In this way, for instance, all the cruives in the County of Sutherland were removed many years ago; the Ugie cruives are kept open, the Beauly cruives are kept open, and so on. I have no doubt a time will come when the Earn cruives will also be opened up. The general interest demands it. There is little hardship if compensation in good angling is secured to the holder, or otherwise if compensation in hard cash is forthcoming from those who will obtain the good angling.

With regard to the product of the Earn, at present it has to be further realised that a dry or a wet season make all the difference between a bad and a good autumn fishing in so far as the water above Dupplin is concerned. A flood may let fish over Dupplin and have fallen away before they can ascend Strathallan, or they may ascend Strathallan and be unable to get over Colquhalzie, and so on. Only stage by stage can they ascend the river. Under these circumstances the results in the reaches near Crieff are liable to great fluctuation. Striking a somewhat rough mean in the fluctuations which I know have existed recently, I estimate that the annual produce to the rod is about 330 fish, of which Dupplin Reserve Water has by far the greatest share. Lord Kinnoull has very kindly allowed me to publish this Reserve Water Catch for the last six years :

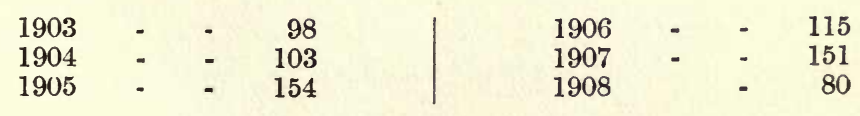


At Dupplin the hatchery of the Tay District Board is situated. It is not of great size, but is compact, and supplied with excellent water. The number of ova laid down has varied from about 130,000 to 530,000 , and the practice has been to rear a certain percentage of the fry at Stormontfield above Perth. The Board have now, however, abandoned all hatching, in the belief, I understand, that the number of fry hatched in a district such as the Tay was quite inappreciable, a view with which, I may say, I entirely agree. 


\section{CHAPTER IV.}

\section{RIVERS NORTH ESK AND SOUTH ESK.}

Angling Season: February 16th to October 31st.

Netting Season: February 16th to August 31st.

The District Fishery Board of each river sits in Montrose.

Clerk for North Esk: J. R. Findlay, Solicitor, Montrose.

Clerk for South Esk: D. S. Campbell, Solicitor Montrose.

THese two Forfarshire rivers have great possibilities in their yield of salmon at all seasons of the year. The coast in the immediate neighbourhood is more heavily netted than any part of Scotland. The estuaries are not large, and nets are therefore allowed fairly close to the river mouths. Yet the salmon are, and have been for many years, a rich harvest, although a decided decrease is alleged.

Both rivers have in the past been much obstructed by the erection of dam dykes, but for the most part these have now been modified for the benefit of ascending fish. At their sources each river springs from high country of rather Highland character, but each in the greater part of its course flows through undulating pastoral and cultivated land, often richly wooded. Long stretches of beautiful spawning ground exist; at other parts the water is sluggish, the banks overgrown with a tangle of vegetation, and the bottom inclined to be muddy. The latter conditions are frequently brought about or accentuated by the dam dykes being placed where the natural gradient of the river is slight. Of the two the South Esk is the more prone to this characteristic, and in its course it is flatter and more given to winding.

\section{RIVER NORTH ESK.}

The mouth of this river is three miles north of Montrose in an open sandy bay. Large sand dunes are piled up all along the shore above 
high water mark by the action of sea and wind, while at the back of these sand hills the land is flat for fully half a mile inland. Half way between Montrose and the North Esk the southern boundary of the district occurs, the northern boundary being nine or ten miles up the coast at Gourdon. There are fully 120 nets fished in this stretch of coast, and they are chiefly concentrated in St. Cyrus Bay and the stretch just north of the river mouth. The nets are much outrigged one on end of the other, so that one may see two or it may be three fly nets set on poles sunk in the shelving sandy beach, one beyond the other, and, outside of these, one or it may be two bag nets, i.e. five or six nets in a line end to end. These nets and bag nets, it may be explained, are precisely alike in principle, but the former are adapted for fishing smooth and shallow beaches between high and low water mark, while the bag nets are floated to moorings in deeper water. It has been estimated by one arguing in favour of the positions of those nets that the ranges of netting are not closer to each other than 500 yards.

The shore frontage where these nets are set is of great value, although in recent times there has been a slight depreciation. In 1884 the rental for nets outside the North Esk estuary was $£ 4795$. In 1894 it was $£ 3636$, and in succeeding years after that $£ 3954$, $£ 3872, £ 3827, £ 3776, £ 3636$, and in $1900 £ 3753$. The rental for

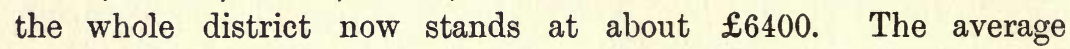
number of boxes of salmon sent from Rockhall Fishery in forty-six years is 195 .

The estuary is drawn as an arc of a circle of 400 yards radius from the centre of the river at low tide equinoctial spring tides, and owing to the sandy nature of the shore this estuary is liable to variation through the shifting of the river mouth. A large lagoon exists behind the dunes just north of the present river mouth, and having a separate entrance to the sea practically a mile away from the present river mouth. This was at one time the course of the river, and some curious stories are told of how it ceased to be the mouth. It is sufficient here to say, however, that the North Esk now runs straight into the sea from what is called the North Water Bridge. I have no doubt the straight mouth is much better in the general interests of the river than the old mouth.

Four miles and a half up from the mouth Marykirk Bridge occurs, and a short distance below this a dam dyke, called Craigo Dyke, exists. Net and coble fishing has for a great many years been steadily carried on up to this bridge. Three or four years ago an 
attempt was made by Lord Dalhousie, who owns all the head waters of the river, to modify this netting by taking a five-years' lease of the nets down to a certain point. It is to be feared, however, that since boats' crews were hard at work below, were perhaps much harder at work than formerly on account of the competition, the success of the endeavour has been very partial. The upper proprietors would fain have all river nets removed and the obstructions opened up, but it would appear from a well-organised effort lately made, that to carry through a project of this kind in the North Esk district is not an easy matter.

The first obstacle in the ascent of the river is Morphie Dam Dyke, by means of which, through the Kinnaber Lade, water is carried to Montrose. One hears a great deal in the district about the objectionable character of Craigo Dyke. The evidence of the upper proprietors before Lord Elgin's Commission was almost entirely directed to the need for the opening up of Craigo; it is the bete noir of the upper heritors. A pass at Craigo which will be of real service is badly needed, but it is perhaps almost as important that a better pass be also erected at Morphie. When all the netting below Craigo was in one hand, fish might or might not be netted at Morphie. If fish ran the Morphie Dyke they could be got below the Craigo Dyke. When, however, one party fishes from Craigo down to just above Morphie and another party fishes from Morphie to the sea, as is the case at present, the effect of Morphie Dyke as a check to the ascent of fish is such that by steady fishing in the lower section a proportion of each run of fish is not allowed to pass. It is significant that the Morphie netting is rented at $£ 1010$ a year, and Craigo at $£ 400$. The number of spring fish netted at the opening of the season at Morphie Dyke is sometimes enormous. A good fish pass at Craigo would not help this one whit. The pass at Morphie Dyke has been described as probably affording as easy an ascent as is possible in a pass of the kind, but the pass is of a poor kind. Moreover, it would be very easy to construct a pass of a much better kind. I do not mean to argue for a moment that the commercial fishings should be sacrificed for the sake of sport, but in the North Esk the commercial fishings keep the stock of breeding fish low and to this extent are injurious to the best interests of the river. It happens incidentally that if more fish are allowed up to breed, the rods above will have the first benefit. The North Esk should really be a splendid spring fishing river.

An arrangement has recently been come to by which Middle 
Morphie Water is not netted for the first month of the season. In this first month in 1909 reports showed that Lord Dalhousie and party took 75 fish. They twice got 20 fish in a week, and had a day of 12 fish, on Friday, 19th March.

The pass in the Craigo Dyke, or the goil as it is locally called, was erected in 1867 under the supervision of the Court of Session. On the merits of this goil I do not propose to enter. Its every feature has been studied and fully described elsewhere, and this is not intended to be a contentious treatise. I may refer, however, to some interesting evidence given about it before Lord Elgin's Commission, from which it appears that in February, 1881, the structure was broken down by floods, and that it remained in this brokendown state till the summer of 1882, "and during that time," says a witness representing the upper interests, "we enjoyed wonderfully good fishing. Personally, I caught 23 fish in seven days' fishing in a bit of water 200 yards long, and I have not caught 23 fish altogether since." This was said in 1900. The witness continues, "As a matter of fact, in that year at least 220 fish were killed, 100 in Millden Water, which is six miles above the Loups, and 120 in Invermark. Mr. Shiell, who is Lord Dalhousie's factor, says that there were 300 that year. The usual catch is two, three, or four. . . I can prove that one man alone caught between 50 and 60 to his own rod above the Loups when the Craigo dam was breached." This evidence is not only extremely significant as to the usual effect of Craigo Dyke, but also indicates what the value of the upper waters might be if the fish had better chance to ascend.

It is contended by some in the district that if the regulations of the Salmon Fishery (Scotland) Act, 1868, respecting salmon passes were rigidly complied with at Craigo, the dyke would offer a greater obstruction to the passage of salmon than it does at present. This is not flattering to the Salmon Acts, but no doubt it would not be difficult to suggest a pass of a much better type than the one indicated by Schedule $G$ of the Act referred to. As a matter of fact, a plan of a quite good pass is in existence, drawn specially for Craigo. The difficulty is the consent to its erection. I have no hesitation in saying that the dyke in its present form is much against the best interests of the river, and that if the North Esk was owned entirely by one individual, or owned by a number of proprietors who unitedly strove for the best interests of the salmon fisheries, this dyke and Morphie Dyke would long ere this have been rendered easily surmountable to salmon. 
The line which separates upper and lower proprietors is "aran "wn across the ford above Fluke Hole, from the east end of the land embankment on the right side of the river, to the pigeon house under Kirkside plantation, on the left side of the river." This defines six fisheries as lower proprietors' fisheries, and twice that number as upper proprietors' fisheries, and as the average value of a lower fishery is fully twice that of an upper fishery, the greatest monetary interest remains with the proprietors of the coast and estuary-Brotherton and Lauriston, Woodstone, Kirkside, Kinnaber and Charleton, Rockhall, and Comieston, but a part of Kinnaber is in the upper waters.

It will be gathered that owing to the netting of the lower reaches, rod fishing in spring and summer is here not thought of. I have no doubt, however, that if the netting was stopped, a most valuable spring rod fishing would grow into being, and the experience of, say, the Dee, and of other rivers I could name, goes to show that from the point of view of mere profit to the proprietor, rod fishing pays better than netting. As a large proprietor on the Dee once said to me when discussing this subject: "No one but a fool would now think of putting in a net here." The course would also have the very great advantage of benefiting all proprietory neighbours above, and perhaps even of bringing harmony into the fishery councils of the district.

A very considerable success attends the autumn angling in those lower reaches, during the two months after the nets come off till the rod fishing ends, 31st August to 31st October. The number of fish taken in this period during the five last years was :

$\begin{array}{cccccc}\text { Year. } & & & \text { Salmon. } & \text { Grilse. } & \text { Total. } \\ 1908 & - & - & 379 & 73 & 452 \\ 1907 & - & - & 209 & 39 & 248 \\ 1906 & - & - & 149 & 114 & 263 \\ 1905 & \text { - } & \text { - } & 207 & 55 & 262 \\ 1904 & - & - & 163 & 99 & 262\end{array}$

The heaviest fish taken on the rod in 1907 was $37 \frac{1}{2} \mathrm{lb}$. It was taken at Craigo, but in that season quite a number of fish approaching this weight were taken at other parts of the river. In 1908, the heaviest rod caught fish was $34 \mathrm{lb}$. In 1904, $37 \mathrm{lb}$. was the top weight-there having been nothing so heavy in the intervening years. In this year, also, a $58 \mathrm{lb}$. fish was taken in the coast nets of the district, and a $40 \mathrm{lb}$. fish in the sweep nets of the river.

With regard to the earlier fishing on the river above Craigo, it will be understood from what has already been said that the run of 
fish : edeperds treryimuch on the water-flow at the obstruction in question. If fish are able, owing to early floods, to surmount the dyke-which they mostly do at the extreme north end-the pools above become occupied to a greater or less extent. If dry weather prevents this, the fish are sooner or later netted out.

Only one other obstruction occurs in their further passage, viz. The Loups, i.e. I presume, the places where fish have to loup or jump. Before reaching The Loups at The Burn, fish pass the fishings of Kirktonhill, Gallery, and Pert, Balmakewan, Inglesmaldie, and Kinnairdie, Stracathro, Edzell, and The Burn and Arnhall. The Loups, as the writer has seen them, are not very formidable, being cascades in a rocky gorge. With the deep water which exists below, autumn fish will easily surmount the obstructions in suitable water-flow, and once past The Loups fish have a run of 15 miles to Loch Lee, all of which water is fished by Lord Dalhousie. On the West Water, a tributary of considerable size entering from the south-west at Stracathro, loups also occur, situated from the sea about the same distance as The Loups of The Burn.

\section{RIVER SOUTH ESK.}

This river rises in the extreme north-west of Forfarshire, in the high lands of Glen Doll, where the White Water issues from its springs close on three thousand feet up, and descends to beautiful Glen Clova. The source of the Isla, which drains into the Tay at Meikleour, is only some three or four miles to the west.

It is a comparatively small stream which descends Glen Clova, nor is it swelled by many burns in its run of about seventeen miles to Cortachy Castle. Here, however, it is joined by an important head feeder, the Prosen Water.

From the junction downwards, the river becomes of some size, though in summer it dwindles away to a rather serious extent, and flows other 20 miles to Montrose Basin, where it becomes tidal, finding outlet to the sea at Montrose itself. Only one tributary of size similar to the Prosen enters the main river in this its main course, viz. the Noran Water, which, rising in Glen Ogil, north-west from Tannadice, enters the main river on the left bank about midway between Tannadice and Brechin. The entire drainage area is about two hundred and forty-five square miles, and a great part of the river, as stated at the commencement of this chapter, is of a very flat gradient.

The South Esk is a river in which great improvements have been 


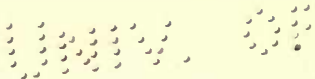

$$
\begin{aligned}
& \therefore
\end{aligned}
$$

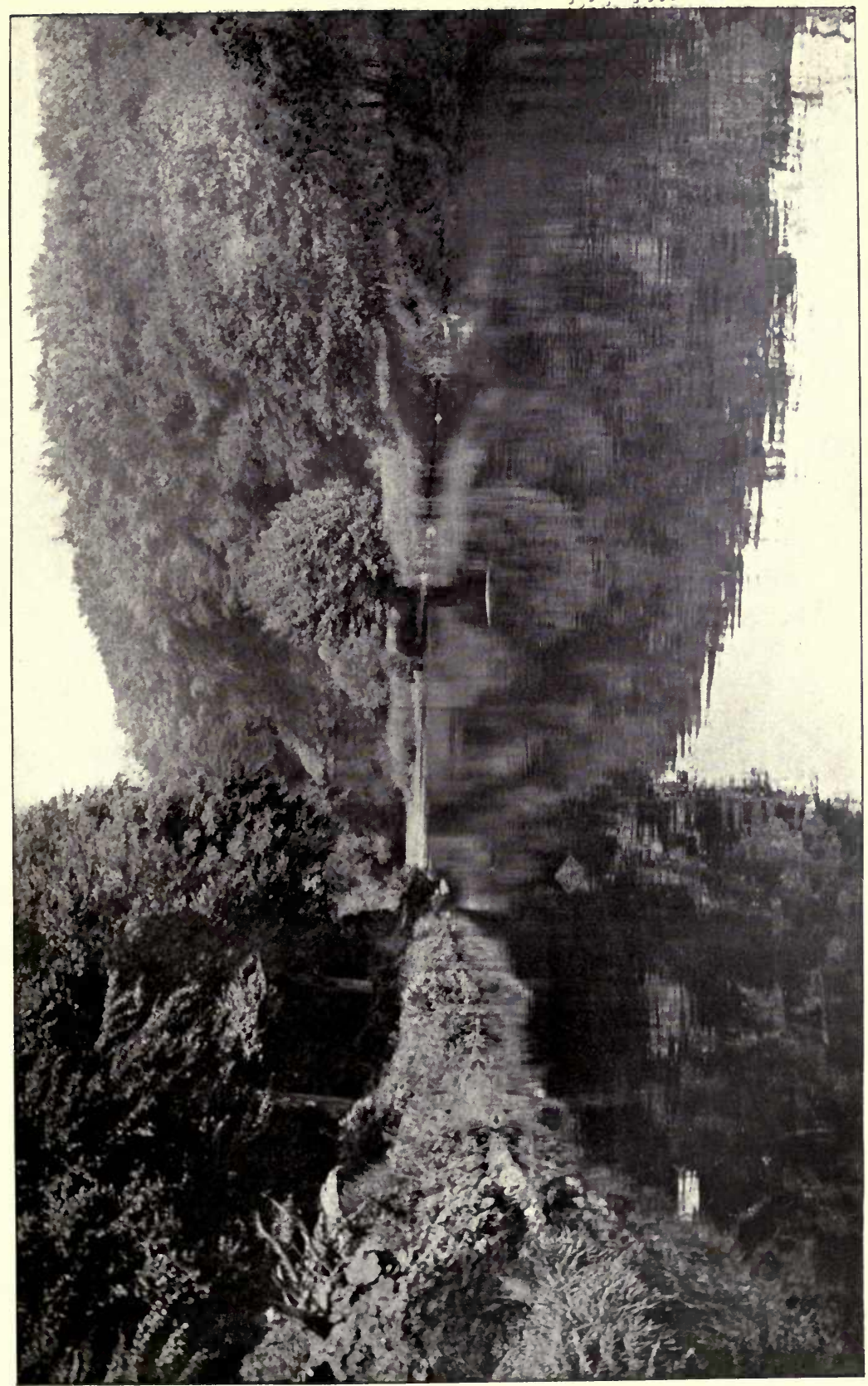

完 


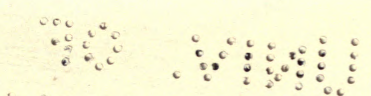

and 
made during recent years. Three elements combined to fatally retard the stock of fish in previous days-over-netting, eight dam dykes, and pollution. The proprietors of the district have combined to combat all three, and with considerable success. In 1897 all nets were removed from fresh waters and from the upper part of the tidal estuary of Montrose Basin, and in 1906 the agreement was continued for another term of years. Netting, therefore, now ceases at Rossie, about two miles up from Montrose. This netting which remains is steadily worked all along the southern shore of the estuary, and during about two months in summer some sweep netting is also carried on on the north shore. The actual limits of the estuary are a line drawn "from Scurdy Ness to the outermost point of Scurdy Stone; thence a straight line extending due north 500 yards; and on the north a straight line to be drawn from the lastnamed point to a point at high-water mark, spring tides, 800 yards distant from the low lighthouse, the distance to be measured in a straight line." Fixed net fishing, therefore, ceases at this line. When referring to fixed nets, it may be mentioned as a matter of interest that the one and only stake net, properly so called, which now exists on the coasts of Scotland outside of the Solway, is on the South Esk shore at Bodden, about three miles south of Montrose.

In former days net and coble fishing in the river was carried on right up to Brechin, to the foot of a weir which there stopped fish, and thus enabled the netsman to feel, I imagine, the satisfaction of the man who has worked out his job to a point of completeness. Brechin Dam was, as it were, the Craigo of the South Esk. Some sixteen nets were fished in the 5 miles of river below Brechin, although I suppose a couple of crews could have secured all the fish had there been no competition. As a matter of fact two crews have, in about four and a half miles of river, got 878 salmon, 488 grilse, and 4766 sea trout in a season. It is needless now to give other figures concerning netting which no longer exists, but I may mention that more than once, over 5000 sea trout were taken, which reminds me to state that the South Esk is naturally prominent as a sea-trout river. In all probability the attractions of Montrose Basin is a factor in the abundance of a fish which is much more estuarial in its habits than the salmon.

Brechin Dam Dyke was opened up to the better ascent of fish in 1894 , and with the removal of the nets three years later, an important step in the interests of the river was secured. The pass is of easy gradient round a small island and the end of the weir, at the 
right bank of the river. Two other dykes exist below this point, the first at Kinnaird, the property of the Earl of Southesk, and the other at the East Mill, Brechin. The Kinnaird Dyke is a large structure, but it has a fish pass which is reported to answer its purpose well. The East Mill Dyke has also a pass, but is very leaky.

Above Brechin, about a couple of miles, the Blackie Mill Dyke occurs. This structure had to be rebuilt not long ago, and the fish pass was then conveniently omitted, but the District Board have now got this matter put right; but the dyke is only 4 to $4 \frac{1}{2}$ feet high. The river is considerably broken up in different channels, but after these unite a great pool occurs, which has received a good deal of attention by "croy" building on a fine gravelly bottom. The corner of the river next below is a favourite one with the pearl fisher. The other weirs are at Finavon, Murthill, Craigessie, and Cortachy. The second and last named of these are unprovided with fish passes, but the obstructions are not of great moment, and the District Board do not consider passes necessary.

With regard to the third factor, that of pollution, there is still considerable difficulty. The impurity comes almost wholly from the town of Brechin and its sewage farm. This farm is about a mile below the town on the left bank and occupies a small haugh at the side of the river. It may at one time have been sufficient to deal with the sewage of Brechin, but for several years it has been quite inadequate; the land has become sewage-sick, and the effluent to the river-which enters a large and rather still pool-is most impure. The whole place advertises its position for a considerable radius by the objectionable odour, and no self-respecting fish would remain in the water immediately below. In low-water conditions a horrible scum floats on the surface of the pool referred to, and the side of the river near the outfall is loaded with sewage fungus. Certain proposals for improvement are now under consideration.

The Kinnaird fishing begins at the foot of this pool in a thicklywooded stretch of water, represented in the photograph. No doubt the success of the lower water angling depends much on the condition of water-flow. The whole river indeed, owing to the rather easy gradient, and the weirs, is much benefited by a rainy season, and the pollutions are at the same time minimised in their injurious effects. In 1907, for instance, 200 spring fish were taken on Kinnaird Water alone. In $1908 \mathrm{I}$ believe the tenant could not score up many more than would be represented by the two first figures alone. This is a rather violent fluctuation; but some good 
scores have been made in the spring ere this, and no doubt will be again, in Kinnaird Water. The spring fishing in the North Esk would be just as good if the nets were off.

Above Brechin as far as Tannadice, 12 miles, the river has a tendency to flow with too great uniformity; there is rather too much smooth gravel-bed between lines of tree-skirted bank. I believe much of this water could, however, be improved by a little judicious croy or incomplete weir building, and if the stock of fish increases as it may be expected to do, some attention should be given to this possibility. There are over 30 pools at the present time which are good, the angling rights being divided chiefly between Finavon and Careston. Above Tannadice the streamy character becomes more accentuated, the bed of the river being boulder strewn and the banks tree-clad. In summer this section of the river becomes very shallow and rather hopeless for holding salmon. Good holding pools exist, however, at New Mill, Inshewan, and Shielhill.

The class of fish in the North and South Esks is somewhat similar, and not a few large salmon are got in the South Water, as already reported for the North Water. The heaviest rod-caught fish in the four last years were $37 \mathrm{lb}$., $34 \mathrm{lb}$., $35 \frac{1}{2} \mathrm{lb}$, and $34 \mathrm{lb}$. In 1907, and also in 1906, a $52 \mathrm{lb}$. fish was taken in the nets of the district. 


\title{
CHAPTER V.
}

\section{THE DEE.}

\begin{abstract}
Angling Season: 11th February to 31st October.
Netting Season: 11th February to 26th August.
\end{abstract}

District Fishery Board meets in Aberdeen.

Alex. Duffus, Esq., Advocate, Aberdeen, is Clerk.

THERE is no river in Scotland which offers so much first-class angling water as the Dee. If the Tweed were unobstructed by nets, weirs, and pollutions, it would offer perhaps an even greater amount, but the beautiful reaches of Tweed above Peebles scarcely hold a fish till "the back end," while the corresponding section of the Dee offers the cream of fishing from late spring onwards. The Dee also has a general character throughout its whole course which is not found in many rivers. The Helmsdale is perhaps the nearest in character, but it is only a fourth of the length.

The Dee rises from two little streams which drain the slopes of Braeriach in the Cairngorms. The Garrachorry Burn, which hurries down the deep cleft between Braeriach and Cairn Toul from the socalled Dee Well, may be considered the highest head-stream. A more romantic spot for the birth of the grand river could not well be imagined. The mountain masses rise steep and magnificent; Cairn Toul conical with a great crater-like hollow gouged out of its side, where a little tarn reflects the ridges above, and where deer are frequently to be seen feeding round the juicy margin; Braeriach, the prototype of its opposite neighbour Benmacdhui, impressive in great mass and solidity. Dee Well is 4060 feet above sea-level, and therefore more than 1300 feet above the stream which drains the eastern side of the Larig-the high pass through the mountains from Strathspey. Here there are two or three pools, usually bluish and snow-fed in appearance, named also the Wells of Dee. How 
trout came to be there, and how they survive there, is not easy to understand, for frequently the stream below disappears amongst the chaos of great rocks which strew the so-called path to Braemar; but I have seen and have "gumped" them there. From these

"Grizzly cliffs that guard

The infant rills of Highland Dee"

the river has a course of 87 miles to the sea at Aberdeen.

As it emerges from the Larig it is a mere mountain torrent; but presently it is joined at right angles by the Geldie from the southwest, and the united waters start off eastwards down a magnificent Highland glen of wild slopes and ragged Scotch fir to the Linn of Dee, $6 \frac{3}{4}$ miles above Braemar. This water belongs to the Duke of Fife. There is no great fall at the Linn-and there is no other fall from here to the sea-but just at the bridge, opened by Queen Victoria in 1857, the channel of the river becomes suddenly contracted by great masses of rock, through which the concentrated water rushes in a channel only about four feet wide. The pool below is deep and black, and much overhung by the rocks, and in this at times great numbers of fish congregate. A considerable extent of the Mar fishing is rented for the early part of the season-which usually means, I believe, to the end of July-by the Fife Arms Hotel at Braemar, and is commonly sublet according to arrangement. Mr. MacDonald, of the hotel, usually divides the water at his disposal-about seven miles-into three beats, which are fished by rotation. The best time is usually from about the middle of April to the end of June, but much depends on water-flow and temperature, a mild winter bringing fish up earlier, while a dry, hot June reduces the river rather fast. When the Duke's party come to New Mar Lodge the fishing is taken over, with the exception of about two miles, which Mr. MacDonald holds throughout the season. The Mar water yields on an average about 200 salmon and grilse, though in seasons when fish are to be got in March, this number may be considerably increased. With the exception of the Linn Pool, the water is ideal for fly, although all sorts of baits are used, and the variety of the casts, apart from the magnificent surroundings and exhilarating air, is such as to yield most interesting angling.

The earliest fish of the Dee, owing to the complete absence of barriers, are able to ascend to the upper waters if the season is not severe and the river very cold. In the late eighties and early 
nineties fish were freely taken in the Balmoral waters at the opening of the season in February. Mr. Michie, the King's factor, informs me, however, that the spring fish are apparently not coming as far up at an early date as formerly, and the opinion has been expressed by more than one that the actual stock of fish has recently become rather less in spite of the removal of nets, to which I shall refer presently.

It is unsafe to make any deduction without first acquiring statistics, which will show if the reported decline really exists. After that, the question of whether the existing fish are changing their habits, owing, it may be, to changing thermal conditions, would have to be considered. Unfortunately the production of reliable records of catch for a series of years has always been a matter of great difficulty in waters which are largely let. It would appear, however, that the early fish are still got in good numbers as far as Ballater. I will only say here, in passing, that the spring fish of the Dee are almost exclusively of the small class, and that to understand the upkeep of stock of those small spring fish, we must carefully watch the upkeep of grilse, for the small springers belong to the same hatch of fish as the grilse of the previous year.

The Linn stops the further ascent of early fish, as comparatively small falls do in all other districts, until such time as the wintry conditions of temperature are no longer present in the water. By the second or third week of May, as a rule, the fish are willing to ascend the Linn and to push on through the rough streams above. In the pool above the linn, I understand, the Princess Louise had 12 fish one day.

As the river proceeds towards Braemar, past Mar Lodge, the glen gradually widens, and the open, sinuous, and gravelly character so familiar in the main section of the river, appears. Pools and streams succeed one another in pleasant, open, shingly bends, beautiful to the eye of the angler and the lover of nature. At the Linn the river is 1214 feet above the sea; at Braemar it is about 1066 feet up. Passing Invercauld, the current slows up for one or two quiet pools skirting Invercauld Park, then passes below the road to the right in the direction of Balmoral Forest, and is in about a couple of hundred yards crossed by the picturesque old Bridge of Dee-one of General Wade's structures-seen in the illustration. ${ }^{1}$ The view here is over a considerable part of Ballochbui Forest, up

\footnotetext{
${ }^{1}$ Another bridge, also called the Bridge of Dee, or the old Bridge of Dee, exists on the outskirts of Aberdeen.
} 


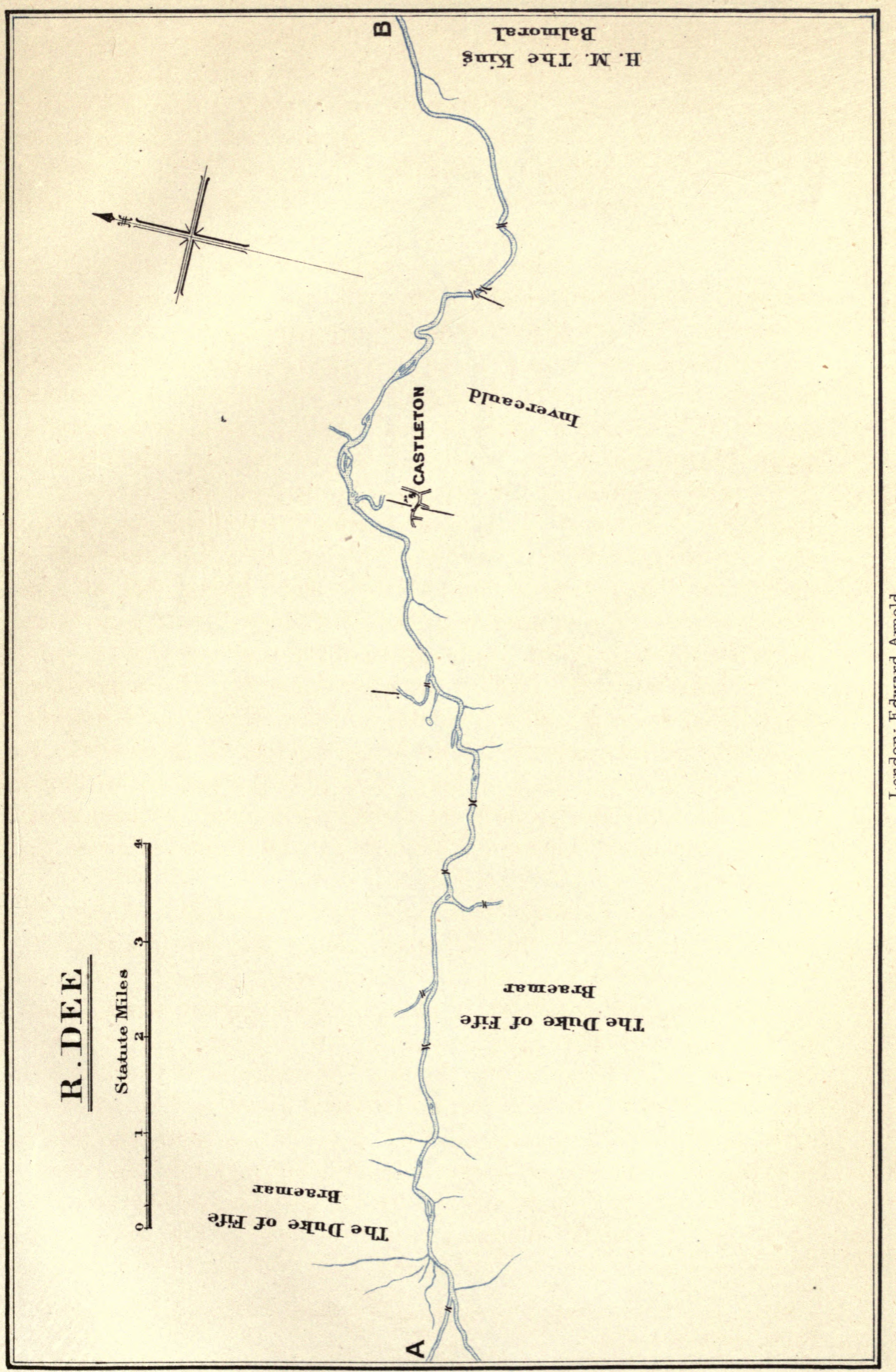




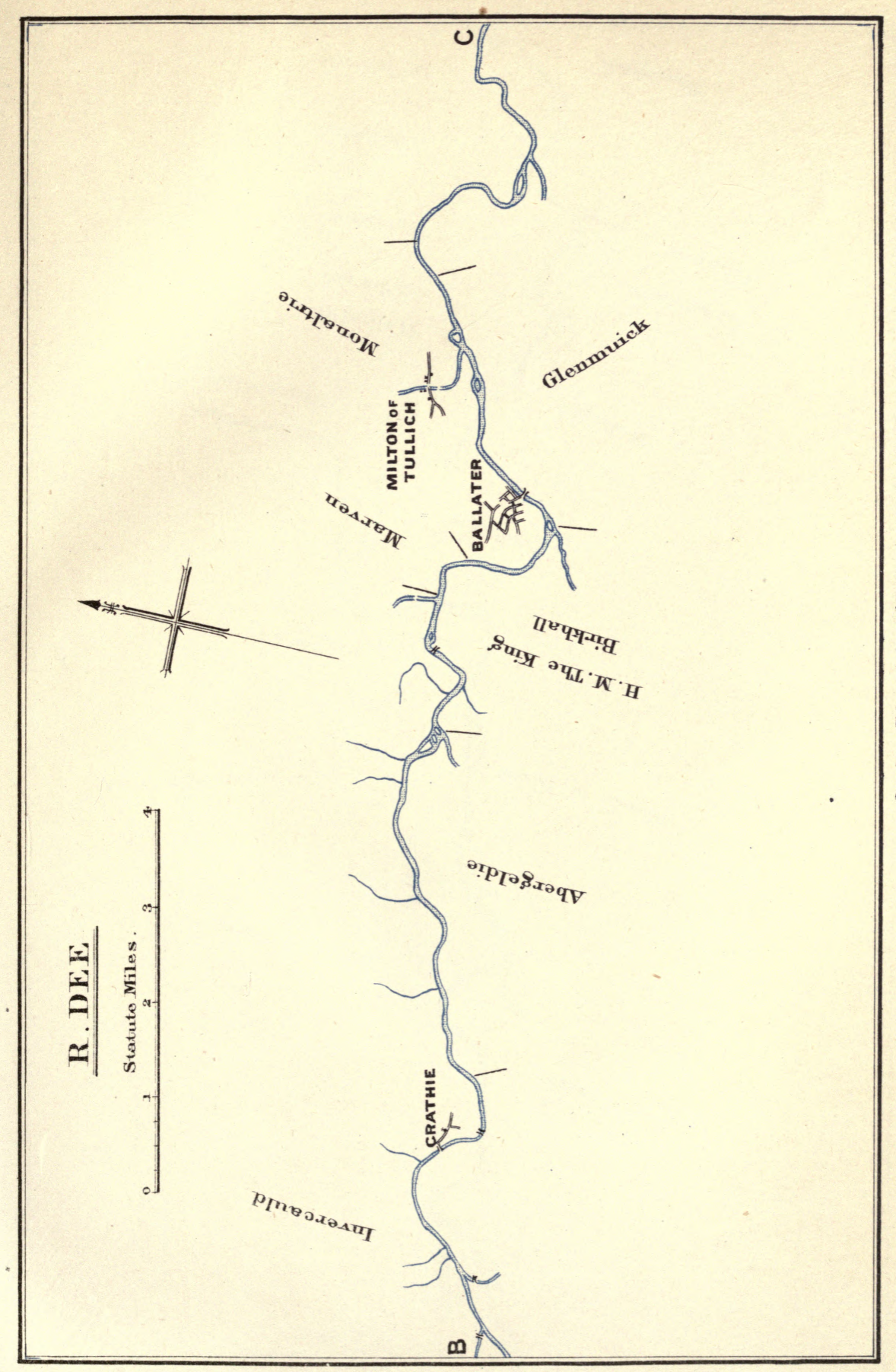





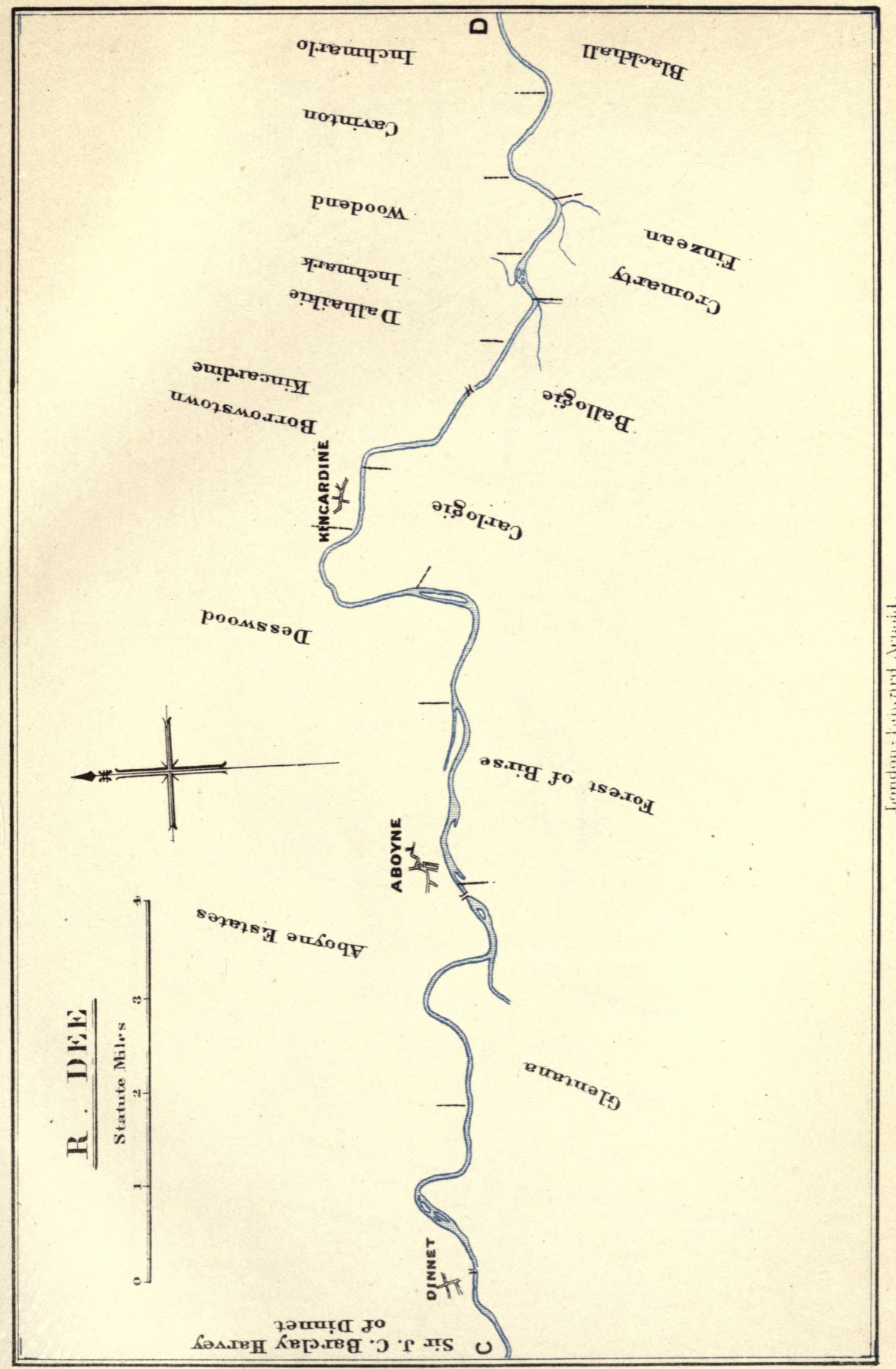





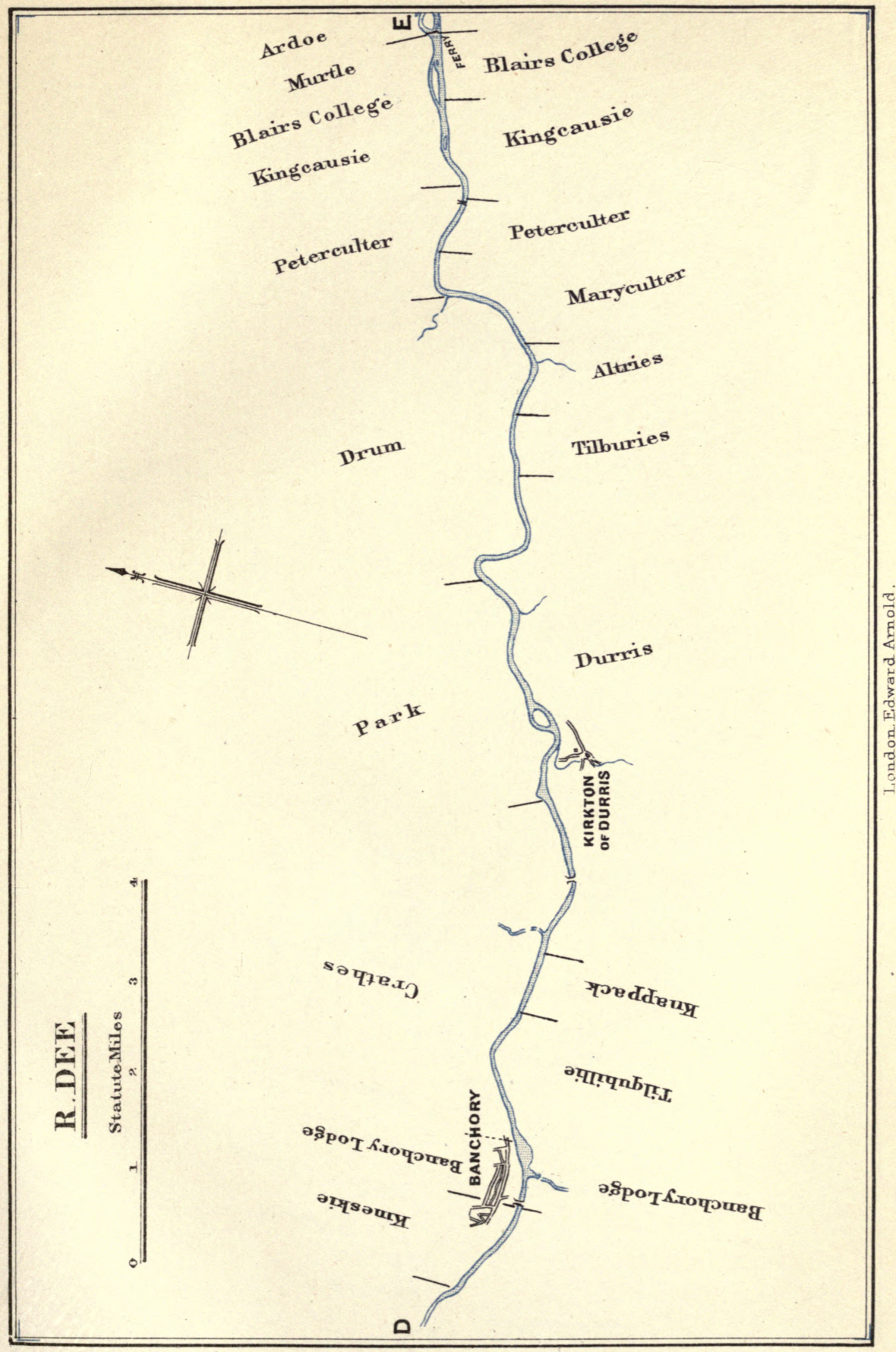





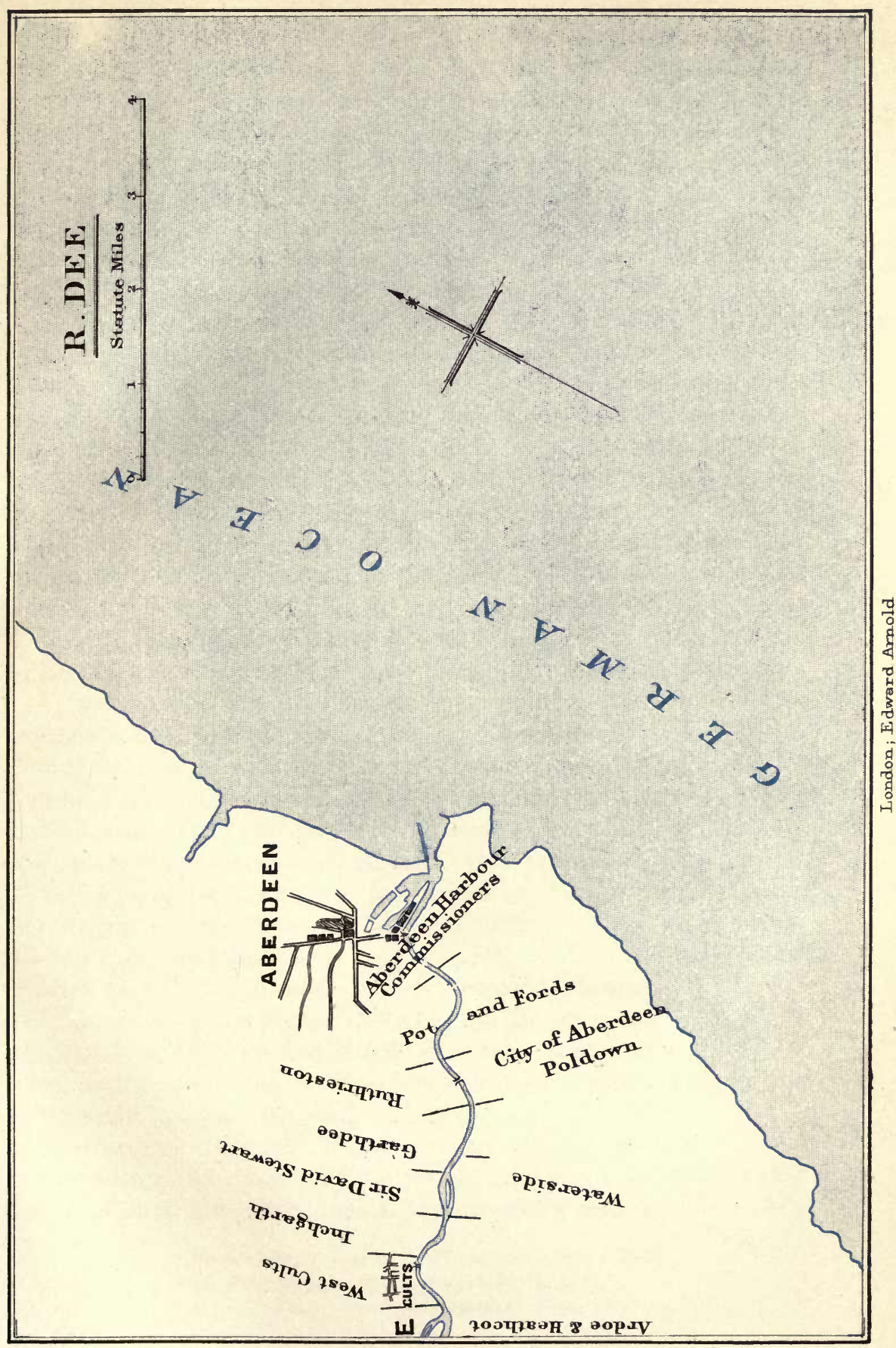



the course of the Garrawalt, a rough and obstructed tributary, to the mountain of Lochnagar (3768 feet) in the distance. This mountain takes its name from a romantic little tarn, the loch of the hare, overhung by high precipices, situated far up on its northeast side. It is reduced to contemptible insignificance in my photograph, but is a mountain of beautiful outline and outstanding character. Byron called it "the most sublime and picturesque of the Caledonian Alps." Queen Victoria, writing from Balmoral in $1850,{ }^{1}$ calls it " the jewel of all the mountains here."

In the lower Invercauld Water in May, 1892, two rods got 156 fish in sixteen days. One day yielded 25, another 24, and another 20 fish. In the same month in 1896, two rods had 257 in twenty-two days' fishing. ${ }^{2}$ These were, however, rather exceptional performances. The river now settles down to an almost uniformly fine character. It is not a big river in its run of 16 miles past Balmoral to Ballater, and it is never deep. The bottom is stony, at times very roughly stony, and again opening out in fine shingly stretches. It has been estimated that from Braemar to the sea the pace of the Dee, under normal conditions, is $3 \frac{1}{2}$ miles an hour, and the average depth about 4 feet. It is ideal fly-fishing water in almost its whole length, although in great stretches of the river all manner of lures are used.

It will be seen from the map of the river that Invercauld Water extends a long way on the left bank. The section below Balmoral Bridge used to go with Ballater Hotel, and a very fine section it is ; indeed, I understand it was considered by many the best hotel water in Scotland. It is now let to a syndicate of anglers. His Majesty the King has Balmoral, Abergeldie, and Birkhall Waters on the right bank, and rents part of Invercauld on the left bank, from the old Bridge of Dee down to Balmoral Bridge. This gives nearly 15 miles on the right and 6 on the left bank. The royal forest ground extends southwards to the summit of Lochnagar. It was just above Balmoral Bridge that the late Queen and Prince Albert witnessed, in 1850, an exhibition of salmon leistering. "It had a very pretty effect; about one hundred men wading through the river, some in kilts with poles and spears, all very much excited." 3

The present Balmoral Castle was erected in 1853-1855, and is rather nearer the river than the former edifice. I understand that improvements and enlargements have recently been effected. The

${ }^{1}$ Journal of our Life in the Highlands, 1868, p. 122.

${ }^{2}$ Grimble, Salmon Rivers of Scotland, ii. p. 57.

${ }^{3}$ Journal of our Life in the Highlands, 1868, p. 125. 
building is of Aberdeen granite, and its appearance is so well known and so justly admired, that no feeble description of mine is necessary. A vista is maintained to the west giving a view up the river towards the mountains. No view of this river was possible from the old house. My photograph is taken from the bank of the river looking down the vista to the castle.

Abergeldie (the mouth of the clear stream) is 2 miles down the river from Balmoral. It is a most picturesque old castle with its massive square tower harled yellow. The swinging river splashes along quite close at hand, and the grounds are richly wooded with fir, larch, and birch. There is a belief, I know not how it originated, that when Burns wrote, in 1803, "The Birks of Aberfeldy," he used considerable licence, since no birches existed at Aberfeldy in those days, while Abergeldie was famous in this respect. There is nothing in the wording of the song to guide one as to the precise locality.

There are, I believe, about 15 good pools in Abergeldie, of which Pal Mahalmoch and the Boat Pool of Clackenturn (what a name for a mill!) are generally considered the best, as they fish at any reasonable height of water. Birkhall comes next below on the right bank and extends nearly to Ballater.

Morven, Kinord, and Monaltrie Waters are on the left bank. The first is a short stretch of about half a mile, which is said to fish well in low water in early summer. Monaltrie extends to between 4 and 5 miles, and belongs to Invercauld. This water has been altered, and not improved, by the action of floods, but it produced 92 fish in 1908 . On the right bank, from the termination of Birkhall at Muick Burn, the Glenmuick Water comes in. Then comes Glentana with Cambus o' May opposite. The pools called Tassack and Waterside on the Glentana Water are considered by some to be about the best in the whole river. The whole of the Glentana Water fishes well when the river is fairly high. The Cambus side is, however, much the better when the water is low. From Tassack, or the needle rock just below Tassack, where Cambus ends, Glentana fishes both banks for between 4 and 5 miles. Dinnet Bridge divides this splendid fishing into upper and lower beats, and two rods on each beat have plenty of water. One rod has made a score of 25 fish in a day on Glentana; other great days were 21 and 15 fish. The water is good for over a thousand fish in a good year. In 1902, for instance, it is reported to have produced 1097 fish - a great total. The average for Glentana is about 900 , and the bulk of that total is made in spring. 


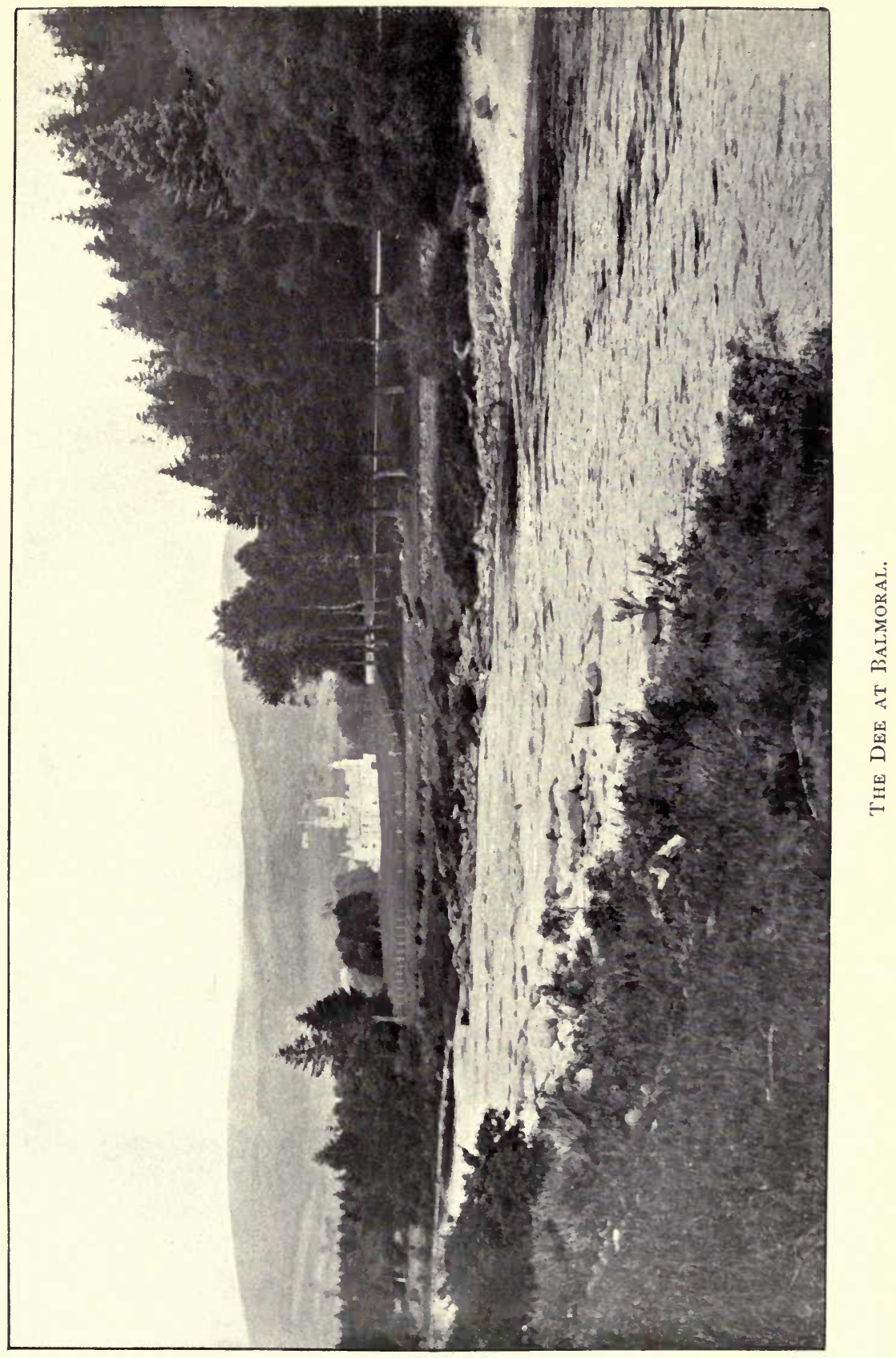



Lower Glentana is let to the Huntly Arms Hotel at Aboyne, and is as good hotel water-perhaps I should say about the best hotel water-as can be found in Scotland. From the opening of the season to the end of May, the hotel fishes not only Lower Glentana, but the Forest of Birse Water, and a further stretch of about 2 miles goes with the hotel the whole season through. The whole is equal to about 8 or 9 miles. Mr. Sandeson of the hotel has kindly given me the following records of recent years :

$\begin{array}{ccccc}\text { Year. } & & & \text { Spring. } & \text { Total for Season. } \\ 1904 & - & - & 188 & 199 \\ 1905 & - & - & 226 & 255 \\ 1906 & - & - & 160 & 183 \\ 1907 & - & - & 170 & 218 \\ 1908 & - & - & 155 & 183\end{array}$

These figures speak for themselves.

Opposite Lower Glentana is Aboyne Castle Water, and both terminate at the suspension bridge at Aboyne, or more correctly, I believe, to the middle of the island above the bridge. The Lorren is, perhaps, the favourite pool, a fine, if broad, piece of water with gravel beach.

Below the hotel water, on the left bank, is the Upper and Lower Dess Water, and the Kincardine and Borrowstone Waters, opposite which Carlogie and Ballogie Waters come in. This brings us down to Potarch Bridge, where the river is rocky and somewhat confined. An extraordinary incident which occurred at Potarch Bridge was reported lately" in an article on "Some Indelible Riverside Incidents," by Arthur Francis Paterson. The angler was Mr. Duncan Davidson of Inchmarlo. He hooked a fish in the pool above the bridge, had to follow the fish down-stream till it went through the bridge and broke him. "Naturally much disappointed, he retraced his steps and began again. Almost immediately he was in another, which made out of the pool and forced him down to the bridge, where he again held and broke." Again the angler returned to his pool, and again hooked another fish, and a third time he was taken down to the bridge where the fish broke away. I expect it was just a little difficult to be quite cheerful after that. Lord Granville Gordon's account of how a similar misfortune was served on the Galway River is worth recalling. ${ }^{2}$ "There, whenever a fish was hooked and made off down-stream between the arches of the bridge, the gillie would pull out a pocket-knife and hand it to you

1 The Field, March 13, 1909, p. 446.

${ }^{2}$ Sporting Reminiscences, p. 101. 
with a quick 'Cut when he runs you out.' Armed with a longhandled gaff, he would next dash for the bridge, stoop over the parapet at the far side, and catch the line on the gaff hook. When you had cut the line and informed him of the fact, he would haul in quickly, jump over the parapet at the side, and then run down the bank and handline the fish if still on." I should think this expedient is not possible at every bridge, and that Potarch is certainly too high for it.

Ballogie runs below the bridge on the right bank and is succeeded by Commonty and Blackhall, the former with about 2 miles and the latter with about 5 miles, faced by Woodend, Cairnton, Inchmarlo, and Kineskie. Banchory Bridge then completes another section of the river.

With regard to the Blackhall Water, I am enabled, thanks to the kindness of the proprietor, Mr. Hay, to give the totals for the last 12 years. They are as follows:

$\begin{array}{llll}1897 & - & - & 332 \\ 1898 & - & - & 186 " \\ 1899 & - & - & 228 " \\ 1900 & - & - & 336 " \\ 1901 & - & - & 358 " \\ 1902 & - & - & 328 " \\ & & & \end{array}$

$\begin{array}{llll}1903 & - & - & 423 \text { fish } \\ 1904 & - & - & 423 " \\ 1905 & - & - & 304 " \\ 1906 & - & - & 380 " \\ 1907 & - & - & 454 " \\ 1908 & - & - & 444 "\end{array}$

The totals I have added for the first and for the second period of 6 years show a pretty substantial increase for the latter. The water opposite is all held by Sir Thomas Burnett, and will be referred to presently.

The Crathes Water, below Banchory on the left bank, consists of eight pools, and is divided into the Upper or House Water, and the Lower Water. With the former, go The Old Kiln, Floating Bank, Birkenband, and Kashentrosh. The Lower Water has the Mill Pool, the Bridge Pool, Kelpie, and the Greenbanks. The spring fishing of the whole should yield 50 to 60 fish, though in mild open winters fish are somewhat apt to run past. The autumn fishing of late years has been rather disappointing. Sir Thomas Burnett kindly shows me by his records that the average for the last 7 years is only 22. From Crathes and Kinneskie Waters, in the early nineties, Captain Ashton, who was then tenant, killed over 200 fish one autumn. I do not know, however, what the conditions were, and it may well be that fish were prevented running in summer, or that the pools of this water afforded better holds for fish than at present. 
A little judicious croy-building, with consent of the opposite proprietor, might be found to make a wonderful difference in securing lies for fish, so that the angler has a longer opportunity of trying for them in the bye-going.

Sir Thomas Burnett rents Kinneskie, Cairnton, and Woodend Waters. The first has been held for the two last seasons by the Tornacoile Hotel, the manager of which informs me that the average for the two seasons is 60 fish. There are five pools in this water. Captain Quintin Dick, who has rented the Woodend Water since 1904 , and has regularly fished it, has kindly given me a statement of his catches. He informs me that low water suits Woodend best, and that Commonty, which is opposite, and which he also rents, fishes best when the water is high.

$\begin{array}{cccccc}\text { Year. } & & & \text { Spring. } & \text { Autumn. } & \text { Total. } \\ 1904 & - & - & 174 & 16 & 190 \\ 1905 & - & - & 123 & 21 & 144 \\ 1906 & - & - & 141 & 16 & 157 \\ 1907 & - & - & 156 & 39 & 195 \\ 1908 & - & - & 101 & 19 & 120\end{array}$

Writing on 27th March, Captain Dick also states that during the present season, 1909, to date, 87 fish have been taken.

Lord Penrhyn, who has rented the Cairnton water for a considerable time, also gets corresponding results.

I understand that Feughside Hotel frequently arranges for the right of fishing on the upper Blackhall Water. Two or three rods can be put on this section, although I believe four rods are on occasion allowed to fish it. The chances are that the overcrowding of four fishers is not conducive to either successful angling or comfort to the anglers. I have also heard it said that one of the results is to induce overwading in order to reach water near the opposite bank, thereby spoiling the lies on the near bank. I have no personal knowledge of the matter, but one knows the ardent nature of the keen angler, and how at times a taint of selfishness enters into the actions of the best of us.

Opposite lower Crathes, the Durris Water comes in. It is divided into upper and lower beats and continues down-stream for about 6 miles, the lower section being opposite Park (vide Map). There are some splendid pools in this section, which as early as December have already got their complement of early clean fish. I netted the whole river from Banchory to Cults one December in order to mark and return fish. I have a recollection of seeing a fine lot of clean fish streaming out below the net in Floating Bank Pool. They went 
as driven sheep do through a gate after a leader has discovered the way. The recollection which is much more vivid, however, is how we got our net hung up in almost every other pool. Cleeks, or anchors, or "huds," in other words strong curved and often barbed irons sunk in large stones in the river bed, had been introduced to prevent poaching by net. The position of these was always pointed out, and in every case had shifted to where we put in our net. Hours were spent in the two or three short winter days, while the net, torn to shreds, was spread out on the bank, and the netting needles got out. I would not recommend any man to go poaching the Dee with a good net.

In the last 4 or 5 years the average take by rod from the Durris Water has been about 350 fish, but I believe the year 1906 yielded the great total of 1038. The water here is thoroughly characteristic of the river Dee. The pools succed one another in pleasant series; nowhere too deep, but "streamy" interesting water. With West Durris, Durris proper, and Lower Durris, Park Bridge is passed. The combined Durris Water extends to about $7 \frac{1}{2}$ miles, and is capable of great results. Below Park we come into the reaches of the river, which fish better in autumn than in spring. Early fish swim past to a great extent, for the current is not much broken, and the usual temperature not sufficient to act as a check. Drum, Culter, Kingcausie, Blair, Murtle, Inchgarth, and Garthdee, brings us down to the foot of the angling water. These are all on the left bank, with both Kingcausie and Blair College fishing both banks. The remaining waters on the right bank are Tilbouries, Altries, Heathcote and Ardoe, and Banchory Devenick, from which last the nets have just been removed.

In the case of some of these low waters no very accurate records are secured by the proprietors and the scores are not very great. I have been favoured with a statement respecting the last 4 years in the case of Altries. The totals are $23,36,31$, and 30 fish. As may be expected, however, some of the heaviest fish are taken in these low reaches.

Lord Granville Gordon, in his Sporting Reminiscences, has a chapter "In Praise of Salmon Fishing," and in it are many good things well told. After describing what the behaviour of a wild fish is like, and how it usually gives rise to wild language, he continues, "While on salmon memories, I may as well recall the death of the largest fish, $46 \mathrm{lb}$., that I ever killed. This was on the Dee, at Coulter, in the big pool just below the railway station. I hooked him about a third 


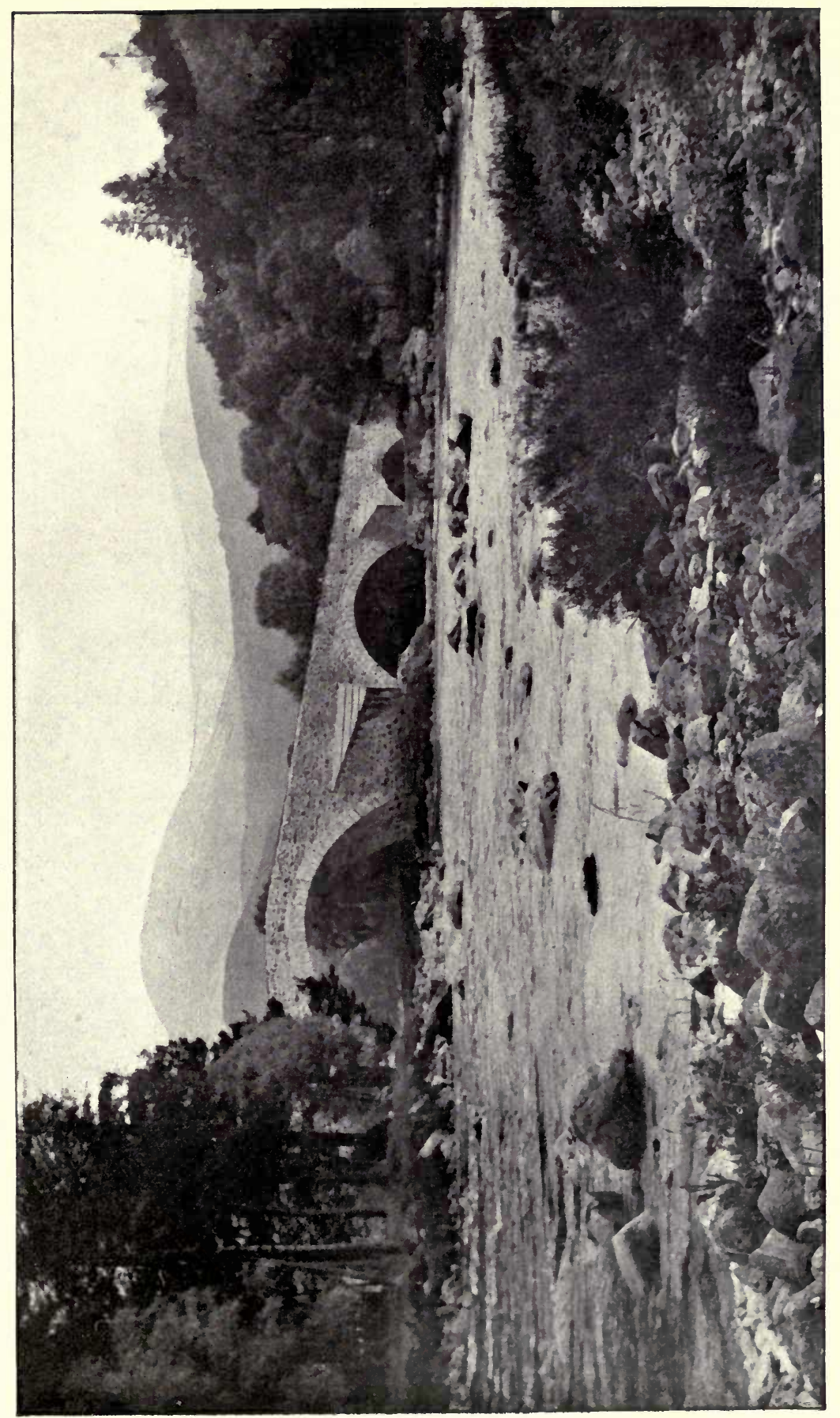

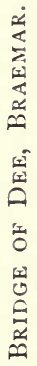



of the way down, and after a few preliminary trials, so to speak, he went straight up the river into the heavy water at the neck of the pool. The river was high at the time, and the whole force of the Dee came down under the south bank, on which I was fishing. In such water, right under my nose, the brute sulked, but I was using very strong tackle on the strength of the water being much discoloured, so I simply turned the point of the rod down-stream and gave the gentleman the butt. Minutes passed without a sign, and I was beginning to think that the fish must have surreptitiously fouled me and made off. Three or four times, in fact, I was on the point of breaking, deeming it impossible that any fish could stay motionless in such water. At last, however, I felt a quiver, and knew that the fish must still be there. My landing him was a matter of luck. It would probably have been an impossibility from this deep side of the river, but a ferry boat happened to ply two or three hundred yards further down, and by good luck I managed to hail the ferryman. He soon put me on the opposite bank, playing the fish all the while, and it was in quite shallow water that I gradually tired my salmon out. . . . That fish took an hour and three-quarters in the killing."

The Dee is a conspicuous example of what can be done to improve a district's salmon fisheries by removing river nets. The operations of the Dee Salmon Fishing Improvement Association have been referred to in more than one publication, ${ }^{1}$ but it is impossible to refer to the Dee, as one desires to do, without referring to this Association. In 1872 the Dee was netted up to Banchory, about sixteen miles; the stock of fish was comparatively small, and the rental of the river amounted only to $£ 1254$, the total of the district including the coast and other fishings being $£ 7031$. The Association was formed in that year "with the view of improving the river fishings by leasing net fishings, commencing at Banchory-Ternan, there being no nets above that point, and going downwards as far as funds would permit; and this with the view of removing the nets, and thereby allowing a larger number of fish to reach the spawning beds in the upper waters."

The alternative of commencing hatching on a large scale had previously been considered by the District Fishery Board, and plans of rearing-ponds, etc., had been drawn and submitted, but it was decided that to allow breeding fish in greater numbers to reach the splendid

\footnotetext{
${ }^{1}$ Sir Herbert Maxwell, Bart., Salmon and Sea Trout, Appendix A.; Augustus Grimble, The Salmon Rivers of Scotland, vol. ii. p. 49.
} 
reaches of natural spawning grounds in the Dee was the better plan. The District Board could not undertake the removal of nets, so the proprietors above Banchory formed themselves into an Association for the purpose, the initiative being taken by the Marquis of Huntly. The process was in each case to lease the net fishing and to keep the net off. In the middle of season 1873 the commencement was made with the Banchory Lodge nets. By 1875 Tillquhillie, Crathes, Durris, Park, Altries, Drum, and Tilbouries had been added. Funds did not permit any extension after this till 1881, when the clearing operations reached to Kingcausie, but Blairs, Murtle, and Heathcote soon followed. In 1892 Inchgarth came in, and in 1896 the Waterside nets were reached. This allowed only about three miles of netting to remain, most of which was in tidal water. The sum paid

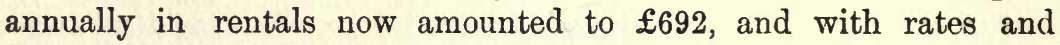
expenses $\mathbf{1 7 5 7}$. The money was raised by voluntary effort.

Now let us see what was happening to the rental. The river fishings (angling), apart from sweep netting, started at $£ 1254$ as we have seen. In ten years it stood at $£ 3751$; in twenty years at $£ 6312$; and in twenty-eight years it had reached the substantial total of $£ 10,939$. The total rental started at $£ 7031$; in twentyeight years it stood at $£ 18,990$. In 1902 it reached the perhaps rather inflated figure of $£ 19,445$. There has been a slight shrinkage since, but the figure has always been about $£ 19,000$. At the present

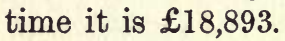

At the commencement of the present season (1909) a still further addition to the scope of the Association's influence has been amicably secured, after failure of negotiations on two consecutive years, by the taking over of two netting stations above the Old Bridge of Dee. The river is therefore completely free of nets from this point upwards, and practically only the tidal area of the river remains. The actual distance in which nets appear now to be used is about $2 \frac{3}{4}$ miles.

Since the commencement of the Association's operations the rodfishing has much improved. In the first ten or fifteen years the advance was steady and evident to all. The zenith appears to have been reached in "the eighties," when very great runs of grilse occurred, and prospects therefore seemed at their very brightest. In 1883 and 1884 about 5000 rod-caught fish are reported to have been taken; in 1885 about 6000 was believed to be the total. ${ }^{1}$ After this great advent of grilse the number of salmon increased for some years

${ }^{1}$ Fourth Annual Report Fishery Board for Scotland, Ixxiv. 
but the grilse began steadily to fall off, and I fear they are falling off still. Last season (1908), as everyone knows, was distinctly poor from the angler's point of view, yet from the figures I have obtained it would appear that the total for the river must have been well over 3000 fish.

As in the case of the rods so in the case of the nets; the operations of the Improvement Association proved a distinct benefit although naturally a benefit less marked in degree. The Marquis of Huntly gave the following rentals in evidence before Lord Elgin's Commission :

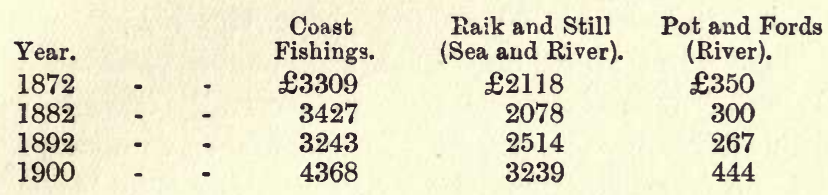

I am indebted to the Aberdeen Harbour Commission for a statement of the number of fish caught in their nets, from which I quote the quinquennial totals :

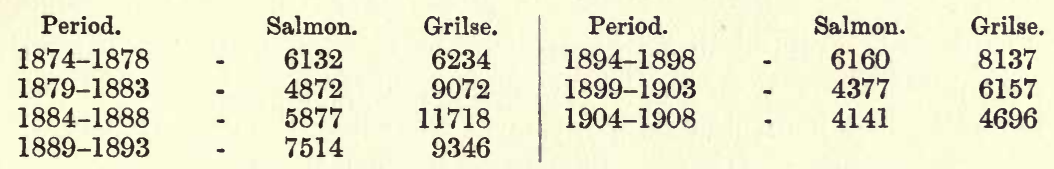

The period of the great grilse run is indicated in the third line, while on the fourth line the salmon column reflects the abundance of the five years preceding.

The fact that the Aberdeen Harbour Commissioners, proprietors of all the valuable net fishings now remaining, have for many years subscribed to the funds of the Association referred to, is sufficient proof that they consider the operations as in their interest.

With regard to the estuary of the Dee, a rather peculiar position has come about. According to the schedule of the 1868 Salmon Act the estuary is defined as "A portion of a circle of 400 yards radius to be drawn from a centre placed midway between the outermost point of the north pier and the outermost point of the breakwater, and continued shorewards by tangents to the circle drawn to the nearest points of the shore of the respective sides of the river at high-water mark of equinoctial spring tides." This definition did not take into account the possibility of any extension of the harbour works; the peculiarity of the position has arisen by operations of this kind. About 1870 the Harbour Commissioners extended the 
north pier 500 feet, practically demolished the old breakwater, and constructed a new breakwater 1100 feet further down the tideway. The result is that the south breakwater now in existence is outside the estuary as previously defined. Considerable argument has arisen as to whether or not the estuary should or should not be shifted with the extension of the works, but as no powers exist for the creation of a new bye-law which would redefine the estuary, the interpretation remains as it was before the extension of the works. This being the case, the Harbour Commissioners, being, as has already been said, extensive salmon fishers in the neighbourhood, set three bag-nets on the south breakwater. These nets have the benefit of the breakwater as a kind of leader, which cannot be removed during the weekly close time, and have, perhaps naturally enough, excited the criticism of the upper heritors. If one wishes to obtain a good view of a salmon bag-net extended for fishing, there is no better place that I know of than this south breakwater.

The question of pollution at Aberdeen had become a very serious question a few years ago. The District Fishery Board, the millowners, and the Aberdeen District Committee of the County Council, and others attempted to arrive at some joint scheme by which purification could be secured. After prolonged negotiations and considerable disappointment, a solution of the difficulty was arrived at in quite another way. An immense sewer was constructed in such a manner that the Aberdeen pollutions were carried below the river Dee, across the neck of land southwards to the Bay of Nigg (where the marine laboratories and hatcheries of the Fishery Board for Scotland are situated), and along the shore line to the Girdle Ness, the most easterly point just south of Aberdeen, and the mouth of the river. This has been a great work, occupying several years in completion, but now seems to result in giving every satisfaction.

The water supply of Aberdeen is taken from the Dee about twenty miles up-proposals are at present being canvassed for an additional supply from a much more distant source-and the river above this point may be regarded as quite pure. Villages of the lower reaches discharge a certain amount of impurity into the river, and at Culter large paper works have been repeatedly complained against. Taken all over, however, the Dee cannot be said to be a seriously polluted river. If the views of some proprietors in the upper waters, that a decline is really going on, should prove to be correct, and there is no gainsaying the fact that the recent totals have not approached those of "the eighties," the cause of this decline 


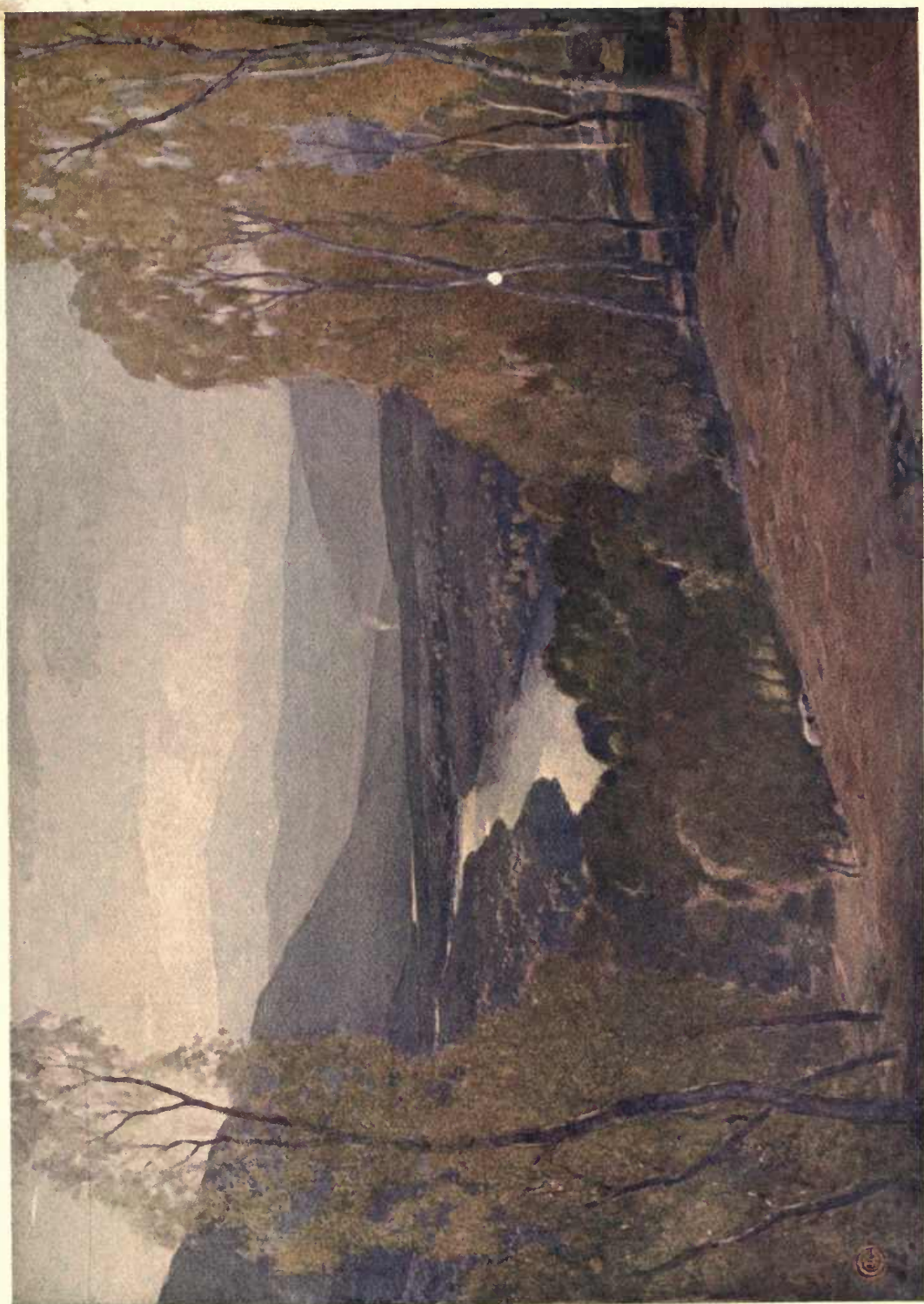

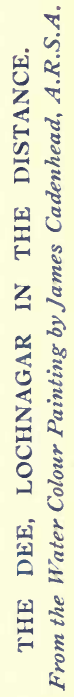



need not be looked for in the river itself. The reduction of the stock of fish is marked in the decline of grilse, and in the ratio which exists between the number of grilse and the number of salmon. If we are to strive for the preservation of more grilse, the question is a large one, involving the fisheries outside the actual river, it may be beyond the limits of the river district; a question which has to be gone into with regard to the whole of Scotland some day. 


\title{
CHAPTER VI.
}

\author{
THE DON.
}

Angling Season: February 11th to October 31st.

Netring Season: February 11 th to August 26th.

District Fishery Board sits in Aberdeen. Clerks, Messrs. Wilsone \& Duffus, Advocates, 7 Golden Square, Aberdeen.

THE Don is an ideal trouting river, and should by nature be also a first-rate salmon river. Owing chiefly, however, to manufactories of great importance which have sprung up and become well established along its banks, the king of fishes does not get a very good chance. Our interests are, of course, all on the side of the salmon, our broad contention being that there is room both for the manufactories and for the salmon, and that the former need not be so conducted as to injure the latter.

The Don rises away on the ridge which separates Carn Ealasaid and Ben Avon, close to the point where the river Avon emerges from Glen Avon and turns sharp to the north to join the Spey. The divide is an interesting one, for it appears that in conformity with the geological axis of the country the Avon at one time flowed on to form the Don. It is one of those complications of erosion which have played tricks in the formation of many parts of Scotland. The Don from its source to the sea has a course of about seventy miles. As far as Alford, which is practically the upper half of the river, the channel is carved out through steep and often well-wooded hills, the character being that of a Highland river. A few miles below Alford this gives place to a gentler, and presently to a flat, surrounding, and the river, by the time Inverurie is reached, winds through meadow land with earthy banks. At Kintore and for several miles further on, the Don is like a river in some fertile English county; the margins of the river are weedy, and sedge-grown islands occur here and there, where water-hens and coots bob about. 
At times old river channels are passed where bends and loops of the river have been cut off, where now there are deep stagnant pools, and muddy marshes choked with iris and horsetails. Within a few miles of the mouth the banks again become steeper, and the river passes through woods of beech and plane trees, while rocks frequently show up in the river bed. Before the old Bridge of Balgownie is reached, near old Aberdeen, the river becomes much contracted, deep and still. Emerging from the old bridge it flows freely in an open stony channel through the tidal Bridge of Don, and, breaking through great banks of sand, enters the sea.

The estuary of the Don, as prescribed by the Salmon Act of 1868 , is a portion of a circle of 400 yards radius drawn from the centre of the river. Since the estuary of the Dee is arranged in precisely the same way, it follows that fixed engines may be set pretty close to the river mouth and between the Don and the Dee. A constriction of sand occurs where the river joins the beach line, and beyond this, when the tide is out, the river flows directly across the sandy beach to the sea. A barrier of posts and stones has been erected at some early date, along the south side of this channel, which appears to have preserved the course of the river mouth. What the age of this barrier is I have been unable to ascertain; but the present straight course of the mouth seems to have persisted for at least a hundred years. Above the Bridge of Don and below the old Brig o' Balgownie, the concentration of the water-flow is secured by stone barriers, that on the right bank being shaped like the letter $\mathbf{L}$ standing out from the river bank, the horizontal part of the letter being made to point up stream. The arrangement is peculiar, but apparently most efficient. A large water cushion must be formed against the shaft of the letter, so to speak, thus protecting the whole structure during floods.

The Brig o' Balgownie, with its high and pointed arch, is a venerable and interesting structure. The narrow roadway takes a curious angle as it crosses the bridge, and the paving and parapet savour of the middle ages. Large rings are fastened to the sides of the masonry for the purpose apparently of closing the passage. A bevy of plumed knights disputing the crossing, with lances in rest, would be quite in keeping. It dates from about 1320, and was built, it is believed, either by Bishop Cheyne or by Robert the Bruce.

"Brig o' Balgownie, though wight be your wa', Wi' a wife's ae son, and a meer's ae foal, Doun ye shall fa'." 
Byron was an only son, and is said to have crossed it with some amused trepidation.

The pool below the brig is netted, as also are two other pools further up. The highest netting station is a short distance below Muggiemoss Dam Dyke, four and a half miles from the mouth of the river.

The first obstruction to the ascent of salmon is at Kettoch Mill (a meal mill), above Old Aberdeen, but the obstacle is reported to be not a very serious one, and the pass provided in the dyke efficient.

Not very far above Kettoch Mill come the cruives at Gordon Mills. These cruives have been much complained of. The dyke is not high, but is sufficient, at ordinary levels of water, to stop fish. At high levels fish can without difficulty make the ascent. There are four boxes of the minimum type-i.e. four feet across-and these are regularly fished. I believe, however, that the cruive boxes are not so remunerative as the net and coble fishing just below the dyke. The cruive fishings are divided amongst several owners with varying shares. There is no gap or slop in the dyke, and therefore the structure acts chiefly as a check to ascending fish, which may be taken by the sweep net in great numbers.

In the Statistical Account of $1797^{1}$ the chronicler, referring to salmon fishing above, says the profit " is very trifling, owing to the number and construction of the cruives and dykes between this place and sea. The salmon fishing company, who farm that part of the river which lies nearest the sea, have built dykes for the security of the cruives, which rise considerably above the surface of the water, and prevent any fish of size from forcing their way up the river, unless when it is extremely swelled with rain, and the Saturday's slap is said to be but little attended to." The same complaint seem to have continued from that day to this.

Next obstruction, in the ascent of the river, is the Grandholm Mill Dyke. The lade which supplies water to the tweed mill is nearly a mile long and is well sluiced and hecked. There are five sluices at the intake. One benefit from having so long a lade is that, although in this instance it carries off a considerable volume of water, it enables the dyke across the river to be comparatively low. As a matter of fact, the dyke is an irregular structure, presenting no great difficulty to fish, and having a "slap" in it. Woodside paper or rag work, above Grandholm Dyke, is situated at an angle

${ }^{1}$ Vol. iii. p 68. 
of the river, where the lade is made, as it were, to cut the corner. Owing to the natural configuration of the river bed, there is but slight obstruction here.

The next structure is, however, most formidable, being Mugiemoss Paper Mill Dyke, already referred to as just above the last netting station. The structure has an elliptical form, the downstream face sloping from each side towards the centre of the river. Here a huge flat apron, covered with cement, has been formed. It fills up the space between the extremities of the curved dyke, and measures about 60 feet in length. It ends quite abruptly above the very deep water of the pool immediately below. This pool I very nearly examined more closely than I wished to; for at my first visit, when wading about on the flat apron, the water being dirty, as, alas, it always is in this much-abused river, I pretty nearly waded plump into the foul depths of the pool below. I am sorry for salmon that cannot get out of that pool.

Down the central line of the sloping down-stream face a so-called fish pass has been formed. It is quite simple, being an unbroken chute 45 feet long, with a gradient of 1 in 5 . When the flat surface of the apron has insufficient water to allow a fish to swim over it, the water in the chute is not very formidable for good strong fish. Unfortunately, however, the shallowness of the water on the apron quite prevents a fish getting to the pass under these conditions. When the water on the apron has become deep enough for fish to move along it without difficulty, the water in the chute has become a raging torrent, which washes the fish back into the pool again.

Salmon congregate in the pool below in great numbers both in the spring and towards the end of the season. I have known of 700 fish being netted on the opening day. The District Board have repeatedly in autumn hired the Aberdeen water carts, driven them to Mugiemoss, filled them with water, and then with salmon, and given the fish a drive beyond these dangers.

Next in order come the Waterton and Stoneywood dykes, made famous by reason of the abstraction-of-water-case, which was carried to the House of Lords before a decision, in favour of Lord Kintore and others, would satisfy the defenders. Neither lade is really high above the bed of the river, but the two lades have only one conjoint outlet below the lower dyke. Before the decision referred to, and before the Court of Session had arranged for the proper amount of compensation water to the river, it was usual all through 
summer for the whole river Don to pass through the works of Messrs. Pirie. I have walked up the dry bed of the river, and wondered if Scottish salmon would ever learn to do the same. Now, happily, this state of matters is improved.

It would not be difficult to make both weirs easier for fish to ascend, and here, as at Mugiemoss and the cruive dyke, the Board, I hope, may at length succeed in giving salmon a better chance to ascend at normal levels of water.

As an additional drawback to the obstructions named, the unfortunate fish have to contend with gross pollution. The last time I visited the outlet of Messrs. Pirie's works (June 1908), the lade (and I think it is the largest lade in Scotland) was sending forth water of an abominable dirty yellow colour highly charged with suspended matter. The bottom of the river below was coated with sludge, and the discoloration continued down the right side of the river almost to Mugiemoss. The latter mills are also far from guiltless. Hot water spouts out, soot is thrown over, and most objectionable refuse of other kinds is only too obvious.

There is also an apparent and general disregard for the river's purity on the part of almost everyone in the neighbourhood. It is the place of all others in which to get rid of broken crockery, old boots, tin cans, thread-bare linoleum, and so on.

For the last two or three years a large sewer has been in course of construction along the north bank of the river from Grandholm Bridge, about 3 miles from the sea, and at the northern extremity of the Aberdeen city boundary, which is regarded with great hopes by those who would see the river purified. This sewer is to discharge directly into the sea, and should have been finished in 1907. Now, towards the end of 1908 , it is nearing completion. It will carry off the large amount of domestic sewage and refuse from works of the lower river, but it will not do anything for the gross pollutions from works above Grandholm Bridge.

Above Stoneywood the river is unmolested as regards any serious obstruction, while no very apparent pollution occurs for over 20 miles, past Parkhill, and Pitmedden, Fintry Water, and Keith Hall.

Below the town of Inverurie a quite unusual arrangement of lades is resorted to in order to supply the North of Scotland Milling Company's works, and the Port Elphinstone Paper Works, with water. No dam dyke of any kind occurs to draw off water. Below Inverurie Bridge the river takes a wide bend, and the lade cuts off this bend. The intake or intakes-for at first there are two lades-are simply 
built into the river bank immediately below the bridge. Both intakes are protected by a substantial pile railing a few yards out in the river and parallel with the bank. The distance to the lower of the two works is quite half a mile from the intake, the water is clear and contains a lot of trout. The gradient of the lade is evidently so arranged as to secure a good flow of water. One cannot see this arrangement without wishing that in other places where water power is desired, a similar absence of all obstruction in the river could have been secured.

Net and coble fishing is practised in the lower Don for about $4 \frac{1}{2}$ miles, but the hauling grounds are only seven or eight in number, distributed amongst six proprietors, at Nether Don, the Cruives, Grandholm, Persley, Mugiemoss, and Waterton, but the last-named fishing is not now worked. The Grandholm and Mugiemoss fishings are considered as of highest value, The Nether Don fishings at the mouth are in value not much below them. A monthly return of salmon, grilse, and trout for the years 1894 to 1900 was handed into the Elgin Commission by Mr. Davidson, the chief holder, with the Shipmasters' Society. This return shows that the most productive month for salmon is August, and the best grilse month is July. The combined totals of salmon and grilse for the years named are:

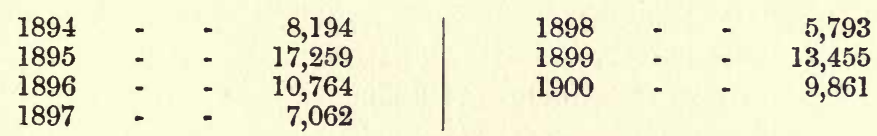

The highest totals are all the result of good grilse years. In 1895 and 1899 over 5000 grilse were taken in July alone.

Of late years the fishings are reported as having fallen off considerably, and I believe the rod-fishing has suffered most. Don fish are of a fine class, and quite a number of heavy fellows enter the river at the end of the season. In a recent paragraph in The Field I noticed an account of how an angler at Grandholm landed a $41 \frac{1}{2} \mathrm{lbs}$. fish, and, leaving it on the bank, hastened a little lower down to a fellow-angler and gaffed a 43-pounder for him. I wondered as I read of his leaving his fish on the bank, if the sequel was not going to be that he could not find it on his return. Some people hang about Grandholm at the back-end who are not to be trusted when one's back is turned. I have known them scheme to draw off the patient river watchers by showing lights in a suspicious manner, in order to allow time for a comrade to do some 
rapid snatching at Mugiemoss. The local poacher is both expert and bold, and moreover is apt to take unto himself seven others, etc. With the large population of mill-workers which exist in the immediate neighbourhood, the nightly duty of the bailiffs is arduous at the back-end of the year. It takes men of hard mettle to carry out the work really well.

With regard to the rod results I am greatly obliged to Lord Sempill, who has kindly given me averages in periods of ten years since 1868 for his Fintray water, which are sufficiently startling to require little or no comment.

1868 to 1877 - 378 salmon

1878 to 1887 - 254 "

$$
\mid \begin{gathered}
1888 \text { to } 1897-127 \text { salmon } \\
1898 \text { to } 1907-87 \text { " }
\end{gathered}
$$

It may be seen from this that in the last forty years the decline amounts to practically 80 per cent.

The conditions with which Donside proprietors have to contend are undoubtedly both serious and obstinate. A good deal of activity has, however, been recently displayed, and it is devoutly to be hoped that the salmon fishing interests of so fine a river will shortly be more adequately safeguarded than they have been in the past. 


\title{
CHAPTER VII.
}

\author{
RIVER YTHAN.
}

\author{
Angling Season: 25th February to 31st October. \\ Netring Season: 25th February to 9th September.
}

District Fishery Board sits in Aberdeen. Clerk, D. W. B. Chalmers, Esq., Advocate, Golden Square, Aberdeen.

THIS river and the Ugie flow quietly through the gently undulating country which lies between the districts of Formartine and Buchan.

The Ythan rises at the springs called the Wells of Ythan, and takes a course east and then north-east to Auchterless, where there is a low fall. The stream then turns abruptly south-east, and, with the road to Turriff on the right hand, and the railway on the left, flows in this direction to Fyvie. It then meanders with many windings through the flat stretch between Fyvie and Methlick, past the old House of Gight, which belonged to Lord Byron's mother-the thickwalled castle is now a most picturesque ruin, the property of the Earl of Aberdeen. From Gight to beyond Haddo House the stream is richly wooded on either bank. I am afraid to say how many thousand trees I have heard were planted on the Haddo Estate by the distinguished statesman and forebear of the present peer, who then held the property. The Ythan is most enticing to the trout fisher in many of the reaches near Methlick.

The general course of the river is thereafter south-east, with one or two curves before reaching Ellon; and soon afterwards, at the Kirkton of Logie Buchan, it expands into the estuary, which is 4 miles in length and rather more southerly in direction. The actual mouth is somewhat constricted, the outgoing water having to contend constantly with a sand-bar fed from a perfect wilderness of sand-the Sands of Forvie. The total course of the river from the Wells of Ythan to the mouth is about $36 \frac{1}{2}$ miles.

The estuary, as defined by the 1868 Salmon Act, is " a portion of 
a circle of 300 yards radius, to be drawn from a centre placed midchannel in the river where it joins the sea at low-water, of equinoctial spring tides, and continued shorewards by tangents to the circle drawn to the nearest points of the shore of the respective sides of the river at high-water mark, also of equinoctial spring tides." This is one of those estuaries so defined, apparently, as to provide for a shifting river mouth. I am not aware, however, that the Ythan estuary has to be remeasured at regular intervals as the Bervie estuary has to be, where, according as the little river has gone a few yards this way or that, a stand of nets on a rocky point is thrown out or put in. On a flat sandy shore, such as that of the Ythan, a few yards makes little or no difference to the position of a net, so long as it is placed in proper relation to the river mouth.

The district of the river Ythan does not extend more than about a couple of miles along the shore southwards, whereas the mouth of the next river, the Don, is 10 miles distant. Since the Don netting ceases on 26th August, there is a whole fortnight's difference in the length of time the Ythan's nets may fish. The Don fishers, who are just alongside the most southerly Ythan nets, feel this to be rather a grievance. It is, of course, only what occurs in several localities, only here the difference is specially obvious.

With regard to netting in the estuary, this has somewhat lessened in recent years. Practically only one net is fished for about two hours daily. This suits the rod fishers of the tidal waters, the fishing of which is leased in part to the Udny Arms Hotel at Newburgh. The Ythan is an excellent sea-trout river, and as this salmonid favours an estuarial habit much more than the salmon proper, the long tidal reach of the estuary forms a good rod fishery for both adult trout and finnocks. The fishing is carried on from boats, and from July to September inclusive the sea-trout are in best condition. They vary in weight from 4 ounces to about $2 \frac{1}{2} \mathrm{lb}$. and larger. Salmon are seldom fished for in the estuary, but a basket of $10 \mathrm{lb}$. of sea-trout is considered satisfactory by those who know how to do well there.

Fourteen miles of the river is held by Lord Aberdeen, who has right of fishing on both banks. With his usual generosity, a most liberal share of this water is made available to the public, though his Lordship's tenants have the benefit of a cheaper rate. Eleven miles are thrown open in this way, and a ticket for the whole season may be secured for $20 \mathrm{~s}$., while single-day tickets are also issued at $2 \mathrm{~s} .6 \mathrm{~d}{ }^{1}$

${ }^{1}$ Apply C. G. Smith, Estate Office, Haddo House, Aberdeen. 
The lowest 3 miles forms the reserved water, part going with Haddo House and part being let to a sporting tenant.

The take of salmon in the Ythan varies very much, a list of the approximate rod totals from 1893 to the present time (which I have before me) showing a range of from about 90 to about 300 . The river sometimes fishes very well in spring, the average for the last twenty-two years being about 70 salmon. In 1891 the spring catch reached the respectable total of 140 , the majority being taken on Lord Aberdeen's water. Owing to the gentle nature of the river, spring fish make a fairly rapid ascent.

The autumn fishing, on the other hand, is usually most successful on the lower reaches, and some of those fish are of heavy weight for a river of this size. In 1905 the best fish was $27 \mathrm{lb}$. taken in Upper Haddo House water; in 1900 a $28 \mathrm{lb}$. fish was got. On the coast, fish of 40 to $50 \mathrm{lb}$. are caught annually, and evidently these big fellows sometimes ascend the river, for in the Haddo House Museum there is a fish of $51 \frac{1}{2} \mathrm{lb}$. which, I believe, was found dead in the river.

There are several good burns, tributaries to the Ythan, and up these sea-trout run in great numbers as the season advances. In the past I have heard that certain Aberdeen worthies have thought it worth while to visit those burns when they thought they would not be seen. The method of fishing under such circumstances has for its primary object the securing of a maximum number of fish in a minimum length of time. Nowadays, however, the burns on the Haddo House estate are closed for fishing of any kind on 14th October. 


\title{
CHAPTER VIII.
}

\section{RIVER UGIE.}

\author{
Angling Season : 25th February to 31st October. \\ Netting Season: 25th February to 9th September.
}

District Fishers Board sits in Peterhead. Robert Gray, Esq., Solicitor, Peterhead, acts as Clerk.

THE inland parts of the district of Buchan form a flat plain, where the old land surface has been worn down by great denudation. Only one or two slight rises exist, one of these being dignified by the name of hill-the Hill of Mormond-standing 769 feet above the sea. In this flat or only gently undulating country the Ugie cuts its way with many a winding to the sea at Peterhead. The main section of the river is only some 6 miles in length, two head streams of considerable length, though of rather small volume, uniting abruptly at the Haughs of Rora, near the village of Longside. The North Water of Ugie and the South Water of Ugie are about sixteen and eighteen miles long respectively, the latter being named in its most inland part the Water of Fedderat. The maximum length of the river may therefore be said to be 24 miles.

A remarkable circumstance about the North Water is that it rises within $2 \frac{1}{2}$ miles of the sea at Aberdour Bay in the Moray Firth, and within a short distance of a burn which flows into that bay, yet its waters enter the sea on the east coast as described. The appropriate name of the rise in the land which determines the initial course of this stream is Windyheads Hill. There is not much shelter in this region, though here and there rich woods surround such places as Pitfour or the old Castle of Brucklay on the South Water; but the streams are frequently cut down in pleasantly fertile dells unsuspected as the eye ranges over the wide expanse of land. Some distinctly picturesque views are also to be had near the mouth of the main river at Ravenscraig Castle, where the banks are steep and 
bold, or at Inverugie, or at the section of the river where the old cruives used to be fished, or where the Ugie Board now have their hatchery.

Much of the water is rather sluggish, as is inevitable from the flat nature of the country, but at other parts, as the stream is turned about this way and that, an interesting succession of streams and pools exist, charming to the trout fisher, if not always so to the salmon angler. Speaking of trout, I may add that the North Water is, I believe, the best, although the opposite has been stated. Mr. Murray of Ravenscraig says: ${ }^{1}$ "At one time I was under the belief that trout of fabulous size inhabited the pools; but, since then, I have fished it up and down with real minnow, and have neither hooked nor seen any much above $2 \mathrm{lb}$. . . .

"As the result of many years' fishing, I have never killed them above $4 \mathrm{lb}$. (and that on one occasion only), $3 \mathrm{lb}$. being quite an exceptional weight.

"Worm-fishing is not allowed on a great part of the river.

"The takeable size is fixed at 9 inches; but I think this might be reduced somewhat, seeing that the best trout are under that length, and those above it are not so good. Most of the native anglers affect to despise brown-trout fishing. . . .

"The Ugie can hardly be called a salmon river. . . . What can be said of a river containing miles of good fishing water, vigorously fished every day by twenty anglers (most of them experts) during the whole month of October, and yielding only a grand total of 11 salmon! Yet this was the case on the Ugie last season (1907).

"I am glad to admit that it was a particularly bad season; but I do not think the average catch is more than 35 salmon. I do not include grilse, of which a few are taken. The Ugie salmon are exceptionally heavy for such a small river. I believe the average is equal to that of the Don or Dee; $18 \mathrm{lb}$. to $25 \mathrm{lb}$. being quite common fish."

I may say, with regard to the number of fish taken by rod in 1907, that the Twenty-sixth Report of the Fishery Board for Scotland gives the number of salmon and grilse as 21 . Without doubt, however, the chief sport in the Ugie is the sea-trout and finnock fishing in the lower reaches-Scott's Pool, which is a long tidal pool and forms the first resting-place for all the migratory fish on entering, the Cruive Pot, Pot Sunkan, and the Craig Pot are the favourites. This angling is carried on during July, August, and September, and

1 The Scottish Field, January 1908, p. 12. 
further up stream in October, almost exclusively at night. The first run of sea-trout is generally composed of fairly heavy fish, averaging about $3 \mathrm{lb}$. Good baskets are quite commonly made in an evening, and in order that others may share in the sport, Mr. J. W. Forbes, Bronte Cottage, Inverugie, who has taken a lease of the fishing, has arranged that tickets may be secured from him.

The right of salmon fishing is owned almost exclusively by Colonel Ferguson of Pitfour. Peterhead is the best place to stay at, and the railway is most convenient for visiting the best parts of the water.

The takes for the last few seasons, as reported by the Clerk of the District Fishery Board through the river watcher, and published in the annual reports of the Fishery Board for Scotland, are:

\begin{tabular}{|c|c|c|c|c|c|}
\hline & $\begin{array}{c}\text { Salmon } \\
\text { and } \\
\text { Grilse. }\end{array}$ & $\begin{array}{l}\text { Sea Trout } \\
\text { and } \\
\text { Finnock. }\end{array}$ & & $\begin{array}{l}\text { Salmon } \\
\text { and } \\
\text { Grilse. }\end{array}$ & $\begin{array}{l}\text { Sea Trout } \\
\text { and } \\
\text { Finnock. }\end{array}$ \\
\hline 1901 & 35 & 300 & 1905 & 32 & 1500 \\
\hline 1902 & 12 & 800 & 1906 & 34 & 1100 \\
\hline 1903 & 48 & 885 & 1907 & 21 & 1000 \\
\hline 1904 & 13 & 2000 & 1908 & 8 & 500 \\
\hline
\end{tabular}

A considerable drawback to the entrance of the largest fish is caused by the nature of the mouth of the river. From Scott's Pool the run into the sea often becomes very shallow. The coast at this point is completely exposed to the east and north-east, and storms wash in quantities of sand and gravel, through which the comparatively weak force of the Ugie is not able quickly to cut its way. When the tide is out the fresh water runs out across the beach, and in ordinary conditions, as I have seen it, the stream is a quite shallow one. Fish can only enter at all freely when the tide is up.

The estuary is defined as a portion of a circle of 200 yards radius drawn from a centre in the middle of the river where it joins the sea at low-water. It is possible, therefore, for fixed nets to be set, as they generally are set, pretty close to the river mouth.

Sweep netting is also carried on off the mouth of the river, in July, August, and September.

Angling for finnock is much carried on in spring. This sport begins in February, and reaches its height in April. Taking the whole rod and line catch of the season 1907, and expressing it in monthly percentages, the result is :-February, $9 \cdot 7$, March, 19.5, April, 29.3, May, 9·7, June, 4.8, July, 0·9, August, 9·7, September, 9·7, October, 6.9 . It is the great amount of finnock fishing which here produces the high percentage for April. In this season, the heaviest fish caught by rod was $28 \mathrm{lb}$., the heaviest by sea net $48 \mathrm{lb}$. 
A salmon hatchery exists some little distance up the river, which annually treats from 80,000 to 150,000 ova. The old cruives of the river are not now fished for commercial purposes, but are maintained in order that fish may be conveniently secured for ova stripping. The water of the Ugie is practically free from all pollution, but in times of flood it becomes much discoloured. A supply of water for the hatchery from a separate source was, therefore, recently arranged for. An unexpected mortality at first resulted, caused apparently from solutions passing off from new cement work. 


\section{CHAPTER IX.}

\section{RIVER DEVERON.}

Angling Season: 11th February to 31st October.

District Fishery Board sits in Banff. Clerk, James Morrison, Esq., Solicitor, Banff.

THE Deveron rises from a high mountain ridge on the western borders of Aberdeenshire, from which streams flow south-east into the Don, and north-west into the Spey. The head stream of the Deveron proper-the Alt Deveron as the Highland source of this lowland river is called-passes through the high and bleak district of the Cabrach soon after its birth. The water is dignified by the title of "river" after it is joined by the Blackwater at a place called Dalriach, but the volume is still insignificant. Leaving the Cabrach, it flows north with an easterly trend for 17 miles to Huntly, below which it receives its two chief tributaries, the Bogie from the south, and, a few miles further on, the Isla from the north-west. These two tributaries are of equal length, each being about 16 miles, and in these waters, unfortunately, a good deal of pollution occurs. Huntly drains into the Bogie, and Keith into the Isla, the latter being perhaps the worse, since not only does domestic sewage enter, but waste products from a distillery and from Kynoch's chemical factory are added.

The Deveron is not polluted by distilleries to the same extent as the Spey is or was, but there are seven in the upper waters estimated as capable of distilling 6,000 bushels a week during the five or six months of what is called the distilling season, which unhappily embraces the spawning season. I shall deal with the recent and successful methods of treating distillery refuse when describing the Spey.

The Deveron, after receiving the Isla, enters upon a series of wide curves as it works its way into the lower parts of Banffshire. 


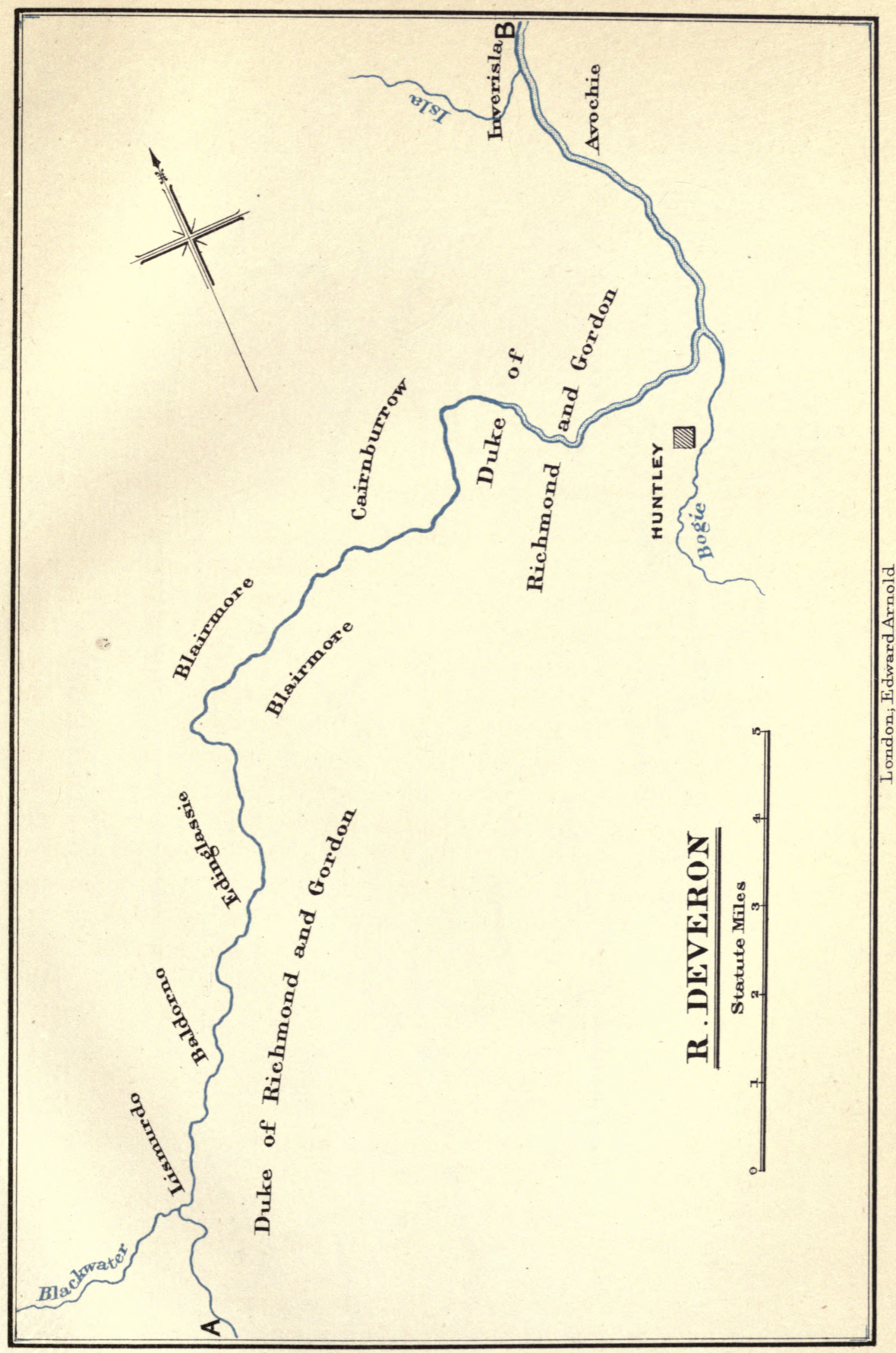





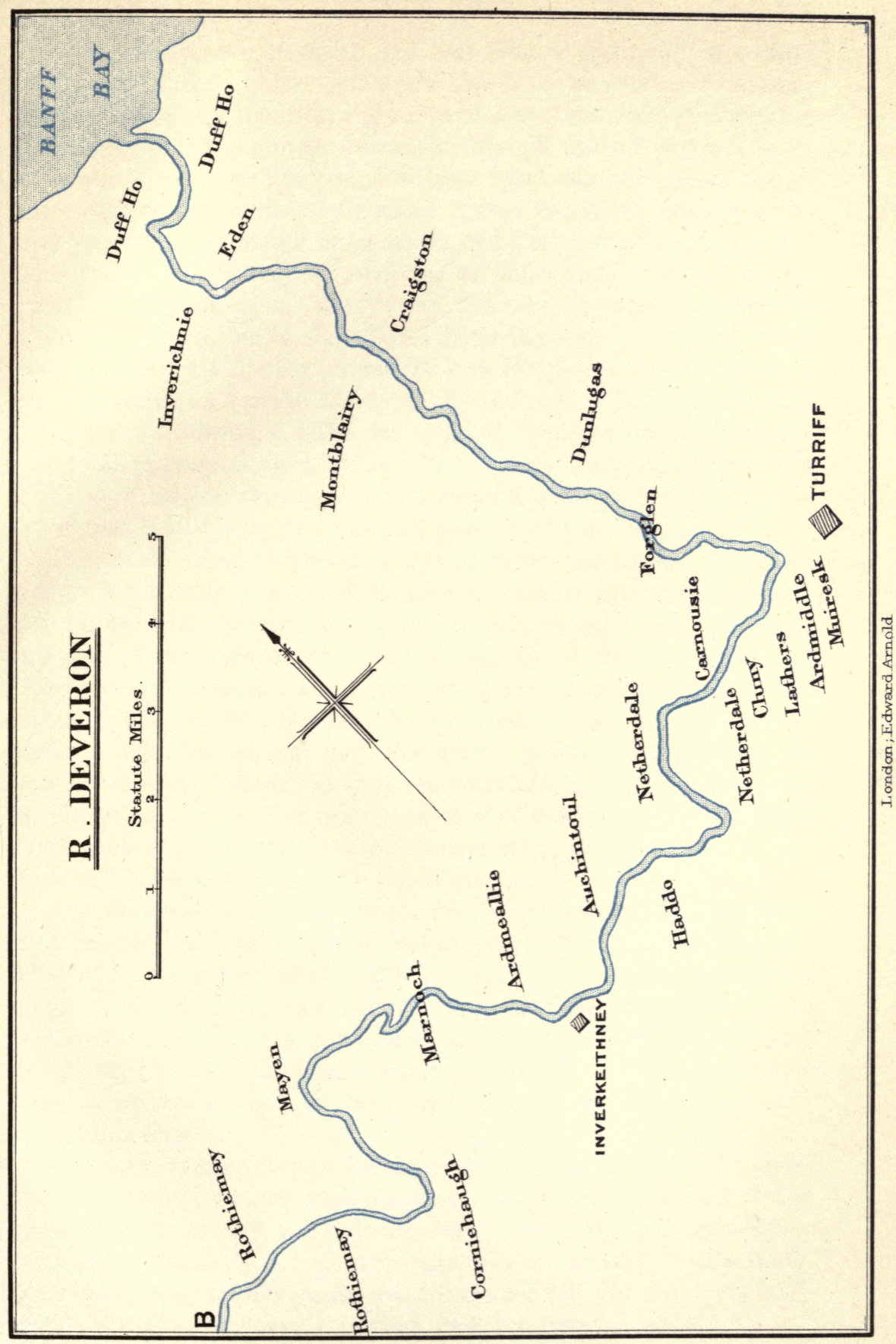


Its general character is varied and very similar to the upper section of the river Don. Like that river also it is famous as a trouting stream, and many beautiful brown trout are taken from it annually. The river at times glides pleasantly through upland pastoral land, at times through rich woods, now over sparkling shingle, or breaks more roughly through rocky glades. Often it hurries along merrily, and yet often it pauses mid meadows, or by some overhanging woods. The course from Huntly to Turriff is 22 miles, and for the most part in an easterly direction. At Turriff, the river is turned abruptly at a sharp angle to the north. For a little it seems to hesitate which way to direct its further course, but at Forglen it settles down to its northerly run for the Moray Firth at Banff, a distance of about 11 miles. Allowing 4 miles for the hill burns above the Cabrach, the total mileage is thus 54, and in the main the character of the river, as a salmon stream, is first-rate, and without doubt it should by nature hold plenty of fish at all seasons of the year.

I say "should hold," because the Deveron has passed through a very considerable period of depression, and is not yet recovered. It has paid the penalty of having been overnetted and fished by cruives; it has suffered from bad silting up at the mouth, and has been polluted to some extent, as already described. By degrees the fishing declined, till at last the proprietors rose up in conjoint action, and decided to pay the price necessary to secure the control of their fishings, so that resuscitation might take the place of depletion. It is slow work, and it also has been very expensive work, but only perseverance is now needed to bring the river back to a well-stocked and valuable condition.

The first step was the removal of the cruives, which from time immemorial had been fished by the Duke of Fife. This was accomplished in February, 1898. The cruives were situated about two miles from the river mouth. At the date mentioned, the dyke across the river was entirely cleared away. Now it is very difficult to exactly identify the place where the dyke stood. The pool above was, of course, at once lowered, and the site of the dyke is now a rippling stream.

The improvement looked for, after the removal of the cruive dyke, did not unhappily show itself strongly. Fish did not ascend to the upper waters in any marked numbers. The fish that did spawn were not apparently sufficiently numerous to resuscitate the stock. Year after year improvement was looked for but did not come, and, after waiting eight years, a further step was resolved upon. 
Netting was at that time carried on in the river from the mouth up to the bridge of Alvah, a distance of 3 miles. In the early part of the season this extent of water was fished by one boat's crew alone, one crew by day and another crew by night. From July onwards this amount of netting was doubled, two crews fished by day and two by night. Outside the river mouth, in Banff Bay, nets were set within 400 yards, this being the limit of the estuary, and those nets were "outrigged" so as to project well out into the bay.

Another factor most adverse to the fishing interests of the river had also developed in the peculiar formation of gravel banks at the river mouth. Banff Bay is open to the north, and receives the full force of the sea, which frequently sweeps in from the Moray Firth, piling up huge beaches of gravel, and, even in moderate weather, rolling the finer stones about to a surprising extent. Nowhere, I think, have I seen such perfectly round stones as in Banff Bay, and at the mouth of the Spey further to the west. The river Deveron entering the bay in a direction opposite to that of the waves brings about a combat of forces, and according as the sea is stormy and the river low, or the river in flood and the sea calm, so one force or the other temporarily gains the mastery, and arranges the gravel accordingly. A current in the bay sets, however, in a westerly direction, and so, with the on-shore action of the waves, a lateral action is also imparted, as is also noticeable in Spey Bay. The result of this is that the gravel is constantly being pushed along in a westerly direction, and that the river is at its mouth also deflected in this direction. A considerable change may result from a storm at any time, but the common appearance is a high unbroken beach of gravel right across the natural position of the river mouth a tidal lagoon of greater or less extent at the back or landward side of this, and a contracted and shallow outlet for the fresh water as far to the west as the limits of the bay will allow. This limit has commonly been a built up front to a street in Banff called Low Shore.

At long intervals the river has, as it were, asserted itself and broken through the high beach. In or shortly after 1834, after a severe storm, it even broke away to the eastward and entered the bay at the Macduff side, near rocks called Palmer's Cove; but as a rule the natural conditions compel the river mouth to be at the west side of the bay. The lagoon and high beach are much against the entrance of fish, for not only is the actual mouth obstructed, but a very great amount of water percolates through the high gravel barrier, and robs the outflow of its proper force and volume. 
It will be seen, therefore, that with frequently very small inducement for fish to enter the river mouth, they were liable to be captured by the fixed nets of Banff Bay; and that when fish found suitable conditions for entering the river, they were at once liable to be caught by the net and coble fishing of the first 3 miles. The removal of the cruive dyke was not sufficient to bring about a marked improvement while this combination of circumstances prevailed. The proprietors, therefore, in 1905 opened negotiations for the purchase of the river netting and the netting in Banff Bay, and early in 1906 the negotiations were completed. Having secured all the nets, the proprietors then sold the rights in the sea outside of a line between the towns of Banff and Macduff, and reconveyed the river fishings to their original owner, with the condition attached that rod and line fishing alone was to be carried on.

The new arrangement came into force at the termination of season 1907, so that from the 26th August of that year the Deveron has been entirely free of nets. It happened also that in 1907 a severe storm damaged the sea wall at Low Shore, Banff, and the local Town Council, in order to properly repair it, opened a direct mouth for the river through the gravel beach. In June of that year, when I visited the mouth of the river, I found the lagoon no longer a part of the river channel to the sea, and the former mouth at Low Shore already completely closed up by the unchallenged action of the sea. The salmon fishery proprietors succeeded further, in persuading the Banff Town Council to allow the direct river mouth to remain.

Duff house was, some time since, presented to Banff by the Duke of Fife. It is now to be turned into a "Sporting Hotel," from which fishing in the lower reaches of the Deveron will be possible.

The direct entrance of the river is, I am persuaded, of great moment, if only to prevent the wastage of water, by filtration through the beach, and the consequent dissipating of attraction to fish in the sea. If nature is simply allowed to take its course, there is no doubt that before long the mouth will again be at Low Shore, and the lagoon re-established. An engineer was consulted as to the possibility of preventing the westward shifting of gravel, and made proposals for works of enormous strength and cost. $\mathrm{He}$ no doubt understands engineering necessities much better than I do, but I have seen no reason to change the opinion which I then ventured to express, that a simple row of stakes at right angles to the beach, and running down to low water mark, placed some distance to the east of the direct mouth, would cause the gravel to accumulate there, so that a 
bank would be formed which would at any rate shed its superfluous stones at a much slower rate than this gravel is moved along the beach at present; and such stones as were washed over would be not too numerous to be carried out by the action of the river. It is, I think, idle to suggest a structure to resist the action of the waves here. It is wiser and infinitely less expensive to use the action of the waves to construct the desired bank in a natural way. I believe the North Esk mouth has never shifted since the simple barrier to the south of it was formed many many years ago, and previous to that there was a lagoon larger than the one referred to here, with the mouth of the river half a mile away in the direction of St. Cyrus.

So far as appears, the removal of the cruive dyke resulted chiefly in the limited number of early running fish getting to the upper waters before the netting came on. The year after the dyke was removed a few such fish were taken by rod several miles up the river. With a reduced stock, however, and a bad river mouth, the number of very early fish was not great. With the dyke still acting as a check to ascending fish all through the year, the pool below the dyke was the chief netting station, and I believe as many as 3000 fish were at times taken from it in a season. Practically no fish got further up till nets were off and the cruive-boxes opened.

When the cruive pool was no longer in existence, the nets were chiefly used lower down, where the water was fairly quiet within and at the top of tide-reach. That the nets still continued to take a fairly heavy toll seems borne out by the few returns published, which I have at command. In 1902 they are reported to have taken 1500 fish, and in 1903 as many as 2005 fish, being 582 salmon and 1423 grilse. On the whole, however, the rods were beginning to do better. The total catch for the river was in-

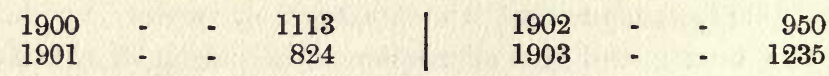

I am not able to give totals after 1903, and it may be they would not look as well as some of the above. The weather conditions generally were perhaps adverse in the last season or two, and the last of the netting may have been extra severe; but it is at all events cheering to notice that, with regard to the number of fish seen spawning, the returns published in the Annual Reports of the Fishery Board for Scotland speak to a marked increase. The report for 1907 , for instance, says the numbers of breeding fish were "far above the average." Corresponding with this, also, I am aware that large numbers of kelts were caught in the spring of 1908 by those 


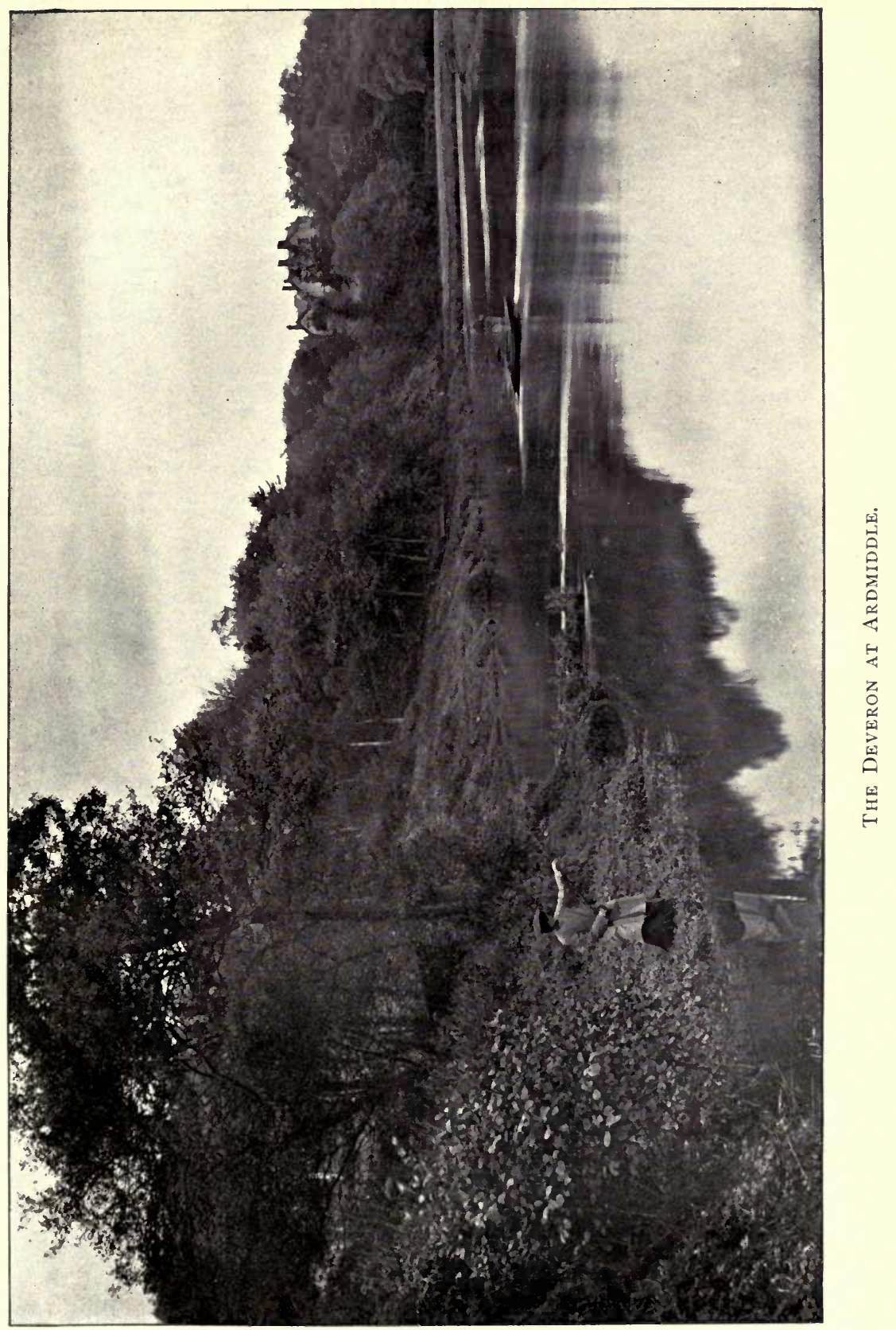



who tried patiently, and, it is to be feared, with rather small success, for clean spring fish. Fifty kelts were marked at Rothiemay, and others were marked at Ardmiddle, Ardmeallie, and Upper Forglen. Yet these very waters, along with others, should before long yield excellent spring results.

The spring fish of the Deveron is of the small variety, 8-10 lb., with very possibly an occasional example of the larger class. The autumn fish, on the other hand, runs fairly large, not uncommonly up to 20 and $25 \mathrm{lb}$. The other year a $31 \mathrm{lb}$. fish was taken, and the record is, I believe, $44 \mathrm{lb}$.

At Huntly the Town Council appoint annually a committee who regulate fishings in the neighbourhood which are leased from the Duke of Richmond and Gordon. These fishings extend to 17 miles, or thereby, not only in the Deveron proper, but in the tributaries of the Bogie, Isla, Ness Bogie, and Kirkney. Visitors to Huntly may receive a ticket enabling them to fish on the waters referred to, the bounds of the various waters being set forth on the ticket itself. Mr. J. R. M'Math, solicitor, Huntly, acts as secretary. The water holds some famous trout which, in the lower sections, come into very fair condition as early as the middle of April. Above Baldorney, June and July are perhaps best. There are probably no waters open to the public in Scotland which offer finer trouting than these, and the chance of a salmon is considerable and the available pools most inviting. Of late years the river above Huntly has yielded more salmon to the rod than the lower water. In course of time we may expect that the upper Deveron will fish like the upper Dee. Persons resident upon the Duke's property at Huntly have a preference in the matter of charge, but a stranger has only to pay 15s. a month, or $£ 22$ s. for the season. He may also fish for a day or a week at lesser charges. Salmon fishing permits are issued from 1st March, trout permits from 1st April. Fishing at night is not allowed in September and October, and in fishing for salmon during the month of March fly only is allowed, and the gaff may not be used in landing fish. Other regulations are those which every right-minded sportsman will be glad to agree to, and concern legal fishing and the preservation of property. It may be noted that the proprietor reserves power to interdict any person whether possessed of a ticket or not, but any one knowing the Duke of Richmond and Gordon knows that this is merely a precautionary measure.

The Deveron is fortunate in this, that it is not obstructed by weirs or by natural falls. There is only one weir on the main 
river, at Rothiemay; but it is a low structure of rough stone and only acts as an obstruction when the water is low, and when in all probability fish would not in any case be running. The Bogie, on the other hand, is rather badly obstructed by two dam dykes, one at Stephen's Mills, a structure of stone and cement with a very deficient fish pass, and the other at Brander Brothers' Mills, which is a rough stone dyke without a fish pass. In view of the pollution, and the fact that in these upper tributaries gravid fish have to be considered, it is very desirable that easy access to the pure waters above should be possible.

At Turriff, on the burn of Turriff, a nasty little obstruction exists, which I am afraid must be totally obstructive to fish. It is of smooth cement, is abrupt, and has no pass. The burn has a good run into a fine pool above the road bridge, where, as already described, the river is sharply turned off to the north. It is such a stream as one would expect grilse to take at spawning time, but the dam dyke is only some 500 or 600 yards up.

In a river such as the Deveron, where much has been done to secure improvement of the salmon fishings, it is highly advantageous that some sort of record be kept either privately, officially, or publicly, showing in general terms the catch of the various sections. So far as I can find, however, no record of the kind exists, and, moreover, some fear of assessment causes rather a repression of results. None the less I think it would be most valuable if, say, the river was divided into three sections and totals for each section were kept, as for instance:

$\begin{array}{llllll}\text { Banff to Turriff, say } & - & - & - & - & 250 \text { fish. } \\ \text { Turriff to Huntly, say } & - & - & - & - & 265 \\ \text { Above Huntly, say } & - & - & - & - & 310\end{array}$

The figures are not actual results of any one year, but they happen to be as near an average of recent years as may be. I venture to prophesy that the first good fishing year will see a total for the river well over 1500 fish; but if no regular record is kept, how are the proprietors to know if their great outlay is being repaid? Each may know something of his own water, but he probably does not know what results are obtained beyond his next neighbour's section. Personally, I believe the Inspector of Salmon Fisheries in Edinburgh might be persuaded to keep the totals if they are not safe in the district.

The relative positions of the various fishings will be best understood by reference to the accompanying map. 


\section{CHAPTER X.}

\section{THE SPEY DISTRICT.}

\section{Angling Season: 11th February to 15th October. \\ Netring Season: 11th February to 26th August.}

District Fishery Board sits in Elgin. Clerk, T. R. Mackenzie, Esq., Solicitor, Elgin.

THE drainage area of this district is 1097 square miles, being the largest but one-the Tay-in Scotland; but the district is peculiar in this, that large lochs do not exist, and the entire length of the area is practically occupied by the river. Tributaries such as the Druie and Avon rise in part from lochs, and at one part of the main river a shallow loch (Loch Insh) exists, but this last is merely a large widening of the river over a flat surface of surrounding country. None of the tributaries is of first-class importance for angling; but several of them are first-class spawning streams. The Tweed is the only other district in Scotland in which so much actual river channel exists, and in which spawning grounds may be found over a very widely-extended waterway.

\section{THE RIVER SPEY.}

The total length of the river is about a hundred miles, and in character it may be divided into an upper and lower section at a point a short distance above Castle Grant. From this point downwards the Spey is uniformly good in its succession of pools and long streams of fine flowing water; and this section of the river is the one over which angling is most steadily practised with success. Above this point the river is very variable in character, now presenting a broad rippling surface, now an eddying pool, and not infrequently a long stretch of still, meandering water with earthy banks and weedy edges.

The river actually rises away in the western portion of Badenoch, 
south-west of the Findhorn's source, on the high ground to the east of Loch Oich, near where the Roy flows south to the Spean.

Lonely little Loch Spey here catches the rivulets and unites them into the little stream which has so many miles before it as it flows away to the east and north. A mere tarn is Loch Spey, and hard to get to, although the Highland Railway passes within some 16 miles of it. An ill-defined track goes through the pass beyond the loch to the head of the Tarff, and so down into the great glen, as it trends north to Fort Augustus.

The Spey for some miles below its loch of origin is gravelly and well suited for spawning purposes. Before the Truim joins it, however, in the deep wooded defile, one may see on the left from the railway track between Dalwhinnie and Newtonmore a stretch of still water has supervened. The Truim is also a fine spawning stream of crystal water, but in the present state of the stock of fish I am not aware that very many reach these head waters. They are the natural places for the spawning of the earliest spring fish. Down to Newtonmore there is again some fine water. The growing district of Newtonmore sends in summer time a most noticeable and undesirable supply of sewage to the river by a long pipe carried in a mound across the local golf course. With plenty of room to adopt a simple system of land filtration, it is a pity that quite an effort should be made to reach the river with the direct sewage outfall.

Below Newtonmore a stretch of sluggish water exists which, with one break opposite Kingussie, terminates near Kincraig in Loch Insh, which, as has already been said, is in reality a widening or spreading out of the river over a flat part of the strath. This loch is commonly described as about a mile long and half a mile broad, but it is often extremely difficult to say where the loch ends and where the river channel is, for in times of tlood the water gets over the retaining banks of the river above the loch proper and covers a great extent of flat meadow land. It is not an unfamiliar sight in passing by train between Kingussie and Kincraig (the old name of which was Boat of Inch) to see the water up to the top of the fence at the side of the railway embankment, and to find it encroaching also on the haughs beyond the railway. Yet in winter, when the water is frozen, the track of the river out in the centre of the loch can frequently be made out more certainly than at any other time. It has often seemed to me that the making of hay on those Loch Insh meadows must be peculiarly heartbreaking. I have seen haycocks floating about in autumn, and once the water gets beyond the proper 


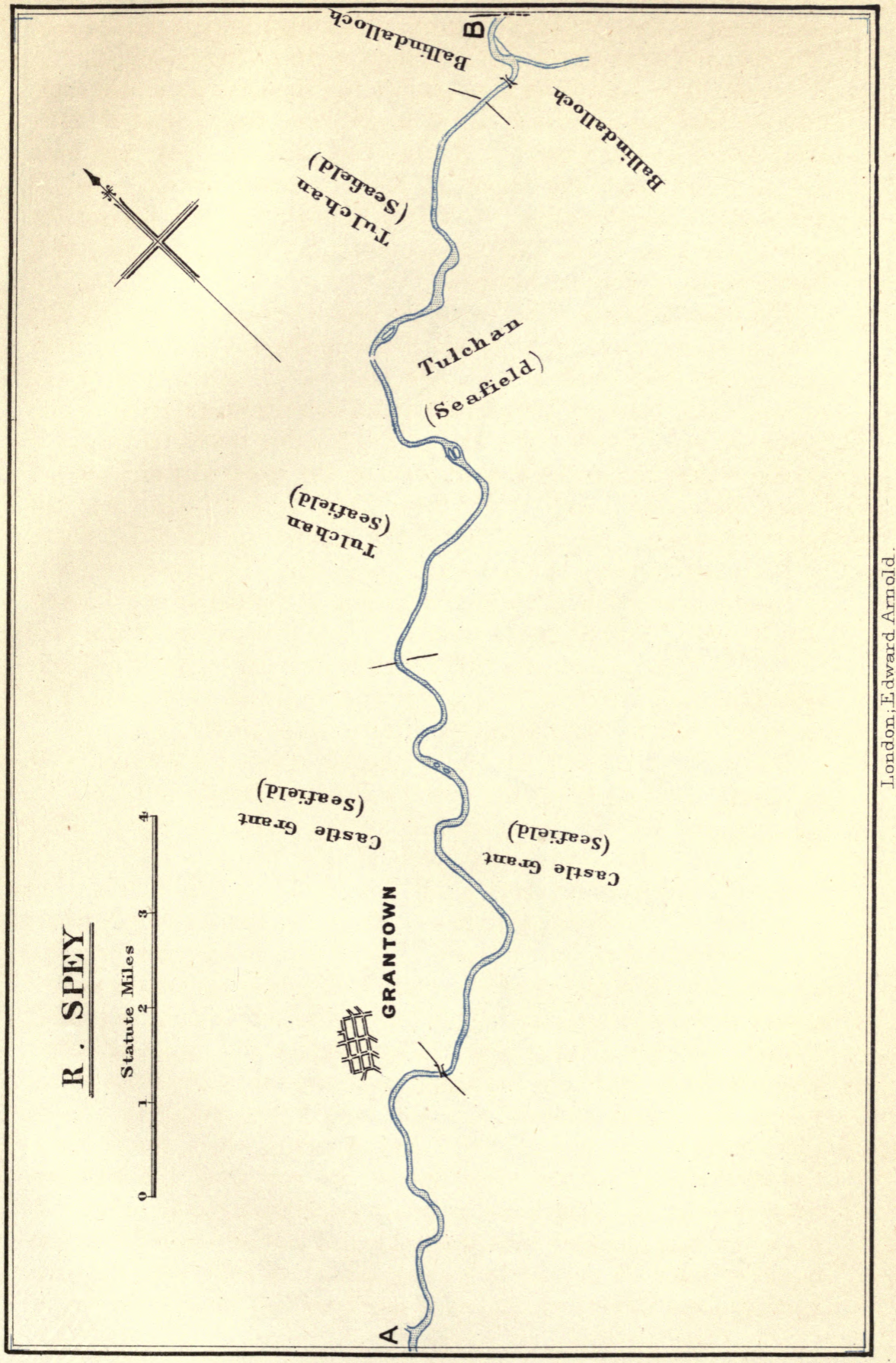





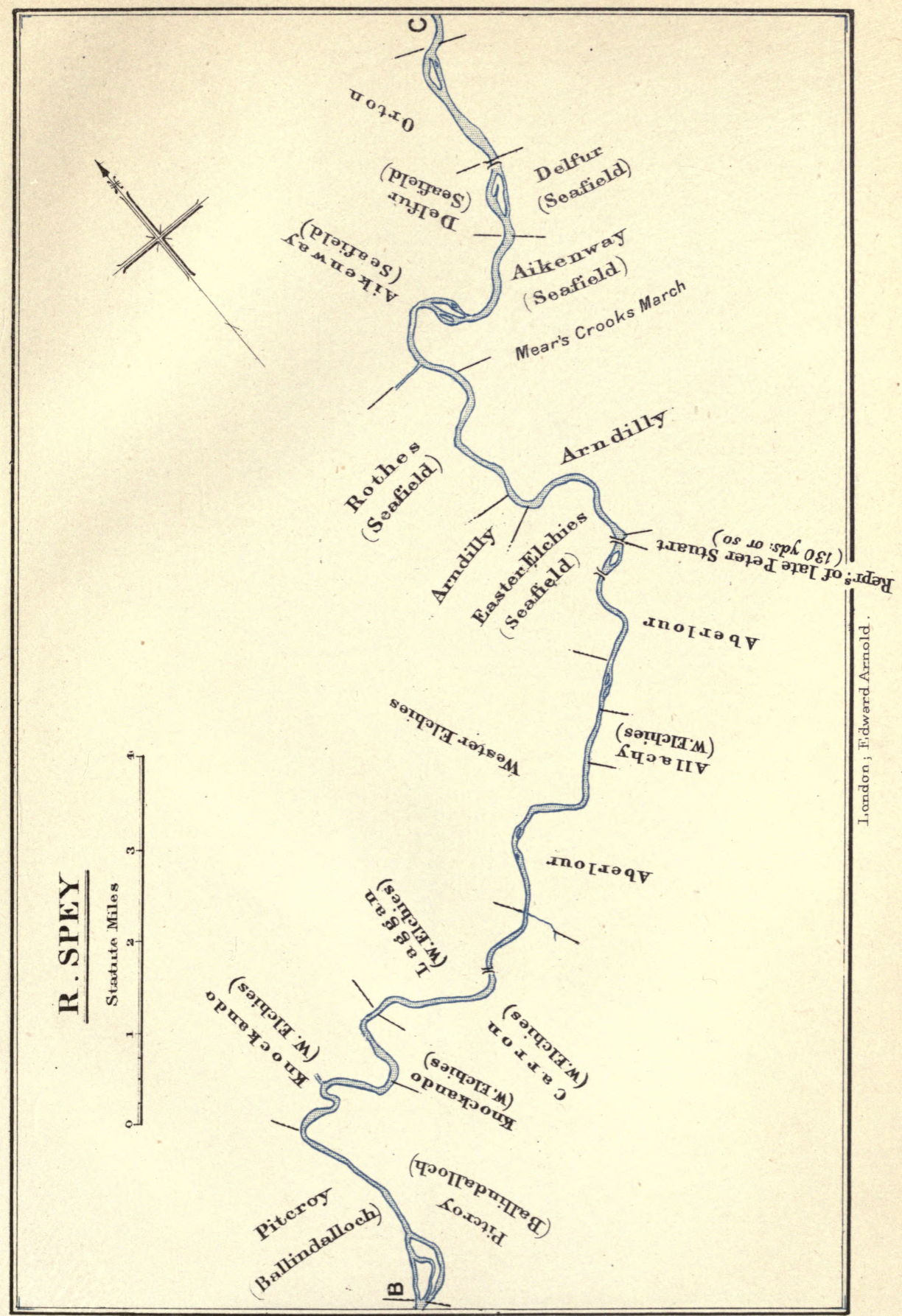




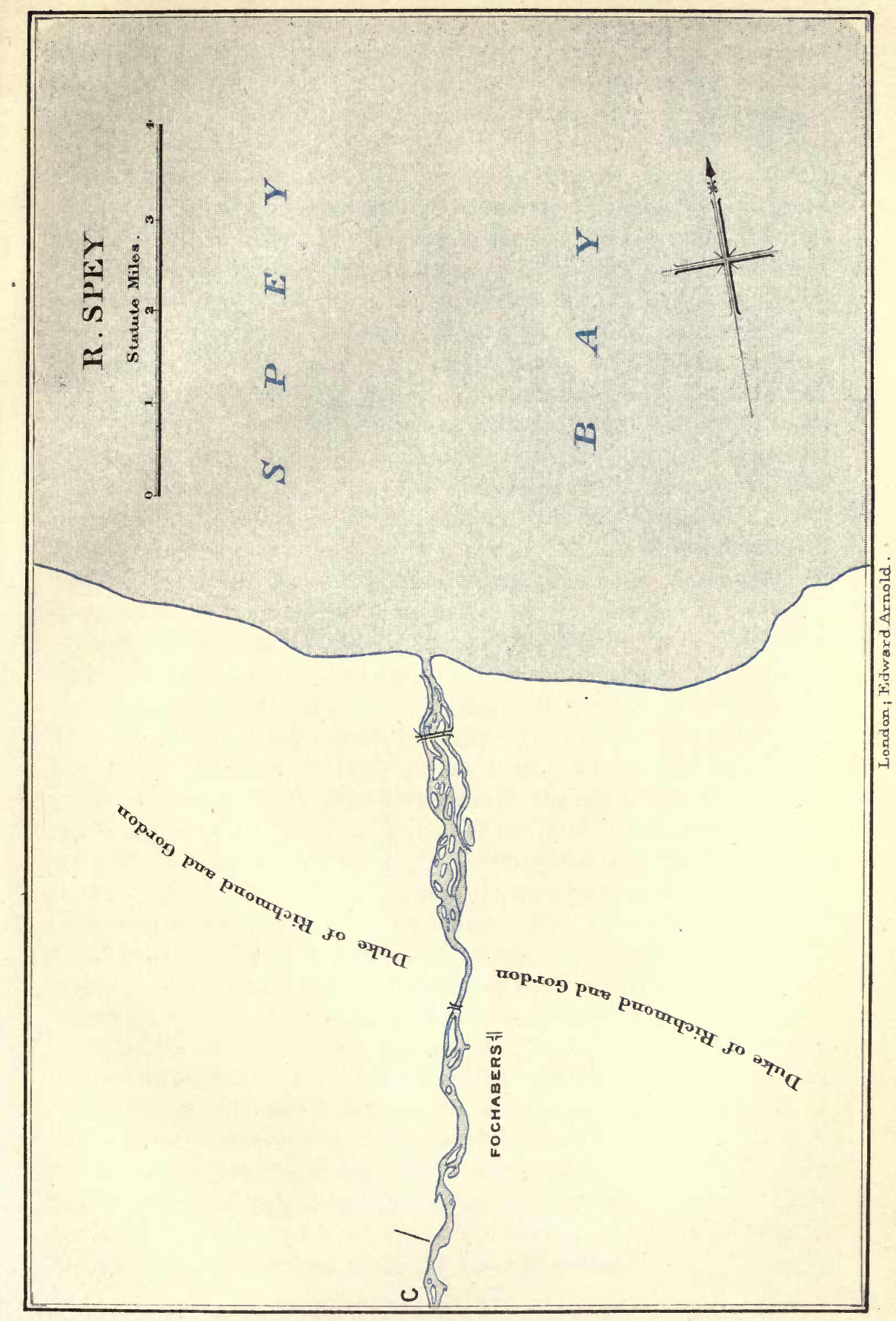



bounds it stays there for a long time. The river banks seem constantly breaking away, and much labour is expended in combating the force of the water. The cause of the whole difficulty is the action of the River Feshie, a tributary of some size, which enters the Spey a short distance below the loch. The Feshie rises in the heart of the Grampians south of the Cairngorm range, on the western side of the divide which separates the new-born Dee on the one hand from the source of the Tilt flowing to the Tay on the other. It has in early ages scooped out a deep glen of the most wild and picturesque sort, and poured vast quantities of detritus into the Spey valley, levelling up the natural gradient and damming back the upper waters. Landseer painted many of his deer in Glen Feshie, where, when last I visited it, a studio hut, with the mouldering fragments of a large subject of grouped stags was still visible on the plaster. Thompson of Duddingston also painted those wild solitudes where, he said, "the sky over such a scene seemed the floor of heaven." The Feshie is still subject to most violent floods, and is still carrying down its talus of gravel. Yet the feat of draining Loch Insh is not insurmountable, although greater interests than those of the salmon would be necessary to promote it.

It is curious that in close proximity we should have Loch Insh and Loch an Eilan, two lochs with Gaelic names meaning practically the same thing. The island in the latter, with its ruined castle, the erstwhile home of the osprey, is sufficiently evident and completely beautiful. The Insh or Inch of the other loch is only existent in times of flood. At the northern end of the loch, where the river again takes shape, there is a double knoll of considerable extent, covered with trees. This is at times converted into an island, and is the origin of the name Loch Insh. It is, moreover, of such remarkable interest as to demand some notice. The more northerly of the two knolls is called Ion Enonan, otherwise the Island of Adamnan. Now, Adamnan was the biographer of Saint Columba, and became himself a saint. On this knoll is the modern church of Insh, which occupies the site, and is actually built upon the remains, of what is I suppose the oldest ecclesiastical edifice in all broad Scotland. The dedication of the early building to Saint Adamnan is recorded as having been conducted by Saint Columba himself when on his visit to the Picts north of the Grampians, about the year 690, and although several churches may have taken shape on these foundations, the fact remains, it is believed, that Christian worship has been carried on continuously on this spot since the seventh century. 
Loch Insh is reported to hold many pike and large trout. It and Loch Alvie were the pike-fishing haunts of Colonel Thornton who, a hundred years ago, as recounted in his Northern Tour, ${ }^{1}$ took some monsters by means of his "greyhounds" or live-trout baits attached to floats. It would be a good thing to continue the destruction of the pike in this neighbourhood and in the sluggish parts of the Spey. I am not aware that it is any one's business to attend to this, but, as is done in certain other rivers, the District Fishery Board might with great advantage give attention to the matter, since a very considerable number of salmon certainly spawn above this point, and leave their fry to descend through the happy huntinggrounds of the natural enemy. Some guide to the number of salmon to be found in the loch may be got when it is stated that 275 were netted and sold in 1891, and 400 netted and sold in 1895 . Since 1898 this netting of the upper waters has been discontinued, but at the end of the season a very considerable number of fish have become distributed over the upper Spey, as well as in the Feshie and Tromie.

Below Loch Insh some really fine pools exist, but these have for the most part fallen into neglect. Broken banks and submerged and overhanging trees now make one or two of them quite unfishable. Kinrara, where the famous Jean, Duchess of Gordon, used to hold sway, and where she is buried, has the fishing on the left bank, while Rothiemurchus has the right bank. The havoc to the pools is, however, almost all on the Kinrara side.

For a considerable number of years the presence of salmon in those waters has been considered practically past praying for. A few people fished, and no one caught anything unless he fished for trout, which, by the way, are here quite worth catching, for many of them run to quite good size in my experience. The keepers could always explain why salmon were not to be expected, and by degrees the river was left severely alone. With 20,000 acres of splendid moor to shoot over, the absence of fishing was not difficult to put up with.

It is proper to remember, however, that a very material change has taken place in the amount of netting at the mouth of the Spey. An increase in the stock of fish, and in the number of fish which may be able to ascend in the early part of the season-the particular fish which are of interest in this connection-will, I trust, before many years are over, bring about a new condition of things. People who have got out of the way of fishing those upper waters may

\footnotetext{
${ }^{1} \mathrm{~A}$ reprint of this interesting book has been edited by Sir Herbert Maxwell, Bart. London: Edward Arnold.
} 
find it worth their while to throw an experimental fly over the water now and again. After mild winters I should especially expect fish here earlier than they have been known in the memory of the very oldest and most authoritative ghillie.

Below Aviemore there are two or three nice pools belonging to Kinveachy, which is the furthest up possession of the Seafield estates. These often hold a lot of fish at "the back-end," but have not, so far, yielded anything to the rod in spring. Between Boat of Garten and Broomhill the last stretch of slack and uninteresting water exists, and with it ends the upper section of the river as I have ventured to divide it.

So far the whole of the course has been in the county of Inverness. Between Broomhill and Grantown, the Dulnain tributary enters on the left bank. This river is second only to the Avon in size and importance as a tributary of the Spey. It rises about 28 miles to the west, far back in the solitary slopes of the Monadliath mountains, not far from the source of the Findhorn. It holds a few fish in summer, and used to be known as a sea trout stream. A few sea trout may still be taken from it, but the real value of the Dulnain is as a spawning stream. After a little fall near old Muckrach Castle, the former seat of the Grants of Rothiemurchus, there is no obstruction of any moment for about fifteen miles, and in spite of a distinct peatiness of water, the spawning ground is excellent almost the whole way. Many fish surmount the upper falls also-as I have seen more than once-and spawn in the most lonely part of the stream in the outlying section of Kinrara property.

From Grantown to the mouth of the river is a distance of about forty miles, the left bank being chiefly in the county of Elgin, while the right bank is for the most part in the county of Banff. This is the important part of the river from a salmon-angling point of view, and the splendid character of the water cannot be more easily and speedily viewed than from "The Speyside Line" of the Great North of Scotland Railway between Grantown and Craigellachie. From the latter point to the sea the same fine character continues, one might almost say an even finer character is found.

The particular fishings are Castle Grant, Revack, Tulchan, Ballindalloch, Pitcroy, Knockando, Laggan, Carron, Western Elchies, Aberlour, Easter Elchies, Arndilly, Rothes, Aikenway, Delfur, Orton, and Gordon Castle. Their relative positions will be seen on the map.

As fine salmon fishing water as can be found in all Scotland is included here, but one has to lament that for a considerable number 
of years the returns from not a few sections of this fine water have not been satisfactory. There is probably more than one cause, but I will endeavour to deal with causes a little later.

At Ballindalloch the largest tributary of the Spey enters. This river, the Avon, commonly pronounced Aan, has a course of some forty-five miles from little Loch Avon, at the back of Cairngorm, to Ballindalloch. Its direction is very largely parallel to the main river, flowing as it does close to Tomintoul-reputed to be the highest village but one in Scotland-and along the east side of the hills of Cromdale. The water of this stream, coming as it does from clean rocky country, is quite remarkably pure, so much so, that one is warned to be extremely careful in wading, since depths are very deceptive. It contains some fine trout, and, as the season advances, a fair number of salmon may be got on suitable days. About five miles from the mouth the Livet joins the Avon. The purity of Glen Livet water, of the strong variety, is well known amongst thirsty Britishers in many parts of the world.

The only other important tributary is the Fiddick. It is not a large stream; but in spite of certain dangers to fish from the distilleries of Dufftown and the neighbourhood, as well as from domestic sewage, it is an extremely valuable tributary to the Spey. Late running fish at times enter it in very great numbers at the back-end of the year. It is the first tributary which such fish encounter on this ascent of the main river, although it is about sixteen miles from Spey mouth. The descriptions which have occasionally been given of the show of fish in the Fiddick reminds one of accounts from the Fraser River in British Columbia-where they still "eat what they can, and can what they can't." I have not myself seen the water stiff with fish either in the Fraser River or the Fiddick, although I have looked in the latter at spawning time. I once asked a most reliable and venerable friend who had just visited the Pacific coast, if the account one heard of the number of salmon in the Fraser River could be true. "I don't know what you've heard," he replied, "but it's true."

Of the fishings mentioned between Castle Grant and the mouth of the river and extending over about forty miles of water there are only six proprietors. The Seafield estates have the longest mileage, viz. 15 miles of both banks, besides 7 more on the left bank and 2 on the right; in other words, 39 miles of river bank counting on each side. This includes the private water of Castle Grant, Revack, Tulchan, Easter Elchies, Rothes and Delfur. The estate of Ballin- 


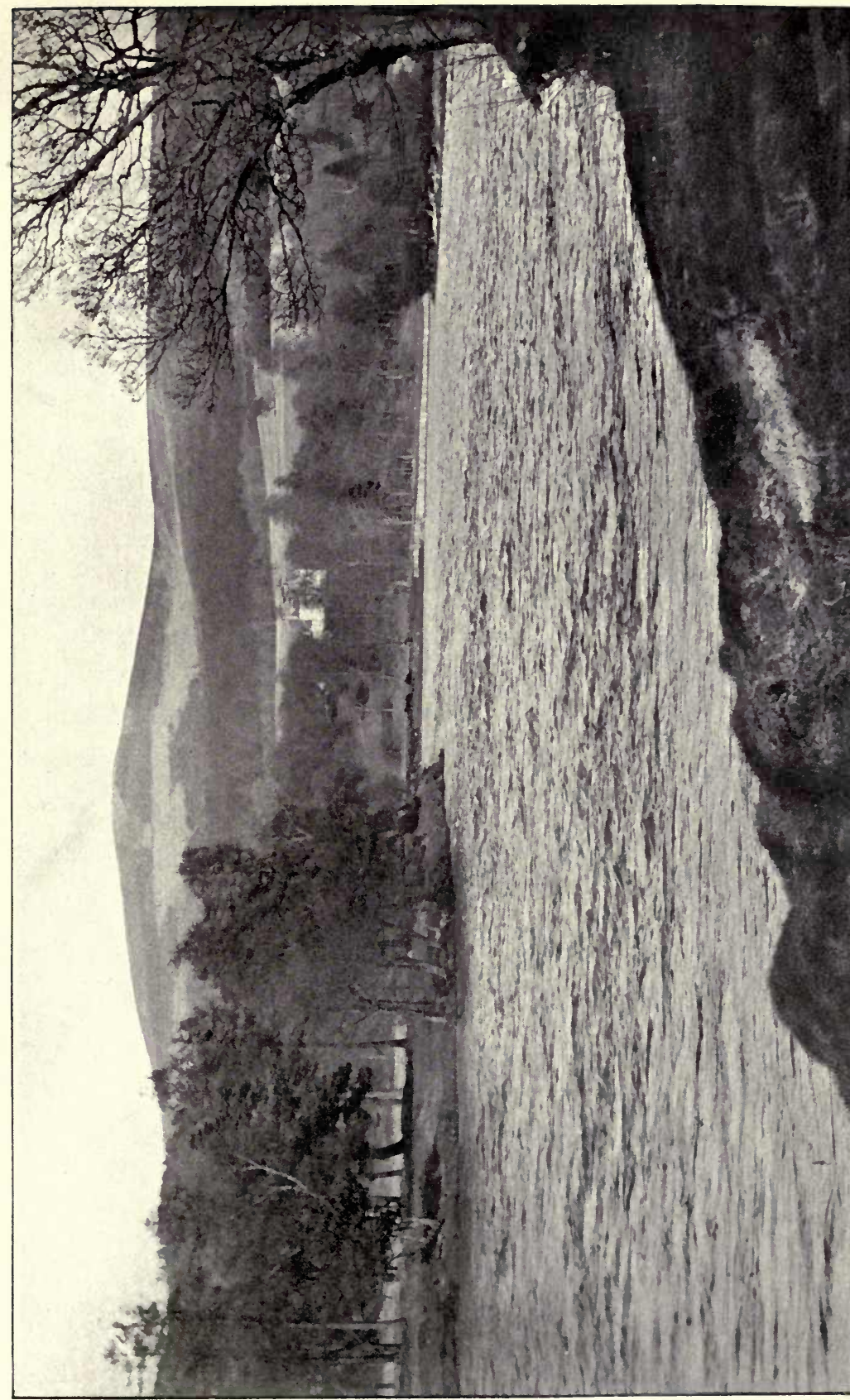

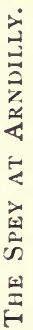



dalloch includes Pitcroy and is the property of Sir John Macpherson Grant. Knockando, Laggan, and Carron belong to J. W. H. Grant of Western Elchies. Aberlour is the property of J. R. Findlay and is on the right bank as far as the railway bridge at Craigellachie. Arndilly belongs to Mrs. Kinloch Grant, and Aikenway, with its fifteen fine casts, to W. G. Stewart Menzies. The remainder of the river is fished by the Duke of Richmond and Gordon. There are about nine miles, including Orton and Gordon Castle waters, and this section is without doubt the most productive in the whole river. Before netting in the Gordon Castle water was reduced, and part let to a syndicate, as many as ten to twelve rods could be sent out at a time. The angling only commenced about 1st September, when the netting ceased, and continued till 15th October; but as many as 70 fish are reported as having been landed in one day. Mr. Augustus Grimble in his book ${ }^{1}$ gives a few returns of this fishing which perhaps I may be allowed to quote. They relate to the period referred to, and represent a month and a half's fishing each year :

\begin{tabular}{lllll|lllll}
1890 & - & - & - & 452 & 1895 & - & - & - & 696 \\
1891 & - & - & - & 889 & 1896 & - & - & - & 583 \\
1892 & - & - & - & 950 & 1897 & - & - & - & 495 \\
1893 & - & - & - & 705 & 1898 & - & - & - & 426 \\
1894 & - & - & - & 813 & 1899 & - & - & - & 445
\end{tabular}

With regard to actual numbers of fish caught by nets in the river and on the coast, all at the Duke of Richmond and Gordon's fishing stations, Russel of the Scotsman gives some interesting figures of an early date: ${ }^{2}$

\begin{tabular}{|c|c|c|c|c|c|c|c|}
\hline $\begin{array}{l}\text { Year. } \\
1851\end{array}$ & $\begin{array}{c}\text { Salmon. } \\
-\quad 6,515\end{array}$ & $\begin{array}{l}\text { Grilse. } \\
33,285\end{array}$ & $\begin{array}{r}\text { Trout. } \\
8,660\end{array}$ & $\begin{array}{l}\text { Year. } \\
1856\end{array}$ & $\begin{array}{cc} & \text { Salmon. } \\
- & 14,103\end{array}$ & $\begin{array}{l}\text { Grilse. } \\
27,528\end{array}$ & $\begin{array}{r}\text { Trout. } \\
8,118\end{array}$ \\
\hline 85 & - $\quad 10,980$ & 46,041 & 8,549 & 1857 & 13,466 & 54,949 & 31,473 \\
\hline 185 & - $\quad 15,772$ & 58,166 & 16,675 & 1858 & - 30,840 & 35,409 & 15,313 \\
\hline 85 & - $\quad 29,780$ & 36,148 & 16,025 & 1859 & - 23,608 & 17,263 & 5,853 \\
\hline & 1 & 48 & 60 & & & & \\
\hline
\end{tabular}

The year 1851 was the first the late Duke worked the fishings in his own hand. Previous to this Mr. Hogarth was tenant of the fishings for many years, and during his tenancy it was remarked that the stock of sea-trout fell off very much indeed. Sea-trout have, I believe, never since been numerous in the Spey.

The figures just given are sufficient to show that in the fifties the stock of fish was very considerable. Older accounts go to show that the stock of salmon in the Spey was "vast." The angling returns for 1890-1894 are also sufficient to show that at the end of each season the number of fish in the lower waters is still very considerable.

\footnotetext{
${ }^{1}$ The Salmon Rivers of Scotland, ii., p. 197.

2 The Salmon, p. 106.
} 
But everyone who has any interest in the Spey and its salmon knows that for many years a very strong feeling has obtained amongst proprietors that a too heavy toll of the fish was taken by net in the lower reaches, and that the proportion of fish which were allowed, or which were able, to pass the nets and to afford sport to the upper proprietors was unduly small.

Certain steps had been taken in the past by the proprietor of the net fisheries to benefit the district stock. In 1851 twenty-three bag and fly-nets were removed from the coast at the mouth of the river, so as to leave an estuary of larger dimensions than laid down by statute. In this way a stretch of coast between four and five miles long, and containing the mouth of the river, became free of fixed nets, and has remained so ever since. In 1883 a cruive dyke, which used to be fished, was removed. In 1888 the weekly close time at the Orton water-that is where the top nets were fished-was increased from 36 to 42 hours, and in 1897 a more direct mouth to the river was cut through an extensive gravel bank. These measures, however, did not satisfy the other proprietors, and in 1894 a lease of the Orton net was taken for six years at an annual rent of $£ 175$. The benefit from this was not, however, considered to be in proportion to the price paid, and the arrangement was not renewed.

It is possible to obtain some idea of the angling results of the upper proprietors in question from the evidence which the late Sir George Macpherson Grant of Ballindalloch gave before Lord Elgin's Commission in 1900. Returns were put in from six of the fishings. Those returns Sir George did not vouch for, and for purposes of comparison it is possible to use only four of them, and to restrict the period from 1887 to 1899 inclusive; but regarding them in this way, we have four very representative waters, viz. Ballindalloch, Knockando, Wester Elchies, and Aikenway. The figures are:

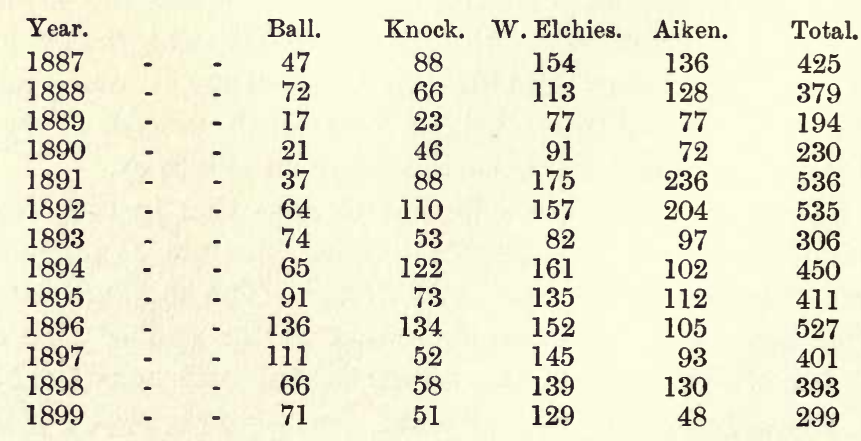


The average take in Gordon Castle water at the back-end, drawn from the figures already given, is 645 , and $53 \mathrm{lb}$. is the record weight (1897). The average for the corresponding period of ten years from the four fisheries just mentioned is only 408. Perhaps it was natural in view of such circumstances that the proprietors above Orton should consider they were not getting their fair share of the fish. There is no call for me to act as arbiter, and the evidence either way is inconclusive; but there are certainly one or two considerations which should not be lost sight of. The sound policy with regard to the extent to which it is wise in the general interests of any river to continue netting, depends on the just operation of the weekly close time, the desire being so to adjust the netting as to make it certain that a proportion of each run of fish entering the river can pass through to the unnetted waters. The lower reaches of the Spey are rapid; when the water is cold, spring fish ascend very slowly. In the close season of 1896-97, 150 clean fish were marked in the Gordon Castle water. At the commencement of the netting season 67 of them were recaptured in the same water. Of this number 25 had actually dropped lower down the river, 8 were in the same pools as when marked, and 34 had moved up slightly. Only 2 fish were recaptured by rod after having left the Gordon Castle water and ascended the river. In other words, the natural conditions of Gordon Castle water are such that at certain seasons fish are more likely to accumulate there than elsewhere, and, this being the case, they are more likely to be caught in greater numbers there than elsewhere. With the netting which used to exist in the Spey, there can, I think, be little doubt that an undue proportion of spring fish were caught before they could pass through to the angling waters.

I have no hesitation in saying that the best interests of the river were considered when, at the end of 1903, an agreement was come to between the proprietors above Orton and the Duke of Richmond and Gordon, by which nets were removed from Orton and the upper part of Gordon Castle water. Netting now reaches only to the Cumberland Ford below Fochabers Bridge, a distance of barely three miles from the mouth of the river. In the agreement as to proper compensation, I understand it was decided that between 6000 and 7000 fish would on an average be thus allowed to ascend annually. A limited amount of water close to Fochabers Bridge was retained for private angling; the rest was let.

Those 6000 fish have not been accounted for by the upper rods, so 
far as I have heard. One may naturally expect that a reasonable proportion of them should swell the records, and I certainly think the records have materially risen. The rod results of one water, for instance, have increased some 56 per cent.; but one or two bad seasons, climatically, have supervened, and in 1908 the small class of spring fish were very deficient in all rivers where they usually most abound, e.g. Dee, Brora, Helmsdale, Thurso. The grilse of the summer previous were also conspicuous by their absence, and they made the small springers of 1908 . The results of 1909 , so far as I have learned, point to a quite definite improvement; 400 fish were got in spring in one fishing.

Apart from those considerations, however, is the possibility that the fish which are present in the river, be they numerous or few, are not so prone to take as they used to be. I am inclined to think this supposition has more truth in it than many suppose, and that the cause requires most serious consideration. I call it a supposition because I personally have not obtained any direct evidence as to the effect of distillery effluents, which are sufficiently diluted in the great volume of the lower Spey to make the actual poisoning of fish improbable, but which, nevertheless, seems to influence the life of the salmon. I am aware, however, that the opinion is very generally held in the district that the distillery pollution is not nearly so serious as it used to be, but that when a discharge of pollution from any distillery takes place, angling is useless for some little time.

The favourable water of the Spey has therefore, I am inclined to think, been in a sense its undoing, since, in the last thirty years, the number of distilleries has greatly increased. Mr. George Muirhead, the Duke of Richmond and Gordon's Commissioner, in giving evidence before Lord Elgin's Salmon Fisheries Cornmission, submitted an exhaustive return as to the increase of distilleries. From this it appears that

\begin{tabular}{|c|c|c|c|c|c|c|c|c|c|}
\hline 185 & the & were & 1. & a & & & & & \\
\hline " 1860 & $"$ & " & 9 & " & $"$ & 2,280 & " & " & \\
\hline 1870 & " & " & 10 & " & " & 3,450 & ", & $"$ & $"$ \\
\hline 1880 & $"$ & $"$ & 13 & ", & " & 7,150 & $"$ & $"$ & $"$ \\
\hline 1890 & " & " & 14 & $"$ & " & 12,400 & $"$ & $"$ & \\
\hline 1900 & $"$ & " & 27 & $"$ & ," & 50,800 & $"$ & " & \\
\hline
\end{tabular}

The peculiarly poisonous waste product is "pot ale" or "burnt ale," which is the residue of the first distillation in the process of whisky making. This first distillation produces what is called "low wine," the bye-product being of an extremely complicated nature 
chemically, liable to rapid putrefaction and the evolution of great quantities of lactic acid through the growth of a specially luxuriant fungus. This "pot ale" is about fifty times as poisonous as the most gross and complex sewage of such a city as Manchester. The redistillation of "low wine" results in whisky, with "spent lees" as a bye-product, a substance which, compared with pot ale, is comparatively harmless.

It is true, I suppose, that the industry of whisky-distilling does not now flourish as it did, that there has been overproduction, and that some of the distilleries in Strathspey, especially in view also of the recent high price of grain and coal, have become practically idle; but it is clear that a little pot ale goes a long way.

The matter has received great attention from the proprietors, and the famous Macallan Case-the Countess Dowager of Seafield $v$. Roderick Kemp-which was won in the Outer House, and appealed, resulted in interdict being granted against the polluters. In the Outer House Lord Kyllachy held that pollution had been proved, and found that the evidence led was insufficient to show that the pursuers were adequately secured by the remedial works of the defender. Time was, however, granted to further test the remedial work in an attempt to satisfactorily purify the effluents. The First Division, after a most extensive proof, adhered to this judgment, and, resulting from this, various other distillers have from time to time been proceeded against.

Pot ale has been dealt with in a great variety of ways in order to secure adequate purification or destruction, but it has proved a very puzzling fluid to deal with. The distillers offered a large reward to any one who would discover a satisfactory plan of dealing with the bye-product; but this reward has not been secured, so far as I am aware, although expensive plant has been erected at various distilleries. Only very imperfect methods, so far as I have been able to understand, have resulted from these numerous investigations.

From a separate source altogether has come the demonstration of a quite satisfactory method. The Royal Commission on Sewage Disposal, under the chairmanship of Lord Iddesleigh, found it necessary to institute a thorough series of investigations into the chemistry and bacteriology of the pollution of rivers. Every kind of pollution was taken up and studied, and amongst others a series of experiments were started at various Strathspey distilleries. Dr. M'Gowan, the chief chemist to the Commission, is, I believe, the one who, more 
than any other, is responsible for the perfecting or adapting of bacterial filtration in the treatment of pot ale, Dr. Cowie of Mortlach Distillery having first carried out a number of valuable experiments as to this particular method. The process is quite simple and quite scientific, being in essence Nature's method carried out in a conveniently concentrated manner. After a certain amount of precipitation by lime, the pot ale is diluted and sprinkled by an automatic arrangement on the surface of a high percolating filter. The bacteria, which soon multiply enormously in the filter, devour the noxious properties in a few minutes, just as in a garden bed the bacteria consume and convert into ammonia and nitrates the manure beneficial to the surrounding plants, and which is in this form transmitted to the plants. The resulting effluent gives an excellent analysis, and may be run into any stream quite safely. The degree of filtration can be regulated and refined to a very considerable extent. The effluent, for ordinary practical purposes, is very slightly cloudy, but no longer resembles pot ale; it has no smell, does not putrefy, and is well supplied with dissolved oxygen. A feature of the effluent, which has caused a certain amount of apprehension to one or two eminent chemists who have examined it critically, is that it certainly contains a considerable amount of nitrogenous matter. Under ordinary circumstances this is naturally regarded as impurity of a harmful kind. It has to be specially noticed, however, that the nitrogenous matter in the effluent referred to is reduced to a stable or unchangeable condition, so that when carried off from the filter it does not cause pollution; it is carried off in the fluid in its stable condition. Had the effluent been harmful in any way, it could not have stood the tests to which it has been subjected, and to which I shall presently refer.

I cannot but regard this purification of pot ale as a notable achievement of the greatest importance to those interested in the welfare of our salmon rivers, as well as to many others. Moreover, the method, as compared with other plans which have been tried, is comparatively inexpensive. Bacterial treatment is the form which future purification works must adopt to obtain satisfactory results from all impurities of an organic nature.

In its application to salmon fisheries, I may mention that I was asked by Lord Iddesleigh's Commission to supervise some experiments designed to test practically the effect of the purified effluent upon fish life. For this purpose a hatchery and tank-house was erected at Coleburn Distillery, where the latest pattern of filter had been 


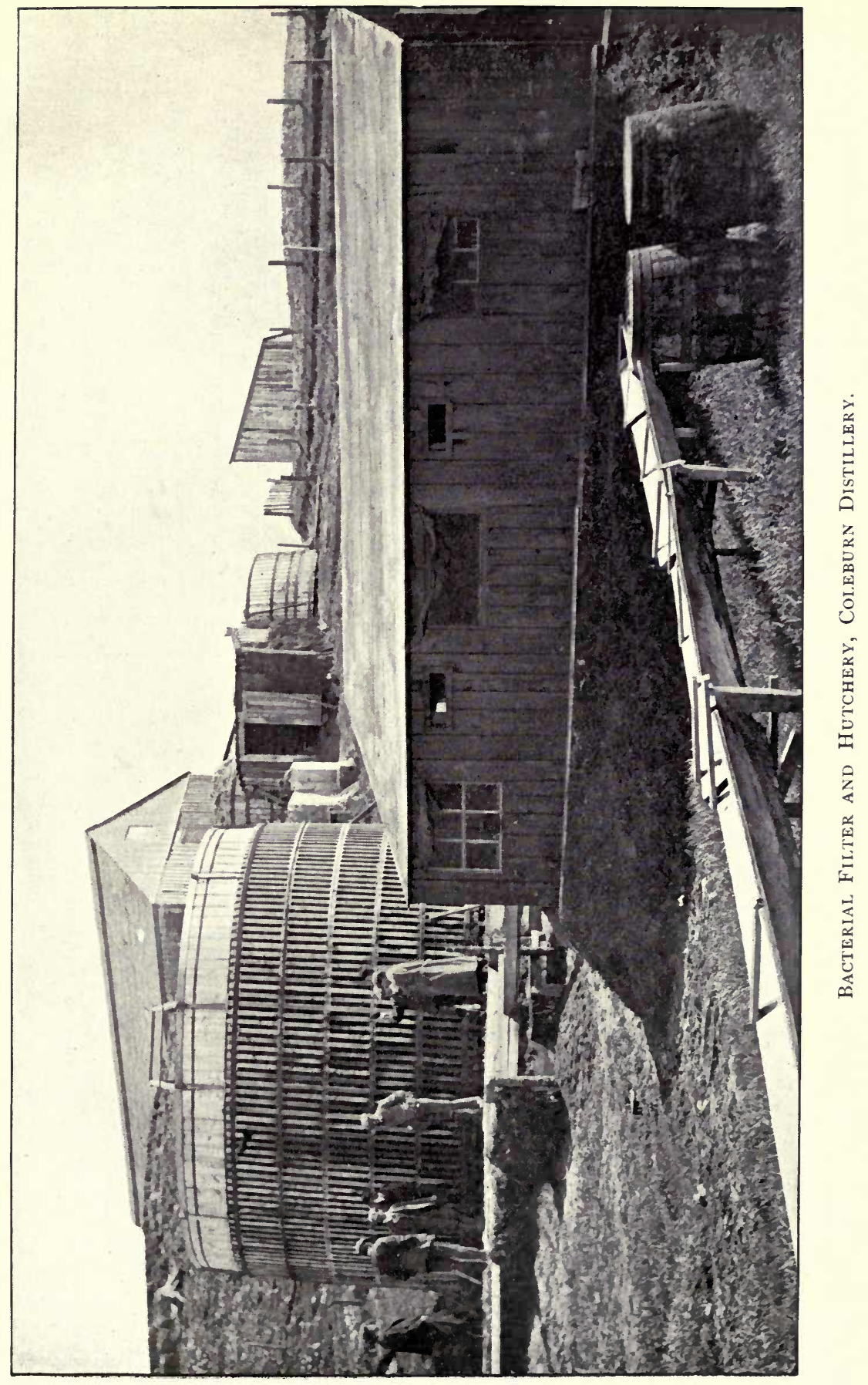



operating for two years. In this, in the winter of 1907-1908, a series of four double tanks were placed. Three of these were for testing the effluent, the fourth being a control experiment in pure water. Through the kindness of the Duke of Richmond and Gordon we obtained salmon ova and salmon fry of two ages. Each pair of tanks was provided with, in one case, a glass grill of ova, and in the other a number of fry. One pair of tanks contained the pure effluent as it came from the filter, another the effluent of 40 per cent. strength, another the effluent reduced to 4 per cent. The first and second were regarded as quite exceptionally severe tests; the 4 per cent. tanks may be regarded as probably similar to the condition found in a small stream below a distillery discharge after treatment by the bacterial method. A full account of the experiment has been published in the Sixth Report (1909) of the Royal Commission on Sewage Disposal, in which details respecting the rate of development of the ova, temperatures of the various tanks, feeding and growth of the parr and smolts, etc., are given, along with a description of the hatchery arrangements and full analysis of the effluent taken weekly throughout the time of the experiment. The accompanying photograph shows, in the foreground, the small hatchery, and just behind the group of figures the bacterial filter, with above that the mixing and precipitation tanks.

It is sufficient to state here that the hatching of the ova followed a perfectly natural course, the rate of hatching being in proportion to the variation of temperature, and that no unusual mortality occurred either amongst eggs or fry. The open nature of the percolating filter resulted in a very low temperature in the effluent during the winter months, and, according as the mixture of water was small or great-the water temperature being relatively higherso the rate of development was slow or rapid. But there was practically nothing to choose between any of the tanks, the ova even in the undiluted effluent hatching out with as good percentage as the ova in the control tank of water only.

The young fish introduced were of two ages, eight months and twenty months. These fed and throve well. Not a single death occurred amongst the older fish, which were reared to the smolt stage and acquired the silvery scale. A few of the younger fry became pugnacious and died through fighting. A curious result was that the fry in the tank containing the undiluted effluent grew more rapidly than the others. This, however, was probably in no way due to nourishing properties of the effluent, but to the fact that as 
spring advanced great numbers of fly larvae were hatched out in the filter and from it were carried to the hatchery, the greatest numbers being carried to the tank which received the effluent alone.

From the successful results of this experiment, I think we are justified in deciding that a solution has been found for the worst kind of river pollution problems in Scotland. 


\title{
CHAPTER XI.
}

\section{FINDHORN.}

\author{
Angling Season: February 11th to October 10th. \\ Netting Season : February 11th to August 26th.
}

District Fishery Board meets in Forres. William Grant, Esg., National Bank Buildings, Forres, is clerk.

THE Findhorn is an interesting example of successive stages of erosion in its long course of $62 \frac{1}{4}$ miles, and eventually of the combat of sand, sea, and river in nature. It rises on the northern slopes of Carn Mairg, the highest hill of the Monadhliath range, situated about six miles north-west of Newtonmore in Invernessshire. The source is 2800 feet above sea-level, and the first descent of the head streams is rapid to the lonely upper part of Strathdearn. Many side streams drain a wide ellipse of hills, all of them over 2500 feet in height, which, as far down as Glen Mazeran, form the skyline of this mountain-valley tract. The name Strathdearn is applied to the greater portion of the Findhorn course, and in it seems to lie the origin of the present name of the river. The early name used in thirteenth century charters was Earn, which sufficiently explains the name of the Strath, while Findhorn is thought to be a corruption of fionn-Ear-an, signifying the easterly flowing stream.

Some distance below the new railway viaduct of the Highland line, as it leaves Moy estate it enters a rocky gorge and the county of Nairn. This gorge tends to deepen and become more precipitous as the river proceeds, and at length becomes a veritable canonn of magnificent beauty, which forms the dominating character of the river. When one thinks of the Findhorn one naturally pictures this great winding and wooded defile, which continues some 23 or 24 miles to Darnaway. Near Dulsie Bridge the river forms a succession of black and deep pools, linked together by swirling and 
tortuous rapids, where, in autumn, salmon may be seen leaping and plunging as they make their ascent.

On the slopes lower down the junipers grow in great profusion, and silver birches add their graceful translucent shapes, and here and there forest trees of several kinds lend variety to the defile. Before Relugas is reached, the river enters the county of Elgin, where the combination of effects has impressed many a one. Mr. Charles St. John, who knew the river well and had the keenest possible appreciation of its beauty, writes of this section." "Hemmed in by the same kind of birch-grown banks and precipitous rocks, every angle of the Findhorn river presents a new view and new beauty. ... At Logie the view of the course of the river, and the distance seen far up the glen till it is gradually lost in a succession of purple mountains, is worth a halt of some time to enjoy." All through this long defile the type of view is distinctly scenic, the steep banks close in and frame the picture, the eye is caught by the moving light on the river, and led away to a beautiful vista. Between Logie and Sluie the rocks are perhaps at their highest, and one may look down from a height of several hundred feet into the black whirling eddies. "At a particular gorge, where the river rushes through a passage of very few feet in width, you will invariably see an old salmon-fisher perched on a point of rock, with his eye intent on the rushing cataract below him, and armed with a staff of some sixteen feet in length ending in a sharp hook, with which he strikes the salmon as they stop for a moment to rest in some eddy of the boiling torrent before taking their final leap up the fall. Watch for a few moments, and you will see the old man make a peculiar plunge and jerk with his long clip into the rushing water, and then hoisting it into the air, he displays a struggling salmon impaled on the end of the staff, glancing like a piece of silver as it endeavours to escape. Perhaps it tumbles off the hook, and, dropping into the water, floats wounded away, to fall a prey to the otter or fox in some shallow below. If, however, the fish is securely hooked, there ensues a struggle between it and the old man, who, by a twist of his stick, turns himself and the fish towards the dry rock, and having shaken the salmon off the hook, and despatched it with a blow from a short cudgel which he keeps for the purpose, covers it carefully up with wet grass, and lowering the peak of his cap over his eyes, resumes his somewhat ticklish seat on the rock to wait for the next fish. On some days when the water is of the right height, and the fish

\footnotetext{
${ }^{1}$ Wild Sports of the Highlands, p. 210.
} 


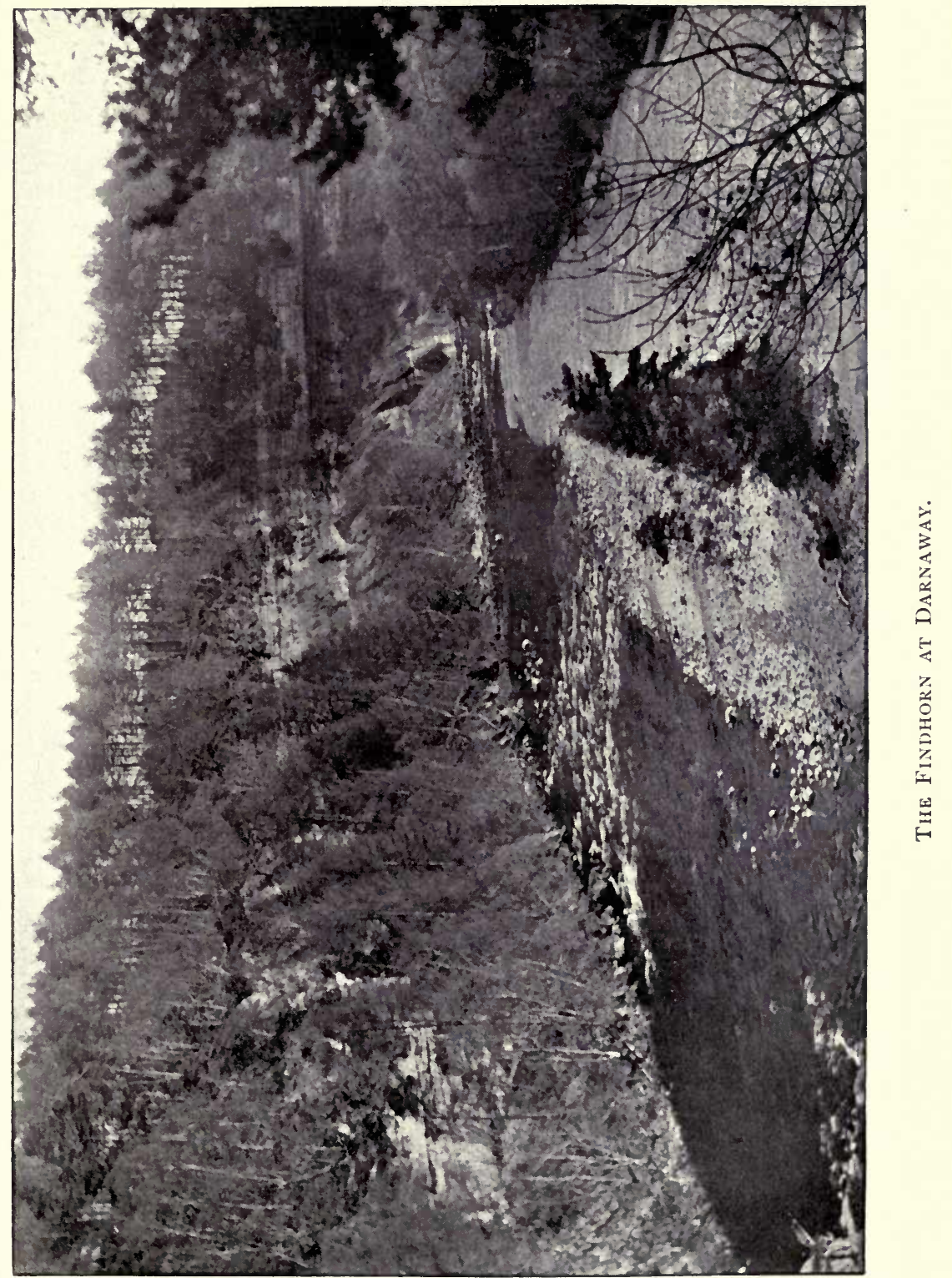



are numerous and inclined to run up the river, the old man catches a considerable number; though the capture of every fish is only attained by a struggle of life and death between man and salmon, for the least slip would send the former into the river, whence he could never come out alive. I never see him catch one without feeling fully convinced that he will follow the example of his predecessor in the place, who was washed away one fine day from the rock, and not found for some days, when his body was taken out of the river several miles down." 1

This picturesque old fisherman and his manner of fishing can no longer be seen. Whether or not the salmon claimed him in the deep pool, I know not. At Relugas the Divie tributary, which receives the waters of the Dorback Burn from Lochin Dorb with its castellated island, once a stronghold of the "Wolf of Badenoch," enters the main river in a birch-clad defile similar to that of the Findhorn. Some distance lower down is the curious rock-sculptured pool called Sluie Long Pool, which acts as a hold for salmon at most times, and has been the scene of some extraordinary catches by net in the past, as the following paragraph taken from the 13th volume of the new Statistical Account of Scotland shows. It is dated February, 1842.

"There is a considerable salmon fishing within the Parish, at Sluie, the property of the Earl of Moray. Four men are employed there to fish with a boat and draught nets the Sluie Pool and two other pools near to it, with two or three more considerably further down the river. Before salmon fishing near the sea was so well understood as it is now, the fishery at Sluie was of great celebrity. It appears by a letter dated 7 th June, 1648, from the Earl of Moray to his Countess, that "in one night, on the pool of Sluie alone, 1300 salmon were taken; and at one draught 620 scores. About thirtysix years ago, 360 salmon were caught in the same pool in one day. But the number now taken in all the pools connected with the net fishing there does not now average about 700 yearly."

This is second only to the miraculous draught of fishes reported in the same account as having been made in the Thurso (vide p. 242). Lord Moray does not now allow the Sluie pool to be netted, but it is only $7 \frac{1}{2}$ miles by the river from the head of Findhorn Bay, and to confine early fish to this seems a pity. The opening of the falls would not be matter of great difficulty, and would, I certainly think, be in the best interests of the river. The woods of Darnaway and Altyre and the Meads of St. John below Sluie now expand

${ }^{1}$ Ibid. p. 211. 
more broadly, as the defile opens out into the more pastoral and agricultural part of the country. The names recall the many romantic incidents woven by Sir Thomas Dick Lauder into his "Wolf of Badenoch."

Below the suspension bridge which earries the Forres-Nairn road, the river widens out into a rather shallow straggling expanse, but opposite the town of Forres it becomes again a steady swinging river of fine pools ere it enters the Bay of Findhorn. This so-called bay is in reality a wide triangular lagoon or tidal basin, 2 miles in length, bounded towards the mouth on the west side by the famous Culbin Sands-huge hills of piled wind-blown sand, which form a landmark for many miles out in the Moray Firth, and can be clearly seen from the Sutherlandshire coast. The actual mouth of the river is comparatively narrow and has, on the right or east side, the village of Findhorn, where a great peninsula of sand runs out in a northwesterly direction into the sea, and suffers constant washing away and rebuilding as the action of river or sea predominates. Two other Findhorn villages have existed in the past. The first was some two miles to the west, on the opposite side of the river mouth as it now exists. This was entirely buried by the drifting of the Culbin Sands already referred to. The second Findhorn stood about a mile to the north-west, on ground now covered by the sea. It was swamped by a great inundation which occurred in 1701. It is an uncanny region this between "The Bar" some ten to fifteen miles along the coast to the west, where the river had its mouth, I suppose, in early days, and the present village of Findhorn. Some folks would not give much for the permanency of the present village. I don't know if Insurance Companies take the vagaries of sea and sand into account, but the salmon fishers are bound to do so.

Much uncertainty has arisen in the past as to how netting can be lawfully carried on by opposing interests from foreshores which are liable to alteration. A question of very material importance was settled a few years ago by the case of Hogarth $v$. Munro Ferguson and Grant, and as a result netting may be continued in the mouth of Findhorn Bay so long as the spit of sand on the east side of the mouth remains uncovered by the tide. The very valuable netting held by the late Mr. Hogarth has now been purchased by Mr. Sellar, who fishes upwards from the mouth a distance of $3 \frac{1}{2}$ miles to a point in the river about a mile above the suspension bridge, called the Red Craig. Judging by the price which was given for these fishings they should yield a substantial revenue. 
The estuary of the Findhorn, as laid down by the schedule of the 1868 Salmon Act, secures a rectangular space at the mouth of the river $1 \frac{1}{2}$ miles long, measuring westwards from the outermost of the "two shipping piers of the town of Findhorn," and extending to 200 yards below low-water mark of equinoctial spring tides. Beyond the limits of this estuary a pretty formidable array of fixed nets immediately crop up.

With regard to the take of fish by fixed net on the coast of the district (about twenty-two miles), sweep net in the river and estuary, and rod, I find that the returns published in the recent Fishery Board Reports and sent in to the Inspector by the District Board, show that approximately the fixed nets catch from 13,600 to 18,600 fish, the sweep nets from 3600 to 6060 , and the rods from 150 to 206 . July is the month when by far the largest catches are made, but the nets get fish from the opening to the closing of the season. There is rod fishing below Sluie in spring, but fish do not run the narrows just above Sluie till May, so that all the upper water can be fished only in summer and autumn.

The Findhorn was one of the rivers which caused greatest damage at the time of the Moray floods in 1829. The gorge hemmed in the flood to such an extent that at Dulsie Bridge the level rose 40 feet, and at the narrow part already referred to called Randolph's Bridge, "from Earl Randolph, the Regent having had a bridge here for crossing from his castle of Tarnawa," the water rose right out of the gorge altogether and flooded the Haugh of Rannoch (Randolph), the rise of the flood here being 50 feet. The phenomenal rains which caused this flood occurred on 2nd, 3rd, and 4th August, and Sir Thomas Dick Lauder in his book on the Moray floods gives a very full account of the awful damage done, the new river courses opened, and the trees, bridges and houses that were carried away. Writing of the scene at the Haugh of Rannoch on 4th August, he says: "Before I left the spot, I saw one of the under-gardeners wade into the water as it had begun to ebb on the haugh, and with his umbrella, drive ashore and capture a fine salmon at an elevation of 50 feet above the ordinary level of the Findhorn." Most remarkable accounts are given of the humorous and pathetic incidents which occurred during those three fearful days. Four fishing boats sailed up over the flooded country from the village of Findhorn, to rescue people from their house-tops, sailed miles and miles over the fields and hedges round Forres, the boat bottoms sometimes brushing through the tops of wheat and oat crops. The s kipper of the 
"Nancy," which carried a crew of six men, wrote a log of his extraordinary cruise, in a breezy, amusing style. For instance, after making his passage down the turnpike road and landing at the Little Bridge End, he set off again, and writes, "set all sail, scudded with a fair wind over Mr. Davidson's farm, and steered for a small house on the north side of the estate of Tarmachy. . . Having taken in Mr. Smyth of Waterford's grieve and two men servants, we sailed down the market green, and by the end of the Lee-brig, and out the road to Waterford."

There were many branches of the lower Findhorn when the floods began to subside, and it is impossible nowadays to picture the scene of wreckage and desolation. The Divie opened a considerable stretch of entirely new course. I believe floods of more recent date have at times reminded the inhabitants of this fertile Forres region of what happened in the past. Strangely enough, Forres is one of the dryest regions in the country, and if it be true that the average rain-fall in Scotland or elsewhere is slowly becoming less and less, they may be secure in trusting that the like will never occur again.

Here and there in the gorge above Sluie the water is hard to reach, but if early fish were allowed up, there is much of the river which would become of greatly increased value; and at the same time the distribution of the available stock would become much more uniform at the spawning season. 


\section{CHAPTER XII.}

\section{THE RIVER NAIRN.}

\section{Angling Season: 11th February to 31st October. Netting Season : 11th February to 26th August.}

District Fishery Board sits in Nairn. Clerk, H. T. Donaldson, Esq., Solicitor, Nairn.

THIS little alder-skirted river rises to the west of Glenmazeran Forest, in Inverness-shire, and after finding its way down to the lower ground between this point and Loch Ness, not more than about two miles from the upper reaches of the Farigaig, and presently, about the same distance from Loch Ruthven of modern trouting fame, it settles down to a course almost directly north-east to the sea at Nairn. It is a beautiful river, fringed with trees-rather too much fringed with trees for the angler-throughout almost its whole length. It is, moreover, a river of much splendid spawning ground, for the bed of the stream is gravel at almost all points, and frequently the current is uniform and the water not very deep.

The stock of fish is, unfortunately, not what it might be. The estuary is no doubt only an imaginary arc of a circle 400 yards radius from the mouth of the river, and many fixed nets are fished outside-though their number may in future be slightly diminished; but I believe the real trouble is the number of weirs which are thrown across the river, and which form-especially one or two of those in the lower waters-obstructions to the natural ascent of salmon to the spawning grounds above; while the mouth of the river at Nairn Harbour, where fish naturally congregate before making, or attempting to make, the ascent, is rather seriously polluted at the very time fish chiefly seek to run.

The town of Nairn, with its adjoining golf links, is visited by great numbers of people in summer and autumn. There is a sewage farm on flat, stony ground across the river from the town, but it is unable to treat the great amount of sewage run on to it, and in addition to this the waste products of a distillery are or were mixed with the 
sewage. The volume of water in the river is usually not very great; indeed, except in time of high flood, the volume is never great. The whole length of the river is only about thirty miles, and although several good burns act as feeders, the district is one of light rainfall, and floods are not frequent. The total catch of rods may be said to vary from 100 to about 300 ; the figures for four consecutive years, published elsewhere, are: $175,250,294,175$. A considerable number of sea-trout and finnock are not counted in these returns.

The first weir encountered by ascending fish is at Miltoun of Kilravock. It is a long, slanting structure, situated just above two alder-clad islands, so that the stream is divided into three channels. The weir at the point to which fish are most naturally led is by no means high, and cannot be regarded as seriously obstructing fish. It could be very easily improved, however.

The Nairnside Weir, which comes next in order, is much more formidable, except in high water, because the river here is naturally shallow, and the water passing over the sill of the dyke is very thin. There is no fish-pass of any kind, and the river banks being flat at this part and above, it unfortunately happens that very little fall is possible in the mill-lades, so that the tendency is to prolong the lades beyond more than one obstruction. In this way the water drawn from the river by means of the Bridgate Weir next above-a structure formed of boulders and stones-is not returned to the river above the Nairnside Weir, thus still further depriving that obstacle of water.

The next weir is that of Holm Rose, and here again the water from two lades rather than only one is carried to the river below. The lades are not, perhaps, very large, but neither is the river, and the loss is material. I understand that the levels make any other arrangement rather difficult. Holm Rose Weir is perhaps the most serious obstacle in the river. It is not high, but the down-stream face is steep, and there is no gap or fish-pass.

The other weirs are the Cantray Dam Dyke, the Kinrea Weir at Dalcross, and lastly, the Colchunaig Weir. The first is an important structure; but although there is no fish-pass, the sill is lower at the left bank than at the right bank, and a good stream of water is thus enabled to descend even in dry weather. The two other structures are insignificant, being rough stone dykes about a couple of feet high, which divert water to small local meal mills. It is noticeable, however, that no fish-pass exists in the river Nairn, in spite of the bye-laws in the Salmon Acts requiring that such structures should be inserted in every dam dyke. In districts where no District 
Fishery Board exists, the competent excuse is possible that only by action on the part of a Board, through their clerk, can such provisions be carried out. But in the Nairn district there is a Board.

The fishing rights at the mouth go with the Brodie estate, and a certain amount of sea-trout and finnock fishing can usually be obtained here by members of the public. Both banks for about two miles up are fished from Brodie. Above this, on the left bank, Kilravock has 5 miles; and on the right bank Geddes property, and then for four miles or so the Earl of Cawdor. Above this on both banks is the Holme Rose section of about a mile; then on the left bank the three next miles are held by the Culloden Trustees, and five miles on the right bank go with Cantray. Above this the Mackintosh owns both banks for a considerable distance; then a short piece goes with Failie, then Farr has two miles or so, then Flichity and Brin fish both banks. The last-mentioned property is about the furthest up on which any salmon fishing is to be had, and I fancy the fish are not in very good condition when they get there, unless the season has been a wet one, and the various dam dykes have been less hindrance than usual.

The main line to Inverness strikes the Nairn valley at Daviot, and at a high level, but with a gradual descent, follows the valley downwards to the crossing at the high stone viaduct not far from the station named Culloden Moor. On the run down to the viaduct a view of the famous battlefield is obtained, and the Cumberland Stone, as it is called, is distinctly visible, at which "The Butcher" is said to have breakfasted, and from which he afterwards surveyed the battle. The battlefield now presents a very different appearance from what it must have done in April 1746, for many trees have grown up to cover the brow of the slope, and hill draining has brought about further modification. Nowhere now could horses and cannon get bogged, as happened apparently when the Duke of Cumberland made his final advance within half-a-mile of the Highland army previous to receiving the first attack. In the peaceful aspect of the country nowadays, when nothing more warlike than the distant pop-pop of the sportsman reaches the ear on a summer day, it is difficult to realise the revolting scene which succeeded the defeat of the gallant Highlanders; when wounded men, unable to retire across the Nairn river with the main body, were for days dragged from their hiding-places and brutally massacred in cold blood. Culloden was a great victory, but it left a deep stain which is only now fading from memory. 


\title{
CHAPTER XIII.
}

\section{THE NESS DISTRICT.}

RIVER NESS, LOCH NESS, RIVER MORISTON, RIVER OICH, LOCH OICH, AND RIVER GARRY, LOCH GARRY AND LOCH QUOICH.

\author{
Angling Season: 2nd February to 15th October. \\ Netting Season: 11th February to 26th August. \\ District Fishery Board sits in Inverness. Clerk, Duncan Shaw, Esq., W.S., \\ 15 High Street, Inverness.
}

\section{THE RIVER NESS.}

THE River Ness is about six miles long, and flows from Loch Ness to the sea in Inverness Firth. Coming as it does from one of the largest and deepest lochs in Scotland, it contains a great body of water, and, in its short course with 52 feet of fall, presents a fine swinging current with a succession of long running pools and broken streams. Just above the town of Inverness it divides into several channels to encircle "The Islands," the unique public park of the capital of the Highlands. These beautifully wooded islands, linked together by suspension bridges, so that one may walk from one to the other and so cross the river, present in themselves some beautiful views, and at the same time enable one to enjoy the prospect of a clear flowing river from its very midst.

As lochs Ness, Oich, and Lochy form the chain through Scotland opened for navigation by the Caledonian Canal, we have in the Ness and the Lochy districts certain features not found elsewhere in the country. Close to a considerable part of the river the Canal runs to the loch at Dochgarroch, and close to this a retaining weir of great extent forms the sill or outlet of the river from the looh, and at the same time maintains the necessary water level for navigation. This extreme north end of the loch is a diverticulum, and receives the separate name of Loch Dochfour, since, like the highest stretch 
of the river, it is in the Dochfour property belonging to J. E. B. Baillie, Esq.

At ordinary levels the water from the loch flows over only a section of the weir, where also a deep gap, which acts as the fishpass, exists. When the loch is high, or when strong winds from the south and south-west blow the surface water in this direction, the rest of the weir comes into operation, so that the storm water passes into the river over a wide extent of sill and sweeps round through the first pool of this, the Dochfour water, and through the Horse Shoe Pool which immediately succeeds-and which is perhaps the best pool of the river-in great style. It is the sight which at once fixes the gaze of the many tourists which pass in and out of the Canal by steamer in the summer time; and if in addition a happy angler is at work in a boat in the swirling water, he becomes the focus of all eyes till the lock gates open and the red-funnelled steamer paddles on behind a screen of gorse and briars.

This water used to be netted in the spring, and a very profitable fishing it was to the tacksman in cold frosty years when the loch, and therefore the river, had fallen to a low level. At such times fish have some difficulty or reluctance in ascending the weir into the loch, and consequently accumulate in great numbers. A catch which occurred on the opening day some dozen years ago is likely to remain in the memory of the netsmen till they cross the floods of Jordan. It was almost phenomenal, and therefore was much reported. The following year was also an excellent one for the tacksman, but the goodness was the death of his fishing from that time forward. There is an old Scots proverb, "When you're pooin' runts, you're no' plantin' kail." The tacksman was pulling out the fish at Dochfour, so none could possibly be swimming in the Garry where the netted fish would otherwise have gone. The absence of spring fish was most marked. The Duke of Portland, who fishes Loch Oich and the Garry in spring, has shown me his records.

The matter was serious for the future stock of the river. Either open winters and full running waters had to be arranged with the clerk of the weather, or the netting had to cease, if the Garry was. to retain its prestige. In Scotland the clerk of the weather is an "ill man to bind," so His Grace selected the alternative and leased the net for its removal.

Other netting stations existed near the mouth of the river-the Friars Shot, the Cherry Shot, and the Longman's Grave. These nets have since followed the course of the Dochfour net through the 
instrumentality of the Ness Angling Association-of which more anon-so that the whole waterway is now clear or practically clear of netting

I anticipate, therefore, that salmon angling in the Ness and in the waters above will now steadily improve.

For a great many years the river Ness has been regarded as a summer and autumn river only. As a matter of fact, when netting

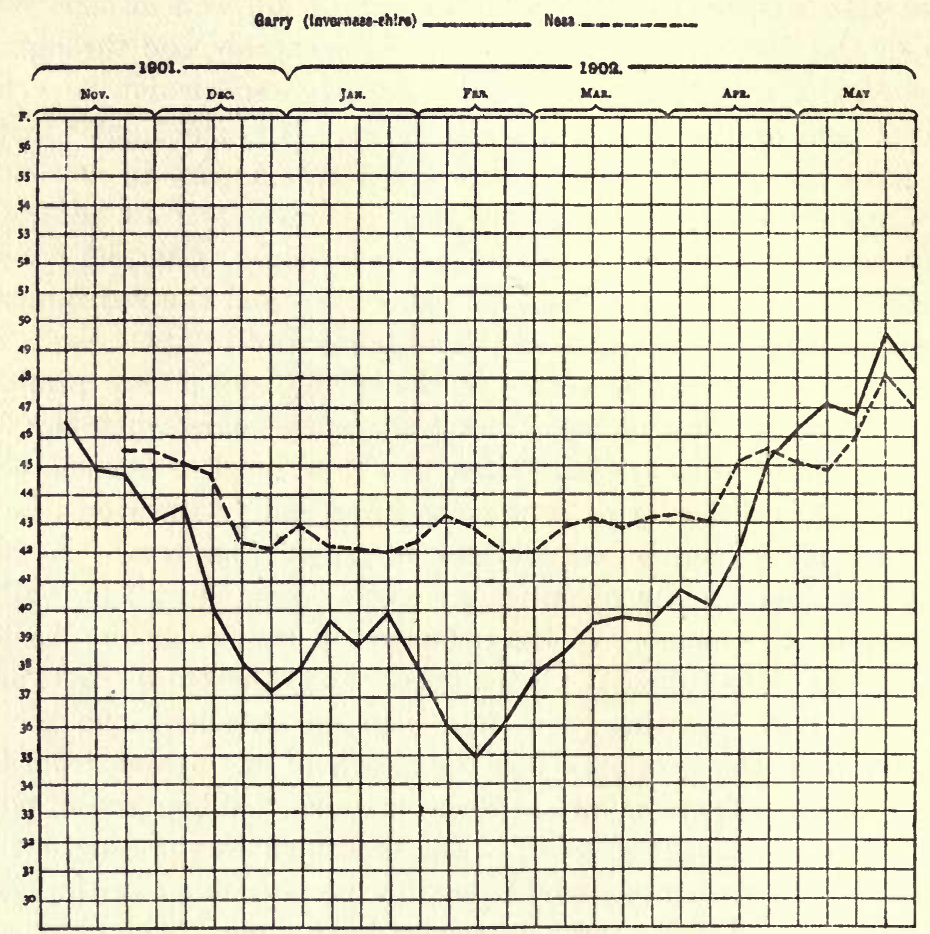

Weekly Mean Temperatures of Rivers Garry (Inverness-shire) and Ness, Winter, 1901-1902.

was steadily carried on the effect was that while a certain number of early fish ran through the river into the loch and on to the Oich and Garry, they chiefly did so, in many years, before the netting season commenced. Many of the fish taken in the Garry in February are well coloured. Others were netted out, and the remainder were not over numerous. In addition to this the temperature of the river Ness is relatively high-I have found the mean in spring to be $4^{\circ}$ higher than the mean of the Garry-and fish are induced to ascend rapidly in the open "streamy" water 
which so largely exists. While, therefore, it was evident that all Garry fish had of necessity to pass through the Ness, the belief arose that they did not take in the Ness, and hence they were not fished for.

With the removal of the nets and the belief that more fish are in the river, together, no doubt, with the increased desire for salmon fishing at any season, people are realising that spring fish are to be caught in the Ness, and that under certain conditions this spring fishing is really quite good. Dochfour water is certainly the best, and always will be the best; but, in my opinion, the spring fishing and the autumn fishing also, in the waters below, viz. Ness Castle, Ness Side, Holm, The Four Cobles, and Bught, and the town water of Inverness, could be considerably improved by some attention to the formation of croys or low jetties, in properly selected spots, so that suitable lies for fish might be created. There are one or two very serviceable croys in the Garry, which have been there for many years, and were no doubt erected by someone who knew his business. In many parts of the Tay, and especially in the upper waters where fish are apt to run rapidly into Loch Tay, fishing has been vastly improved by well-placed croys. Indeed, without the croys of the upper Tay the spring fishing would be as poor as the Ness spring fishing has been in years past.

Dochfour at present is good for 30 to 45 fish in the spring, and 50 to 70 in the autumn. The lower Dochfour water, however, like the Laggan Pool of Ness Castle Water and several other pools lower down, is a broad, even, unbroken flow passing along a uniform river bed. It is in such pools that croys of considerable size should be placed as a sure means of drawing ascending fish into quiet lies for a time. Breaks in the uniformity of the stream concentrate the fish into selected spots and greatly increase the interest of the angling.

The results of Ness Castle Water may, I think, be taken as indicative of the general results of the river within recent years. Here are the five last quinquennial averages till the lowest ebb was passed :

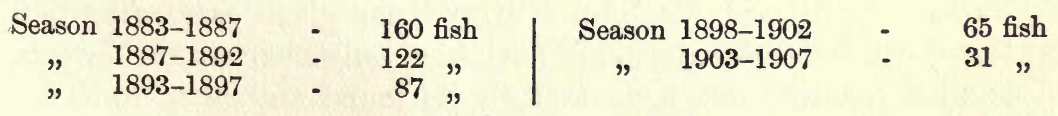

In this period the maximum is 217 , occurring in 1885 , and the minimum is 26 , occurring twice in 1889 and in 1893 . The lowest in the last ten years has been 32 .

It is reported that the results for 1908 have been the best 
for a considerable number of years, and that the score nearly reaches 400 fish. This is encouraging to those who are seeking to increase the stock, the more so since 1908 was by no means a good angling year. Modern anglers have a fairly good record to break, however, for in 1876 the late Mr. Denison-then well known also on Tweedhad 16 fish to his own rod on 7th August. In 1885 he killed 120 fish in the Ness and 180 in the Tweed. He died suddenly in Ness House in 1887. A great story is told of him in the Fur, Feather, and Fin Series (Salmon). He hooked a fish at six o'clock one Friday evening in the Holm Port, found it to be a monster, played it through the night till 4 a.m., and eventually lost it just under the gaff. Oh! the missing of it!

The Four Cobles Water is in reality a part of the Bught Water, the property principally of Colonel Warrand of Bught, but the town of Inverness has a certain share in the right of fishing. This share is held for the benefit of the lieges and is interpreted by freedom to fish this water every eighth fishing day. A list of the free days is drawn up each year, and is to be obtained from the various fishingtackle makers in Inverness. This water is the lowest section, from The Islands to the mouth past the town, and fishing is carried on from both banks as well as from The Islands.

\section{LOCH NESS.}

For a long succession of years Loch Tay has been held in high repute as a spring fishing loch, where any one who cares for the sport may go and catch salmon, or at all events practise the peaceful if cold art of fishing for salmon from a boat. Nowadays a successful rival has come to the front in Loch Ness.

Including the small basin of Loch Dochfour at the northern end, the loch is $24 \frac{1}{4}$ miles long, and has an average breadth of about a mile. It is, further, profoundly deep, being indeed the deepest loch but one in Scotland, and it is not very long since the greater depth of Loch Morar was discovered.

The members of the Bathymetrical Survey of Scottish Lochs, under the direction of Sir John Murray, have given great attention to this great body of water, and have not only charted the loch in a detailed manner, but have studied its fauna and flora, its seches and its sprungschicht; in other words, its irregular tides, and its sharp separation into different layers of water These rather mysterious physical phenomena appear to have no connection with the salmon fisheries of the loch, although if seches, are caused by 
differences of barometric pressure-a point which appears to be still under discussion-it is quite possible that they may accompany changes in the fortunes of fishermen.

So far as superficial area of water goes, Loch Ness comes second to Loch Lomond. The area of Loch Ness is $21 \frac{3}{4}$ square miles, of Loch Lomond $27 \frac{1}{2}$ square miles. ${ }^{1}$ The maximum depth of the loch is, however, 754 feet (in the centre of the loch about a mile south of Castle Urquhart) and, what is even more remarkable, the mean depth is 433 feet, or 57.4 per cent. of the maximum depth. Loch Morar, the deepest loch, has a mean of only 284 feet. On account of this great mean depth, the volume of water is surprisingly great. "The volume of water contained in Loch Ness is estimated at 263,000 millions of cubic feet, or $1 \frac{3}{4}$ cubic miles. In no other Scottish loch does the bulk of water amount to a cubic mile-in fact Loch Ness contains about three times as much water as the two lochs which most nearly approach it in this respect, viz. Loch Lomond with 92,800 million cubic feet, and Loch Morar with 81,000 million cubic feet. . . A As far as we are aware the volume of water contained in the large lakes of Ireland has not yet been carefully worked out, but, taking Loch Neagh, for instance, which is said to cover an area of 153 square miles (or seven times greater than the area of Loch Ness), and to have a maximum depth of only 48 feet, a rough calculation will show that the bulk of water in Loch Neagh must be less than that in Loch Ness. It seems quite possible, therefore, that Loch Ness may be the largest body of fresh water, not only in Great Britain, but in the United Kingdom."

Another remarkable feature about the loch is the steepness of the shore in many places. The contour lines drawn at each 100 feet of soundings show this. ${ }^{2}$

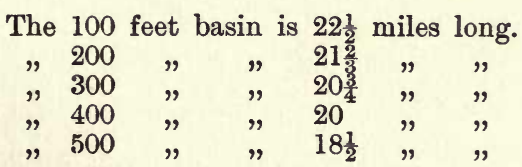

"Gradients exceeding 1 in 1 are of frequent occurrence, and in certain places the slope approaches the precipitous. Near the southern end of the loch, off the south-western shore at the entrance

1 "Bathymetrical Survey of Fresh Water Lochs of Scotland," Scottish Geographical Magazine, xxiv., No. 4, April, 1908.

${ }^{2}$ Ibid. 
of the River Oich, a sounding of 204 feet was taken about 100 feet from shore; but the steepest slopes were observed off the northeastern shore in the vicinity of the Horse Shoe craig, where a sounding in 236 feet was taken about 100 feet from shore; another in $\mathbf{1 7 5}$ feet about 50 feet from shore; and off what is known as the Cormorant rock, a sounding in 206 feet was taken about 50 feet from shore. This last-mentioned sounding gives a gradient exceeding 4 in 1 , or an angle of about $15^{\circ}$ from the perpendicular."

The fame of Loch Ness as a spring salmon loch has arisen largely since the formation of the Loch Ness Angling Improvement Association in the end of the year 1903. This association is composed of proprietors of salmon fishing rights in the loch, and was formed in order to regulate the existing fishing and improve the prospects for the future.

The rules of the association with regard to salmon and sea-trout fishing are as follow :

1. Parties may obtain the right of angling for salmon and seatrout on payment of the following:

(a) For whole season, $£ 5$ for each boat;

(b) For period from 1st May to 15th October, £2 10s. for each boat.

2. All subscriptions must be paid in advance to the secretary, who will issue distinctive badges for each boat. Each badge will be marked with the registered number of the boat, and subscribers are strictly prohibited from angling from any boat without its proper badge. Any person angling from a boat not marked with a badge will be liable to prosecution.

3. A subscriber's right will be strictly limited to himself, the members of his family, and visitors residing with him.

4. Only hotelkeepers, the members of their families, and the hotel visitors, shall be allowed to fish in the authorised hotel boats. Boatmen and other servants are strictly prohibited from fishing.

5. No kelts may be gaffed, and a net for landing kelts must be carried in every boat until lst May.

Mr. Hugh M. Graham, solicitor, 51 Church Street, Inverness, is the secretary of the Association, and issues the badges to those who desire to acquire licensed boats, as well as tickets to those who wish to fish for trout either from a boat or from the shore. A separate code of regulations are drawn up for trout fishing on very generous 


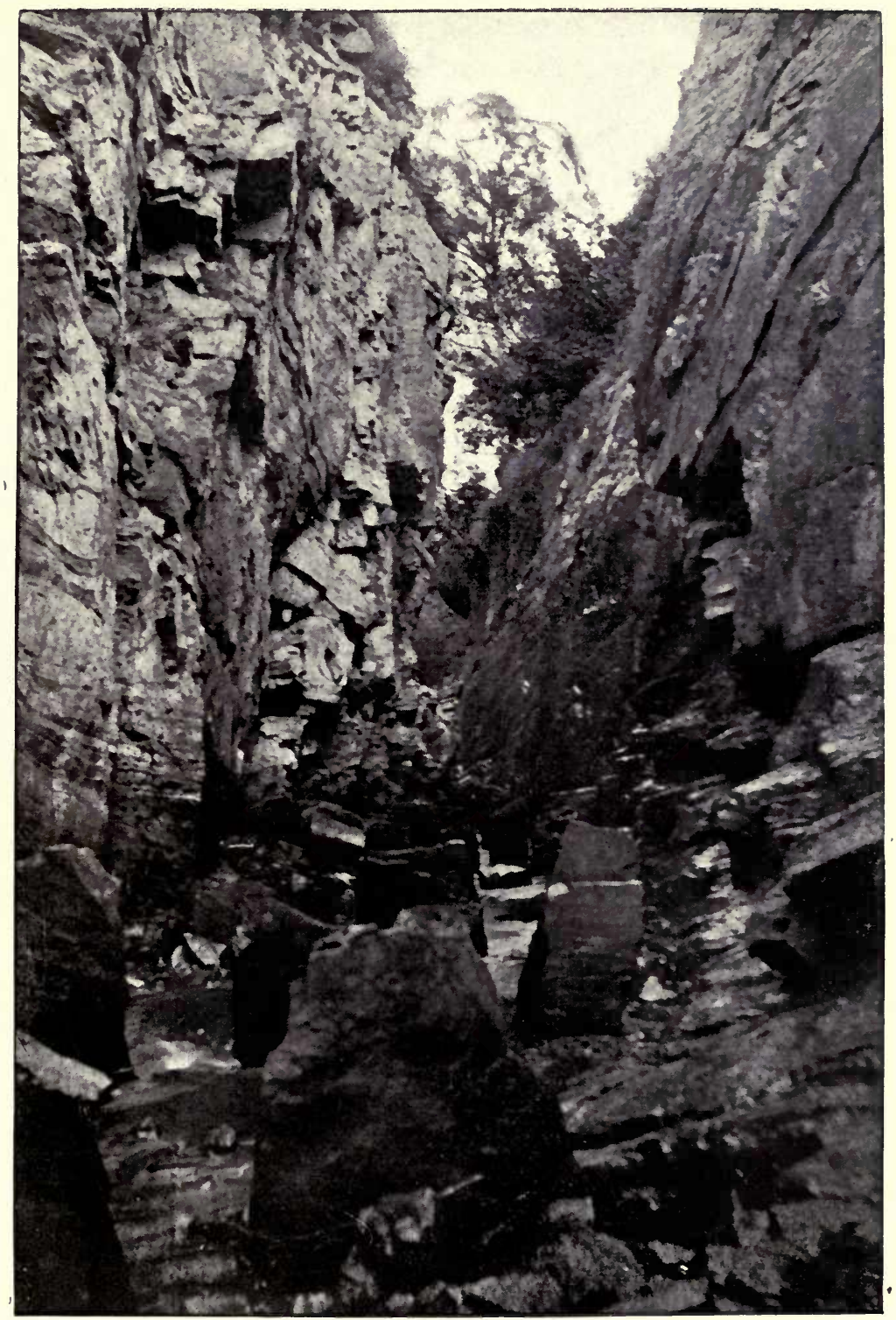

The INvermoriston Pass, from bottom of Cutting (water turned off). 

terms, viz. five shillings for the use of a boat and no charge for fishing; but trolling for trout is prohibited.

The efforts of this Association have been followed with distinct success. The various hotels in the neighbourhood at once took advantage of the arrangement, and since 1904, when the operations of the Association came into force, there has been a growing demand for salmon fishing.

At the same time the Association turned its attention to the removal of the nets in the river Ness, and succeeded, as has already been stated when referring to the river, in acquiring leases of the three river shots for the purpose of keeping off the nets, and so providing for an increased stock of fish in the angling waters and in the spawning grounds of the district.

A few nets used to be fished in Loch Ness also, but by arrangement these have also been removed with the exception of the net at the Fort Augustus Monastery where, however, Lord Lovat has prescribed a limit of 25 fish.

The number of boats licensed since 1904 has steadily increased, and in 1907 the number was 45 . The take of fish has also correspondingly increased, and so far as I have been able to estimate, after enquiry from the most reliable sources, the total number of fish taken in 1907 was about 500. The actual number taken by licensed boats is slightly under this figure; but a certain number have to be added as taken by the Glenurquhart boats, which have unfortunately, as I believe, remained outside the regulations of the Loch Ness Association, and the return from which source is therefore uncertain. Mr. Robert Campbell, the water bailiff at the Fort Augustus end of the loch, has for some years kept an accurate return of the fish caught in his beat, and as this is a favourite section of the loch with many, the totals may be of interest. At the same time it has to be understood that the return includes not only the Fort Augustus hotels and the Invermoriston Hotel, but the monastery net, the return of those who privately have taken out licences between Invermoriston and Fort Augustus inclusive, but also the results from the rivers Oich and Moriston.

\begin{tabular}{|c|c|c|c|c|c|c|}
\hline 1904 & - & & Total, & 287 fish & weighing & $4548 \frac{1}{2}$ \\
\hline 1905 & - & - & ", & 211 & " & $3122 \frac{1}{2}$ \\
\hline 1906 & - & - & , & 350 & ” & $5412^{2}$ \\
\hline & - & - & " & 412 & $"$ & 6139 \\
\hline
\end{tabular}

The record for one rod in the loch is, so far, 59 fish, I believe; but totals of between 30 and 40 fish have several times been got in a season. 


\section{THE RIVER MORISTON}

Enters the western side of Loch Ness, and flows through a magnificent glen a distance of 25 miles. Its course is, therefore, parallel to the more famous river Garry, which enters Loch Oich, and the character of the hills from which it springs is very similar. Each descends from rocky hills, which form the watershed close to the west coast, and after a somewhat varied course, secures a period of quiescence in the centre of its glen-the Garry as a loch, the Moriston in a stretch of sluggish water. Each then rushes off again over a rocky bed, plunges over a fall, and enters its respective lake. But the Moriston has to come to a considerably lower level at Loch Ness than the Garry at Loch Oich, hence the lower part of the former is steeper, and more than one fall of some moment to the salmon occurs. The lowest of all is the Invermoriston Fall, which originally was a complete barrier to ascending fish.

In 1880 a pass was formed round the left side of the fall, and probably no pass in Scotland was better known; but from time to time this pass has required modification; sluices had to be erected at the intake to prevent overflooding-the Moriston river is peculiarly subject to very sudden changes of level-the mouth, or lower opening of the pass, was brought nearer the foot of the fall, masses of rock were carried or slid into the pass, and had either to be circumvented or removed. The gradient of this pass was, or is, one in ten; it is cut out of the solid rock, and cost, I believe, about $£ 2000$. Reports as to its efficiency have, however, always been reserved in tone. It has never been described as an unqualified success, as, for instance, the Ballisodare Pass in Ireland is said to be. A certain number of fish have always managed to ascend, but the pass has never been the means of raising a good stock of salmon in the upper river. In the autumn of 1902 it was decided to proceed with the construction of a second pass on the south or right bank of the river. It happens that as far back as 1870, when Buckland and Young inspected the fall, a pass was recommended very much in the position now opened up, but the suggestion was then departed from on the ground of expense, it being believed that an efficient pass could be constructed on the left bank.

When the first pass was opened, and salmon admitted to waters in Glenmoriston, which they previously could not frequent, the Crown claimed the salmon fishing rights in virtue of the fact that the fishings had never been alienated to any subject, and would ipso 


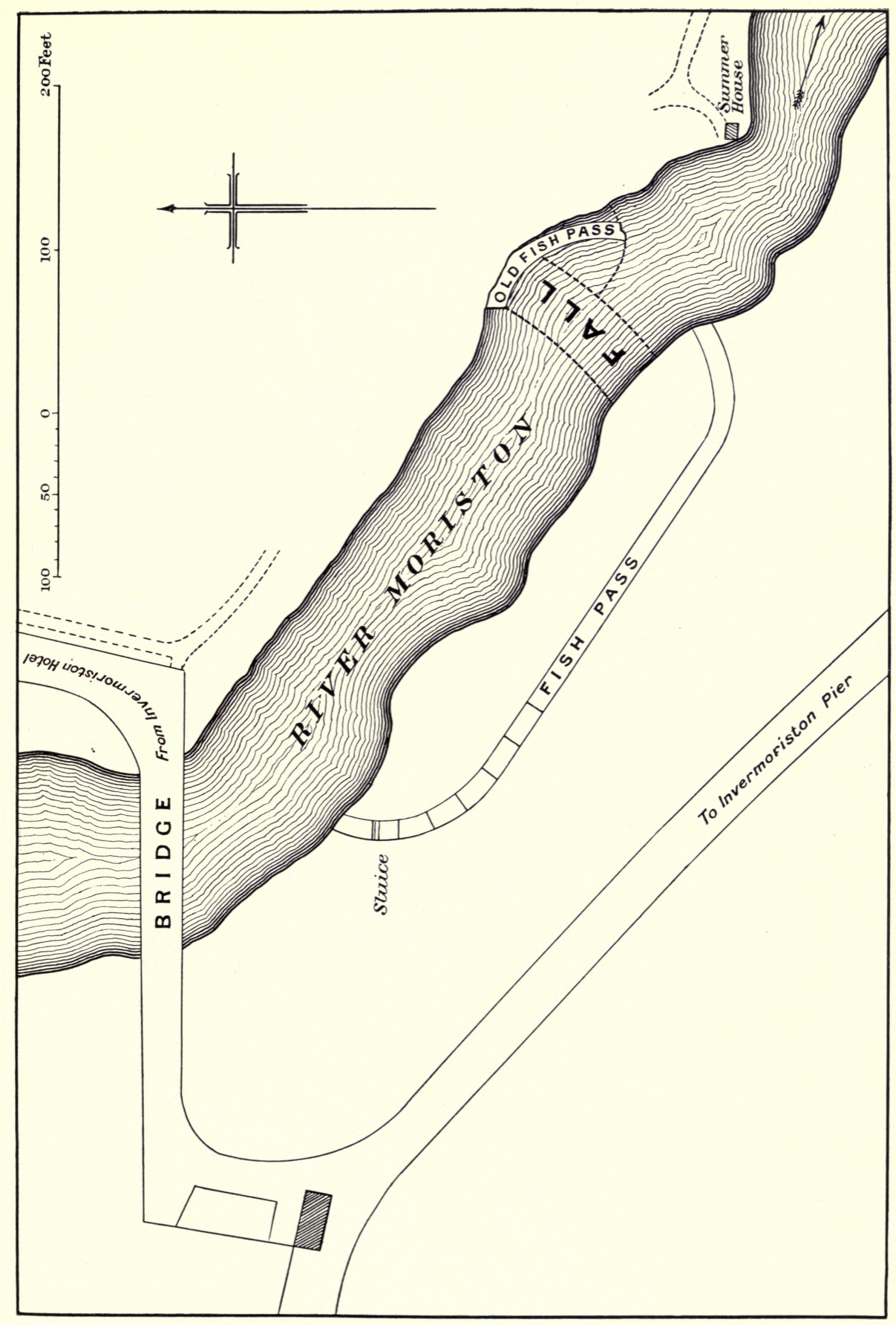



facto have to be regarded as Crown property. Subsequently, Mr. Grant of Glenmoriston obtained a Crown charter, in fee, for the fishings above the fall. As reported by the late Mr. Young, he was already in possession of a barony title, fortified by prescription, to the salmon fishings ex adverso his property below the fall.

The new pass, on the right or south bank of the river, has been carried upstream a considerable distance above the fall in order to secure an easy gradient. The general arrangement of the pass is shown in the plan here given. The surface of the pool at the head of the pass is 24 feet above the surface of the pool below the fall. The length of the pass, exclusive of modifications in the upper pool for the purpose of directing the water-flow, is 240 feet. The breadth is 10 feet, and the gradient is 1 in 21.7 throughout. The entire excavation has been in solid rock, as may be seen by reference to the photograph given, and the cutting towards the lower end of the pass is fully 35 feet deep. The mouth or entrance to the pass is carried, at the gradient already mentioned, into the fall pool, so that fish do not require to leap into the pass, as was the case in their attempts to enter the old Invermoriston Ladder, but may swim into and up the pass. The mouth is not appreciably nearer the fall than is the mouth of the old ladder on the opposite side, but a very considerable volume of water can be brought down the pass to influence the fall pool, and a ledge of rock above the mouth acts as a good guide. The intake of the pass is provided with three substantial sluices arranged originally to suit different levels of water, the middle sluice being one foot higher in the sill than the sluice on one side, and one foot lower than that on the other side. A short arch of rock exists just below the sluices. For the purpose of acting as breaks or stops to the force of descending water, stones 36 inches long are sunk into the bed of the pass so as to project 20 to 24 inches. These stoneswhich may be noticed in the photograph, taken from inside the dry pass looking down through the mouth to the river below-are 14 inches broad and about 12 inches thick, and are placed in rows at right angles to the sides of the pass, three stones in a row with spaces of about 16 inches between each. From the sluices to the first row of stones the distance was 20 feet, but for the rest of the way down the pass rows of stones occur every 15 feet.

After the pass was completed, some alterations had to be made at the intake in order to overcome the too great rush of water which occurred in certain conditions of the river. It was found that fish could easily swim up the pass, but had difficulty in getting through 
the sluices into the river again. It was also noticeable that the rate of flow was more gentle half-way down the pass than it was at the intake. Two strong buttresses of concrete gave a narrow and zigzag entrance to the water, and by the placing of a series of wooden weirs where the rows of stones were, a series of $4^{\prime}$ deep pools has been formed in the upper section of the pass. Without these the pass would not have been a success. The practical result has so far been that a valuable new spawning area has been opened up to the fish of Loch Ness, and the accounts which have reached me go to show that a very considerable head of fish have taken advantage of it, and have been spawning in recent winters in the head waters of the glen. As regards angling results, one cannot perhaps speak quite so favourably. The fish which ascend do so only in summer, and many of them having in all probability been sometime in Loch Ness, are not free risers. Still, as the best conditions and lies in the river are gradually discovered, the results may improve. In 190727 salmon were caught above the fall and 14 below. In 1908, which was a year of small water during the summer months, only 12 salmon were caught above the pass, although in the latter part of the season a considerable number of fish were seen.

\section{THE RIVER OICH.}

The River Oich, which flows from Loch Oich into Loch Ness at Fort Augustus, is about the same length as the River Ness, i.e. fully six miles, and the descent in this distance is also practically the same. In character it is the Ness over again, only with rather less water, exhibiting a fine series of pools and streams, rather rapid in certain places but always interesting.

The upper part belongs to the Ellice Estate of Glengarry, the lower and larger portion to Lord Lovat. The water is always clear, even when in flood, since the Garry and the lochs above are fed from rocky hill streams.

The river is said to fish best when fairly high, which means that best success is obtained when the flooded Oich is drawing fish from Loch Ness. It is a spring river, and its success as an angling stream depends upon catching Garry fish in the bye-going.

In the pools of the lower portion of the river fish rest in their ascent, and, given suitable conditions, results may be quite good; and, of course, the class of fish is the same as that of the Garry. The upper pools do not appear to hold fish well, however, and here, 
as well as in certain parts of the lower water, the placing of croys at well selected spots would, I have no doubt, materially improve results. fish.

At present the annual eatch may be said to be from 30 to 50

\section{LOCH OICH.}

This loch is a very important adjunct to the Garry fishings. At the opening of the season, and more especially in very cold winters and springs, fish which have run the river Oich usually check their upward progress in Loch Oich for some time. It usually happens, therefore, that a good deal of boat fishing is done in the loch in the early part of the season, and as a matter of fact the heaviest fish are generally caught in this way.

The record salmon for the Ness District was taken by the Duke of Portland in the loch on 23rd March, 1907. The weight was $44 \frac{1}{4} \mathrm{lb}$. Seven fish were landed the same day with an average weight of $21 \mathrm{lb}$. In $19052 \mathrm{fish}$ of $40 \mathrm{lb}$. were taken in the loch, one in February and the other in March; these were, I think, the first fish of this weight recorded for the district.

The loch has also the reputation of harbouring a good many pike. The southern end certainly looks " pikey," but the Invergarry fisherman wages constant war by means of trimmers. This end of the loch is not usually trolled for salmon, and so far as the northern end of the loch is concerned, I may say that in March, 1908, I netted this part for the purpose of marking salmon kelts, and only caught one pike; she was, however, a beauty of $23 \mathrm{lb}$. It was marked in quite another way, and was not returned to the water. In referring to this netting, I may add that the kelts we caught were without exception the finest, healthiest, and handsomest I have seen in Scotland, and I have seen a large variety of kelts in the last ten years. A good number, certainly, had healed scars, either from wounds caused by rocks in the upper waters, or the attentions of seals in the Inverness Firth, but the scars were healthy, completed cures, and there was no disease even in these cases.

Loch Oich is a narrow, straight sheet of water, the long axis lying in a north-east and south-west direction. Rich and varied wooding clothes the western shore, more especially in the neighbourhood of Invergarry, where the eye is naturally focused on the ruined Invergarry Castle, standing up, as if to catch the light, on the summit of its rocky knoll. The loch, the woods, the castle, and 
the noble sweep of the hills beyond make the most charming view in the whole of the Caledonian Canal route. The castle was in stirring times the headquarters of the Macdonells of Glengarry who threw in their lot with the Bonny Prince. It was here he first allowed himself sleep in his precipitate flight from Culloden, before pushing on through Lochiel's country to the lonely head of Loch Arkaig, and so over Glen Dessary to the west. Here he was tracked by the royalist troops, who burned and sacked the old castle only. a few hours after Prince Charlie had fled from it. Lochiel's castle shared the same fate; but while the modern Achnacarry stands on the site of the old-and a beautiful site it is-the modern Invergarry occupies a position rather more to the north, closer to the river, and this hoary old ruin remains a monument of the ' 45 .

Loch Oich is 4 miles long and has a maximum breadth of a little over quarter of a mile, and a mean breadth of barely one-fifth of a mile. It is comparatively shallow, and the water contained in it has been estimated as only one-fourth the volume of Loch Garry.

"A great part of the loch, equal to 68 per cent. of the entire area, is less than 50 feet in depth. The central part of the loch is shallowest. Opposite the mouth of the Garry the greatest depth is 20 feet, close to the island. There are four areas of over 50 feet. The first of these is close to the north-east end of the loch. It is three-quarters of a mile long, and encloses an area half a mile long over 100 feet in depth. Near the south-west end of this 100 feet area is the maximum depth of the loch, 154 feet, and near the other end of the area there is a sounding of 129 feet, with a depth of only 108 feet between them." 1 The other 50 feet areas are to the south of the river mouth. The level of the loch above the sea is 106 feet, and the drainage area, including the Garry and all head waters, amounts to 170 square miles.

\section{THE RIVER GARRY.}

When one speaks of the Inverness-shire Garry, one means the four miles of river between Loch Garry and Loch Oich; and when one speaks of the Garry one conjures up a prospect, perhaps a rather hazy prospect, of ideal salmon fishing, a fine sparkling river, beautiful scenery, plenty of salmon. Very many people even in the Ness district have never seen the Garry, but they know it as a famous salmon river.

1 "Bathymetrical Survey of Fresh Water Lochs of Scotland," Scottish Geographical Magazine, xxiv., No. 5, p. 242. 


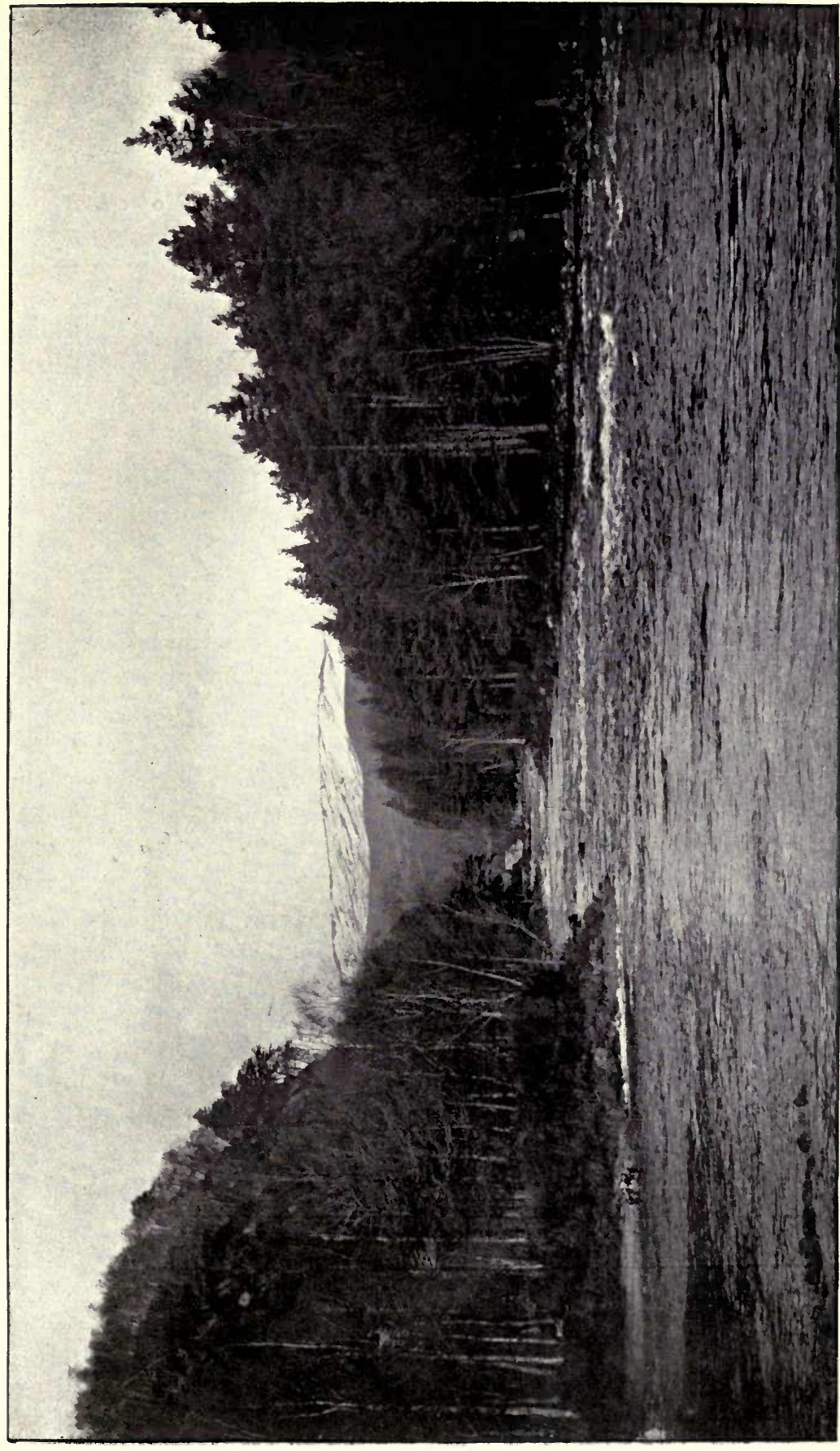

告 

There are other places where one may catch just as many fish, but there are circumstances in the case of the Garry which make it peculiarly attractive. True it is not all river fishing; a proportion of the fish are taken by the less interesting method of trolling in Loch Oich. But again, Loch Oich is a specially beautiful place to troll. In the Helmsdale I have no hesitation in saying there are more spring fish, but the average weight is just about half the average weight of the Garry fish. In the Dee the fish are the same class as the Helmsdale fish-small springers which have passed through their grilse stage in the sea and are entering fresh water for their first ascent. In the Tay the fish are rather larger, but they are not easily to be got on the fly in as good numbers. For the rest the Garry presents most inviting pools, which can be fished from the bank; is an exclusive fishing for a couple of rods; is a tumbling river of beautiful water in a mountainous and richly wooded glen; and holds fish which have, so to speak, run their distance, and are not going to pass further on till the spring fishing is over. In its short run of four miles the Garry descends 151 feet, so that the gradient is more than three times that of either the Oich or the Ness.

This lower Garry is a free-rising river. Very few of the pools are of any depth; the water is lively, and takes out the fisherman's line and fly most pleasantly; the fish lie where the appearance of the water lets one know they are likely to be; there is no dull moment in one's fishing; it is quite clear "he" may come at any moment. Of all pools in the river, and, counting small casts, there are about twenty, the Little Crooked has the reputation of being the surest for fish. "If there's a single fish in Little Crooked he'll rise to you at once," was the remark made to me by one who knows the river intimately. It is the highest pool in the river with the exception of two casts, one at the falls, where the river descends from Loch Garry, and the other a short distance below called the Otter's Hole, both of which can only be fished when the water is low.

The Big Crooked, where the river takes a sharp turn to the left, is also in high favour, as are the Dog Pool, the Englishman, the two Mill Pools, the Carry, the House (so named from Invergarry House, which is close by), and the River Mouth. The photographs show the Big and Little Crooked from the bend below the former, with the fall in the distance, and a stretch lower down including the Dog Pool.

Catches of 36 and 24 fish have been made at different times in 
one week, and about 440 have been got in a spring season. These were great doings. It is a good sign of the river that the weights appear to be increasing. I believe that with the increase of stock resulting from the cessation of netting in the river Ness and Loch Ness, the Garry will do still better. In February, 1909, Sir Kay Muir (two rods), sublet from the Duke of Portland, had 74 fish, averaging $17 \mathrm{lb}$.

The fall of the lower Garry deserves some mention. It is situated at the outlet from Loch Garry in a deep rocky gorge. It has three rises or breaks in its formation, and fish have to make two successive springs in making the ascent. The second spring is a difficult one, partly because it has to be made from broken water, but chiefly because of an upward burst of water caused by a large submerged rock upon which the water strikes, and which interferes materially with the "take off" of the leaping fish. The total height of the fall at low-water conditions is apparently about ten feet, and it is only during low-water conditions that fish are able to ascend. Owing to the narrowness of the gorge a slight rise in the loch is multiplied considerably, and only a moderate rise of level is sufficient to transform the fall into a huge surging rapid with force enough to wash every fish out of the pool below, and to send white superaerated water away down through the Otter Hole to the neck of the Little Crooked Pool. When the winter conditions of water temperature have yielded to the advance of summer, the Garry fish succeed in making the ascent. They are still shapely athletic fellows, well suited for the undoubted effort; yet it is more the question of temperature than the nature of the obstacle which causes them to delay till May before making the attempt. A less serious obstacle would check their ascent in the same way. Garry fish are frequently much marked by old wounds having healed up, and while the seals of Inverness Firth may no doubt account for many of the marks, I suspect that the rocks of the falls have also much to do with the condition. I have noticed the same in the Moriston fish-the few I have had an opportunity of observing. Further, it is believed by those who have much experience in stripping and artificially hatching fish that violent struggles in the overcoming of obstacles have a serious effect upon gravid females in materially reducing the percentage of eggs which will fertilise.

Summer and autumn runs of fish do not, it is said, penetrate as far as the Garry in this district, and therefore the Garry fish when ascending the falls in question in May and June cannot be called 


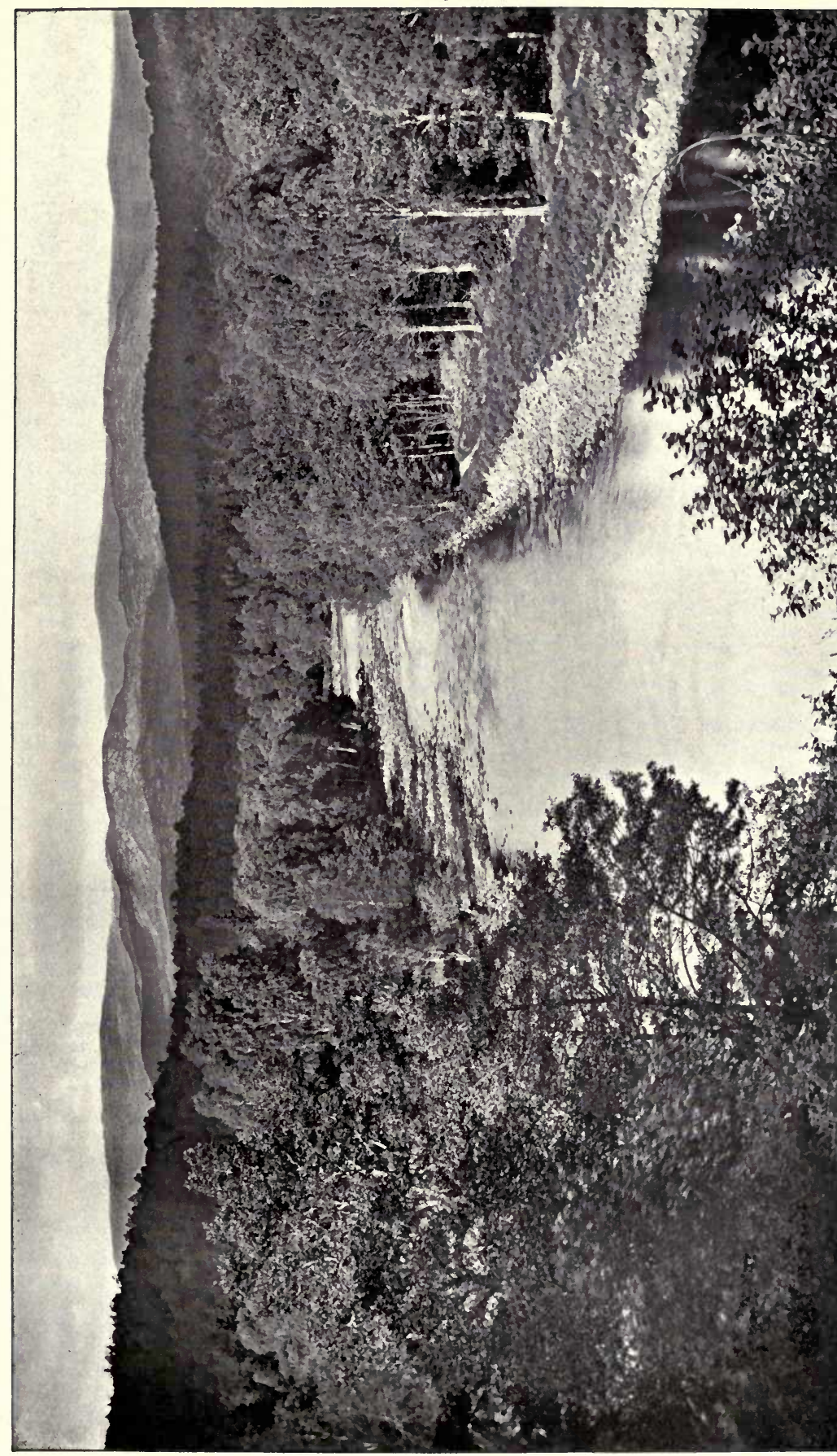

 

gravid fish markedly open to this danger, but to reduce the difficulties at such places is all in the interests of the fish, and would not influence the total catch of the lower Garry.

A point of considerable interest in this district is the reason why the Garry, the farthest up river of all, should be the place where the best spring fishing is obtainable. What attraction is there in the Garry to make it a spring river? This question has repeatedly been asked.

With the object of obtaining some definite information on this point I arranged in the winter of 1901-1902 that a series of maximum and minimum temperatures should be taken both in the Garry and in the Ness from instruments kept constantly immersed and read daily at stated intervals. From the readings thus obtained I calculated the weekly means and plotted the results on a chart which is reproduced on page 166 .

The flat and relatively high curve representing the Ness will be at once noticeable, and that through January, February, and March the weekly mean varies less than a degree and a half. The Garry curve, on the other hand, is not only at a much lower level, but is subject to great fluctuations. The temperatures become equalised in the third week of April. I believe the Garry curve in this particular winter to be exceptionally low. There were four weeks of continuous hard frost in February, accounting for the deep $\mathbf{V}$ in that month.

The Upper Garry flows from Loch Quoich, a beautiful sheet of water about $7 \frac{1}{2}$ miles long. On the northern shore of this loch stands Glenquoich Lodge, which was tenanted for over 30 years by Lord Burton, and visited by the King in 1904 and 1905, during the stalking season. The river Quoich enters about a mile beyond the Lodge, and drains the steep hills between Cluny on the one hand and the head of Loch Hourn on the other. It is a beautiful little mountain river, but of little use for sport. The stream which enters the head of Loch Quoich-the Gairowan-must be regarded as the source of the river system. It rises on the high ridge of mountains which form the watershed of the country, and which on their western slopes overlook Barrisdale. The ridge is only some two miles from the sea in Loch Hourn, and is the most westerly part of Scotland's watershed. The source of the Gairowan is 65 miles by river and loch from Inverness. Like the Quoich, this head stream holds a few spawning fish in the autumn. The finest spawning river of this upper district is, however, the 
Kingie, which enters the Upper Garry rather more than a mile below Loch Quoich, from the south. It rises on the slopes of Lochiel's country, across the divide from Glen Dessarg at the top of Loch Arkaig. The source of the Kingie and the source of the Quoich are about equidistant from the mouth of the river, each being about three miles short of the source of the Gairowan. The glen of the Kingie is steep and wild, a splendid example of a remote Highland fastness. The river is subject to very rapid floods, but in many parts the spawning ground is very fine, and the water is of course clear as crystal at all times. At Lochan is the site of an old loch basin, and the river here becomes still as it meanders through the old lake bed. There is no lack of rain in the district. The beauties of the Kingie were lost to me not long ago by torrents of rain and a tempestuous wind. I had made an expedition in November to mark fish, and was quite drowned out. The record of rainfall hanging in the billiard room of Glenquoich Lodge, where most hospitable shelter was offered, made a subject of melancholy study. There seems to be some pride locally in the fact that Glenquoich holds the record in this respect. The average is 108 inches in the year, the maximum being about 150 . When I was there the rainfall was 30 inches short and only six weeks to go, but the elements were doing their very best to make up for lost time.

The Upper Garry is also a beautiful river, though in places the channel is distinctly rough and broken. As a rule, I understand, it is not much fished for salmon, although over 30 have been taken in the autumn. Lord Randolph Churchill used to be a regular visitor, and succeeded in catching 20 fish one season, but the deer are the chief object of pursuit in these parts.

In the neighbourhood of Tomdoun Hotel the trout fishing is distinctly good, and visitors there can fish a section of the river and Loch Garry. Loch Poulary is a series of diverticula or expansions of the upper river Garry. It merges with the river, so as to be ill-defined as a loch, but may be said to be about a mile and a half long; its western portion narrow and from 9 to 23 feet in depth; its eastern portion a basin half a mile long and a fifth of a mile broad. This basin has been found to have a maximum depth of $\mathbf{4 7}$ feet, the deep water being confined to a channel in the centre. 


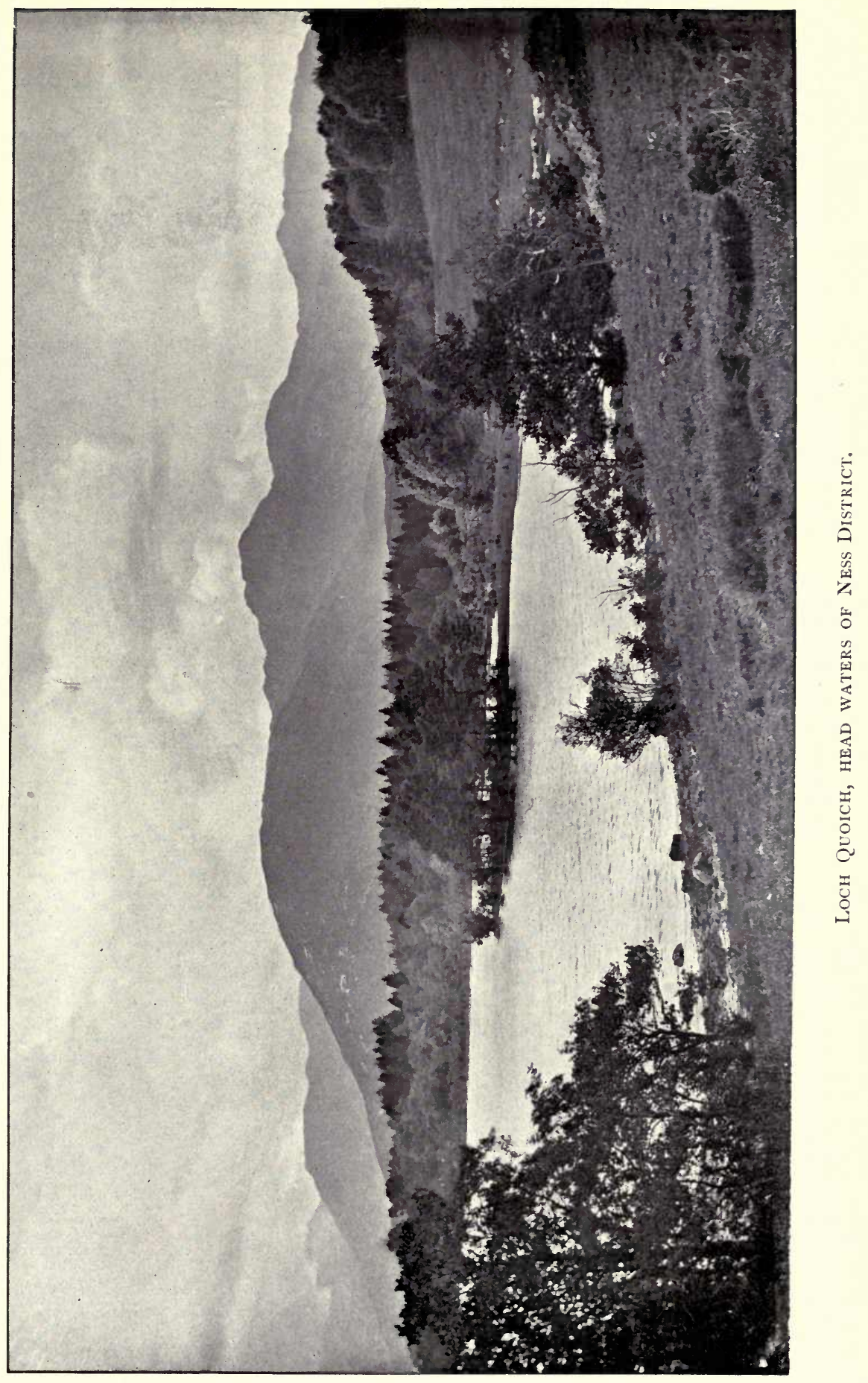





\section{LOCH GARRY.}

This is a beautiful sheet of water, with many birch-clad bays and points, lying also in the direct east and west line of the river. It is five miles long, and has a mean breadth of one-third of a mile, and a maximum breadth of half-a-mile. A considerable stream flows into it on the south side from the glens round Ben Tee, a well-marked conical hill 2936 feet high, but the stream is steep and rocky and unsuited for the ascent of migratory fish.

The loch is 257 feet above sea-level, the descent of the lower river to Loch Oich being 151 feet. The high barrier of rock which forms the eastern end of the loch is deeply cleft at the narrow outlet of the river, and the fall, already referred to, occurs just as this barrier is past.

"As in Loch Quoich, there is a large portion at the east end, one mile in length, which is quite distinct from the basin, and is of moderate depth.

"This eastern part is cut off from the main loch by a large, low, wooded promontory, called the Garbh Eilean (Rough Island) and a sandy island (Eilean Bàn), to the south-west of it. An irregular channel, varying from 9 feet to 18 feet in depth, leads to the small eastern basin, which has a small island at each end, and a narrow arm running to the north." 1

The greatest depth is 213 feet, found in the centre of the western basin towards the south shore. The mean depth is 78 feet.

Salmon are hardly ever taken in Loch Garry, although all fish in their ascent to their natural spawning grounds have to pass through it. This is another example of the manner in which salmon which lie long in waters below an obstacle go off the rise after their ascent. No lochs into which spring fish enter after some months of waiting till summer conditions have come round are of much use to the salmon angler. Streams above may be better, because the fluctuations of level and the upward movement of the fish seem to act as enliveners of the rising propensity. But in a district such as this, with its all-satisfying combination of beauty and grandeur, one need not always ask for heavy bags.

1 "Bathymetrical Survey of Fresh.Water Lochs of Scotland," by Sir John Murray

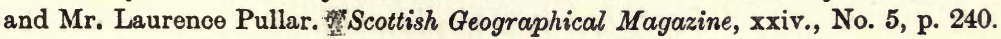




\section{CHAPTER XIV.}

\section{THE BEAULY DISTRICT.}

RIVERS BEAULY, GLASS, FARRAR, CANNICH, AND AFFRIC.

Angling Season: February 11 th to October 15th.

Netting Season: February 11th to August 26th.

No District Fishery Board, but right of salmon fishing over practically the whole district is held by Lord Lovat. Factor J. T. Garrioch, Lsq., Lovat Estates Office, Beauly.

THE river Beauly, like the river Conon, is of a complex nature; it is not a simple river with steep upper waters gradually becoming reduced to more easy gradients as it reaches the sea, and with inflowing streams distinctly subordinate in character to the one main river. The case is not so extreme as that of the Kyle of Sutherland, but is sufficiently well marked to be obvious even in the names given to the river at certain parts. It is, for instance, matter of some doubt where the river ceases to be the Glass and to become the Beauly. The name Glass is still given to the Strath, and only the last few miles, from about Eilean Aigas, have at times been called the Beauly. It is convenient, however, to regard the Beauly as commencing at the junction of the Glass and the Farrar.

The Glass is formed by the junction of the Affric with a comparatively unimportant stream which drains the Guisachan Forest. The head waters of the Affric itself are of no interest to salmon fishers, because fish cannot get there owing to the impassable falls in the fearsome gorge below Loch Beneveian (Beinn a Mheadhoin), where the stream drops some 400 feet in about a couple of milesa place well worth seeing by those who have good heads; but the Dog Fall and the Badger Fall are quite without hope for the salmon.

Glen Affric Forest and Glencannich Forest march, and are very similar in character. Each has two considerable lochs at practically the same level above the sea, and each is scooped out of splendid hills 3000 to 3700 feet high. 
The river Cannich is also a rocky stream with falls and rapids; like the Affric, a stream which is still at an early stage in the formation of its valley. The lowest part of the channel, below little Loch Crash, is cut down in the form of a gorge, but the upper waters are hill torrents and rock basins. Loch Lungard is the highest; then after about two miles Loch Mullardoch, $4 \frac{1}{2}$ miles long, occurs. This gives place to Loch Sealbhag, which, after a long canal-like prolongation, opens into Loch Car. These glens are 700 to 760 feet above sea-level, and along with the Farrar, to which greater reference must be made, form the mountain valley section of the river system.

Mr. Hinxman ${ }^{1}$ of the Geological Survey has well described the Beauly basin as divisible into four well-defined sections-the mountain valley section; the flat valley track; the gorges of Eilean Aigas and Druim; and the low course of the river between Kilmorack and the sea. The Glass throughout its whole course, and the upper part of the Beauly form Mr. Hinxman's "flat valley tract." The river winds a great deal in the sandy bed of this old valley bottom, the site no doubt of an early lake about thirteen miles in length, which was only drained by the erosion of the conglomerate rocks at Eilean Aigas. Before this erosion took place, it is likely there was a water fall such as is nowhere now to be seen in Scotland. A mile or two from the top of the valley, the scenery of which is very fine, there are some pools of a very inviting character, and a good many fish are taken even in the stiller reaches lower down, which go with the Struy fishings. The banks are, however, inclined to be sandy and steep.

In the neighbourhood of the junction with the Farrar some interesting water occurs, and the junction pool itself is a beauty. Lower down again, near Erchless Castle, some excellent running pools with gravelly banks occur which yield 70 to 80 fish to the rod. They are pools which might well be converted into good spring fishing water if it was possible at some future time, by the easier passing of the Kilmorack Falls, to enable spring fish to ascend thus far. Although Erchless Castle comes in in the middle of this valley tract and has inviting waters close to its doors, the right of salmon fishing is held by Lord Lovat, a matter which was decided in a somewhat famous case ${ }^{2}$ in which the Chisolm of the day argued prescriptive possession "by rod and spear," in order to validate a general title cum piscationibus, but which plea was rejected. As a result of this decision, the water in the neighbourhood of Erchless

1 The Scottish Geographical Magazine, April, 1907.

2 " Chisolm v. Fraser," Dict. App. i. voce "Salmon Fishing." 
Castle is fished from Lord Lovat's Eskadale House, which stands a short distance above Erchless, while the right of salmon fishing remaining to the latter is now at a great distance and of insignificant value, viz. away at the head waters, the Affric and Cannich, and a small part of the Glass below the junction of the latter tributary.

The land boundaries are curiously divided up in the neighbourhood of Erchless, the result of operations of which I know little or nothing, but to many the arrangement as to right of salmon fishing is much more inexplicable. Yet, owing to the source of all such titles in Scotland, such arrangements are not very uncommon. The Farrar is the most important tributary and is fishable for some fourteen miles. It flows out of Loch Monar, a sheet of water 5 miles long and 663 feet above sea-level, to which, however, salmon are unable to ascend owing to an extensive and picturesque fall 15 to 16 feet high, situated about half-a-mile below the loch. The opening up of this fall has been in contemplation in view of the fine spawning streams at the head of Loch Monar, but it is doubtful if the very considerable necessary expense would be to any extent recouped in increased stock of fish. The channel of the Farrar for some little distance below those Falls of Monar is rocky and uninviting, and, so far as I have been able to learn, not much frequented by fish at any time. A fine spawning stream enters from the south below the rocky belt, and this, I am informed, draws the fish which penetrate to these head waters.

Below this point Glenstrathfarrar is open, and for some distance below Braulen Lodge the river is winding and at times not at all rapid. The hills of the deer forest attached to the lodge rise high and are often of beautiful outline. The fishing of the Farrar down to a point about two miles from the mouth goes with Braulen Lodge and is let on long lease. About 60 fish are got each year, and most of them are of light weight. I believe the great majority of the fish are grilse. A fish weighing 12 to $14 \mathrm{lb}$. is considered heavy, although the present tenant has repeatedly taken fish of $16 \mathrm{lb}$. His best day was obtained in 1908 when 8 fish were killed.

Two small lochs now occur in the course of the Farrar, Loch Muilinn, which is 418 feet above sea-level, and a mile lower down Loch Bunacharan 367 feet. Thereafter the river passes through the most beautiful and varied part of this fine glen. Fir and birch clothe the lower slopes, the trees being sufficiently open to allow of deep heather growth. Everywhere the ground is much broken and 
irregular, while the hills on either side rise well over 3000 feet. I would fain have given a photograph of this ideal Highland glen with its rushing, lovely river, but on the occasion of my last visit an enveloping haze completely defeated me.

About two-thirds of the way down through these open woods another but much less formidable fall occurs-the Daenie Fall. The tail stream from a large and inviting-looking pool is suddenly contracted as it passes a vertical wall of rock, and immediately thereafter the water drops over a ledge with an appropriate amount of fuss. On the right bank this ledge is between 6 and 7 feet high, but it gradually slopes to the left bank, where the current has considerably undercut its rocky wall, and is now only about 3 feet high. The breadth of the river at this point is narrowed to about 20 feet, and the current is therefore strong; but fish manage in suitable water to ascend close to the left bank under the overhanging rock. It would not be difficult to make the fall easier-which sounds a little like the congratulation given to the Irishman who had won the race. His friend said he was glad he was first at last, to which the victor replied that he was too, because he had always been behind before.

The remaining waters of the Farrar go with Struy Lodge, and the sport here is better than it is above, although under existing conditions fishing does not begin much before July. When the grilse reach Struy the sport seems to be excellent. In 1908, 121 fish were taken in three weeks. The autumn's score is usually from about 120 to 160 . The largest fish taken here was $19 \mathrm{lb}$. The mouth of the glen opens out to some extent, and many of the pools become more "streamie," and the river bed and banks more gravelly and boulder strewn. As already mentioned, the Struy fishing includes a good section of the Glass. In the whole district this fishing comes next in value to Beaufort Castle Water.

The remaining sections are those of the main river Beauly, forming first the extraordinary gorge in the old conglomerate, and lastly, the open section of the river from the Lower Kilmorack falls to the sea.

The gorge in the Druim Pass is about three miles long, and is in many parts so precipitous as to be quite inacessible to the angler. There is, however, a break of some distance, and some nice water reported to yield little, a short distance above Kilmorack. From the public road, which winds up to the summit of the cañon on the left or north-west side, views are at intervals obtained of the great gap and 
the river at the bottom. Where the ground is sufficiently sloped above the sheer precipices, a variety of trees grow in profusion and make the view at once finer and more difficult to see. At Eilean Aigas a bridge spans the gorge at no great height, and a path descends or rises on either side, and from this point of vantage an excellent view up and down stream is obtained of the sheer walls of conglomerate. The photograph is taken from the edge of the wooded slope near the path that runs above the gorge on the left bank, looking down-stream to the bend above Kilmorack. It is a wild place to fish, and a wilful salmon is here likely to have his way; yet the Eilean Aigas rods get a fair number of salmon and grilse in summer and autumn. There is a considerable fall or heavy cascade below Eilean Aigas, which is quite sufficient to check fish, but the difficulty is less here than at Kilmorack.

The Upper Kilmorack Fall, or the Red Fall as it is locally named, is a very considerable obstruction, being about 13 to 14 feet in average height. Photographs of this fall are common. The ledge runs directly across the river, and the drop is almost sheer, except at the right bank, where the action of the water has sculptured a sort of pot hole of considerable size at a rather higher level than the fall pool. The course of the river immediately bolow becomes so narrow that the water is kept constantly in turmoil, so that fishing here is useless. From the pot hole already referred to a wooden fish-pass leads up the extreme edge of the fall in a slightly angular manner. It does not look by any means an easy pass for fish to ascend, but it is the road by which all fish go to the upper waters. With the force of water hopelessly great, I have seen plucky fish leaping boldly as far into the pass as they could get. By judicious blasting, a natural pass of a comparatively easy gradient could be created round the fall at the left side.

The action of the water plunging over the fall seems to have gouged out a channel of great depth, rather than to have eroded the upper walls of the gorge. The result is that a short distance below the fall the rocks on either side of the river approach as near as about 7 or 8 feet, the whole volume of the Beauly, which shortly before was contained in perhaps a hundred and fifty feet of channel, being carried in an infinitely black and deep-looking cavern below.

In times of flood these subterranean channels are unable to take more water, and, the upper rocks being so narrow, the water is pent up so that the level rises at an exceptional rate. About 50 feet of a rise has, I understand, been noticed here in high flood, and 


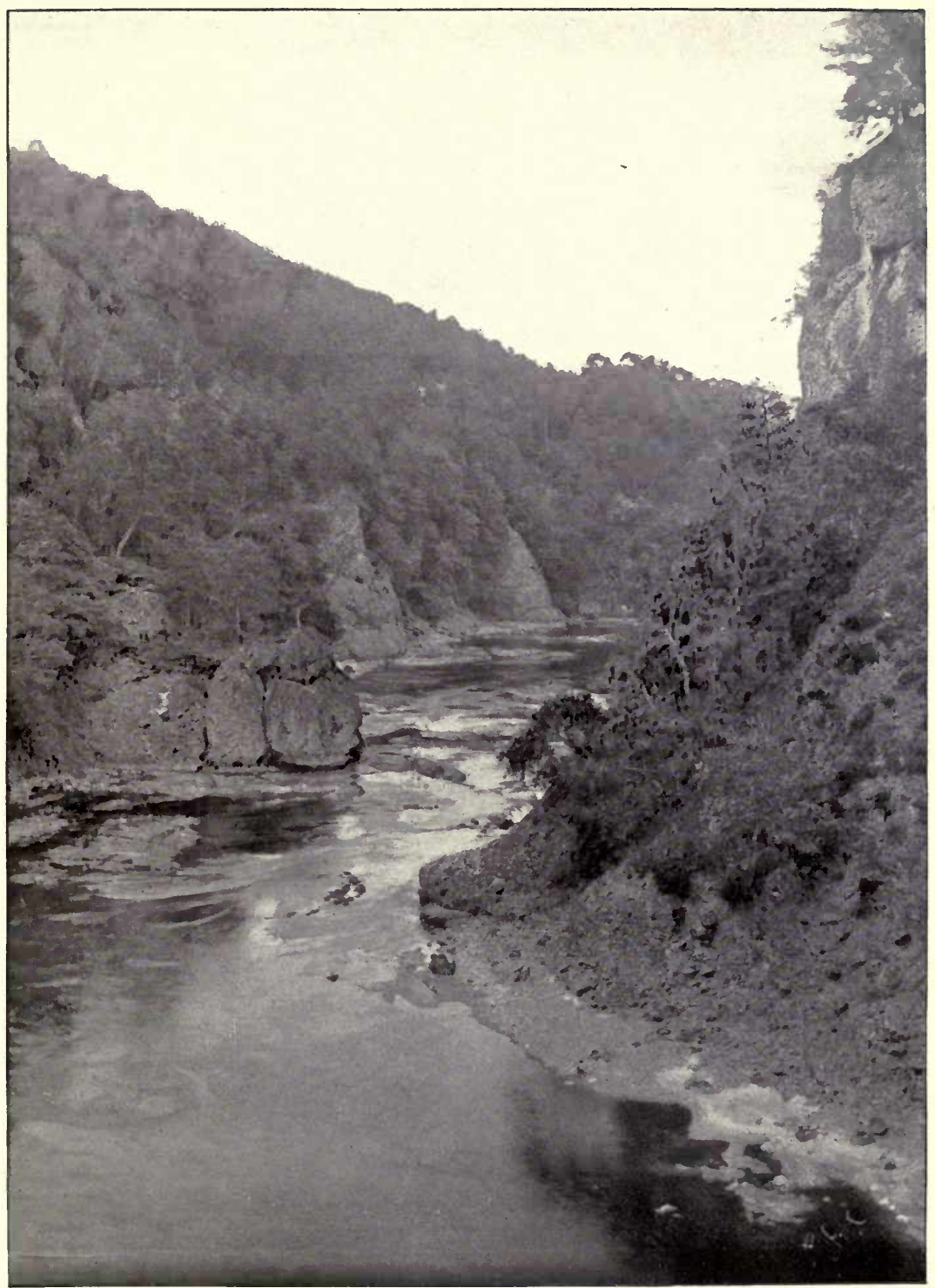

The Beauly below Eileax Aigas. 

Major the Hon. Hugh Fraser tells me he has seen a fall 10 feet high pouring down through the narrow rocky aperture into the Mare's Pool below. The Mare's Pool is the highest of the Beaufort Castle water, and usually holds a lot of fish. A long flight of steps lead down to it from the top of the cliff, and the lower portion is fished from a platform which projects across a side gully. It gets its name, Fraser the ghillie tells me, from the fact that a horse fair used to be held in the field at the top of the cliff on the Kilmorack Church side, and that on one occasion a mare fell over into the pool below.

The tail of the Mare's Pool is no distance from the foot of the gorge, where a fine stream-which cannot be reached from either side-spreads out above the Lower Kilmorack Falls. The barrier of rock here is divided by many streams, and a boat is necessary to cross from one part to another, and to land upon an island from which two streams can be fished. From the remains of old but substantial posts which are noticeable at the sills of several of the runs, it appears that these falls were at one time used as a natural cruive dyke. Two passes exist, one in the rock of the central stream, where the fall has a good slope, though the actual height must be 6 or 7 feet, the other at the back of the island in the form of a wooden shoot as at the upper fall. I understand that the majority of fish go up the wooden shoot, but, again, it would not be difficult to make the ascent easier.

The barrier of rock which causes these lower falls is made use of as a natural weir to supply water on each bank, on the left to a small meal mill, from which the water is immediately returned to the river; on the right to a saw-mill by means of a lade of some length. This lade has also been made to serve a small hatchery which Lord Lovat erected some years ago, capable of dealing with about 300,000 ova. I understand that the use of this hatchery is now to be discontinued.

The river below the lower fall soon becomes rather still and broad, with a smooth bottom. This section fishes well when the river is high, but under ordinary conditions is not of much use. That the current must be heavy at times is sufficiently shown by the torn state of the left bank where the river sweeps to the right. The high wooded banks of the Beaufort Castle policies again turn the river northwards, a wide and flat grass land being formed on the left side. The stillness of this bend is accentuated by the cruive dyke which is presently reached. 
The time of ascent of fish at Kilmorack is fixed by the thermal conditions. As in many other places in Scotland, such as the Garry falls, Kildonan, Orchy, Dochart Falls, etc., fish do not ascend owing to the combination of the otherwise passable obstruction and the low-water temperature. Scottish fish will not jump at a fall when the water is in a wintry state, as Norwegian fish will do, but if the obstruction is removed they will continue to ascend. In heavy and broken water such as occur in the gorge above Kilmorack they will not ascend rapidly, and if floods of snow water come down upon them they will be checked in their ascent, and may even be impelled to drop back till such floods are over. In those early months of the year the river temperature is constantly lower than the temperature of the sea from whence the fish come; these fish leave a cold sea for a colder river. Not till April does the river temperature become equalised with the sea temperature. Those conditions have been well worked out, and comparisons made between many rivers. ${ }^{1}$ We require more information as to how far clean spring fish which ascend fresh water drop back to the sea and reascend at a later period. That the habit is fairly common has been believed for many years by observant netsmen, but very little reliable information exists. The best recapture of a marked clean fish showing a descent and reascent comes from the river we are now considering.

When fish were being netted in order to secure ova for the hatchery, on 9th December, 1907, a clean fish of $22 \mathrm{lb}$. was also captured. It was marked with label No. 4054B. The place of capture was the Castle Pool below the Cruives. This fish on 19th March, i.e. in ninety days, was recaptured on the rod in the river Ness at Dochfour, six miles up. It was then a fish of only $20 \mathrm{lb}$.

Two other clean Beauly fish were recaptured, one in 52 days, the other in 115 days, but neither had left the river in the interval; the recaptures were both made in the Beauly. The case of the fish migrating, when clean, from the Beauly to the Ness is, so far as recaptures go, quite unique, although some four fish in the kelt state have been recorded as having changed their rivers. The rivers Beauly and Ness have, of course, a common estuary, and the distance from the mouth of the one to the mouth of the other is only about ten miles. Whether or not clean fish which ascend many miles up a river do commonly return as this fish did, remains, I hope, to be

\footnotetext{
1 19th, 20th, and 21st Annual Reports, Fishery Board for Scotland, Part ii. Journal Scottish Meteorological Society, 3rd series, No. vi., p. 336.
} 
ascertained in the future, but it is not easy to believe that fish in the Ness district which have ascended to the Garry, descend again. A clean fish marked in December has been recovered in the same high pool in June. We have taken marked Garry fish after they have remained in Loch Oich for a considerable time. Moreover, the Garry has no summer or autumn run of fish, and the same class of fish which are found there in the spring are seen ascending the falls in May and June, and are found spawning in the high tributaries in the early winter. If we could suppose for a moment that the Kilmorack Fall-the red fall-was blown sky high, the chances are that a considerable rapid would be produced in the river just above. Near Eilean Aigas a considerable rapid already exists. We would, therefore, have two strong rapids instead of one big fall and one rapid. The thermal conditions of the water could not be altered, but the physical difficulty of ascent would be greatly lessened, and fish would reach the flat valley tract above the gorge at an earlier date. It is this flat valley tract which seems to me to offer much greater possibilities of good angling than can be expected under existing conditions. Many of the pools are very fine, and some could be greatly improved by a little croy building, others are too dull and sandy for early fish to lie in. A better fishing here would be of great value. But I do not imagine the rocky barriers could be sufficiently reduced to materially rob the lower waters of the fishing which exists at present. I set down these thoughts purely by way of suggestion, and because of the fascination which belongs to the development of natural resources. I venture to think also that much good might result from the systematic killing down of pike and eels. Eel fishing might, indeed, serve a double purpose, for eels are of good market value in England, and their capture is a neglected industry in Scotland.

In descending order, reference may now be made to the Cruive Dyke just above Beaufort Castle, the residence of Lord Lovat. The Beauly Cruive Dyke is the largest structure of its kind in Scotland, and if the boxes were fished, the stock of fish in the river would run a very poor chance indeed. For many years, however, the boxes have not been fished, although the dyke is kept up and certain of the boxes closed by means of hecks.

Taking advantage of an island which here exists, the builders of the cruive dyke-as was very commonly the case in early daysfounded the apex of a down-stream V-shaped wall upon it. The structure is very substantial, and at ordinary levels of the river 
stands for the most part a foot or two higher than the level of the pool above. The height above the bed of the river must be from six to seven feet, the whole forming a broad causeway which, when the river is not high, was a convenient means of crossing from bank to bank, before the private bridge further down was reconstructed. There are seven boxes, four in one arm of the $\mathbf{V}$, and three in the other. Fish congregate in great numbers below the cruive, and the fine running pool immediately below and on the Castle side of the island is certainly one of the best in the river. Some great days have been experienced here when the grilse were running; but of this later.

The cruives were not always in their present position, but in early days were close to the mouth of the river above the new Lovat Bridge, which replaced the old structure carried away in The Moray Floods. The houses which were attached to the old cruives still exist and are still in use-called Cruive End. Here the old coppers of roomy dimensions are yet to be seen, in which, before the days of ice-packing and railways in the North, salmon were cooked or par-boiled preparatory to being steeped in vinegar, packed in flat firkins, and shipped to London.

The Beauly nets are still kept at Cruive End, but netting since 1897 to 1907 was restricted to two days a week during the months of June and July. This arrangement has recently been improved upon, and netting is now reduced to a minimum. An estuary netting station, formerly in the possession of Rosehaugh, has also been bought up by Lord Lovat and left unfinished.

From the cruives to the commencement of the estuary at the top of tide-reach is a distance of about $2 \frac{1}{2}$ miles. Counting the pools between the cruives and Kilmorack-and from the Falls to the sea is the Beaufort Castle water-there are fifteen good pools, the majority of which are almost ideal fly pools. Till the shooting season begins. the Castle water is let annually for two rods, and the tenants usually reside at the hotel in Beauly. The spring fishing is not perhaps as good as it used to be, for the stock of fish declined some years ago; but, given suitable weather, the results are reliable, and when the grilse begin to run the takes are often great, for the Beauly is a very good grilse river. Between 200 and 300 fish may be got after the grilse begin to run, and July is the best month.

The record performances on this stretch of the Beauly were made by the late Lord Lovat and Colonel Duff. They are results the like of which are never obtained nowadays, even in the Grimersta, 


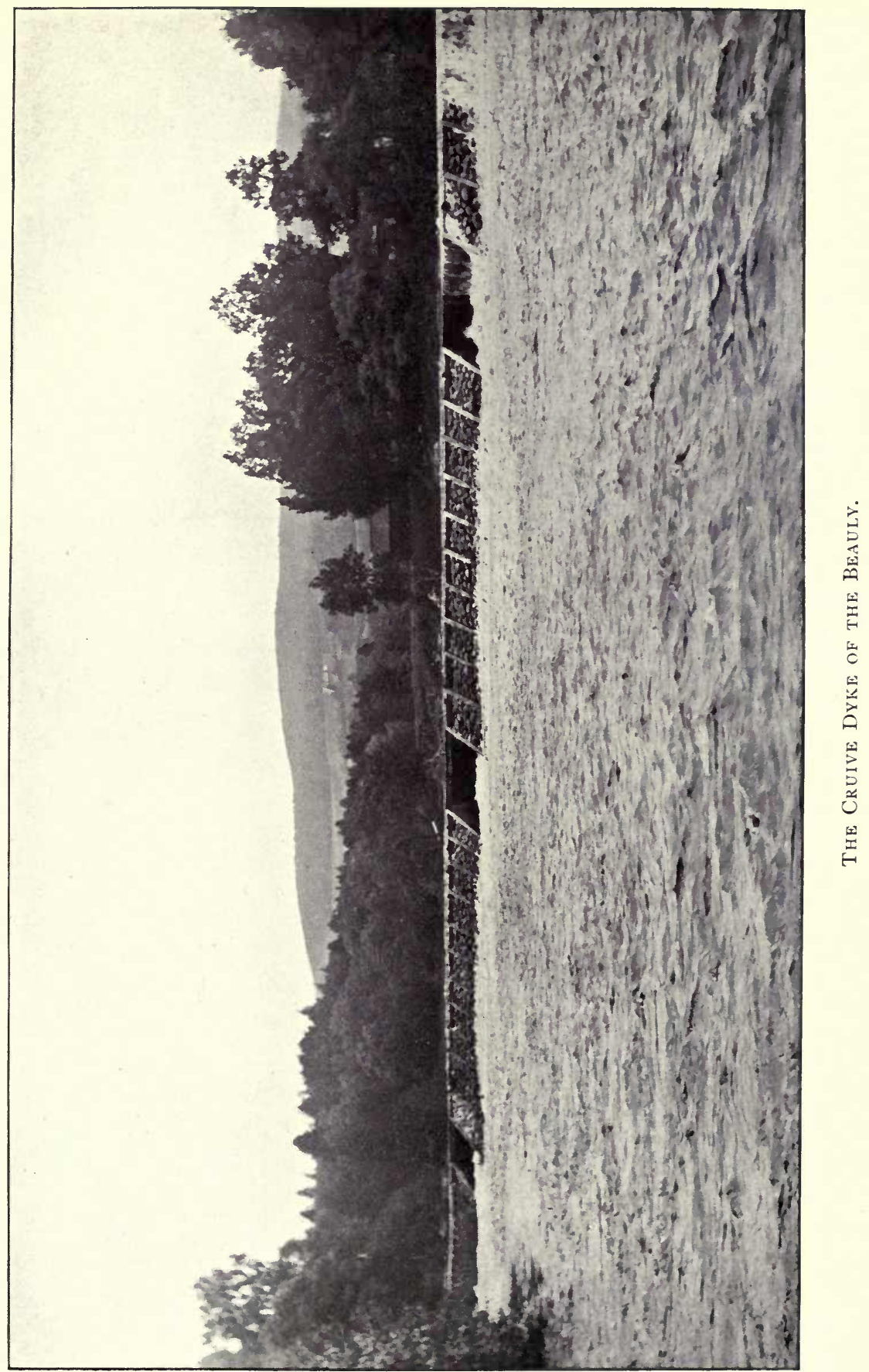



where 54 fish have been killed on one rod in one day. In 1854 Lord Lovat had 128 fish in eight days. In 1859 Colonel Duff had 106 fish in seven days. In 1864 Lord Lovat had 146 fish in five days. Ye gods! think of 29 fish a day for five consecutive days. These results were got when the grilse were running either at the end of June or beginning of July.

The spring fish of the Beauly are commonly of the small class, i.e. the fish entering fresh water for the first time, and which have passed their grilse stage in the sea, fish rising four years old and 8 to $10 \mathrm{lb}$. in weight. Examples of the large class of spring fish, 15 to $20 \mathrm{lb}$., are comparatively rare, so that the $22 \mathrm{lb}$. fish marked in the Beauly and recaptured in the Ness was exceptional. It is quite possible this fish belonged to the Ness or Garry, and had run up the Beauly before finding its proper river.

The total number of fish taken by rod in the Beauly is usually estimated by the estate as being from 800 to 1000 , but in 1908 this was considerably exceeded if sea-trout are included, as over 900 sea-trout were taken in the tidal pools alone-a quite unprecedented number-and 364, I believe, in the Home and Falls beats. Including Downie and the Home and Falls, the total reported take is 208 salmon and grilse, weighing $1666 \mathrm{lb}$., and 428 sea-trout, weighing $436 \mathrm{lb}$.

In April, May, June, July, and August, the Home and Falls beats were let in 1908. In February and March an occasional rod fished from Beaufort Castle, and in September and the available half of October fishing was also carried on from the Castle. The results for this year were given in The Field, ${ }^{1}$ and are of interest as showing the value of the various months. I also have a record of salmon and grilse taken in 1907 , which I may also add. ${ }^{2}$

\begin{tabular}{|c|c|c|c|c|c|}
\hline \multicolumn{3}{|c|}{1907.} & \multicolumn{3}{|c|}{1908.} \\
\hline & & Salmon and Grilse. & Salmon and Grilse. & Sea-trout. & Total. \\
\hline February and & March & 31 & 10 & 54 & 64 \\
\hline April & - & 22 & 6 & 98 & 104 \\
\hline May & & 32 & 40 & 5 & 45 \\
\hline June & - & 21 & 16 & - & 16 \\
\hline July & - & - 48 & 65 & 33 & 98 \\
\hline August - & - & - $\quad 21$ & 30 & 70 & 100 \\
\hline September & - & 25 & 13 & 86 & 99 \\
\hline October - & - & -16 & 7 & 18 & 25 \\
\hline & & 216 & 187 & 364 & \\
\hline
\end{tabular}

${ }^{1}$ A. Ross, Oct. 23rd, 1908.

${ }^{2}$ Fishing Gazette, October 26th, 1907. 
From The Field report as to 1908, the lodges further up the river seem to have secured 314 salmon and grilse and 76 sea-trout, making a total for the season of 1887. This is not far short of double the number usually estimated. Now 1908 was a notoriously bad year in almost all other districts in Scotland. The inference is that the reduction of nets is now beginning to tell by the improvement of the natural stock of fish in the district. The dictum which my old friend Dr. Almond, of Loretto, use to lay down is generally correct: "If you want to catch more fish you must fish less." The heaviest salmon of 1908 was a fish of $19 \mathrm{lb}$, caught by Hon. Elspeth Campbell; the heaviest sea-trout, a fish of $5 \mathrm{lb}$., caught by Mr. C. W. Ogden.

The nets in the lower water in the old days used to make great scores, and the natural productiveness of the river must be very great. A return was supplied to Lord Elgin's Commission by $\mathrm{Mr}$. Garrioch, Lord Lovat's factor, from which I have drawn the following sexennial periods, putting salmon and grilse together:

$\begin{array}{rcccccr}1827-1832 \text { (inclusive) } & - & - & - & - & 9831 \\ 1833-1838 \text { " } & - & - & - & - & 11374 \\ 1875-1880 & \text { " } & - & - & - & - & 5071 \\ 1881-1886 \text { " } & - & - & - & - & 5972 \\ 1887-1892 & " & - & - & - & - & 3654\end{array}$

After 1862 daily netting ceased.

In connection with the capture of great numbers, it is interesting to notice what Richard Franck, writing in 1658, has to say of the Beauly." He describes it as "replenished with salmon; whose numbers are numberless, if not improper to say so; and careless of their lives, they cast them away.

"I must confess, the strength of such strange reports, oftentimes meets with a foreign faith, that raises more scruples than arguments can answer. And so it hapned to me at first, till convinced by some persons of considerable reputation, that when fishermen with their sanes have drawn these streams, they have counted many times five hundred at a draught; the truth of which relation, should any man doubt of, they are ready to assert and vindicate the truth on't by pregnant demonstration. However it shaked my credulity at first, though possibly it may remove the jealousy of another, if when provided with patience he can suspend his suspicion till better inform'd, or confirm himself of the plenty of salmon in these remote northern parts. For I grant, others with rnyself of a like per${ }^{1}$ Northern Memoirs. Edition 1821, p. 203. 
swasion may question this report, till convinc'd by the truth of ocular demonstration; that these northern rivers are the riches of the country."

The gallant Richard is nothing if not obscure in most of his writing, for he is a victim to the vice of verbosity, and what, with fulsome floweriness, might be called fine writing. The passage quoted is by no means so bad as many others which occur in his Memoirs. One has to practise much patience to gain the good points. "Many times five hundred" may, I suppose, be translated like certain passages in Old Testament history which relate of prodigious slaughters in battle. One can say that they refer simply to a very great number.

\section{THE NESS AND BEAULY ESTUARY.}

includes what is commonly called the Inverness Firth and the Beauly Firth, a shallow sea basin extending in a north-easterly direction from Beauly to the narrow bottle-neck between Chanonry Point and Fort-George. The scour of the tide at the narrows is very considerable, and a deep channel is here hollowed out, the current forming a fine natural lead in for fish. At this point most remunerative netting used to be carried on as well as at Fortrose inside the narrows. It is naturally a point where fish congregate, and where therefore fishing by means of fixed engines becomes a danger to the upkeep of a proper stock of fish.

In fixing the estuary limits scheduled in the Salmon Fisheries (Scotland) Act, 1868, the policy followed by the administrative Commissioners appointed under the 1862 Act was to push the estuary limits beyond any place where fish in approaching fresh waters naturally congregate. For this reason the limits of the Ness and Beauly estuary were not drawn across the narrows already mentioned, but were drawn some little distance outside from the centre of "The Three Burns"-a point, by the way, rather difficult to define-to the buoy off the Whiteness Sands.

Net and coble fishing has regularly been practised at the narrows on the Chanonry Point side, and this cannot, of course, be objected to. At the same time I have noticed that the temptation to work a sweep net as a fixed engine has not infrequently been too strong for the fishermen here employed. 


\section{CHAPTER XV.}

\section{CONON DISTRICT.}

RIVERS CONON, MEIG, BLACKWATER, ORRIN.

Angling Season: February 11th to October 31st.

Netring Season: February 11th to August 26th.

District Fishery Board sits in Dingwall. Clerk, W. R. T. Middleton, Esq., Solicitor, Dingwall.

The Conon District is an example of a complex river system, a district in which various rivers of not very different size unite, as compared to the simple river system in which one large river can be traced as distinctly the predominant waterway, all other streams being subordinate tributaries to it. In this instance a large loch, Loch Luichart, occupies a central position, receiving water at its head from the river Bran and from other streams, discharging its waters over a high and beautiful waterfall, or rather over two falls close together, into what is thereafter known as the Conon River. On either side of this central flow an important river also converges, on the north, through Loch Garve, the Blackwater; on the south also from high deer country, the Meig. The Meig is not so great a stream as the Blackwater, but the glen through which it flows is called Strathconon, suggesting that the Meig is in reality the upper section of the Conon. It is perhaps unnecessary in a complex district like this to distinguish any one stream as the head waters proper of the district, but if we take the waterway which springs from furthest inland, and at the same time that which seems to gather the greatest amount of water, we must select the central line through Loch Luichart and Loch Rosque. The Meig is 24 miles in length down Strathconon to its junction with the main river. The distance from the stream above Loch Rosque to the mouth of the Meig is 27 miles.

Loch Rosque is at present the abode of only trout and char. It 
is a very straight and regular basin, lying almost due east and west. It is $3 \frac{1}{2}$ miles long, and has a mean breadth of between a quarter and half a mile. The greatest depth found by the officials of the Bathymetrical survey is 168 feet, near the centre of the loch. Most of the loch is over 100 feet in depth, and the height of the surface above the sea is 507 to 508 feet.

Loch Luichart is a considerably larger sheet of water, being five miles long, a maximum breadth of nearly a mile, and mean breadth of one-third of a mile. It is rather famous as a loch in which heavy trout may be caught, although, like other deep lochs inhabited by large trout, it is at times very dour or "stiff." I find the surprising statement made in a descriptive account much referred to by sportsmen, that the loch is 8 to 10 miles long and one mile broad, and that grilse sometimes penetrate to it in spite of the falls below. I have not yet met the grilse that can climb 28 feet in an almost perpendicular cataract. The Falls of Conon, immediately below the loch, are quite that height, and immediately above the main fall is a lesser one of about 9 feet. The lesser fall would alone be quite sufficient to completely stop grilse, although an athletic summer salmon might perhaps manage this if provided with an aeroplane, or a really good fish-pass by means of which to ascend the big fall below. Invermoriston Fall, in the Ness District, is about four feet lower than the larger fall here, and has been provided with a pass which lets a fair number of fish up, and may therefore be described as fairly successful.

Various proposals have been made for opening up the Conon Falls, from a pass 454 feet long, so as to include both falls, to a complete clearing away of the obstructions by the summary agency of dynamite. I am afraid there would be a big flood to start with if the latter plan was put into execution, since the rocky barriers of crystalline schists at the falls practically hold up Loch Luichart. Up to the present, however, I think the chief difficulties in the way of opening up the falls are more connected with questions of title and proprietary interest than of rock. When the benefit of improving the lower reaches of the river are more fully realised, more hope may be entertained that the upper parts will receive the attention they deserve.

Loch Luichart has been found to have a maximum depth of 164 feet, and a mean depth of 67 feet, ${ }^{1}$ but this floor is irregular, there

1 “ Bathymetrical Survey of Fresh.Water Lochs of Scotland," by Sir John Murray and Laurence Pullar. Scottish Geographical Magazine, xxi. No. 9, p. 471. 
being three 50 feet basins, separated by shallower waters. "The largest and deepest lies in the wider north-western half of the loch, and is about $2 \frac{1}{4}$ miles in length, approaching to within less than 200 yards from that end. The central 50 feet basin is separated from the north-western basin by an interval of half a mile, in which lies the single small island in the loch, and where the depth in the centre at another place is only 5 feet, and is over $1 \frac{1}{4}$ miles in length. Immediately to the south-east of this central basin there is a narrow constriction in the outline of the loch, in which a depth of 16 feet was recorded, succeeded by a slight expansion containing the third 50 feet basin, with a maximum depth of 55 feet, and of small extent."

Two things seem clear from this, first, that if the falls were blown up the last-mentioned area of 55 feet would be at once drawn upon; and secondly, that if, say, the level of Loch Luichart was lowered by 20 feet, two, or even three, lochs of a more or less imperfect formation would be formed instead of one.

The river Bran, above Loch Luichart, is a beautiful little river, with some pools and streams which would make interesting casts were salmon present, and much of which would make excellent spawning ground. This river flows from Loch Rosque (Loch à Chroisg), and until about a couple of miles above Loch Luichart has a fairly even gradient. At the point referred to a moderate cascade occurs, which in certain stages of the river would form an obstacle to ascent.

The river Grudie, which flows from Loch Fannich to join the Bran a mile above Loch Luichart, is a brawling, rushing stream, which does not offer much prospect of ever being satisfactorily opened up. It falls 460 feet in three miles and a half, and is a mass of difficulties, none of them perhaps very great, but taken collectively, in my opinion, rather too serious.

The upper regions of the district show signs of great denudation. The terraces of alluvium which may be seen around Achnasheen Railway Station are delta deposits laid down in an ancient lake. On every hand the mountains have been formed by the gouging away of their sides in torrents and icefloes. The eastern section of the district is already denuded to a low level, and the Cromarty Firth, the present estuary of the Conon district, represents no doubt a portion of the early river course, the opening between the Old Red Sandstone suitors of Cromarty being, as Hugh Miller pointed out, the original mouth of the early river. The line from one suitor 
to the other is now the limit of the estuary, which estuary also serves for the river Alness.

The upper estuary and lower river have for many a long year been steadily netted. Now at last there seems some prospect of overnetting coming to an end, although the usual netting will continue during season 1909. Twenty-seven shots are fished here in three and a quarter miles of water, and since at the top of this netted section the Brahan Castle Cruive dyke exists, which is also fished at two boxes, all other openings being closed, it will be readily understood that a very complete control over all ascending fish can be exercised, and, except during floods or the weekly close times, fish have poor chance of reaching the upper waters. In 1907 the nets are said to have secured considerably over 4000 fish. On the opening day 150 clean fish were got at the first sweep.

The proprietors of fishings above the cruives have always been anxious to secure a more adequate stock of fish. An arrangement of a private nature by which the cruives were formerly left open was entered into by the late Mr. Stirling of Fairburn and Colonel Mackenzie of Seaforth for the years 1889 to 1900 , and during this period of twelve years the rentals above the cruives steadily rose. The subjoined table shows the rentals above and below the cruives, while the rectangular line encloses the period during which the cruives were open :

Assessable Rentals.

\begin{tabular}{|c|c|c|c|c|c|c|}
\hline $\begin{array}{l}1885 \\
1886 \\
1887 \\
1888\end{array}$ & $\begin{array}{l}- \\
- \\
-\end{array}$ & $\begin{array}{l}- \\
. \\
\end{array}$ & - & $\begin{array}{c}\text { Above Cruives } \\
-\quad £ 575 \\
-\quad 575 \\
-\quad 605 \\
-\quad 605\end{array}$ & Averages. & $\begin{array}{c}\text { Below Cruives. } \\
£ 1884 \\
1884 \\
2046 \\
2046\end{array}$ \\
\hline 1889 & - & - & - & 605 & & 2019 \\
\hline 1890 & - & 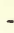 & - & 746 & & 2004 \\
\hline 1891 & - & - & . & 751 & & 2004 \\
\hline 1892 & - & - & - & 741 & & 2233 \\
\hline 1893 & - & - & - & 721 & 713 & 2222 \\
\hline 1894 & - & - & - & 676 & & 1847 \\
\hline 1895 & . & . & - & 676 & & 1778 \\
\hline 1896 & - & . & - & $-\quad 7167$ & & 1873 \\
\hline 1897 & - & - & - & - $\quad 716$ & & 1916 \\
\hline 1898 & - & . & - & $721\}$ & 732 & 1832 \\
\hline 1899 & - & 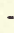 & - & 721 & & 1782 \\
\hline 1900 & - & - & - & $788 \mathrm{~J}$ & & 1679 \\
\hline 1901 & - & $=$ & $=$ & 688 & & 2453 \\
\hline 1902 & - & - & - & 648 & & 2459 \\
\hline 1903 & - & . & - & $648\}$ & 616 & 2466 \\
\hline 1904 & - & . & - & 525 & & 2449 \\
\hline 1905 & - & . & - & 575 & & 2399 \\
\hline
\end{tabular}


With the conditions which we hope are to be brought about in the future, a more substantial rise should soon show itself, for while the arrangement referred to above obtained, the sweep netting below the cruives was still in full swing. It was, I believe, the steady continuance of this netting which determined the late Mr. Stirling to discontinue his agreement. The netting was let to an energetic tacksman who very naturally did not wish to let more fish past him than he could help. The removal of the nets and the opening of the cruives, if these come about, may, therefore, be hailed as the very best step which could have been taken in the general interests of the Conon fisheries.

A rough estimate of the product of the Cromarty and Culloden fishings, which are both situated at the mouth of the river, below the Seaforth fishings, shows that the average annual take amounts to between three and four thousand fish. A further estimate, which was published in the Reports of the Fishery Board for Scotland, showing the total product of the netting and cruives of the whole district as compared with the estimated total product of rods in Conon and the Alness (which enters the same estuary) for four consecutive years is :

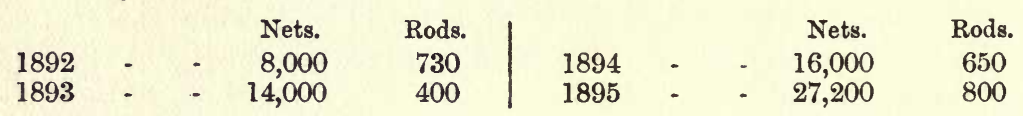

If only one or two shots near the mouth of the river were netted, I should think it probable that several thousand fish would be annually added to the breeding stock. While this great benefit would also follow, that the weekly close time would in future be really operative; that fish passing through the lower netted area, and being checked by the cruive dyke when the river is moderately low, would no longer fall a prey to the nets on the Monday morning, but would be allowed to remain till able to continue their ascent.

The increase to the future stock through the additional number of breeders will follow in time, but not for some time. Such increase is in all cases slow; for when the hatched fry have grown in two years to be smolts, and when they go down to the sea, the mortality in the sea is great; the grilse of the following year are only a proportion of the fish which so far have escaped the perils of the deep; the spring fish of the year succeeding represent an additional proportion of those smolts, but others visit fresh water, and become breeders only at still later periods. 


\section{RIVER CONON.}

From the falls already referred to, the main river has a course of about twelve miles to the head of the Cromarty Firth near Dingwall. This course may be said to be across a plain interrupted at one or two points by remnants of the old higher formation which have resisted erosion to a greater extent than the surrounding flat valley. At Comrie there is a constriction, and just above Newton the rocks which form the Achilty Hill also make their mark in the river bed in the shape of the Muirton Rapids. The river then bends in a northerly direction with an even flow to the point where the Blackwater enters. A large pool results, and the course becomes easterly in a straight run to Moy Bridge.

The Conon Fall and the fishings on the left bank down to Moy Bridge belong to Coul, and the average number of fish taken is about 50 , with a maximum of about 100 . On the right bank, the short stretch between the fall and the mouth of the Meig-about a mile of water-goes with Little Scatwell. From the mouth of the Meig on this bank the right of fishing goes with Scatwell Estate for a distance of about five miles, when Fairburn comes in and continues right down to the mouth of the Orrin. The estate also includes the Orrin, where Fairburn Tower stands, as will be mentioned later.

At Moy Bridge the river flows evenly over a clean gravel bed, and presently divides round a considerable island. The mouth of the Orrin is two miles below the bridge, and from the bridge to the cruives has in the past always been considered the best spring angling. Seaforth's fishings commence at the bridge, and continue on the left bank to the mouth of the river, and on the right bank from the mouth of the Orrin downwards. In the future the fly rather than the net will ply, I hope, on the water below the cruives, and I have no doubt this stretch will also yield its proportion of "springers."

Seaforth's Brahan Castle fishings have in the past been commonly let from the opening till the end of April. I am able to give a few recent spring results :

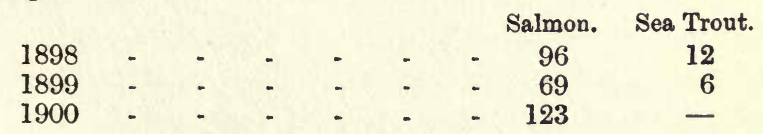

In the last-mentioned year 56 fish were taken by two rods during the first ten days. In 1899 the tenant did not commence at the beginning of the season. 
From a note in The Fishing Gazette at the end of season 1907 it appears that in that year the chief Conon fishings yielded a total of 212 salmon and grilse. The spring fish of the Conon are of the small class, 8-10 lbs., and are shapely and, in my opinion, of uncommon good flavour.

The cruive dykes are situated where an island of perhaps 60 acres or so divides the river into a right and left channel. This island is situated opposite Conon House, and about a mile above Conon Bridge on the high road from the Muir of Ord to Dingwall. The left channel is intercepted at its upper end by a dyke built right across to the upper end of the island. The other channel continues with a wide sweep round half the island before the dyke is thrown across in a long $f$-shaped formation. The left or upper cruive dyke has one fishing box; the lower cruive has three boxes. Only the box next the island used to be fished, the others being closed by hecks. The photograph shows this cruive box with its inscales in place in fishing order. It will be readily appreciated how little chance the upper waters have had with this sort of device as the only passage for fish except during the weekly close time.

\section{RIVER MEIG.}

The total length of this river is about 24 miles, or double the length of the Conon, which it joins at Little Scatwell. Two-thirds up from its mouth Loch Beannachan exists at a level of 465 feet, or nearly twice that of Loch Luichart. There is a fall a short distance above the loch, and thereafter the Meig is steep and broken by the various rock terraces which cross it in its descent of 735 feet from source to loch. The description of the river below this loch is admirably given by Mr. Hinxman in his description of this district. ${ }^{1}$

"The Meig issues from Loch Beannachan through a deep accumulation of fluvio-glacial sand and gravel, which to some extent holds up the waters of the loch; the rock is first met with in the bed of the stream a mile below the outlet. Between Inverchorainn and Milltown of Strathconon the river runs N.N.E., and nearly at right angles to its higher course, through a straight cañon-like valley, whose lofty and precipitous eastern wall of shattered and reddened rock forms one of the most striking features in the scenery of Strathconon. This valley has been determined by a powerful line

1 "The Rivers of Scotland: The Beauly and Conon," Scottish Geographical. Magazine, xxiii. No. 4, p. 200. 


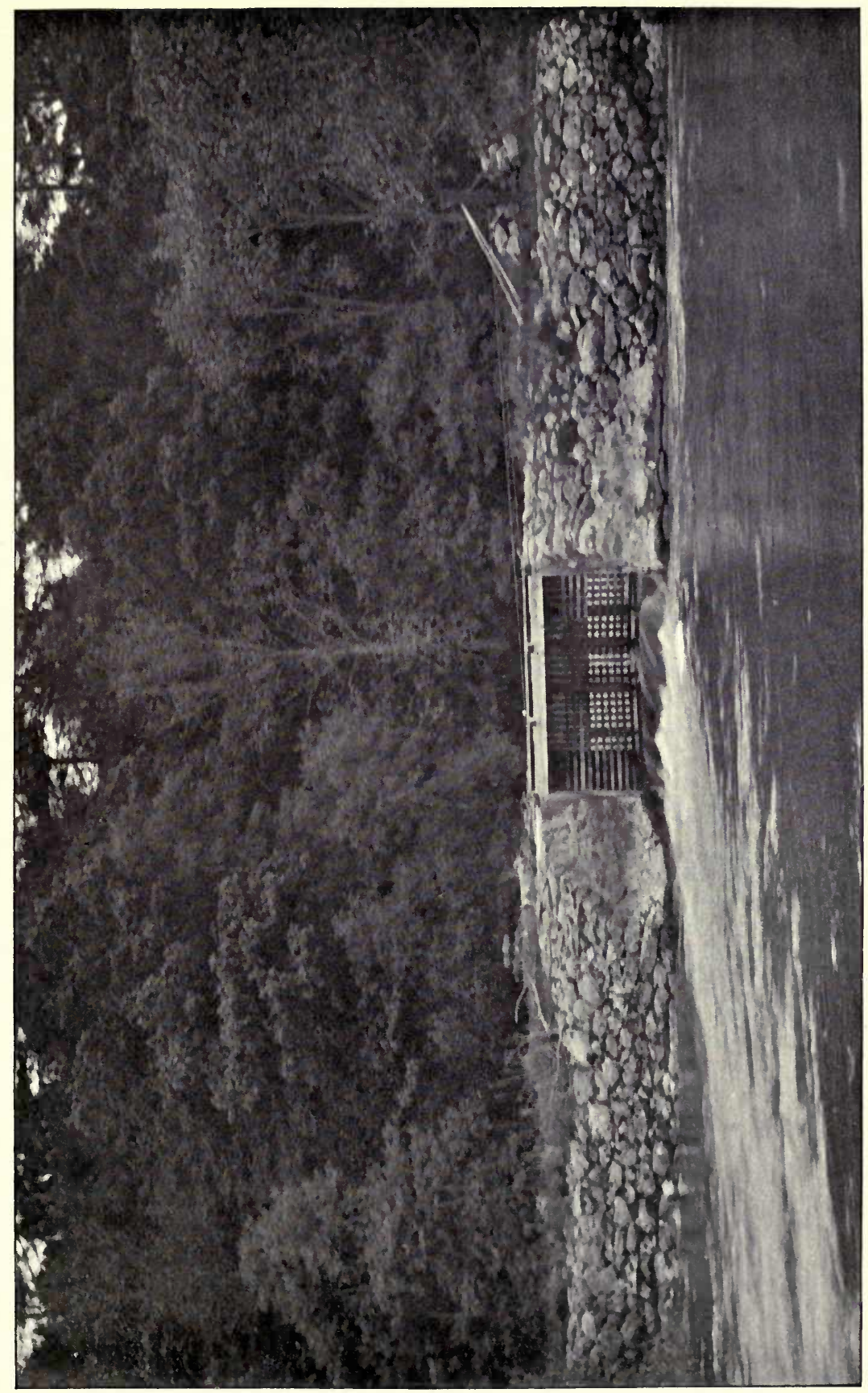

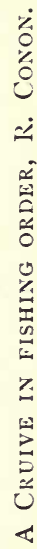



of dislocation, which can be traced for a great distance through the counties of Ross and western Inverness, with a trend parallel to that of the faults which have determined the Great Glen and the upper part of Strath Glass. This Strathconon fault has already been mentioned as crossing the head of Loch Luichart. At Milltown the Meig leaves the fault-valley and resumes its normal easterly course with a fairly even fall through Strathconon. For a distance of half a mile above Little Scatwell the gradient is less matured, and the stream struggles in a deep and narrow gorge through the silicious flagstones of Torr and Bhealaich."

It is unfortunate, since the Meig is the tributary which enters a short distance below the falls, that it does not contain a greater extent of spawning ground. Fish hang about the Little Scatwell pools, just above the Meig junction, being barred in their further ascent of the main river. On dropping back, these fish naturally ascend the Meig, where much of the water is in rocky chasms not easily fished and of no use for breeding. Where the river assumes a direction east and west, however, some gravelly streams occur, as below Strathconon Woods and at the outlet of Loch Beannachan. Summer is well advanced before fish are to be found in any numbers, however, and late comers are not able to ascend the river very far.

\section{RIVER BLACKWATER.}

This river is, in my opinion, the one which above all others in the district must be looked to as likely to reap marked benefit from a scheme for the improvement of the stock of fish. It rises in three head streams, the furthest east from Glen Rannoch and the two others converging from the sides of the Strath Vaich deer forest. The chief line of waterflow is the Glascarnoch river, which springs from high streams and hill loch on the western side of the forest, and presently accompanies the road from Loch Broom, from Ford to Alguish Inn and on to the mouth of Strath Vaich and the mouth of Strath Rannoch, and so southwards to Garve. The road and river are in company for about 20 miles out of the total of 24 , for the former skirts Loch Garve, and, crossing the railway, passes down the defile, where the Falls of Rogie are situated, and right on to the junction with the Conon below Contin.

It is only after the junction of the three head streams that the river is called the Blackwater, and if the title represents the natural character of the channel and the presence of deep pools where the 
water looks black, it is barely applicable till the outlet of Loch Garve is reached and the overhanging woods entered.

Ford is 760 feet above sea-level, the mouth of Strath Vaich about 690, Strath Rannoch 559, and before the woods of Little Garve are entered the elevation is barely 350 .

Loch Garve, the remnant of a once much larger lake, is 218 feet above sea-level, is fully $1 \frac{1}{2}$ miles in length, with a maximum breadth of half a mile. The loch drains an area of 114 square miles, and is a simple basin with a maximum depth of 105 feet. Through the defile where the Falls of Rogie delight so many visitors, a run down of more than a hundred feet is soon accomplished.

One is loth to suggest the spoiling or reducing of such beautiful falls as those of Rogie in order that salmon and salmon fishers may be benefited, but the upper waters of the Blackwater, as may be seen by any one who drives along the road already referred to, are of a splendid character in many parts and deserve more fish. The falls at the present time are only a partial barrier to ascending fish. They are considerably cleft in part, but the leap, though not too high, is rendered very difficult by a cross force of descending water. As a matter of fact a considerable number of fish do get up. To increase the facilities for ascent would not be very difficult, and would be of immense benefit to the whole district, for the total water-way above the falls, including the three head streams, is about 30 miles, and there is much fine spawning ground. The fear of injuring the angling below the falls need not be seriously entertained. Fish which lie below a fall are never good risers, and are much more usefully employed ascending the waters above.

The chief angling in the Blackwater is, of course, below the falls, the right of fishing belonging to the Coul Estate, and the extent of water about four miles. Some of this water will, I anticipate, form excellent spring fishing if the alterations as to netting proposed for the lower Conon and already referred to are carried out. In the past, four days a week have been commonly let to a neighbouring proprietor.

In the early nineties over a hundred fish have been taken here, but in recent years the bag has apparently been very seriously reduced.

\section{RIVER ORRIN.}

This river is the last of the contributary waters to the Conon. It enters the main river lower down than the others, and comes from the south-west. It is, in total length, some 23 miles, but 
barely three and a half are open to salmon. Like the Meig, it rises away in the Strathconon deer forest, and has a long course down a high valley. Just before reaching Fairburn it emerges from the mountain region, and immediately below Fairburn it tumbles over the curious Orrin Falls, and so across the flat plain to the Conon. The rocks of the fall are conglomerate like the rocks of the Beauly at Kilmorack. The drop is in part perpendicular, and about 15 feet is the total height. It would not be difficult to let fish up to the long stretches of the upper Orrin. The increase of breeding ground would be very great, and the benefit to the general stock would in time be felt in proportion. The sole right of fishing goes with Fairburn Estate, and I understand that the reason why nothing has ever been done to let fish up the falls is because the Fall Pool is netted. I recollect being informed some years ago that about 1200 fish had been netted here by the end of May. It has been argued before now that it is no one's business but the proprietor's whether the fish are netted or allowed up the fall and kept for rod fishing. In a sense no doubt this is perfectly true, but there is also, surely, the general interest of the district to consider also, and I would not venture to suggest that the upper proprietors of the Conon district failed in this respect. It seems to me that what is wanted most of all is a beginning in the way of less netting at the mouth, and the opening up of the cruives, when it will immediately be a sound policy for upper proprietors to deal with all natural obstructions in the semicircle of rivers which go to form the Conon, viz. the Orrin, Meig, the central and main falls of the Conon itself, and also the Falls of Rogie on the Blackwater.

I have already quoted Dr. Almond's saying, "If you want more fish you must fish less," but in the Conon, when you fish less and get more fish, you want to give a much wider extent of spawning ground over which to distribute the fish. Is this a condition beyond hoping for?

In the Orrin, the bed of the river beyond the fall is, of course, alluvium, liable to much shifting during floods; but it is taken advantage of by many spawners. The water is rather stony and shallow as a rule to be described as really good rod-fishing water. I confess I have never visited the water above the falls. No salmon are to be found there at present, and one hesitates unnecessarily to penetrate into deer country, but a careful noting of the gradient of Glen Orrin shows that the descent of the stream is comparatively uniform, except perhaps at Cambaan, about the 
centre of the glen, where the descent is more rapid than elsewhere. The eight miles which form the main section of the glen show a fall in level of only 153 feet. I have pointed out that in the case of the Blackwater the descent to the main river from the outlet of Loch Garve, past the Falls of Rogie, is fairly rapid. In the case of the Orrin the descent from the mountain valley tract to the lower ground below the fall is considerably greater, there being a drop of fully 400 feet in 4 miles.

\section{THE ALNESS.}

This little river enters the Cromarty Firth on the north-west, and has, therefore, a common estuary with the larger river Conon. It has also the same close times for rod and net.

The river rises from a number of hill streams in the Kildermorie Forest, which collect from the south of the ridge separating Glencalvie Forest on the north. The resulting stream flows north-east and then south-east, a distance of ten miles, to Loch Morie, a sheet of water about $2 \frac{1}{2}$ miles long and 622 feet above sea-level. From the loch, the stream passes off in an easterly direction, and in about three miles is joined from the north by the Rusdale, which has a course very nearly as long as that of the upper Alness. From the junction at the Inchlum Woods the main river has a course of seven miles to the sea below Alness village. The total length of the river is thus about twenty miles, and as the fall in level in the lower ten miles from Loch Morie is 620 feet, it will be readily understood that the gradient in many parts is rather steep. I understand that the river is considered by some to be the swiftest in Scotland. A considerable part of the course is deeply cut down in a deep glen, and the scenery is often beautiful.

From a salmon fishery point of view the upper river may be discarded, as salmon do not reach Loch Morie. The lower river fishings are divided chiefly between Ardross and Novar, Dalmore and Teaninich. A netting station of some importance exists at the mouth, the nets being drawn on a great gravel beach and on artificially constructed cairns, which give good facilities. Each side of the mouth and the lowest pool of the river are drawn by net and coble. When the grilse make their appearance about the middle of June the netting is brought into full swing, and July is recognised as the best month of the year. The sporting value will probably greatly improve if a project to remove the nets is carried out.

When the season is wet and the river in good running order, 
salmon and sea-trout have an opportunity of ascending freely; but if the summer is dry, the nets are able to take a very heavy toll. Below the railway viaduct, but some little distance up the river, a dam dyke occurs by which water is carried to Dalmore distillery. There is a simple form of fish-pass, and the intake of the lade is guarded against the descent of smolts by a heck of stout woven wire, giving diagonal apertures half an inch across. So far as I know, this is the only smolt heck of the kind in Scotland, and it is interesting to learn locally that it gives no inconvenience if cleaned every day. The water of this lade is not returned to the river, but is carried from the distillery to the sea. On the other side of the river also a distillery exists-Teaninich-and from this also water is carried through a meadow to the sea without return to the river.

By the kindness of the proprietors, I am able to show the presentday catch of the river in the following list:

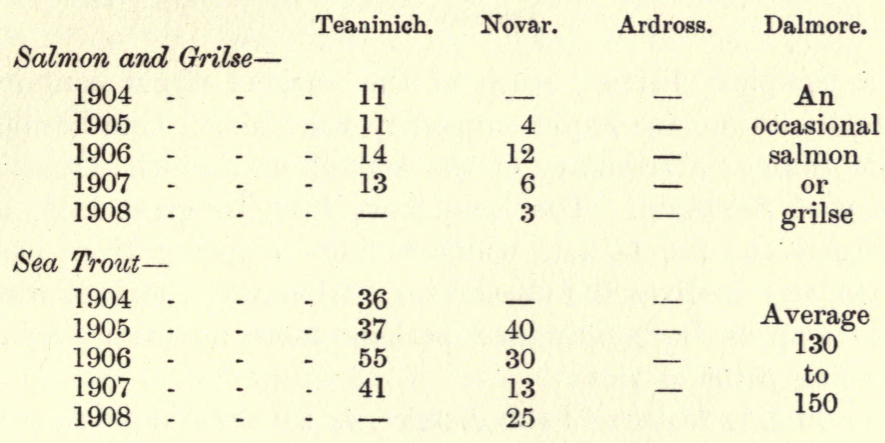




\section{CHAP'TER XVI.}

\section{KYLE OF SUTHERLAND.}

\section{RIVERS CARRON, OYKELL, CASSLEY, AND SHIN.}

Angling Season: February 11th to October 15th.

Netring Season: February 11th to August 26th.

District Fishery Board meets at Bonar Bridge. Clerk, John M'Crone, Esq., Solicitor, Dornoch.

THIs is a complex district, since of the various rivers contained within its limits no one is pre-eminently the chief. One hesitates to say the Shin is a tributary of the Oykell, or that the Oykell is a tributary of the Shin. The Shin flows from its great loch, and is a spring river; the Oykell, which is also a spring river, has a long course, and receives the Cassley as a tributary, a stream which is quite as long as Loch Shin, and perhaps more important from a salmon fishing point of view.

The outstanding feature of the district, as its name implies, is the kyle, or narrow channel of tidal water. This forms the natural estuary of all four rivers, and, in its lower or eastern section, forms the Dornoch Firth. From the statutory limits of the estuary the firth winds inland between Tain and Dornoch, past Skibo Castle and the mouth of the little Evelix river, which holds salmon and seatrout in the autumn, and is now converted by Mr. Carnegie into a loch at its mouth, up to Bonar Bridge, a distance of about 16 miles. It is shallow with numerous sand banks. At Bonar Bridge the river Carron enters from the south almost at right angles, and in post-glacial times has brought down such an enormous amount of detritus that the firth has been practically cut in two at this point. The narrow channel which alone remains is bridged, is subject to a rapid inflow and outflow of tidal currents, constitutes the most important part of the Kyle, and is the centre of local net fishing. Through this part of the Kyle the waters of the neighbouring Carron 
pass, and also the waters of the other rivers of the district which lie to the westward. It is a sort of bottle-neck to the upper estuary, and the key to the whole district so far as the ascent of salmon to fresh waters is concerned.

From Bonar Bridge the upper estuary continues for four miles westward past the junction of the Shin. The high railway viaduct crosses to Invershin Station, about a mile below the junction. After passing the mouth of the Shin the flat tidal channel still continues away inland for about seven miles to the ford between Oykell Lodge and Posehall; but this stretch is usually considered as the lowest part of the Oykell, although in certain maps the Kyle, as low as Bonar Bridge, is marked as the mouth of the Oykell. The total length of the tidal waters in the Kyle and Firth is, therefore, about 27 miles. The separation between the counties of Sutherland and Ross is the line of the river Oykell and of the Kyle. The Shin and Cassley are, therefore, Sutherland rivers; the Carron is in Rossshire, while the left bank of the Oykell is in the former and the right bank in the latter.

The district has ever been famous for its salmon, and this can be sufficiently understood when the great extent of beautiful spawning ground is realised. With the exception of the river Shin, which is rocky in almost all its short course, the rivers exhibit great stretches of spawning ground, while the numerous smaller feeders, which are of no great moment as angling streams, are of great importance as spawning areas, such streams, for instance, as the burns around Loch Merkland away at the head of Loch Shin, the Einig, which enters the Oykell from the south near Oykell Bridge, and, to a less degree, the Tirry, which enters Loch Shin from the north near Larig. In those lonely hill regions the water is pure from the wells of nature, and man cannot destroy very many fish, either by fair means or foul, for man is a rather scarce creature where there are no villages and the country is either under deer or under sheep.

If one regards the Kyle District broadly one notices that in conformity to the physical features of the glens at East Sutherland and Ross, the river courses, as one follows them downwards, present long flattish stretches of considerable uniformity, followed by abrupt falls. If an ellipse be drawn from a centre not far from Bonar Bridge, touching the falls of Carron in the south and the falls of Shin on the north, it will also touch the falls of Einig, Oykell, and the lower falls of the Cassley. They are all in this rocky outcrop in its 
elliptical line round the Kyle basin. The second abrupt rise is not so uniformly exposed, the erosion of the valleys being uneven, but 10 miles up Glen Cassley one finds a second rise-the upper fallswhile the site of the old Limestone Quarries at Shiness, on Loch Shin, probably indicates the line in that valley. Various shallow belts traverse Loch Shin, seeming to repeat and exemplify the manner of valley erosion in the schistose rocks of this region.

Improvements in netting, increased facilities for marketing salmon, and consequent keen competition, have, however, done for this district what they have done for others. The rivers do not now teem with salmon. This was so far realised by the proprietors of salmon rights, that in 1906 a syndicate was formed for the purpose of acquiring control of the nets, reducing their number, and improving the rod-fishing. For many years the netting had been confined practically to the Kyle at Bonar Bridge, but to improve the catching power at this the key to the whole district, much had been done in the formation of good hauling grounds; even long platforms, with sloping gravel shores, had been created so as to enable nets to be shot and drawn some distance from the actual beach. Above and below the mouth of the Carron, above the bridge, and on a natural bank opposite the mouth of the narrows below, this proved most effective.

The syndicate, following up the efforts of the late Dr. Almond, of Loretto, who for years had striven along the same lines individually, took over all the nets of the Kyle, and, by means of a committee, arranged that no netting be carried on above Bonar Bridge; that netting be not commenced till 1st April; that the Balnagoun and Skibo nets be alone fished in April and May; and that a 60 hours' weekly close time be observed from 6 p.m. on Saturday till 6 a.m. on Tuesday. These operations came into force in the season of 1907 .

It was not expected that a profit would be made, but it was hoped that the results would go far to recoup the outlay in rentals, etc. Unfortunately, the loss on the first season's fishing was heavy. The syndicate was compelled to retreat from the standard upon which they started. In 1908, although the 60 hours' weekly stop was continued, the nets were put on again above the Bridge. Unhappily it was again a poor season.

The arrangement holds good without a break for four years, and, in my opinion, it will be most unfortunate if the syndicate's endeavours to reduce the Kyle netting are abandoned. All opera- 
tions along this line have shown most conclusively that the policy of reducing netting where fish specially congregate before ascending to their spawning grounds, is thoroughly sound. The Kyle is in this district the spot where regulative treatment is most vital, and as far as possible keen fishing should here be avoided. Netting rental may for the present bulk somewhat largely in the argument, but all experience goes to show that, even from a purely remunerative point of view, really good angling pays better, and has the great advantage of leaving an adequate breeding stock of fish. It is, of course, easy for one whose pocket is not affected by the matter to give advice, yet the advice is prompted purely in the general interests of the district as a whole. Let a proportion of every run of fish past the nets, is the golden rule.

The district was also rendered famous in the "thirties" by the investigations of Young, of Invershin, who came to the locality in 1828 , and exercised the netting at the junction of the Shin and Oykell. Young died in 1865, but he was the pioneer of salmon marking in Scotland, and although entirely wrong in many of his conclusions, since he held that smolts went to the sea when a year old, and came back as grilse the same season, he did much by writing on the results of his observations to draw attention to the interest surrounding the migratory habits of the salmon. Especially did he draw the attention of a good fighter in Mackenzie of Dundonnell, who published a book, ${ }^{1}$ which makes good reading if only by reason of its incisive combativeness. Great was the scorn of Dundonnell for the arguments of his opponent. Young's son, now getting up in years, still occupies the farm at Invershin, but, as already explained, no netting is now carried on except at Bonar Bridge, if we exclude the bag-net fishing in the sea outside the estuary.

\section{THE CARRON.}

This river rises in the steep hills which form the deer forests of Freevater and Glencalvie, and has a length of fully 20 miles. It has a fine Highland character, especially in its upper waters, where the scenery is remarkably impressive. There are many rocky sections where the river tumbles over cascades in little gorges and flows in deep long pools, but the greatest extent of the river bed is of a fine open gravelly character, affording beautiful spawning ground. Above Amat Lodge, at a point 11 miles from the mouth

${ }^{1}$ View of the Salmon Fishery of Scotland. Wm. Blackwood \& Son, 1860. 
of the river at Bonar Bridge, a serious fall occurs in a deep rocky defile, surrounded by woods of birch and pine. The chief fishing in the Carron is in the 11 miles below the fall, and the rights are held by Invercarron and Downie, Gledfield, Braelangwell, Amat, and Glencalvie. The greater part of the water is let for salmon angling, and accommodation of a most comfortable sort may be secured at the Ardgay Hotel, beside Bonar Bridge Station. A good road goes up each side of the river. Invercarron water fishes best in February, March, and April. By May and June fish are generally congregated in considerable numbers below the falls.

The Carron is a great river for platforms and casting places perched upon its banks. Wherever the water in any rocky defile is inspected one finds a comfortable path with a wooden platform erected here and there on iron supports, so as to insure a cast in the most likely spot. At other places isolated rocks have gangways out to them, while below the Amat Falls there are hundreds of yards of wooden paths supported from rocky walls, large platforms high above the water, and long flights of steps here and there to get up or down. A great deal has, therefore, been done to make fishing easy in difficult situations.

The water is somewhat peaty, yet fish do not seem to get coloured rapidly. The colour is one to encourage the fly fisher. It looks black in the deep rocky pools, but in the fine streamy waters belonging to Braelangwell some ideal fly pools exist, although the river is never of great size when in fishing order.

Owing no doubt to the very steep nature of the land at the source, the Carron is subject to rapid fluctuations of level. To one fishing the lower reaches a rise of a foot or two may come as an unexplained surprise. Similarly, the water may in a night fall away to nothing. On the one hand it has been raining hard, or on the other has been freezing or otherwise drying up at the sources. This condition in any district can only be brought under control by damming up head waters in an artificial loch. This course has already been suggested for the Carron, and I understand that a very suitable site seems available, subject to the proper examination of the subsoil. Some good grazing ground for deer might possibly have to be sacrificed, and the question touches more than one interest. It is certain, however, that there must be plenty of waste water which could be stored up.

The falls are perhaps the most serious in the whole Kyle district. Fish do ascend them when the water is low, but the ascent is 
difficult and, to all gravid fish, quite impossible. Without taking actual levels I estimate the height of the total obstruction as not less than 21 feet. The rock is tilted at a high angle, the dip being up-stream, and the direction of the bedding an oblique down-stream slant from the left bank. A deep chasm has been washed out along the line of bedding, and is so narrow at its upper end, close to the left bank, that one may jump across it. As the chasm passes obliquely downwards it becomes deeper, and water pours into it at right angles from the ridge above. Yet fish lie in the lower part of the chasm when the water is small. From the chasm to the fall pool is a further descent. This takes the form of a sloping chute, and, if the water is not too high, only requires a short leap from the immensely deep fall pool, followed by a vigorous swim. Once in what I have called the chasm, fish can only ascend further when the river is dead low. Anything approaching a flooded condition will at once wash fish back into the fall pool.

This is not an easy fall to alter for the advantage of the fish. Owing to the lie of the rock and the shallow nature of the river immediately above, a very considerable amount of blasting would be necessary to make the obstruction less serious. To blow out the head of the chasm, and to continue an easy gradient by blasting some distance up-stream, seems the most convenient plan.

\section{THE OYKELL.}

We have already seen that from Bonar Bridge the tidal Kyle extends inland about 11 miles, seven of which are to be regarded as the lowest section of the Oykell. This tidal section seems to form a sort of haven of refuge for fish which, having passed the nets and ascended into fresh water, find themselves, when rivers are low, unable to ascend the various falls which in one river or other have already been referred to. The river watchers inform me that on July evenings great numbers sometimes show themselves below Inveroykell Lodge, which marks the top of tide reach, or the point to which fresh water is dammed back by the action of the tide.

Above this point the Oykell presents for five miles a beautiful succession of long pools with gravel banks. The river winds a good deal, and is never very rapid, but is always inviting. Just before the sharp turn to the north, where at Oykell Bridge the first rocky section begins, the river Einig enters from the south. The lowest section of the Einig is let to Oykell Bridge Hotel, and is often quite worth fishing. The river carves its way through a deep rocky 
defile, with birch-clad slopes much admired by the late William Black, who used to rent the neighbouring Langwell Lodge, and who describes it characteristically in one of his novels. About $3 \frac{1}{2}$ miles up the Einig the inevitable fall occurs. It is a beautiful fall when there is an extra drop of water in the river. The height is about 14 or 15 feet, but a break occurs towards the left bank, causing the greatest flow to keep this side. Breaking against a projecting barrier the water is thrown across towards the centre of the stream. This, when the river is at a fairly low level and when practically no water descends the abrupt section of the fall, is passable to fish. It would not be difficult to greatly increase the ease of this ascent by further lowering the cross current and carrying a cut round the rocks of the left bank, where the fall breaks, to a quiet little rest just above. In July great numbers of fish are to be seen below this fall.

From the junction of the Einig, the Oykell has a distance of nine miles till Loch Ailsh is reached, yet Loch Ailsh is barely 500 feet above sea-level. With Oykell Bridge 125 feet and 90 feet of a rise in the comparatively short rocky section where the river passes over its barrier, the ascent to the loch is seen to be fairly gradual. The main fall, a short distance above Oykell Bridge, is singularly like the upper section of the lower Cassley falls. The height does not exceed 12 feet, and the fall is broken to some extent by the action of the water, so that, although the obstacle is serious, and, of course, completely checks all spring fish, it is negotiable to the active when the water temperature has reached a point which makes salmon inclined to leap at such obstructions.

The water above the fall is of an interesting character, there being a fine succession of streamy pools, and plenty of good gravel for spawning purposes. The Cassley has a very similar character, running as it does in a very similar glen on the other side of Carn na Ceardaich. The Oykell has a course of about five miles above Loch Ailsh, and rises from the high slopes of Ben More, Assynt, and Coniveall. The Cassley flows down from the northern side of the same great hills.

\section{THE CASSLEY.}

This river deserves, in my opinion, a rather higher relative place among the Kyle rivers than it generally seems to get. Its full value to the district is perhaps not yet attained. It enters the tidal section of the Oykell below Rosehall, and it has a grand mouth, but, as already indicated, it has two most serious falls. Ten 
miles of beautiful water occur between those falls, the pools being of most interesting character. The river is as it were the best of the Oykell over again on a slightly smaller scale. Many of the turns and pools in the Cassley remind me much of the Helmsdale below Kildonan or on beat three below.

The spawning ground is particularly good, and I am informed by the river watchers that although there are not as many fish up the Cassley at spawning time as are to be seen up the Oykell, some of the spawning fords, and more especially the Rosal ford, attract more fish than any others in the whole district. As many as 70 pairs of fish have been counted simultaneously making redds in the Rosal ford. If fish had a better chance of distributing themselves over those splendid spawning grounds, the full value of the Cassley to the district, as well as to the immediate owners, would be more nearly realised.

Both falls are most formidable, and, although some modification of the upper fall has already taken place, the greatest benefit to the river is certainly in the proper opening up of the lower falls at Rosehall. As things are at present one is almost surprised that so many fish appear to manage the ascent. Compared, for instance, to the celebrated Falls of Tummel, which are difficult enough for the class of large fish which attempt them, these lower Cassley Falls are much higher, but thanks to the less concentrated body of water and to the fact that a good large pool exists between the two sections of the fall, the smaller and athletic Cassley fish do manage to surmount the obstacles in considerable numbers. Of course, no spring fish do so till quite the end of May or middle of June, and I should say that all gravid fish which run the Cassley at the end of the season are entirely debarred. For the most part the spawning stock of fish are bound to be summer fish. Like other purely hillfed streams, the Cassley is subject to great fluctuations of level, and fish have therefore to be at the foot of the falls at the most suitable level for making the ascent, after the water temperature has reached that point which induces our Scottish salmon to leap; for although Norwegian fish will leap in snow-fed water (and they must do so or forego ascent) our fish will not.

The total height of those lower falls may be estimated as about 30 feet, the upper section being 10-11 feet and more abrupt than the lower section, which is a mass of cascades of varying heights, so that fish have a choice of courses, and do as a matter of fact use the small side channels and cross runs to a considerable extent. 
It is not at all likely that with the best of passes which fish can swim at a gradient of, say, 1 in 20, the upper river will yield early spring fishing. The earliest arrivals would still remain below for some time. But a great number of fish, including the late heavy spawners, which at present cannot make the ascent, would be able to do so. At present about 20 fish are taken on the rod below the falls in May, about another 20 in April, and a less number earlier in the year. Ninety to about one hundred and twenty is the annual yield of the river, but I understand that it is by no means steadily fished.

It would be out of place to indicate in any detail how suitable a pass on each section of this fall might be arranged, but I believe with some attention to this matter the yield of the Cassley could be multiplied by three, and a much larger stock of breeding fish left in the water. The left bank belongs to Rosehall and the right bank to Balnagoun. At the present time Mr. Gilmour, of Rosehall, rents the rights on the Balnagoun side from Sir Charles Ross, so that he or his tenants fish both banks of the whole river.

The upper falls, above Glen Muich, 10 miles from Rosehall, are as high as the lower, and are practically complete obstructions. They also are in two sections, the upper being about $11 \mathrm{ft}$. and the lower about 22-24 ft. They are capable of treatment at considerable cost. The river above is still of some volume, and runs for about six miles from a number of small lochs on the north side of Ben More. This top section is reported to hold large trout.

With reference to the falls of Cassley, here is an interesting account of how fish used to be procured as if by the special provision of Nature: "The way of fishing here is neither by cobles or cruives, but at a line (? linn) or cataract, which is within a quarter of a mile to the sea, the fish cannot pas this lin except in time of speats. When the water is low, it endeavours to leap up, but being at length wearied with leaping, it ordinarly rests in holes and pitts at each side of the catarect or line out of which the fishers take them at pleasure alive with their clipps or large hooks and sometimes with their hands."

\section{THE SHIN.}

This is the shortest river in the district, but the best spring fishing stream below the falls. Thanks to its source from Loch

${ }^{1}$ Geographical Collections relating to Scotland, made by Walter Macfarlane, 1726. Edited by Sir Arthur Mitchell for the Scottish History Society, 1906, vol. i. p. 201. 
Shin, it is less liable to sudden fluctuations of level, and is also, we may safely presume-arguing from analogous cases from which thermometric data are available-of higher temperature during the early months of the year, than the other rivers of the Kyle district.

Loch Shin is 17 miles long, and receives water at its head from Lochs Merkland and Griama. It is never broader than a mile, and lies in a N.W. and S.E. direction. The mean breadth is half a mile, which is a smaller percentage of breadth to length than any other loch in Scotland, except Loch Shiel. It covers an area of $8 \frac{3}{4}$ square miles, and drains an area of 150 square miles. The greatest depth found by the Bathymetrical Survey was $162 \mathrm{ft}$., the mean depth was ascertained to be $51 \mathrm{ft}$. The surface is 270 $\mathrm{ft}$. above sea level, and the rise and fall amounts to about $7 \mathrm{ft}$.

Salmon enter Loch Shin in numbers and spawn away up in the head streams around Loch Merkland, and also in the Tirry, which enters the loch from the north-west, not far from Larig-a rough stony stream-but for salmon fishing purposes Loch Shin is of little use. An occasional fish is taken by sportsmen trolling for large trout (usually termed "ferox"), but Loch Shin cannot be called a salmon-fishing loch. In this respect it is like all other Scottish lochs with obstructed spring rivers flowing out of them. By the time salmon are able to ascend, they are no longer "taking tish " in a loch. The fish, say, of Loch Tay or Loch Ness, run through the river in December and January and later. By the time Shin fish will leap at the fall, they are also doing so, and are moving on to their top waters, the Dochart and Upper Garry respectively. Salmon do not take in Loch Dochart or Loch Garry any more than they do in Loch Shin, or Loch Lochy, or Loch Garve, or Loch Morar. ${ }^{1}$ If the obstruction in the spring river is removed spring fish will travel on, but not otherwise. So long, therefore, as the falls of Shin remain, salmon need not be fished for in the loch.

In a case such as that of the river Shin the complete removal of the falls would, in my opinion, be a doubtful benefit. The river is very short, and from a sporting point of view fish might pass through it rather rapidly. It is not a case of letting fish up to a long mileage of river with good spawning ground. The Shin is only about six miles in length, and two miles of water are below the fall.

From the mouth to below the island where the old cruives used to be, at Inveran the river has an open character, with stony and

\footnotetext{
${ }^{1}$ In this connection the account of early alterations in the Lochy District may be of interest.
} 
gravelly bed and running pools. From Inveran to a short distance above the falls the river is in a rocky channel, in some places narrowing to a most picturesque gorge, fringed with birch. In this the water surges along in black and frothing rapids. The falls themselves are objects of beauty and interest to all who visit the district, although the lower Cassley Falls at Rosehall are in many respects finer. In the case of the Shin the river makes one plunge in a contracted rocky chasm. The height is, however, not great, and the crest of the fall is considerably sloped, so that although the actual difference of level may be 11 or 12 feet, salmon are able to ascend when the water is fairly low by a leap of about five feet into the slope, succeeded by a strong swim upwards. Any June or July evening, if the river is low, fish may be watched making the ascent, and fish generally move about freely in the pool below.

Once clear of the rocky gorge the river shows, for about three miles, a fine series of pools, which deserve more attention from the salmon angler than, I understand, they get. There is a sort of belief that this upper water is only secondary, but in the summer months these fine pools should yield interesting sport, and be pleasanter fishing than some of the black eddying pools of the gorge lower down. The mile of water just below the loch is inferior to the rest; yet in a month in early summer ten or a dozen fish may be taken.

In the spring months, below the falls, the Skibo tenants, during April and May, usually run up a good score of fish, and although some days are blank, as they are everywhere, other days yield as many as 5 or 6 salmon to one rod. The tenants on the Shin don't change much.

Here is the list of rod-caught fish from the year 1873 to $1899 .^{1}$ The nets were removed in 1888 .

\begin{tabular}{|c|c|c|c|c|c|c|c|c|}
\hline Year. & & Fish. & Year. & & Fish. & Year. & & Fish. \\
\hline 1873 & - & 198 & 1882 & - & 315 & 1891 & - & 388 \\
\hline 1874 & - & 156 & 1883 & & 368 & 1892 & - & 373 \\
\hline 1875 & - & 75 & 1884 & - & 301 & 1893 & . & 175 \\
\hline 1876 & - & 108 & 1885 & - & 376 & 1894 & - & 231 \\
\hline 1877 & - & 199 & 1886 & 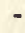 & 298 & 1895 & - & 357 \\
\hline 1878 & - & 98 & 1887 & & 230 & 1896 & - & 371 \\
\hline 1879 & - & 145 & 1888 & 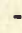 & 135 & 1897 & - & 328 \\
\hline 188 & - & 134 & 1889 & 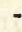 & 93 & 1898 & - & 286 \\
\hline & - & 203 & 1890 & - & 183 & 1899 & - & 222 \\
\hline
\end{tabular}

Some alterations have recently been made in the Shin, which must be referred to briefly. The most noticeable is the contraction

\footnotetext{
1. Report of Commissioners on Salmon Fisheries, 1902. Part iii. Appendix, Section ii. p. 60.
} 
of the mouth by the formation of stone barriers covered with cement. In Young of Invershin's time the then Duke of Sutherland constructed two parallel walls as a prolongation of the Shin into the junction pool. This gave rise to great opposition at the time, some of the Duke's neighbours even going so far as to hint that His Grace's titles were not over clear, and that he was in any case endangering the right bank of the Oykell mouth. Mr. Carnegie acquired the rights of fishing in the Shin from both banks, excepting the top mile or so of the river which still goes with Lairg Lodge. The contracting of the mouth was brought about by building in the inside of the old parallel walls. The mouth was brought down to, I understand, some 16 to 18 feet in order to increase the current and draw fish from the Kyle. The buttresses were, however, not sloped downwards towards the centre of the river, so as to allow high floods to pass over them, and were moreover constructed of stones not grouted in cement, but only skimmed over by it. The work was completed in autumn 1907, and during the winter the structure yielded and was, in its most central part, broken away, so that when I visited it in June 1908 the mouth was about 22 feet or so.

The original walls were, I believe, constructed for the purpose of saving the banks on the Invershin side from the action of a strong eddy caused by the junction of the Oykell Water. A cross current still remained, but instead of reaching the banks as an eddy, the action was to form a bank of gravel opposite the left or down-stream wall. By the contraction of the mouth this cross current seemed to be accentuated. A deep spoon-shaped depression occurred just outside the river mouth, which shallowed at the lip of the spoon (the river between the walls being the handle of the spoon) to a depth of about two feet, and the bulk of the water poured out to the left close to the left wall and at right angles to it. This sideward action is evidently caused by the Oykell coming in from the right, and in my opinion it would best be met by shortening the right-hand wall and removing on this side the contracting barrier. At present the Shin cannot be said to have a good mouth.

In the pools below Inveran converging jetties or croys from both banks have been introduced in order to deepen the pools. In one case the action seems successful, but in the other the faulty workmanship has again yielded to the water, large stones having tumbled out of the structure and water allowed through, so that no alteration in the water-level results.

It is of course extremely difficult to estimate the ultimate action 
of water in a river if the natural course or channel is altered. Other jetties have been erected above Inveran, some for the purpose of influencing the water-level, others apparently merely as convenient stances for casting.

It is perhaps necessary to allow some time to elapse before the influence of these structures can be fairly estimated. 


\title{
CHAPTER XVII.
}

\author{
RIVER BRORA.
}

\author{
Angling Season: February 11th to October 30th. \\ Netring Season : February 11th to August 26th.
}

The whole river belongs to the Duke of Sutherland, and is let with shootings.

Factor, Donald M'Lean, Esq., Sutherland Estates Office, Golspie.

THIs excellent little river flows parallel to, and not far south of, the Helmsdale. It is, however, different in its general formation. In the case of the Brora the junction of upper waters takes place only about eleven miles from the mouth, and in the main channel between this junction and the sea a loch, Loch Brora, occurs. There is, therefore, less good fishing water than in the Helmsdale, although much of the river is of the same fine character.

The Upper Brora rises in the hills which overlook the Tirry, a stony stream falling into Loch Shin, not far from Lairg, but from a salmon fishing point of view the one leading tributary which forms the other branch of the head waters-the Blackwater-is more important than the Brora above the junction. The Blackwater rises from both the north and south sides of Ben Armine at an elevation of close upon 2000 feet. It descends through a fine moorland glen, and affords summer salmon fishing for 8 or 10 miles. Balnacoil and Gordonbush Lodges are the chief centres for fishing. The former is close to the junction. Ben Armine Lodge is situated away at the head waters of the Blackwater, where a certain number of fish are got in summer and autumn. The lodge on the Upper Brora is Sciberscross. From the junction to Loch Brora is fully $2 \frac{1}{2}$ miles. All the lodges belong to the Duke of Sutherland.

Loch Brora is fully $3 \frac{1}{2}$ miles in length, and has a maximum breadth, towards the head, of about half a mile. It is really three diverticula of the river, separated by two narrow channels formed, no doubt, by the side streams pouring their alluvium into the main 
valley from the north. Between Carrol and Kileain the passage is now extremely narrow, and only 7 feet deep, so that the most easterly basin may almost now be considered a separate loch. A large burn, the Alt Smeoral, which enters the most westerly basin is apparently forming by degrees a third constriction in the loch, but the area of deep water is here larger than in the other basins, so that this process takes longer. The Bathymetrical Survey of the loch was made in October, 1902, when the level above the sea was ascertained to be 92.9 feet. The Ordnance Survey of July, 1870, found the elevation to be 91.3 feet. The highest drift-mark found in 1902 was fully 7 feet above the level surveyed, and it was estimated that the variation in level may be 9 feet. The drainage area of the loch is nearly 140 times its extent, which gives a very great capacity for water supply, yet in summer the river commonly runs down to a practically unfishable condition.

The members of the Bathymetrical Survey found the maximum depth to be 66 feet about a mile and a half from the head of the loch. The mean depth was found to be $22 \frac{1}{2}$ feet. The report states: "Loch Brora is extremely irregular in conformation, varying greatly in width, with corresponding undulations of the lake-floor. There are four basins, in which the depth exceeds 30 feet. Proceeding from the foot of the loch, the first, smallest, and shallowest basin has a maximum depth of 31 feet. Passing through the first narrows, where a depth of 7 feet was observed, one enters the second expansion of the loch, which is shallow until Eilean nam Taoileag is passed, the second basin lying to the north of that island, and having a maximum depth of 43 feet. Passing through the second narrows, where a depth of 9 feet was found, one enters the third and deepest basin, enclosing the maximum depth of 66 feet, which was recorded approximately near the centre of the basin. Passing through the third and most northerly narrows, in which depths of 4 and 7 feet were recorded, one enters the fourth and largest basin; this basin is cut into two portions by the slight shoaling of the bottom where the alluvial cone laid down by the Alt Smeoral projects into the loch, the deepest water to the south-east being 59 feet, and to the north-east 64 feet, while on the shoaling the greatest depth observed was 50 feet." 1

The Carrol Rock is a conspicuous and picturesque object on the southern shores, a bold buttress, projecting from the low wooding, but the views on every hand are pleasantly varied, and as the upper

' Royal Geographical Society volume; London, 1908. 
waters are reached, often extremely fine. At Carrol a small hatchery has been in existence since 1878. The loch is netted near the Carrol narrows in the early months of the year, and often contains great numbers of salmon. Why they are not more fished for by rod in the spring of the year I do not know, unless it be that the salmon fishing being closely preserved, the tenants naturally disregard boat work in favour of the river bank. A fair number of sea-trout also enter the loch. The brown trout may be fished for by visitors to Brora Hotel, but they run very small.

Below Loch Brora the lower river has a course of 4 miles to the sea. The mouth is 12 miles south of Helmsdale. The total angling water, discounting the water above the junction, is about 18 miles.

The best section is undoubtedly the lower river. Ascending from the sea the tidal water, which can be seen from the train as it slows across the bridge before stopping at Brora Station, is in a rocky gorge with a comparatively narrow, black-looking pool, down the side of which a rope and snatch block may be seen-facilities for the netsmen.

Rising out of tide-reach over a stony ford the river is followed to the southward in a wide bend upwards, skirting the edge of an old and much larger river channel now covered with peat and heather, and supporting a tile work which, during any visit of mine, has been particularly noticeable both to the eye and the nose. An old cruive used to exist a short distance from the mouth, its presence being still notified by the name of the pool. There are nine pools to the Ford Pool, where a footbridge now crosses, and above this the river passes through about half a mile of fir wood with one other pool (the Otter) before the outlet from the loch is reached.

The lower river is fished by two rods, one from each lodgeBalnacoil and Gordonsbush. The Duke, however, reserves the right to fish this part of the river in April if he wishes to do so, or if guests are at Dunrobin Castle, and motors don't make much of the distance between Dunrobin and Brora. After 10th August the lower river is retained, as attached to the Dunrobin shootings, or perhaps one should more correctly say, attached to Uppat, an outlying appendage to Dunrobin.

On approaching the foot of the loch a curious square timber erection catches the eye, and one is reminded that a former Duke commenced the establishment of an eel fishery, and that this square 
receptacle still survives as the only monument of the abandoned project. Eels still enter both Brora and Helmsdale in great numbers, but are not fished for. The fear of injury to the salmon fishing interests has hitherto been the chief reason, I believe. Our Scottish eels are really quite wasted upon us. We require an Irishman or two to show us what to do.

Salmon enter the river freely in spring, and usually ascend pretty rapidly to the loch. In the loch they are practically lost, although all through the early part of the season it should be possible to catch them there, and after experimenting for some years Mr. F. C. Gunnis succeeded, I believe, in taking a fair number. That they congregate in numbers is well enough shown when a net is put in for a short time each spring. In rod-fishing over the whole district fly is the only lure allowed.

The river above the loch becomes stocked with spring fish in March, and the upward progress is not in any way checked till the fall at the foot of the Blackwater is reached. There are ten pools from the Deadwater Pool, just above the loch to the Fall Pool. The slack water above the loch extends for about three-quarters of a mile, and if the upper river runs low-as not infrequently happens - fish congregate here in great numbers. But for the much more beautiful surroundings the fishing of this stretch is not unlike that so commonly experienced on the lower Thurso, where a good upstream breeze is a blessing, and where under such conditions half-adozen fish may be obtained.

There are two beats on the upper water-one from the loch to the Fall Pool, and the other the Blackwater above the fall. The latter is exclusively a summer beat, for, like the Kildonan Fall on the Helmsdale, fish do not ascend the Blackwater Fall till the winter and spring temperature has left the water early in May. From the time when fish reach the junction till the time when they ascend the fall, the Feddar Pool is certainly one of the best on the river.

The class of fish found in the Brora is exactly the same as in the Helmsdale. The majority of the spring fish are of the small classthe fish which passed their grilse stage in the sea during the previous summer, and are in spring and early summer ascending fresh water for the first time. They run from $8 \mathrm{lb}$. to $10 \mathrm{lb}$. in weight. Amongst these are also a fair number of larger fish of from $15 \mathrm{lb}$. to $20 \mathrm{lb}$. The total varies from 300 to about $450 \mathrm{fish}$, but much depends upon the condition of water-flow. As many as 
400 fish have in the past been taken by the end of April in the lower river alone.

Although Loch Brora acts to a certain extent as a reservoir, I should say the chief drawback of this excellent river is the frequent lack of water. There is no impounding of head waters and consequent regulating of floods as is now possible in the Helmsdale, and with the approach of summer the river is frequently unduly small. It is not at all uncommon now to hear that when the Helmsdale rods are still working away with success, the Brora river is deserted.

The following is the Brora rod-fishing score since 1900 :

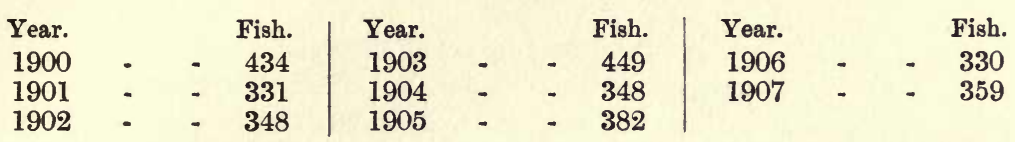

A quaintly interesting reference to the Brora is made by friend Franck ("Philanthropus") 1 when he visited the locality some 250 years ago: "I mention this Broroh, for no other purpose, than to reflect on her plenty of salmon, where they barrel up for France and other parts annually (as reported), so much salmon as amounts to three hundred pounds sterling a year; and the price of a salmon (among themselves) seldom exceeds one single denare. Where note the profits of this contemptible Broroh, are farmed by the inhabitants inhabiting thereabouts, but the propriety belongs to the Earl of Sutherland."

The mouth of the Brora is netted by means of net and coble after 1st May. Two cobles are employed, and a watch tower is erected on the beach at the river mouth, so that a sentry may better notice the approach of salmon from the sea. This netting, while it frequently takes a heavy toll of grilse in summer, allows the valuable spring fish to remain untouched. In this connection it is interesting to observe that both in the Helmsdale and Brora fish are on the spawning beds by the middle of October. Reports go to show that the greatest number of fish spawn in some seasons as early as between 20th and 30th October, and seldom later than 20th November. Compare this with the dates of spawning in rivers where all early fish are netted, and it is seen that the spawning period runs well into January.

I have a complete list of the numbers of fish netted each summer at Brora mouth. It seems unnecessary to burden the reader with these, but I may mention that on several occasions fully 2000 grilse

${ }^{1}$ Richard Franck, Northern Memoirs, new edition, 1821, p. 212. 
have been taken, the poorest grilse year being 1880 , when only 209 grilse and 641 salmon were obtained. The figures, while showing fluctuations for periods of years, do not point to any material reduction in the stock of fish, although naturally when other nets were fished in the immediate neighbourhood, the sweep-nets showed poor returns. 


\title{
CHAPTER XVIII.
}

\section{RIVER HELMSDALE.}

\author{
Angling Season: January 11th to September 30th. \\ Netting Season: February 11th to August 26th.
}

No District Fishery Board. Whole river belongs to the Duke of Sutherland, and is let to tenants of six lodges-Salzcraggie (including Torrish), Kildonan, Suisgill, Borrobol, Badanloch, and Auchintoul.

Factor to His Grace the Duke of Sutherland, Donald M'Lean, Esq., Sutherland Estate Office, Golspie.

There is now no netting in the district.

For ideal conditions of salmon angling with the fly there is no river in Scotland which surpasses the Helmsdale, and very few which may be compared with it. The river has a length of only about 20 miles through Kildonan Strath, and falls into the sea on the east coast of Sutherland, not far from the Caithness boundary. It is a river of beautiful running pools and gravel beaches, of low, open banks and laughing shallows; again, of rock-broken pools skirted with birch and alder; yet again, of silent channels and sandy shores.

Half-way to the sea it pierces a rocky barrier, and forms the Kildonan Falls, which determine the limits of the spring fishing. Those falls are no obstacle to fish in summer, but when the water is cold, salmon will not ascend them. They act, therefore, precisely as do the falls of the Orchy, the falls of Mucomer, or the falls of the Inverness-shire Garry. There are six beats below the Kildonan falls and six beats above. Spring fishing is confined to the beats below, summer fishing is carried on over the whole river.

The altitude from which the Helmsdale rises is not very great. In this it resembles the Thurso and differs from the Brora, the early rivers on either side of it. The Helmsdale is generally described as rising from a series of small lochs about 390 feet above sea-level. It really rises a considerable distance beyond Lochs-nanCuinne, Chlair, and Badanloch. Two head streams flow into the north and south ends respectively of Loch-nan-Cuinne. The Rims- 
dale Burn, on the north, rises by various small feeders from the hills which form the right side of Strath Naver at Dalvina, while the south inflow to Loch-nan-Cuinne, the Halmadarie Burn, rises from a considerable height on the hill called Craig-na-Iolaire, which overlooks the Mallart, an important tributary of the Naver, which enters Strath Naver close to the outflow of Loch Naver.

These feeders to the Badanloch district have, I think, to be regarded as the head waters of the Helmsdale, although on some maps the name Helmsdale is entered against another branch altogether, viz. that which flows out of Loch-an-Ruathair, a sheet of water close to the Highland Railway line, about midway between Kinbrace and Forsinard. Without doubt, however, the main river Helmsdale is formed by the confluence of the streams from Badanloch and Loch-an-Ruathair at Kinbrace, and it is from this point that the river measures 20 miles to the sea.

The Helmsdale has ever been famous as a spring fishing river, and amongst all the smaller yet first-class salmon streams of Scotland it has more than any other maintained that reputation. The angling tenants who hold long leases of the shootings and fishings in the strath have realised to the full the value of conserving the stock of fish. When bag nets were introduced along the coast in the neighbourhood they bought out the tacksman, and they shortly afterwards secured the removal of sweep nets at the mouth of the river. In addition to this they decided to adopt the system of impounding the head waters, so as to secure a better flow of water during dry weather. This, perhaps more than anything else, has made the Helmsdale famous during recent years, and, if imitation be the sincerest flattery, the proprietors and tenants of other districts are now becoming ardent flatterers of the Helmsdale tenants. In 1901 a dam dyke was erected at the Badanloch outlet to raise the water-level six feet, and form a loch of six square miles, and a smaller dyke was also constructed at the Loch-an-Ruathair outlet. At each there are sluices and a fish-pass. The supply of water from Loch-an-Ruathair is made use of in spring if weather conditions require it, and the supply from Badanloch is held up till summer, when in former days the river was apt to run so low as to make fishing hopeless. The Badanloch sluices may not be operated till after 1st June, and the decision as to when the stored water is to be drawn upon rests with the tenants and the estate factor, and must be exercised in the general interests of the river as a whole.

It has often been said that one of the reasons for the decline of 


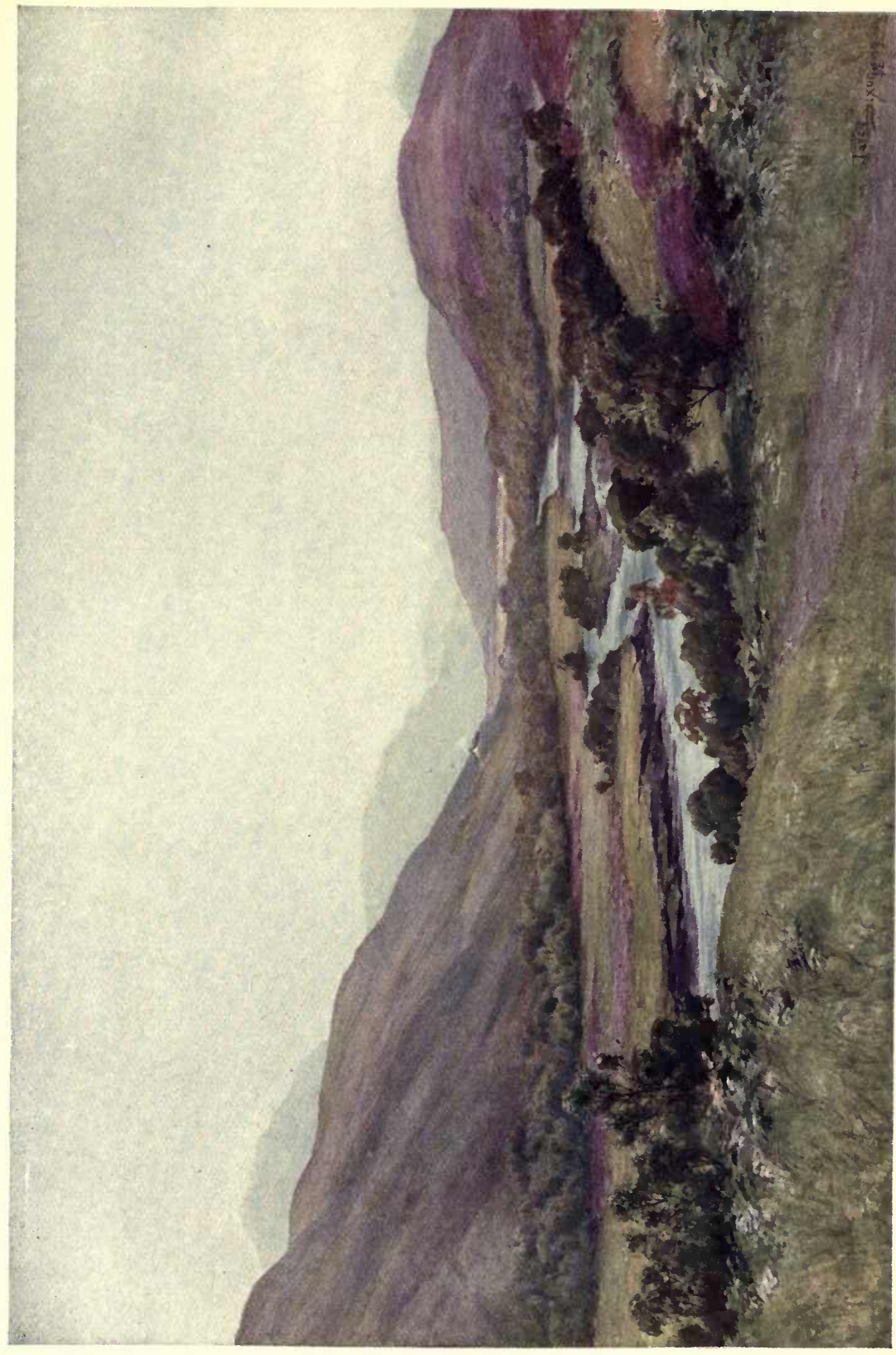

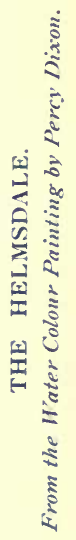



our salmon is the great increase of land drainage. In the Helmsdale, as in other districts, this was felt to have brought about an alteration in the old flow of the river; the rainfall was more quickly carried off, floods came down rapidly, but they lasted a much shorter time, and consequently fish had much shorter periods of good running water. In impounding the head waters, an attempt was made to restore to the river the advantage of the old slow drainage of the hill land. Mr. Frank Sykes, who has the longest acquaintance with the river of any tenant, writes to me as follows on this subject: "The object we had most in view was to have such a reserve of water that we could keep the river at such a height that it would be possible for fish to run up at any time during the summer months. . . We realised that sometimes fish could not run from the sea, nor in some cases from pool to pool for weeks together; and it was to try to secure a share of every run of fish which came on the coast, and to keep the fish that were already in the river healthy that we impounded the water. Of course, the summer fishing has wonderfully improved, and no one is more pleased than I am about it."

The original level of Loch-an-Ruathair was 415 feet, and all through summer it is still at its natural level. The height of Badanloch above the sea was originally 392 feet. The junction of the streams from these lochs, at Kinbrace, is about 330 feet above the sea.

I confess I do not admire the kind of salmon pass erected at either dam dyke, but the type conforms to the requirements of the Salmon Acts, and fortunately in this instance does not require to be very serviceable since, at the close of the fishing season, the sluices are opened, and fish are enabled to reach the high spawning grounds as they formerly did. ${ }^{1}$

Since in dealing with the Helmsdale mention must necessarily be made of the storing of head waters, I must follow the question up by giving such statistics as are available to show the result of these operations. At the same time it must not be lost sight of that the removal of nets is also largely responsible for the benefit. The combination seems to act in this way, that while the cessation of netting allows more fish to enter the river, the action of the artificial floods induces the fish to rise more freely to the fly-the

\footnotetext{
${ }^{1}$ A description of the Badanloch Dam Dyke and Pass, with a plan and section, is given in 23rd Annual Report Fishery Board for Scotland, Part ii. Appendix v. This dyke was subsequently heightened 3 feet.
} 
only lure used or allowed in the Helmsdale or other Sutherland estate rivers.

The Helmsdale tenants do not fish each his own particular water, but the river being divided into beats, and the railway and a road running one on each side of the strath, the various beats are "pooled" and fished by each in rotation, as will be described later.

Since the beats are taken in descending order, any unfair advantage which might arise through a man working up-stream and following a shoal of fish is obviated. For convenience, the tenants of Auchintoul and Badanloch Lodges at the top of the river have erected small lodges in the lower part of the strath to suit the early fishing.

The bag net fishing on the coast began in February, 1896, a lease having been given for a period of fifteen years; but the angling tenants bought them off in Martinmas, 1899, so that this fishing lasted for only four years. Sweep netting at the mouth of the river had previously been carried on for a long period, although since 1876 this netting began only on 1st May, after which year the stock of spring fish in the river very naturally improved. With the advent of bag retting the sweep net fishing at once fell off, and when the bag nets were removed the sweep nets were also taken from the water. The year 1899, therefore, marks the cessation of all netting in this district.

The return on the following page shows the catches by nets and rods, and is of considerable interest.

In the 33 years of net and coble fishing before the bag nets came into use, and including the first year of bag net fishing, there are only two years in which the takes were under 1000, viz. in 1879 and 1880. The average for the 33 years is 2557 fish (salmon and grilse). Immediately after the commencement of bag net fishing the results fall to 820,348 , and 342 .

The four years of bag net fishing show an average of 6092 fish. At the end of this period the nets were bought off by the angling tenants, who found that the supply of fish in the river had most materially decreased.

There are three quinquennial periods of rod returns, the first being only approximate, the second commencing two years after the commencement of the bag netting, and the third ending with 1907 . The first gives an average of 971 , the second, being that following and apparently affected by the bag netting, giving an average of only 620 , and the last rising to the substantial average of 1217 . 


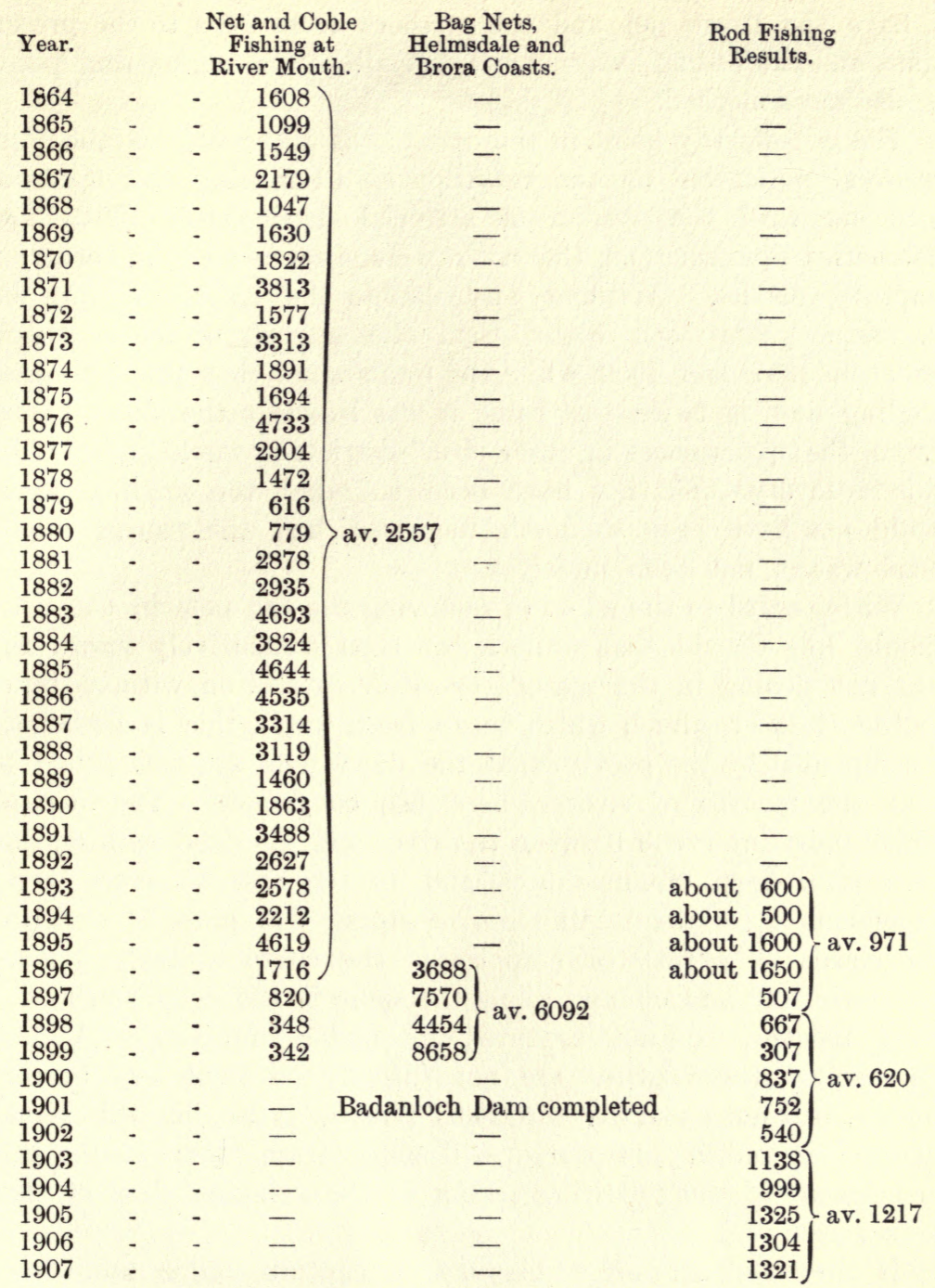

The reduction in the stock of fish in the river in 1899 should be specially noticed. The combined results of both net and coble and rods is only 649 fish, while the bag nets have 8658 . The combination of the two forms of netting is too great for the Helmsdale. No doubt the bag netting result shows more than Helmsdale fish, since the nets were set along the coast to the Brora estuary, and I have been informed that the Kintradwell net-which is nearer the Brora than the Helmsdale-took the greatest number of fish. 
I have the Brora net and coble record from 1864 to the present time, and the falling away at and just after this bag-netting period is also most marked.

The noteworthy point in the case of the Helmsdale is the rapid recovery noticeable on the cessation of all netting and the commencement of the system of artificial floods after 1901. Two hatcheries operating on the river were also erected in order to improve results. Without any doubt, the spring angling has in recent years been better than the angling of whole seasons between 1897 and 1902, while the totals show that the Helmsdale angling now is twice the value it was between the dates named. From the experiences in other river districts it would appear that this recovery could not have been so rapid, the angling results could not have been so much increased, had the storing of the head waters not been undertaken.

With regard to the effect of removing the bag nets in the sea, I should like to add that while it has been conclusively shown that bag net fishing in the sea can be safely carried on without injury to the stock of salmon which enters fresh water, this is necessarily accompanied by the proviso that the fixed nets are not fished too near the mouths of rivers where fish congregate. The distance which must intervene between the river and the fixed nets depends on several local circumstances, and, in the case of rivers largely dependent upon the small class of spring fish, must be such that the shoals of grilse which approach the shore in early summer, and swim off and on and along the shore in the neighbourhood of river mouths, be not captured in undue numbers. A large number of those grilse are not directly on their way to fresh waters, will not naturally enter any river as grilse, but will remain in the sea and, if uncaptured, will enter fresh water at the commencement of the following season as the valuable class of small spring fish.

If the fixed nets are so placed as to capture undue numbers of those grilse-and it is the tacksman's endeavour to capture as many of them as he can-the valuable spring stock of next season is reduced. Even under natural causes grilse may fail, and consequently small springers may fail; under conditions in which unwise netting is superadded there is risk that such failure be turned into bankruptcy.

As I have already said, the Helmsdale was always famous as a spring river; what seems now to have happened as the direct result 


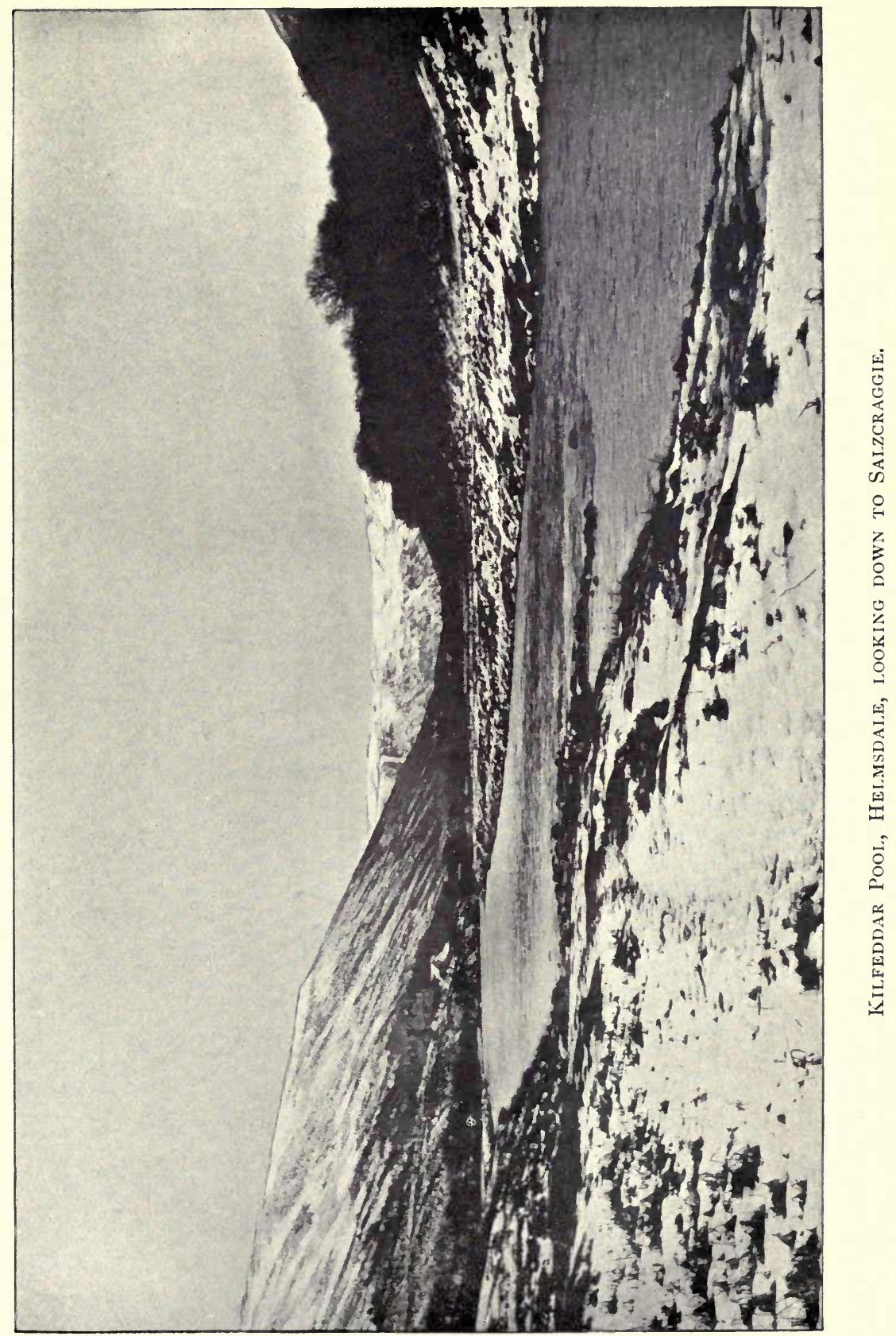



of the tenant's operations just described, is that a most productive summer fishing has also been brought about. Take, for instance, the spring and summer rod results of Borrobol for six years before and after the Badanloch Loch was opened (1901), kindly given me by Mr. Frank Sykes, than whom no one has had longer associations with the river.

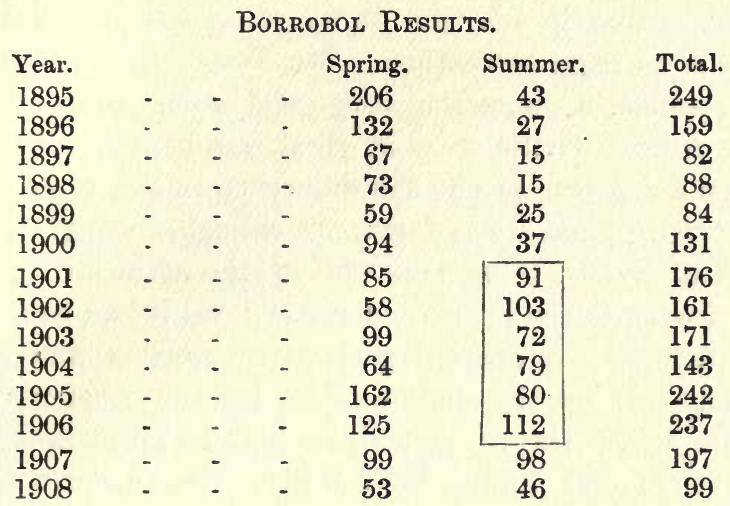

Quinquennial averages of the Borrobol totals since 1878 are as follow : 97, 184, 109, 136, 156, and 183.

Mr. J. B. Taylor, tenant of Salzcraggie and Torrish, and who acts as secretary of the Helmsdale Tenants' Association, has kindly given me the returns showing the takes from 1905 onwards, separated into months and into the upper and lower divisions of the river. These results are for the whole river. They do not correspond quite precisely with the figures already given.

\begin{tabular}{|c|c|c|c|c|c|c|}
\hline \multirow[t]{2}{*}{$1905\left\{\begin{array}{l}\text { Upper, - } \\
\text { Lower, - }\end{array}\right.$} & $\begin{array}{r}\text { April. } \\
6 \\
228\end{array}$ & $\begin{array}{l}\text { May. } \\
112 \\
104\end{array}$ & $\begin{array}{c}\text { June. } \\
117 \\
62\end{array}$ & $\begin{array}{r}\text { July. } \\
43 \\
57\end{array}$ & $\begin{array}{r}\text { Aug. } \\
14 \\
27\end{array}$ & $\begin{array}{l}\text { Sept. } \\
17 \\
15\end{array}$ \\
\hline & 234 & 216 & 179 & 100 & 41 & 32 \\
\hline \multirow[t]{2}{*}{$1906\left\{\begin{array}{l}\text { Upper, } \\
\text { Lower, }\end{array}\right.$} & $\overline{229}$ & $\begin{array}{l}150 \\
162\end{array}$ & $\begin{array}{r}164 \\
43\end{array}$ & $\begin{array}{l}82 \\
59\end{array}$ & $\begin{array}{l}46 \\
76\end{array}$ & $\begin{array}{l}25 \\
19\end{array}$ \\
\hline & 229 & 312 & 207 & 141 & 122 & 44 \\
\hline \multirow[t]{2}{*}{1907\{\}} & $\begin{array}{r}49 \\
177\end{array}$ & $\begin{array}{r}191 \\
84\end{array}$ & $\begin{array}{r}143 \\
50\end{array}$ & $\begin{array}{l}57 \\
53\end{array}$ & $\begin{array}{l}59 \\
43\end{array}$ & \\
\hline & 226 & 275 & 193 & 110 & 102 & \\
\hline \multirow[t]{2}{*}{$1908\left\{\begin{array}{l}\text { Upper, - } \\
\text { Lower, - }\end{array}\right.$} & $\begin{array}{r}8 \\
120\end{array}$ & $\begin{array}{l}54 \\
59\end{array}$ & $\begin{array}{l}69 \\
38\end{array}$ & $\begin{array}{l}39 \\
70\end{array}$ & & \\
\hline & 128 & 113 & 107 & 109 & & \\
\hline
\end{tabular}


It has to be explained in considering these figures that by the month of July the angling is not carried on so steadily as in the earlier part of the season. The tenants very commonly go south for a short time before the shooting season commences, and only a few rods are at work. With regard to 1908 it must be explained that the grilse of 1907 were scarce, and hence the small spring fish of 1908 were scarce, in addition to which it was a notoriously bad fishing season as regards weather. Mr. Taylor informs me, however, that as the season advanced a very good stock of fish were to be seen in the river. Grilse were in great numbers in 1909.

Now let me describe briefly the difference in the river noted when during a very dry June I was fortunate enough, through the kindness of Mr. Frank Sykes, to witness one of the artificial freshenings of the river. Owing to the lowness of water-level it had become difficult for fish to ascend. A few energetic grilse were at times to be seen pushing their way up the shallows, but for the most part fish were getting stale in all the pools, and, as I had experienced, they were all coming short and taking hold badly. On the previous day, for instance, of 8 fish hooked on one of the beats only one was landed. It was agreed therefore to let down some extra water, and one of the two Badanloch sluices was accordingly opened to the full, i.e. $4 \mathrm{ft} .3$ ins.

The rise in the upper waters was immediate and most marked, while at a distance of 7 miles down-stream the rise in the water presently amounted to 5 inches. The sluice was held up for 21 hours, and during this interval the river remained in beautiful running order, and fish were enabled to ascend freely from pool to pool. On visiting Badanloch dam at the expiry of the 21 hours, I found that the level of the loch had fallen only 3 inches, so great was the storage in 6 square miles of water. An ample stock, therefore, remained for subsequent use if the dry spell of weather lasted.

I may now state the limits of the twelve beats as expressed in the Estate "Arrangements," and at the same time mention such particulars as to big days or particular pools as may be of some interest.

\section{LOWER BEATS.}

No. 1. "From the sea to the head of Salzcraggie Pool." There are ten pools, but the tidal pool is not fished by the tenants and is not usually counted. The lowest is therefore the Flat Pool, then the Marrel, a deep pool beside a shelving cliff, and having a large eddy from which fish may be drawn out rapidly. Then the two 
Caen Pools, upper and lower, the Railway Bridge, the Sand Pool or Tumble Down Dyke-a cast which does not seem to yield much-I am informed that owing to the tumbling in of Richard Dawson, after lunch one day, the late Sir John Kerslake christened the pool "Tumble Down Dick." The next pool is probably named after the same Sir John, but it is now called Jone's Pool or Jones. Mr. Sykes suggests that this pronunciation is in all probability simply the result of the Highland manner of pronouncing John. Above this are the Alder, Stall, and Salzcraggie Pools. From the last, 15 fish have been taken in a day.

No. 2. "From Salzcraggie to the tail of Lower Torrish Pool." There are six pools including Kilpheddar, which takes a long time to work over, but often yields good results.

No. 3. "From Lower Torrish to a post to be fixed at the tail of Baddywood Pool." I fear the post has never been fixed as described, but probably the tail of Baddywood Pool is sufficiently distinct. This is a short beat containing three very fine pools. 15 and 12 fish have been taken in a day.

No. 4. "From Baddywood to top of Kilearnan Dyke Pool." This is, perhaps, the least interesting beat in the river, as the seven pools are almost all sluggish. It fishes best in high water or with an upstream breeze. In spring, kelts are apt to be much in evidence, and in cold springs it is apt to get frozen over.

No. 5. "From Kilearnan Dyke Pool to top of Kildonan Dyke Pool." This beat contains the Duible Pool, which in old days was considered quite one of the best on the river. It does not now yield as good results as formerly, owing, it is believed, to the shifting of the gravel banks and flow of the main current. The Short Pool is also an excellent cast. The Boat Pool, is best with an up-stream breeze, and on its particular day has yielded as many as 18 fish.

No. 6. "From Kildonan Dyke Pool to Kildonan Bridge." The pools are The Manse, Little Rock, Big Rock, Flat, Fall, and the two Station Pools. Fish usually congregate in great numbers below the fall as the early season advances, and sport is often very good. I believe 16 fish is the best from the beat, but the average is high, and certainly the best in the whole river. When the weather is cold all through spring, fish do not ascend beyond the fall; but it is evident that very early fish, running in a mild winter, occasionally do so, since in the winter of 1908 , when netting for hatchery purposes above, two clean-run fish were taken. This beat more than once has produced over 800 fish in the season, and this quite recently. 


\section{UPPER BEATS.}

No. 1. "From Kildonan Bridge to Parapet below Suisgill Lodge." There are two parapets at Suisgill, one above and the other below the lodge. In this beat are three pools and several pleasantly broken-up streams where fish may be taken by those who know the water well.

No. 2. "From said Parapet to Foot of Island above Surfaceman's House." The island has before now been described as at old Suisgill ; it is, however, on Borrobol and properly on beat No. 3. There are five pools in this beat, and as many as 12 fish have been taken from it.

No. 3. "From said Island to Kinbrace Railway Rridge." This is a long beat with eleven pools, which in early summer sometimes yield great sport. In 1896 a total of 81 fish were, I understand, taken from this beat in ten days. It is the best upper beat.

No. 4. "From said Bridge to junction of Badanloch Water." This junction is that already referred to as near Kinbrace Railway Station, and which properly forms the river Helmsdale. There are five pools.

No. 5. "From said Junction to Loch-na-Moine." This was the beat the late Mr. Buckley was fishing when he made the wonderful catch referred to later. The top pool Mr. Buckley calls "Still Water Pool"; its usual name is "The Canal." There is really only one other pool in the beat, also rather quiet, called Crockan. These two pools have to be in just the right order to fish really well. Under ordinary conditions most fish are taken not so much from the pools as from a number of little streams and runs which are also included in the beat. The river is now a small one.

No. 6. "To be Loch-na-Moine." This is an expansion of the river in the form of a small loch, a short distance below Badanloch. It is in this respect analagous to Loch Beg on the Thurso, and, like it, is fished from a boat. The short length of river above Loch-naMoine is reserved for the tenant of Badanloch shootings. As I write I have the sad news that the tenant who has occupied this well-known lodge for many years has died.

With regard to the manner in which the various beats may be fished, definite rules are laid down by the estate. I have already explained that the tenants do not confine themselves to their own water, but fish the various beats by rotation. The order in which the beats are taken are from above downwards, and from the time 
the upper beats are fished each tenant has the same number above and below the division at Kildonan Bridge. If No. 1 is fished on the upper section No. 1 is fished by the same tenant on the lower section, and this tenant fishes the two next beats the following day. A list is drawn out at the beginning of the season which sets the order throughout, but after lst August No. 1 upper beat is fished exclusively by the lessee of Kildonan; No. 2 upper beat by the lessee of Suisgill; and No. 3 by the lessee of Borrobol. Torrish has the water below Kildonan Bridge; Kildonan, in addition to No. 1 upper, has the right to fish Loch-na-Moine; while the river above Kinbrace Railway Bridge is fished conjointly by the lessees of Achintoul and Badanloch. Two rods may be fished on each beat, but between 11th January and 15th May the lessee must be one of the rods. Any one fishing during the last month of the season (September) must return all female fish caught. The use of the gaff is not allowed.

It is sometimes said that the charm of salmon fishing is its uncertainty. One never knows when a great day may be experienced, or, on the other hand, when the most unforeseen accidents may happen, or again when fish will behave in the most extraordinary and unpardonable manner. No doubt men who go to fish in the few places on this planet where salmon are still very plentiful and quite unsophisticated, where, in other words, a big score is almost certain to be made at any time, return in a blasé frame of mind, and lose their zest (for a considerable time at least) for angling in the old country. None the less it is remarkable that all of us wish more fish, and cannot be satisfied with the infrequency of really good days. There is perhaps no river in Scotland where good days are more frequent than the Helmsdale. Given reasonable weather conditions in spring, one goes out with a fair feeling of confidence that one won't be unrewarded, that the probability is two, three, or four fish will be got, and with the secret hope that one's particular beat on the particular day in question, being in all probability full of fish, will yield a really great day. One perhaps never really gets that great day; personally I never have got it, but one always knows the possibility is there. One never suffers from the dispiriting feeling that perhaps there are no salmon in the pools one is diligently flogging.

I have several times fished above a new salmon pass or in the upper reaches of a river where, owing to altered conditions, fish may be expected, just to see if any fish could be found. 
Unfortunately at such times I have never found any, and I have repeatedly experienced the deadening influence of the surmise that no fish are in the water. The temptation to stop fishing becomes more and more strong, till at last one's mind is chiefly engaged in determining when the conditions of a fair trial have been complied with so that one may reel up and be done with it. One does not feel this sort of thing when one throws a fly on the Helmsdale. The fish are there, and if you can't get them to show up, it is the fault of the angler, or the weather, or the water, or any of the other more or less imaginary causes with which the fisherman commonly tries to console himself. At times the fish are in great plenty, and more rarely, oh how rarely! many of them come on the rise. Red-letter-days are then scored up.

The greatest angling performance of which I have ever heard was made on No. 5 upper beat of the Helmsdale by the late T. E. Buckley on 9th June, 1896. Buckley always preferred, if possible, to fish with fine tackle and without a ghillie. He was undoubtedly a very fine fisherman, and a man of fine sporting sense. My friend, Mr. Charles Akroyd, at one time well known on the Helmsdale, and a cousin of Buckley's, has often told me of the pains the latter would take to seize a chance of promising sport. On the day in question Buckley had his fly on the water at the early hour of halfpast four, and had five fish out of "Crocken" before breakfast. Adding another after his return, he then shifted to the "Still Water Pool," which is just below Loch-na-Moine. At the tail of this pool he spent the rest of the day, with fish rising keenly all the time. Unhappily his rod-a 12 foot single-handed trout rod-broke, and he had to walk about $4 \frac{1}{2}$ miles to and from the house he was stopping at to secure another and get to work again. The remarkable thing was that in spite of the bold way in which fish were taking, Buckley did not yield to the temptation which would have seized most men to bring a stronger weapon and a ghillie, and so secure a phenomenal score. He returned to the water with a 10 foot trout rod, and continued to use merely trout tackle. By half-past seven he had landed 22, including 2 fifteen-pounders, and had lost only 3. The banks of the river here are abrupt, and the single-handed operation is a matter of great difficulty, a deal of time being necessary to coax fish to the gaff in deep water at the side of the river. With strong tackle the time necessary to land each fish would have been greatly reduced, and many more fish would have been hooked. I have seen one or two accounts of this great day, 
the best being a long letter written most modestly by Mr. Buckley to Mr. Grimble and published in the latter's book on The Salmon Rivers of Scotland. In this the writer says that his reason for using a trout rod was because it "was more handy for bringing the fish near to the gaff," and that when he saw the fish so madly on the rise he recollected that the late Mr. Richard Rutherford, the farmer of Kildonan, had once killed 21 fish, mostly grilse, in a day, so thought he would try to beat this. It would appear that Buckley stopped when he had done so; but the total weight of his catch was $230 \mathrm{lb}$., or an average of nearly $10 \mathrm{lb}$. a piece. With a grilse rod, he says, he might perhaps have had 40 or 50 fish. Yet he preferred to stick to the trout tackle.

Higher scores have at times been made on several rivers, the top score of all being, I think, Mr. Naylor's 54 salmon taken from the first loch of the Grimersta in the Lewis (vide, p. 303), but I think all performances pale before Buckley's 22 fish, averaging nearly $10 \mathrm{lb}$., and including 2 fish of $15 \mathrm{lb}$., landed single-handed on trout tackle. 


\title{
CHAPTER XIX.
}

\author{
THE WICK RIVER.
}

\begin{abstract}
Angling Season: 11th February to 31st October. Netting Season: 11th February to 26th August.
\end{abstract}

THIs little river has perhaps no great reputation as a salmon stream, has indeed been entirely overlooked as a salmon stream before now, but it yields salmon and sea-trout to the rod every year, and is certainly capable of yielding more. It has been described as rising from the Loch of Watten, distant from the town of Wick about four miles; but it cannot be said to rise from this loch, although a small stream issues from the loch-a shallow sheet of water $2 \frac{3}{4}$ miles long with good trouting - to join the Wick. Moreover, the course of the river beyond Watten is quite eight miles.

The river has its origin in the junction of two burns which flow from the south towards the eastern end of Loch Watten, and unite about a mile and a half from the loch. These burns are the Strath and the Acharole, and taking the source of the former as the real origin of the Wick, the river is about 18 miles long. The Strath rises on the northern slopes of the low hills behind Lybster, and flows north and west to Watten.

Loch Watten is only 55 feet above sea-level, and it would not be difficult to enlarge the outlet so as to make a more important connection with the Wick, but the flat nature of the surrounding country makes it somewhat problematical if the level of the loch could be materially raised. A survey of the margins of the loch with the taking of levels could alone determine this. At the same time, with the rainfall which exists, it is certain that a great quantity of surplus water is at times available; and it might be possible so to arrange matters that, with a larger outlet, this could be held up till the Wick is running low.

The river from Watten to the sea is rather sluggish as a whole, 
although several nice pools and streams exist. It winds about in the wide bed of the prehistoric Wick river, and in times of flood it readily overflows its banks. As it approaches the town of Wick the current becomes more and more gentle, and in latter days its waters have here been converted into a boating lagoon by the building of a weir $2 \mathrm{ft} .3 \mathrm{in}$. high and about $170 \mathrm{ft}$. long-the breadth of the river at this point. This weir is a short distance above the Bridge of Wick, and the tide reaches it at high water. No proper pass exists at this weir, but in the near future I hope it may be possible for fish to ascend more easily than they have been able to do in the past.

From this weir downwards through the town of Wick, the river bed, at time of low tide, presents a rather polluted aspect. The town drains into the river here, and the all too familiar habit of throwing miscellaneous refuse into the water is not neglected by the inhabitants. In summer-time when the immense herring fishing industry is at its height, there is a great amount of added pollution. The harbour is also crowded with boats, steam drifters, and cargo steamers. So tightly is the harbour packed at times that the last boat in, must practically be the first boat out, for passing is wellnigh impossible. To watch the outward stream of great brown sails, luffing and filling and tacking about as they clear one another outside the pier-heads, and gradually merge into the blue haze of a summer sea, brings with it a wondrous fascination. At Wick the sailing of the boats goes on for hours, and if one is quite at the pierheads one almost loses the smell, the all-pervading smell, of herring.

The Town Council constructed an additional weir some few years ago, at the inner end of the tidal basin-apart from the harbourfor the purpose of forming a second lagoon in order to store boats which otherwise would block up the harbour. This has now, however, become disused as it interfered with the town's drainage, and itself soon became particularly foul. A new scheme of harbour construction has, therefore, been proceeded with. Harbour construction is a sore subject in Wick. Since 1810, when the first harbour was formed for $£ 14,000$, there have been many disasters and much rebuilding. The British Fisheries Society, which was founded in 1786, has played a prominent part in those Wick transactions. Disasters with great loss of life occurred in 1845 and 1848. In 1862 a large harbour and breakwater was commenced, but year after year great portions were knocked down by the heavy seas which sweep in here from the east. The British Fisheries Society spent about 


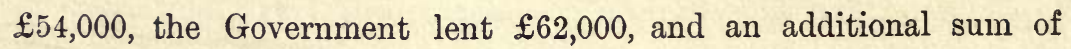
$£ 40,000$ was raised locally. Then a terrific gale in 1872 practically swept the whole structure away. In 1879 the Fisheries Society obtained an Act empowering them to hand over the whole concern to a body of trustees elected in Wick. These trustees have succeeded in persuading the Treasury to deal leniently with their heavy debts, have constructed the present works, and are going to construct the new works. A long pier is to be built on the north side, and the basin of the river mouth is to be dredged, enlarged, and remodelled.

What will become of the salmon and sea-trout is not, as yet, very clear, but I hope it may become less easy for local netsmen to use small mesh nets at the river mouth. An attempt has recently been made to form a District Fishery Board, and this, I hope, may yet be accomplished. Sir Robert Usher is superior of the tishings in the burgh, and the estate of Hempriggs holds salmon rights in the river. In suitable weather a fair number of salmon are taken by shooting tenants in autumn; and if more sea-trout were allowed up, I believe the stream would yield excellent sport at times, just as the Ugie and Ythan do. The conditions are very similar indeed, except for the polluted mouth of the Wick and the great amount of traffic; yet this latter consideration does not seem to affect the runs of fish at Aberdeen. The fact that in the past the interests of the river have been largely neglected, seems to have encouraged a good deal of laxity as to the taking of fish in the upper reaches at the "back end" of the year. There is some good spawning ground, however, and the careful supervision of the district would enable a considerably increased stock of fish to develop in a few years.

A good many fixed nets are fished on the coast, but not in any way to interfere with the proper adjustment of the fisheries. They cannot approach the river mouth. The Wick is the only stream of any size between Thurso and Berriedale, and should naturally offer most serviceable spawning ground to migratory fish on this wide extent of coast. It is not likely that many salmon would enter till summer, but sea-trout should be got rather earlier, and in good numbers. 


\section{CHAPTER XX.}

\section{THURSO.}

Angling Season : January 11 th to October 5th.

Netting Season : February 11 th to August 26th.

District Fishery Board sits in Thurso. Clerk, David Keith-Murray, Esq., Solicitor, Thurso.

THE river Thurso has a great record, but for some years has had to be regarded as distinctly on the down-grade. Now, the lowest ebb has in all probability been passed, and we may look for a brighter future. The river is about 34 miles long, including the not much frequented water above Loch More, and drains an area of 162 square miles. It is the important river of Caithness, but the river fishing is practically confined to the 24 miles of water below Loch More. The source is away at a lonely part of the Sutherlandshire march in the Knockfin Hills, the water is peaty, and the direction of the river is north to the Pentland Firth at the town of Thurso.

Caithness is one of the flattest counties in Scotland, and although many parts of the river have a fine running character, there is a tendency throughout the whole course to ease up in long flat stretches, some of which are deepened by imperfect or partial dykes, where, for good angling, an up-stream breeze is desirable, and where in summer weather the frothy scum common in peaty water is most noticeable.

The average fall from Loch More to the mouth is only about 13 feet a mile, but with the conditions which usually obtain in spring and late winter, early angling is often most productive, and quite exceptional takes have in the past been made. There is no obstruction in the river, unless the rocks at Westerdale Bridge be so considered.

The stock of salmon must at one time have been such as we never see nowadays. There is a record catch for one haul of the 
net which has more than once been already given, ${ }^{1}$ but which will bear repeating; no account of the Thurso would be complete without it. This catch was vouched for in the written statement of three eye-witnesses on 23rd August 1792, and runs as follows: "Mr. George Paterson, now Bailie of Thurso; George Swanson, shoemaker there; and Duncan Finlayson, senior fisher there, do hereby certify and declare that upon the 23rd day of .July, old style, we think in the year 1743 or 1744, there were caught at one haul in the Cruive Pool, upon the water above the town of Thurso, 2560 salmon. These fish were caught by a large net beginning the sweep at the Cruive, and coming down the stream to a stone at the lower end of the pool. The net was carried down the water by eighteen or twenty men with long poles in their hands keeping down the ground rope, and the fish were afterwards taken ashore by dozens in a smaller net. Each man got a fish and some whisky for his trouble. We further personally certify and declare that we were personally present when these fish were caught.-Signed: George Paterson, George Swanson, Duncan D. F. Finlayson." This miraculous draught of fishes, occurring as it did in summer, was in all probability owing to the presence of the cruive dyke-now removed-preventing the natural distribution of tish in the river. Salmon had been able to run in from the sea, but for some time had been unable to surmount the cruive dyke, and so congregated in great numbers below the obstruction. That their presence there in unusual numbers had been noted, and that a special effort was made to secure a great catch, seems suggested by the unusual methods adopted by the large number of extra hands employed. One is inclined to surmise that there were few fish to be found in the upper waters in the autumn after this big catch. But it is surprising how the stock must have kept up, since for many years after this date the river as well as Loch More were netted, and kelts seem to have been systematically killed. In our present way of regarding matters we would not give much for the chance of fishing a river so severely handled by nets, cruives, cross-lines, and leisters as the Thurso used to be.

The fame of the river is almost wholly in connection with the early fishing, and for very many years the Thurso was regarded as the earliest river in Scotland, as well, perhaps, it may even be said,

1 Third Annual Report Fishery Board for Scotland, p. 122, and Augustus Grimble, Salmon Rivers of Scotland, i. p. 239. Reference to this take is made in Sir John Sinclair's Statistical A ccount of Scotland, vol. xx. p. 522. 
as the best early river. With the decline already mentioned, it has been found that the summer and autumn fishing has become more productive. More fish appear to have entered the river at a later date than formerly, a condition quite in harmony with the dictum that when the stock is unduly reduced the tendency is for the runs of fish to become later, the first effects being noticeable in the reduction of early fish.

The Thurso is now divided into eight beats, number one being next the sea, and there are quite a hundred named pools below Loch More. During the early months of the year angling tenants reside at Braal Castle, near Halkerk, about seven miles up the river. Accommodation is here very ample, and in the spring of 1908 considerable alterations were undertaken in the internal arrangements of the house, which should result in increased facilities of service and in greater comfort. The habit is to fish the river exclusively during the early months-fly alone is allowed-and to fish Loch More during April and May. From 1st April, therefore, for greater proximity to Loch More, the angling quarters are taken up at Strathmore Lodge some miles further up the river, and an equally desirable residence.

Some very notable takes have been secured on favourable days on the Thurso. A single rod has secured 21 fish; on two occasions 19 fish have been taken; and when we come down to 7 and 8 fish in a day-surely enough to satisfy most anglers - the records are fairly numerous and from almost every beat in the river. The heaviest fish, so far as I know, was one taken by Mr. J. R. Walker out of Loch Beg, a short distance below Loch More: it weighed $35 \frac{1}{2} \mathrm{lb}$. When we determine the best combined day, the take is a great one, but we have to go back to 1863 to find it. On 9th May in that year, six rods out made this score:

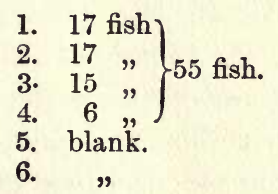

Another day in the same year produced 45 fish. The total number of fish taken in 1863 was 1510 , the record year.

A considerable series of annual records are available from the Thurso, referring chiefly to angling from 11th January to the end of May each year. We may commence with the record year just referred to, and include therefore 45 years to date. In the last five 
years the angling covers a period of 11th January to end of June, and eight rods may be estimated as pretty steadily at work.

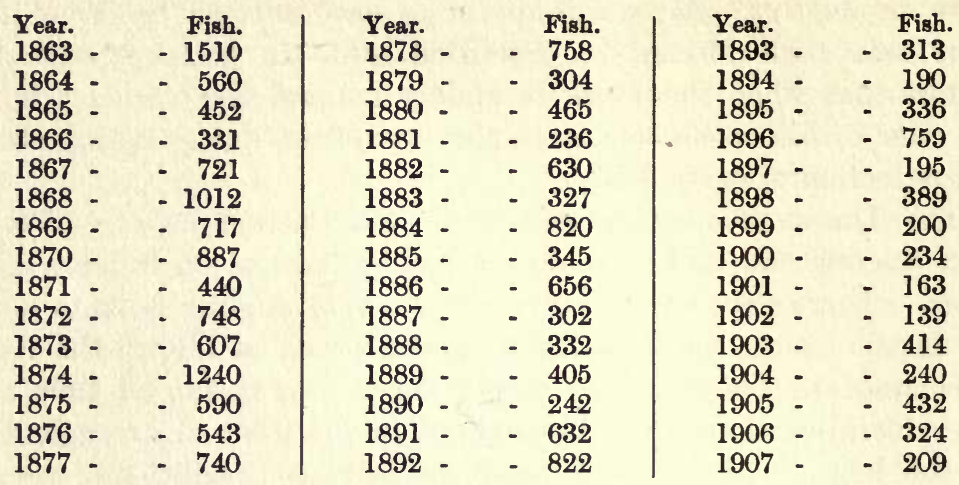

The nine quinquennial averages derived from these 45 years are $714,760,744,438,490,486,357,225$, and 323 . The marked drop comes about the year 1880, after the first three periods have closed, when the change is from 744 to 438 . A slight recovery follows, and then a steady decline sets in till 1902, when the lowest point is reached, and only 139 fish are taken by eight rods in four and a half months-very poor fishing for the famous Thurso. As we shall see presently, however, various operations have been undertaken in order to secure a steady continuance of the improvement, so that the river may once more attain its high reputation.

The right of fishing in the entire river is held by the Ulbster estate. Previous to 1888 the river fishing was tenanted by Mr. Dunbar; but in that year he died and Sir Tollemache Sinclair took over the control. In 1891 he let the spring fishing on a lease of 14 years to a syndicate of six anglers. The syndicate had a right of netting in the river but did not exercise it, and no netting has been carried on since. When the syndicate gave up the river it was taken by Mr. Pople, the tenant of the Grimersta fishings in the Lewis. Mr. Pople, however, gave up the Thurso in 1907, and now Sir Tollemache has again the management.

Nothing has occurred in recent times in the fresh water to injure the river in any serious way, although the sewage of Thurso, including the effluent from a gas work, sheep washings, and the presence of one distillery at Halkirk (which does not appear to do much distilling) may have had some influence.

What then, it may be asked, had been going on in the sea near the river? The coast line of the Thurso district is about 30 miles 
long, and extends from Duncansby Head to Brims Ness. The estuary of the river, i.e. the artificially delimited area in which fixed nets of any description may not be set, is small, being "A portion of a circle 400 yards radius to be drawn from a centre placed midchannel at the time of low water of equinoctial spring tides, and continued to the shore at high-water by tangents, that on the east being to a point 500 yards north-east of Thurso Castle, and that on the west being in the direction of the toll-house." 1

I am unable to determine when bag nets were first set on the Thurso coast, but it was almost certainly long before the period during which rod fishing records are available for comparison. The first stake net set in Scotland, i.e. the net from which fly nets and bag nets were gradually developed, was in 1821 on the coast of Forfarshire, from which point the practice of fixed net fishing spread north and south. But certain old fixed nets were already in use in the Solway, and appear to have arisen independently. A stake net is still fished on the Forfarshire coast.

So far as I can estimate, when the estuary of the Thurso was fixed in 1868 only about a score of nets were on the coast in the neighbourhood. The fact of importance in the present connection is that as facilities for sending fish to market increased, and salmon fisheries became more valuable, the number of nets increased till about the year 1900 when there were 46 , including some nets set in Thurso Bay not far from the river mouth. The netting in the river itself had by this time been long discontinued, but the channel of the river just above the town of Thurso was very shallow, so that in summer, when the grilse naturally seek to ascend, they were often unable to do so and had to fall back and wait about Thurso Bay. This drawback has recently been obviated. It is certain that July was always the best month for the nets in the sea, and that the great proportion of the catch in this month consisted of grilse. The nearest nets, those at Pennyland, were within 500 yards of the river mouth. The Pennyland and Scrabster nets were fished the whole season, while those on the more exposed parts of the coast were not commonly put in the water till May, when the grilse were expected.

A successful spring angling in the Thurso and in all other northern rivers depends on a good grilse run in the previous summer. This at first may seem rather enigmatical, but since the small class of spring fish are chiefly relied upon, and since those

${ }^{1}$ Schedule B, Salmon Fisheries (S sot.) Act, 1868, 
small spring fish are the same class of fish as the previous season's grilse, being the members of that class which did not elect to enter fresh water as grilse, a poor grilse year is commonly followed by a deficiency of the small class of spring fish.

Mr. J. G. Walker, one of the leading members of the syndicate which leased the river in 1891, in giving evidence before Lord Elgin's Commission stated that in a good angling year the average weight of the fish is about $10 \mathrm{lb}$., but in a poor year, numerically, the average weight is much greater, because then the bulk of the fish are more exclusively of the large spring class, older fish. The large records of fish in the past were made from fish averaging about $9 \mathrm{lb}$, which clearly indicates that when the Thurso was at its best the small spring fish were very numerous. In a river of this class an increase in the average weight of fish is not as a rule a blessing.

It would appear, therefore, that to prevent the capture of an undue number of grilse in the sea, is of great moment in maintaining the proper stock of fish in our northern rivers, or in any river dependent, for good spring angling, upon the small class of fish.

From observations made after receiving full particulars of the numbers of fish caught in certain netting stations elsewhere, I am satisfied that the grilse which approach our coasts in shoals in summer, which swim off and on, and along the coast, do not enter the rivers in proportion to their numbers in the sea; that in other words, the great proportion of the grilse caught in bag nets near the mouths of rivers are fish which would not enter the rivers as grilse, but which if not captured would in considerable numbers enter fresh water the following spring as the small class of fish referred to.

With such a small estuary as that prescribed for the Thurso, I do not believe that the proper conditions for maintenance of the stock of grilse can be secured, if netting is carried on close up to the estuary limits. This netting just at the river mouth was not practised in the old prosperous days of the Thurso. It is, therefore, with great satisfaction that one learns that Sir Tollemache Sinclair has recently taken steps which inter alia will secure the preservation of fish approaching within a quite wide area of the river mouth.

He has arranged not only to keep the nets out of Thurso Baythe Scrabster and Pennyland nets-but has also leased the nets further west at Holborn Head. He further now holds a lease of all the Crown Fishings in the district and has just arranged (1908) to have all those nets removed. The unnetted area is now, therefore, 
about 13 miles, being 9 miles west of the river mouth, the important direction as, I believe, and 4 miles east of the river mouth.

Another important step has been taken in erecting at the outlet from Loch More, a dam dyke and fish pass. The dam dyke raises the level of the loch 12 feet, the purpose being to impound such a quantity of water as will enable artificial floods to be let down the river at will. This action has been taken in view of the success of the dam dyke built on the Helmsdale at Badanloch. In future, therefore, when the Thurso runs too low, when fish become a little stale from lying long in one pool, or when fish off the mouth of the river are unable to ascend, a flood will be let down of sufficient volume to create good "running-water," fish will be moved from pool to pool and will be drawn into the river from the sea. The system employed may now be regarded with some degree of confidence after the seven years' experience of the Helmsdale, and the much older but similarly successful experience of " sixty-one," the pioneer of this class of operation in the Lewis. ${ }^{1}$

The dam and fish-pass were designed and constructed by Mr. P. D. Malloch, Perth. The dam dyke is in the form of an obtuse angle, the apex being at the natural river outlet. The arm of the angle which runs to the right bank has a bye-wash overflow for storm water; the arm of the left bank is the longer of the two, and has running alongside of it the gradually ascending fish-pass. The angular design of the dam dyke is apparently in order to allow an easy gradient in the pass. The wall at the angle of the dyke is 17 feet high, and the length of the main overflow is 310 feet. The fishpass is 200 feet long, 12 feet wide at the top, and 25 feet wide at the bottom; it has a gradient of 1 in 20 . To act as breaks to the descending water, rows of stones are erected at intervals and these have since been modified, I understand, by the placing of wooden battens against the stones. To allow of fish entering the loch when the level does not permit of the highest part of the pass being filled, two openings, or passages, through the dam dyke at right angles to the direction of the pass are provided at lower levels. Each opening is 3 feet square, and is sluiced. During one of my visits to this pass, the level of the loch was such that only the spray from loch waves came through the upper of those square openings, while the lower opening had 2 feet of water. In other words the loch was practically half-way down the dam dyke. The 2 feet head of water in the lower opening produced in the pass, in my opinion, a

1 Twenty Years' Reminiscences of the Lews, 1871, p. 97. 
too great amount of white superaerated water. Another point which struck me was the manner in which a head of water 2 feet by 3 feet suddenly thinned out when debouching across the pass at right angles. The Helmsdale dam dyke has no difficulty of this kind, because no attempt is made to allow salmon into Badanloch when the sill of the fish-pass is dry. Sluices come right down to the stream bed, the dyke being only half the height of the Loch More structure.

Time will show to what extent spring fish are disposed to run this pass. In all probability the very early fish of the Thurso may find their way up before the temperature of Loch More has seriously fallen, and this will be so after mild autumns for the most part. When the water has become cold in spring I do not think fish will ascend, but it has never been the habit to fish Loch More at the coldest season.

My first visit to this pass was in the first week of March, 1908, just after the loch had first risen to its new level, and since much snow had recently melted and been washed down from the upper river by a night of very heavy rain, the Thurso was in high flood. I therefore witnessed the first severe test of Mr. Malloch's new dam. Since then the apron of the dyke and pass has been well pitched with stones as far as the road bridge below.

\section{LOCH MORE.}

Previous to the construction of this dam-dyke, Loch More used to be about 170 acres in extent, with an average depth of $6 \mathrm{ft} .10 \mathrm{ins}$., and a maximum depth of about 15 feet. Now, the area is increased to 511 acres. The maximum depth will be 27 feet, and the mean depth has yet to be determined. Instructions have, however, been given for a survey of the loch, to determine as far as possible the depths at all parts, after which eight beats are to be delimited, corresponding to the eight beats of the river.

The habit has been in the past to fish indiscriminately-casting with fly from boats-all over the loch, and salmon rose at any part of the loch. It remains to be seen how equitably the new beats can be adjusted, and whether or not the increased depth of water has affected the rising of the fish.

I have already said that the Loch More fishing only commences with April, but there is no doubt that in most years in the past the loch must have been well stocked before that day, or rather must have been well stocked at quite an early date. Clean fish run in the Thurso in November and December, and even in October, I understand. Those fish must get up into the loch before the 


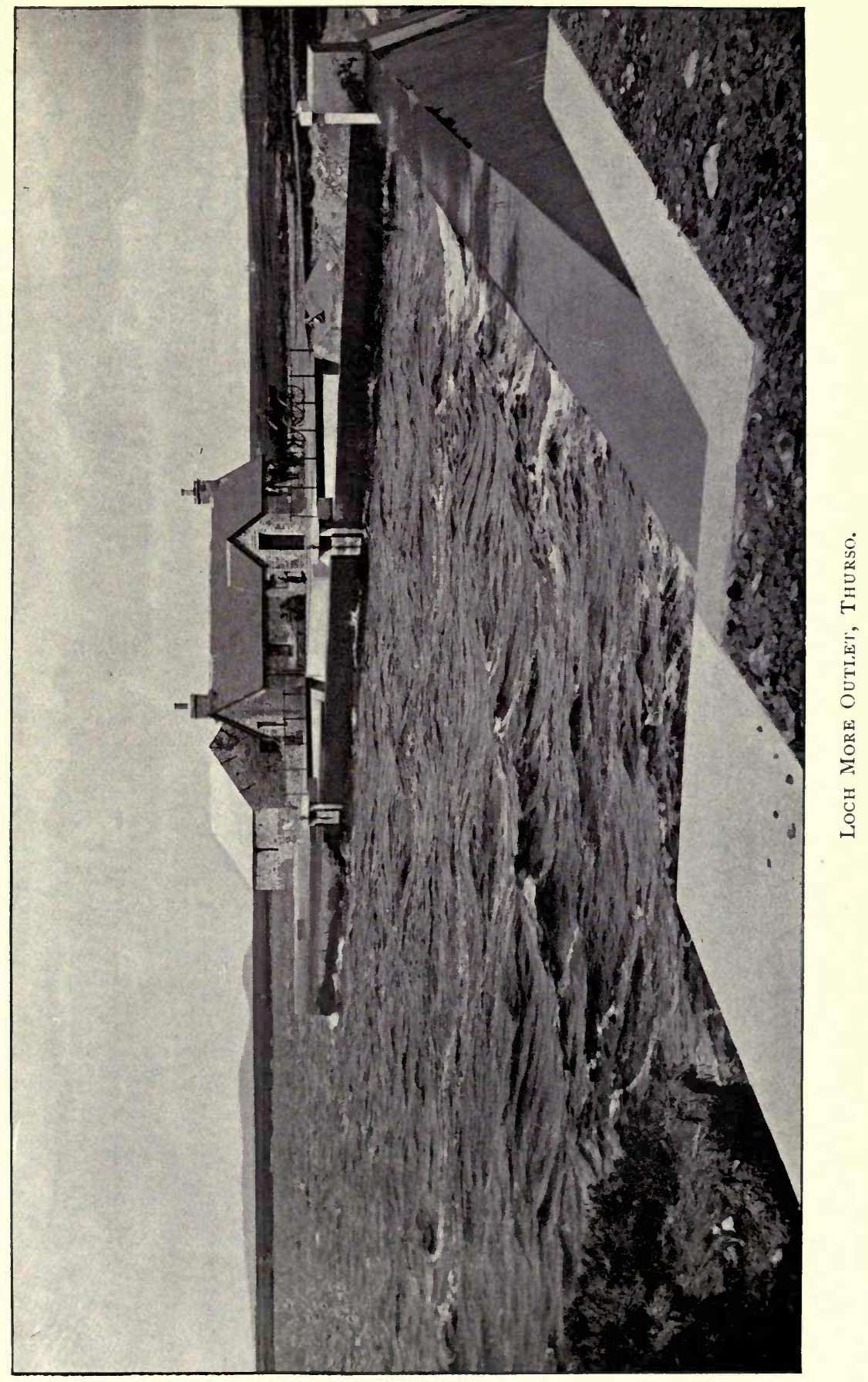



severity of winter lowers the water temperature and checks ascent. The same, I believe, happens on the Naver. In both rivers practically no obstructions occur. The earliest of the fish are reported to average from 15 to $25 \mathrm{lb}$. They have frequently been specially observed because some doubt existed and exists as to their subsequent movements. The late Mr. Dunbar was convinced that those very early tish returned to the sea and reascended before spawning. The obtaining of reliable evidence on this point is difficult, but from the evidence of netsmen who work at the mouths of rivers, and who not infrequently catch coloured fish, apparently descending from fresh water, and from the recapture of a clean fish which was marked in the Beauly on 9th December, 1907, and recaptured, a clean fish, in the Ness at Dochfour on 19th March following (1908), I am inclined to the view that the descent of spring fish and of fish at later seasons-fish which have not spawned-is more common than is usually imagined. The record of this recapture is, so far as I know, the first of its kind. The fish was netted in the Beauly when fish were being collected in the close time to supply ova to Lord Lovat's hatchery. Its weight was then $22 \mathrm{lb}$. When caught in the neighbouring River Ness, 101 days later, the weight was found to be $20 \mathrm{lb}$. This does not look as if any feeding, even in the sea, had gone on in the interval.

The reason why Loch More is not commonly fished till April is not so much, perhaps, that it does not hold fish, or did not hold fish, but that once boat fishing begins in the loch, men are apt not to return to the river and fish it properly. I stoutly contend that men should not prefer to cast from a boat in a loch, but the fact remains that if more fish are to be had by this plan men will forsake the river. To my mind the interest of fishing a river from the bank or by wading is always superior to fishing in the best of lochs. In the syndicate's. time the boat-house was kept rigidly locked till 1st April. That. fish were to be got, however, seems sufficiently clear from a story told me by Sir Herbert Maxwell. A friend of his, being on one occasion tired of fruitlessly flogging the river, which, owing to a. bright, dry January, had run down too low, walked up to Loch More one day early in February. He and his ghillie broke open the boathouse and commenced fishing about 3 o'clock in the afternoon. In an hour and a half he had killed 4 fish weighing from 15 to $21 \mathrm{lb}$. each. ${ }^{1}$

\footnotetext{
${ }^{1}$ A series of Thurso temperatures, taken at Loch More, Dale, Thurso, and in the sea, for the year 1886, will be found in the Journal Scottish Metereological Society. Series iii., No. iv., 1886.
} 


\title{
CHAPTER XXI.
}

THE RIVERS FORSS, HALLADALE, NAVER, AND BORGIE.

\author{
THE FORSS.
}

\begin{abstract}
Angling Season: 11 th February to 31st October.
Netting Season: 11th February to 26th August.
\end{abstract}

ThIs little Caithness river rises from the central loch in a series of three small lochs close to the Sutherland boundary. Like many other small things this little loch has a long name, viz. Loch Torr-naCeardaich. The burn first flows in an easterly direction, and is called the Cnocglass or Torran Water. Bending northwards it passes close to another small loch called Loch Calam, 435 feet above sea-level, which empties into it by a small stream. After several windings the course trends more to the north of the Cnocglass, and ends in Loch Shurrery, 321 feet above the sea, and about a mile long, the property of Mr. Pilkington of Sandside and the Trustees of Forss Estate. It is a trouting loch, although salmon reach it in autumn.

Thereafter the stream is called the Forss, and continues its course due north for some miles. Then winding to the north-east, it receives a stream from Loch Calder, a good trouting loch, which also is reported to contain char. A further course of about three miles brings the little river to the bridge of Forss and Forss House. Here a serious fall occurs, which gives the Norse name to the river, and from the fall to the sea at Crosskirk Bay is only a mile. The total length of the course described is about fifteen miles.

The rocky creek known as Crosskirk Bay, which forms the estuary of the river, is sufficiently narrow at its seaward opening to admit of bag nets being run out from either shore, one attached to the outer end of the other, so that fish can be seriously debarred from entering. It has happened in the past that competing tacksmen fished opposite sides of the bay and had small mercy on the river. 
The Crown hold the rights on the west side, and the Forss Trustees on the east, and difficulties having arisen as to the proper line of demarcation, the matter has now been settled by the erection of iron posts by a competent engineer. Netting is now reduced.

The fall on the river is so serious that late-running fish, if at all heavy with spawn, are not all likely to surmount it. A limited amount of spawning ground exists in the mile of water below, but the excellent extent of spawning ground above could accommodate more fish than manage to reach it. Spring fish enter the river, but are of course found only below the fall. This stretch of water is very sluggish, and fishes best with a stiff breeze. Twenty to thirty fish may be regarded as the average spring catch. I am aware that on two occasions 48 fish have been taken, and when the Crosskirk netting was most keenly carried on, the total ran down to below 20 . I think 18 fish were hooked and only 9 landed, which may have been the fault of the fishermen to some extent. Two rods usually fish the water in March and April. It is let separately from the shooting and autumn angling, and accommodation is commonly obtained in a neighbouring farmhouse. It has been reported that in 1902 two rods, Colonel Philpotts and another (probably Mr. Arkwright, who was shooting tenant of Westfield, for each fished three days a week at that time), killed 160 fish in six weeks' spring fishing. I fear there is something wrong about this. I think a naught has somehow been inserted after the 16 . But at this time, as reported, Colonel Philpotts had 7 fish one day.

Black, who was then keeper, and who is now at Brawl Castle on the Thurso, tells me that the best spring fishing he saw on the Forss was in 1903 when, from the opening to the end of May, 55 salmon were killed.

Fish begin to ascend the fall towards the end of May, but for the most part the grilse, which come rather later, are the fish which succeed in surmounting the obstacle. About 50 to 60 fish are taken in the autumn, above and below, so that the yearly average may be estimated roughly as 100 .

Measuring the height of the fall with the eye, I estimated it as about 25 feet. It is divided roughly into two sections, each of which is composed of many ledges, the rock being bedded horizontally. The fall, therefore, has a tendency to form a series of cascades, and as the ledges become worn or give way, the water receives a certain zig-zag direction. This is taken advantage of by ascending fish, indeed without these zig-zags no fish could possibly accomplish the 
ascent. Fish go up at the extreme right-hand side (looking upwards) of the first section; then turning, they have the shelter of an overhanging ledge as they swim to the left to gain a small pool situated between the two sections of the fall. The upper section has a better break than the lower, so that fish, with one more zig-zag, reach the top. It would not be at all difficult to elongate the zig-zags so as to produce easier gradients. Some building-up would be necessary in the lower section, where the channel would be carried into the present bank of the river. The value of doing so would be very great, as the increase to the stock of fish would be material in a few years. It is a little difficult to understand why something has not been done long ago. The cost would be comparatively trifling. Spring fish would never ascend, if the pass was formed in the present fall as suggested, but summer fish would do so, and late gravid fish would for the first time be of real use to the district.

All along the Pentland Firth coast the bag nets catch more grilse than salmon. I find on examining a series of returns from Forss, covering a period of 20 years, that from four to seven grilse are captured for every salmon. It should be realised that the spring fish of our northern rivers are the fish which did not enter fresh water as grilse, but remained over that period in the sea, and further that the grilse which do enter our rivers spawn. It is, therefore, highly important that they be given every opportunity of doing so. It is, indeed, a misfortune if the particular grilse which succeed in passing the nets and enter fresh water are not able to ascend freely.

A considerable amount of hatching was at one time carried on at Forss, and a special feature was that the fry, instead of being turned out in the main stream or into side streams in the ordinary way, were turned only into streams which had been first cleared of trout, parr, and eels. A section of a burn was run dry by diverting the water temporarily. It was then screened off, and again supplied with water, the result being that the fry occupied a perfectly natural stream free from enemies. Here they were hand-fed, and grew to an unusual size. They were also believed to have migrated seaward considerably sooner than the wild smolts. These operations were carried on by Mr. Nicol, now with Mr. Pilkington at Sandside, where hatching on an extensive scale is carried on, and where some very interesting experiments have been made. 


\section{RIVER HALLADALE.}

Angling Season : 12th January to 30th September.

Netring Season: 11th February to 26th August.

Whole river belongs to the Duke of Sutherland, and is supervised by his factor at Tongue, Mr. J. Morrison.

This river, which is wholly in Sutherland, is almost exactly 20 miles in length. It has been described as forming the boundary between Caithness and Sutherland, but the boundary is some miles to the east, and does not even cut the small tributaries which flow from this side.

It rises south-east of the railway line at Forsinard at an elevation of about 1100 feet, but makes, at first, a rapid descent, so that when it passes below the railway it crosses also the 500 feet contour line. Thereafter the main direction is north to the Pentland Firth at Bighouse Bay, and in its course there are comparatively few windings till within about four miles of the sea. The road from Forsinard to Melvich, opposite Bighouse, follows the course of the river the whole way. There is only one tributary of any importance, the Dyke Water, which enters from the west, close to the remains of a Pictish tower, six miles from Forsinard.

The upper sections of the Halladale have good running character and rocky pools, and plenty of spawning ground. The lower sections are rather sluggish, and generally require a breeze to fish well. At one point, not far from the mouth, the late Duke of Sutherland cut the river into canal form in order to protect certain crofting lands. This is a very dull piece of water, and never yields much.

The river is not very dissimilar to the Naver, but on a smaller scale, and without a head loch, yet it has never had the reputation of the Naver, and has never, perhaps, had a proportional chance, for the netting at Bighouse Bay is pretty hard. Like all the rivers from here west to the Borgie, it enters a beautiful sandy bay. Like the Naver and Thurso, it holds fish quite early in the season in the quiet lower pools, but very few are taken. The impression prevails that the early fish drop back to the sea. This view was always maintained also in the Thurso when that river was netted, for early in the season fish, which were coloured as if they had been in fresh water some time, used to be taken at the mouth of the river. A great drawback to the Halladale is the rapid diminution of the water-flow. No loch communicates with the river; the high ground near the 
source receives considerable rainfall, but the lower river seems to do little to support this, and rapidly gets out of order. A high river is best for the Halladale, and the month of April the most productive time for the lower reaches.

After June, the best fishing is in the rocky pools of the upper reaches. These can be reached without much difficulty from Forsinard, but, if horse conveyance is alone possible, are scarcely worth the trouble and time of 15 miles drive from Melvich or Bighouse.

The river is divided into six beats. The shooting tenants at Bighouse and at Forsinard have the right of fishing, the former by one rod, the latter by two rods. Forsinard Hotel has a rod, and Melvich Hotel a rod, and another rod is generally let by the Sutherland estate. The year 1907 was a very good one on the Halladale, 64 fish being secured, but the average for the last five years is 34 . Fly is alone allowed, a lure which is perhaps not very well suited to the upper pools in summer. No one need grumble when fly is alone used in a river where salmon are likely to respond well to the fly. But in a river where few fish are secured by fly, and where another lure might greatly increase the sporting interest without in any way injuring the stock of fish, even a fly purist is inclined to reflect that men who like to work with gudgeons and minnows would probably do little harm to their brethren and greatly increase their own chances of sport.

\section{THE NAVER AND BORGIE.}

Angling Season : 12th January to 30th September.

Netring Season : 11th February to 26th August.

The river belongs to the Duke of Sutherland and is supervised by his factor, Mr. John Morrison, Tongue.

The Naver, the largest river of North Sutherland, flows from Loch Naver to the Pentland Firth at Torrisdale Bay, a distance of 18 miles. Loch Naver is six miles long, and into the head of this loch flows the Mudale, a small river which is the head water of the Naver. The Mudale has several sources, one from Loch Coire-naSich, a lakelet lying at the foot of the north-east slopes of Ben Hee, and $8 \frac{1}{2}$ miles from Loch Naver at Altnaharra, is perhaps the chief source, as it is the longest course. On the other side of Ben Hee lies Loch Merkland at the head waters of the Shin, so that the mountain forms the most westerly dividing point for the largest 
water-ways flowing east and flowing north. The Amhainn Fhinn, as this head stream is called, is joined by the Amhainn Bheag from Loch-na-Meide, which lies further north, and these, uniting also with smaller streams, form the Mudale. In this way the total length of the Naver and its head waters is fully 32 miles.

The Naver, as it flows from the loch in a shallow and rockstudded continuation, presently passes the site of a dyke which with wooden hecks was built across the river here in 1900 for the purpose of checking the ascent of salmon from the river to the loch. The hecks were removed each weekly close time, I understand, but the structure was wrecked by a flood. In 1902 it was renewed, but in 1903 was again washed away. A short distance below this the river Mallart, the one tributary of any moment, enters on the right bank.

The course of the Naver is at first stony and rough with occasional rock ledges. As the neighbourhood of the loch is left behind, however, the river settles down to a steadier running character, the large boulders and rocks give place to coarse gravel, and this to finer gravel; some miles further down the gravel is mixed with sand, and presently the river is seen to be flowing through great banks of sand, and winding about in the rather flat river bed of the prehistoric Naver, which cut the valley and piled up the sand banks. As the sea is approached near Bettyhill, Torrisdale Bay opens out in a wide sweep of the purest sand, the rocky escarpment which separates the mouth of the Naver from the mouth of the Borgie being as it were stripped of its natural covering of vegetation, its rocks torn asunder and the whole then smothered in sand.

About $4 \frac{3}{4}$ miles down the river from the loch, the old shooting lodge of Dalvina stands on the right-hand side. This at one time was the only lodge on the Naver, and with it went not only a wide extent of country but the fishing in the whole river. Now, the river, like the Helmsdale, is divided into six beats. Dalvina is no longer occupied by a sporting tenant. The modern wish, or need, for more commodious, not to say luxurious, lodges has brought about the change. Opposite Dalvina, Syre Lodge stands, with a new lodge called Langdale Lodge, a short distance further along and higher up the slope, only recently completed. No fishing goes with Langdale, however.

Between Syre and Rhifail Lodge, about four miles lower down on the right bank, the gravel banks and pools are of beautiful character. 
Some of the pools are perhaps a trifle uniform in character, but always fine water for the fly. The gravel from a spawning point of view is ideal. A good deal of the spawning is also carried on above Loch Naver in the Mudale and its head streams. In 1903 the best days at Syre for one rod were 8 fish, 7 fish, 6 fish, and two days with 5 fish. Since that date I believe the yield has not been so good.

It is below Rhifail that the sand begins to make its appearance. Here the banks of the river have in many places been supported or protected by barricades, and the river winds about a good deal in its more level course. Skelpick Lodge, which is also on the right bank and about equidistant between Rhifail and the mouth, has in its vicinity some good boulder-strewn pools, but just below that lodge the character of the pools becomes again most uniform and at the same time somewhat flat and shallow. This part of the river almost reminds one of the lower Thurso, but the surrounding country is much more pleasing to the eye. From 120 to 160 salmon are expected at Skelpick. Before a couple of miles is past, however, the gradient of the river increases slightly, and some beautiful running streams and pools occur before the tidal water is reached. Many parts of Strath Naver are very beautiful owing to the birch and fir with which the lower slopes are clothed. The surrounding hills are not high or bold in outline, but the prospect is ever varied and charming as seen along the course of the river.

The estuary of the Naver is a joint estuary with the Borgie, and includes the sea bay-Torrisdale Bay-into which both rivers flow. "A straight line drawn from Aird-in-iaskich on east to Claishaidhe on west (Burnet and Scott's County Map)." I may say that the names in question are not to be found in ordinary maps, but the widest possible limits of Torrisdale Bay are referred to. Two sweep nets are fished at the mouth of the Naver, and one at the mouth of the Borgie. These nets, however, are not put on till the spring fishing is over, and are not continued in the autumn. The netting period is from 15th May to the end of July.

With regard to bag nets, the Naver may be said to be almost without those engines. It is 34 miles from the eastern limit of the Naver district to Cape Wrath, and only some five bag nets are fished towards the eastern limit. In other words, no fixed nets are set between Cape Wrath and the Naver, the direction along which in all probability the majority of fish travel; while the few fixed nets that do exist are some miles to the eastward. 
The best rod results are generally obtained during March, April, and May. The weather conditions determine the matter a good deal, but under normal conditions the Naver is a very early river, and is pretty well stocked with fish at the opening day in January. Loch Naver is only 247 feet above the sea, and unless a low temperature has prevailed during winter the fish are early into the upper reaches. Mr. C. H. Akroyd informed me on one occasion that when his father was tenant at Dalvina, he himself took 6 clean fish from Loch Naver on the opening day (12th January), although, as a rule, they did not trouble to fish the loch. This seems to indicate that the Naver and the Thurso are very much alike in the matter of early fish. So far as I know, however, the river is not regularly fished nowadays in the early days of the season. In 1907 , for instance, only 3 per cent. seem to have been taken in February, while 20 per cent. of the catch were taken in March. The chances are that a fair stock of fish is present in January, although it does appear that the stock generally is not so good as it used to be.

I am able to give, as nearly as the data can be ascertained, the rod catches for the last six years:

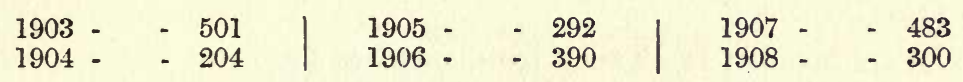

Previous to this I am unable to secure any records except catches for four years given by Mr. Augustus Grimble:

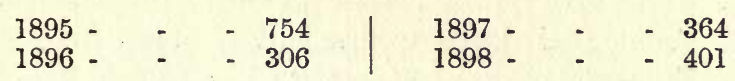

The average for this earlier period is 456 , as compared with the average of 361 for the later period, but with unequal periods this result may be misleading.

There is no obstruction of any kind in the whole course of the Naver, and a descent of 247 feet in 18 miles shows an easy flowing gradient very suitable for spring fishing.

Loch Naver is not much fished by the tenants, although both Syre and Ben Klibreck Lodges have a boat on it, but the keepers, when not otherwise engaged, try the loch. It is a bit difficult to get to in winter, but what would not some men give for the privilege these keepers enjoy when not otherwise engaged. From 1st May the hotel-keeper at Altnaharra, which is at the head of the loch, has right of fishing for his visitors, and about 50 salmon are taken annually. It is reported that a few years ago one rod had 52 fish in 
seven weeks. As in other localities, loch fishing for salmon is not of very much account when spring is over. By that time the fish have been too long in the water to rise freely to the fly. Altnaharra is quite a nice place when you get to it, and when one reads that a daily motor car carries the mails from Lairg, through Altnaharra to Tongue, the journey seems simple. But that long stretch of bleak Sutherlandshire road-about 22 miles of it-is at the present time quite the worst piece of road I have experienced in Scotland, and that is saying a good deal. The last time I was in the district (1908) I alighted at Altnaharra with the certainty that the tyres, the solid tyres, must be in shreds. Only the back tyres were in shreds, and they had been many times over the road. I was amazed when the motor-man said the tyres lasted three months. I felt he was speaking the truth when he said the road, in winter, could not be described in words. Men were at work mending the road, being provided with a caravan to live in because habitations there are none. I feared, however, that if they did not hustle a little more than they appeared to be doing, His Majesty's motor mail would be through the road into the peat shortly. This road to Altnaharra seemed to me the greatest obstacle in the way of getting to the place.

The six beats of the Naver are divided as follows:

No. 1. From foot of Loch Naver to Ceannacoille Burn.

No. 2. From Ceannacoille Burn to low end of Dalvina Pool.

No. 3. From low end of Dalvina Pool to Skail Burn.

No. 4. From Skail Burn to low end of Steep Brae Pool.

No. 5. From Steep Brae Stream to low end of Parapet Pool.

No. 6. From low end of Parapet Pool to Apagill Burn, opposite old cruives.

The beats are fished alternately, in daily succession, from No. 1 downwards, and an order of the beats is drawn out each year so that each rod starts the season one beat lower than on the preceding season. One rod goes to each beat, and fly only is allowed. The use of the gaff is prohibited before 1st April and after 15th August. The sub-letting of a rod is sometimes arranged with the permission of the Duke of Sutherland through his factor, Mr. John Morrison, Tongue. The six rods are apportioned as follows:

The tenant of Syre Lodge has two rods.

The tenant of Rhifail Lodge has two rods up to 31st July, after which he has one rod.

The tenant of Skelpick Lodge has two rods. 
It will be noticed that Beat 6 ends at Apagill Burn. This is 2 miles above the road bridge at Invernaver. This section is reserved for Skelpick Lodge alone.

In the tidal water below the road bridge the public, including visitors staying at Bettyhill Hotel, are allowed the privilege of fishing. In the summer time, I understand, a good many sea-trout may be got here.

The Mallart, the tributary which joins the Naver a short distance below the loch, is a river $6 \frac{1}{2}$ miles in length. It flows out of Loch Car'-an-Thearnay at the foot of Ben Klibreck. It descends about 325 feet in its short course, and is a pretty rough stream. A fall which exists near the mouth was formerly a serious obstacle to the ascent of fish, but in 1900, and again in 1901, blasting operations were carried on, and fish now ascend without great difficulty when the river is at proper height. The Mallart is fished by the tenant of Ben Klibreck Lodge, and this tenant acquires the second Rhifail rod mentioned above from 1st August to the end of the season.

\section{RIVER BORGIE.}

This little river flows out of a chain of three lochs which are situated north of Loch Naver, and about midway between Altnaharra and Tongue. Separated from the Lower Naver by a ridge of rocky land, the Borgie winds in a north-easterly direction, converging towards the Naver, and enters the western extremity of Torrisdale Bay. Between the mouths of the two rivers, as already indicated, there is about a mile of most beautiful sandy beach. The illustration shows Torrisdale Bay as seen from the mouth of the Borgie looking out to the Pentland Firth. The unbroken water on the left is the river water flowing out past the rocky point where, in summer, a net is regularly fished. The New Statistical Account has it that "There is a salmon-fishing upon the water of Borgie where on an average 2000 fish are caught yearly," but that was in 1845 .

There is a considerable tidal lagoon behind the sandy beach of the bay, and, on the western side of this, where a wild little burn enters, the village of Torrisdale is situated. On ascending the course of the stream the channel soon becomes narrow and rocky, and some distance above the first bend a rather serious fall occurs. It is not an insuperable barrier to fish, but is quite sufficient to prevent ascent so long as the river water remains cold in spring. Except in unusually mild seasons fish need hardly be expected above the fall till May. Below the fall, however, are several fair-sized pools, where with 
a grilse rod, provided there is sufficient water-flow, good spring fishing may be secured in February and March. The right of fishing goes with the Borgie shootings, but I understand a sub-let is at times arranged. Unfortunately, if the water runs low through dry weather and frost, the chances are not very good, for as a whole the Borgie does not offer good holding for fish, and much of the channel is boulder-strewn and rather shallow.

A fair run of grilse generally occurs, and these lively fellows make little of the fall when the river is in good running order. The lower reaches also yield a good number of sea-trout. The salmon are of similar weight to the Naver spring fish, 8-10 lb., and from 50 to 60 salmon and grilse are expected in the whole season.

The lochs from which the river flows are Loch Loyal, about $4 \frac{1}{2}$ miles long, lying at the foot of Ben Loyal or Laoghal, an isolated and well-marked hill, past which the main road from Altnaharra to Tongue passes, and Loch Craggie or Creagach, and Loch Slaim, commonly called Slam. In Sutherland, owing to the long period in which Englishmen have been sporting tenants, the corruption of Gaelic place-names is, I think, more marked than anywhere else in the Highlands. One hardly ever comes across a Scotsman who is a tenant in Sutherland. Lochs Craggie and Slam are diminishing continuations of Loch Loyal, and no doubt were at one time part of it, before the erosion was so far advanced as it is now. The lochs stand at the same level (369 feet) and are connected by narrow channels. A few salmon are got in the two lower lochs, but very seldom, indeed, is a salmon caught in Loch Loyal, although great numbers pass through it to ascend in autumn the Loch Cuil-na-Sith stream (corrupted into Coulside) which forms the head waters. If this stream from its chief source, the three lochs and the Borgie be taken together, the total water-way is 20 miles.

Loch Slam is preserved along with the Borgie, but before the 1st of August it may be fished by visitors at Tongue Hotel. Loch Craggie may be fished the whole season in this way. There are three boats on it, and the brown trout run heavy. Loch Loyal is also fished from Tongue, and at the same time visitors at Altnaharra Hotel can fish it, and it is rather nearer the latter than the former. A few years ago the Duke of Sutherland sold the land which stretches from the east side of Loch Loyal and Loch Craggie (but not including Loch Slam) towards the River Naver. This track touches the Naver from Langdale Burn down to the Carnachy Burn about a mile below Rhifail, but on the west bank. 


\title{
CHAPTER XXII.
}

\section{THE RIVERS HOPE, DIONARD, KINLOCH, AND POLLA.}

\author{
Angling Season: Hope, 12th January to 10th September. \\ " $\quad$ Dionard, 11th February to 31st October. \\ Netting Season: Hope and Dionard, 11th February to 26th August.
}

The rivers Polla and Dionard or Grudie are the property of Mr. W. Ewing Gilmour of Rosehall. The river Hope separates the properties of Mr. Gilmour and the Duke of Sutherland.

RIVER HOPE.

While the Naver and Borgie have lochs from which they flow at a considerable distance from the sea, the Hope suffers from having its loch quite close to the sea. Loch Hope, a sheet of water 6 miles long-and a very beautiful sheet of water, too-is, at its northern end, within a mile and a half of the sea at the entrance to Loch Eireboll. This mile and a half of water is the river Hope. The loch is only 12 feet above sea-level, so that, as in the case of Loch Maree in Ross-shire, if the great erosion of the land, which occurred at the end, say, of the glacial period, had been carried a little further, Loch Hope would have been a sea loch, and the valley of the river a kyle.

Above Loch Hope the stream of Strath More, as it is called, in contradistinction to the stream of the small strath, which is the Polla, flows a distance of $11 \frac{1}{2}$ miles from Loch-na-Dealachd, a narrow, little, sinuous loch below Ben Hee, and close to the highest source of the Naver. This loch is 805 feet up, and the stream which flows from it makes a very rapid descent, since about a mile below the stalking lodge of Gobernuisgach, where other streams join from right and left, the level appears to be less than 100 feet-a drop of fully 700 feet in 4 miles. The river becomes flat and sluggish before the loch is reached, and all the spawning ground of the district may be said to be in the 5 miles of water between the junctions of the head 
streams already referred to and the river abreast of Ben Hope, which towers up 3040 feet on the right.

Some fine pools exist in the Strath More river, especially below the ruined castle of Dornadilla, and here a very fair number of fish are taken in summer. The salmon average from 12 to $14 \mathrm{lb}$. in weight. The fishing on three days a week goes with Hope Lodge, which stands on a beautiful site at the foot of the loch. Kinloch Lodge also fishes three days a week. Kinloch Lodge has also a boat on Loch Hope, to fish which necessitates about eight miles on pony back over the hill; and, as already explained, Mr. Gilmour also shares right of fishing here.

The river Hope itself is a beautiful looking river of considerable volume, and contains seven good pools in its short length. The river is never fished till summer, and I understand that the average take is about 45 fish. A great number of sea-trout frequently ascend. In this respect the Hope is again like the Ewe and Loch Maree or the Shiel and Loch Shiel. Some of the trout run heavy, and I believe the record for this species is $14 \mathrm{lb}$. But both river and loch have the reputation of being "stiff" salmon-fishing waters; in other words, the take is not what the evident stock of fish might lead one to expect.

It may quite well be that some of the fish which ascend the Hope are bull-trout, by which I mean the variety (eriox) of sea-trout so common in the Tweed and Coquet; but of this I have as yet little proof. These bull-trout are notoriously bad risers. But another reason also has repeatedly occurred to me, viz. more fish may run into the loch in the early part of the season than are thought of, and may be off the take before fishing usually begins. The keepers in the district are no doubt convinced this is not the case. No fish is known to have been caught before, I think, the 12 th of June. The Hope is always described as a late river. But with very similar conditions occurring at two or three other places, notably on the west coast of Scotland, I want some proof that fishing has been tried and has failed before I am disposed to admit that the Hope must be a quite exceptional river in our country. It has considerable volume, and it has a large loch only a short distance from the sea. The temperature of the loch is not at all likely to be unusually low, the temperature of the short river will be similar, the gradient is easy. The conditions suggest that the gradient is so easy and the temperature so suitable that fish run through the river to the loch at once, and that they do so at a comparatively early date. Even 
if we place the Hope in the same category as West Coast rivers there should be fish in its waters by March. So much for theory! To prove it, one must get to the Hope in March, and that takes some doing, more especially since there is no place to live in if one gets there. Heilem Inn, marked on most maps at the Eireboll Ferry, is a snare. There is now no inn there. In any case the distance by road from Larig is about forty-five miles, with no regular communication after Altnaharra, except round by Tongue, which is out of the question.

The exclusive right of fishing the River Hope goes with Hope Lodge. As a matter of fact it would not be easy for any one not living in the lodge to fish here. The road which crosses from the Kyle of Tongue by the Moine has now a good bridge across the Hope in place of the old ferry. I may mention that the road by the Moine-where there is a solitary house provided for possibly stormstayed travellers-is one of the most peculiarly desolate tracks in the north. Salmon vary from 6 to $20 \mathrm{lb}$. in the Hope, and, when the river is in proper order, a fish a day may be got.

\section{RIVER DIONARD.}

This river presents conditions the very opposite to those of the Hope. It is a longish river, flowing from a small loch at its head, and entering a long sea estuary-the Kyle of Durness-within a few miles of Cape Wrath. The length of the river from its little Dionard Loch to the head of the Kyle is $10 \frac{1}{2}$ miles, and but a small stream of a couple of miles flows down to Loch Dionard from two tarns on the slopes of Meall Horn. From the southern slopes of the same mountain a burn runs down into Loch Stack, from which the Laxford flows.

The Dionard is a stony and rocky river, with a great variety of small pools, and of no great volume in ordinary conditions. The upper waters sometimes have done surprisingly well, for, when the river is in flood, the pools are so small and the broken water so continuous, that fish are induced to push on to Loch Dionard. The fishing of this section goes with Gualen Lodge, and in the past it is recorded that in Loch Dionard and the stream above 7 fish have on two occasions been taken in a day.

Gualen Water goes down to a mile or so above the road bridge on the highway between Durness and Loch Inchard, and I understand that the total usually reached is about 60 salmon and grilse and 80 
sea-trout. There is no road up the river, and distances have to be undertaken mostly on foot.

Below Gualen, Durness Lodge water comes in, and continues to the mouth. This water is not so rough as that above, and is both less extensive and more easily reached, since the high road is now at hand. The total here is about 40 salmon and grilse, making, therefore, about 100 for the whole river. This lower water is, however, better for sea-trout than that higher up, and when the water is in good condition some excellent baskets are made. The Kyle of Durness is of course well known as a haunt of sea-trout, and the chief fishing of the visitors at the hotel there is in the tidal water, where from boats sea-trout are angled for and taken in numbers.

This tidal Kyle is fished perhaps chiefly from the Hotel, but both Durness Shootings and Gualen have also a right to fish there. The favourite bait is the natural sand-eel, and when stopping a night in passing I have on occasion seen some large sea-trout brought in. Here also is the famous Croisaphuill Loch containing its so-called special kind of trout. It is, I have noticed, a loch of extremely clear water, and I understand the fish are now very shy. I ain informed that an artificially stocked loch of small size in the neighbourhood has yielded excellent fish.

The crowded state of Durness Hotel in summer, situated as it is at what might be called the northern jumping-off-place of Scotland and about 55 miles by road from the railway station, is about the best testimony I know to the popularity of fishing. Before now, in June, I have been crowded out of the hotel and have with great content occupied a little room in a little cottage all to myself. I recollect so well the inevitable simplicity of one's habits in so small a compass, the clear air that entered through window and door at night, and the boom of Cape Wrath fog horn in the haze of the morning.

\section{THE KINLOCH AND THE POLLA.}

These small rivers of this neighbourhood need not be referred to at any great length. The former has an angling season from 11th February to 31st October, but does not generally hold fish till summer. It is " a spate river" dependent entirely upon sufficient water-flow to enable fish to ascend, and only to be fished satisfactorily by one who is on the spot to take advantage of the proper moment. When in order, however, it yields excellent sport, 
as many as 6 salmon having been got in one day. It enters at the head of the Kyle of Tongue and has a rough course of a few miles from Loch Deerie. There is a fall which has been made negotiable by the erection of a dam so as to raise the level of the pool below. As a result fish ascend to Loch Deerie, where they are taken. The fishing goes with Kinloch Shootings on 3 days a week. The lodge stands near the mouth of the river.

In the Kyle of Tongue, as in the Kyle of Durness, some excellent sea-trout fishing is often had by spinning or by casting the natural sand eel. The Polla has the same fishing season as the Hope, viz. 12th January to 10th September. It is situated west of the Hope and has already been referred to as the stream descending Strath Beg. It has a course of about $5 \frac{1}{2}$ miles from a small loch about 3 miles east of Loch Dionard, and falls into the head of Loch Eireboll. It is a rather shallow little stream, but when in proper condition is reported to yield good baskets of sea-trout. It is of little use for salmon except as a spawning stream. 


\section{CHAPTER XXIII.}

RIVERS: INCHARD, LAXFORD, INVER, KIRKAIG, POLLY, KANAIRD, ULLAPOOL, AND BROOM.

\section{Axgling Season: 11th February to 31st October. Netting Season: 11th February to 26th August.}

Those rivers on the west coast of Sutherland and Ross may in a sense be classed together, although each has its own characteristics. They are, with one exception, rapid rivers draining the mountainous region of their country, of pure water, rocky or gravel strewn, amidst splendid scenery, and far from the railway and the busy haunts of men.

Taken collectively the first four are of special interest because of the valuable information their treatment has yielded respecting the regulation of netting. They have, as it were, passed through various phases of treatment before the policy now in vogue was finally adopted. We have to go back to 1845 for the commencement of this history. At this date bag nets were fished on the coast-and it should be realised that the estuary limitations on those nets did not then exist-sweep nets were fished at the river mouths, and cruives were fished in the rivers themselves.

The result was a complete depletion, so that the tacksman of the fisheries asked to be relieved of his lease. The total rental was then £400. The tacksman was relieved of his lease and from 1851 to 1856 no netting was carried on, angling alone being the means of fishing. Under these conditions the stock of fish rapidly recovered.

In 1857 sweep nets were again started at the river mouths, but no other netting was allowed, it having been considered that the former depletion was the result of the fixed engine fishing. The

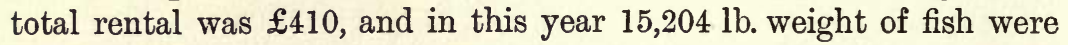
captured. In $1858,6089 \mathrm{lb}$. weight of fish was the take, and in $18597331 \mathrm{lb}$. were captured. 
The lease had been for three years, and at the expiry of 1859 the lease was not renewed, and the rental dropped to $£ 305$.

From 1860 onwards, another period of angling supervened for twelve years.

In 1873 a reversal of the netting policy was adopted. It had been seen that under net and coble alone these small rivers soon went back. Now, at the end of twelve years of rod-fishing alone, the streams were again most fully stocked. The course now followed was to keep the sweep nets off and to keep the cruives off-these last were indeed allowed to fall into ruin or were removed-and to allow bag nets once more on the coast. By this time the Salmon Acts of 1862 and 1868 had come into force, and each river had its prescribed estuary within which fixed nets of any kind could not be employed. The bag-netting rental was fixed at

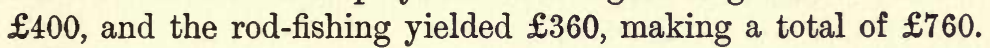

This policy adopted in 1873 has not since been changed, and to the present day the bag nets continue to fish very much as they did then, although in 1891 a station was taken off. This was Fanagmore Station, which yielded on an average $4 \frac{1}{2}$ per cent. of the total catch. The totals since 1873 are of interest, and the rental soon rose above $£ 1000$. The yield of the fishings are given in lb. weight:

\begin{tabular}{|c|c|c|c|c|c|}
\hline Year. & Lbs. & Year. & Lbs. & Year. & Lbs. \\
\hline 1873 & 70,975 & 1882 & 61,010 & 1890 & 68,072 \\
\hline 1874 & 38,658 & 1883 & - $\quad 109,795$ & 1891 & 68,499 \\
\hline 1875 & 44,047 & 1884 & 67,900 & 1892 & 42,197 \\
\hline 1876 & - 109,116 & 1885 & 53,584 & 1893 & 55,357 \\
\hline 1877 & - $\quad 30,568$ & 1886 & 41,013 & 1894 & 66,447 \\
\hline 1878 & - $\quad 48,238$ & 1887 & 47,540 & 1895 & 82,461 \\
\hline 1879 & - $\quad 42,385$ & 1888 & 72,564 & 1896 & 69,023 \\
\hline 1880 & 49,388 & 1889 & 54,097 & 3897 & 31,389 \\
\hline & 74 & & & & \\
\hline
\end{tabular}

It is remarkable that during the above period of 25 years, when netting was restricted to the use of fixed engines on the coast, the nets yielded on an average $60,338 \mathrm{lb}$. weight of salmon per annum, or more than six times the amount yielded when only sweep nets in the rivers and at their mouths were employed, that the rentals increased materially in value, and the take of fish in the sea was well maintained.

Like the netting stations in the Pentland Firth, the fixed nets on this coast always take more grilse than adult fish. A large number of sea-trout also occur on the coast, but these are not taken in any numbers in bag nets, since they are able to extricate themselves from an extended net of legal mesh, unless they are large trout. 
The most important netting station on this coast is Clachtoll, where in an ordinary year from three to six hundred salmon, and two to three thousand grilse may be taken. Clachtoll is in the Inver district, about half-way between the mouth of the river and Rhu Stoer on the north.

The particular features which determine a good or a bad bag-net station are not much understood even by experienced tacksmen, except that a shore with a southern exposure usually fishes better than one looking to the north, and that some places will not fish well simply because tides and currents will not allow of the nets standing properly. Apart from such general considerations, good and bad places are simply found out by experience on this west coast with its numberless lochs and creeks and islands, and since grilse are chiefly expected, the full complement of nets are not put in the water till the beginning of June. At the same time, in the particular district referred to here, some restriction is placed upon the number and positions of the nets.

I may now describe the four rivers separately.

\section{RIVER INCHARD.}

The main line of this river is north-west for barely five miles, through two narrow little lochs called Garbh Bhaid Mhor, corrupted into Garbet Mor, and Garbet Beg. The latter, i.e. the smaller loch, is the nearest to the mouth of the stony, boulder-strewn, little river which flows into the head of Loch Inchard at Rhiconich. The stream from the mouth to Garbet Beg is barely a mile and a half in length.

It is rather astonishing to read in a work much consulted by anglers that the loch specially described in its name as small and rough is three miles long, while the loch of the great rough clump is two miles long. As a matter of fact, the great loch is a mile and a quarter, and the small loch three-quarters of a mile. Similarly each loch is said to be a mile broad, whereas each is a narrow slip, the maximum width of Garbet Mor being about a seventh of a mile. The stream between the two lochs is insignificant, and the hill burn above Garbet Mor, which rises on the lower slopes of Ben Arkle, is obstructed by falls.

To the north-east a perfect labyrinth of lochans occupy the low slopes, about the 500 feet contour of Foinne Bheinn, a steep hill rising abruptly on this side to 2980 feet. These eventually drain into Garbet Beg by the Garbh stream. It is a matter of some 
surprise that such numbers of sea-trout and salmon sometimes ascend the Inchard, for the spawning ground is very limited in this short little river. Fish do not ascend till end of May or beginning of June, and they do not ascend at all, or cannot do so, unless there is a fair rise of water after rain. In July great numbers of fish are sometimes seen waiting at the mouth.

The Inchard is so choked up with boulders that it is only here and there that a nice little pool can be found. When a flood occurs the fish are inclined to travel through the river rather fast on this account, and I think it might be quite worth while to make further attempts to enlarge the existing pools so as to give better holding water and increased sport in the river. As things are at present, salmon fishing is practically confined to Loch Garbet Beg, and if fish pass up from the small to the larger loch they cease to take with the same freedom, and are practically lost. So much is this the case that a proposal has been made to construct some sort of dam below Garbet Mor to prevent the early entrance of fish. It would be much more serviceable to store the surplus water of Garbet Morthere is plenty of it at times-for the purpose of creating floods at will in the Inchard.

The Rhiconich Hotel has the right of salmon fishing on lease from the Duke of Sutherland, and Mr. Grant does all in his power to make anglers comfortable. He usually lets the fishing in Garbet Beg separately at, I believe, $£ 20$ a month. June to the end of the season constitutes the available fishing time, but July and August are the best months. The river, when in good play, sometimes yields excellent sea-trout and grilse results to any hotel visitors, and quite a variety of trouting lochs can also be fished. One might stay for a month and fish a different loch every day, so great is the number of those in Edderachylis district.

Subjoined are a few notes I have as to catches at Rhiconich:

1887. 31 salmon, 17 grilse, 549 seatrout.

1889. In Garbet Beg, 41 salmon and grilse (14th June-17th Sept.); in Oct., 17 salmon.

1890. 87 salmon and grilse. No salmon were killed till $17 \mathrm{th}$ July.

1891. 56 salmon and grilse.

1892. 55

1893. 65
1894. A very dry year. Number of salmon insignificant.

1895. 24 salmon and grilse.

1896. 54 " "

1900. 36 salmon.

1901. 40 ",

1902. 44 ",

1903. 39 ",

1904. 48 ",

1905. 50 "

1906. 43 ",

1907. 50 "

1908. 46 ", 
Sea-trout run up to between $5 \mathrm{lb}$. and $6 \mathrm{lb}$. in weight, but small trout under $1 \mathrm{lb}$. are common. Salmon of $6 \mathrm{lb}$. are common, and sometimes as many as five may be got in a day. The heaviest fish taken amongst those referred to above was $14 \frac{1}{2} \mathrm{lb}$. In 1887, the first year mentioned, in addition to migratory fish, 1076 brown trout were taken in the various lochs. These notes, although they are not of quite recent date, are quite sufficient to show the nature of the sport to be had. A great deal depends on the season's weather. If there is plenty of rain so much the better. If a dry summer occurs, fish cannot easily enter the river.

\section{THE LAXFORD.}

The Laxford-which owes its name to the salmon or lax-is generally considered the best river in the west of Sutherland. It drains a wide extent of country, as compared with the Inchard, including Loch More and Loch Stack, receives numerous feeders from the high mountains on its northern side, which form the famous Reay Deer Forest, and flows into the head of Loch Laxford, a typical ramifying sea loch, at Laxford Bridge, some four miles south of Rhiconich.

The valley of the Laxford is the western continuation of the great transverse valley across the county, and mid-way between the head of Loch More and the western end of Loch Merkland, only a few hundred yards form the divide between water coming to the west through the Laxford, and the water going to the east to Loch Shin and the Kyle at Bonar Bridge. This is the valley naturally selected for the road traffic from Lairg to Rhiconich, Tongue, and Cape Wrath, and, turning south at Laxford Bridge, to Scourie and Kylestrome.

The Laxford and its loch are held on a time-honoured lease by the Duke of Westminster, who has two lodges in the district, Loch More Lodge at the western end of the loch of the same name, from which the stalking is carried on, and Stack Lodge, where the river Laxford flows out of Loch Stack, from which the fishing is carried on. The channel between the two lochs is not much more than half a mile long and is winding and rather flat, the difference in level being a matter of about 9 feet.

Loch More, including the small diverticulum at its western end, is four and a half miles long, and of the very uniform breadth of rather more than the third of a mile. The ordnance maps mark it as 127 feet above sea-level. Like the upper loch just described 
in the Inchard district, it is practically no use for salmon fishing. M'Leod, the head stalker, once informed me when I was passing through the glen, that in his thirty years' experience he had only known of 4 salmon being captured. If I recollect right, I had, the day previously, had a long talk with Mr. Evander M'Iver at Scourie House, a hale and hearty old Highlander, then in his 90th year, who two years afterwards was gathered to his fathers. $\mathrm{He}$ came to the district in 1845, and with his clear memory and wide range of experience was a man well worth listening to. $\mathrm{He}$ reviewed the whole history of the west Sutherland salmon fishing, and maintained that the existing regulations leave little to be desired. I wandered through his garden afterwards, and saw the New Zealand cabbage palms which flourished so well there and at Inverewe.

Loch Stack in superficial area is not very much less than Loch More, but it is entirely different in shape and character. From where the Loch More stream enters to where the Laxford flows out, the line is fairly straight, and this section of the loch partakes of the long narrow character frequently met with in steep glens. On the left, or south side, Ben Stack rises abruptly to a height of 2364 feet-an isolated hill-and naturally gives the straight character to this side of the loch. On the right, however, a broader loch basin has become joined, as it were, to the long narrow section, so that the loch consists of two basins and an elongation. The shore-line of Loch Stack is about $8 \frac{1}{2}$ miles; the shore-line of Loch More about $10 \frac{1}{2}$ miles. The level above the sea is given as 118 , and the distance to the sea is four miles.

Loch Stack is the best sea-trout loch in Sutherland, and I cannot think of any other loch in Scotland which can yield what this loch does. An average basket of sea-trout should weigh from $15 \mathrm{lb}$. to $25 \mathrm{lb}$., and very great catches are sometimes made. Trout of over $5 \mathrm{lb}$. are not uncommon, but curiously enough $\mathrm{I}$ have been informed that it sometimes happens that quite a number of trout of smaller size are net marked when taken. The total number taken in a good year amounts to 1000 or 1200 fish. About a score of salmon may also be got.

The river Laxford proper, i.e. from the outlet of Loch Stack to Laxford Bridge, is $3 \frac{1}{2}$ miles, after which a half mile of tidal river continues. In general character the Laxford is a most attractive stream. The current is merry but not too fast. There is much gravel and not a few boulders, but a fine succession of pools, some 18 in number. The best pool is, perhaps, that called the Duke's 
Pool. It is situated at a rocky constriction in the river, which forms a strong current at the neck, but below this the pool widens, and is of considerable length, so that a fine cast is secured. I believe 14 fish have been taken from this pool in a day. The Duchess Pool comes, most appropriately, next below, and is also an excellent cast when the water is in proper condition. It is fished from a semicircular jetty of stones. Another pool which is fished from a jetty is the Top Pool, which is also reckoned a pretty sure hold.

Fish are also got in the tidal runs well below Laxford Bridge. On my last visit to the neighbourhood, when coming down the hill to the bay at Badcall from Rhiconich, I happened to see a capital fish gaffed on to the beach on the opposite side. A strong current runs out here with the ebb.

At the commencement of this chapter it was shown that the seanetting is fairly well maintained. I am afraid it has to be confessed that the rod-fishing does not now yield what it did. In evidence before Lord Elgin's Commission, Mr. Donald M'Lean instanced the case of the Laxford when referring in 1900 to decline of rod-fishing: "The Laxford," he said, "from 1853 to 1856 yielded an average of 154 salmon to the rods, from 1866 to 1873 , inclusive, 95 , and since that and up to the present. time the average has barely reached 55 . The records show that the falling off began with the re-establishment of the coast nets, and continued, notwithstanding the fact that the bag nets were removed from the mouth of Loch Laxford in 1891 , since which time there have been no nets within four miles of each side of the loch. The same has to be said of the other west coast rivers-Kirkaig, Inver, and Inchard."

This statement hardly agrees with that of the late Mr. M'Tver already quoted, and I strongly suspect that the question of the great capture of grilse in the sea in those regions will have to be most carefully examined. The date of the re-establishment of coast nets was 1873. Mr. M'Lean's statement agrees with local accounts as to the reduced number of salmon seen spawning in the river.

Through the kindness of Mr. Donald M'Lean, the estate factor. I am able to give the following list of recent years, all fish being taken on fly:

\begin{tabular}{|c|c|c|c|c|c|}
\hline Year. & $\begin{array}{l}\text { Salmon and } \\
\text { Grilse. }\end{array}$ & $\begin{array}{c}\text { Heaviest } \\
\text { Fish. }\end{array}$ & Year. & $\begin{array}{l}\text { Salmon and } \\
\text { Grilse. }\end{array}$ & $\begin{array}{c}\text { Heaviest } \\
\text { Fish. }\end{array}$ \\
\hline 190 & 37 & $18 \mathrm{lbs}$. & 1904 & 85 & $28 \mathrm{lbs}$. \\
\hline 190 & 5 & 18 " & 1905 & 49 & 22, \\
\hline 190 & 53 & $22 "$ & 1907 & 66 & - \\
\hline 190 & 41 & $26 \frac{1}{2}$, & 1908 & 43 & $18 \frac{1}{2}$, \\
\hline
\end{tabular}


The average for these years is 47 , but the year 1901 is clearly exceptional, possibly through little fishing having been carried on. The average for the last five years is 56 .

The damming up of Loch Stack, so as to impound water till such times as the river runs too low, so as to induce a greater volume of water at the chief fishing season, seems well worth some consideration. So far as the outflow of the river is concerned, the possibility of doing so rather easily seems considerable, but the affect upon the sea-trout fishing of Loch Stack would have to be taken into careful consideration, if any great deepening of the loch was proposed, as well as possible difficulties on surrounding land and roads.

\section{RIVER INVER.}

From the mouth of Loch Laxford, south, past Handa Island with its countless birds, across the wide Edderachylis Bay, and round $\mathrm{Rhu}$ Stoer to Loch Inver is about 24 miles. The Inchard and Laxford are comparatively close together, flowing north-west, the Inver and the Kirkaig are also close together, but at some distance from the others.

Edderachylis Bay terminates in a curious ramification called Loch Cairnbawn, which narrows to something like half a mile at Kylesku Ferry and then bifurcates into two deep sea lochs, Loch Glendhu and Loch Glencoul. A stream enters the head of each, where fish run up at the "back-end" of the year to spawn. These streams are perhaps hardly worth special description, but Kylesku is worth mention because it is not generally known that bull-trout and seatrout are here caught in the strong salt water currents which run through the narrows and round a few small islands. When I say bull-trout I mean $S$. trutta eriox, the migratory variety of the seatrout so common in the Tweed and the Coquet. This fishing seems to be best in June and July.

The river Inver flows out of Loch Assynt and has a somewhat rapid course of 6 miles to the sea at Loch Inver. A considerable tributary, the Alt-an-Tiaghaich joins it about a mile below the loch outlet. It is a river of no great size but of very varied character, broad and shingly not far from the mouth, where the remains of old cruives may still be seen, stony and rather rough in other places, again deep and rocky, and yet again wide and open. It is divided into upper and lower beats between the Long Pool and the Deer Pool, the latter being the first of the upper section as one ascends. 
July and August are the best months for the Inver, as fish do not generally enter till pretty late in June, but like other rivers of the neighbourhood it is much dependent upon plenty of rain to enable fish to run. Seasons have occurred when fish entered freely as early as May, but this is quite exceptional. The Fishery Board Report for 1884 mentions that in a previous May 2 rods took 39 fish. I fear 2 rods would have to work hard to make the same number now in a better month of the year.

The river is let with the shootings of two lodges, Loch Assynt which fishes the upper beats, and Glencanisp which fishes the lower beats; but in accordance with an arrangement rather common in Sutherland, this fishing only commences each year on 1st August, i.e. when shooting tenants begin to arrive in the north. Previous to this date the upper beats may be fished by visitors staying at Inchnadamph Hotel, and the lower beats, not unfrequently, by visitors at the Culag Hotel, Loch Inver. July and August may be regarded as the two best months for the Inver, so they are fairly divided, but a good wet season is best for success with the rod, as the river is not large, and unless running fairly high does not readily draw fish from the sea.

In the "fifties" one rod could get from 3 to 6 fish in a day under favourable conditions. A fisher has to be satisfied with more modest rewards now and be thankful if he is not blank when he finally reels up. Most of the salmon run small, about 8 to $10 \mathrm{lb}$., but fish over $30 \mathrm{lb}$. have been killed. At times there is a good run of grilse, but sea-trout are not numerous.

The totals since 1900 are as follow, the two hotels accounting for the greatest number each year. I am indebted to the estate for these figures :

\begin{tabular}{l|l|l|l|l}
$1900-34$ & $1902-105$ & $1905-50$ & $1907-96$ \\
$1901-69$ & $1903-92$ & $1906-97$ & $1908-31$
\end{tabular}

Glencanisp Lodge stands in a fine position, overlooking Loch Swordalain, a small loch which is situated about a couple of miles south-east of Loch Inver, and which has a separate stream of very fair size draining Loch Ganive some 5 miles inland. After passing through Loch Swordalain-which is fished by Glencanisp Lodge and contains sea-trout and a few grilse-the stream enters the Culag Loch, a smaller sheet of water fished by Loch Inver Lodge. From this the run into the sea is short. 


\section{LOCH ASSYNT,}

From which the Inver flows, receives the waters of several small surrounding lochs, and at its head the Loanan river descends in a rather steep course from a hill loch called Loch Awe, a very shallow little loch with a maximum depth of about 7 feet. The descent is some 300 feet, but the last 3 miles or so are useful spawning ground for fish from the loch below. Salmon run up the Loanan into Loch Awe and are caught there in the season. The main road from Lairg to Assynt by Oykell Bridge passes close to Loch Awe and follows the course of the Loanan to Inchnadamph, the well-known fishing resort which stands at the head of Loch Assynt.

At the west end of the loch the ground is comparatively low, but a splendid amphitheatre of hills surround the remainder of the loch. Quinag on the north, Glasven, Ben More, Coniveall, Breabag, and Canisp, are all conspicuous, Ben More and Coniveall (Coinnembeall) being, respectively, 3273 and 3234 feet.

The general trend of the loch is west-north-west and east-southeast, while the western end bends at right angles to the south where Loch Assynt Lodge stands on the north shore. A recent writer, who does not seem to have measured distances at all, describes the loch as 10 miles long. Perhaps a boatman rowed him up it against the wind and thought so. An eminent guide-book says it is 8 miles long. The officers of the Ordnance Survey mapped it, and the more recent Bathymetrical Survey reports that "It is $6 \frac{1}{3}$ miles in length, and nearly a mile in maximum breadth, the mean breadth being half a mile or 8 per cent. of the length. The waters cover an area of nearly 2000 acres, or over 3 square miles, and it drains an area fourteen times greater, or over 43 square miles. . . .

"The floor of Loch Assynt is rather irregular . . . this is more especially the case in the half lying to the north of the medial line. The 100 feet contour running along the northern shore is of a most sinuous character, quite independent of the shore line, and is in striking contrast to the same contour running along the southern shore. . . The 50 feet, 100 feet, and 150 feet basins are continuous areas, while the area over 200 feet in depth is cut up into four portions, and that over 250 feet in depth into three portions. The 50 feet basin extends practically from one end of the loch to the other; the 100 feet basin stretches from 200 yards from the eastern end to beyond Rudh'-an-Alt-toir, where the loch bends sharply to the south-west." 
The maximum depth is 270 feet and, as the surface of the loch is about 215 feet above the sea, it follows that the floors of the three 250 feet basins are below the level of the sea at Loch Inver. Some 29 per cent. of the loch, however, has a depth of less than 50 feet near the shores. The shallows are more noticeable on the north than on the south shore, the various bays between the rather marked little peninsulas varying from 10 to 30 feet, but no shallow bank of any kind exists away from the immediate shore line.

Inchnadamph Hotel has the right of fishing in Loch Assynt as well as in the upper section of the river Inver before 1st August, or other date which may from time to time be arranged by the estate.

The hotel also has a boat on little Loch Awe which, in addition to the chance of a salmon, yields good red-fleshed trout. The tenant of Loch Assynt Lodge also fishes Loch Assynt and has the exclusive right on the upper section of the Inver after the specified date.

Mr. Wallace of Inchnadamph Hotel kindly supplies me with the numbers of salmon and grilse caught by his visitors in Loch Assynt, including a few fish from the river Loanan and Loch Awe.

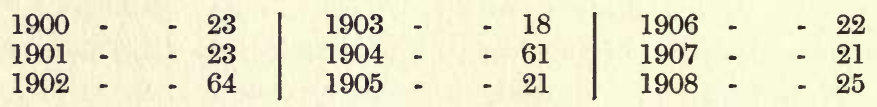

This is practically an average of 31 fish.

\section{RIVER KIRKAIG.}

This is a nice river, but a short one. Only $2 \frac{1}{2}$ miles of it are available for salmon fishing owing to a perpendicular fall about 50 feet high. There is about half a mile of river above, flowing out of the Fionn Loch-and a nice little bit of water, too-and then the stream drops over its precipice. This fall is a very fine spectacle, but it is likely for all time (unless, say, another glacial period should come upon us) to remain quite impassable to salmon. The Kirkaig is the southern boundary of the county of Sutherland.

The catchment basin is rather less than that of the Inver, but rather greater than that of the Laxford. In the area closed to salmon there are many fine trouting lochs, such as Fionn, Veyatie, Cam Loch, Urigill, and Borrolan, by the side of which the fishing hotel of Aultnacallagach stands. The western portion of this area as well as the whole coast belt up to Rhu Stoer, is a rough and endless succession of rounded and worn bosses of rock formed of the 
Archaean gneiss. Wherever this ancient rock is exposed, as it is so largely in western Sutherland and Ross, the general features of the landscape are similar. The hollows between the innumerable rounded knolls are occupied by lochs great and small, while at intervals great landmarks rise in isolated masses on the surface of this ancient foundation. In this neighbourhood the most remarkable is Suilven-the Sugar Cone. To mention Loch Inver and the Kirkaig and make no reference to Suilven, would be like describing London without St. Paul's. Suilven rises a bare, gaunt, and impressive monument of Torridon sandstone 2399 feet above the sea. The other mountains in the district-Canisp, Quinag, Cul Mor-are of the same formation. In Suilven the sandstone is bedded horizontally, in the others there is a gentle dip. From a great distance out in the Minch it is easy to identify Suilven. A vast thickness of strata has been denuded by the ice between those isolated hills. When we look at the rocky knolls by the Inver and the Kirkaig we are seeing the foundation-stones of Scotland, at one time buried deep by the stuff Suilven is made of. That hill is merely a remnant of the old surface.

In the $2 \frac{1}{2}$ miles of the Kirkaig there are twenty-two separate casts. In general character it is a rocky, swift-flowing river, with a nice inviting look in many of the pools; but one has to be careful of one's footing, for many of the pools are not too easy to reach, and in coming and going from one pool to another a deal of climbing up and clambering down has to be done in the rocky gorge of the upper section. The Fall Pool is a sort of black abyss when one looks from a height, and where even the fish, as they show on occasion, seem black, for one only sees their backs. The names of the two pools immediately below are significant. They are the Upper Smash and the Lower Smash. There is no leaving either if you fail to keep your fish on pretty close terms. If it goes down-stream in spite of you, you get one or other variety of smash. If you do try to follow, the chances are you have a worse smash than that of your tackle.

The river is divided into two beats, the lower has ten pools, and the upper has twelve, and although only the right bank belongs to the Duke of Sutherland, His Grace has the sole right of fishing. Culag Hotel is allowed four days a week, and Loch Inver Lodge the remaining two days. The Kirkaig fish are rather heavier than the Inver fish, the average being about $11 \mathrm{lb}$, and fish up to $20 \mathrm{lb}$. are not very uncommon. From 40 to 50 are usually got in the season, 
which, considering the shortness of the river, is not at all bad. Here are the totals since 1900, excepting the years 1904 and 1907 :

$$
\begin{array}{l|l|l|l|l}
1900 & -45 & 1902-53 & 1905 & -29 \\
1901 & 52 & 1903-44 & 1906 & -43
\end{array} \mid 10
$$

The migrations of those Kirkaig fish is a matter of some interest. The spawning ground for salmon is distinctly limited. So far as our marking on east coast rivers go, it is clear that the great majority of kelts return to their own rivers again as clean fish-if they return from the sea at all. In a short river such as the Kirkaig, the question naturally arises to one's mind: Can it produce all the fish that ascend it? It is a late river. July is as early as one need start. No one sees the kelts, and the chances are they are not very long in the water. To carry out some kelt marking, and if possible some smolt marking, not only in the Kirkaig but in the neighbouring rivers, might show some most interesting and instructive results. But, from experience, I know it is a difficult matter to secure an adequate number of kelts in those small rivers.

\section{RIVER POLLY.}

This river is within the limits of the Kirkaig district as prescribed by the Salmon Act of 1868. It is the property of the Countess of Cromarty, and enters the sea at the head of Euard Bay, about four miles south of Inverkirkaig. Like the larger river, its upper waters are cut off by an impassable fall, but in general character it is quite different, being in its lower part a still, sluggish stream, which can only be properly fished when there is a breeze. It rises from two sources-the more southerly from a loch 222 feet up, and rather more than three miles from the sea; the other from quite a series of lochs (all closed to salmon), the last of which is Loch Shinaskaig, long famous for its trout.

A little loch just below Shinaskaig, called Loch-an-Dalach, used at one time to be also closed to salmon. In 1878, however, on the advice of Mr. Archibald Young, then Inspector of Salmon Fisheries, this lower barrier was circumvented by deepening a side channel, and so securing a sufficient gradient for fish to ascend. Mr. Young says in a report that, as a result, the fish promptly went up to the loch above; but unfortunately the fall above this and below Loch Shinaskaig is a barrier of 25 feet or so, with conditions which make any further operations well-nigh out of the question.

The Polly, therefore, has only about the same length as the 
Kirkaig. Grilse sometimes run in very fair numbers, and in other years are scarcely to be found. From the return with which I have been favoured, the variation is in the last ten years from 0 to 42 . The number of salmon is never large, but is much more steady than is the grilse record. Ten, twelve, or fourteen in the season represents what may be expected. The fish do not usually run large, and a wet summer is all in favour of the angler. The fishing goes with Inverpolly Lodge.

Sea-trout are much more numerous than salmon and grilse. Recent annual totals are $92,122,47,188,101,163,123,56,129$ and 114, the last being for 1908 .

Loch Shinaskaig has been sluiced at its outlet so as to impound water; a most valuable provision when dealing with small streams. Major Blunt, in a letter written at the end of season 1906, says, touching the effect of this operation, "We had a lot of fish up the river-thanks to artificial spates-in spite of a dry season at the time fish were on the coast." Writing as to the previous season, Major Blunt said: "The little Polly, with its sluice on Loch Shinaskaig, was the only place any could come up. The fish remained about 5 weeks splashing about in shoals-then went south."

Other operations, in the way of improving the fishing, have also been carried out here. A pass round the lowest fall has just been made, and previous to this, about two-thirds of the bag nets on the Coigach coast have been removed.

Another stream and loch holding grilse, and more especially seatrout, is also in the Inverpolly ground, viz. the stream flowing out of Loch Owskaig to the sea at Garvey Bay. Here in July and August, given sufficient water in the streams, some good sport is to be had. It is reported ${ }^{1}$ that as many as 128 sea-trout have been taken in a day, some of them scaling up to $4 \mathrm{lb}$. in weight.

\section{THE KANAIRD.}

In the Rhidorrach Forest, where the Rappoch Water rises from its many head streams and flows away east to Glen Finig and the Oykell, the Kanaird also rises in a flattish glen, called the Strathnan-Lon, which is sandwiched in between two of the Rappach streams. Several small shallow lochans occur in its course at first, the general direction of which is N.W. to Loch-a-Chroisg. From this loch, which is about 627 feet above sea-level, the little Kanaird flows about $7 \frac{1}{2}$ miles to the sea.

${ }^{1}$ Augustus Grimble, Salmon Rivers of Scotland, p. 119. 
The mouth is a longish and flat tidal channel, opening into what is called Loch Kanaird at the back of Martin Island, outer Loch Broom. This is, however, practically a joint mouth for two streams, since the Ruinie joins the Kanaird a short distance above the mouth. The junction pool is the favourite in the river, and often holds large numbers of sea-trout.

Both streams above this have a very rocky course, and are considerably obstructed by frequent small cascades and falls. This is especially the case with the Kanaird which in its upper part is deeply cut into a rocky bed. Salmon are reported to ascend only about 4 miles. Both streams belong to the Countess of Cromarty, and are let with Druimruinie Lodge.

Salmon are to be got here in spring, as is the case also in the Ullapool river, but they are seldom fished for I believe. Grilse are not got in any numbers. In 190711 grilse were recorded, and in the previous year 10, but these are the greatest scores in the last ten years.

Major Blunt has kindly supplied me with the full record since 1809. I append the results in the following form:

\begin{tabular}{|c|c|c|c|c|c|}
\hline Year. & $\begin{array}{l}\text { Salmon and } \\
\text { Grilse. }\end{array}$ & $\begin{array}{c}\text { Sea } \\
\text { Trout. }\end{array}$ & Year. & $\begin{array}{l}\text { Salmon and } \\
\text { Grilse. }\end{array}$ & $\begin{array}{c}\text { Sea } \\
\text { Trout. }\end{array}$ \\
\hline 1899 & 10 & 41 & 1904 & 8 & 21 \\
\hline 1900 & 3 & 84 & 1905 & 13 & 47 \\
\hline 1901 & 12 & 57 & 1906 & 33 & 61 \\
\hline 1902 & 19 & 22. & 1907 & 31 & 115 \\
\hline 1903 & 29 & 56 & 1908 & 20 & 100 \\
\hline
\end{tabular}

In the years when the salmon totals are small, the brown trout totals are usually extra large, which suggests that the shooting tenants preferred to have the comparative certainty of good brown trout baskets to the chance of a salmon. For instance, in 1901 there were 659 brown trout, in 1904 there were 802. The year 1906 was a good all-round fishing year: 3 spring salmon, 20 summer and autumn salmon, 10 grilse, 61 sea-trout, and 821 brown trout. To complete the bag I may add 5 rainbow trout-the best total which has ever been got after turning down about 10,000 fry. This makes a total for 1906 of 920 fish.

In explanation of the great amount of brown trout fishing, I may state that Druimruinie Lodge has some nine or ten lochs it can fish. In a case such as this, therefore, the record of salmon caught is really no indication of what might be got were salmon fishing made a regular and serious part of the season's sport. Tenants frequently do not come till August, and the gun is then more commonly taken 
out than the rod. Salmon fishing is a sort of attractive extra suitable for "off days."

\section{ULLAPOOL RIVER.}

This little river, which flows from the Forest of Rhidorroch, has its source at a very high altitude at the extreme head of Glen Douchary. In its course of nearly 15 miles it receives three names. Down the glen mentioned, it flows in a northerly direction to within a short distance of Loch-na-Daimh from which the Einig flows to the Oykell and so to the Kyle of Sutherland at Bonar Bridge. In this section it is called the Douchary. At the point mentioned it turns sharp to the left and descends Glen Achallt, where it is called the Rhidorroch River. The lodge of the same name stands upon the left bank. It then passes into Loch Achallt, a sheet of water about a mile and three-quarters in length, and from the foot of the loch, continuing its flow westward, it forms the Ullapool River, and enters Loch Broom just west of the village or town of Ullapool.

As a salmon angling stream it may practically be disregarded above Loch Achallt, for it is only late in the season that fish ascend the Rhidorroch, the natural spawning ground. In general character, the Ullapool is a rocky river. In the $2 \frac{1}{2}$ miles between Loch Achallt and the sea it descends 265 feet, and is often cut pretty deeply through the limestone rocks which occur here. Lower down it is more boulder-strewn and gravelly, but about two-thirds of the way up, at Ness, there are one or two little falls about 4 feet high, which are sufficient to stop fish in low water. Below the falls some deep rocky pools occur, where in summer I have known about 30 salmon which had been "potted" there for some time resist all the angler's endeavours.

The river belongs to the Countess of Cromarty, but the fishing is commonly let, convenient accommodation being found in Ullapool. A great deal depends on the amount of water-flow and the climatic conditions in the early part of the season, but after open winters salmon enter the river in March and April. In this western part of Ross and Cromarty the winters are usually mild. From the middle of April to the end of May may be regarded as the best time for salmon. In June and July the grilse ascend.

The Ullapool river, though small, has a good reputation, although I fear, like other small west coast rivers, its glory has somewhat declined. Records of 10 to 12 fish to one rod in a day have, I 
understand, been made in the past. Some time ago, when I visited the water, the month of May had produced only 5 fish. Major Blunt has very kindly given me the recent records from Rhidorroch, explaining at the same time that the amount of fishing carried on is very variable and at times comparatively slight. In some springs I believe the water has not been fished at all.

\begin{tabular}{cccc|cccc} 
Year. & & Spring. & Summer. & Year. & & Spring. & Summer. \\
1899 & - & - & 23 & 1904 & - & 5 & 11 \\
1900 & - & 22 & 13 & 1905 & - & 5 & 6 \\
1901 & - & 2 & 13 & 1906 & - & 10 & 14 \\
1902 & - & - & 10 & 1907 & - & 11 & 20 \\
1903 & - & 11 & 28 & 1908 & - & 5 & 5
\end{tabular}

I am informed by the chief river watchers that sea-trout enter the river in fair numbers, but that, after ascending quite a short distance, they drop back into the sea. I am not sure if this observation refers to more than finnock, whose habit is to fall back into the tide-way. The sea-trout is a creature of peculiarly fickle habit, and one hesitates to make positive statements about its doings without specially watching the particular locality under review. It is comparatively rare, however, to catch a sea-trout in the Ullapool. I believe certain local folks know something about how to eatch them at the mouth of the rivers in the neighbourhood.

\section{THE BROOM.}

A vast amount of erosion has taken place in the glen down which the Broom flows. Loch Broom, the sea loch, must at one time have been the site of a great glacier, which ground its way over the rocky boss upon which the village of Ullapool now stands, and prepared the way for the entrance of the sea as it now exists. The river in its course to the sea flows in a sinuous fashion, now at one side now at the other of the great post-glacial river.

It is formed by the junction of two streams of the Braemore Forest, the confluence being about $4 \frac{1}{2}$ miles from the sea at the head of Loch Broom. The general direction is N.N.W. The two streams are the Droma and the Cuileig. The former comes from a loch of the same name, and receives on its left, about a mile below Loch Droma, a burn coming from a little circular loch 1831 feet above sea-level, which nestles at the foot of the great hills Sguir Mhor, Sguir-nan-Clach Geala, and their outlying ridges, which occupy the space between the two head streams. The Cuileig flows from Loch-a-Bhraoin (Vruin), a sheet of water about $2 \frac{3}{4}$ 
miles long, lying amidst magnificent hills, and fed by streams from the Dundonnell Forest. It contains some splendid trout, and the outlines of many monsters taken from it adorn the walls of the fishing lodge which stands at the end of the loch for the temporary accommodation for the Braemore anglers. On the one occasion when I had the opportunity of visiting the spot in wild weather we did not catch any monsters, and I understand they do not compete for the lure of the sportsman with that avidity which so becomes large trout in the angler's eyes. Nevertheless, as will be understood by all who have been privileged to receive Inverbroom hospitality, we contrived to enjoy ourselves immensely.

No salmon can ascend either head streams of the Broom, for, about a mile above the junction, each stream has an impassable fall where the descent is made from the high mountain-valley tracts of the district to the main lower section. The point at which the Droma falls over is, however, much higher than is the case with the Cuileig. The high road from Garve passes Loch Droma and descends the line of the stream on the north side, but passing through a thick wood the traveller does not realise that the stream so close makes the sudden drop of some 200 feet into a fearsome gorge. There is a foot-bridge a short way below the position of the fall, and which spans the gorge. From the centre of this, between overhanging branches, a splendid view of these Falls of Measach, or Corrie Halloch Falls, can be obtained. There are very few places in Scotland where a similar sight can be enjoyed. The gorge at the head of Glen Afric is one, and the Falls of Glomach in Kintail is another. The latter is the highest fall in Scotland (350 feet, with a total descent to the foot of the ravine of 750 feet), but has not the great charm of rich foliage in its surroundings. I happen to have a rather vivid recollection of one tree which grows out from the end of a crag at Glomach, for by it I was able to extricate myself from a rather tight corner I got into on a solitary climb on one occasion.

The linn on the Cuileig, the other head stream of the Broom, is by no means so extraordinary in the matter of height, but with its precipitous face and great rock ledges below, it forms a most picturesque fall. Salmon reach the linn-pool freely, and are there fished for. Two beautifully constructed pools were formed in the river below the linn by the late Sir John Fowler, of Braemore, and a long stretch of water, which previously had been valueless for fishing, was made to yield excellent results to the rod, but the 
violence of a great flood in 1892 was too much for the artificial barriers, and they have not since been renewed.

From the crest of the Falls of Measach, which is about 615 feet above the sea, and the stream above the Cuileig Fall, which is 530 feet up, the river Broom makes such a rapid descent that at a point about two miles lower down it is only 130 feet above sealevel. Thereafter for other two miles the river has a rapid cheery current, splashing round rocks and rippling over gravelly shallows. Lower down the river becomes more uniform in character, with a stony bed fringed by trees. When it reaches the Inverbroom Bridge it is barely 20 feet above sea-level, and has become almost placid in long gentle pools. At the bridge the channel is close to the north side of the glen, but presently it winds across to the opposite side, and forms an imperfect sort of lagoon behind a great talus of gravel, which has been washed by the little river Lael from the northern hillside. The entire contents of this side glen seem to have been poured out upon the mouth of the Broom, and not only the river has been pushed over to the south side of the glen, where it finds its passage to the sea, but the head of Loch Broom has been in great measure shallowed and filled up. The upper end of the lagoon would probably have represented the head of the sea loch but for the debris from the Lael. Loch Broom Church would then have stood at the head of the loch.

Reference to the church, reminds me that the minister here seems to have a vested right in salmon fishing ex adverso the glebe. I understand that he maintains his right by drawing a net in the tidal pools of these Kirklands of Loch Broom during at least a few nights each season. Netting used also to be carried on in the Linn Pool, but this ceased about twenty years ago.

As a rule, the Broom holds fish about the middle of May, but in exceptional years, such as 1893 and 1896 , for instance, clean fish were taken on the rod on 20th March and 11th March respectively. Curiously enough, when the river was netted for ova on three successive Decembers, 2 clean fish were then found, and quite a number of clean sea-trout in the low pools. I have referred elsewhere to the clean spring sea-trout of the Grimersta. The Broom, like the neighbouring Ullapool river is not what can be called a good sea-trout stream. It is the more singular, therefore, that these fickle fish should be found there in December.

The average weight of the Broom salmon is practically $10 \mathrm{lb}$, but weights vary greatly. In some years the heaviest fish have not 
exceeded 13 or $14 \mathrm{lb}$., but much more commonly the weight has been over $20 \mathrm{lb}$. On several years 28 pounders have been got, and the record weight, so far as I know, is $33 \mathrm{lb}$.

Lady Fowler has very kindly given me a copy of the takes of fish by the rod since 1867. These I will give in quinquennial averages.

\begin{tabular}{cccc|cccc} 
Years. & & Salmon. & Sea Trout. & Years. & & Salmon. & Sea Trout. \\
$1867-1871$ & - & 12 & - & $1887-1891$ & - & 46 & - \\
$1872-1876$ & - & 40 & - & $1892-1896$ & - & 30 & - \\
$1877-1881$ & - & 21 & - & $1897-1901$ & - & - & - \\
$1882-1886$ & - & 56 & - & & & &
\end{tabular}

The maximum annual catch is 98 salmon. 


\section{CHAPTER XXIV.}

\section{THE RIVERS GRUINARD, EWE, AND CARRON (W. ROSS).}

\section{Angling Season: 11th February to 31st October. Netring Season: 11th February to 26th August.}

THE Gruinard has a great reputation, and upon this I fear it has nowadays to live. It is a little river which used to yield great sport, and in spite of the difficulty of getting there, it used to be much sought after.

The fishable part of the river is $5 \frac{3}{4}$ miles in length, being the course of the stream from Loch-na-Sheallag to the sea. The loch itself is $4 \frac{3}{4}$ miles long, and 279 feet above sea-level. Above the loch the stream which flows down from a higher hill loch of small size, called Loch-an-Nid, which is really the source, is about 6 miles, but it is so rocky and so small as to be no use for salmon angling.

One is here impressed by the feeling that for a small country like our own, there are some very remote parts. Gruinard Bay, with its large island, is a deep indentation of the coast. Little Loch Broom is a long, narrow loch amongst great hills, which enters the bay on the north. The Little Gruinard river enters from the south, after its rough course from the Fionn Loch. The whole country drained by the Strathbeg into Little Loch Broom and by the Great and Small Gruinards, lies to the western sea in a region of its own, shut off from the rest of the world by a magnificent amphitheatre of mountains. Habitations are few, the forests of Dundonnell, Gruinard, Inverewe, and Fisherfield, with their bare, rocky buttresses, high slopes, and deep corries, form a natural home for the red deer, but do not offer much support to man. The rainfall is copious, and the little rivers often swell quickly into torrents, but at other times the sun strikes hot, the sheltered waters of the Atlantic loose their longlifting swell in the quiet. lochs and bays, and glitter peacefully along 
the boulder-strewn shores, and the little rivers merely trickle through amongst the stones.

The Gruinard belongs to, and is fished from, Dundonnell, a small iron lodge being erected a short distance from the little-used road, where it crosses the river by a bridge rather less than a mile from the mouth. Right of fishing for one rod goes with Gruinard House, which is at the present time under trust, and which stands facing the bay to the right of the river mouth, and sub-lets are, I understand, not unusual. The Craig Pool, just below the bridge referred to, is the favourite, since from it have been taken surprising scores in the past. It is deep at the left side where the "Craig" slants straight down into the water. On the other side the channel is almost choked with great boulders. It is quite a little place, but 21 fish have been taken from it in a day, and a round dozen have been taken frequently. The river below this point has a steep course, with little cascades here and there, but with inviting poolsthe Pot and the Garden-at intervals. Above the bridge the course becomes much flatter, and seems to occupy the floor of an old lake basin, a prolongation, no doubt, of the present more restricted Lochna-Sheallag. There are about a score of pools in all, "Baring's Flat Pool" being the name of one which may be mentioned, since it recalls the name of a tenant long associated with the river.

No regular record is kept of the fish taken, and the sport is reported to have fallen off greatly of late years. With the commencement of season 1909 a limitation of the bag nets in the bay is to be inaugurated with a view to improving the stock. In 1908 only about 30 salmon and about 900 sea-trout are believed to have been taken in the river and Loch-na-Sheallag. It has to be recollected, of course, that it was a poor season for angling in most parts of Scotland.

About midway between the Great and Little Gruinard is a fishing station called Fisherfield, close to a tidal peninsula or island called Eilean Mor. Here a net is worked. This net has to be a moving net, to be worked legally, since its position is within the limits of the estuary prescribed by the 1868 Salmon Act for both the Gruinard rivers. "The projecting point west of Mill Bay" is the southern limit of this estuary, and some distance beyond this the bag nets begin. I counted thirteen nets on this southern bend of Gruinard Bay in July 1908, which is a rather smaller number than formerly.

The beach just west of the mouth of Little Gruinard is of an unusual kind. It is clearly a glacial moraine, but some of the boulders 
are of great size, and all are packed so thickly, and the sizes are so graded, that at low tide the appearance is very singular. The present line of the Little Gruinard seems to be roughly that of a great glacier which flowed from the upper end of Fionn Loch. As stated when dealing with the Ewe district, the floor of the Fionn Loch, at least at its lower end, is also paved with immense glacial boulders. The Little Gruinard is about the same length as the larger stream, but its course is much steeper, indeed, nearly three times as steep, and its waters are consequently much broken. It is practically a spate river, and can only be fished successfully by one who can reach it in the right condition. As a matter of fact, I believe it is very little fished. The salmon manage to ascend late to the loch at its head. A long, wide pool, a short distance below the loch-a pool which is practically a small loch-is fished at times from Lord Zetland's Lodge of Letterewe.

\section{THE DUNDONNELL RIVER OR STRATHBEG,}

Which flows into Little Loch Broom, has a fishable course of only about three miles, when a fall occurs. Below this the gradient of the river is easy, and considerable numbers of sea-trout ascend. The scenery is magnificent. Fishing is let with Dundonnell shootings. In 190722 salmon were taken. In 1908 about 8 salmon and 150 sea-trout constituted the bag, Mr. Mackenzie, the proprietor, kindly informs me.

\section{RIVER EWE, LOCHS MAREE, CLAIR, AND COULIN.}

\section{No Fishery Board. Rights of Salmon Fishing all over District held by} Sir Kenneth Mackenzie of Gairloch, Bart.

It is doubtful if any district in Scotland surpasses this for grandeur, combined with a singular beauty. Seen under almost any weather conditions the picturesqueness on every hand is most striking. Let the rain pour in torrents, and the bare buttresses of rock are covered with a filigree of cascades. Let the mists wreathe the tops of the great mountain masses, and the colours of the old red sandstone, the schists, and the venerable gneiss only glow with greater intensity. Let the wind lash Loch Maree into foam, it is in perfect harmony. Let the sunshine play upon the wooded islets, and a vista of fairy- 
land is disclosed. On every hand the eye and the imagination are captivated.

It is rather striking that the chief river should be called the Ewe, that the loch from which it flows should be called not Loch Ewe (which name is given to the sea loch into which the river flows), but Loch Maree; and further, that the place at the head of Loch Maree should be called, not Kinloch Maree but Kinlochewe. This name Kinlochewe is, however, believed to be a survival from the time when the fresh-water loch was called Loch Ewe. I am informed that on ancient maps this nomenclature may still be seen. No doubt the sea once came up to Kinlochewe; prominent beaches can there be noticed, but one can scarcely think that there were any human beings about in those days who told their children's children that the water was called Loch Ewe.

The limits of the estuary are not drawn across the entrance to Loch Ewe, but about three miles in from the entrance and before the loch widens out at Mellon Charles to enclose the Isle of Ewe. The limits laid down in the schedule of the 1868 Act are " a straight line drawn from Ru-na-Gavann on the west shore to $\mathrm{Ru}$ Con on the east shore," and the bye-laws of the Act setting forth those limits came into force in 1865, and of course have remained unchanged, since no power exists for any alteration. About ten bag nets are fished at the mouth of Loch Ewe, just outside the limits of the estuary. This number does not seem to have varied much since those nets were first introduced. On other parts of the coast of the district it would appear, however, that since 1896 the netting has been rather reduced.

When Hogarth had those fishings the practice was to boil the fish not only of Loch Ewe but also from Gairloch and Aultbea, at Poolewe: and before 1865, when the bye-law respecting the limits of the estuary came into force, bag nets used to be fished on either side of the upper loch, and just opposite the mouth of the river at Inverewe. Petween 200 and 300 salmon were then commonly boiled and packed at a time, and this number might be treated twice or even thrice a week in July.

There seems no manner of doubt that thirty or forty years ago the district produced a lot of fish.

RIVER EWE.

It is a little difficult to tell where the river begins, for Loch Maree at its low end is prolonged into a narrow channel, which only 
gradually merges into a river bed. From the foot of this prolongation the river has a course of only about a mile and a half to the sea. Where the current makes itself noticeable are three constrictions, named the upper, middle, and lower narrows, and these are regarded as the surest casts for salmon. "The middle narrow" has the highest reputation, but the glamour is rather a reflection from the past, for the number of salmon taken out of the Ewe nowadays is often very small indeed. The total has sunk, I believe, as low as eight. Yet, in the mile and a half of river from the "narrows" to the mouth, the water is beautiful, free running, rapid, yet with nice holding pools.

In general character the Ewe resembles the Awe. "The narrows" corresponds to the Brander Pools, and immediately thereafter the water becomes rapid and broken, and goes hurrying down with two big bends to the sea at Poolewe. A cruive used to exist in ancient times not far above the road bridge at Poolewe. Later this structure was shifted to what is now called "the old cruive pool," about halfway up the river. Ultimately the cruive was moved still higher up below "the lower narrow" to enable more angling to be secured below. The structure was finally removed, Mr. Osgood Mackenzie informs me, in 1847 or 1848 , and the stones may still be seen at the bank of the river. The walls in the old cruive pool were not removed in the same way, but additional walls were put in at the foot of the pool in order to raise the water level, and enable water to be taken to Pool House by means of a ram. This old cruive pool is, therefore, a much-built pool, while in one or two other pools piers or jetties have been erected for the purpose of securing a better cast. In the cruive pool and in those jetties we have other resemblances to the river Awe. The only difference is that the Ewe is a fourth of the Awe's length, and that fish, therefore, run through it all the more rapidly.

Great numbers of fish were taken out of the river when the cruive existed. In the early thirties an old man, lately dead, saw three cobles full of fish taken by one haul of the net in the tidal pool at Pool House. Sea-trout were then given away to the poor. As a boy Mr. Osgood Mackenzie started fishing nearly 60 years ago. His first two days resulted in 12 fish, the heaviest being $27 \frac{3}{4} \mathrm{lb}$. Another tale, reminiscent of the former plenty, is that of a few young bloods who were at a wedding dance at Poolewe one night in autumn, and realising that all the neighbourhood was there also, and that, therefore, no one would be "burning the water," these young 


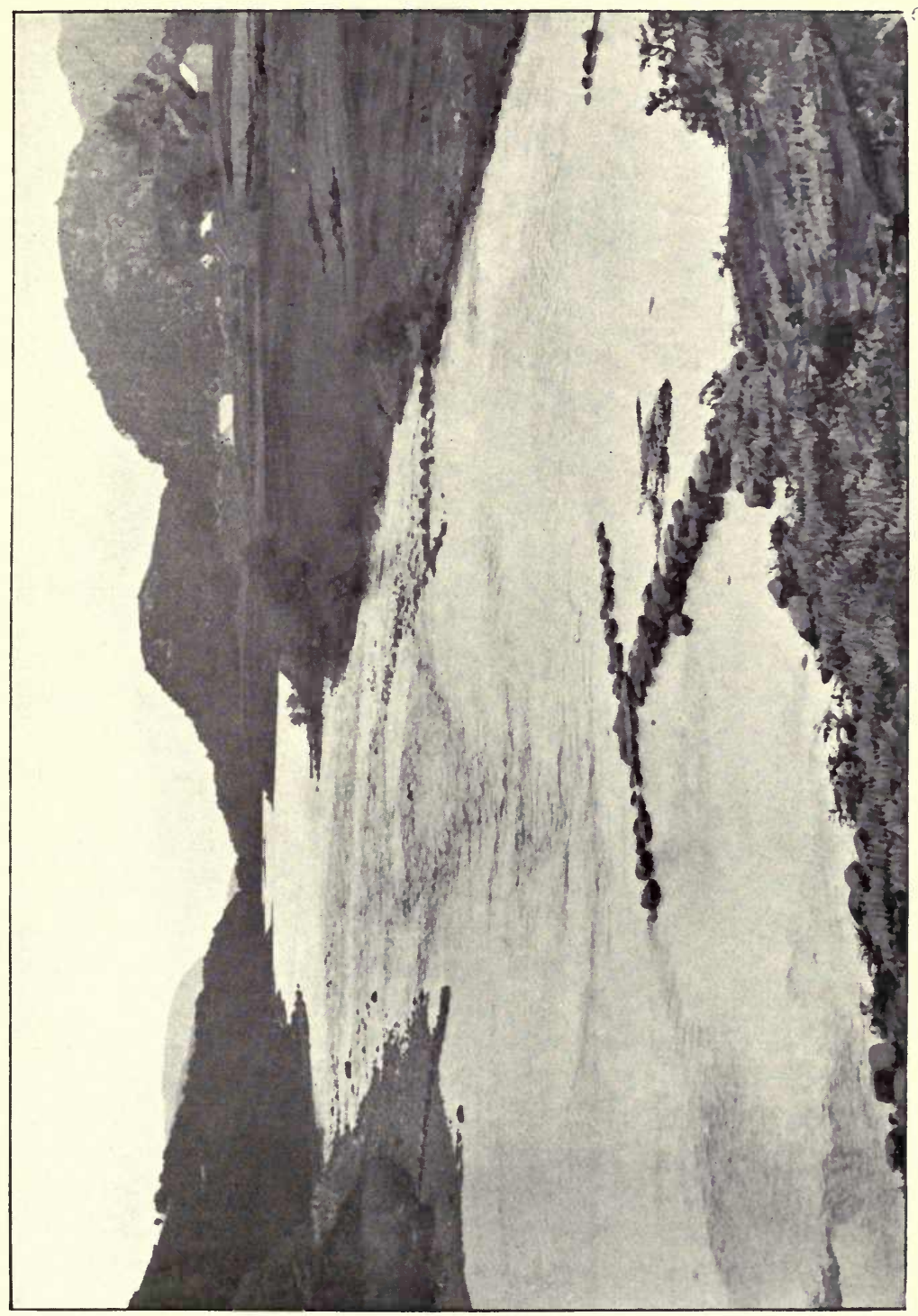

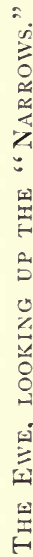



fellows set off to the Inveran river, a stream which enters Loch Maree a short distance above the outflow of the Ewe. They speared 17 fish out of the river, and were back at the dance again almost before they were missed.

Sir Kenneth Mackenzie, in giving evidence before Lord Elgin's Commission, explained that the cruive dyke which formerly stood at what is now called "The New Cruive Pool" was never fished by means of cruive boxes with inscales, and that the reason for its removal in his father's time was to lower the level of Loch Maree in order to prevent flooding on farms at the head of the loch.

It is noteworthy that, since the removal of the cruive dyke, the rod-fishing on the Ewe has declined. It need not be asserted positively that the decline was consequent upon the removal of the dyke, but that the result has been to make the floods on the Ewe more severe in their scouring action in the river bed, and to facilitate the uninterrupted run of fish through this short and rapid river.

If, as has been stated by Sir Kenneth, the removal of the dyke lowered the level of the loch, it seems to follow that after periods of low level in the loch the presence of the dyke would act as a regulator of the river flow till such time as the loch reached the level of the top of the cruive dyke, and that, therefore, in spite of the two gaps which probably existed in the dyke, the structure acted in a modified way as an impounding dam. Spring fish were in former days taken from the date of opening. Grant, the Pool House keeper, informs me he has taken two fish of $8 \mathrm{lb}$. or $10 \mathrm{lb}$. on the opening day, and that he always expected, in former years, to have a fair number of fish in February and March, fishing on the four days a week which are allotted to Pool House. Sometimes the March fish were a little coloured. In April the Pool House rod has taken as many as 24 fish.

This speaks to a fair number of fish in or passing through the river in spring. The action of the cruive dyke would be first as a direct check to ascending fish, thus enabling the angler to have a much longer time at his disposal to ply his art on the congregated fish, and, secondly, to produce on the whole a less violent current. Spring fish do not readily lie in strong broken water as summer fish will often do. The total gradient of the river is roughly about 1 in 85. I an inclined to the view, therefore, that the cruive dyke made for the better angling of the river, while it in no way reduced the value of the upper water fishing in Lochs Clare and Coulin, to which fish easily ascended in early summer, as they do still. 
If the additional scourings out of the river bed, consequent upon the unrestricted floods from the loch, have reduced the spawning beds of the Ewe itself, additional harm has been done by the removal of the dyke, but I do not consider that fish which formerly spawned in the Ewe would necessarily form the habit of frequenting the Ewe and not penetrating to the upper waters.

July is generally considered the best month on the Ewe, but I have heard the opinion expressed by one who has had considerable experience of the river that there are even now more fish to be got in spring than in summer. The late Sir Kenneth Mackenzie's best day is reported to have been 10 grilse-presumably in June or July -and Mr. Dixon, who was tenant of Inveran for a number of years, had a day of six grilse. Sir Humphry Davy, in his Salmonia, speaks of the Ewe as a certainty for sport in summer, and adds that when the cruive existed further up the river than at time of his writing (1813) the Ewe was a good second to the Brora. The statement about the cruive does not seem to me to be accurate if my information as to the history of that structure is correct.

Mr. Dixon, who at Inveran had two days a week on the river, the four others going with Pool House, reported to the Fishery Board for Scotland that in his 17 years' tenancy the take of fish averaged about 40 in the season. On looking over the bridge at Poolewe one day in July, 1908, I saw more than that number swimming about in the tidal pool, most of them were probably grilse, and a large number of sea-trout were also in waiting, leaping from time to time all over the pool, as their habit is. The river was dead low, and ascent was well-nigh impossible. A shoal of fish kept moving about the pool, headed by a salmon of $15 \mathrm{lb}$. or $16 \mathrm{lb}$., now approaching the pure water inflow at the top of the pool, again retiring to the brackish water further back.

If the number of fish taken be small, the size of individual fish is sometimes great, and the "playing" proclivities remarkably active. The record fish is one of $50 \mathrm{lb}$., killed on the fly, by Grant, the Pool House keeper. Several fish over $30 \mathrm{lb}$. have also been taken.

The Ewe is, I consider, a river which will be most readily restored to a condition for good angling by reverting to something analogous to the artificial obstructions of its better days. I know not if the raising of the loch would now flood farms at Kinlochewe, and in any case it is not desirable to make the river steeper than it is or to have recourse to any barrier thrown completely across the stream. The most suitable line of action, in my view, is to have resort to 
rather extensive croy building in order to improve the holding capacity of the existing pools and streams. I see no prospect of dealing in any practicable manner with the reduction of netting, for netting cannot be said to be severe, or to be greater than in the best days of the river. The object must, I think, be to improve the rests and lies of the river itself.

This can be done by a careful study of the water and the introduction at properly chosen places of properly adjusted croys or jetties which will direct the water-flow as may be desired and, in this instance, materially aid in holding up the volume of the streams without creating too heavily concentrated rushes of water in the lower section of the river.

It is an operation which requires great judgment, but $I$ believe would result in re-making this splendid river, if properly carried out.

\section{LOCH MAREE.}

This magnificent loch is also a disappointment so far as salmon are concerned. Very very seldom is a salmon encountered, although numbers of sea-trout are got, and the water is much fished by visitors at Loch Maree and Kinlochewe. From the former 12 loch beats are fished by 12 boats, and four or five boats fish from Kinlochewe. The narrow channel already referred to as occurring at the outlet, in the bay where the Inveran river enters, used to be famous for sea-trout, as many as 70 having been taken in a day.

The loch is about $13 \frac{1}{2}$ miles long, and the mean breadth about nine-tenths of a mile; the maximum breadth occurs where the numerous islands exist, and is two miles across. The water covers 11 square miles, and the drainage area is 15 times that extent, or 171 square miles. Many shallows occur between the islands, and the bottom soundings show three basins with a mean depth of 125 feet. The loch is 32 feet above sea-level.

The line of the loch lies along that of a powerful fault in the earth's surface, and Messrs. Peach and Horne, of the Geological Survey, in writing of it say that on this account they prefer not to discuss its features in connection with the theory of the glacial origin of lake-basins; $;^{1}$ but at the same time they add : "Throughout the Loch Maree district, and especially in the mountainous region embracing the Torridon sandstone and Cambrian quartzite, there is evidence of intense glaciation. During the climax of the glacial

${ }^{1}$ Scottish Geographical Magazine, xx., No. 12, p. 638. 
period even the highest mountains in the Loch Maree district were overridden by the ice, and further along the top of Ben Slioch (3217 feet), which, as already indicated, is composed of Torridon sandstone, blocks of thrust Archaean gneiss, Cambrian quartzite, and Moine schists are met with, all of which have been derived from the East. Similar evidence is obtained on Meall Ghuibhais (2882 feet), on the south side of Loch Maree. Again, in the Coulin Forest, on the lofty ridge running south from Sgura Dubh (2566 feet) to Beinn Liath Mhor (3034 feet), striae have been recorded pointing in a westerly direction at elevations ranging from 1750 to 2000 feet."

At the close of the glacial period the high mountains on either side of Loch Maree seem to have been independent centres of glaciers moving in a westerly direction, and uniting in the main basin. A visit to Fionn Loch, parallel and to the north of Loch Maree, the source of the Little Gruinard River, and celebrated for its large brown trout, shows in this valley also great glacial moraines. The bottom of the loch, at its lower end at least, seems filled with immense boulders. A brown trout of $18 \mathrm{lb}$. was taken from this loch, and trout of $14 \mathrm{lb}$. and $12 \mathrm{lb}$. have also been recorded. Trout of $6 \mathrm{lb}$. and $8 \mathrm{lb}$. are apparently not very uncommon. These trout seem to escape the designation of ferox.

Loch Maree is remarkable also for its number of beautifully wooded islands. There are twenty-seven of them lying in the centre of the loch immediately opposite and to the west of Loch Maree Hotel. The loch bottom between many of the islands is extremely shallow, so that, when the loch is very low, a rowing boat can scarcely pass. Between others the channel is amply sufficient for the passage of the little steamer which plies on these beautiful waters in summer.

The water is very clear since the loch is fed by streams flowing from bare mountain ridges. During heavy rain enormously steep little water courses drain the very summits of the mountains, and rush their streaks of white water straight down into the loch as torrents descend the sides of Norwegian fjords. The river Ewe is always as clear as crystal no matter how it may rain. The streams which enter the loch on the south side at Talladale and Bridge of Grudie are of little use to the angler, although the latter has about three miles of comparatively level, if very stony, course before entering the loch. The stream from Lochan Fada on the north side is quite impassable to salmon.

The Kinlochewe river, as its name implies, enters at the top of 


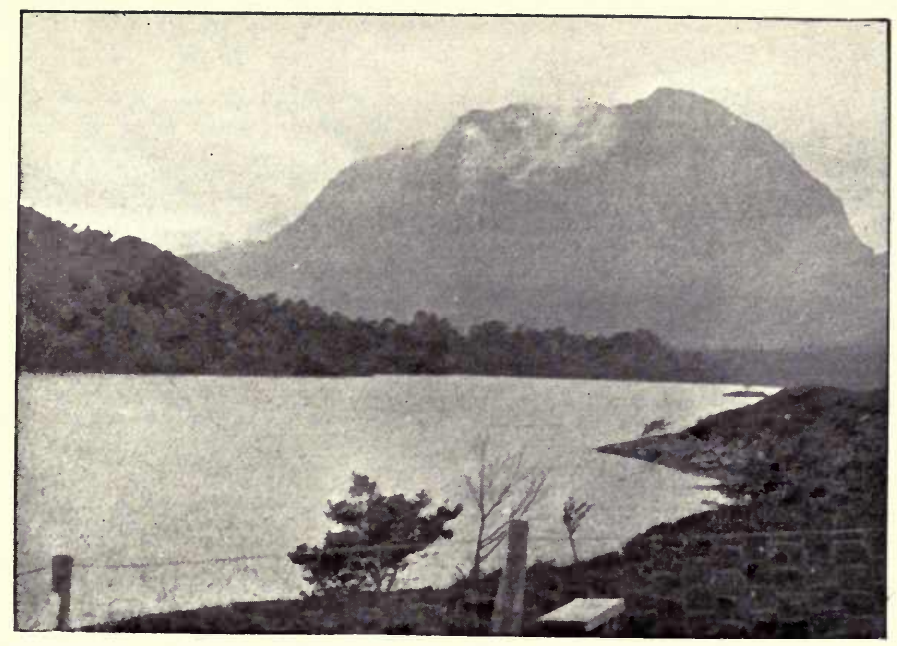

Loch Ci.ake.

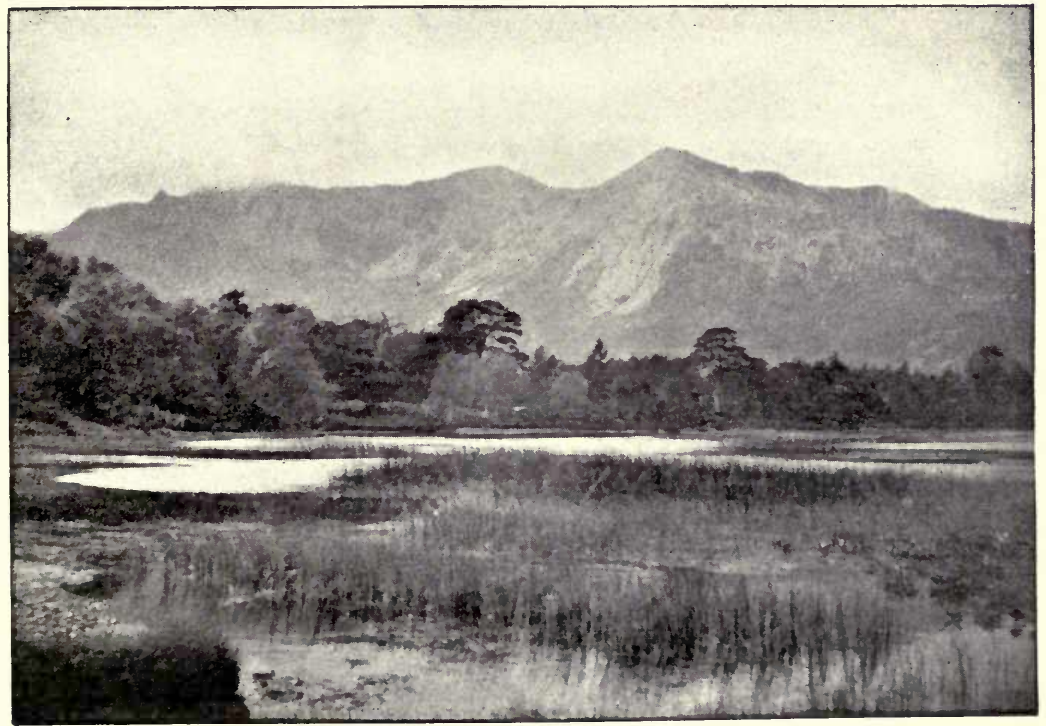

Loch Conlin, head waters of Ewe District. 

the loch, and flows gently with great bends through an alluvial flat edged with raised beaches. Close to Kinlochewe Hotel it receives two streams, one from the north, the Bruachaig, a useful spawning stream, the other from the south, the Ghairbhe, which drains Loch Clair and Loch Coulin, and as the Coulin river rises from the high ridges 900 to 1200 feet up overlooking Glen Carron a short distance above Achnashellach. This is the channel up which ascending fish chiefly pass and where, in Lochs Clare and Loch Coulin, they congregate in considerable numbers. Near Kinlochewe there is a small hatchery and two rearing ponds where both salmon and sea-trout are dealt with. In 1908 some 60,000 yearling salmon were turned out by Sir Kenneth Mackenzie's direction.

\section{LOCH CLARE AND LOCH COULIN}

Fish well from June onwards, the fly alone, I understand, being used. I have known of 7 salmon taken in Coulin in a June afternoon. The fisherman was a naval officer, who, like myself, was stopping at Achnashellach Lodge. He kept us waiting till about nine o'clock for dinner, and rode in on a bicycle carrying 4 fish. As he dismounted he remarked that there were three other's he could not carry. He said he had fished for salmon twice before. Michie, the old stalker, held up his hands in amazement, and said he had never seen as many as 7 salmon brought from Loch Coulin.

The lochs are most beautifully situated, and Loch Clare, where Sir Wm. Ogilvie Dalgleish has a lodge, has the reputation of being the most beautiful loch in Ross-shire. It lies, as it were, in the bosom of the hills encircled by belts of grand old Scotch fir, and varied by lovely little islands. It is a typical glacial basin, the islands being composed of the old moraines. The late Lord Elphinstone caught 140 salmon here one summer, and a good score is generally obtained, not a few of the fish being heavy. Like most really good places, it is a strict preserve, and one does not hear much as to results.

The land around the two lochs is divided between Sir Kenneth Mackenzie and Sir Wm. Ogilvie Dalgleish, but the fishing rights belong exclusively to the former, who rents the fishing to his neighbour. 


\section{THE CARRON OF WEST ROSS-SHIRE.}

\section{Angling Season : February 11th to October 31st. Netting Season : February 11th to August 26th.}

In a region where most of the rivers are small, the Carron, although in itself not large, has to be regarded as a river of considerable importance. It is the largest river in the whole stretch of coast opposite the Isle of Skye, or between the Ewe from Loch Maree and the Shiel in Moidart. It is, moreover, a river of fine natural features, and of good spawning ground. It should have a much better stock of fish than it appears to possess.

The river rises from Loch Scaven (Sgamhain), 491 feet above sea-level, past which the railway line from Dingwall to the Kyle of Loch Alsh runs, and flows south-west for 14 miles to the sea at the head of Loch Carron, being followed very closely by the railway throughout its course. It is divided into two well-marked sections by Loch Doule (Dhughaill) at Achnashellach. The upper portion from Loch Scaven to Loch Doule is steep and rocky through Glencarron, till the stony flat is reached above the latter loch. This section is of little use for fishing, although the streams in the stony flat are of great use as spawning grounds. Loch Doule is barely two miles long, and, from the lower end, the river emerges by a long sluggish channel, and gently flows off to descend about 100 feet in the remaining $5 \frac{1}{2}$ miles to the sea. This is the angling section of the water. It is tortuous in its upper section, and rather shallow in some of the streams. A short distance below the railway bridge, where a burn joins on the right from a high hill loch, reported to be full of small char, a large pool occurs which holds fish all through the summer. When Lord Wimborne had the river he had hecks placed across the sluggish outflow from Loch Doule to prevent fish passing through the river too rapidly, and at this time the large pool referred to was a familiar haunt of the late Lord Randolph Churchill, whose gillie told me he had a trying time of it plunging into the water to rescue precious flies for the somewhat impetuous fisherman, who at last rather blamed him for taking so much trouble.

Between this and New Kelso the course of the river is comparatively straight, and then a series of fine bends, with good flowing gravelly pools, succeed to the mouth of the river. The head of Loch Carron, like the head of most sea lochs of its kind, has a shallow 
sandy flat through which the fresh water is very apt to open up side channels in time of flood. These, under ordinary conditions of water-flow, spoil the concentration of volume which is so desirable at the mouth of a river, and result at times in a condition unfavourable for the ascent of fish. It is notorious, moreover, that not many miles from the mouth of the river two or three crews of fishermen have their dwellings, who, in the past at least, have made it their business to "scringe" the mouths of streams for salmon and seatrout. It is believed that the Carron has frequently been seriously affected by the nightly nettings of these men.

The volume of water in the Carron is usually sufficient to induce spring fish to ascend. Clean fish have been caught in the river as early as 11th February, and, given suitable water-flow, April and May yield very fair results to the rod. The land drained by the river is very steep and rocky, and in dry summer weather the shrinkage of the river is apt to be too great for sport. A very excellent result would be obtained, I believe, if Loch Doule could be raised a few feet, and sufficient water impounded to create increased water-flow in summer. The ground at the outlet is very hammocky and uneven. In early geological times it seems probable that a much larger lake existed here, and when glacial erosion was carried to its climax the present loch resulted, and the hummocks were formed. If an examination of the levels showed that the erection of a suitable dam for raising the loch were possible, it is more than likely that an additional benefit would result in preventing early fish becoming practically lost in the loch. A certain number of fish are caught in the loch at present, but an increased number taken on fly in the river would far more than compensate for the reduction of the loch take which might result, even if the best of salmon passes were added to the dam. The run of summer fish, when the temperature of the water had lost its wintry conditions, would not be greatly influenced by the change.

Takes by the rod at present vary very much indeed, due not only to the fluctuations of water-level, but to the varying amount of fishing which is carried on. For instance, in Lord Wimborne's time, the maximum was 122 salmon in 1883 , but the minimum was 5 in 1880 . 


\title{
CHAPTER XXV.
}

\section{THE STREAMS OF THE OUTER ISLES AND OF SKYE,}

\author{
INCLUDING GRIMERSTA, BLACKWATER, LAXAY, ETc.
}

\author{
Lewis Angling Season: 11th February to 31st October. \\ " Netring Season : 11th February to 26th August. \\ Harris and Uist Angling Season: 25th February to 31st October. \\ " Nemting Season : 25th February to 9th September.
}

AuIDst the almost innumerable lochs and streams of the Outer Isles there are some which are of considerable importance for salmon fishing, others of importance as sea-trout waters. I do not propose to refer to the labyrinth of lochs and tidal streams which form such ideal sea-trout fisheries in North and South Uist, although these are dear to many an angler. Reference to sea-trout is only made in connection with waters where salmon are chiefly looked for.

Away in those Outer Hebrides are one or two waters which for years very few knew about as fishing places. A few enterprising sportsmen had found them, and had quietly settled down to a period of enjoyment; but it is only within comparatively recent times that it became generally known that certain fishings in those parts were worth considerable effort to secure. For many years a small and close company of anglers made great scores in the Grimersta, but they did not tell the public much about it, and their little fishinglodge contained only enough bedrooms to accommodate themselves. There are to this day 6 bedrooms and 2 sitting-rooms in Grimersta Lodge, and to the stream and lochs fished from this base I must first refer.

Before doing so, however, it is well to state that the system of impounding or holding up the waters of the lochs, from which various streams come, was first adopted in the Long Island by that splendid old sportsman Mr. Hutchinson, who, writing under the nom. de plume of "Sixty-One," gives such charming accounts of his life in 
the Lewis. ${ }^{1} \mathrm{He}$ was the tenant of Soval, and gradually improved the sporting value of the place so much that at length a time came when he could no longer pay the increased rent demanded. His book is well worth searching for by any who are keen with rod and gun, and, we may add, with dog, for "Sixty-One" dearly loved his dogs.

He had suffered, on the Blackwater river, which enters near the Grimersta, from seeing fish unable to ascend, and having them eventually caught by bag nets, which were then permitted up near the head of Loch Roag. "In this state, then, memory, not inspiration, came to my aid," he writes. "I bethought me of the Costello in Galway, by whose pleasant side I had, in former days, killed buckets-full of fish; and in imitation of what I had there seen practised, I dammed up Loch Dismal (his name for one of the lochs from which a source of the Blackwater flows). Across the mouth of this loch I erected a dam and sluice similar to the common milldams of the country, taking care, of course, not to shut the sluices so close as to run the branch of the river dry. I thus kept back water enough to create an artificial spate, which I let go exactly in time to meet the high spring tides that bring the fish up to the rivers' mouths, which they take, wind and water permitting.

"I found the experiment answer perfectly, and over and over again I ascertained to demonstration that the fish took the river with my artificial, just as they would with a natural spate. By judiciously keeping up a supply of water, I freshened up my river as it grew low, and brought up, ever and anon, fresh fish."

This experiment met with much opposition, of course. It was an interference with the arrangements of nature. Gillias said fish would not run in "rotten water," as they described the artificial spate water; it was not rain fresh from heaven. The same sort of criticisms were made in the Helmsdale district when damming operations were carried out there. But in both places the damming has been a distinct success. The operations on the Blackwater were ultimately so widely acknowledged as successful, that similar operations were carried out on neighbouring lochs. The Grimersta had a dyke, as it is called in Scotland, or a dry-stone wall, as it would be called in England, thrown across the outlet of each of its lochs. These form only very imperfect impounding walls, but are found to be sufficient. No sluices are used, even at Loch Langabhat, which is $7 \frac{1}{2}$ miles long, although here at one time a grating was in exist-

1 Twenty Years' Reminiscences of the Lews. By "Sixty-One. Horace Cox. 1871. 
ence to prevent fish running up too fast and being lost in the large loch. The formation of the dyke on the lowest loch carries a tale with it, which will be given presently. At other lochs in the Lewis the dams have now been allowed to fall into disrepair and uselessness.

A peculiar affection sometimes is noticeable amongst the fish which lie long in the shallow salt-water bays waiting till suitable floods come for their ascent. It is locally described as the White Spot, and has no connection with the ordinary salmon disease.

Through the kindness of Mr. George Pople, the present tenant of the Grimersta fishings, I have received several specimens of fish showing this peculiar ailment. When the streams become sufficiently swollen after rain to admit of their ascent in fresh water, "the white spot" disappears. The only reference to this disease of which I am aware is in Scottish Moors and Indian Jungles, p. 141, by Captain J. T. Newall, who was at one time tenant of Scaliscro shootings, just south of Grimersta. It is as follows; "The summer in the Lews in 1880 was remarkable for the unusual heat. Salmon, in consequence, could not ascend the rivers, which became so attenuated as to afford no waterway for them. Fresh water being equally necessary as sea for the health of the fish at the proper season, they suffered in consequence. Many became quite blind, and developed a white spot on the head, the result being the death of numbers near the mouths of rivers." The natural inference is that the lack of fresh water is responsible for this trouble. This I consider very unlikely indeed. The blindness, the bright sunshine of hot weather, the perfect translucency of the sea water around these western islands, and the shallow nature of the estuaries or bays in which the fish congregate, seem to me to suggest a different cause. One is reminded of the pale-skinned, sightless condition to which fish are reduced when confined too long in aquaria exposed to sunlight. When in Stornoway in 1902, I was informed by a former gamekeeper at Stornoway Castle, the present lessee of the Royal Hotel, that in summers when this disease is really bad, the fish become so helpless that boys stone them and drag them ashore in the neighbourhood of the harbour, but it is evidently unusual for fish to become blind or to die of the disease. Mr. Pople, in sending me the specimens referred to, informs me that he had never seen a fish dead from this cause. The summer of 1905 was unusually dry, and one of the specimens sent was described as the worst Mr. Pople had seen during his tenancy. The dull white appearance had 
developed into a raw, red sore. The significant remark is also made in a letter of 14th August, " although we have had it very dry, it has been more or less cloudy and windy, it (the disease) would have been worse in brilliant sunshine and light east or no wind." One specimen examined by me was killed on 14th August, and represented, I believe, an average state of the peculiarity. The skin was unbroken, the white area being noticeable not only on the crown of the head but to some extent in the occipital region behind the head, it also extends downwards to the operculum, in which region, I am assured, it first appears. It was not noticeable in front of the eye, which organ appeared to be normal and functional. The colour was a dead white, slightly clouded here and there with a bluish tint. Pigment remained in the dorsal region only at the end of the snout and in a patchy manner above the eyes. There was a distinct depression in the region of the cranial cavity above the brain. The fish was otherwise healthy and in splendid condition, with pyloric appendages loaded with fat; indeed, it may be stated that the disease does not appear to reduce the plump condition of the fish affected. In another specimen received, killed on 24th July, and showing the disease in a more advanced state, no very marked difference was noticeable on the crown of the head, but the white area above the muscular tissue just beyond the head showed the surface broken and ulcerated in three places. The spreading of this condition over the circumscribed area ultimately seems to give rise to the prevailing red colour seen in the worst specimens. On lifting the specimen killed on 24th July from the box in which the fish came: the pupil or lens dropped out from one of the eyes. The specimen was certainly not very fresh, having been sent during the hottest of the summer, and having taken three days to reach Edinburgh from Grimersta Lodge. Still this could not, I consider, account for the ease with which the lens of the eye dropped out. In no specimen which I have seen or of which I have heard has the fish been affected except in the region of the brain and medulla.

\section{GRIMERSTA.}

This, the best fishing in the Lewis, and for its size one of the most productive fishings in Britain, consists of a chain of four lochs and a short little river to the sea at the head of Loch Roag, on the west side of the Long Island, about 15 miles across from Stornoway. The great benefit of the lochs to this fishing is that of water supply. It 
is fed primarily from the largest fresh-water loch in the Outer Isles, Ioch Langabhat, or the long water, a name which, like very many of the place-names in those parts, has a marked Scandinavian tincture, reminiscent of the days of the Vikings.

Where catchment basins are so small as on those islands, the presence of lochs are more or less indispensable, for although the rainfall is very considerable, the streams are of necessity very small, and a short spell of dry weather results in marked shrinkage. It is a wonderful sight, in bright hot weather, to see the salmon jumping in the bay at the mouth of the Grimersta. At times when the fish have congregated in great numbers, being unable to ascend the little river to the first loch, they leap with surprising frequency. Almost every second a bar of glittering silver seems to flash out in the sun, and one may sometimes see quite a number in the air at once. If this display happens to be going on when the jaded traveller rounds the last bend of the road in his journey to this Ultima Thule, how his spirits revive, how smartly he sits up in the trap to feast his eyes on the wonderful sight.

The fishing is almost entirely from boats in the four lochs, and this to some is a drawback, to others an advantage. The Grimersta river proper is only a mile long, and is not of much account for fishing, since fish, when they can run, generally run through into the first loch at once. It is, therefore, portioned off as only a part of the second beat. The streams connecting the other lochs are only short runs, where a cast or two may be taken, as it were, in the bye-going.

There are five beats, and a single rod fishes each, fly alone being allowed. The beats are arranged as follows:

"No. 1.-The north half of the first loch as divided and marked out. "No. 2.-The river up to the boats ;on first loch; also, the second loch from the top of the stream to the top of Mackay's Stream.

"No. 3.-The south half of the first loch as marked, including the stream.

"No. 4.-From the top of Mackay's Stream to M'Phail's Island.

“No. 5.-From M'Phail's Island, including M'Phail's Bay, to the top of Loch Langabhat."

When one or more of the party are absent for more than two days, the beats are rearranged in a definite order, so as to suit 2,3 , or 4 rods as the case may be. 
A great feature about these lochs is that they are shallow, and for the most part with gravelly bottom. Like other small and shallow lochs into which fish quickly pass, they are free rising places. The fish do not usually run heavy, about $7 \frac{1}{2} \mathrm{lb}$. being the average for salmon and grilse, with occasional examples of 18,20 , or $27 \mathrm{lb}$. When floods occur the fish usually become pretty quickly distributed over the chain of lochs. The great record fishing was, however, accomplished under quite unusual circumstances, an artificial flood being induced which allowed fish into the first loch only.

Mr. Naylor, who made the record score of 54 fish one day, has already given an account of his fishing in the "Fur, Feather, and Fin" Series (Salmon). Another account of the whole week's fishing was contributed to the pages of The Field of November 8, 1902, by one of the two others who participated in it-Mr. Hansard-and this I take the liberty of quoting. The fishing was by fly alone, but it is the habit on the Grimersta to fish two flies on the cast. The year was 1888 :

"That year there had been no flood or even high water since the spring, and I never saw the moors so dry, the edges of the peat looked just like the stacks of fuel ready for burning. By the tine we arrived (July 30 ) there was a great accumulation of fish waiting to run up, and, the river remaining impassable, the stock kept increasing daily. The great run of fish on the Grimersta is from the middle of July till end of August.

"As I have said, the lodge stands on the seaside some mile and a half down the fjord into which the river flows, the fjord opposite the house not being more than half a mile broad. The strength of the tide there runs very strongly on the side opposite to the house. It was a curious thing to notice how at every tide the shoals of fish followed the current, jumping regularly at just the same places at the same stages of the tide as it flowed and ebbed. This gave me a very good insight of what must happen when fixed nets are set along a coast line, for the salmon seemed to play up and down the tideway for many days, even when the river was quite passable to them. Owing to low water the river was impassable, and this daily promenade of the shoals of salmon and sea-trout was much more remarkable. Just outside the river mouth was a round sort of basin, and it was round and round this that the fish seemed most to congregate at high tide, showing their back fins as they swan round.

"Though the fish swarmed here, and though I tried for them with all sorts of baits, as well as with the fly, I never caught a salmon in salt water there fairly, and but a few sea-trout. When we wanted any for the house it was a simple matter to get then there, for one only had to wait for a shoal to come by, cast over them with a big weighted fly, and snatch into one. The fish staying so long in the estuary after they were ready to run into fresh water, seemed to sicken, and many got large white patches on their sides and heads; but directly they got into fresh water this disease left them. Some were so 
badly diseased that we used to find a good many left dead on the rocks at low tide.

"The party, five rods, of which I was one, had the fishing for the month of August, and things got more and more hopeless as time went on. So bad, indeed, that two of the party left before the end of the month. From the formation of the lochs, it struck us that an artificial spate might be made by cutting away the river bed and letting down water from one of the upper lakes. We explored all the likely places, and at last hit upon the lower end of Loch Langabhat as being a suitable place for the work. This was easier to do than it sounds, as some years before a hatchway had been made there, with a grating to keep the fish from running into Loch Langabhat. Unfortunately, this useful work had gone to ruin, but it was easy to grub up the bed of the stream where the grating had been, and so let down nearly 2 feet of the big lake, which is ten miles long by half to one mile across. At the bottom of our first loch, i.e. the one nearest the sea, we then made a dam across the river head, some 6 feet high, as solidly as we could with rocks and turves. All this was rather against the opinion of the gillies, who declared that no salmon would run up except in water fresh from the sky. As the water gradually worked down through the chain of lochs it filled up this lower lake to the top of the dam. But this took a long time, nearly a week. When at last this was accomplished we were ready to cut the dam, and, as it was some one and a half miles from the sea, we reckoned (as it proved, correctly) that it would take an hour for the water to reach the sea from the lake. On August 22 the high tide was about 4.30 , so the dam was cut after lunch, and, as a fact, did not take much cutting, as in a few more hours it must have given way.

"As I had described, at the mouth of the river was the large sea basin, at high tide crammed with fish pressing up as near as they could to where the little trickle of fresh water was still running. As the fresh water fron the loch came rushing down the excitement began. First a small shoal of salmon tried the passage, then more came rushing in. So madly did they swarm in that they pressed each other to the sides, and many ran right ashore or scrambled up in water not deep enough to cover them. Had we wished, nothing could have been easier than to have scooped them out in landing nets by the score.

"We sat watching this wonderful sight till it grew dusk, and had long given up counting or trying to estimate the numbers of fish running in. They nust, without exaggeration, have run in by thousands in the forty-eight hours that our spate lasted. The next morning, I well remember, was clear and bright, and, walking up the river, the pools seemed literally paved with fish, even in all sorts of unlikely and unaccustomed places. A day or two before I had tried for some fish in the sea, and, as usual, they would not play the game, so the snatch hook was put on. I hooked a big fish, nuch marked with disease on the head, but, after playing, I lost him in the seaweed, a not unusual occurrence in the sea. The cast broke about a foot from the large Golden Eagle I had on. On the morning after the dam cutting I saw my fish amongst some others on a shallow. So also did my sharp-eyed gillie, little Jhonit, who was much excited at the chance of recovering the 'Wooley Dog,' as he used to 
call the Eagle fly. In he rushed, jumping like a monkey across the stones. He got right up to the fish, made a grab at it, and got hold of it for a moment; but lost his footing, went head over heels into the water, and away rushed the never-to-be-forgotten, ever-to-be-remembered, Eagle-bearing fish. For the first few days after the fish had gotten into the first loch they had not settled down, and we did not have more than average sport. Two rods were fishing on the loch and river, and got 17 and 12 on Wednesday ; Thursday, 31 and 18 ; Friday, 2 and 6 ; Saturday, 15 and 23. But the big week was to come. Unfortunately, as I before said, two rods left on Saturday, the 25th, leaving only three for the finish of the month.

"I have often been asked how it was that one loch produced all the fish, a quite unusual state of things, as in a normal year No. 1 was by no means the best beat. Our flood was made by damming up one lake; so unlike a natural flood which would have taken the fish up to the head water had they cared to travel so far ; our spate rushed them all into No. 1 loch, and there left them, for it was only at quite the early stage, when the level of the lake was still high, that they could run into No. 2 loch. As a fact, we did catch some in that loch in the next week. So fish enough to stock twenty miles of lochs were crammed into one loch not three miles in circumference.

"Now as to my experiences on the days on which I fished the loch. The rules of the fishing were laid down with great preciseness, and, as there were only three rods instead of the usual five, it was ordained that only one rod should fish this first lake, though in an ordinary way it made two beats. As things turned out, we made a great mistake in not overriding this law, and all three could well have fished in the one loch, where I really believe we should have killed 500 in the week. Instead of which, by the rule, we only got the lake two days each in the week, and on the other four days got practically nothing, there being only a stray fish in the river and in No. 2 loch. The first of these days was, I have often thought, the one on which I should have caught the most fish. But I had asked a lady who was staying at Moorsgale to come over and fish, she never having caught a salmon. She came at about ten, and stayed till five in the afternoon. Just as in the sea, the fish kept in shoals, and whenever we caught sight of them we rowed hard towards them, and as soon as the fly went over it was quite a certainty to rise one. But the fly would not go straight, and striking was very difficult. Over and over again I saw a fish rise open-mouthed at the fly, seize it unmolested, and spit it out of his mouth. Then a panic strike, too late to hook the fish, and, as the fly was dragged away, another mad fish would go for it, all this only a few feet from the boat. After many troubles the lady caught quite by herself nine fish. At intervals in the day I caught some half dozen, and, after the lady had gone home at five o'clock, I caught twelve more fish by seven o'clock, when I stopped fishing.

"The second day on which I had this lake was Saturday, September 1, the last day of our month. A. M. Naylor had broken all likely records by killing on Tuesday 54 fish and on Friday 45, so I had no great hopes of anything to approach his scores. I began well at 9.15. The day was a perfect fishing day, cloudy, enough wind, and slight showers, but the mist was low on the hills, which, we had always been told, was a bad sign. Since September 1, 1888, I 
have always treated that particular omen with little heed. From 9.15 till one o'clock I was hard at work killing fish as quickly as I could; but then, for some strange reason, not a fish would move, and for two hours I literally flogged without rising, or, if I remember rightly, seeing a fish. I thought the game was up; but then the fun recommenced, and, working hard till seven o'clock, I killed 46 fish, just beating Naylor's second best.

"It was a grand day's slaughter, but, as far as fishing went, most demoralising. As soon as a fish was hooked there was no nonsense about playing him scientifically, down went the point of the rod, and pull hard was the order of the day. If the fish broke away, as often happened, it did not matter, as another was soon on again. George Probyn's experience of being for an hour and a half towed about the lake by a foul-hooked $27 \mathrm{lb}$. fish showed me that no wasting time must be indulged in. Break or come in quick was the rule.

"The great majority of the fish were grilse about $6 \mathrm{lb}$., so they came in very quickly; but every now and then one got a big fish. My best that day was $18 \mathrm{lb}$., which, as I thought, wasted a lot of time. George Probyn was very unlucky in his two days, for one was dead calm and bright, and on the other he foul-hooked (of course, accidentally) a large $27 \mathrm{lb}$. fish, which, as I before mentioned, took him more than an hour of the best of the day. We always fished a tail and a bob fly, but before I had been fishing half-an-hour the breaks were so numerous that I only used one fly all day. I did most with a Jock Scott, but any fly seemed equally good; and, all the dark-bodied ones being exhausted, I remember I finished the day with a Silver Grey. There was no skill required, only hard work, and not wasting time with playing fish when on.

"By the end of the last week, August 30, natural rains had fallen, and the rivers had risen, so that the fish could, and did, leave the first loch, and worked up, as usual, all over the upper lakes; consequently, the Monday following our big week was the last abnormally good day of that season's fishing, 24 being taken in No. 1 lake on that day. This proves that, where an artificial spate is made on a river, to be a great fishing success, as ours was, the fish must be stopped from running too far up, and, above all things, from being allowed to lose themselves in a big lake at the head of the river system.

"Instead of being gradually spread over the whole water system of the Grimersta basin, the fish were confined to one small lake. It was just this peculiarity of our experiment that made its great success. The fish must have been so thick in the lake that many of them could not have found suitable resting places. So this may account for them still keeping to their eccentric habit of swimming in shoals close to the surface with their fins showing as they did in the sea, and as they continued to do in the loch. Our great week's fishing was practically all done in this one loch. Though a few fish were caught in the river and No. 2 loch, none got into the upper lakes.

"The following is the tabulated record of our week :

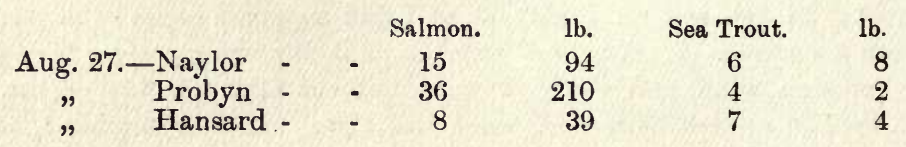




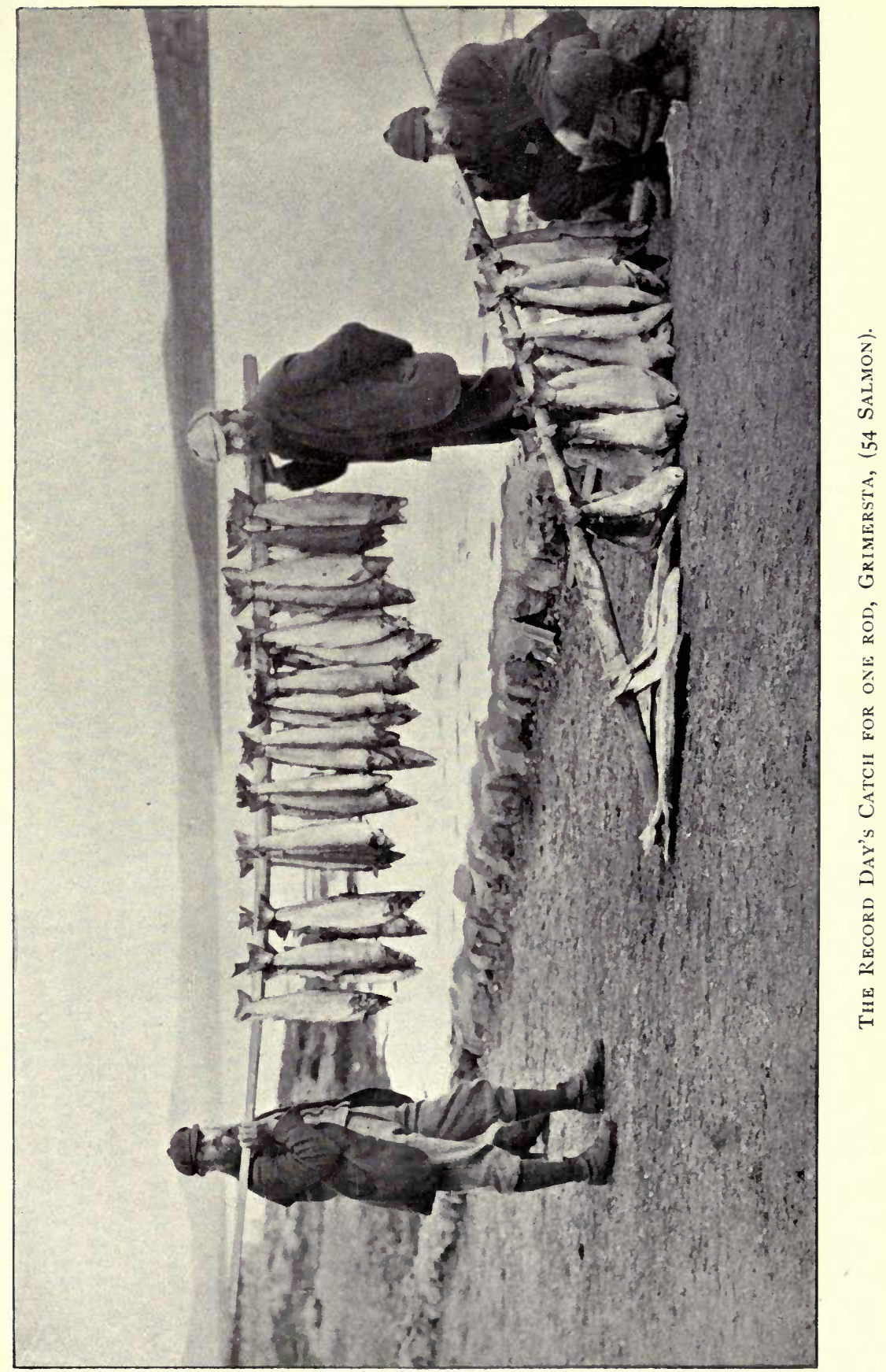





\begin{tabular}{|c|c|c|c|c|c|}
\hline Aug. 28.--Naylor & 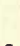 & & $\underset{54}{\text { Salmon. }}$ & lb. & Sea Trout. \\
\hline Probyn & - & - & 15 & 80 & 3 \\
\hline Hansard & - & - & 9 & 57 & 3 \\
\hline Aug. 29.-Naylor & - & - & 15 & 89 & 3 \\
\hline Probyn & - & - & 1 & 6 & - \\
\hline Hansard & - & - & 27 & 184 & 5 \\
\hline Aug. 30.-Naylor & - & - & 2 & 16 & 3 \\
\hline Probyn & - & - & 18 & 113 & 4 \\
\hline Hansard & - & - & 5 & 29 & - \\
\hline Aug. 31.-Naylor & - & - & 45 & 269 & 5 \\
\hline Probyn & - & - & 7 & 37 & 3 \\
\hline Hansard & - & - & 11 & 63 & 4 \\
\hline Sept. 1.-Naylor & . & - & 12 & 74 & 2 \\
\hline Probyn & - & - & 7 & 44 & - \\
\hline Hansard & - & - & 46 & 308 & 7 \\
\hline
\end{tabular}

TOTAL FOR THE WeEk.

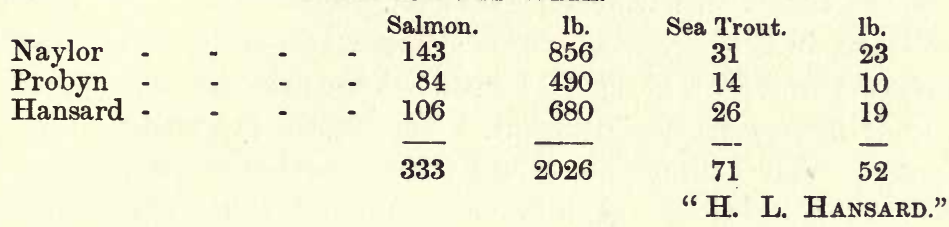

A photograph of Mr. Naylor's great catch hangs in the lodge at Grimersta. John Mackay, the head keeper there, whose property it is, has kindly allowed me to have it copied.

The peculiarity of the Grimersta is that it holds spring salmon and spring sea-trout. It is often doubted if such things as clean sea-trout are to be caught anywhere in spring, but I think there is no doubt about the matter here. Whether the fish remain any length of time in fresh water is another matter, but both the condition and appearance of those fish, as well as the ultimate test of the boiling pot, go to show that the sea-trout which are present in the Grimersta in March are really of very high quality. The Chamberlain of the Lewis should be a connoisseur in the matter of sea-trout, the species abounds so plentifully in these islands; and I recollect his saying that some Grimersta trout caught in March, which he ate, were as fine as any he had tasted. Very few anglers are ever in a position to test those waters in spring; but the present lessee of the Grimersta, Mr. George Pople, New House, Perth, has occasionally visited the district with one or two friends, and some salmon marking has then been done in the district. I may say that one specially interesting recapture of a Grimersta-marked fish was made at Castleton, near Thurso, after an interval of five months. ${ }^{1}$

By the kindness of Mr. Orrock, the Chamberlain of the Lewis, I I Iwenty-fourth Annual Report Fishery Board for Scotland, Part ii., p. 67. 
am able to give the rod catches in quinquennial periods from 1871 to 1900 , and the annual totals for the last eight years. It will be noted that the period 1886-1890, in which the great week already referred to was made, seems to have been a prolific one in the matter of fish. The figures are:

\begin{tabular}{ccc|cccc} 
Years. & Salmon. & Sea Trout. & Year. & & Salmon. & Sea Trout. \\
$1871-1875$ & -695 & 1239 & 1901 & - & 741 & 1351 \\
$1876-1880$ & -547 & 755 & 1902 & - & 714 & 1499 \\
$1881-1885$ & -661 & 873 & 1903 & - & 969 & 1750 \\
$1886-1890$ & -1074 & 1433 & 1904 & - & 1081 & 1306 \\
$1891-1895$ & -695 & 1174 & 1905 & - & 1112 & 856 \\
$1896-1900$ & -659 & 1342 & 1906 & - & 764 & 1742 \\
& & & 1907 & - & 688 & 693 \\
& & & 1908 & - & 961 & 571
\end{tabular}

An earlier record from all the principal fishings in the Lewis was published in The Fourth Annual Report of the Fishery Board for Scotland (for 1885), p. 282. I give the list without Barvas and Uig, as their figures are insignificant. The blanks are either because the shootings and fishings were unlet or because no record was kept. The Grimersta record is, however, complete since 1871. The best period seems to have been between 1886-1890.

List of Salmon and Sea Trout killed in the Lewis, 1871 to 1884, inclusive.

(Extracted from 4th Annual Report Fishery Board for Scotland, p. 282.)

\begin{tabular}{|c|c|c|c|c|c|c|c|}
\hline & 1871. & 1872. & 1873. & 1874. & 1875. & 1876. & 1877. \\
\hline Soval - & $\begin{array}{c}\text { Sal. S.T. } \\
-\end{array}$ & $\begin{array}{rr}\text { Sal. } & \text { S.T. } \\
40 & 200\end{array}$ & $\begin{array}{cc}\text { Sal. } & \text { S.T. } \\
109 & 150\end{array}$ & $\begin{array}{c}\text { Sal. S.T. } \\
-\end{array}$ & $\begin{array}{c}\text { Sal. S.T. } \\
-\end{array}$ & $\begin{array}{c}\text { Sal. S.T. } \\
-\end{array}$ & $\begin{array}{c}\text { Sal. S.T. } \\
-\end{array}$ \\
\hline Gress - & $27 \quad 544$ & $52 \quad 90$ & 16300 & - & $43-$ & - & - \\
\hline Park . & 4300 & -300 & $\begin{array}{ll}3 & 300\end{array}$ & 1501500 & $57 \quad 870$ & $14 \quad 140$ & 1798 \\
\hline Aline - & - & - & $\begin{array}{ll}2 & 72\end{array}$ & $\begin{array}{ll}2 & 67\end{array}$ & 274 & 11412 & - \\
\hline Scaliscro & - & - & - & - & - & - & - \\
\hline Grimersta & 2981284 & 6191489 & 10001073 & $800 \quad 932$ & 7561415 & $722 \quad 627$ & $722 \quad 585$ \\
\hline Morsgail & - & - & - & - & - & - & - \\
\hline & 1878. & 1879. & 1880. & 1881. & 1882. & 1883. & 1884. \\
\hline & Sal. S.T. & Sal. S.T. & Sal. S.T. & Sal. S.T. & Sal. S.T. & Sal. S.T. & Sal. S.T. \\
\hline Soval - & $56 \quad 240$ & $\begin{array}{ll}69 & 185\end{array}$ & $\begin{array}{ll}10 & 349\end{array}$ & $109 \quad 337$ & $\begin{array}{ll}74 & 403\end{array}$ & 145636 & $88 \quad 444$ \\
\hline Gress - & - & $\begin{array}{ll}8 & 21\end{array}$ & $-\quad 25$ & $\begin{array}{ll}38 & 257\end{array}$ & $21 \quad 170$ & $\begin{array}{ll}78 & 94\end{array}$ & $20 \quad 111$ \\
\hline Park - & 18400 & $17 \quad 104$ & $\begin{array}{ll}45 & 861\end{array}$ & $76 \quad 844$ & 91392 & - & - \\
\hline Aline - & $1-$ & - & - & - & 1400 & $6 \quad 120$ & -200 \\
\hline Scaliscro & - & - & - & 580 & $\begin{array}{ll}9 & 13\end{array}$ & -68 & $-\quad 49$ \\
\hline Grimersta & 495804 & 412796 & $373 \quad 965$ & $525 \quad 899$ & $399 \quad 859$ & 8651339 & $647 \quad 462$ \\
\hline Morsgail & - & 33648 & $25 \quad 492$ & $25 \quad 492$ & 91375 & $94 \quad 926$ & $86 \quad 356$ \\
\hline
\end{tabular}




\section{THE BLACKWATER.}

This stream ranks next to the Grimersta, and is moreover accessible to the public in a more general way, since visitors at Garynahine Hotel, which stands at the river mouth at the head of Loch Roag, can arrange to fish it. A number of lochs contribute to the Blackwater, but they are not arranged in a chain, as in the Grimersta district. They feed two separate streams which, on uniting some six miles from the sea, form the Blackwater. In the days of "Sixty-One" this stream went with Soval, and in his book, already referred to, he gives an excellent account of the little river.

"From the junction there are two or three miles of rough water before you come to the first legitimate salmon pool. I call it legitimate; for, though I have done such a thing as catch a fish in the rough water above this pool, yet, generally speaking, fish don't stay in it, but run through for the two lochs. From this legitimate pool to the Major's Pool, about a mile, when there was plenty of water and you knew it well, the fishing, to my mind, was always charming; for the gentlemen were very merry, and dodged about in the little narrows and pools in a very artful way. . . From this pool to the big pool was about another mile and a half of charmingly varied water-pools, streams, and narrows; but it required fishing, though not long casting. . . . The big pool, and the stream running into it, was the crack cast of the river; but I confess it was not my pet, for when in prime order it was necessary to cast a long line in the teeth of the wind, or rather across the wind, three-quarters against you, so that it was all but impossible to prevent your line bellying; and your fish rose on a curved, not a straight, line, which is not as it should be. . . But what with the wind and the stream, when you hooked a fish there he fought. Strange to say, though the pool was alive with fish, and rising in all parts by the weeds, you seldom took one anywhere but in the stream and its entrance into the pool between the two high banks of sedges. If by chance you ever did rise a fish in other parts, he generally beat you and got off.

"I put a boat on this big pool, and got very nearly drowned two or three times, but never did anything to repay me for the trouble. From the big pool there was about half a mile of still, deep water, with little or no stream, but full of fish. When the wind was right -anything east, north, or south, each was useless, as it was still water on all the good casts-there were plenty of fish to be got, and 
here generally lay the heaviest fish. From the end of this long still water there was about a mile or so of rough water, in which you occasionally got sea-trout, and I have caught grilse. You then came to the pools into which the tide ran up near the Garynahine Inn and bridge. There occasionally, particularly in the latter end of the season, you got fish; and if you watched the turn of the tide well, and caught the pools as the fish were coming in, and before the tide had made too much, you might get a good many sea-trout. I once got 87 , but they were small. From this description it will be seen that the Blackwater was a very nice little river. It was no Highland or Irish stream, but it had plenty of fish; and it had one thing about it I never saw equalled-it was the best rising river I ever threw line on."

It must be explained that with the river in his own hand, "Sixty-One" did not over-fish it. $\mathrm{He}$ was a great believer in resting the water thoroughly, so he picked his days, and did not show himself in the intervals. Then, again, he used a light rod and very fine tackle. He refers to his flies in one place as "not more than midges." In this he not only also prevented disturbance of the water, but secured the maximum of sport when he did get into a fish. He was, as we have shown, a very keen sportsman, but he was also a very observant and thoughtful one. "Heaven defend me from one of your very keen fishermen, who rushes at a river in all weathers," he writes; "I have as great a horror of him as ever Old Noll had of Sir Harry Vane."

The Blackwater is, however, not a spring river as the Grimersta. On rare occasions, I believe, spring fish enter it, but they need not be sought there regularly. Very probably the Grimersta draws them off, simply because of its extra water volume.

\section{THE RIVER LAXAY}

may be considered as ranking third in the Lewis. It is on the opposite side of the island, and has a course of about four miles from Loch Trialaval to Loch Valtos, from which it flows by a short course of about a mile into the sea, about half-way up Loch Erisort, some ten miles south of Stornoway, as the crow flies.

There are two or three good casts between the sea and Loch Valtos, but the fish do not generally rise freely here. Between Trialaval and Valtos there are only about two good pools, generally, I think, called the Rock Pool and the Reedy Pool. The specialty 
of the Laxay is that, like the Grimersta, it has a spring run of fish; again probably attributable to the fact that Loch Trialaval holds a lot of water. It is neither a long nor a broad loch, but its ramifications are extraordinary, and it communicates with quite a number of other lochs to the north and west. It was because of the great amount of water which at times descended from this loch that "Sixty-One" had his dam carried away repeatedly, and found the greatest difficulty here in applying the system of impounding water, which he had so successfully carried on at the head of the Blackwater.

Loch Valtos generally yields the best results, and the fish are heavier than in the Blackwater. The streams also often hold great numbers of sea-trout, but in dry weather they become very shallow and useless.

Other streams of Lewis, but noted more for sea-trout than for salmon, are the Creed, which falls into Stornoway Harbour; the Laxdale and the Gress, north of Stornoway, on the east coast; the Morsgail, which flows into Little Loch Roag, on the west; and the Barvas, away up on the flat and bare north-west of the island. William Black's Laird of Barvas will still be remembered as well, surely, as John, who was " a tevil of a good piper."

\section{HARRIS.}

The streams of Harris-the High Island-are, for the most part, sea-trout streams, and a very great many of the small lochs communicating with the chief streams yield good sea-trout fishing in early autumn. To other lochs sea-trout are unable to climb, but in South Harris-which is that part of the island south of the Tarbert-owing to the arrangement entered into by the proprietor, Lord Dunmore, and an association called The Hebridean Sporting Association, Limited, a good number of the obstacles have recently been modified, a new fishing lodge built at Inisbay, and roads and paths constructed by means of which access is more easily obtained to the various waters. Inisbay and Rodel are now the two bases of the association from which fishing is carried on. At the former a deal of fly-fishing is practised in the narrow sea channels or kyles, and some large baskets have been made, especially in the year 1890, before the association took up residence. Rodel was formerly the residence of the proprietor, and from it the famous Obe fishings are reached at the south end of the island. 
OBE.

The principal features here are a fairly large fresh-water loch, called Loch Steisevat, close to a large salt-water channel, winding in from the Sound of Harris. From time to time artificial channels have been formed in different places so as to make the communication between the fresh and the salt water in the most advantageous manner, and these channels have commonly been sluiced for the purpose of controlling the water-flow. Now, the short run of water passes out at its south-eastern extremity, and in this way the most use is probably made of the tidal water.

The fresh water flows first into what is called The Mill Pool, a shallow basin not reached by salt water in the lowest neaps, but freely filled during spring tides. Ordinary half-neap tides raise its level about 18 inches. From this Mill Pool the tidal channel has a strong current up and down, and about half way to the sea there is a pool in which fish congregate.

The Mill Pool yields good sport with sea-trout as early as March and April, but the great bulk of the fish are finnock or herling, i.e. the juvenile grilse stage of the sea-trout. More adult fish of 2, 3,4, and even on occasion up to $8 \mathrm{lb}$., are, or have been, got. About 600 to 700 sea-trout, small and great, may be expected in a good spring.

The tidal channel lower down yields the chief fishing in summer and autumn, particularly in the pool already referred to. It is. noticeable, however, that fish do not take well in the salt-water channel if much fresh water is descending from Loch Steisevat and the lochs above. If a flood or considerable rise is "on," fishing is transferred to Loch Steisevat into which the fish naturally travel.

A considerable sprinkling of salmon and grilse, mostly grilse, also enter fresh water at Obe. They are not usually susceptible to the lure of the angler in salt water, and do not hang about tidal channels as sea-trout do. Loch Steisevat is the chief place to expect the salmon to rise, and in its mile of water there is considerable space for plenty of sport. The salmon seldom exceed 9 or $10 \mathrm{lb}$. in weight. So far as I know, a fish of $14 \frac{1}{2} \mathrm{lb}$. (which in all probability was a big bull-trout, as known in the Tweed or Coquet, i.e. Salmo trutta eriox) constitutes the record weight.

About 1000 to 1200 sea-trout and about 70 salmon are expected each season at Obe, but it may be noticed that sea-trout here have: to be referred to before salmon, as in other Harris localities. 


\section{LAXDALE.}

At low tide this stream winds over a sandy flat, called the Traigh Luskintyre, for about $1 \frac{3}{4}$ miles. At high tide the great Traigh, or stretch of shore, is a lagoon shut off from the Sound of Taransay by a narrow barrier of sand and rock. I recollect crossing the narrow channel from the end of this barrier to Luskintyre House on one occasion in a boat which literally leaked like a basket. I don't suppose the passage is more than some three or four hundred yards, but I had my feet on the seat, and we were all awash when we landed. "Row hard, row hard," shouted a man with me, "I cannot swim, I'll be drowned." He only ceased shouting when we touched bottom. The knee of one of the thwarts came away in my hands when we attempted to pull the boat up.

A pool has been constructed just above the point where the Laxdale enters the head of the Traigh by the formation of a broad dyke from the left bank, a mass of rocks on the right hemming in the water largely in that direction. This and the sea-pool just below is said to fish well when the tide is out. It has to be remembered, however, that the Laxdale is a late river. On one occasion when I tried this pool on 5th July I was still too early. From the pool, fish are able to ascend freely to four lochs. There is also a Laxdale in Lewis.

Other sea-trout streams of similar nature occur along this eastern side, some fished by visitors to Tarbert Hotel, those further south by the Hebridean Association. July, August, and September are the best months.

On the northern side of West Loch Tarbert, at the head of a. small secondary loch with a very long name, is a stream named

\section{BALLAN A' CISTE,}

which flows out of a small loch called Loch-na-Morcha, or on the maps Loch a' Mhorghain. A great attempt was made here in 1885 to open up the stream in order to allow sea-trout up to the loch. When I mention that this loch is 469 feet above the sea, and only a little more than a mile distant from the shore, some idea of the gradient will be understood. If this were reduced to a uniform gradient of one in twelve, it is impossible to conceive fish managing to last a mile of such ascent. But the incline is in part tremendously steep. The road to Stornoway, which goes alongside, seems to have a much easier 
gradient, and yet looks in parts as if this must be about one in seven. Up this steep ascent, at immense cost, a tortuous way was constructed for the benefit of the sea-trout. In 1886 it was described as a complete success, but as a matter of fact it is a complete failure. Some of the embankments have now burst, and the stream in part descends in its old steep channel. It is a monument to the most sanguine belief in what a sea-trout will climb, as well as one of the most extensive operations of its kind $I$ have ever seen. Only one other instance occurs to me as worthy to compare with it, and that is the equally ruinous works in the island of Rum, originally constructed by the late Lord Salisbury.

There is a famous fishing on the property of Sir Samuel Scott, not far to the west. It is commonly called Avonsui (Amdhuinnsuidh). Here a chain of five lochs joined by a stream called the Eavat come down from a great height in a steep glen. Below this the stream enters a sheltered little sea-creek at the mouth of the West Loch Tarbert, opposite the north end of Taransay. The lowest two lochs are very small, but the loch next above, Loch Leosaidh, is about three-quarters of a mile long and only 131 feet above the sea. A fish-pass, formed by rock blasting, was necessary to make this fishery what it is, but the gradient is comparatively easy, and the fishing in the lochs above is not only first-class, but constantly reliable.

\section{RIVERS OF SKYE.}

Angling Season: 11th February to 31st October.

Netting Season: 11th February to 26th August.

A Joint District Fishery Board sits in Portree. The Clerk is Kenneth Macrae, Esq., Sheriff-Clerk, Portree.

The Isle of Skye is divided into two fishery districts, Snizort and Sligachan, and although many small streams exist with short courses at different parts of the island, salmon are chiefly confined to the two main rivers which give their names to the districts.

\section{THE SNIZORT}

is the largest river in the island, and flows in a northerly direction into the large and ramifying sea loch of the same name on the north-west coast, the district of Trotternish being on the right hand, and Vaternish on the left. It may be said to have three sources; 
that in the central position-which is also practically the centre of Skye-rises below the hill called Roineval; that to the west from Loch Duagrich in the parish of Bracadale; that from the east from beside the Glenmore and Mugeary clachans.

These head streams unite at a point about six miles from the mouth of the river at Skeabost, and about 300 feet above the sea. In general character the Snizort is a rocky rather rapid river, flowing through one of the long gentle inclines of this northern portion of the island, which have been described as "weary wastes expanding to the skies." At times the river slows up in a few open pools, but much of the channel is rather shallow and stony, with occasional cascades. At Skeabost there is a fall sufficiently difficult to check fish if the volume of water is not well above normal. As a result, the condition of the river has to be watched on the spot, and successful angling is attained only by one who is able to sally forth on the proper days. At other times the river is rather "dour." A large number of salmon frequently ascend at the spawning season, and make a short stay in fresh water, falling back to the tidal pools at the mouth to recover condition to the necessary extent before putting to sea again.

The arm of Loch Snizort Beag, into which the river flows, is a shallow tidal channel, left bare at low-water for about half its length-a place where oysters grow well. The estuary of the river is drawn, as regards its seaward limit, at the mouth of Loch Snizort Beag, but no fixed nets are now fished on this side of Skye.

\section{SLIGACHAN RIVER,}

like the Snizort, flows, as it were, along the main axis of the island, about north-north-west, although Loch Sligachan, the sea loch into which it discharges, lies north-east. Loch Sligachan, which forms the natural estuary of the river, is a dark-looking narrow inlet with high land on either side; its entrance is directly opposite Kyle More-the passage between the south end of Raasay and Scalpay, as if the denuding force which formed Loch Sligachan had also carved the separation of the two outlying islands. On this east coast of Skye numerous bag nets are fished, but none come near this river. Most are set along the high straight coast north of Portree.

The Sligachan may be said to rise from the little Dubh Loch, which is four miles from the mouth, but the stream which comes down Harta Corrie for two miles from a very high source joins the 
outlet from the Dubh Loch, and must, therefore, be regarded as the real source. This Harta Corrie drains the steep ridge of Drumhain, which on its southern aspect overlooks Loch Coruisk.

To those who know the Cuillins, the mention of Sligachan is the mention of the eastern boundary of those wonderful hills. The inn, near the mouth of the river, just before the sharp bend to the right, takes the river into its sea loch, is the headquarters for climbing. Many a tired man has thankfully reached this hospitable roof. Here for many years the only map of the Cuillins-drawn by Mr. Pilkington-was to be found, for the Ordnance Survey never attempted to plot those mountains, the expense being considered out of all proportion to the value.

Receiving its main supply of water from these enormously steep faces of gabro, in a country famous for its rains, it will be understood that the Sligachan is capable, in a wonderfully short time, of rising in great flood. When the river is dead low-as it sometimes is in a dry June, and I have really seen several Junes dry in Skye-the river is little but an exposed track of boulders. As a fishing stream it has to be taken just at the right time by the man on the spot. It belongs to Lord Macdonald and to Macleod of Macleod, but visitors at Sligachan Inn can fish it on the west bank. It is better for sea-trout than for salmon, and the best months are July, August, and September.

But the man who goes fishing in Sligachan is compelled to give as much attention to the wonderful surroundings as to his sport. There is an impressiveness about the dark-coloured Cuillins, with their weird outlines, which is in a manner separate from the impressiveness of other grand scenes in Scotland. Loch Coruisk, perhaps of all places, makes a man feel very humble. The upper part of the Sligachan Glen comes near to it.

"The enormous bulks, their gradual receding to invisible crests, their utter movelessness, their austere silence daunt you. You are conscious of their presence, and you hardly care to speak lest you be overheard. You can't laugh; you would not crack a joke for the world. Glen Sligachan would be the place to do a little selfexamination in. There you would have a sense of your own meannesses, selfishnesses, paltry evasions of truth and duty, and find out what a shabby fellow you at heart are; and, looking up to your silent father-confessors, you would find no mercy in their grim faces."

And what a deep-set grip the all-mastering hand of Nature takes; 
what a fascination is conveyed in it. You are completely captured, but you resign all willingly. Other and beautiful scenes seem tame. Bright and gay places are not thought of. As a son of Skye writes $:^{1}$

"Let them sing of the sunny South, Where the blue Aegean smiles, But give to me the Scottish sea, That breaks round the Western Isles ! Jerusalem, Athens, and Rome, I would see them before I die! But I'd rather not see any one of the three Than be exiled for ever from Skye."

${ }^{1}$ Sheriff Nicholson. 


\title{
CHAPTER XXVI.
}

\section{THE MORAR AND SHIEL DISTRICTS.}

\section{MORAR DISTRICT.}

\author{
RIVER MORAR AND LOCH MORAR.
}

\begin{abstract}
Angling Season: February 11th to October 31st. Netring Season: February 11th to August 26th.
\end{abstract}

No District Fishery Board. Rights of salmon fishing held by Lord Lovat, J. A. Macdonald, Esq. of Glenaladale, Mrs. Cameron Lucy of Callart, and Mrs. Nicholson of Arisaig. There is no netting.

MORAR district is remarkable in having the deepest loch and the shortest river in the British Islands. There are a few places where a mere tidal stream separates fresh and salt water, or where a short burn, or little more than a burn, joins a lake to the sea, but I think I run no risk of contradiction in saying that nowhere else is there a combination like that of the Morar district. As a consequence the salmon fishing conditions are somewhat peculiar.

The loch is some $11 \frac{1}{2}$ miles long, and the river some 600 yards, but the fishable part of the river is practically confined to the lower half of its course. The loch is 30 feet above sea-level, and the outflow is sluggish, with a bend first to the south and then to the west. Two hundred yards beyond the latter bend the water suddenly plunges over a fall, confined in a narrow channel, and varying from $4 \frac{1}{2}$ to about $7 \frac{1}{2}$ feet in height, the rocky ledge being lower at the left than at the right bank. Thereafter for 300 yards the river flows somewhat rapidly to the sea.

There are really only three pools, of which the fall pool is generally considered the best, because it is here fish naturally congregate, being checked in their ascent. But fishing in the fall pool is almost exclusively with "the garden fly." The area is very prescribed, and the water often heavy. A long pole, with a wire ring at the end of 
it, may generally be discovered near the pool. I believe the weapon is quite innocent, and is used for the purpose of freeing the angler's worm-tackle from the rocks of the pool bottom, as "hanking" is frequent.

The streamy pool below is a pleasant cast, but fish are there only in the bye-going. The lowest pool-called for some, to me, unknown reason, the Island Pool-is just above the road bridge, which crosses close to the river mouth below the railway bridge. In this pool fish pause just after leaving the sea creek immediately below. In the narrow gut into which the river empties, large numbers of fish may sometimes be seen, as in the fall pool. The water is never dirty, though in flood it is much broken and aerated. The deep loch above is a perfect settling pond.

The sea creek is a joy to the eye. The floor and margins are in great part of white sand, over which the translucent waters of the Western Ocean show green and pure. Here and there a rocky point runs out with a rim of foam, shining over violet and purple weeds. The land on either side is broken and polished. Beyond is the vivid streak of the Sound of Sleat, and the whole is backed by the wonderful outlines of the Cuchullin Hills of Skye.

The right bank of the river is owned by Lord Lovat, the left bank by Mrs. Nicholson of Arisaig. North Morar Lodge and South Morar Lodge stand on each side respectively, and the fishing is let with the lodges. The other proprietors previously mentioned come in on the loch.

The high railway bridge which now spans the river has considerably altered and has certainly not improved the aspect of the place. But before the railway came, Morar was distinctly inaccessible, and one has generally to yield a certain amount of beauty to utility.

At the railway terminus at Mallaig, which is next station, there is now a large hotel with every comfort, as well as a harbour-of a somewhat prescribed order, perhaps-where daily steamers come and go in the summer time.

On my first expedition to Morar and its neighbourhood Mallaig was a mere clachan of thatched cottages, a sort of jumping-off place, from which a small lug-sail ferry-boat could take one across Loch Nevis to Inverie. I recollect that when I made that crossing my appearance as a casual stranger seemed to excite such curiosity that I was almost ashamed of myself for being so conspicuous.

It is not in every case easy to decide if a waterfall should or should not be opened up, and Morar Fall is one which seems to 
create, as it were, the fishing in the river. If the fall were blown up and completely removed, the majority of people who have fished the river, or who know the district at all, would agree that the angling would be much injured, since fish would then run right through the river and get lost for sport in the loch above.

It is certainly true that if sport is to be secured with salmon in the Morar district, the fish must be "held up" in the river. It seems to me, however, that a greater extent of water might be utilised; that fish might be let up the fall more easily, and checked to a greater extent in the water immediately above. In this way six pools might come to be fished instead of only three.

It would not be difficult to lower the fall to some extent-say about two feet; the operations in the upper river require more consideration. The most satisfactory spots would have to be selected for the erection of croys on such a scale as to create lies for fish. It might also be possible to do something in the way of impounding a certain amount of water, so as to regulate water-flow in the river, and move fish up at spring tides or when the river falls unduly low.

\section{LOCH MORAR.}

This loch naturally received considerable attention from the members of the Bathymetrical Survey, Mr. J. Y. Buchanan having shown in 1879 that there were depths of over 1000 feet. The particulars which I now give are principally taken from the report of Dr. T. N. Johnston. ${ }^{1}$

The loch is a little over $11 \frac{1}{2}$ miles in length, and the maximum breadth is over $1 \frac{1}{2}$ miles near the west end. The mean breadth is $\frac{9}{10}$ of a mile, or about $7 \frac{1}{2}$ per cent. of the length. The area covered by the lake is 6596 acres, or nearly $10 \frac{1}{3}$ square miles.

There are several islands towards the west or seaward end of the loch, and these and the surrounding low ground are richly wooded. Towards the upper end, however, vegetation becomes more and more scanty, and the hills rise with greater abruptness, till at the head of the loch three peaks rise to 3133,2718 , and 2818 feet.

About two-thirds of the way up on the north side a narrow neck or tarbet separates the loch from the sea in Loch Nevis. Dr. Johnston points out that should the land be depressed 40 feet, Loch Morar would be converted into a submerged valley like Loch Etive, with, I presume, a rapid at the present Morar Fall corresponding to the Falls of Lora at Connel Ferry.

1 "Lochs of the Morar Basin," Scottish Geographical Magazine, xx., 1904, No. 9. 
With regard to the depth of the loch, Dr. Johnston writes: "In April 1887 Sir John Murray took a series of eighteen soundings down the centre of the loch, the greatest depth recorded being 1050 feet. . . . In 1896 Sir John Murray and the late Mr. Fred. P. Pullar made a bathymetrical survey of the whole loch with a wire-rope machine, but the chart they prepared was not published, as it was found that the machine employed was untrustworthy. It was, therefore, resolved to make a complete new survey. This was carried out in June and July 1902 by Dr. Johnston, Messrs. Garrett, Hewitt, Parsons, and James Murray. ...

"The surface of the loch at the time the survey was made in June 1902 was 30.5 feet above sea-level, and in March 1903 the level was found to be 35 feet above the sea, a difference in level of $4 \frac{1}{2}$ feet. Altogether eleven hundred soundings were taken in the loch, or about one hundred soundings to the square mile; the maximum depth recorded was 1017 feet. This is less than previous results, but it is to be accounted for by the use of wire-rope, which nearly always gives a lesser depth than the soundings with ordinary sounding-lines.

"Loch Morar is of simple conformation, the bottom falling on all sides down to the deepest part, but with here and there a few minor undulations of the lake floor. . . .

"The deepest part of the loch is at the wide portion opposite the mouth of the Meoble river, . . . at a spot nearly midway between the two ends of the loch. The area over 1000 feet in depth is not large, extending only to a little over 4 acres. . . .

"As the surface of the loch is only 30 feet above sea-level, almost the entire bed of the loch is below the level of the sea. ... In the sea to the west of Loch Morar there is no depth approaching 1000 feet, with the exception of a deep spot 834 feet (139 fathoms) between the islands of Rum and Skye, so that to get a depth of 1000 feet one must go west of St. Kilda and Ireland, beyond the 100 fathom line in the Atlantic Ocean."

The fall at the outlet precludes the ascent of any early fish, and frequently causes salmon and sea-trout to congregate in great numbers. On this account, i.e. the stopping of early fish, Loch Morar is of little use as a salmon fishing loch. An occasional fish is taken, however, in summer or autumn.

Loch Beoraid, on the south, drains into the loch by the Meoble river, but is rendered inaccessible to salmon by reason of a fall a short distance from the outlet. The Meoble and the two small streams 
at the head of the loch are the chief spawning places, and are limited enough for the size of the district.

\section{THE SHIEL (LOCH SHIEL) DISTRICT.}

Angling Season: 11th February to 30th October. Netting Season: 11th February to 26th October.

No District Fishery Board. The river Shiel is fished by Lord Howard of Glossop, who owns the north bank, and by C. D. Rudd, Esq., of Ardnamurchan, who owns the south bank. Loch Shiel is open to the public.

This, like the Morar, is a large district with a short river. In each case a large loch, not of first-class importance for salmon fishing, but of great grandeur, occupies the bulk of the area. Loch Moidart, the sea loch into which the Shiel and Moidart rivers flow, forms the estuary for both rivers. The line is drawn from Farquhar Point on the south shore to the south-west point of Eilean Shona, and from the north-west point of Eilean Shona to the nearest point of mainland on the north. Bag nets used to be fished on the outer coast of Eilean Shona, but the two proprietors already mentioned have arranged that they be taken off, and now no netting of any kind exists near the mouth of the rivers.

Reference to Eilean Shona reminds me of an excellent example I witnessed, when running up Loch Moidart in a steam-launch, of how land animals may find their way to islands. The channel at the point in question is nearly a mile broad, if shallow. In mid channel we sailed right on to a weasel swimming hard for Eilean Shona. He screamed with terror when run down, but speedily reappeared under the stern-we had stopped the engine-and struck out again with surprising agility for his destination. We saw him land successfully on a tidal rock of some size close to the island. I wondered how Mr. Spencer Thomson's Canadian turkeys would receive him.

Loch Shiel is $17 \frac{1}{2}$ miles in length, not 23 as commonly stated, and is, I believe, for its length the narrowest loch in Scotland. The mean breadth is less than half a mile, and the maximum only ninetenths of a mile. From Glenfinnan, at its head, it runs $11 \frac{1}{2}$ miles in a south-westerly direction, and then, from a tortuous construction, six miles west by south. Glenfinnan is ever memorable as the place where Prince Charlie's standard was raised in 1745 . The Finnan water is about five miles long, descends from an altitude of 
1586 feet, and spreads its flat stretch of alluvium at the junction with the loch. It was on this small flat that the standard was raised, and here a high monument or tower was erected in 1815 by the late Colonel Macdonald of Glenaladale and others. The Macdonald of Glenaladale of the " 45 " entertained the Bonnie Prince on the previous evening, and took a prominent place in this stage of the rising. The long inscription at the base of the monument is in Gaelic, Latin, and English.

Hill Burton relates that on the 19th of August, the date fixed for the ceremony, the Prince had to wait two hours and undergo considerable anxiety and forebodings before any supporter arrived. Then Lochiel's pipes sounded from the hill and a body of between seven and eight hundred Camerons appeared over the sky-line. Before evening the assemblage amounted to 1500 men.

Queen Victoria visited the spot in 1873 by driving over from Inverlochy. She writes": "I thought I never saw a lovelier or more romantic spot, or one which told its history so well. What a scene it must have been in 1745 ! And here was $I$, the descendant of the Stuarts and of the very king whom Prince Charles sought to overthrow, sitting and walking about quite privately and peaceably."

The hills on either side of the head of the loch are extraordinarily steep-especially Meall-a-Bhainne-and of splendidly bold outline. When seen pouring with many white streams, just as clouds break up after rain and mists rack and vanish, the effect is magnificent. A few minutes after the rain ceases, the little streams cease also, for the water runs off as from a house-roof. While it lasts, on the other hand, my experience here is that the rain is really very wet.

The loch forms a splendid reservoir, by means of which the river Shiel is enabled to maintain its level better than would otherwise be the case. Yet in June and July, which are about the best fishing months in the district, the rivers often get too low. The head streams in which fish spawn are the Finnan, already mentioned, which has fine spawning ground in its lower reaches; the Doilate, the largest feeder, which enters the loch about 11 miles from the head on the east side, just before the narrows of the loch are reached. It descends a comparatively even glen, and has a course of nearly eight miles. It is variously called the Hurich when in the glen-which has the same name-and the Polloch at the mouth, where the course is quiet and sluggish. The name Doilate, or Dilate, is given because it passes through a small loch called

${ }^{1}$ More Leaves from the Journal of a Life in the Highlands, 1884. 
Doilate, situated a few miles from Loch Shiel, and $10 \frac{1}{2}$ feet above its level. About half-way from here to the top of the loch, but on the west side, the Aladale enters, and at the head, through the gap in the direction of Kinlochiel, the Callop winds its dull, sluggish course round the foot of Meall-a-Bhainne. The Prince Charles monument at the head of the loch is between the mouth of the Callop and the mouth of the Finnan. It is a conspicuous object on the left of the modern railway track to Arisaig and Mallaig.

The erosion in glacial times has been extreme in this region, and the deeply-cut valleys and lake basins run in curiously diverse directions. The larger section of Loch Shiel lies in the line of chief mountain formation in Scotland, and this is the steep and mountainous section of the loch. To the seaward end, from the narrows onward, the land surface has been more completely cut away and levelled. Up at Glenfinnan, however, the line of valley now occupied by the Mallaig railway is a transverse line of erosion which runs right across from Fort-William to the western sea at Arisaig, by Lochiel (sea) on the east, Loch Eilt in the centre, and Loch Ailoch (sea) on the west.

The long upper part of the loch is deep, the shorter section, between the narrows and Acharacle, is shallow, but the floor of the loch, as revealed by the Bathymetrical Survey of Sir John Murray and Mr. Laurence Pullar, is very irregular. The greatest depth found was 420 feet, about four miles from the head of the loch, but there are two depressions of more than 400 feet, the second and smaller one being still nearer to the head of the loch. The foot of the loch, on the other hand, is extremely shallow, being little more than one foot at the nutlet, and deepening slowly for three miles till the 50 feet line is reached off Langal. Thereafter, as far as the narrows, the 50 feet line takes a sinuous outline in conformity with the shore and approximately in mid-channel. Only at one small spot in this distance do the soundings reach a little over 100 feet, off Rudha Leatham. In the many bays and round the islands the water is fairly shallow. The mean depth of the whole loch is stated to be $81 \frac{1}{2}$ feet. "Loch Shiel was surveyed in July 2 to 9, 1902. The elevation of the lake surface above the sea was determined by levelling from bench-mark as being 11.4 feet; when levelled by the officers of the Ordnance Survey on November 6, 1897, the elevation was found to be 12 feet above sea-level. The water may rise 4 to 5 feet higher than the level given above." 1

I The Geographical Journal, xxv. No. 3, p. 271. 
The public have very considerable facilities for fishing Loch Shiel, although some points are not very easy to reach. "The Stage House" at Glenfinnan is now, of course, on the railway line, but the head of the loch is not as a rule considered the best for fishing, or at least this is so if sea-trout are sought. The Strontian Hotel has a boat, but is rather far from the loch. The favourite places are Loch Shiel Hotel, built in recent years for the benefit of anglers, and overlooking the foot of the loch, and Ardshealach House, which, I understand, is made available in the same way. The shootings are rented by Lord Howard of Glossop, as they adjoin his own property of Dorlin at the mouth of the river. Great advantage in reaching this district, and for the transport of mails, have been possible through his Lordship maintaining a small steamer on the loch, the use of which was open to all. Difficulties with the Post Office were, I understand, the reason for the discontinuance of this most serviceable little vessel. It is hoped, however, that by the time these pages are printed the steamer will again be plying to and from Glenfinnan. The place of landing and departure there is at a small staging in the mouth of the Callop. When this service stopped, mails and passengers were driven round by Strontian and Salen Sunart, or the passengers could sail from Oban to Salen, and so across to Loch Shiel. Either route occupied a fearful lot of time, and gave one ample leisure to admire the beauties of Argyll.

At the lower end of the loch the chief sport is got with sea-trout, of which large numbers are often present. It sometimes happens, however, that fish are mostly found above the narrows or even at Glenfinnan. Salmon and grilse are not got every day, but may be fished for either trolling or with fly. The brown trout often run heavy.

\section{RIVER SHIEL.}

This river, which forms the boundary between Inverness-shire and Argyll, is only about $2 \frac{3}{4}$ miles in length, and as Loch Shiel is only between $11 \mathrm{ft}$. and $12 \mathrm{ft}$. above sea-level the gradient of the river is extremely easy. The photograph showing the river pouring down into the tidal basin at the mouth scarcely gives this impression, but this part, when the tide is out, is the only piece of rough water there is. Most of the river is also three or four times as broad as is shown at the mouth, for here the rocky barrier confines and dams back the flow. The pool just above this barrier is called the Sea Pool, but although the rise and fall is very considerable in Loch 
Moidart, I am not aware that the tide ever flows into the Sea Pool, although high springs may dam up the fresh water. The Sea Pool is about 200 yards long, and has a fair stream.

I think the point is worthy of consideration whether or not benefit would not result from cutting down the rocky barrier at the mouth, and at the same time deepening the channel upwards so as to draw a better current through the St. Columba and Road Pools above. I understand that the Road Pool is not now a productive cast, and that there is a troublesome growth of weed in all the still parts of the river. If action of this kind were taken, it is possible that the Sea Pool might be reduced in value at the expense of the others, and at present I believe the Sea Pool ranks about third favourite in the river. But besides the increased current a compensating advantage would very likely follow in giving fish an easier entrance from the sea, when, in all probability, fish would run at an earlier date. When the water is cold, spring fish will not run the rough fall as it is at present. A more gradual transference to fresh water would certainly be a great benefit in this particular respect.

At present fish are not looked for till the end of May-the time when wintry conditions of temperature have given place to the approach of summer, and when spring fish all the country over ascend rough falls for the first time. A few fish have occasionally been taken in April I believe, probably in mild springs.

The next pools are The Captain's and The Garrison, both very sluggish, and requiring an up-stream breeze for good results. The latter is, however, of good repute. Above this is a pool called The Cliff, which only fishes in high water, but which usually has a good stream. I think it not at all unlikely that this pool could be materially improved by a little judicious croy building, but the conditions require to be studied in different conditions of water, and with greater care than I have had time to give.

Next in order of ascent comes the Rock Pool at a narrow and deep rocky channel. It has this advantage, that owing to the draft between the high banks, a slight breeze is readily felt on calm days. Above this is the Bridge Pool, which is not only the best, but much the widest in the river. There are seven different casts in the Bridge Pool: Grassy Point, Providence, Between the Trees, the Parapet, the Gullet, the Big Rock, and the Upper Stage.

Mr. Stone, who has rented Lord Howard's rod during May, June, and July for many years, has become intimately acquainted with the river. He informs me that the time-honoured lies of fish are 


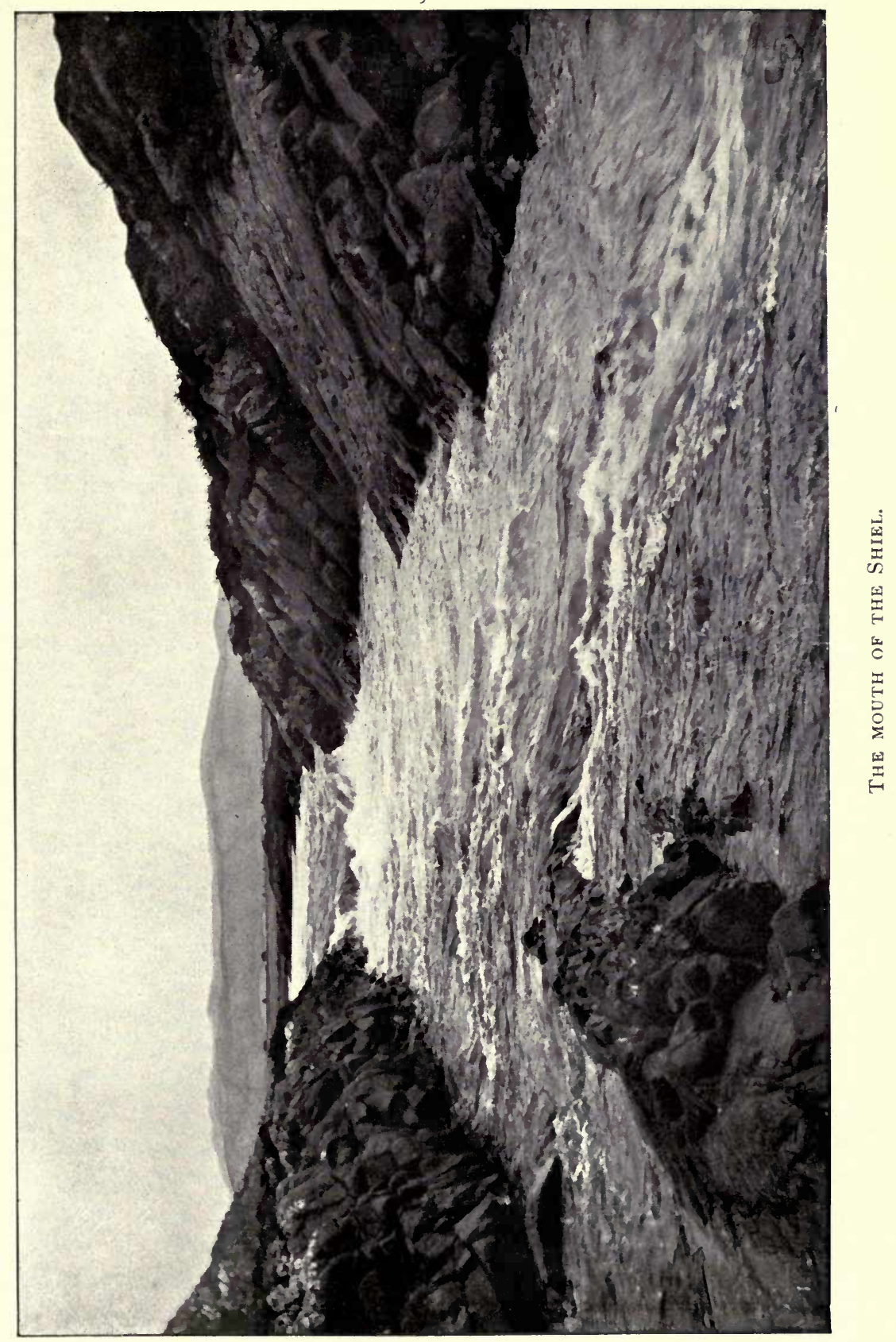



now very largely deserted, and that the stock of fish is not what it was. To account for the altered habits of Shiel salmon, Mr. Stone blames the growth of weeds in the river bottom. It seems to be borne out by records that when the river was regularly netted, the sport with the rod was better than it is now. One can well believe that by the regular action of the nets, the weeds had no opportunity of growing. As many as 100 fish are reported to have been taken from the Bridge Pool in one haul, while 63 salmon and grilse were got by two rods in six weeks.

No netting has now been carried on for twenty years, and after the nets were taken off, the rod results improved, but during the last ten years a decline seems to have set in. Suggestions have been made for the possible increase of the weekly close time in the sea nets and even for the re-introduction of netting in the river for one day a week.

I certainly think the weeds should be got rid of, but I am inclined, so far as I see at present, to think that some such method as that already hinted at by me is likely to be more in the best interest of the river than resorting to netting, especially if the netting is done by a tacksman.

The picturesque old bridge is now closed for traffic, and Mr. Rudd has built a new bridge some little distance further up. The old bridge is a simple structure of one arch, spanning the river at the Gullet, which is a narrow and very deep cleft in the large barrier of rock which here projects, and which probably at one time formed the lower end of the loch.

I believe the water in this narrow neck to be about 30 feet deep. More than half a mile of river still exists, but for the most part is broad and rather shallow, with no pool-like character, and with flat, grassy banks. The upper part merges imperceptibly into the loch. This stretch is called the Boat Pool, since it is fished from a boat, although $I$ understand that from a point above the new bridge a cast from the bank is possible when the river is high. The boat is used on alternate half days by the two proprietors. It is reckoned that on an average season 100 fish should be landed on each bank. Mr. Stone has, I believe, taken as many as 72 fish in eight weeks. To secure better lies, no device seems to answer so well as the erection of croys or partial weirs to direct the water-flow, scour out runs, deepen the water at advantageous points, and so hold fish. ${ }^{1}$

A good run of grilse generally occurs in June, and the grilse are 
heavy. At the same time the river holds a large number of seatrout, many of the casts not very productive for salmon being excellent for the smaller salmonid. The best single day's catch by one rod of sea-trout is, I believe, 88. At the back end of the year salmon run fairly heavy, although I am not aware that any fish over $27 \mathrm{lb}$. has actually been landed.

The neighbouring river Moidart has a total length of 7 miles, and passes through a small lochan near Glenmoidart House. The water available for fishing is not very extensive, and the river is subject to very heavy and rather sudden floods, like others, draining the steep land of this region. It flows into the head of Loch Moidart, a shallow and muddy arm of the sea, completely sheltered, and 2 miles inland from Eilean Shona. The fishing is in the hands of the proprietor, and the district is as completely isolated, physically, from the outer world as any in Scotland. Success depends a good deal on the rainfall, but I understand that about a score of salmon are looked for in the season. 


\section{CHAPTER XXVII.}

\section{LOCHY DISTRICT.}

RIVERS LOCHY, SPEAN, ROY, ARKAIG.

LOCHS LOCHY AND ARKAIG.

Angling Season: February 11th to October 31st.

Netting Season : February 11th to August 26th.

District Fishery Board sits in Fort-William. Clerk, Nigel Mackenzie, Esq., Solicitor, Fort-William.

THIs district contains two separate river systems, the Lochy and the Spean, which unite a few miles from the sea, the united river being termed the Lochy, flowing into the head of Loch Linnhe in the Lochaber district, the southern termination of the great fault which cuts through Scotland in a north-east and south-west direction, and is now utilised as the Caledonian Canal.

The district is a rather remarkable one. We have the southern drainage from the line of Loch Lochy, which extends back to the low divide from Loch Oich, but which also receives the water from Loch Arkaig to the west at right angles. On the eastern side the rocky Spean tumbles downward 800 feet from the Moor of Rannoch, and enters the main valley at an equally abrupt angle; and to still further carry out cross-lines of water-flow, we have the Roy entering the Spean at right angles from the north.

There is no other district in Scotland where rivers unite at such abrupt angles from such diverse directions, and in no district, except perhaps in that of the Findhorn, have we such an example of prolonged and deep rock erosion as is to be seen in the course of the Spean. The main axis of the land is certainly north-east and southwest, but in this district from the lower Lochy the transverse valleys are also most marked, so that it may be said great gaps in the mountains extend like arms of an immense cross to four points of the compass. 
Ben Nevis and the high land which holds alike the head waters of the Roy and of the Spey is a great example of what weathering can do in carving the scenery of a district. The high ridges of the Ben are sometimes only a few yards broad across their crests, and much of the mountain's surface is piled with broken fragments of its granite. The precipice which frowns down upon the north-western approach is 1500 to 2000 feet high, its rifted buttresses of porphyry adding to the sense of vast disintegration. The great screes of broken rock drag from the upper walls like stretched skins of primeval beasts; while the small hill torrents wash down the debris and undermine the loose rocks.

The great transverse valleys are believed by geologists to be of very early formation, and to have been hollowed out before the last subsidence of the land, when layers of deposit largely or entirely filled up those glens then beneath the sea. On the later elevation of the land, the first drainage was naturally again at right angles to the main axis, but not always at the same places. When in the same places, however, as appears to have been largely the case in the district now under review, the new erosion again laid bare the old rocks. The glaciers which occupied the valleys certainly found Glen Roy and the Upper Spean in the same general condition as to their upper levels as we see them to-day. In both localities we see the so-called Parallel Roads, which represent the old shores of those glaciers before the terminal moraines were broken down by the impounded melted ice and snow.

\section{THE LOCHY.}

The river Lochy is, as it were, the counterpart of the river Ness, Loch Linnhe being the counterpart of the Inverness Firth. It is a fine open, swinging river, with gravel bed and open shores. A river to wade in and throw a long line. Some of the pools, and notably Mucomer, cannot, however, be well covered without the help of a boat.

The length of the river is about nine miles, and the volume of water considerable, since from Mucomer onwards the water of the Spean is added. The artificial channel between the loch and Mucomer, to which reference will presently be made, is not considered worth fishing, I understand. Certainly no attempt seems ever to have been made to create lies for fish, the channel as it exists being shallow and uniform. 
The Lochy, with the exception of a short stretch on the lower water lately acquired by Lochiel, belongs entirely to Lord Abinger, and is let in beats.

The lowest is beat 7, which extends from the Suspension Bridge to the sea. This beat is let for the whole season in one period.

Beat 6 is from the dyke at the Canal Pool to the Suspension Bridge. In this beat Lochiel has now acquired two pools, but the arrangement is that he leases the whole beat from the Abinger Estate at the former rental, and is refunded a sum determined as the value of his two pools.

Beat 5 is from the tail of Garrybuie Pool to the dyke at the Canal Pool. It is let in two periods, viz. from the opening (11th February) to and including 9th August, and from 10th August to the close of the season, 31st October.

Beat 4 is from the head of the Pile Pool to the tail of Garrybuie. It is let in the same manner as Beat 5.

Beat 3 includes the lowest part of the Spean, and runs from Spean Bridge to the head of the Pile Pool. This is the coveted beat since it includes the famous Mucomer Pool. The beat is let in three periods, viz.:

(a) From 1st April to and including 31st May, during which months the lowest section of the Spean does not contain many fish, and angling is confined practically to Mucomer and the stream below.

(b) From 1st June to 9th August.

(c) From 10th August to the close (31st October).

Beats 2 and 1 are referred to under the Spean.

The right to net is reserved by the Abinger Estate, the limit being 100 fish, but I understand that this right is not exercised, and that practically the only river netting is in the close season for the purpose of securing ova to stock the little hatchery at Corriechoillie. I at the same time may plead guilty to a limited amount of close-time netting for the purpose of marking fish. Of five fish marked at Roy mouth in November, 1907, one turned up at Minard at the mouth of Loch Feochan, south of Oban, in July, 1908.

The estuary is unnetted except at one small fishery opposite Fort-William, which does not belong to the Abinger Estate. The estuary extends down Loch Linnhe, a distance of about fourteen and a half miles to Cuil Bay, from the westernmost point of which (Rudha Mor) the line is drawn due north-west across the loch. 
Cuil Bay is north-east of Balnagown Island and south of the mouth of Loch Leven, so that the limits of the estuary include not only the Lochy and the Leven, but also the mouths of the rivers Scaddle, Gour, and Sanda.

A ghillie is provided by the Estate with each beat let to a tenant, together with a boat or boats wherever necessary.

The rents of the various beats vary somewhat according to the season, but all particulars are at once obtainable from the agent in Fort-William-Mr. Thomas Allison, solicitor.

The lowest beats are most readily fished from Banavie, the upper from Spean Bridge or neighbourhood. If tenants use motors the distances are little or nothing. The roads are good.

Fish begin to run in March, as they do in the other early rivers of the West Coast. The average weight is about 11 to $12 \mathrm{lb}$., but a good number of the large class of spring fish may also be expected16, 20, $25 \mathrm{lb}$. Several fish of over $30 \mathrm{lb}$. are usually taken. The heaviest reported in recent years are: 1902, 38 $\frac{1}{2} \mathrm{lb}$; $1903,36 \frac{1}{2} \mathrm{lb}$. ; 1904, 35 lb.; 1905, 47 lb. ; 1906, 35 lb. : 1907, $32 \mathrm{lb}$. Good days of $5,6,7$, and even 8 fish are sometimes got.

In 1898, 222 salmon, 327 grilse, and 1742 sea-trout, or a total of 2321 fish, were secured, and this season was reported as below the average.

More recent seasons, and it must be understood that the figures include both Lochy and Spean, make it tolerably certain that about the total mentioned above may be pretty regularly expected.

The natural conditions of this river in its outflow from Loch Lochy were materially altered about a hundred years ago, when the southern end of the Caledonian Canal was constructed.

The old outlet of the river was appropriated for the formation of the canal in order to keep the southern end of the canal on the west side of the lower river. A new channel for the river in its course from the loch to its junction with the river Spean had therefore to be formed; hence at the present time this section of the river Lochy is purely artificial.

The conveyance by George Cameron of Letterfinlay to the Canal Commissioners of part of the lands of Mucomer, "being the ground appropriated for a lockhouse and for a towing-path between the said lockhouse and Loch Lochy. . . . and for a new water course for the said river Lochy," may be seen in the Record Office. (27th September, 1811. P.R. 20-14.) From a perusal of it, it appears that the solum of the ground was conveyed without any express 


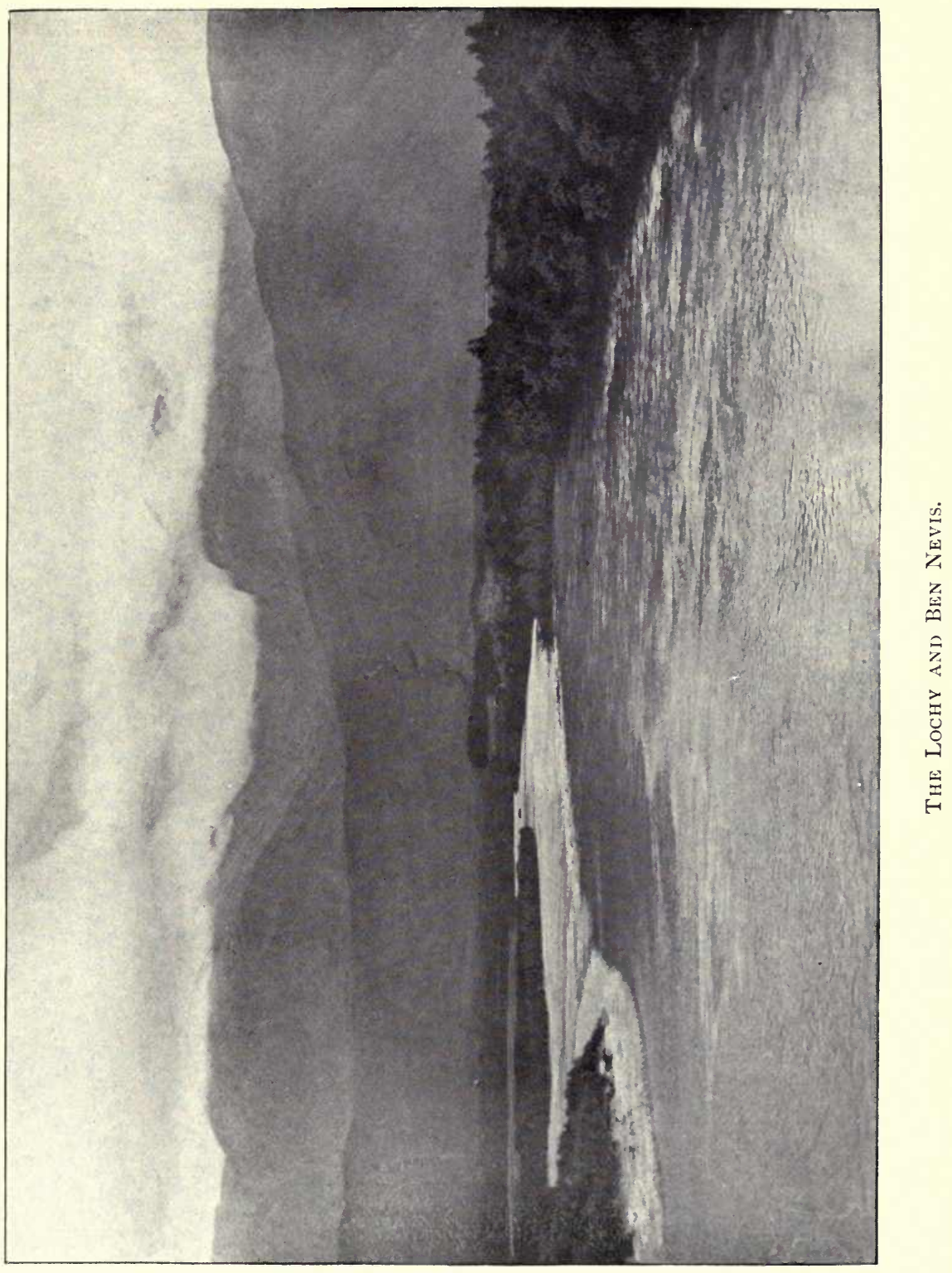



reservation. For all purposes, therefore, the Canal Commissioners are the owners of the artificial upper part of the river Lochy. They are at the same time, I understand, owners of the road bridge which crosses the channel above the fall of Mucomer.

The old junction of the Spean with the Lochy may still be clearly made out close to the canal bank, at the bend of the river below Gairlochy. The new water-course was cut considerably to the east, and joins the river Spean at Mucomer Pool. Between Mucomer and the old junction has now to be considered as part of the river Lochy rather than part of the Spean.

From the old junction to Loch Lochy by the original river was a distance of about three-quarters of a mile, with an easy gradient and uninterrupted channel. Without question the spring fish of the Lochy ascended through the old channel to the loch instead of turning off into the colder waters of the Spean. It was therefore only after the making of the new water-course that spring fish accumulated in Mucomer Pool. The water flowing from a large loch like Loch Lochy may be considered without dubiety to be similar to water from Loch Ness and Loch Awe, which have been carefully tested ${ }^{1}$ and have been found to be in winter and spring invariably warmer than the waters from tributaries draining from land unfed by large lochs. In these comparatively warm waters spring fish readily ascend, provided no serious obstruction stops their swimming upwards. On meeting with a sudden influx of cold water, ascent is stopped. Hence early Ness fish accumulate in Loch Oich and afterwards in the lower Garry, and Lochy fish now congregate in Mucomer Pool. Such spring fish, even without the influx of a cold tributary, are, in Scotland, completely checked by falls, which at a later time in the season, when summer conditions of water temperature obtain, would be but slight and temporary barriers. In this way we see all the Helmsdale early fish remaining below the small fall at Kildonan, about eleven miles up the river, Orchy fish remaining below the Orchy Falls, Loch Tay fish remaining below the Dochart Falls.

When the new water-course for the upper Lochy was cut, the Commissioners were allowed to create the Mucomer Fall, and now we see the early Lochy fish remaining below this fall and, at the same time, refusing to continue their ascent in the Spean (in the

1 "Water Temperature in Relation to the Early Annual Migration of Salmon from the Sea to Rivers in Scotland." Twenty-first Annual Report Fishery Board for Scotland, Part ii. Appendix v. 
early months), which is perfectly free to them at this point, but which in the early months of the year contains cold water.

In part the creation of the Mucomer Fall and its weir under the west arch of the road-bridge was intended by the Commissioners as a safeguard against the undue lowering of Loch Lochy. I understand, however, that Loch Lochy now generally contains a surplusage of water for canal purposes, and that in all probability the amount of water now discharged from the loch is not equal to the amount formerly carried out by the unobstructed upper Lochy. At the same time, I have no doubt, since the river Lochy was in those early days freely netted by the then proprietor of the Barony of Lochaber (the Duke of Gordon), as well as fished by cruives about two miles from the mouth, the keeping down of the fish, i.e. the prevention of their ascending into Loch Lochy through Mucomer, was regarded apparently as good policy for the net fishing. When Lord Abinger, who acquired the fishings, decided to remove all nets and cruives from the river for the sake of securing a good angling river, which, even from a purely monetary point of view, is to a proprietor of more value, Mucomer Pool became the best in the river, because the creation of the new water-course from Loch Lochy poured the warm waters of the loch into Mucomer Pool, thus inducing early fish to run this length, while the creation of the obstruction now known as Mucomer Fall prevented these fish leaving the pool. Fish, therefore, accumulated in Mucomer Pool.

In 1863 a statement was prepared on behalf of the late $\mathrm{Mr}$. Edward Ellice, and presented to the Commissioners of Salmon Fisheries, whose powers and duties are now transferred to the Fishery Board for Scotland. This statement was approved and acquiesced in by the late Lochiel, and deals very largely with the matter now under review-the change in the fisheries of the district owing to the creation of the obstacle at Mucomer. The following extracts are of special interest:

"Apparently at one period considerable value was attached to the salmon fishing in Loch Lochy. The different stations where it was prosecuted upon the shores of the loch are specially named in all the old titles. But since the formation of the Caledonian Canal the access of fish from the sea into the loch has been prevented, and the salmon fishing entirely destroyed. . . .

"The improvement of the fishing generally, the chief object of the late Act (1862), has also to be considered. The tributaries of Loch Lochy suitable for spawning ground very greatly exceed in extent all 
those of the River Lochy to which salmon have access. If the Loch Lochy tributaries were again made available by the admission of fish into the loch, a very large increase of salmon in all the waters of the district would be the certain result. . . .

"It is submitted, therefore, that more than a merely practicable access or stair is wanted at Mucomer. The proprietor of the Lochy fishing (Mr. Ellice) considers that as far as possible the same facilities for the passage of fish as existed previously to the construction of the canal should be restored. With this object the bottom of the artificial cut should be so sloped down from a point considerably above the Bridge of Mucomer as to present no greater obstruction than any other rocky part of the river between Mucomer and the sea. This can easily be done at no great cost, and since, but for the exceptional circumstances before stated, the expense must have been incurred when the canal was first made, the Canal Commissioners may reasonably now be called upon to render Loch Lochy at its present outlet, which is part of the works of the canal, as accessible to salmon as was the case before the outlet was changed.

"It is, moreover, submitted that this is exactly a case to which the provisions of the existing Act, and the powers it confers upon the Commissioners to make bye-laws, are intended to apply."

As a result, apparently, of negotiations respecting this obstruction at Mucomer, Mr. Ellice and Lochiel obtained the consent of the Canal Commissioners to the construction of a salmon pass in 1874 . In 1878 the pass was completed. It is a little difficult, at this date, to see the full design of the pass either from the banks at the fall or from the bridge above, but on communicating with $\mathrm{Mr}$. Malcolm, Commissioner to Mrs. Ellice, I have received for inspection the original plans and specification. The elevation of rock dealt with was $16 \frac{1}{2}$ feet. The top of the pass enters and traverses the central arch of the bridge, where a series of irregular step-like excavations of considerable extent were formed. The pass is then carried in a transverse manner across the fall below the bridge and the weir in the west arch; then curving down-stream, enters Mucomer Pool close to the right bank of the fall, where three pools were formed (which still remain) by the erection of built barriers. The length of the pass was about 120 feet. Including the clearing of rock at the entrance and outlet, the average gradient is only one in eight. The volume of water is large, and many of the seven steps and breaks are so abrupt that even now, when 31 years of wearing have passed, the amount of broken and very heavy water is 
very marked. This is quite out of keeping with what experience teaches are the essential features of a good pass at an obstacle of this kind. Moreover, if the fall be viewed when the water-level is above normal it will be seen that the transverse section of the pass is completely swept by the water descending the weir already referred to. Indeed, at such times two-thirds of the pass is raging white water. When the river is not too high, large numbers of salmon and sea-trout do, in the summer and autumn, ascend this pass. It is not, however, a pass which spring fish will ever freely ascend, and only spring fish would be of sporting value in Loch Lochy, as they are in Loch Ness or Loch Tay or other large and deep lochs through which salmon pass early to their natural spawning grounds. For this reason the pass erected at considerable expense at Mucomer has never been a complete success. Those who fish the lower Lochy grumble that it takes a proportion of their summer and autumn fish away; it certainly has not recreated any sport or value in Loch Lochy, and it allows only a fair number of fish to reach the best spawning grounds in all the upper waters of the district-the Pean and Dessary above Loch Arkaig.

If it were desired to create good angling for salmon in Loch Lochy, the river Arkaig, and Loch Arkaig, the pass would have to be so modified as to allow a very easy gradient for the ascent of spring fish, or else an entirely new pass of very easy gradient would have to be constructed. I would consider a pass 400 feet in length, thus giving a gradient of 1 in 25 , as suitable to meet the conditions. I have several times examined Mucomer, and I consider it is quite practicable to create a pass of the gradient suggested. With such a pass I would not hesitate to state that spring salmon fishing in Loch Lochy and the lower Arkaig would result, and this would undoubtedly be a new and valuable asset to the fisheries of the district. How soon the fish would find their way into Loch Arkaig would depend upon the spring water temperature. The rise from the one loch to the other is 47 feet, and the distance is barely a mile. The one abrupt descent occurs just above Achnacarry House, where a view from the south or right bank shows a fall of considerable magnitude, and certainly of great beauty. Two wooded islands separate the waters at this point, the island nearest the north or left bank being of some length. When the river is viewed from the north side, it is seen that a natural channel or pass is formed by the stream beyond the larger island, so that a comparatively easy passage is already secured to the fish. 
I am quite well aware that those who habitually fish Mucomer Pool and the river just below will regard any proposal to open up Mucomer Fall with disfavour. In their view the fish are more valuable in Mucomer Pool than in Loch Lochy or the river Arkaig. To put the matter shortly, the project would in their view ruin the best pool in the Lochy and very largely spoil the Spean above. I admit a certain amount of the argument. The object of a good pass at Mucomer would be to get spring fish up, fish which at present congregate in Mucomer Pool and afterwards ascend the Spean. In my view the question is purely one as to the best interest of the district as a whole. I would present these arguments for the consideration, it may be, of those who are at present opposed to any change :

(a) The fish which lie long in Mucomer Pool are not the best taking fish; their absence would probably make little difference to the angler.

(b) The best of passes will still form only a makeshift for a river of easy gradient, and a certain check to early fish would still result.

(c) The distribution of spawning fish would be better than at present, the streams of the Arkaig district being made as accessible as the Roy is at present.

The strong argument, from my point of view, is the increase of stock of salmon which would result, in a few years, from the better distribution of salmon and the fuller use of the fine spawning grounds of the Arkaig district. With this increase secured I do not believe that the fishings of Mucomer and the lower Lochy would be materially affected, although a falling-off might be noticeable for a few years. At the same time new and valuable spring angling would have been brought into existence, and the District Board provided with a new source of revenue for carrying on the policing of a wider area, and for regulating the fishings of the district as a whole.

\section{THE RIVER SPEAN}

Flows out of Loch Laggan on the confines of Badenoch and Rannoch, a sheet of water 7 miles long and 819 feet above the sea. The divide for the east and west coast drainage occurs a short distance beyond the far end of Loch Laggan, and is curiously shown in the course of the river Pattack, which drains into this end of the loch. 
The Pattack rises from a small loch of the same name, lying southeast of Loch Laggan, and runs almost due north as if it would certainly join the Mashie, a high tributary of the Spey. When only about a mile from the Mashie it is however abruptly turned off in an acute angle backwards to the head of Loch Laggan. The Spean, when it reaches Tulloch, on the West Highland Railway, is joined by the water from Loch Treig, and now passes along the floor of an ancient lake site, with its well-defined terraces.

All this water is, however, beyond the reach of salmon, and, I fear, is likely to remain so. Leaving the gravelly streams of the old lake bed, it cuts its way through a deep, rocky barrier, and shortly afterwards plunges over the formidable falls of Inverlaer. Then comes a gorge, after which another beautiful stretch of open, gravelly water succeeds. But the same sort of rocky barrier again occurs, after cutting through which the plunge over Mounessie Fall is made. Those falls mark the furthest point to which Spean salmon can possibly ascend; and I am informed by the river watchers that fish are never seen jumping at the falls. Possibly the tremendous weight of water which plunges unchecked into the pool below, a drop of about 23 feet, is too great to induce fish to do so. The gorge below gradually opens out again, and some inviting pools occur, with a ledgy break here and there, before Spean Bridge is reached.

The water from Mounessie to Spean Bridge forms the two top beats of the Abinger fishings. Beat 1 is down to the burn at Corriechoillie, and has one boat on a nice pool near Roy Bridge. Beat 2 is from Corriechoillie to Spean Bridge. Between Spean Bridge and Mucomer much of the river is unfishable, owing to its being in a continuous deep gorge.

In 1908 a fish of $43 \mathrm{lb}$. was taken on the topmost beat in October. 


\title{
CHAPTER XXVIIL
}

\author{
AWE DISTRICT. \\ RIVER AWE, LOCH AWE, RIVER ORCHY, RIVER ETIVE, \\ RIVER ADD.
}

Angling Season: 11th February to 31st October.

Netting Season : 11th February to 26th August.

(The River Orchy, by private arrangement of Lord Breadalbane, who owns the whole river, closes on 10th October.)

The District Fishery Board sits in Oban. Alex. MacArthur, Esq., Solicitor, Oban, is Clerk.

THIs large Argyllshire district is one of the most important salmon fishing localities on the west coast of Scotland, and is, perhaps, of more interest than many people suppose. The large loch vies with Loch Lomond and Loch Ness in area and capacity of water; the Orchy, which is the chief feeder, is a river of some size; the whole catchment basin amounts to about 271 square miles. Inasmuch, however, as the river Awe does not flow out at the far end of the loch from the Orchy, but within a few miles of the Orchy mouth, a very restricted amount of the loch is in the direct line of the salmon's chief path. From a salmon fishing point of view the benefit of this large and very beautiful loch is chiefly that of a reservoir. The district being extremely mountainous, and the rainfall heavy, the rise and fall of the many hill streams which enter the loch, as well as those independent of the loch, is very rapid. The benefit to the Awe of a great reservoir is therefore very great, since the flow is thus steadier than would otherwise be the case.

The district is peculiar in this, that within its limits are two smaller but independent districts having no connection with the Awe Fishery Board, and without independent means of supervision. The limits of the Awe district are: "On the north point Appin Ferry, including the east shore of Lismore Island; on the south, Craignish 
Point, excepting Loch Crinan, the loch to be defined by a line drawn from the southernmost point of the mainland immediately north of Eriska Island, and continued along the outer face of that island to the projecting point of the mainland nearest to the south-west point of the said island, and excepting the portions of the sea-coast and estuary and river, contained between Minard Point and the bridge from the mainland over Siel Sound to Siel Island; the Awe district to include all the islands within the said limits south of Lismore Island, east of the Island of Mull and north of Jura; and that the district shall consist of the portions of the sea-coast and the estuary and the river contained between the said points."

The exception of the coast from Minard Point to Siel Sound Bridge isolates the Nell district, with the little river flowing from Loch Nell to Loch Feochan. It does not seem to provide in any way for the isolation of the Creran district, yet the limits of the Creran district are separately given in the first schedule of the 1868 Salmon Fisheries (Scotland) Act, along with the limits above quoted for the Awe and other rivers. For this reason, therefore, the Creran district is considered along with the Nell district, as separate from, although surrounded by, the Awe district. Curiously enough, no separate mention is made of the Etive, which is twice the size of the Creran, so the Etive is considered as part of the Awe district in spite of the fact that in the last line of the definition first quoted the word "river" and not "rivers" is used, a distinction sufficient to entirely isolate a separate stream in some parts of Scotland.

Loch Etive, one of the most remarkable sea lochs in Scotland, runs away inland like a huge boomerang for 20 miles, its upper end pointing north-east. Near the entrance, where a marked constriction takes place for about a mile and a half of the length of the loch's course, and where also a rocky barrier exists, are the famous Connel Falls, or Falls of Lora, if the Ossianic title is preferred. At low tide the rocks of the barrier, which runs about two-thirds of the way across, stand some 4 to 5 feet above the level of the sea, and the great mass of water which has filled up the inland and wider portion of the loch being unable to recede as fast as the ebbing tide of the more open side seawards, pours over the rocks in a huge rapid or salt-water fall. The cantilever bridge of the Connel and Ballachulish branch railway now spans the old ferry immediately below the falls.

Loch Etive forms the estuary of the Awe and Etive, the statutory limits of which are "the point north-west of Dunstaffnage Castle on 


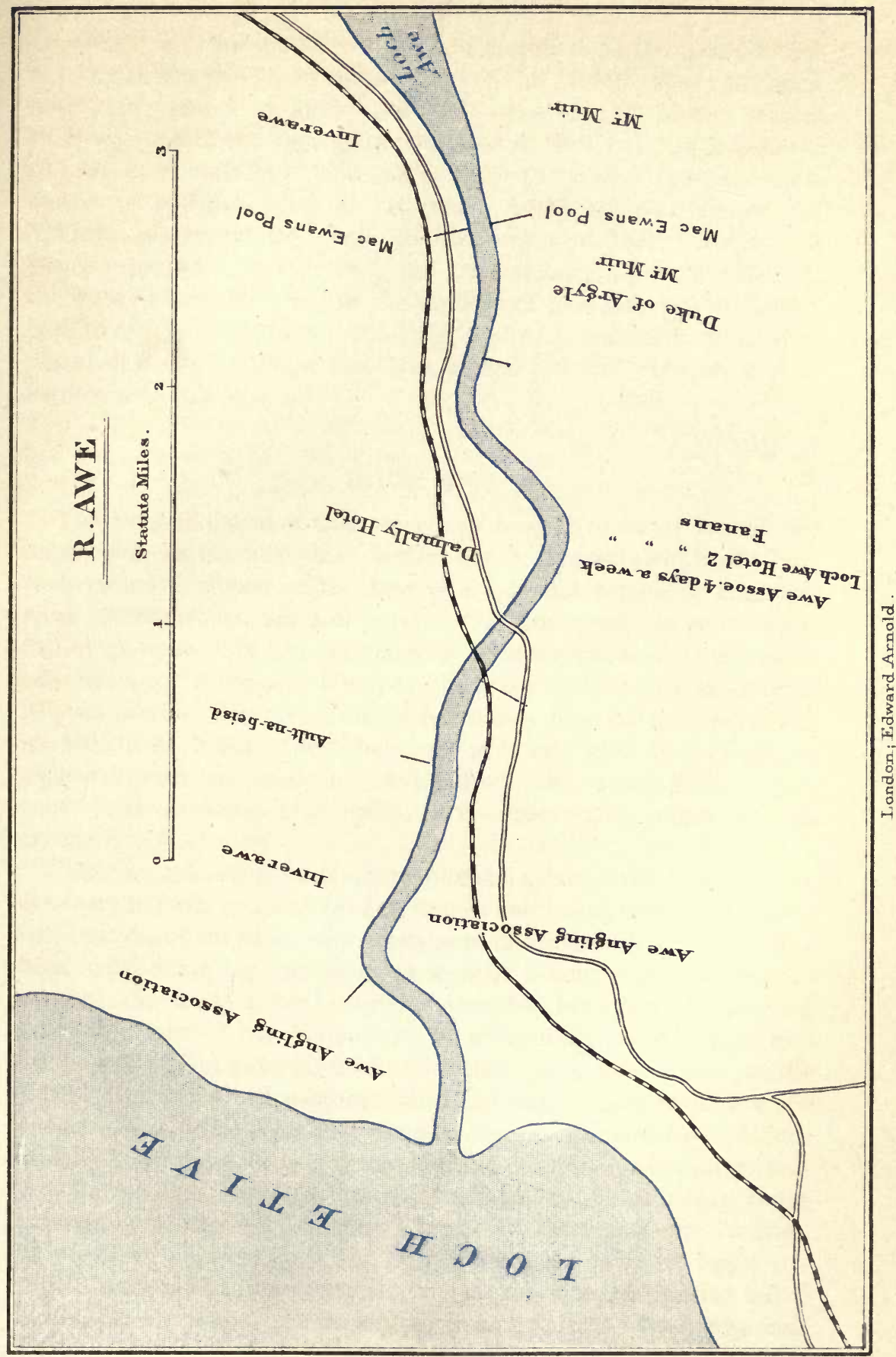



the south, and the south-west point of Garbhart on the north." The old Dunstaffnage-for in some period of the Middle Ages an almost new castle seems to have been built-the original of the present ruin, was one of the very early fortresses in Scotland. It is believed to have been built by a monarch of these parts, who was contemporaneous with Julius Caesar. It was a fairly old place when the Vikings came cruising about in the ninth century. Robert the Bruce captured it in 1308 from the Lord of Lorn after his victory in the Pass of Brander; and in the same year, it is believed, he held a parliament in Ardchattan Priory opposite Achnacloich. In quite recent days Dunstaffnage has, from a legal point of view, once more become a causus belli.

\section{RIVER AWE.}

The characteristics of this river may be said to be its broken and impetuous course, its clear water, its boulder-strewn banks and steep wooded slopes. The Awe is a splendid type of a Highland river; it has that dash and swirl about it, at once courageous and full of purpose. It has no time to meander amongst meadows or rest in rocky caverns. When it glides out of the Pass of Brander below towering Ben Cruachan, it has barely four miles to go, at the nearest, to Loch Etive, and down its widening glen it goes with a gladsome rush and sparkle. A hundred and sixteen feet or so it runs down in those four miles, so it doesn't turn often to look behind.

The Awe salmon seem to partake of the spirit of the river. They are lusty fellows, deep-keeled and fine in the lines; hard fighters that will cut you if they can, and perhaps rush for the sea if they cannot. Men who have had far more experience fishing salmon in various parts of the world than I, say the Awe fish are amongst the very finest to catch. I can believe this, in spite of the fact that men who fish other districts have no doubt that their particular salmon are the finest in the world. I recollect venturing some remark about the fine appearance of some Ness fish to an Inverness fishmonger. He was positively ashamed of my ignorance, and informed me that it was well known that Ness fish are the handsomest in Scotland. I was buying one of the ugliest kelts I ever saw in a shop at the time. It interested me because it had been taken from the Ness in July.

The Awe used to be pretty heavily netted, and this netting dated from an early period. In recent years, and probably for a very long 
time, it was customary to commence netting about the middle of March, and to work up to the Inverawe summer-house. The bottom was kept very smooth, and several nets were used so completely that, except in floods, it was believed no fish were allowed to ascend save in the weekly close time. Fortunately, the netting could never be taken so far up the river as to make the weekly close time inoperative, and a fair stock of fish always persisted in the district.

This netting in the river was first reduced in 1906 by one net only being worked for twelve hours out of the twenty-four, viz. from $10 \mathrm{a} . \mathrm{m}$. till 10 p.m., and at the same time a weekly close time of 40 hours being arranged for from 6 p.m. on Saturday to 10 a.m. on Monday. A further modification took place at the commencement of season 1908. Two gentlemen, Major Macdonald and Mr. Plevins, associated themselves in an endeavour to materially improve the Awe angling. They, with Lord Breadalbane, rented the nets, and entirely removed them from the river, and they also removed a net in Loch Etive. They also took a lease of the water on the left bank, which used to be fished from Taynuilt Hotel, including the water at the mouth, and sublet seven rods (from 1909 the number is, I understand, to be six). They are prepared to pay a large proportion of the expenses incurred in these operations.

In the upper part of Loch Etive Lord Breadalbane and Mr. Ian Nelson, of Glen Etive, took off other nets, and now only two stations are fished in this sea-loch, one belonging to Inverawe and the other to Ardchattan. Both are a short distance up the loch from the mouth of the Awe, and both are now worked by several boats.

In the rod-fishing acquired by the River Awe Association referred to, no lure save the fly is allowed, and fishing for the season ceases on 15th October, i.e. a fortnight earlier than the statutory time. The following are the rules to be observed, and the scale of charges :

1. It must be distinctly understood that one rod only is permitted to fish any section at one time. No objection will be made to an angler giving a friend or his ghillie a cast.

2. Anglers are requested not to fish before 9 a.m., except in bright weather when the river is low. Anglers are recommended then to leave the water quiet during the day and fish at sun-down. This will be to their own benefit.

3. Anglers fishing for sea-trout must not be on the water after midnight.

4. A record of all fish killed will be kept. 


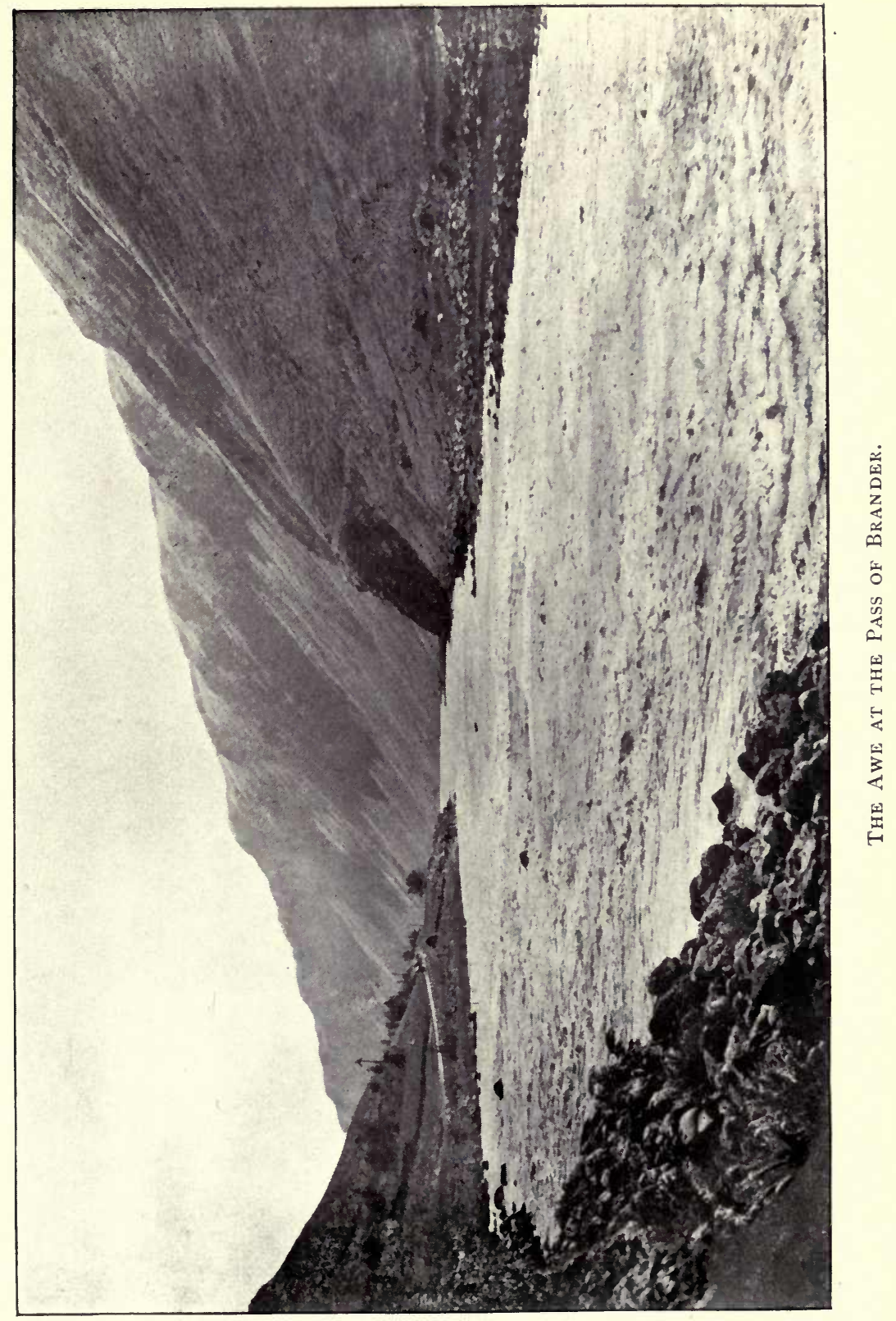



5. All luncheon paper, bottles, etc., should be buried, and not thrown into the river or left lying about.

6. The Association reserve to themselves the right to disallow the further employment of any ghillie misbehaving himself.

7. Tickets must be shown to the Association's representatives on demand.

Scale of Charges.

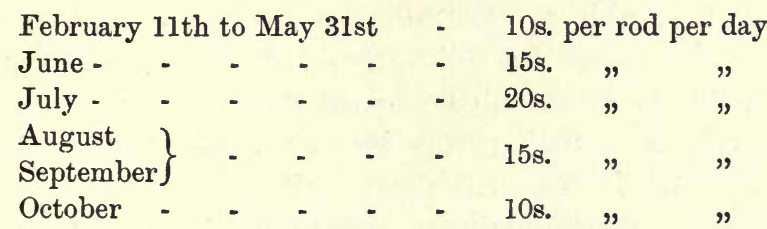

Major Macdonald has kindly given me the returns for this section of the water for the three last years, and this section produces the largest score to the rod:

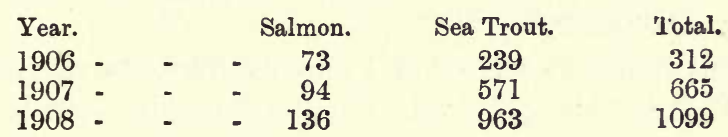

If we add to this the Dalmally Hotel scores for the same years, kindly given by Mr. M'Laren, we have a total of salmon:

\begin{tabular}{|c|c|c|c|c|}
\hline Year. & & Awe Association. & Dalmally Hotel. & Total. \\
\hline 1906 - & - & 73 & 51 & 124 \\
\hline 1907 - & - & 94 & 60 & 154 \\
\hline 1908 - & - & - $\quad 136$ & 35 & 171 \\
\hline
\end{tabular}

The marked increase is full of promise, and it is additionally encouraging to hear that a distinct improvement has been experienced in the number of spring fish. We have already remarked that the Awe is a rapid river, with much broken water. Only at the mouth and in the middle section is there any extent of water quiet enough to be readily associated with spring fishing. The fact of the large loch at the head giving a large volume of water, as well as the comparatively high temperature of the water, must, however, be taken into consideration as a factor gauging the value of prospective spring fishing. The tidal part of the riverjust above Polfearn-where, previously, netting was carried on, is now reported as yielding excellent results to the rod, when the tide is out. In the spring of 1908, 2 fish were taken in March, and 10 in April, including weights of $36 \mathrm{lb}$., $31 \mathrm{lb}$., $26 \frac{1}{2} \mathrm{lb}$., $24 \mathrm{lb}$., and $21 \mathrm{lb}$. During the season about 30 fish were got from this new piece of water. I believe the development of this river's fisheries will be of great interest. 
The season 1908 was, on the whole, bad for angling. More especially in the autumn the weather was dull and hazy; fish did not rise freely, and for the most part laid hold poorly. On all hands I was informed that an unusual number of salmon were in the Awe, and apparently anglers have experienced some exasperation in seeing large fish and being unable to get hold of them. Yet, as far as I have been able to ascertain, the total catch was 253 salmon and grilse, made up of the following: 136, 28, 5, 37, 35, and 12 . I have no doubt the river will do better still.

In February, 1909 (25th to 1st March), 4 fish were taken, $18 \mathrm{lb}$, $21 \frac{1}{2} \mathrm{lb}$., $23 \mathrm{lb}$, and $29 \mathrm{lb}$. All these early fish are reported as particularly shapely; the 29-pounder just referred to, for instance, was $42 \frac{1}{4}$ inches long and 24 inches in girth.

The various fishings of the river and their relative positions will be most satisfactorily understood by referring to the sketch-map which I have prepared.

Great apprehensions were felt by many interested in the district on account of certain proposals for leading water-power from the head of the river to Bonawe, which seemed to imply a considerable abstraction of water. Such proposals are at present, at least, in abeyance. The interests of the salmon are perchance too strong for the money-making instincts of man.

The Awe is famous for heavy fish, and several over $40 \mathrm{lb}$. are usually taken each year. Some years ago a 54-pounder was taken from Pol Verie, and a 52-pounder from the Cruive Pool. Another $54 \mathrm{lb}$. fish was hooked in Cassan Dhu and landed at Crubeg, i.e. from the top to the bottom of what previously was the Taynuilt Hotel water. Mr. Augustus Grimble describes this famous run, having seen part of it. He says that in following the fish from the Otter Pool into the Stepping-Stones the schoolmaster was up to his chin, and that the man was fortunately tall. Well, I have heard of an Irish angler swimming down through a bridge with his rod rather than allow a good fish to break him.

In 1907 the heaviest fish was a 51-pounder, I believe. I do not recollect who caught it, but a 50-pounder was also landed by Dr. Childs, a photograph of which he has kindly allowed me to see, as an example of a large Awe fish. It was $51 \frac{1}{2}$ inches long and $28 \frac{1}{2}$ inches in girth, breadth of tail 15 inches. I understand that a photograph of this fish has already appeared in Country Life.

Lord Breadalbane's Awe water used to be fished by the late Colonel Murray of Polmaise, who, with his twenty-feet rod, also 
accounted for a good number of large fish. He used to fish about six weeks from 25th June to 7 th August, and Mr. Grimble says ${ }^{1}$ that in that period the average was from 70-100 salmon and grilse, the weight of the salmon averaging never less than $16 \mathrm{lb}$., and being in some seasons $21 \mathrm{lb}$. A fair number of sea-trout would also be taken.

A short distance above Inverawe House there is a cruive which is of interest since it is the only structure of the kind in Scotland which does not present a complete barrier across the river in which it has been constructed. In other words, it conforms to the old requirements for a "mid-stream," since the central flow of the river is unimpeded by the cruive dyke. This old requirement was never repealed by any statute, but it has happened that in cases brought before the Courts with reference to cruive fishings in Scotland, witnesses have been unable to point to any cases in which " midstreams" still existed, and for this reason, apparently, the Courts have considered that in process of time-and these structures are all very ancient-the requirement for a mid-stream has fallen into desuetude.

The Inverawe cruive dates from 1480 , in the reign of James III., and the structure has never been modified since that time, except that an iron heck was substituted for a wooden one in 1839. There is one cruive-box, measuring approximately $11 \mathrm{ft}$. across and $7 \mathrm{ft}$. 6 in. high at the heck. The up and down stream measurement of the box is 9 feet. There is a considerable drop in the gradient immediately below the box, so that the ascent for fish is steep. As a matter of fact, the cruive does not yield many fish in the year, and now, by agreement, it is not fished during the night.

The only other artificial structures of note in the Awe are the platforms from which, more especially in the autumn, many of the casts are fished. Owing to the broken nature of the water-flow, the river has in it many spots where the art of reaching the proper lie is difficult, and some spots where a lie on the opposite side cannot be reached, or cannot be fished properly if reached. Under these conditions many pools are much more satisfactorily negotiated by the aid of planks run out to iron frameworks fixed in rocks. With the rapid flow of the stream some of these casting places are somewhat "airy," and not a few fishers new to the Awe have found that they require to cultivate a little confidence in themselves before they can make use of the stagings with much pleasure. Gradually, I suppose,

${ }^{1}$ Salmon Rivers of Scotland, vol. ii. p. 24. 
familiarity breeds contempt for their own fears. The Meal Pool has the worst plank.

The pools of the river from the mouth upwards are:
1. Palfearn (tidal).
2. Crubeg.
12. Little Otter.
13. Long Pool:
3. Race Wall.
14. Yellow Pool.
4. Grey Pool.
5. Clay Pool.
6. Cruive Pool.
15. Cassan Dhu.
16. Oak Pool.
7. Upper Cruive.
17. Garraralt.
8. Errachdt.
9. Stepping stones.
10. Red Bank.
11. Big Otter.
22, 23, 24. The Three Ash-Tree
Streams.
25. Bothy Pool.
26. Stone Pool.
27. Pol Verie.
28. Seal Pool.
18. Meal Pool.
19. Shepherd's Pool.
20. Yellow Spring.
21. Colonel's Pool.
30. The Shallows.
31. 'The Disputed Pool.
32. The Brander Pool.

\section{LOCH AWE.}

The loch is perhaps more celebrated for its romantic beauty than its salmon, although many resort to it for trout fishing. The fact remains, however, that all the early fish which ascend the river in March (the Orchy fish) necessarily pass through a section of the loch to get to the head river. With the removal of the Awe nets the expectation naturally is that the stock of both early and late fish will be increased. If this is so, the chance of successful salmon fishing in the loch will also be increased. The development of Awe spring fishing will be most interesting to watch. In the loch none but spring fish may be expected to take in any numbers.

The main line of the loch is along the main axis of the country, i.e. N.E. and S.W.; but when one regards the peculiar arrangement of this large loch, and the fact that the main inflow and the main outflow are within a few miles of one another, the latter on a deep cross-arm at right angles to the main axis, one naturally wonders how this came about. What one may for convenience call the railway and river end of the loch is by far the most important and by far the most beautiful and attractive. Personally I have never been able to rid myself of the feeling that this is the head of the loch. Yet I know on reflection that what is commonly called the head of the loch is 24 miles away at Ford. What seems to me to dominate the head of the loch are the head streams-the Orchy, Stray, and Lochy. These pour their waters in by Dalmally, and are certainly the chief feeders of the loch, as they are the rivers up which the salmon ascend, or, shall we say, try to ascend. The far end of the loch in many ways is the low end of the loch, but of this later.

The length of Loch Awe from Ford to the mouth of the Orchy is practically the same as the length of Loch Ness, including Loch 


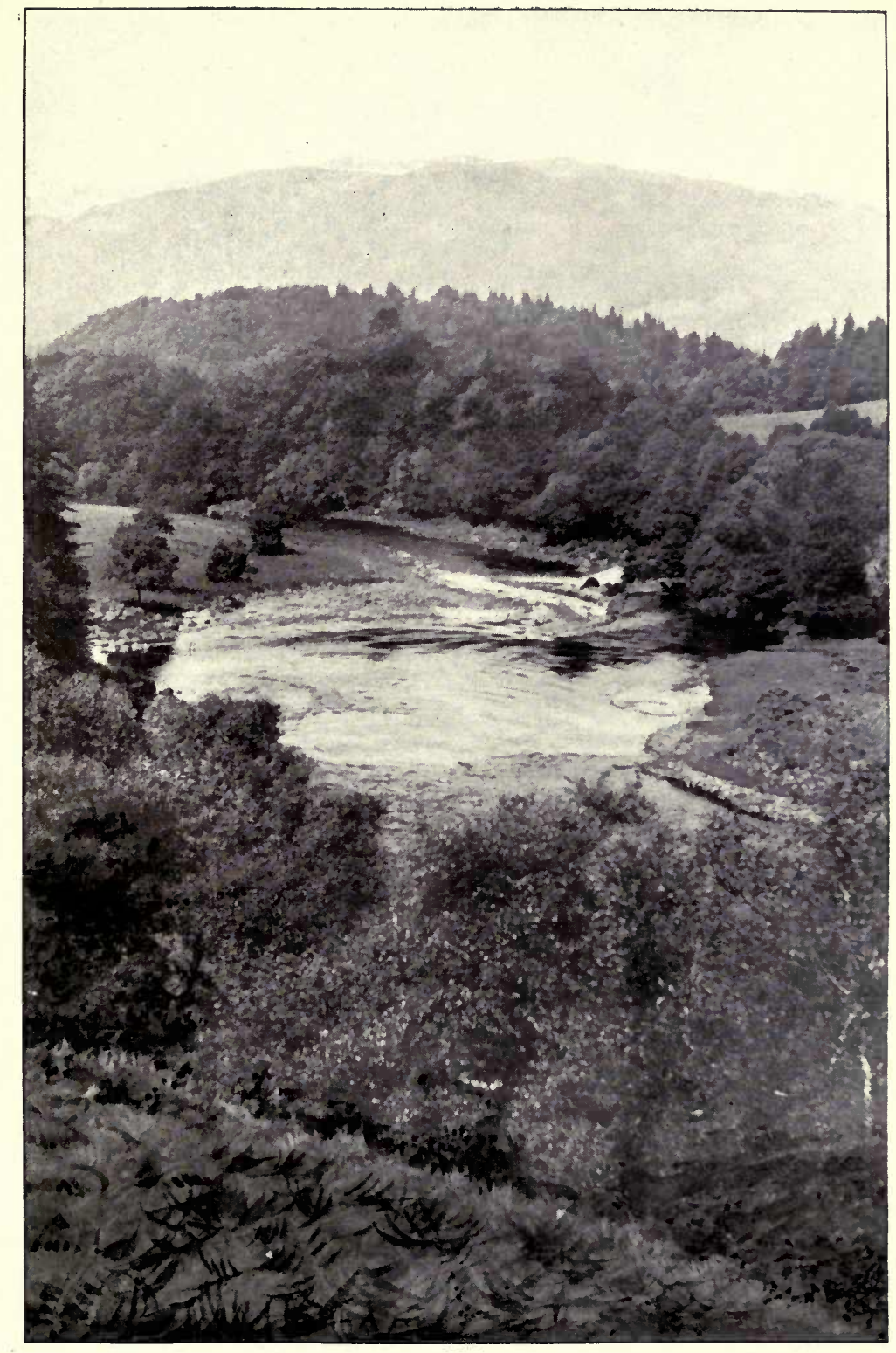

Awe, at Inverawe Cruive. 

Dochfour. The mean breadth is about half a mile, or 2.3 per cent. of the length when the cross-arm to the Pass of Brander is taken into account. The narrowest part is barely a quarter of a mile, while at the cross-arm a measurement of 2 miles may be obtained. The level above the sea is usually stated as 118 feet. The loch was surveyed and charted by naval officers in 1861, and again by Sir John Murray's Bathymetrical Survey in May, 1903. During the fourteen days of the latter survey "the level of the water varied to the extent of about 2 feet, the highest level, as measured from benchmark, being 117.9 feet above the sea, and to this level all the soundings . . . have been reduced."

The bottom of the loch is peculiarly irregular. The deepest part is 4 to 5 miles from the head of the loch where soundings of 306 feet or 51 fathoms were found in four places. The 200 feet contour line encloses five separate areas, and the 100 feet contour line three separate areas. A deep channel runs from below Loch Awe Station to the Pass of Brander. A deep channel also runs down the long narrow main line of the loch. It is noticeable that between the right angle point at New Inverawe and the point N.E. of Inistrynich a long shallow runs out, including Inishail and several lesser islands, and that only a narrow channel of water deeper than 50 feet exists near the Inistrynich shore. This almost suggests that the present loch was at one time two; that the line from the Orchy through the Pass of Brander formed one, and the long narrow stretch from Inishail to Ford another. In this case the more southern loch may have fed into the more northern, as the line of the various hill burns from the Cladich to Sonachan House on the east side, and the line of the Avich on the west side, rather seem to indicate. Or it may be that the outlet of the whole loch was originally at Ford into Loch Craignish or Loch Crinan, and that a great dislocation of the earth's surface along the south of Ben Cruachan, where the Pass of Brander now is, opened a new outlet. I am not aware, however, that there is any evidence of such a dislocation. It is more than likely, I should think, that the glaciation of the district indicates the line along which present day appearances came about, and I have no doubt great glacial outflow went on at one time where Ford now stands.

We need not, however, concern ourselves overmuch with these speculations. The peculiarity of Loch Awe is that the greater part of it, some twenty miles in length, is simply a blind end. The main line of ascent for fish is from the Brander across a few miles of 
water to the Orchy mouth. In this line depths of fully 200 feet are found most of the way, till the gradual shallowing opposite Loch Awe Station announces the approach to the peninsula upon which old Kilchurn Castle stands.

The castle seems to divide the honours of the loch with Ben Cruachan and the Pass of Brander, although the islands have more interest connected with them than most people suppose. Tradition gives it a very early origin, and apparently the ground upon which the castle now stands had a fortress in the days of the MacGregors before it passed to Sir Duncan Campbell of Lochow, and then to his youngest son, Sir Colin Campbell, the founder of the Breadalbane family. This Sir Colin died in 1478, and is regarded as the first builder of the present castle, the date generally assigned being 1440 . The south side of the building is assigned to the beginning of the sixteenth century, and the north side, which is the most impressive as well as the largest portion of the building, was erected in 1615 by the first Earl of Breadalbane. As a matter of fact the castle was occupied by the Breadalbane family till 1740 .

\section{RIVER ORCHY.}

This river forms the chief head water and the chief spawning ground of the Awe. In this respect it is important, but also as an angling river it occupies a high place.

It rises from a number of small hill burns, which flow northwards on the slopes of Guala Mhor, a hill of 2618 feet, the summit of which is cut by the Perthshire boundary a short distance to the north of the upper river Lyon, which flows into the Tay near Aberfeldy. The small hill burns presently unite to form the Water of Tulla, which flows in a south-westerly direction along the borders of the Blackmount Forest for 10 miles to Loch Tulla. From Loch Tulla the river is named the Orchy, and the course is $16 \frac{1}{2}$ miles to Loch Awe, so that the total length of the river is about 27 miles.

The gradient of the Water of Tulla is for the most part steep. From the junction of the hill burns the fall to Loch Tulla is quite 1000 feet, which represents a gradient in 10 miles of 1 in 52, but this is pre-eminently the spawning area, and, although many rough places exist, salmon are able to penetrate to the top of the waterway. The railway line to Fort-William passes up the valley of the Tulla as it rises from Bridge of Orchy to the Moor of Rannoch. 
Loch Tulla is $2 \frac{1}{2}$ miles in length, and averages half-a-mile in breadth. It covers an area of over one square mile, and with its island and wooded slopes round Forest House and Inveroran, forms a beautiful point of focus in the wild glen. It has a mean depth of 33 feet, and a maximum depth of 84 feet. The level above the sea is usually estimated as 555 feet. Forest House is on the north side, and Inveroran Hotel at the south-west end. The whole country round and the rights of salmon fishing, which are distributed between lodges and hotels, belong to the Marquis of Breadalbane. The basin of the loch "is of simple conformation, except that a small depression, with depths exceeding 50 feet, occurs to the south-west of the island Eilean Stalchairichd, separated from the larger deep portion of the loch lying to the north-east of that island, where there is a depression three-quarters of a mile in length and over 75 feet in breadth, the maximum depth of 84 feet having been observed near the southern end of this depression, and a quarter of a mile from the island." 1

A stream of some little size, but interrupted by falls, enters the loch at the southern end about midway between the lodge and the hotel. It drains the hills to the westward, and has its origin in a small loch called Loch Dochard, and little tarns and streams beyond, which rise near the divide to Glen Etive.

Loch Tulla used to be very famous for its trout, some great stories being on record of what could be done on a good day by wading round the margins. It would appear that trout of $1 \mathrm{lb} ., 2 \mathrm{lb}$., and $3 \mathrm{lb}$. were common, and that trout up to $9 \mathrm{lb}$. have been taken. Curiously enough they were not, apparently, described as ferox.

Some sixty years ago, however, about the year 1848, the late Lord Breadalbane was advised by some dangerous person to introduce pike. He did so, and Loch Tulla and the neighbouring streams have not been quite the same since. The pike increased wonderfully. They were quite a success in this respect. The increase was, however, at the expense of the trout and salmon-fry. Nowadays a systematic war is waged against them when they enter the weedy shallows to spawn in the spring. To increase the stock of trout, the present Marquis has established a small hatchery.

No mention of the pike is made in the First Statistical Account of this neighbourhood, written in the last decade of the eighteenth century. Salmon, char, trout, and eels are alone mentioned. It has been repeatedly stated that the pike of Loch Awe are sprung

1 James Chumley, "The Survey of British Lakes"; Scottish Geographical Magazine, xviii. No. 8 , p. 422 . 
from the pike of Loch Tulla, introduced as described. I cannot, however, find any real reason for this view. There is, of course, no impossibility in pike coming down the river Orchy from Loch Tulla to Loch Awe, but pike seem to have been in Loch Awe before they were in Loch Tulla. Possibly the dangerous person who advised the Marquis had already been acting on his own initiative in the neighbourhood. His name is unknown, but his works do follow him. The Second Statistical Account, which was written by a Rev. Duncan Maclean in 1843, i.e. five years before the introduction of pike to Loch Tulla, contains the following passage: "Various kinds of trout abound in all our lakes, especially in Loch Awe, viz. salmon, eels, char, now rather scarce fish, perch, and pike; the pike is only of recent importation, and it is greatly feared that the character of the lakes will suffer from the ravages of this active and voracious fish." The term " recent importation" may mean several years, as apparently the all-too-well-known effect was already showing. It seems to me probable, therefore, that pike were in Loch Awe eight or ten years before they were in Loch Tulla. The use of the word "trout" as including salmon, eels, char, and pike, etc., is unusual. It clearly means "fish," just as sailor-men, when speaking of foreign craft, be they French, Italian, or what you will, class them all under the name of "Dutchman."

There is a fishing story related in the Life of Christopher North connected with Loch Tulla which is worth recalling. ${ }^{1}$ The celebrated Professor of Philosophy was staying at the school-house at the foot of Glen Orchy, for the neighbourhood was a favourite resort of his. He started very early one morning to tramp to Loch Tulla to fish, thirteen miles distant. On reaching it he discovered that he had left the top of his rod behind. "Nothing daunted, he walked back, breakfasted, got his fishing rod, made all complete, and off again to Loch Toila. He could not resist fishing on the river when a pool looked invitingly, but he went always onwards, reaching the loch a second time, fished round it, and found that the long summer day had come to an end. He set off for his home again with his fishing basket full, and confessing somewhat to weariness. Passing near a farmhouse whose inmates he knew (for he had formed acquaintance with all), he went to get some food. They were in bed, for it was eleven o'clock at night, and, after rousing them, the hostess hastened to supply him; but he requested her to get him some whisky and

\footnotetext{
${ }^{1}$ Christopher North, a Memoir of John Wilson, by his Daughter, Mrs. Gordon. Ed. 1879, p. 137 .
} 
milk. She came with a bottle full and a can of milk with a tumbler. Instead of a tumbler he requested a bowl, and poured the half of the whisky in, along with half the milk. He drank the mixture at a draught, and whilst his kind hostess was looking on with amazement, he poured the remainder of the whisky and milk into the bowl, and drank that also. He then proceeded homeward, performing a journey of not less than seventy miles." He truly was a man of immense strength and capacity.

The river Orchy flows from the south-east side of Loch Tulla. Its course is at first broken and stony, presently rocky, and often deeply cut, finally the river becomes quieter and of fine fishing character; a typical example of mountain valley erosion. From the salmon fisher's point of view there is a lot of most interesting water in the Orchy.

Seven miles above Dalmally and nine below Loch Tulla the Falls of the Orchy occur. There are really three separate falls on the river, of which the lowest, already referred to, is the most serious. When the river is in good running order I estimate this lowest fall as about 16 feet in height. In low water conditions the obstruction is somewhat higher, since the rock is cut into a deep and narrow cleft just below the main plunge, where during floods the water, being confined, rises somewhat in height. The rocks of the Orchy bed dip across from left to right, and slant slightly down-stream. All the falls show somewhat of the same formation. The rocky barrier has broken away towards the left bank, and here the main flow occurs. Towards the right bank the rocks still stand at a high level, and are likely now to remain so. At the main falls are many sculptured hollows and pot holes. With the trees fringing the river bank and the setting of great hills on either side, the scene is extremely picturesque, but to the salmon the place is an ugly one. A channel has been blasted out of the rock close to the right bank to form a pass, and up this I fancy practically all the fish go, for only in very exceptional conditions of water can the side cliffs of the main fall be at all passable to leaping fish. The pass is, however, very steep and rough, and could be easily improved. Only in fairly high conditions of water is this pass negotiable. In low water it is dry. Not till summer will any fish attempt this obstruction.

The second fall as one ascends is not nearly so high, but, nevertheless, it is a distinct difficulty to fish. It is situated about 400 yards above the first fall, and is an abrupt descent at its lowest of about six feet. 
The third fall is about 5 feet high, but is not abrupt like the middle fall, and when there is good running water fish do not appear to experience much difficulty. It is situated about three miles further up-stream, a short distance above the mouth of a deep glen which enters from the west. Above the middle fall is a canal-like stretch of water between steep rocky banks. It looks good holding water, but I am informed it does not fish well. Once the fish surmount the second obstacle they appear to push on pretty rapidly through the often shallow and rather straggling and stony water below Bridge of Orchy. A mile below the bridge a considerable stream or large burn enters on the left bank, flowing in a northwesterly direction. The lower part of its course is very rocky and steep, and is very difficult for fish. Some beautiful spawning ground exists a couple of miles up, and some recent blasting operations have made this more accessible to salmon than formerly. Mr. Glen, Lord Breadalbane's factor, informs me that fish are now seen above. The whole river Orchy belongs to Lord Breadalbane, but seven distinct fisheries exist, viz. Craig, Dalmally Hotel, Succoth, Arichastlich, Inveroran Hotel, Auch, and Blackmount.

To understand the arrangement, it is necessary to view the river as fished separately from north or south bank. Craig and Blackmount waters are fished from the north or right bank; Dalmally Hotel, Arichastlich, Inveroran Hotel, and Auch waters are fished from the south bank. Arichastlich and the topmost beat of the Craig water are opposite each other, as also is the Blackmount and Inveroran fishing immediately above. In each case, since the river is not large, the water is fished day about by one side and the other. The longest stretch of water is held by Dalmally Hotel, but it is not continuous from the mouth upwards. Above Dalmally road bridge and below the hotel the Craig Lodge Pool is excluded, and above the hotel a short stretch of water about 200 yards in extent is reserved for Succoth Lodge. This is not marked by posts as other fishings here are, but is situated between the mouths of the Lochy and the Fhuaran Burn. The up-stream limit of Dalmally Hotel water, about $3 \frac{1}{2}$ miles above this point, is marked by a boundary post, as are the limits of all the other fishings further up. The total extent of Dalmally Hotel water is about $7 \frac{1}{4}$ miles. Then comes the central section of Craig water, being the pools below the falls. Above this comes the water divided between Craig and Arichastlich already mentioned; next the water divided between Blackmount (Forest Lodge) and Inveroran Hotel; and then, between this and 
Bridge of Orchy, about a mile of water, the Auch fishing. As a matter of fact, the Blackmount water properly extends from the upstream limit of Craig fishing to Loch Tulla, but there seems to be an understanding that opposite the Auch bank the Forest Lodge tenant does not fish.

Spring fishing is confined to the water below the falls. The water above the falls fishes only in summer and autumn. From what has been already said of the main fall, this will be sufficiently clear. The Craig pools below the fall are the chief pools where early fish congregate, since it is against their habit to proceed further till the water rises in temperature.

The Dalmally Hotel water is, however, of great beauty, there being a fine series of streams and pools with gravel banks. In general character this lower Orchy is singularly like the lower Lochy on a smaller scale. Much depends, however, on the condition of the Awe in the early months of the year in making or marring the success of the Orchy. Mr. M'Laren, the Dalmally hotel-keeper, has kindly furnished me with his returns for the three last years. In 1908, the river running very low, the fishing was unusually poor. By 6 th June only 3 Awe fish had been taken, and the season throughout was certainly exceptional. The years 1906 and 1907 may, however, be taken as fairly representative of what may be done in the Orchy.

\begin{tabular}{|c|c|c|c|c|c|c|}
\hline & & & & & & Dalmally Hotel. \\
\hline 1906 & - & - & - & 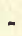 & - & 36 \\
\hline 1907 & - & - & - & - & - & 40 \\
\hline 1908 & - & . & - & - & - & 16 \\
\hline
\end{tabular}

With regard to the upper Orchy, there is the additional uncertainty of suitable water for fish to ascend the falls below. What is wanted is that early summer should be wet, and that a good stock of fish should have run through the Awe in Spring. The best performance I know of on the Inveroran water is 15 salmon in eight days to one rod. Taking the Blackmount and Inveroran water together, the best result I know of was got in 1882, when three rods killed 49 fish in Inveroran and 23 in Blackmount. These catches were recorded at the time in the Annual Reports of the Fishery Board for Scotland.

The Orchy is to the Awe what the Garry is to the Ness. The upper part of the waterway is the early fishing river. The district now under consideration is not so celebrated as the other, but the conditions are very similar. The Ness and the Awe are, or were, generally considered later rivers, or rivers in which spring angling 
was not likely to yield much result. But all the spring fish of the district passed through them into the large loch from which each river flows, and ascended to the river above. The Garry fish leave Loch Ness, and, passing up the river Oich, enter the cold waters of Loch Oich, fed from the Garry. Here, while the cold conditions of spring continue, they remain. In the case of the Orchy, tish in the same way leave Loch Awe and enter the colder waters of the Orchy, but they ascend the easy waters of the lower Orchy only to be met by the falls. These falls are capable of ascent given suitable conditions of water-flow; but it happens here, as in the Garry, fish will not attempt to make the ascent till the wintry thermal conditions have passed out of the water. Scottish salmon will not jump rough and steep barriers till the water has become comparatively warm; and if it is considered desirable to take them above such places, it is imperative that they should swim easily either in a pass of gentle gradient, or in the river bed after the barrier has been removed, if this is possible without creating other difficulties above.

I refer to this question of temperature and the ascent of fish when dealing with other districts, such as the Ness, Lochy, and Tay, and it seems unnecessary to deal with the matter further here; but I may add that in referring to the Orchy as being colder than the Awe in the spring, I am speaking from actual thermometric readings as shown on a chart of curves representing weekly means for both rivers in the winter of 1901-1902, and already published. ${ }^{1}$

Salmon are not expected in the lower Orchy in any numbers till April, although a few are usually captured in March. Up to the present, I believe, the earliest date is 3rd March, and this was regarded as exceptionally early. In 1908 the first fish was taken on 10th April. Fish pass through the Awe in March, and, when the nets were regularly at work at the mouth of that river, salmon were then taken in some numbers. The spring fish of this district are usually of the big class, and in the pool below the lower fall in the Orchy one may see, at times, a fair number weighing apparently between $20 \mathrm{lb}$. and $26 \mathrm{lb}$. On one occasion I counted $21 \mathrm{fish}$ swimming slowly about the pool below the iron footbridge. Fishing generally begins with April, and is best in the lower Orchy about the middle of that month. Kelts are very seldom seen, being presumably already out of the river. The average weight of Orchy fish is about $14 \mathrm{lb}$. Lord Breadalbane institutes an earlier closing date

1 Twenty-first Annual Report Fishery Board for Scotland, Part ii., Appendix v., p. 71. 
than is required by statute, all rods having to cease fishing by 10 th October.

The Inveroran Hotel water comes into ply about the middle of June, when the fish are ascending the falls, and continues to the end of the season. An occasional salmon is taken in Loch Tulla, but as a rule the trout are fished for in the loch and the salmon in the river.

Before leaving the Orchy it may be as well to mention that, in existing conditions, the Strae, which joins it at its mouth, is of practically no use as a salmon angling river, although a few spawning fish-late comers-enter it.

\section{RIVER ETIVE.}

This river rises from the Lochan-Mathair-Etive in the Moor of Rannoch, and from a number of small converging burns east of Kingshouse, and some 970 feet above sea-level, and has a course of about 15 miles to the head of Loch Etive. Unfortunately only barely six miles of the river are open to the ascent of salmon, for at Dalness a fall occurs which effectually stops further progress.

In general character the Etive is not unlike the Orchy, but on a rather smaller scale. There are stretches of streamy water with gravel banks, and at intervals rocky and very deep pools, which have a tendency to form into long rocky channels. The river is, however, subject to violent changes of level, for the rainfall is not light and the surrounding country is extremely steep. The floods move the gravel banks to a great extent, and the last mile and a half of the river is cut, with a winding course, through masses of alluvium carried down from the hills and poured out at the head of the loch. Mr. Nelson, of Glen Etive, informs me that he has seen the river rise 12 feet, in one of the rocky channels, in the course of a day.

After each flood the river is in good ply for salmon for about one day, but successful sea-trout fishing is carried on for some time. Salmon commence to run in May, and some heavy fish are reported to ascend pretty early in the season, and to remain in the deep rocky pools up the river. Sea-trout are found in great numbers in the lower reaches.

The head of the sea loch near the mouth of the river used to be a most profitable netting station, for in summer when the river has fallen low there is not much inducement for fish to run. All the 
upper loch shore was also netted at suitable places. At the end of 1907 , however, all the nets in the upper loch were entirely removed by purchase by the conjoint action of Mr. Nelson and Lord Breadalbane, and now, as in the case of the Awe, a much larger stock of fish may be expected in fresh waters. The average take by rods at the present time is about 15 to 18 salmon and fully 400 sea-trout. but the prospects seem good for a considerable addition to this bag.

The whole available river on the right bank, except the Dalness Fall Pool, goes with Glen Etive. Dalness fishes below the fall on both banks and the upper river on the left bank, then Lord Breadalbane comes in also on the left bank, and Glen Etive has in two sections about $2 \frac{1}{2}$ miles of the left bank on the lower water.

In addition to the removal of nets already referred to a good deal is being done by Mr. Nelson to give greater facilities than naturally exist for the spawning of salmon and rearing of fry. A loch has been formed about four miles up the glen, with a water-course into the Etive, having a gradient of 1 in 28. Numerous steep burns descend from the hills all along the glen, and three of those have been diverted for the service of the loch. The last burn brought in is carried by an artificial channel cut along the fase of the slope in a direction parallel to the main river, and so formed as to provide spawning ground for fish which enter the loch. A hatchery is also established in order to artificially increase the stock of salmon.

The Etive is one of those West Highland streams in which much spawning ground may at any time in winter be washed away by floods, and in addition to this, as already explained, a considerable proportion of the river bed is rocky, this being especially the case in the upper reaches where salmon most congregate-and a good many salmon apparently do congregate there in the close season. The effort at improvement of stock is, therefore, directed to hatching and rearing salmon artificially, and to the providing of extra spawning ground of a semi-artificial kind.

The sea-trout, which are in great numbers in the river, have greater security from floods through their habit of ascending small and often rather broken side streams, and spawning in these. Salmon, on the other hand, are entirely restricted naturally to the main river below Dalness. As a result of this, and also since apparently very many sea-trout spawn before the salmon do, so that great numbers of sea-trout fry are feeding before the salmon fry are hatched, the young of the more valuable species have to enter into rather serious competition with their more advanced fellows. 
As an additional sanctuary for salmon fry a small loch or pond close to Glen Etive House is to be requisitioned as a rearing place. With this and the operations already referred to a very considerable increase will accrue shortly to the growing salmon stock, and as smolt-marking operations are already commenced, a most interesting test will in course of time be made of the benefits of these most carefully considered operations.

The opening up of Dalness Fall would no doubt add spawning ground to the river, but the fall is a serious one of about 20 feet, and is, moreover, surrounded by high rocky banks which do not very readily lend themselves to pass-construction. A short distance above the large fall, also, are several smaller obstructions, while three miles further up there is another serious fall of about 13 or 14 feet. After this there are no obstructions to speak of, and a run of water some $4 \frac{1}{2}$ miles as far as Kingshouse.

\section{THE ADD.}

Angling Season : 16th February to 31st October. Netring Season : 16th February to 31 st August.

This little river really occupies a position of considerable distinction. It is not, perhaps, a famous salmon stream. I dare say many people fairly conversant with Scottish geography never heard of it. The distinction comes to it because of the way its name is spelt. In any alphabetical list of Scottish rivers it comes first. Therefore, in the bye-laws scheduled to the Salmon Acts, the duties of the Commissioners are stated, and are then expressly carried out with reference to the river Add, and then follows this instruction : "The same bye-law shall apply to the several districts, according to the limits thereof, and take effect from the date undermentioned respectively." In this way the Add figures most prominently with regard to the limits of its district, limits of its estuary, the annual close time, the "slapping of its fixed nets during weekly close time, and so on."

The name Add appears to be derived from the Gaelic AvonThada, i.e. long river, so called in Gaelic, it is understood, because Ptolemy, in his famous exploration of our savage land, called it Longus Fluvius - though how Ptolemy, in his senses, could do such a thing I cannot think. It is only 16 miles long. It rises from a number of small burns on the hills behind Furnace on Lochfyne side, and takes a direction, behind those hills, parallel to the long axis of Upper Lochfyne. It has here a rapid and rocky course, 
coming down its hill tract some 400 feet in about four miles. When about 300 feet above sea-level it suddenly bends to the northwest, and in about a mile and a half it passes out upon the northern part of the flattish moor through which the Crinan Canal is cut.

At Glassary the Add is only 50 feet above sea-level, and it has still six miles to go to the sea at the western end of Crinan Canal. Through this last stretch of flat country the river meanders in deeply-cut loops. This is the best fishing section, although near the mouth and practically in the estuary some great takes of sea-trout are reported to have been made. In the sluggish waters of this chief section a strong breeze is usually necessary to success in angling, and on account of the highness of the banks-the river having eroded the peat and earth deeply - the breeze can scarcely be too strong up-stream.

The Hon. A. E. Gathorne-Hardy has written of the Add from long personal knowledge, ${ }^{1}$ to which I can in no way lay claim, and relates that on one occasion, in a dead calm, he stood watching a shoal of small salmon and grilse swimming round and round one of the slack quiet pools. From his position on the high bank he says he must have been as clearly visible to the fish as they were to him. Nevertheless, one after another followed his fly when he presented it and began to lay hold, so that he ultimately landed three and hooked and lost one or two more.

With reference to the water near the mouth, he says that 99 seatrout were on one occasion landed by a local angler in a single tide. The salmon average $7 \frac{1}{2} \mathrm{lb}$., and the largest fish Mr. GathorneHardy has taken, or that has been taken, was just over $20 \mathrm{lb}$. He has had as many as 7 salmon in a day, and has on several occasions taken 6, but I expect one has to be on the spat to take advantage of the quickly passing opportunity to score like this. The rise and fall of the Add is naturally very rapid, and it goes quickly out of ply. Mr. Gathorne-Hardy says, in the book referred to, that the largest season's catch he has made was 49 salmon and 167 sea-trout. Fish do not put in an appearance in this little river till about the end of July. About that time in 1909, not long after I had paid the stream a visit, as many salmon and trout must have been taken in a single day by net. The weight of fish shipped at Ardrishaig was very considerable.

${ }^{1}$ Fur, Feather, and Fin Series (Salmon), p. 98. 


\section{CHAPTER XXIX.}

\section{RIVERS OF THE CLYDE AREA.}

\section{LEVEN AND LOCH LOMOND, ECHAIG, AND LOCH ECK AND RUEL.}

\section{THE CLYDE AND LOCH LOMOND DISTRICT.}

Angling Season: 11th February to 31st October. Netring Season: 11th February to 26th August.

IN the Schedule of the Salmon Fishery Act of 1868 there is no District defined for Loch Lomond. The District is that of the river Clyde, and Loch Lomond is a part thereof. Since the early sixties, however, the Clyde has ceased to be a salmon river owing to the pollution poured into it from Glasgow. One states the cause of the absence of salmon in this case without any hesitation, yet if one were asked to prove it one would have great difficulty. There are statements showing, for instance, what Richard Franck in 1658 described as the "multiplicity of salmon in the Clyde," one of the three "fair imbellishments of Glasgow," but we have no record, so far as I am aware, showing how, with the rise of population and manufacture, and ergo of pollution, the famous salmon fisheries of Clyde declined and died. Yet everyone knows it has been almost impossible for any self-respecting salmon to inhabit the Clyde below the Broomielaw while the entire pollutions of the "second city of the Empire" were poured into it. ${ }^{1}$

Of recent years Glasgow has commenced to set its house in order in this respect, and, like other things Glasgow undertakes, the business is being well done. Already down the river there is a noticeable change for the better; the water is less opaque, the deposit of sludge is less heavy, and the floating impurities which used to form a horrid scum, are now less noticeable. A considerable part of the city has yet to be brought under the direct control of

${ }^{1}$ The last records of salmon at Glasgow seem to be dated 1871. Mr. M'Creath who knows the Bothwell Castle and Blantyre water well tells me that in $\mathbf{1 8 8 0}$ salmon were still fished for there, and that even at the present day one or two are sometimes seen. 
the sewage system, and I have no doubt when this is done a still further improvement will follow. ${ }^{1}$ It is premature to say much about the prospects of salmon returning to the river, but I believe there is now better chance for salmon in the Clyde than there has been for very many years. The sine qua non is the sufficiency of dissolved oxygen in the purified water, the avoidance of a great mass of practically unoxygenated water-a sewage zone as it is calledmoving up and down the dredged channel with the flow and ebb of each tide.

In this connection it has to be realised that fresh and salt water are of very different densities and do not mix freely, and that even when mixed in a tidal estuary the salt water contains nearly twenty per cent. less oxygen than the fresh, although deaerated salt water is capable of taking up oxygen almost three times as fast as fresh. The danger to fish of pollution, apart from the active toxic properties which may be present, is the rapid absorption of oxygen which goes on. The water bacteria can do a great deal to devour and convert the impurities, but there must be a balance of oxygen in the effluents from sewage works, introduced by dilution with a sufficiency of natural water, or else fish cannot breathe.

The river Leven, flowing from Loch Lomond, enters the Clyde at Dumbarton, 13 miles below Glasgow, and in spite of many pollutions here also, salmon have never quite forsaken this channel. It is foul enough in all conscience, but it is improving, and thanks to its great body of pure water from Loch Lomond the dilution of impurities is very considerable.

The Vale of Leven is famous as a centre of the Turkey-red industry, and quite a number of large works for both dyeing and calico-printing are situated on the banks of the river at such towns as Renton and Alexandria. Dumbarton, again, is a shipbuilding centre, and in the whole Vale there is a large and thriving population. Sewage works on an extensive scale are now completed for the whole district of Alexandria, with a population of about 25,000, but at the other two places all pollutions other than a small amount of the dyeing bye-products are as yet poured straight into the river. The Orr-Ewing works of the United Turkey-red Company, Limited, are provided with settling tanks, which retain a certain proportion of the heavier matter in suspension and as much grease as can be

${ }^{1}$ The Burgh of Motherwell has recently acquired 10 acres of ground for Sewage Purification Works, and the Burgh of Hamilton is likewise extending her sewage. treatment. 
skimmed off, but the effluents run out into the river are still very highly coloured, so that at times the river seems almost as if it were turned to blood. This alizarin colouration is not per se, I believe, very harmful to fish life, but with the many other impurities associated with it in the river, the stones of the river-bed become coated with a greasy sludge which is far from what it should be.

Certain bleach works produce an effluent which, while being brilliantly clear, is much more harmful than the highly-coloured liquids. I recollect a few years ago the salmon netted in the Clyde just below the mouth of the Leven were found to be quite unmarketable owing to their extraordinary iodoform taste; the water also in which such fish were cooked had a smell of the same kind. This was traced to chlorine from the bleach works.

All the works also boil and discharge great quantities of water quite destitute of oxygen, since the process of Turkey-red dyeing and scouring involves liquors at very high temperatures; $120^{\circ}$ to $130^{\circ} \mathrm{F}$. seem usual, and in clearing and fixing processes temperatures as high as $190^{\circ}$ and even $200^{\circ} \mathrm{F}$. are attained. Water, after having been raised to such temperatures, is incapable of supporting any form of life, and as some of the works seem to use as much as about three million gallons of water in twenty-four hours, some idea may be gained of the condition of the lower Leven. The trouble is, that while at certain works fair attempts are made to reduce pollution, at others there are no efforts to do so, and that as the descent of the river is made, the appearance of the water becomes more and more appalling, till finally all respect for it seems to be lost, and it becomes nothing more or less than a sewer. Nevertheless I do not doubt that if all impurities were thoroughly mixed and subjected to proper bacteriological filtration, the river might run quite pure. The actual chemical conditions present have been thoroughly established by repeated analyses. We wait still for the thorough remedy.

It is surprising that any salmon and sea-trout venture through the Leven. Fortunately the river is only 6 miles long, and only about half that distance is grossly polluted; but in dry weather fish are much sickened in the lower reaches, and are apt to become rather easy prey to loafers. An angling association-the Loch Lomond Angling Improvement Association-have in recent years extended their sphere of operations from Loch Lomond and the upper streams, to the Leven and the Clyde, having leased the net fishings of the lower waters. A new lease for a period of five years has just been entered upon, and fishings in the Gare Loch have also been taken. 
An excellent system of granting tickets on easy terms to workers in the Vale of Leven has had a wholesome effect of securing many protectors; 338 of these were taken out in 1907, and 294 in 1908.

The nets at the mouth of the Leven and in the Clyde just below are, I understand, worked three days a week, in order to recoup the Association in their expenses. From 500 to 1000 salmon and grilse and 2000 to 5000 sea-trout are taken. This seems a fairly heavy tax on a rather depleted stock of fish, and the rod fishing in Loch Lomond does not appear to mend as it might, but I am in no way familiar with the financial necessities of the Association. One point which is of interest, however, is that clean fish are now being got as early as April. I have no doubt that with a revival of stock an excellent spring run-that most valuable asset-might be obtained, and sport secured not only in the upper Leven but also in Loch Lomond. I recollect that Colonel Thornton, in his Tour in the North, written about one hundred years ago, describes how he caught 8 salmon one morning before breakfast in the Leven.

\section{LOCH LOMOND.}

The change from the polluted Leven to beautiful Loch Lomond is like a step from a sordid slum to fairyland. The richly-wooded islands of the broad southern end, the varied shores, the long vista of water towards the head of the loch framed in the steep slopes of the mountains, the dominating peaks of Ben Lomond and Ben Vorlich, all combine to give one of the most charming loch scenes in Scotland.

In winter when the bracken is red, when the hill-tops have a powdering of snow, when the light is brilliant, and a nip of frost sharpens the air, the loch looks its finest. I have seen the loch, too, in one of its wildest winter moods, when terrific squalls struck down from the hills, sending spindrift flying 40 feet high, through which rainbows played for a moment as the sun flashed out and vanished. I recollect helping a friend to take temperatures and lose thermometers in the 90 fathom deeps of the loch on such a day. As the storm increased we worked down to Inchtavanach Channel, below Luss, where I broke first one oar and then another, and got blown on to the island on each occasion. We were soaked to the skin with the spiudrift and breathless with the struggle, but by borrowing an oar from a boat on the island we just managed to reach Luss in a lull.

In summer the hills are perhaps a trifle too green, for the bracken 
is climbing to their tops and killing out the heather, but on a quiet, lazy day the scene is sublime. When thunder rumbles about in the distance, and the surface is calm as a mirror, the powans or freshwater herring, which inhabit this loch in great numbers, show themselves in sporting shoals. They are first cousins to the vendace of Lochmaben, and are not only pretty to look at, but good to eat, yet the angler's fly is no use to them. Even when they are spluttering all round one's boat, I have failed to foul-hook a single one, although it puzzled me to know how the hooks missed, so thick were the fish.

From the mouth of the river Falloch, which enters the head of the loch-and which has a fall a short distance up-to the lower end of the loch at Balloch is a distance of 21 miles. The wide portion of the loch at its southern end, where the islands are and where most of the fishing is carried on, is 4 miles across. The long narrow section of the loch above Inversnaid has an average breadth of threequarters of a mile. The west side of the loch is in Dumbartonshire, the east side in the county of Stirling. Luss, just beyond the islands on the west side, is the place where most of the boats are kept for fishing purposes, since the best grounds can be most easily reached from this point. A considerable number of boats are also, however, to be found at Balloch, and by arrangement boats can be towed by steam launch from here to the nore distant parts of the loch. Angling is free for salmon, sea-trout, and brown trout.

I cannot attempt to give an estimate of the brown trout taken annually, but with regard to salmon and sea-trout the records of the Loch Lomond Angling Improvement Association ${ }^{1}$ for the last few years show the following takes by the rod:

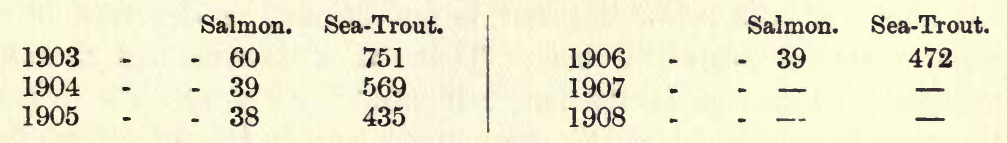

I am indebted to Mr. Lamund for this information.

The streams which enter the loch on the west side are, in order going northwards, the Fruin, Finlas, Luss, and Douglas Waters. These are good streams for sea-trout as the season advances, if there is sufficient rain to keep up a good flow of water. Only one river enters on the eastern side, the Endrick, and this forms the main line of ascent for salmon.

This river rises in the high undulating country to the south-east of Loch Lomond, and after a hill course of a few miles, descends the

${ }^{1}$ The Secretary is Henry Lamond, Esq., 163 West George Street, Glasgow. 
Loup of Fintry by three falls, calculated at 94 feet in height. From this total obstruction to the ascent of salmon to the mouth of the river the distance is about twenty-one miles. For a distance of ten miles or so below the Loup the river presents a fine succession of pools and streams, with much beautiful spawning ground; then for a few miles the bed is rather deeply cut in steep pastoral and, at times, richly-wooded land where, in the neighbourhood of Gartness, two rocky barriers are passed which require special mention; then lower down, where the railway viaduct crosses west of Drymen Station, the river passes through flat meadows and the beautiful woods round Buchanan Castle, the residence of the Duke of Montrose. Here the course of the river becomes highly tortuous and the current gentle.

The two obstructions at Gartness are, in descending order, first the double obstacle of a dam-dyke and fall at the village of Gartness; and second, beyond an extensive loop of the river course a more serious fall at the Pot of Gartness. That salmon manage to surmount both obstructions is sufficiently evident, for I have seen numbers of fish above; but certainly the ascent must be accomplished with difficulty. Both obstructions might with great advantage be modified or provided with fish passes, so that the splendid spawning ground above might be rendered of greater utility to the district. This is the more desirable since, in proportion to the size of Loch Lomond, the other available spawning streams are comparatively small and rocky.

The dam dyke at the village of Gartness is for the purpose of supplying water-power to a small wool mill. The weir is above the fall and the mill below the fall, hence the fall is deprived of the water carried down the lade. There is a well-defined S-shaped channel to the edge of the fall. It would not be difficult to lower the crest and to improve the channel for some 30 to 40 feet, so as to secure a much easier ascent for fish. The dam dyke just above is about $5 \frac{1}{2}$ feet high, but is unprovided with a gap of any kind.

At the Pot of Gartness the obstruction is, as I have said, more serious. The pool, forming the so-called Pot, is large and deep; and at times holds a very large number of fish unable to ascend. The entire face of the rocky barrier is precipitous, and, in low-water conditions, about $5 \frac{1}{2}$ feet high. In times of flood this will no doubt be sensibly lessened. The natural lead up for fish is by the left bank, and on this side of the river the rock has been worn away to a greater extent than elsewhere, so that the barrier starts in a curving 
line across the river. Above the precipitous face of the barrier, the bed of the river is rocky and much broken into ledges for a distance of about 70 yards, with an additional rise of about 7 feet. Through those rocky ledges it would not be at all difficult to construct an efficient pass. If all stories are true, there would be great benefit in preventing the crowding of fish which occurs in this Pot of Gartness at the "back end" of the year, and in enabling the fish to become distributed over the upper waters before they become heavy with spawn. Several abortive attempts have been made to negotiate for the opening up of the Endrick, but, unfortunately, the matter is beset with some difficulty.

With regard to the operations of the Loch Lomond Angling Improvement Association, to which reference has already been made, I may add that the hatching of salmon and sea-trout is now regularly carried on at Luss, and that in addition to this, large consignments of brown trout have from time to time been purchased and turned down in the loch and adjacent streams. Prosecutions against offenders under the Salmon Fishery Acts are conducted, and a staff of watchers kept. For the more complete patrol of the loch the Association propose to run a motor boat in future. Netting in the loch for pike, eels, and powans are also regularly carried on. Between 300 and 400 pike seem to be killed annually by this means, over and above the number taken by angling. About 8 to 9 tons of powans are annually taken and a considerable quantity of eels. I should think it very possible that a material increase to the Association's revenue might be secured by developing an eel fishery in the river Leven during each autumn, in the manner adopted in Ireland. A good market exists in England, and the catching of eels is a neglected industry with us in Scotland. Were this found possible a reduced amount of salmon netting might then be possible at the mouth of the Leven and in the Clyde.

For the convenience of anglers in the loch a shelter has been erected on the island of Darroch. Members of the Association can provide themselves with keys, and in accordance with the wish of the proprietor, the Duke of Montrose, any unattached angler can secure a key for the day by applying to the Luss or Balloch hotels. A new locality for fishing has recently been added by the Association leasing rights of salmon fishing in Gare Loch. It is reported that sea-trout are got by spinning with minnow. The Leven, Loch Lomond, the Fruin, and this Gare Loch fishing constitute the sphere over which the Association operate. 


\title{
THE ECHAIG AND LOCH ECK.
}

\author{
Angling Season: 16th February to 31st October. \\ Netting Season : 16th February to 31st August.
}

The river Echaig has very considerable possibilities as a salmon stream. Although it is short, having a run of only $4 \frac{1}{2}$ miles, it flows from a large loch-Loch Eck-and, therefore, maintains a better volume of water than is the case in Argyllshire streams which flow directly from the hills. Loch Eck is six miles long, of very considerable depth, narrow, surrounded by high and most picturesque mountains, and 67 feet above sea-level. The stream which flows into the head of Loch Eck is the Cur, which gives its name to the village situated on Lochfyneside, Strachur, from which a bend of the Cur is only about a mile distant, but with which the strath has really no connection. This Cur is the head spawning ground of Echaig fish. It is about six miles in length, and a good running, gravelly little river, although slack and gentle as it approaches the loch.

The Echaig has a rather winding course, and on the whole an easy gradient in its run from Loch Eck to the sea at the head of Holy Loch-well known to Clyde yachtsmen. The exclusive salmon fishing rights go with the Benmore property, and are strictly preserved. The rainfall in this district is generally copious, although in summer, owing to the steep rocky hills on every side, if the season does become dry, the heat is often intense, and, perhaps, I might add, the midges most bloodthirsty. With the physical features as they are, a splendid opportunity presents itself for the storing up of Loch Eck waters in order to secure an ample water supply in the river during the summer months, when fish naturally will run, and when sport may be had. When the Echaig runs low, and I have seen it very low indeed, fish, unable to get up, accurnulate in great numbers at the mouth, where, perhaps with ample verity it may be said, they unduly tempt the local "scringer." I know that plenty of unlawful netting has been carried on here in the past, and, although some wholesome lessons have been given, a new generation will inevitably arise. An artificial flood let down at such a time would draw fish up into the pools, as it does in the Helmsdale or the Grimersta.

One of the troubles in the Echaig in the past, also, has been that when the river was in good running order fish did not take long to travel straight through to Loch Eck. There would inevitably be a fish-pass on the weir at the loch outlet, but even a very low weir- 
and a high structure would not by any means be required-would afford in all probability a most useful pool below it, and for the rest a little judicious croy-making would, I believe, work wonders. It is, I admit, more or less unseemly, almost impertinent, to write thus all unasked about another man's river, but I plead as my excuse that I have a sentimental interest in the Echaig. In it as a small boy I caught my first grilse-I can recollect yet how my knees knocked together when the awful fear that the fish might get off presented itself. In the Little Echaig, which joins below the Cott House Bridge, I learned to swim-and nearly drowned myself too. Up the Masson, the largest tributary, which joins below Benmore House, I received a wholesome lesson to overhaul my outfit before starting for a day's fishing. I had trudged up to the falls, full of youthful ardour. The sea-trout were rising freely; great big ones too. I put up my rod with speed all eager for the fray, when lo! I had left my reel behind. I had to walk to Kilmun Cottage to get it, and, of course, when I got back after about an hour and a half's hard going, the fish were not rising freely at all. Since that day I think I have never failed to repeat to myself, if starting out alone:

$$
\begin{aligned}
& \text { "Rod, reel, basket, } \\
& \text { Hooks, worms, flasket." }
\end{aligned}
$$

One has only to make a mental reservation about the worms as a rule.

I recollect seeing some blasting operations carried out opposite the deer park in those early days. The late Mr. Duncan was then proprietor. The object was to deepen the water. A different method has since been adopted, viz. by building a low weir, and I understand the latter method has been attended with considerable success.

The Echaig is, however, much more of a sea-trout than a salmon river, although when a club of six rods used to fish the water, and there was no netting, very good catches of salmon were made. Nowadays the pool above and the pool below the Cott House Bridge, not far from the mouth of the river, are netted, intermittently, I believe, about three days a week. In the three first years of the present proprietor's time the netting was let to a tacksman in Dunoon, and in this period, I have been informed, he secured 33,000 sea-trout. Of course, the river was then netted as hard as men could do it who had the one object of making money out of it. Nowadays the netting is not carried on in this fashion, being worked by the proprietor 
himself. A net is occasionally also drawn in Loch Eck, mostly at the top of the loch. Three other nets are also employed in the loch, but the proportion of salmon taken is not great.

Whistlefield Inn is one of the places from which netting is carried on, which reminds me of a "character" of an old lady who used to dispense her most limited hospitality there in former days. Sir Daniel MacNee used to fish the loch, and finding sport dull on one occasion, he bethought him of lunch at the inn.

"Well, Mrs. —_, what can you give me for lunch ?"

"Och! and what would you like, Sir Daniel ?"

"Well, have you any cold salmon?"

"Saamon! There's no saamon in the loch, Sir Daniel."

"Oh yes, there are salmon in the loch. I've seen them, although I have not caught them."

"Well, I have no salmon. But what would you like, Sir Daniel?"

"Can you give me a steak?"

"Och, Sir Daniel, the man who should bring me the meat has not come."

"Well, well, what can you give me?"

"Och, but what would you like, Sir Daniel?"

"Can you give me some chicken?"

"Chicken! Would you have me kill the hen, Sir Daniel ?"

"But, bless me! what have you got?"

"Och! och! but what would you like, Sir Daniel ?"

"Have you any ham?" with certainty that this she was bound to have.

"Och, it was a fery good ham I had, Sir Daniel, but a drover body was here last night and he just finished it, Sir Daniel."

Matters were now becoming desperate. What was there more homely than ham? Ham and eggs, a fail-me-never all the Highlands over, was evidently too much to expect at Whistlefield. Then a bright thought struck the painter.

"Have you any whisky?" he asked.

"Hoch, aye, of course I have some whisky, Sir Daniel."

"And have you any oatcake and cheese?"

"Yes, yes, whatever you would like, Sir Daniel."

"Then give me some whisky and cake and cheese."

So on this frugal but quite sustaining fare he lunched."

At the Royal Academy Dinner Sir Daniel, who, of course, was famous as a raconteur, gave the tale in great style.

The sequel was equally amusing. 
A brother artist happened to find himself at Whistlefield next year, and determined to fire a shot, so to speak, at the old lady.

"That was a dreadful way you treated poor Sir Daniel MacNee, Mrs. - . "

"How did I treat Sir Daniel MacNee?" she demanded promptly.

"Oh, he came back to London and told us you could not give him anything to eat."

"Did he say I could not give him anything to eat?"

"Yes; he asked for salmon and steak and chicken, and then for ham and goodness knows what else besides, and said you could not give him anything but cheese and whisky."

"Did he own to the whisky?" she demanded, with much earnestness.

"Oh, yes; he said he got some whisky all right."

"'Deed it was all he wanted after all," she concluded.

Sir Daniel MacNee was careful to add the sequel to the story when he was asked to tell it afterwards.

Fishing in Loch Eck may be secured by staying at Whistlefield (under entirely new management) or at Loch Eck Hotel. Both are on the Glenfinnart Estate. About 20-30 salmon and grilse and about 200 sea-trout, besides a larger number of loch trout, constitute the catch. Salmon have been taken up to $25 \mathrm{lb}$., but about 9 or $10 \mathrm{lb}$. is the average weight.

\section{THE RUEL.}

Angling Season: 16th February to 31st October.

Netring Season: 16th February to 31st August.

Glendaruel is perhaps as beautiful a glen as there is in Argyll. At the head of Loch Ridden, which opens on the Kyles of Bute, the entrance to the glen is surrounded by most typical Argyllshire hills. Bold escarpments of rock rise one above another with great abruptness to a height of over a thousand feet. The little shelving slopes and terraces are richly covered with heather and grass. The lower bluffs have a dense covering of trees and scrub. Here and there groups of dark pines crown well-marked eminences, or shining declivities seem to slide sheer to the sea. Some of the finest larches $I$ have seen anywhere stand around Ormidale, and the young Japanese striplings are springing up in healthy coverts.

Three head streams meet near Dunans at the top of the glen, the central one being the longest. From the head of this Caol glen it is 
a short step over to Strathlachlan on Lochfyneside. The river from Dunans to the mouth is fully 8 miles long, and winds a good deal in a rapid sinuous manner in the upper part, and again below Glendaruel House.

Ormidale water extends to about 6 miles, $2 \frac{1}{4}$ on both banks at the mouth of the river, and the remainder on the right bank further up. Then Glendaruel comes in with a considerable stretch of water, and Dunans has the topmost section. The whole is strictly preserved. For the most part the Ruel is a pleasant running stream of stony character, with pools at the many bends; but near Ormidale House some quieter stretches occur amongst trees and meadow land. This is the most productive water to the angler.

Sea-trout are much more numerous than salmon, but when conditions of water-flow and weather are right sport is often very good. In a mild and rainy season fish begin to run in June, but as a rule July is the month when regular fishing commences. Colonel Burnley Campbell has kindly furnished me with the catch for the Ormidale water during the last thirteen years:

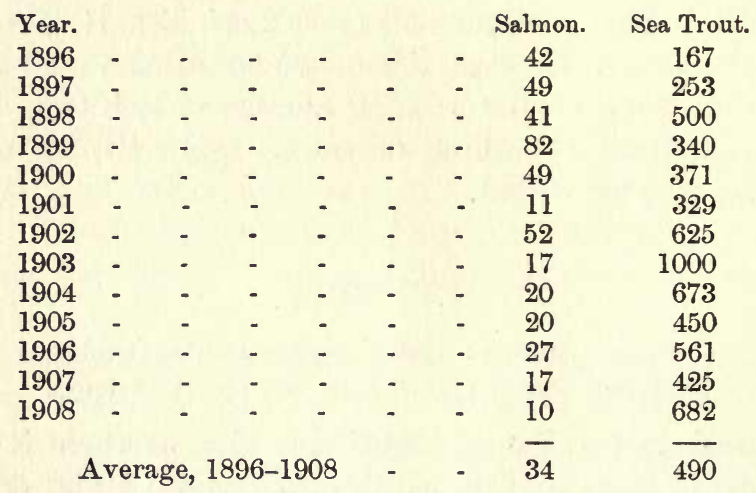

Like most Argyllshire streams, the Ruel is a good deal dependent on rain for successful angling, but, as most people know, this part of the country is not generally deficient in this blessing. No end of little burns run straight down the steep hills on either side of the glen. They can show all along the slopes like parallel threads of silver filigree; yet in warm, summer weather, or during that more beautiful season when the bracken is red and a sharp frost nips the glittering hill-tops, scarce a trickle is to be seen.

The average weight of the salmon is about $8 \frac{1}{2} \mathrm{lb}$., and fish from 7 to $10 \mathrm{lb}$. are usual. The heaviest weights obtained are $23 \mathrm{lb}$. and $22 \mathrm{lb}$. Colonel Burnley Campbell has on one occasion got 7 salmon 
in a day, weighing $53 \mathrm{lb}$. (19th October). With sea-trout his sport has also, at times, been very good. On two consecutive days (1st and 2nd August) he had one year 56 and 41, and a few days afterwards 54 sea-trout. The average weight is about $1 \mathrm{lb}$., but 9 seatrout weighing $22 \frac{1}{2} \mathrm{lb}$. is the score of one day in July.

Loch Ridden used to be netted pretty hard, and a small river like the Ruel soon suffers, if the fish congregating at the mouth are systematically prevented ascending. Of late years, however, the importance of removing the nets has been fully realised, and nothing now interferes with the free run of fish for the angler. The netting rental is paid, but the nets are not used. 


\title{
CHAPTER XXX.
}

\section{THE AYR, DOON, GIRVAN, AND STINCHAR DISTRICTS.}

\author{
RIVER AYR.
}

Angling Season: 11th February to 31st October.

Netring Season: 11th February to 26th August.

There is a District Fishery Board.

Clerk, Wilfred C. Macrorie, Esq., Solicitor, Ayr.

THE Ayr and its tributaries drains an area of no less than 220 square miles, and is a river of very considerable size. In the matter of salmon fisheries it is much better than it was, but has not yet reached the position it might occupy amongst rivers. In the past it has suffered from hard netting, coupled with pollutions and the presence of dam-dykes unprovided with salmon passes. Of late years all the netting, whether in river or on the coast, right of which goes with Auchincruive, has been suspended, pollution has been diminished, and certain dykes have been provided with passes. As a result, the river is distinctly on the up grade. It is a populous and a sporting district, however, and in certain sections of it the laxity of protection, which prevailed in the past, is still reflected in the freedom with which unauthorised fishers practise their art by curious methods and at strange times.

The river has its source in small hill burns a short distance east of Muirkirk, close to the divide where the Douglas Water rises to flow away north-east to the Clyde above Lanark. It is a dreary, wind-swept country this region of the county march between Ayr and Lanark. The Ponesk Burn, which rises from Priesthill Height, is the highest source, and from here to the sea, by the course of the Ayr, is about 36 miles. The Greenoch Water, the highest tributary of any size, rises a short distance to the north, and joins the Ayr about half-way between Muirkirk and Sorn. The romance of this dreary district lies in the many memories of the Covenanters who 
were hunted so mercilessly because of their staunch religious convictions. It would be as impossible to find men of this particular type here now as it would be, thank God, to find the type of the bloody moss-trooper. None the less Scotsmen may well honour the memory of the Covenanters, if only for their loyal bravery. In these shallow glens have now sprung up the tall chimneys of many coal pits, the glare of iron works, and in places the smoke of the lime-kiln. A short distance below Sorn, at the village of Catrine, are large spinning and dyeing works. These do not exist without their influence upon the river, but of this later.

At Muirkirk, about 31 miles from the mouth, the river is about 700 feet above the sea, the gradient is very gradual, and therefore the general character of the river is easy flowing, with grassy banks, and through many beautiful woods in its lower reaches. There is, however, a good deal of rock in the river bed, and often excellent gravel, although through the ease of the current, the lightness of the soil, and no doubt the convenient pipes of the various works in the head waters, the bottom rather easily becomes foul, and floods are very dirty. Under ordinary conditions, however, the Ayr is a beautiful and most attractive river for many miles from the sea.

The actual mouth is confined between the piers of the town of Ayr, and, as is so apt to be the case in such circumstances, the water is very impure, although a certain amount of the town's sewage goes into the sea rather than the river. The purifying influence of the tide is felt, moreover, in that part of the river which passes through the town.

Spanning this section is the venerable Auld Brig of Ayr, about which Scotsmen have seen much recently in the daily press. This quaint and beautiful old structure, with its four lofty arches, is now substantially fortified against the attacks of the river and of Time. The New Bridge-a thing of yesterday in the eye of the old structure only 150 yards away-was built in $1785-88$ by the energy of the Provost Ballantyne to whom Burns dedicated his famous poem, "The Brigs of Ayr." More than ever now the Auld Brig, with its new lease of life, may shout to the New :

\footnotetext{
"Conceited gowk! puff'd up wi' windy pride! This mony a year I've stood the flood and tide; And though wi' crazy eild I'm sair forfairn, I'll be a brig when ye're a shapeless cairn!"
}

Immediately at the back of the town, on the left bank, the old Nether Mill stands, and here a weir occurs with a fish-pass. A 
short distance below this a new sort of obstacle has recently been added in the form of an immense iron pipe on the bed of the river. The interests of the salmon have here again, however, been attended to.

A couple of miles above this the second weir exists at Overmills. Up till 1898 no pass existed here, and as the river is very wide, the uniform and smooth dyke was commonly covered by a thin flow of water impassable to fish. A pass has now been provided, which is reported to allow fish to ascend freely when the river is in running order.

The course of the river now makes a great loop northwards as we ascend, past the terraced banks and sloping gardens of Auchincruive. At the upper extremity of this loop the lowest tributary, the Water of Coyle, enters from the south. Above this the general trend of the river is north-east, past Stair to Montgomerie, then round several moderate loops to Barskimming and Catrine.

Just above Barskimming the largest tributary, the Lugar, enters from the south-east. This stream drains 86 square miles of country, which is only 10 square miles less than the whole of the neighbouring river Girvan. It rises at "The Martyrs' Grave," about three-quarters of a mile from the side of the river Ayr, and about five miles west of Muirkirk, and describes a crescent-shaped course past Lugar village with its ironworks, Cumnock, and Ochiltree, and so back to the main river. It is an important spawning stream, and, I fear me, a happy hunting ground for not a few from the villages named.

There is no obstacle to the ascent of fish in the main river from Overmills to Ballochmyle, a distance of 14 miles. Here a couple of wooden dam dykes are thrown across the river which require, and, I am glad to say, are likely to receive, attention. At Catrine, two miles further up, a double obstacle, if it may be called so, has entirely prevented further ascent of fish till lately. The lower was the more serious, and has apparently been erected purely in order to protect the scouring of the river banks in a way which might undermine the long and carefully pitched apron of the upper dyke. This lower dyke is practically 5 feet high, has an iron sill, and a smooth concave cement face terminating in a second iron beam. Immediately below is a deep pool. About 150 yards above this is the main weir for the supply of water to Catrine Mills. This is an easy-sloping weir with a bad, and probably pretty recently added sill which materially adds to the height. During last year a pass has been constructed at each of these weirs, and the upper waters of Ayr, extending to about 15 


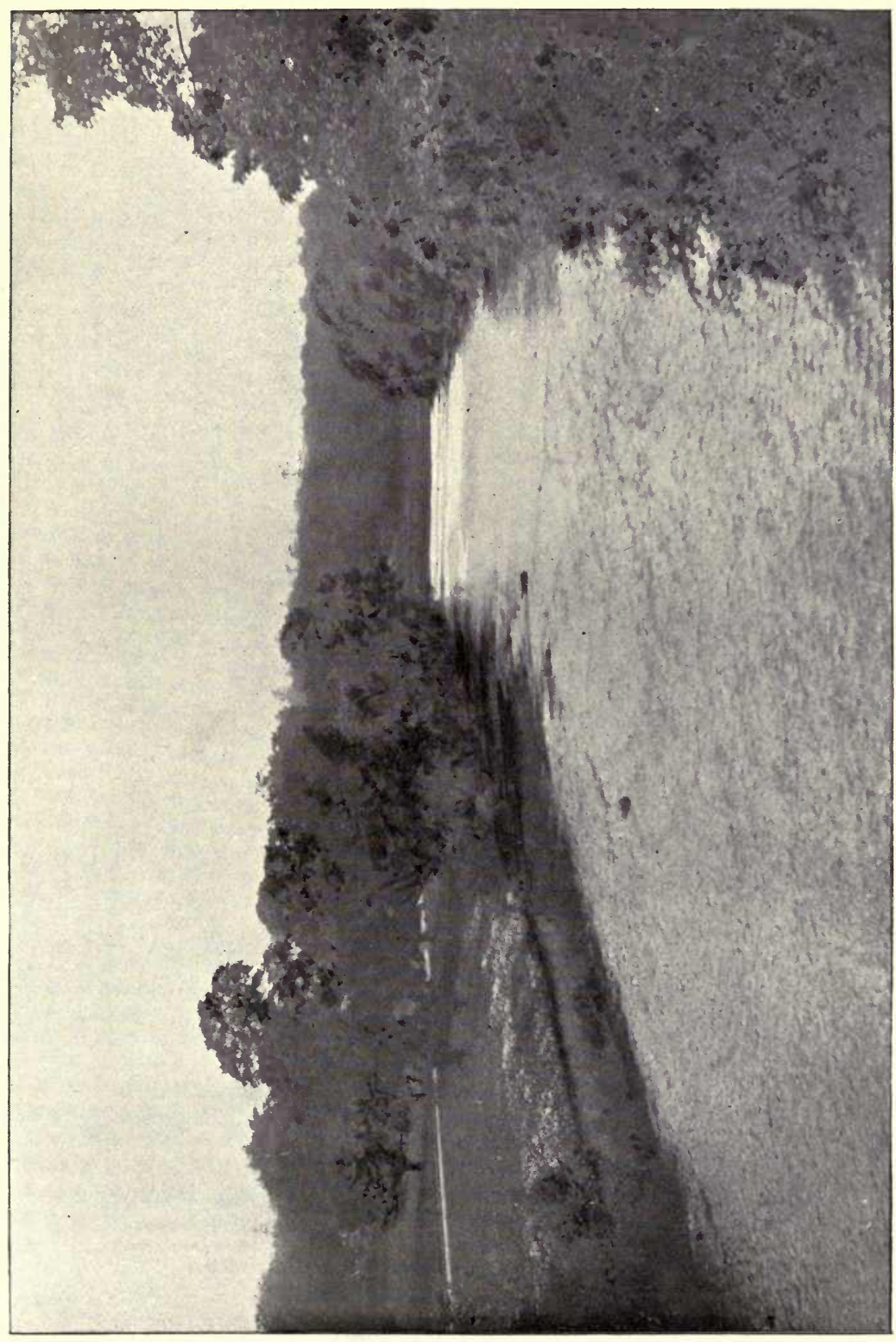

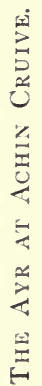



miles, are once more open to salmon. Some conception of the amount of water which is abstracted at this weir will be formed when I say that the deep and broad lade which passes off from the right bank is conveyed by means of a quite extensive aqueduct to the top of a high power-house, in which the famous Catrine wheels are made to revolve and to develop about 500 horse-power. The two water-wheels work in unison side by side. Each wheel is 50 feet in diameter and 12 feet wide. In dry weather all the river Ayr is conducted over those wheels. At a time such as this I have walked up the dry bed of the river for about three-quarters of a mile from the outfall to the intake, and been reminded of the evidence of a certain Scotsman before a Committee of the House of Lords, who, to one interrogation, replied: "Weel, my Lord, in oor country it's a weel kent fac' that whar there's nae water there can be nae fush."

During the last six or eight years the numbers of fish seen in the Ayr are reported as having greatly increased, but as yet fishing is confined to summer and autumn. I see no reason, however, why in course of time spring fish should not be found in the Ayr as in the Doon, unless the pollutions at the river mouth become too much for them. Grilse run early in June, and the fishing commences with the first of the grilse. A good number of sea-trout ascend in July, and help to increase the opportunities of sport. Salmon fishing is practically confined to August, September, and October. In recent years the heaviest fish known to be taken has been $28 \mathrm{lb}$. Other years had as their heaviest fish $25 \mathrm{lb}$., $24 \mathrm{lb}$., and $24 \frac{3}{4} \mathrm{lb}$. With regard to the total taken by rod it is unfortunately almost impossible to speak with certainty. The proprietors either do not keep a score or keep an uncertain record, and on this account one is quite unable in a district of such wide extent to arrive at an estimate of what is taken from week to week. As nearly as may be gathered, however, I believe the legal rod-catch is between 200 and 300 salmon. The actual number of fish known and accounted for in 1907, for instance, was 185, and it was admitted that the proper total was far in excess of that figure. In 1908, in the same way, the actual number known was 175 , and the official report adds: "The actual number caught was far in excess of that figure." 


\title{
RIVER DOON.
}

\begin{abstract}
Angling Season: 11th February to 31st October. Netring Season: 11th February to 26th August.
\end{abstract}

District Fishery Board meets in Ayr. Wilfred C. Macrorie, Esq., Solicitor, Ayr, is Clerk.

The mouth of the Doon is just two miles along the coast, south from the mouth of the Ayr, and the general direction of the river is north-west to this point. The source is away in that high district in the north-west of Kirkcudbrightshire, from which streams radiate not only northwards, but also south-east to the Solway Dee, and in a south and west direction to the Minnoch, the chief head stream of the Cree.

A little shallow loch with several islands, Loch Enoch, collects the hill burns, and gives off two streams. It is very unusual to find two outlets from a loch, but the Gala Lane and the Eglin Lane, the two streams in question, maintain a completely separate course from their source to Loch Doon, a distance of six miles. The word "lane," as applied to a small tributary stream, is, so far as I know, confined to the district of Carrick and to the counties of Kirkcudbright and Dumfries. The Eglin Lane receives the waters of four small lochs by other lanes leading from the west, and, joining with the Whitespout Lane, is thereafter called the Carrick Lane for about a mile and a half before it reaches Loch Doon.

The river Doon proper flows from Loch Doon, a narrow sheet of water four miles long, partly in Kirkcudbright, but chiefly in Ayrshire, and has a course of about 21 miles to the sea. The surface of the loch is 680 feet above the sea, and is studded with five groups of islands. Not far from the upper end is Castle Island, on which stand the remains of an extremely old octagonal tower called Balliol's Castle. Still nearer the head is Pickimaw Island, so called, no doubt, from the nesting of black-headed gulls. The history of the early inhabitants of this region seems to be matter of uncertainty. Chalmers makes Balliol Castle the scene of the death of King Alpin of Dalriada in 741, which Skene believes to have occurred on the eastern shore of Loch Ryan. A sister of Robert the Bruce seems to have lived here, having become the wife of Seaton, the lord of these parts. In 1826 nine "dug-out" canoes were found sunk in the loch near the Castle Island. Two of them are now preserved in small pools just below the outlet from the loch on the left bank, and are to be 
easily seen. One of these, if I remember correctly, is fully 20 feet long. Loch Doon is a capital trouting loch, but does not yield many salmon, since early running fish do not readily enter the loch owing to the rough ascent necessary.

About a hundred years ago the outflow of the river from the loch was sluiced, and a great barrier of rock tunnelled by Earl Cassillis and Mr. Macadam of Craigengillan. The level of the loch was thereby lowered, and an attempt made to regulate the flow of water to the river. Two sluices were constructed, each 6 feet wide and 6 feet 8 inches high, and each sluice communicated with a rock tunnel 66 feet long. One sluice was kept open all the year round; the other, which was at a different level, was seldom opened. I believe this to be the earliest operation of the kind in Scotland, and not anywhere repeated till the "sixties," when Mr. Hutchinson, the tenant of Soval in the Lewis, began operations of a similar kind, if on a much smaller scale, by damming up his "Loch Dismal," after the manner he had seen practised on the Costello, in Ireland.

At Loch Doon outlet, as originally formed, the rush of waters through the tunnels was found to be too great, and, during floods, the sluices could not be reached. In 1885 extensive alterations were made, and now, instead of a tunnel 66 feet long, the principal salmon pass is 155 feet long. The upper end of this pass is level for a distance of 17 feet, and is in tunnel, since it passes below the road. The remainder is an open rock cutting, with a gradient of practically 1 in 20 . It might with advantage be improved at the bottom, but the essentials of an excellent pass are here. If the object, however, has been to get salmon into Loch Doon early, the real difficulty is not in the pass, but in the river Doon lower down.

Ness Glen, through which the Doon first rushes, has a steepish gradient and much broken cascaded water, quite sufficient, when the water temperature is low, to prevent spring fish ascending. It is a beautiful defile, but a rather forbidding stair for spring salmon. When the water temperature has lost its wintry character, fish will ascend without hesitation. Fish tend, as a matter of fact, to congregate in the lower and larger pools of Ness Glen. Unfortunately they are here netted in the spring, I understand. This is against all the best interests of the river, and, so far as value goes, spring angling would, no doubt, be found to be much more remunerative. 
Before leaving this source of the Doon, it is proper to notice that here already exist the conditions under which the regulation of waterflow can be carried out, so as to store water in winter, increase the natural flow in summer, and, if need be, send a moderate flood down the river, when the fishing would be benefited thereby. Reference may be made to the chapter dealing with the Helmsdale for a discussion of the benefits to be derived from well-regulated operations of this kind.

About $2 \frac{1}{4}$ miles below Loch Doon the river, when opposite Dalmellington, widens out into a shallow but extensive diverticulum, known as Bogton Loch. There is something almost hideous in the name, but it is expressive. It is a weedy boggy place, and the stronghold of pike. Below this the river commences to wind about, and this it continues to do to an ever-increasing extent till it reaches the sea, although it does not cross the 500 feet contour till Patna is reached. A couple of miles below Bogton a small burn enters on the right, called the Rongh Burn, which passes through most extensive ironworks, and receives pollutions of various kinds. In crossing the flat grassy meadow between the works and the river, the impurities are subjected to a certain amount of land treatment, but a sufficient amount of the discharge is direct enough to have a high temperature on entering the river. An examination trap exists here, and on one occasion, having the curiosity to test the temperature, I found it $96^{\circ} \mathrm{F}$. Loch Doon on the same day was $55^{\circ}$, so the contrast was violent for a creature like the salmon or trout, whose blood is only slightly higher than the temperature of the water in which it swims. Before now, dreadful and sudden mortality has occurred amongst the fish in the Doon. I don't know if it was these particular ironworks which were to blame, but it was owing to this class of pollution that, on five separate occasions between 1870 and 1893, serious destruction of fish occurred. However, I don't think this is likely to happen again.

Other pollution troubles have, in the past, arisen from a large blanket work called the Skeldon Mills, several miles lower down. The scour-wash was run into a pond, where the soapy waste became very foul; but the sluice of this pond was some time ago placed under the control of the river-watcher, who was able to run it off at times when it was likely to do a minimum of harm to the river. The mills have since, I understand, been closed. The dam dyke in connection with these mills, as well as two other dykes within a few miles, are fortunately not serious obstructions. 
The river now has a very pleasant running character, with a succession of quiet pools, often much sheltered by trees. There is, as might be expected, great similarity between the lower Doon and the lower Ayr. The nature of the country through which each river passes in its lower stretch is of a gentle undulating character, good farming land, stretches of meadow, woods, and now and again well-kept policies. At Dalrymple the river takes an abrupt turn to the south for two miles to Cassillis House, is checked almost immediately in a westerly course, turns back eastwards, and then goes north again. Several times afterwards it appears as if trying again to find its way west, but always has to pass on northwards. It flows over a three-foot weir a little distance above Auchendrane House, takes a bend round Doonholm, and is at the Burns' Monument and Alloway Kirk. There is an Alloway Mill also, in connection with which a smooth cement-faced dam dyke is thrown across the river. It was at one time a rather serious obstacle, but a fish-pass has been erected in recent years, which, after some alteration, is, I hope, less difficult to fish than it was. Above the Alloway Mill a short distance the Dutch Mills have also a weir, some three feet high, with a fish-pass.

The memory of Burns is fondly cherished in this the place of his birth, and apart from those whose business it is to know about the Burns' relics and the "auld clay biggin" "which stands so simply by the roadside, who, as it were, make a living out of his memory, there are not wanting those who have a genuine and a deep knowledge of his beautiful songs and strong, deeply fascinating poems. There is a short cut through the Alloway Kirkyard for anyone wishing to keep near to the river bank. Folk don't now see the "warlocks and witches in a dance" that made Tam o' Shanter "amazed and curious," but stepping over the stile there on one occasion I came upon an old worthy deeply absorbed in a well-thumbed book. A short crack showed him to be steeped in Burns lore, and I had caught him in the act of quietly verifying a reference. As I left the kirk gates I felt that Burns still lives about the old Brig o' Doon.

But we have almost come to the end of

$$
\begin{aligned}
& \text { " the bonnie winding banks } \\
& \text { Where Doon rins, wimplin' clear." }
\end{aligned}
$$

An ever-running stream from the Bridge curves to the right, and at top of tide-reach is brought up by a cement-covered weir, where 
in years only recently passed some deadly netting used to be practised. A fish-pass exists, and the in-coming tide flushes the face of the dyke, but fish are naturally checked if the river is not in running order. However, the Marquis of Ailsa has now entirely discontinued the netting of the tidal water.

The mouth of the Doon offers a rather peculiar question for consideration. The action of the sea in throwing up gravel and sand so acts upon the rather slanting entrance of the river that the fresh water is gradually forced more and more northwards in its direction. Floods, of course, assert themselves, but as the action of the sea is incessant, and the correcting action of the river only very intermittent, the general result is the slow turning northwards of the river channel at its mouth. In defining the limits of estuaries to such rivers as run directly into the sea on open beaches, as is the case here, the Administrative Commissioners under the Salmon Fisheries (Scotland) Act, 1862, commonly directed that a part of a circle be drawn, with a specified radius, from a centre placed in the centre of the channel at low-water mark. In this way a definite estuary, inside the limits of which fixed nets could not be set, was secured to a river with a shifting mouth. This was the first plan adopted in the case of the Doon, but unfortunately it was not acted upon, and in 1864 an estuary was laid down from fixed points on the shore, viz.: "A Segment of a Circle of 400 Yards Radius, drawn from a Centre placed Half-way between the nearest Fnd of the Two Rocks on the opposite Sides of the River Mouth. . . ."

It is clear, therefore, that if fixed nets are fished close to the northern limit of this estuary, and the river-mouth slowly shifts in that direction, the real purpose of the estuary is slowly being defeated. The mountain is coming to Mahomet.

I have already indicated that spring fish are netted in the Upper Doon. These fish enter the river at a quite early date some years, the water-flow, plus the temperature, no doubt determining this to a great extent. In 1907 a run of fish was noticed to enter as early as 8th January. In 1901 and 1902 the first spring fish were taken at the opening of the fishing season on 11th February. On other years they are not present, apparently, till March, or even later. In 1908 the first fish was caught on 24th March.

A great number of sea-trout also run the Doon and yield capital sport in July. In some seasons, 1904 for instance, over 1000 seatrout may be taken by rod, and some of the fish are heavy weights.

With regard to the total number of salmon taken in the season, I 
may say that in 1907 it was estimated that 673 was the score. In the lower reaches, from Monkwood water downwards, the score of salmon taken by rod varies from about 80 to about 300 . In 1908 the total for the Doon is reported as only 372 . The autumn especially was a very bad one for angling.

The Doon fisheries have passed through several periods of depression owing to pollution and over-netting, but under the better regulation and supervision which now obtain, the river, as may be judged from the above scores, has risen to very considerable value. Moreover, the proprietors are further considering propositions for its improvement, and, if the necessary combination of interests can only be satisfactorily secured, I have no doubt the value of the Doon will still further increase.

\section{RIVER GIRVAN.}

Angling Season: 25th February to 31st October.

Netring Season : 25th February to 9th September.

District Board meets in Girvan. J. Gerald Tait, Esq., Solicitor, Girvan, is Clerk.

The Girvan rises in the high ground of Carrick from a little lochan called Loch Girvan Eye. As a small stream it flows northward past the head waters of the Stinchar, through Lochs Cornish, Skelloch, Lure, and Bradan, passes close to Loch Derclach and Loch Finlas, which send their waters into Loch Doon (and also nowadays, I believe, to the town of Ayr), and, after bending to the westward, falls over Fairlaw Linn. On account of this high linn this section of the river is closed to salmon.

The river from the linn to the sea has a course of 23 miles, making a wide bend to the north-west by Straiton and Kirkmichael, and then flowing south-west, with many windings, to the town of Girvan on the coast. So great is the sweep northwards taken by the river, that though the total length is some 30 odd miles, the source to sea distance is only 14 miles.

No one who is familiar with the Girvan would describe it as a rough river, as has been done by a recent writer. In many parts it is sluggish, winding upon itself as sluggish rivers do. In other parts the general character is like that of the Doon; there are pleasant pools alternating with more or less gentle runs. Only in the topmost section is there any roughness. It is a river with thick, grassy banks and many trees, fine parks, and picturesque old castles. 
As a salmon river the Girvan has suffered dreadfully from the three worst combinations-pollution, overnetting, and obstructive dam-dykes. The Irvine and the Garnock rivers, which have their joint entrance to the sea in the centre of Troon Bay, have been ruined by pollution, and are not mentioned separately in consequence. The Girvan a few years ago came very near to sharing the same fate. In the two rivers mentioned the main source of pollution is from iron works. In the Girvan the pollution has also been iron, but in the form of the sulphate, impregnating water pumped from coal pits.

It was in February 1902 that the most serious pollution occurred. A large coal pit had, eighteen months previously, taken fire and been flooded and shut down. In the year mentioned the pit was re-opened and a commencement made in pumping out the water. The discharge was carried into a burn near Dailly, which was immediately turned a bright orange colour. The burn discharges into the Girvan at a point about $8 \frac{1}{2}$ miles from the mouth, and so strong was the pollution that every fish from this point to the sea died. The water of the river was like pea-soup. All the kelts which had not descended and attempted to do so perished, and the smolts fell easy victims to the poisoned water when they attempted to migrate in late spring. Clean fish were unable to ascend, and the nets near the mouth of the river had a rich harvest. The pumping was continued month after month, and although six settling ponds were hastily constructed and the effluent treated with lime, little good seemed to result, since pit pumps were throwing more water than could be coped with. The bottom of the burn between the pit and the river became deeply crusted with the iron deposit. I could push my stick in about half a foot in many places. The result was that the Girvan became void of migratory salmonidae.

An analysis of the water showed enormous quantities of metallic salts (569.9 grains per gallon of sulphate of iron). The necessary oxygen of the water was absorbed. Fish were asphyxiated, having no dissolved oxygen to breathe, and, in addition, having their gills clogged with the matter in suspension. The public analysts of Glasgow gave it as their opinion that if the river water, as it then was, were mixed with fifty times its bulk of pure water, fish would still be unable to live in it.

By degrees the strength of the pollution diminished, remedial measures were entirely abandoned, and the pumps-which were working twelve hours daily, and throwing 475 gallons a minutewere left to get to the last of the water, and so end the pollution. 
Next year (1903) 22 salmon were caught in the river, and in autumn a fair stock of spawning fish were reported.

I understand that the pit referred to has since ceased working. It is to be devoutly hoped that it will not be re-opened.

In 1904 only 14 to 16 salmon were reported as having been captured. In 1905 only 1 salmon and about 300 sea-trout were taken, so far as known. In 1906 not a single fish was reported. In 1907 a recovery was made to some extent, 30 salmon and 400 seatrout being recorded. An important factor in this last year was the copious supply of water. The river ran high for several months. Most of the fish were caught in the upper waters.

This introduces the subject of the obstructive dam-dykes of the river which, under normal conditions of water-flow, act as serious hindrances to the proper recovery of this river. In passing, I may say that the river nets have been removed under lease. The damdykes are five in number, and only one of them has a fish-pass. The lowest on the river is not very far out of the town of Girvan. At what are known as the Bridge Mills two dams occur, but the lower one is a subsidiary structure erected for the benefit of the fish, on the advice of Buckland and Young. It forms a good pool below the main weir, but none the less the two dykes form a material obstacle to ascending fish, for, contrary to the requirements of the Salmon Acts, no fish-pass is on either. A revolving heck exists on the lade of the Bridge Mills, a structure devised to clear itself of leaves.

At Dailly, about five miles further up, the next weir occurs. The water below this is fished in part from Killochan Castle and in part by an Angling Club in Girvan who have about a mile and a half of water from Killochan. Much of the club water is rather still and canal-like, but nine good casts are reckoned. Dailly Dam is 4 feet high, and formed, like all the dams above it, of boulders. It is, as a result, both irregular in form and leaky in structure. When damdykes leak, much valuable water percolates away under the stones, and so reduces the flow for ascending fish, which have necessarily to go over the sill of each weir.

The one pass of the river, if it may be dignified by this name, is at the Kilkerran Dyke, about four miles further up. It is a simple wooden shoot, 17 feet long and $5 \mathrm{ft}$. 5 in. broad, reaching from the sill to practically the foot of the apron. When I last saw this dyke the pass was dry, the sill was dry, and the river was finding its way below the weir. Considerable cavities had formed in the base of the 
dyke, which evidently were suitable " hidie-holes" for little shoals of fry, but the whole structure of the weir had a neglected and dilapidated appearance.

At Kirkmichael an extremely irregular weir constructed of boulders occurs. The gradient is easy, although the height is about 5 feet, and this may be considered the least objectionable artificial barrier in the river; but at Blairquhan, or perhaps more correctly, at Milton, above the Blairquhan policies, a more formidable erection of boulders at a natural barrier of rock occurs, and a great amount of water is carried off to the mill-lade. The dyke is only some 3 to $3 \frac{1}{2}$ feet high, but the obstruction of water makes it a more serious obstacle than it would otherwise be. I understand that fish cannot surmount this barrier till the water is in considerable volume. They have then only four more miles to go till they are completely stopped by Fairlaw Linn.

It will be seen, therefore, that of the three leading drawbacks to the proper development of the Girvan's fisheries, which have been mentioned, the over-netting in the river has ceased, and the pollution is at present greatly reduced. The opening up of the artificial barriers to the ascent of salmon remains. It is a very great pity that these are not dealt with in accordance with the requirements of the Salmon Acts. The river Girvan should yield valuable salmon and sea-trout fishing from the commencement of the grilse run onwards, but the potential value rernains undeveloped.

The estuary of the Girvan is a portion of a circle of only 300 yards radius from the centre, in the mouth of the river. Bag nets may, therefore, be set very close to the river. Taken even at the very lowest it is to the interest of the bag net fishers to see that an increased number of fish, once they have entered the river, get up to the best spawning grounds of the Girvan. It would appear that local proprietors have but faint interest in rod fishing values, which others esteem highly nowadays.

\section{RIVER STINCHAR.}

Angling Season: 25th February to 14th November.

Netring Season : 25th February to 9th September.

District Fishery Board meets in Stranraer. Stair M'Harrie, Esq., Rephad, Stranraer, Clerk.

The river Stinchar, like the main section of the Girvan, flows in a south-westerly direction. It rises very close to the source of the 
Girvan, but at once flows west, whereas the Girvan, as already explained, goes north and west to Kirkmichael, and only then assumes the course parallel to the main flow of the Stinchar. The extreme length of the river is about 27 miles, from its moorland source to the sea at Ballantrae.

The region of Carrick, through which the Stinchar passes, is more hilly than is the case with the Ayrshire rivers further north. Moreover, the whole course is free from the coal pits and other sources of pollution which so seriously affect the neighbouring rivers. Throughout its course this beautiful little river has a most agreeable gravelly bed; pools and streams often alternate most pleasantly; from time to time, and more especially in the lower reaches, it is pretty closely wooded, but there is a fine running character in the stream which adds greatly to the enjoyment of angling.

There are dam dykes at Daljarroch and Pinclantie, nine and twelve miles up-stream respectively, but when the river is in running order, these do not offer much difficulty to ascending fish.

The gravel in the lowest reaches is liable to a good deal of shifting by the action of floods, and at the mouth of the river a great quantity has accumulated. This, owing to the opposing actions of sea and river, is piled up now here now there, and very commonly a considerable lagoon exists behind an extensive beach of gravel. Occasionally, during dry summer weather, the volume of water in the river is insufficient to maintain its combat with the waves, and the mouth practically closes altogether, the fresh water percolating through the substance of the gravel bank. On a larger scale this unfortunate condition has in the past existed both at the mouth of the Spey and at the mouth of the Deveron. In each case now, however, a direct mouth for the fresh water has been cut to the sea. It is clear that whenever a lagoon forms behind a bank of gravel, a great waste of water results. The concentration of flow is lost, and consequently the attractive powers of the river mouth to fish in the sea is greatly diminished.

The estuary is defined as "A portion of a Circle of 350 yards radius drawn from a centre placed mid-channel of the River where it joins the sea at low-water of Equinoctial Spring Tides, and continued by Tangents to the Circle drawn at right angles with the Shore." With a changing river-mouth and bag nets fished in the vicinity, it is necessary, in order that the benefit of such an estuary be secured to the river, that remeasurement be resorted to after each change of 
position. Bag nets cannot be said to be crowded at the mouth of the Stinchar, but one is fished on each side of the estuary and others at intervals along the coast.

From what has been said as to the nature of the river mouth in summer it will readily be understood that fish are only able to enter when the water-flow is sufficient. As a matter of fact the Stinchar is almost invariably pretty late in being stocked with fish, but when the grilse and sea-trout are able to run the fishing begins. It has happened that a spring fish has been caught early in the season when kelt-fishing for the purpose of marking was going on, and it may well be that when water is high and the season unusually mild, a few of those fish may enter-indeed it is reported that clean spring fish are sometimes seen-but the capture of the fish in question was a complete surprise. The best fish come into the river quite late, after the netting has ceased, but I believe the greatest number of fish are generally caught in August if there is sufficient water.

The weights are often surprisingly heavy. The heaviest during the last eight years are: 1900, $25 \mathrm{lb}$; 1901, $29 \mathrm{lb}$.; 1902, 31 $\frac{1}{2} \mathrm{lb}$.; 1903, 35 lb.; 1904, $28 \frac{1}{2}$ lb. ; 1905, 20 lb.; 1906, 28 lb.; 1907, 39 lb.; $1908,29 \mathrm{lb}$. The record rod-caught fish is, I believe, $42 \mathrm{lb}$. In one day it has happened that a single rod has taken 3 fish weighing $33 \mathrm{lb}$., $30 \mathrm{lb}$., and $28 \mathrm{lb}$. In 1897 a sea-net took a fish of $62 \mathrm{lb}$., so large fellows are in the district. The rod catch for the season has sometimes been put down at as low as 40 or 50 fish, but in 1908, which was a distinctly bad year, the total, so far as I have been able to ascertain, was quite 140 . The six fishings between the mouth and Colmonell or Bardrochat are reported to have yielded 15, $45,12,50,10$, and $8=140$.

A net is used in the river near Pinwherry, which naturally tells against the stock of fish above that point.

The Stinchar has two tributaries, the Tig and the Duisk, both of which enter from the south. The Tig is little more than a burn, but since it joins the main river only about $2 \frac{1}{2}$ miles from the mouth, it offers at times a good entrance for sea-trout, which, as a rule, prefer not to run far from the salt water. It has a course of about eight miles from its source at the Wee Fell, runs north and then west. Over the hills to the west of its source rises the Water of App, a remarkably straight little stream, which flows south-west right into the mouth of Loch Ryan. It is rather striking that although no stream other than a burn enters at the head of Loch 
Ryan, bag nets fish successfully all around its shores. In the loch is the best oyster fishing in Scotland.

The Duisk is a very considerable stream, which rises from several small burns close to the head waters of the Bladenoch, or otherwise, to the borders of Wigtownshire, east of the railway line, and flows about $9 \frac{1}{2}$ miles to the Stinchar at Pinwherry Railway Station. Pinwherry is the station for Ballantrae and the river Stinchar generally. This Duisk has on its banks a Kildonan House, a name usually associated amongst fisherman with the distant Helmsdale. 


\title{
CHAPTER XXXI.
}

THE RIVERS LUCE, BLADENOCH, CREE, FLEET, URR, DEE.

\author{
RIVER LUCE.
}

\begin{abstract}
Angling Season : 25th February to 31st October.
Netring Season: 25th February to 9th September.
\end{abstract}

THIS river rises from two sources, both of which have their origin in Ayrshire. The one, which is the more westerly, is called the Main Water of Luce, the other is called the Cross Water of Luce. In this district a cross water is a tributary which joins its main stream at a cross angle, i.e. an abrupt, angle. The Duisk tributary of the Stinchar has a cross water. There is also a cross water at the source of the Tig.

The junction of the two streams is at New Luce, six miles from the sea. The total length of the river along the line of the main water is 15 miles to the sea at the Bay of Luce.

The Earl of Stair owns the two head streams. From the junction downwards the water goes with the property of Dunragit. The whole of the river is carefully preserved.

The Luce is a pretty little river with a gravelly bottom, and a fine succession of some 20 pools and streams in its lower section. The water is distinctly peaty owing to the wide moorlands round the sources, the rise and fall is often extremely rapid, and the pools are liable to much change by the action of floods. The great pool is certainly the Puddle Hole immediately below the railway viaduct, and rather less than a mile from the mouth of the river. Here great execution is done amongst the sea-trout in summer, most of the fishing, or at least much of the successful fishing, being carried on at night. As many as 100 have been taken before sunrise in an August night. The Puddle Hole is the pool where fish running up 
the straight and rather shallow stretch of water from the sea first rest or are checked. There is a weir at the head of the pool, placed there, no doubt, in order to preserve the foundations of the viaduct, but also utilised for the purpose of carrying water to a neighbouring farm mill. The weir is about $3 \frac{1}{2}$ feet high, but has an easy slope on its down-stream face (which is covered with wood). The weir is constructed with an angle towards the left bank, and in this angular section a small, and, in my opinion, perfectly useless, salmon pass exists.

Great quantities of sea-trout frequently congregate in the pool waiting till such time as the rise in water-level will enable them to surmount the face of the weir. Occasionally a salmon is seen moving about amongst his smaller relatives, and for the size of the river the salmon, as well as the sea-trout, are heavy. Fish up to $35 \mathrm{lb}$. have been killed, and fish over $20 \mathrm{lb}$. are by no means uncommon. In the night's catch of 100 trout already referred to, there were 30 fish over $2 \frac{1}{2} \mathrm{lb}$., and the largest was $6 \mathrm{lb}$.

The salmon are not as free risers as the trout, and it may be that the great crowd of the latter tend to put the larger fish off the rise. Only some 30 to 35 salmon are, I understand, expected in these lower waters, and perhaps 5 or 10 in Lord Stair's water above. There is a second dam dyke about half-a-mile above the viaduct. It is about 3 feet high, with a down-stream face of about 12 feet, giving, therefore, a gradient of 1 in 4 . There is a small sort of drain close to the right bank, which, I presume, is supposed to represent a pass. Under ordinary conditions of level no water goes down it, and there can be no pretence of its conforming to the regulations. Indeed, unless the weir is carefully examined, the thing would not be noticed. The lead up for fish is at the opposite side of the river. The lade which passes off from this weir takes a good deal of water, and is unsluiced. A bye-wash, which comes from it to the river some 500 yards, or thereby, below the weir, forms the only pass by which sea-trout are enabled to ascend when the dyke is dry. In justice to the upper waters, and for the proper distribution of fish over the spawning ground, there should be a proper pass towards the left bank. The lade could then be sluiced and hecked, and a deal of water saved to the river which at present simply runs to waste. 


\section{THE BLADENOCH.}

Angling and netting seasons same as those of Cree.

The river Bladenoch and its tributary, the Tarff, drain the extensive moorlands of Wigtownshire. The main stream flows down to Wigtown in a south-easterly direction; the Tarff joins in from the west about 10 miles above the mouth. The Bladenoch rises from Loch Maberry, and receives also a head branch, called the Becock Burn, from Ochiltree. The gradient is very easy for the most part, and the course very sinuous. The total length is about 23 miles. The Tarff rises from a little lochan on the Ayrshire border close to Benbrake Hill, and on considerably higher ground than the Bladenoch. It also winds very much in its course, and while on its southerly course, before it is turned off to the east to join the main river near Kirkcowan, is crossed by the Portpatrick Road.

The mouth of the Bladenoch is tortuous and tidal for some little distance up, but there is here no gradual widening into a broad estuary as in the case of the Cree at the head of Wigtown Bay. Netting is regularly carried on in the lower reaches of the river, where the river passes through a deeply cut defile with much wooding. Fish begin to ascend in March, but the stock is not what it might be, and the greatest number of fish are therefore expected in the autumn.

The water of both the Bladenoch and the Tarff is a good deal used for mill power, the Tarff, being the smaller stream, being affected more prejudiciously than the other.

At New Mills, about a mile from Wigtown, there is a dam dyke $3 \mathrm{ft} .9 \mathrm{in}$. high, and with a down-stream face of 12 feet. This height does not seem excessive, more especially since there is a fish pass of the simple shoot order in the centre of the dyke, but the sill is formed by a beam, however, which makes an abrupt rise in a manner most formidable to any fish attempting to ascend. The water is necessarily comparatively thin and quick on the down-stream face, and when a fish reaches the top of this it has no "take-off" to enable it suddenly to surmount the abrupt sill. At the head of the pass, till a comparatively recent date, as great an obstruction as the abrupt sill was introduced in the form of a stout board. This was not, I believe, placed across the head of the pass for the express purpose of preventing fish from ascending, but in order to provide 
more water-power to the mill. The pass, I believe, does moderately well, but at the right bank, where the river bed is naturally suitable, an excellent pass might without much difficulty be formed.

One other dyke exists in the Bladenoch at the Borhoise Meal Mill, about a mile and a half above the junction of the Tarff. It is not a formidable affair, being composed of loose boulders, and varying in height from 2 to 4 feet; but it is, or was when I last saw it, extremely leaky, so that much water flowed through the substance of the rough dyke instead of over the top of it. A more efficient pass than formerly existed has now been constructed here.

The Tarff, as already indicated, is more seriously interfered with. The three dykes are in the neighbourhood of Kirkcowan, a short distance above the junction. The first is the Tarff Sawmill Dyke, an irregular concrete structure of considerable height, without a pass, and capable, in moderate conditions of water-level, of sending all the water of the stream down the lade. This structure requires modification to make it more passable. Above this the next dyke is that of a wool mill. It is not high, but is a serious obstruction through the great abstraction of water drawn from a deep pool immediately above it. The stream here is rocky, and the dyke is formed of concrete, with smooth cement facing on top of the rocks at the tail of the pool. The lade is deep and capable of drawing water to such an extent that in moderate conditions even a pass with the statutory 6 inch slap in the sill can be left dry.

Above this another wool mill exists, indeed the mill stands on the steep bank overlooking the large pool just referred to, but the dyke is quite half a mile up-stream. A turbine at the mill is able to receive water from a height of some 21 or 22 feet. Action in the Sheriff Court was recently taken for the observance of the Salmon Fishery Bye-laws. As a result, hecks have now been placed on the lade, and the firm have undertaken to see to the due and proper closing of their sluice when the water is not required. Also a fishpass has been formed by the firm in their dam-dyke in virtue of a special arrangement entered into between them and the salmon fishery proprietors.

In 1907, in the Bladenoch district, 1019 fish were taken in Wigtown Bay by fixed net, 214 at the mouth of the river by sweep net, and 56 fish were taken by rod. 


\title{
THE CREE.
}

\author{
Angling Season: 11th February to 31st October. \\ Netting Season: 11th February to 26th August.
}

District Fishery Board meets in Newton-Stewart. A. B. Matthews, Esq., Solicitor, Newton-Stewart, is Clerk.

There are two head streams in this district. One slightly larger than the other is named the Cree, the other is called the Minnock. The former has its source in shallow and isleted Loch Moan, some 700 feet above sea-level, and within a mile of the Kirriemore Burn, which is the head water of the Minnock. The Cree bends away to the west for some distance before it works round to its prevailing S.E. direction. Its total course from Loch Moan to the head of Wigtown Bay at Creetown is 26 miles. The greater part of the course forms the boundary between the counties of Kirkcudbright and Wigtown.

A lonely road, and a long and hilly one, passes Loch Moan as it crosses the hills from Maybole through Carrick to Newton-Stewart. This road follows the course of the Kirriemore Burn and Minnock for 5 or 6 miles, then bends to the west and crosses the Cree at Bargrennan, about $2 \frac{1}{2}$ miles above the junction of the two head streams. The Cree here is a rather stony and straggling stream, but rather less than a mile above Bargrennan Bridge a rather serious fall occurs, which acts as a material obstruction to the passage of fish. At times salmon congregate in numbers below this linn, and are somewhat exposed to the possible attention of the stroke-hauler. In Frank Buckland's time, and at his suggestion, a rough channel was cut in the rock to facilitate ascent. It would not be difficult, however, to do a good deal more in the way of cutting the gradient down; and although much of the water above is in open moorland, the proper distribution of fish would, I have no doubt, be distinctly improved.

The Minnock in its lowest portion has some quiet water, with grassy banks, and the junction pool is of very considerable size, but in following the river upwards fine gravel banks soon appear. These presently give place to stones of a rougher and larger character, and presently rocky ledges and cascades become marked at Glencaird. Three miles above the junction it is joined by the Water of Trool, which descends one of the most beautiful glens of this neighbourhood. It flows from Loch Trool in a narrow, rocky gorge, and at the outlet the stream has been sluiced and the level of Loch Trool 
brought under power of control. Sir Herbert Maxwell informs me that the effect of the Glen Trool sluice is to make a rise of 8 inches possible on the Minnock, and that this rise may last from six to eight hours. The main water is, however, raised only about 4 inches, and the angling is probably unaffected by it; but if there are fish in the Minnock, a rise such as that referred to is quite sufficient to move fish and improve the sport. On account of the level at which certain dwellings are situated on the side of Loch Trool, it is not easily possible to arrange for the storing of more water than at present.

Glen Trool and the line of the Minnock converge from either side of a spur of the hills named the Rig of Stroan, which rises in a succession of eminences culminating in the fine mountain of Merrick (2764 feet). This whole region, with its rich wooding and streams, its lochs and heather-clad slopes, and especially its rockcovered hills, presents on every hand a combination of varied beauty and grandeur which great tracts of the Highlands cannot equal. Few Scotsmen know the beauties of this part of our country. I am always inclined stoutly to maintain that many parts of the Highlands surpass, in their influence upon the mind, anything to be readily found in Europe, and it may be on this planet. Of course, what is most pleasing or impressive to one calls forth no response from another; the personal factor cannot be eliminated in such matters. One man delights in huge Alpine peaks in their brilliant hard atmosphere, another finds repose of soul in the woods and misty distances of flat country. But I know not where refined grandeur can be found as in the Scottish Highlands; while, apart from the actual landscape, the subtle charm of romance, people, sentiment, call it what you will, all combine to captivate both the Celt and the Saxon. At the same time, there is a strong charm about the knot of hills which discharge to the four points of the compass the head waters of Doon, the water of Trool, the Blackwater of Dee, and the Penkill Burn to the Cree at Minnigaff.

The Cree below the junction with the Minnock has a course of $6 \frac{1}{2}$ miles to Newton-Stewart, In this there is much pleasant fishing water, although in the neighbourhood of Penninghame the river expands into a wide lake-like stretch which is sometimes described as Loch Cree-a pikey-looking place. Much of the water is of that character which is most suitable for spring fishing; there is a fine steady run with a swirl here and there, now a break over some boulders, then a shallower and quicker stream, again an even 
rather quiet stretch. Some of the pools are so broad as to make the use of a boat more or less necessary. These are the Kirk Pool, just above Newton-Stewart, the Grey Stone, the Boat Pool, and the West Mains Pool, all below Penninghame Boat House. At other parts in this lower section of the river wading is an advantage to the angler.

As the river nears Newton-Stewart, it passes over two weirs, the Kirk Pool weir and the Minnigaff weir, while below NewtonStewart Bridge there is a low weir to protect the foundations of the bridge. All may be regarded as partial obstructions to the passage of fish, but each has a simple form of pass which satisfies the regulations. These obstructions are, moreover, not sufficient to prevent the ascent of spring fish.

A beautiful little stream called the Penkill Burn enters just above Newton-Stewart. It is the sea-trout stream of the district, but is pretty badly obstructed for the benefit of a large NewtonStewart Sawmill.

Below the town the river soon becomes of very easy gradient, and within a mile and a half begins to wind in the most marked manner. This, the tidal area, as in other rivers entering the Solway, has banks of extremely fine sandy mud, easily stirred by the current. With the action of river and tides it is freely mingled with the water, so that for six or seven miles the current is much discoloured. Gross sewage from the town also mingles. Here the land is quite flat, and the shores of Wigtown Bay, more especially on the western side, dry at low water for a great distance. The limit of the Cree district is reached at the mouth of a little burn called the Bishop Burn, some two and a half miles north of Wigtown. On the eastern side, however, the Cree district extends along the coast to the entrance of Fleet Bay. In the matter of estuary the Cree may be said to be treated generously, since the Cree, Bladenoch, and Fleet are all included in a common estuary, which compasses the whole of Wigtown Bay. In another sense, this large estuary is of small service, since privileged fixed engines are fished far inside its limits at Creetown, Kirkdale, Kirkbride, and also on the western side. In all there are nine nets with twenty pockets.

With regard to the net and coble fishing, the Cree is unhappily in a retrograde position. A few years ago the nets were entirely removed. At the present time the whole of the winding tidal water is netted, as well as the Palnure Burn. Owing to the muddy nature of the banks and their liability to change, no very precise 
fishing stations are adopted in many of the reaches in this seven miles of water; but it may be said that 18 shots are regularly fished. This is certainly more than a river the size of the Cree can stand if an adequate stock of fish is to be kept up.

In 1900, an Association of six anglers interested in the fishings of the river obtained a lease of the angling rights for 21 years (to 31st July each year), a lease of all the river nets, and in 1901 a lease of the Cassencary Stake net. The last was sublet at a reduced rent with the proviso that a 60 hours weekly close time was to be allowed in place of the statutory weekly period of 36 hours. The members further bound themselves to maintain three watchers throughout the year and to use no lure other than fly in their fishing.

Previous to the formation of this Association the stock of fish had become reduced to such an extent that the angling was practically worthless, while the netting tenant had averred that his fishing had resulted in a loss.

Unhappily, unforeseen difficulties arose regarding the tenure of the lease, through the transference of proprietary rights, and after three seasons' fishing the Cree Salmon Angling Association came to an end.

The moving spirit in the attempted resuscitation of this river was Sir Herbert Maxwell, who, as everyone knows, has done so much in the best interests of salmon fisheries in many districts. With the inception of the Association's operations, a chronicle of events and results was commenced, called the "Cree Crew Chronicle." It is a thousand pities that the chronicle is not still in process of compilation, for the perusal of it-with which Sir Herbert has favoured me -whets the appetite for further results.

Not only are the salmon, grilse, and sea-trout recorded with weights and particulars, but an analysis of the various beats and the general character of the weather of each fishing month is noted. The whole starts with the happy motto, "Horas non numero nisi felices." In 1900, up to 31st July, 105 salmon and 34 grilse formed the total for the river. No one fished in February, and the river was dead low in March, when a little fishing was tried. April 5th was the first date upon which a clean fish was taken (by a keeper). Sir Herbert Maxwell had a $9 \frac{1}{2} \mathrm{lb}$. fish on the following day. In May he had a day with 4, and another day with 3 fish, very heavy water running. On 24th May Mr. M'Haffie hooked the first fish seen above the Linn of Bargrennan. The best day of the season 
was 25 th July, when 5 salmon and 3 grilse were taken by one of the rods.

In 1900 the river had been divided into eight beats, numbers 5 and 7 only coming into possession of the Association in the middle of May. In 1901 the water was redivided into 7 beats as follows:

No. 1. From sea to Linloskin.

No. 2. From Linloskin to Penninghame.

No. 3. From Penninghame to Clachaneasy Bridge.

No. 4. From Clachaneasy Bridge to Bargrennan Linn.

No. 5. From Bargrennan Linn to the Ayrshire March.

No. 6. From Minnock Foot to the top of the stream above the Roman Bridge.

No. 7. From the top of the stream above Roman Bridge to the Ayrshire March.

In 1901 a flood came on 6th March, and next day the first fish was taken. The water again falling low, sport was slight, and although a spate came in April few fish came up, and only 32 salmon were got during that month. In the latter part of the month there was too much high water, and the large number of fish that came up then yielded little sport when the river fell dead low in May, the greater part of June, and the whole of July. "Many fish died at the linns, not from Saprolegnia, but some from injuries received in jumping upon the rocks, others apparently from asphyxia." The Association's total for the season to end of July was only 60 salmon and 28 grilse, but the total for the whole season from all sources seems to have been 229 salmon and 9 sea-trout.

In 1902 spring fish were not very numerous in Cree, or for that matter in many Scottish rivers. March produced 5, April 26, May, June, and July were disappointing. The total for the year was 47 salmon and 16 grilse. At the untimely end of the Chronicle is the brief note:

"Explicit the Cree Crew : Lord Galloway having succeeded in his action in the Courts for voiding the lease granted by his brother."

It will be noticed from the brief summary I have given that while the first season of the Association was full of promise, the two succeeding seasons were lean years for the rod, owing partly to scarcity of spring fish-which, of course, could not be expected to make steady recovery in so short a time-and partly to unfavourable weather conditions and scarcity of water.

Since 1903 the nets have again been in full swing. 


\section{THE FLEET AND THE URR.}

Fleet Angling Season: 25th February to 31st October.

"Netting Season : 25th February to 9th September.

UrR Angling Season: 25th February to 29th November.

" Netring Season : 25th February to 9th September.

These two little rivers are situated one on either side of the Dee, the Fleet on the west and the Urr on the east. Each has a typical Solway estuary, rather out of proportion to the size of the river, and each has a course through very beautiful "south country" scenery.

In the Fleet district, in 1879, a claim for the fishing of fixed engines was made to the Special Commission for Salmon Fisheries, and certificates of privilege were granted. It has been found recently that the observance of the weekly close time has been much overlooked, and here, as in the Cree District, so called "white fish nets" which are curiously like salmon nets, are worked in and out of season.

The Fleet rises at a very considerable altitude, and from two sources-the Big and the Little waters of Fleet. To form the Big water of Fleet a series of converging burns descend like the spokes of a fan, or ribs of a fan, I know not which word a lady would employ, from the cluster of hills containing the Cairnmore of Fleet (2331 feet), Meikle Mactaggart (2000 feet), Craigronald and Craigwhinnie-fine-sounding Highland names all of them-to a wide valley-head. This valley no doubt shows the main line of erosion from the hills mentioned, when the shores of the Solway were levelled down, and the shallow estuaries formed. The Big Water now traces its sinuous course in the bed of this great streamtrack, and about a mile below the junction of the burns the Portpatrick and Wigtownshire Railway crosses the valley on a viaduct of 20 arches. About three miles lower down the Little Water joins from the left. This Little Water springs from Loch Fleet, a small triangular sheet of water 1120 feet above the sea, and north of the valley-head already referred to.

The junction is at Castramont, and from this point to the head of Fleet Bay below Gatehouse, the course of the river is $4 \frac{1}{2}$ miles long. Salmon are few and far between in the Fleet during the fishing season, but sea-trout are plentiful and often yield good sport. The sea-trout run from July on till end of September.

The Urr is a much longer stream than the other, having a total 
course, to the head of its estuary-Rough Firth-of a little more than 20 miles. It flows from Loch Urr, a lonely loch some six miles from Moniaive, and through which the boundary line between the counties of Dumfries and Kirkcudbright passes. The course for the first few miles is in open hill land, but by the time it reaches the old Bridge of Urr, it has passed into a wide plain, and the remainder of its track is sinuous and of easy gradient, although usually with a pleasant run. The scenery of the lower reaches is very charming. The river is never of any great size. Before Dalbeattie is reached it flows for a short way parallel to the railway, winding round wooded bluffs and skirting rich meadows. Even as low as this it is a stream you could kick your hat across.

At Dalbeattie it is joined by the Kirkgunzeon Lane, which helps to swell its waters. As Palnackie is approached it becomes flat and quiet, and small craft manage to penetrate the tidal waters. The estuary of the Urr includes not only Rough Firth but Auchencairn Bay, which rounds Almoreness Point to the west. In the latter part of the estuary The Special Solway Commission, in 1879, granted certificates for four fixed engines with seven pockets-opposite Orchardton on the south-east side of Whiteport Bay, at Torr, and at Balcary.

In the matter of close time the Urr has the distinction of rivalling the Tweed in lateness. Angling goes on to 29th November, and certainly, so far as salmon are concerned, angling can only be carried on very late in the Urr. Fish do not enter this little river early. A net is, I understand, occasionally drawn near the mouth, but many fish are not found before the end of the netting season on 9th September. Permission to angle in the Urr may be secured by ticket from Robert Maxwell, bookseller, High Street, Dalbeattie.

Although fish are late they are sometimes surprisingly heavy for so small a stream. I understand that fish up to $40 \mathrm{lb}$. have been taken.

\section{THE SOLWAY DEE.}

Avaling Season: 11th February to 31st October.

Netring Season: 11th February to 26th August.

District Board meets in Kirkcudbright. W. Nicholson, Esq., Sheriff-Clerk, Kirkcudbright, is Clerk.

This is a river which has never had much of a chance, but which should repay someone, or some association, some day, if provision be made for a fuller stock of fish, and proper regulations framed for 
the catching of them. A spring run still continues, grilse are unusually heavy, and large fish enter at "the back end." There is plenty of opportunity for the development of a sound policy of improvement.

Like the Cree, this river rises from two head streams; one the Black Water of Dee, which rises from Loch Dee, near Loch Trool, and receives water from a still higher source in the Cooran Lane, which descends a steep glen in the Rhinns of Kells, the other is the Water of Ken. Now the Water of Ken has a surprisingly long course, and a great number of small burns go to its making. Two sources are, however, sufficiently distinct from all others, viz. the burns at the head of the Water of Deugh, rising from the south side of Wedder Hill, close to the Ayrshire border, and not far from the source of the Nith, the other across a range of hills to the eastward rises within quarter of a mile of the point where the shires of Kirkcudbright, Ayr, and Dumfries meet, and where the Scaur Water, a tributary of the Nith, rises. This latter series of burns really forms the Water of Ken, but the Water of Deugh has a longer course. The water-way from the source of the Deugh to the mouth of the Dee at Kirkcudbright is 46 miles. The Deugh joins the Ken about seven miles north of New Galloway, and before the junction is made the stream plunges over a fall which completely shuts off salmon from those upper waters, when a couple of miles south of New Galloway the river flows into Loch Ken, the commencement of a long stretch of still water which winds, with occasional intervening runs, for well nigh eight miles, and forms a well-marked feature in the Dee district. Loch Ken itself is four miles long, and presents views of very great beauty. The railway crosses the sluggish stream which flows from it before it again expands into the wide diverticula of the so-called river. Kenmure Castle, the ancient seat of the Gordons of Kenmure and Lochinvar, who are of the same stock as the Gordons of the north, stands at the upper end of the loch.

Just below where the railway crosses, at Parton Station, the Ken joins the Dee. The junction is only 150 feet above sea-level, and there are 14 miles to the estuary at St. Mary's Isle, so it will be readily understood that the gradient is easy. The slack loch-like water between Parton and Cross Michael is a stronghold of pike, which reminds me that Loch Ken is reported to have yielded the largest pike on record. A systematic war should be waged against these wretched fish when they spawn amongst the weeds in spring, and all 
the little boys in the neighbourhood might set pike trimmers with advantage. Other base fishes such as perch and eels also abound.

The river only very gradually merges from the loch-like condition, and for several miles has a tendency to revert to it. . Wide bends frequently occur, and several islands of some size are formed as the channel winds onwards. There are many beautiful reaches, and the river is now of large breadth, with rather dark-coloured water, as the name Dee seems to imply. At Agrennan House the waters become more concentrated, and presently the river makes a long straight run to Tongueland. Here a natural barrier of rock has been taken advantage of to construct a series of fish-traps called Doachs (pronounced Dochs). The natural barrier extends almost across the river from the right bank, and the irregularities of this have been built up so that a dyke is formed, which, as a matter of fact, supplies water to the Tongueland Mill.

There are, however, three openings in this dyke, and these are, or have been in the past, used as fish-traps. They are named the Little Doach, the Priory Doach, and the Big Doach. The Little Doach is commonly left open, and the Priory Doach is sparred up, but the Big Doach is employed as a cruive; that is to say, a fishingbox is fitted in the gap having, during legal fishing time, a heck across the up-stream end, and inscales for the trapping of fish which find their way barred. The passage left by the open Little Doach is of small avail, as under all ordinary levels of water it stands too high above the pool below to enable fish to ascend. It becomes of service only in flooded conditions.

These Doachs are very old structures, and one or two singular practices have pertained to them. Speaking of the Solway Dee, in or about the year 1684, one Andrew Symson in his description of Galloway ${ }^{1}$ says: "This River is abundantly plenished with excellent salmon. Towards the mouth, whereof Thomas Lidderdail of Isle hath a large fishyard wherein he gets abundance of salmon and many other fish. Two miles above the said town of Kirkcudbrigh, at the Abbacy of Tongueland, just where a rivulet called the water of Tarfle empties itself into the river of Dee, are great Rocks and Craigs, that in a dry summer do hinder the salmon from going higher up, and here it is that Vicecount of Kenmuir, as Bayly to the Abbacy of Tongueland, hath priviledge of a Bayly-day, and fenceth the river for eight or ten days in the summer time prohibiting

\footnotetext{
${ }^{1}$ Geographical Collections, etc., made by Walter Macfarlane. Edited for the Scottish Historical Society by Sir Arthur Mitchell. Vol. ii. 1907.
} 
all persons whatsoever to take any salmon in that space so that at the day appointed, if it have been a dry season, there is to be had excellent pastime; the said Vicecount with his friends and a multitude of other people coming thither to the fishing of salmon which being enclosed in pooles and places among the Rocks, men go in and catch in great abundance with their hands, speares, listers, etc., yea, and with their very dogs."

Another curious practice which, however, is still carried on at the Doachs is the fishing of the shoulder net. This engine is like a gigantic shrimp-net or landing-net, fitted to a pole 24 feet long. The netting is about 6 feet deep, and is suspended from an iron rim of a rough semi-circular shape measuring about $5 \mathrm{ft} . \times 7 \mathrm{ft}$. 3 ins., the greater measurement being transverse. The net is balanced on the right shoulder of the fisherman, the handle or pole resting on a wooden cranse or slipper strapped to the shoulder; the mouth is turned downwards, and the bag of the net gathered at the base of the pole. With the contrivance in this position the fisherman-who has to be a man of some strength-sallies forth along the rocks after dark. Approaching, let us say, his favourite little pool, called the Black Pot, he throws the net as a man does a spear, and immediately presses downwards on the handle, dragging the net towards him, and at the same time swinging it so as to search all the corners of the pool. I have watched the operation on a fine summer night, and the scene is not without a certain fascination. The moving figures, the constant rush of the water over the rocks, the blackness of the shadows, the tall trees and the old mill blend beautifully; while the silvery fish splashing in the net as they are lifted or dragged out, echo the play of the moon on the water; but the whole is to my mind grievously marred by the feeling that the business comes so very near to the old and equally picturesque leistering, now done away with. I shouldn't mind seeing Indians spearing the spawning fish in the creek of some Pacific coast river where the fish are in countless thousands, but to bale fish out of rocky pools in a Scottish river, where salmon are all too scarce, seems to me a most improvident sort of operation. It will be noticed that neither Doachs nor the shoulder net are expressly referred to in the quotation given above.

The Doachs of Tongueland have been the subject of a good deal of litigation. The late Mr. Archibald Young, when Inspector of Salmon Fisheries, referred to the matter in the following way ${ }^{1}$

${ }^{1}$ Second Annual Report Fishery Board for Scotland, Appen. p. 109. 
when speaking of the regulations governing cruive fishing, and whether or not the Doachs were cruives: "With reference to the above, I may mention that at the time I inspected the 'Big Doach' and the deep pool called the 'Black Pot' below it, the sill or bottom of the Doach was at least $4 \mathrm{ft}$. 6 ins. above the level of the pool, and there was no paved floor or apron of any kind as prescribed in the bye-law. I may further mention that $\mathrm{Mr}$. Stewart, in his well-known Treatise on the law of Scotland relating to Rights of Fishing, states that fishing by means of Doachs is subject to the provisions of the above-quoted bye-law. 'A method of fishing,' he says, 'not exactly the same as, but similar to, cruive fishing, was subjected by the Court to the regulations which affect cruives.' The case he alludes to is that of Peter Johnston and others, Trustees of James Murray, Esq., of Broughton, against the Messrs. Stott of Kelton and their commissioners, decided in the House of Lords, 18th February, 1802. In this case an action was originally raised by the Messrs. Stott, who were the proprietors of lands and salmon fishings about a couple of miles above the Doachs, to have it found and declared that these Doachs were really cruives, and must be constructed and worked subject to the rules and restrictions regulating that mode of fishing. It was found proved that the fishings at Tongueland had been carried on as far back at least as the middle of the seventeenth century by means of Doachs, as shown by an old valuation of 1642 and other documents. The Lord Ordinary found that "cruives or doachs must be regulated in terms of the laws regarding cruive fishings, and that the blind eyes and other artificial obstructions or barricades to intercept the run of the fish in the river, within the bounds of defender's fishings, must be removed as illegal.' On reclaiming, the Court adhered, and found that the barricades termed 'blind eyes' must be removed from the spaces between the rocks, and the said spaces filled up with proper materials, formed and constructed like other cruive dykes. These 'blind eyes' were more effectual to intercept fish than a cruive dyke, because they admitted a passage to the water downwards, without allowing the salmon to proceed upwards; whereas, during a flood, when water was coming over the cruive dyke, the fish were able to ascend. The case was then appealed to the House of Lords, who ultimately found 'that the form and construction of the cruive dykes and boxes, and the construction and position of the inscales are to be regulated according to law,' and remitted back to the Court of Session to give precise 


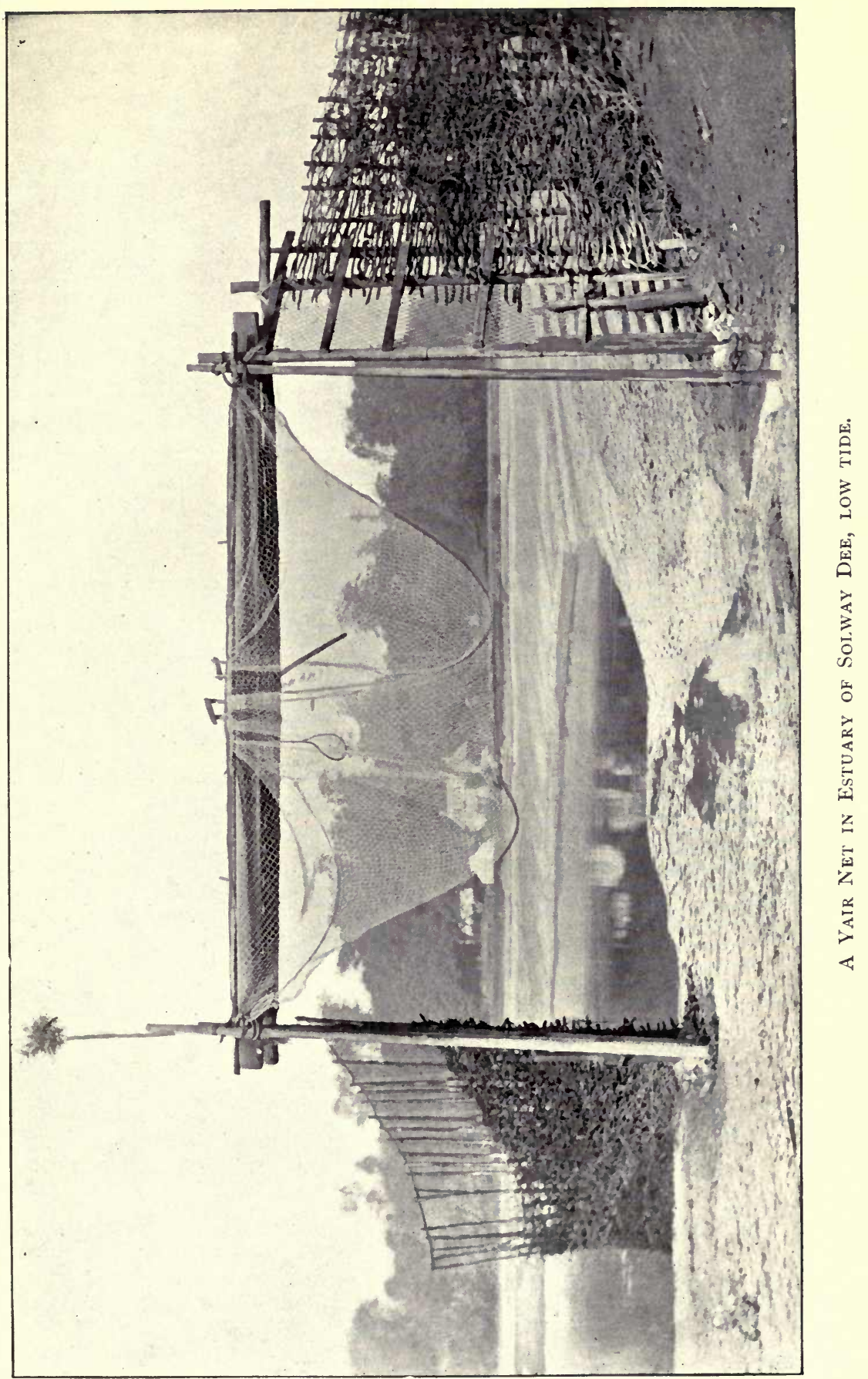



directions to the parties about the form and construction of the cruive dykes and boxes, and the construction of the inscales according to law. I venture to think that it must be held that this case is decisive, and determines the point that these Doachs are really cruives, and that they must, consequently, be subject to the provisions of the bye-law which now regulates the construction and use of cruives in Scotland."

About a mile below the Doachs, the Dee flows into the head of its long muddy estuary and is joined by the Tarff tributary, a stream up which sea trout and a few salmon go. In this section two sweep nets are employed, but with the soft banks of the estuary lower down this method is impracticable. By way of further taking toll of the unfortunate salmon, however, the tidal estuary is fished regularly by six fixed engines, and occasionally by a seventh. These also are unlike the contrivances used in any other part of Scotland, They are called yairs. In the quotation given on p. 400 , written about the year 1684 a single "fish yair" is referred to, but evidently when the Special Commissioners for Solway Fisheries appointed in 1877 made their enquiry the seven yairs had been regularly fished since before 1862. Nevertheless, the Commissioners regarding their position as altogether illegal as apart from the question of use and wont, ordered their removal. Ultimately the Court held that the Commissioners had no right to enquire into the question of legality as a matter separate from "a right to salmon fishing" and "use in the years specified," and the seven yairs were granted certificates of privilege. Four of them belong to Captain John Hope, R.N., of St. Mary's Isle, and three to the Burgh of Kirkcudbright. Captain Hope now rents the town nets and fishes them along with his own.

In the making of a yair there are two long walls of wattling which converge in $\mathbf{V}$-shape; these are the leaders. At the apex of the $\mathbf{V}$ is an aperture 20 feet broad and practically square. In this, when the tide is up and the yair is fishing, a large net is fixed. The net has a capacious bag which streams out with the current, the sides being fitted on rings which can travel on two upright poles, the bottom being lashed to a cross-beam. A man sits on a frail staging at the top of the net and holds in his hand five fine cords attached to different points in the bag of the net. By holding these fairly tight after the fashion of a man driving a team of horses, he is able to feel a fish strike the bag of the net at any point. As in all other Solway Estuaries, the water is so discoloured with the fine silt in suspension, that he cannot see fish entering the net. When a 
fish strikes the net, the man at once drops his cords and seizes a long upright shaft attached to the centre of the bottom cross-beam, and hauls it up so that the retreat of the fish is cut off and the prize secured. The yair net is therefore like a large hoop net, or like the shoulder net just described, but is fished between leaders as a fixed engine. My photograph shows the net hauled up, the tide being out. The long central pole is laid back from the top of the staging. When the net is fishing it reaches to the bottom of the square aperture. The leaders may be arranged either to fish the flood-tide or the ebb-tide. The three top yairs fish the ebb to catch fish dropping back with the tide when the water is low-in high water they do not eatch many since the fish then ascend to the Doachs and become prizes for the shoulder net. The lowest yairs are arranged to fish the flood-tide. The seventh yair, which is smaller than the others, is usually put in the water just at the end of the season,

With regard to the catch of rods in the Dee no one seems to know what the total amounts to. The first runs generally occur at the beginning of March, and during this and the succeeding month a fair number of fish seem to ascend. Mr. Anderson who rented the Doachs for many years told me on one occasion that 12th February was the earliest he had taken salmon. May is rather a blank as a rule, and in June the grilse come. The greatest number of fish seem generally to ascend in July, and if this month is not a dry one, the upper waters have some chance of being stocked. In a dry summer salmon angling is, however, of little value. In the autumn some heavy fish are got. The heaviest during recent years was a 46-pounder taken in 1904. More commonly $30 \mathrm{lb}$. to $35 \mathrm{lb}$. is the greatest weight secured.

The assessed salmon fishing rental of the District is generally £1556. I have no doubt this might easily be doubled if the river was regulated according to accepted ideas. A certain amount of netting might no doubt remain in the Estuary, but if a thorough improvement were desired by, say, some Angling Association, or some combination of proprietors willing to compensate those who removed their nets, the Doachs, the shoulder net, and the yairs would be taken out of the water. Without a drastic effort of this kind the stock of salmon in this fine river will not improve. 


\title{
CHAPTER XXXII.
}

\section{THE RIVERS NITH AND ANNAN.}

\author{
THE NITH. \\ Angling Season: 25th February to 14th November. \\ Netring Season: 25th February to 9th September. \\ District Fishery Board meets in Dumfries. C. Stewart Phyn, Esq., \\ Procurator-Fiscal, Dumfries, is Clerk.
}

THE Nith is a river of very considerable volume. It does not rank with the largest rivers of Scotland, nor with the salmon rivers of even second rank, but that is not the fault of the Nith. The natural features of the country through which it flows are such as go to the making of a beautiful river which should produce valuable salmon fishing.

Unhappily, the fisheries here have been allowed to sink to a very low ebb. Many things have combined to bring about this state of matters, the chief of which I will refer to presently; but the broad fact is, I fear, that the interests of the fisheries have not been guarded in the past. All manner of contending or opposing interests have been allowed to spring up, without the usual and very necessary safeguards which would have enabled at least a much larger proportion of fishing-value to remain.

The river rises in Ayrshire as a burn called the Powkelly, a few miles east of Dalmellington on the river Doon. The course takes the form of a wide curve to the east and south, and the river enters the Solway Firth through extensive sandy flats below Dumfries. The total length from source to Scar Point, in the tidal estuary, is 55 miles, and the river in its course passes through New Cumnock, Kirkconnel, Sanquhar, and Thornhill, as well as Dumfries. In almost its whole length, the Nith is a river of beautiful character, offering many attractions to the angler; gravelly reaches of good streamy water, long holding pools, here and there an outcrop of rock 
beneath steep and richly wooded banks, would make most attractive angling to the fly fisher if only he was assured that more salmon were present to be attracted by his lure. One does not need to catch salmon to enjoy salmon angling, but one requires the consciousness that there is the possibility of catching salmon, that one is not exercising one's skill in quite barren water.

It is remarkable that in the whole drainage area of the Nith, in spite of many tributaries, there is no loch. With the exception of four small lochs which drain into the tide-way south of Dumfries, lochs are conspicuous by their absence.

The neighbouring river Annan is always regarded as a much better salmon river than the Nith; and has a rent-roll from salmon fisheries of fully $£ 3000$. A certain proportion of this, no doubt, is derived from fixed nets in the Solway, the Nith District not having a similar source of income; but this does not account for the great discrepancy of rental. The Nith figure is only a little over $£ 500$, yet the Nith has a drainage area of 435 square miles, while the Annan has only 350 square miles.

The catch of salmon both by net and rod is a mere bagatelle compared with what it should be. In 1905 it had sunk so low that only 119 salmon and 90 grilse and 3907 sea-trout were taken in the nets, while the rod fishings did not yield, I suppose, two score,-a return I have seen for 1902 did not make a total of one score, and the total in 1908 is believed to be 22 fish.

The reasons for the decline in the past have been threefold; (a) pollutions from Dumfries and Maxwelltown, (b) over netting, (c) the obstruction of almost all the tributaries.

An important official enquiry was held on the question of pollution, on grounds other than the interests of the fisheries. The tidal waters below Dumfries were, in consequence, declared by the Secretary for Scotland to be "a stream "-a technical requirement to enable the proper authorities to deal with pollutions in tidal waters-and in consequence the Municipality was called upon to purify its effluents. Sewage works were constructed and were completed in 1905,

This has made a material difference. The Parliamentary Burgh of Dumfries has a population of about 18,000. But up to the present the trade waste-and it comes from such important sources as a dye work, two large tweed mills, and two hosiery mills-has not been allowed to enter the purification works, but, as formerly, is poured straight into the river. Those who have seen what this 
means, as I have, will agree that the Nith cannot be regarded as purified till the trade waste is also treated. At the same time I may add that there seems no adequate reason why such a large establishment as the Crichton Asylum should escape treating its sewage.

The overnetting is not now so serious as it was. Two methods of netting called whammelling, i.e. drift net fishing for salmon, and paedle net fishing, have been largely put down by the action of the local proprietors. The paedle net is a small stake net set on the sandy flats off the river mouth, so that when the tide ebbs the net is left dry. It is in all essentials a salmon fixed net, but is of a smaller size. There are leaders and cross arms and a "head" or enclosed chamber which constitutes the trap. Attached to this there is very frequently a cylindrical "coop" of netting with an inverted mouth, after the fashion of a large lobster pot. This is the innermost recess of the trap. The whole structure is rather elaborate and must necessarily be somewhat costly, yet the owners of such nets tell one they are meant to catch flounders. The flounders of the Solway, I am willing to concede, may be very fine fellows of their kind, but my experience of flounders is that they live on the bottom, and that it is not necessary, is indeed extravagantly expensive, to fish for them with nets of several apartments roofed in six feet from the ground.

I recollect setting up a stand camera to take a nice photograph of some paedle nets one day in the rain, at dead low water, about halfa-mile out on the mud. I had just completed my operations when an innocent-looking fisherman, with his trousers rolled up to the knees and an empty sack under his arms, came trotting out in my direction. He evidently wished to speak but did not know how to begin. I helped him out therefore by asking if these were his nets. No, they weren't his nets.

"What do you catch in these curious nets?" I asked.

The inevitable answer came at once, "Oh, jist a few flounders."

"The fish in this net over here are not flounders."

I may explain that he kept at a most respectful distance during our conversation.

"No! What's in that net?"

"Sea-trout," I answered.

His conversation seemed quite exhausted then. He tucked his sack a little tighter under his arm and immediately trotted off to a range of nets still further out. But the sequel of the story was 
what amused me. I had kept my trap waiting, and drove back to Dumfries, some six or seven miles. After lunch I went into a fishing-tackle shop to ask a question or two, and presently found myself listening to the woes of the local anglers, and to a complaint against the paedle nets and haaf nets in particular.

"But," said the shopman in conclusion, "we're going to have this all altered now."

"How's that?" I asked in some inward surprise.

"The Government Inspector's down here just now, and he's an expert photographer. He's been down playing click here and there amongst the nets," and he slapped his hands to emphasise the sound of the click. "Ah," he added, "the camera doesn't lie."

I felt then that outside of the shop was the best place for me, but I managed to keep my face straight for one more question.

"Where does this Inspector come from?"

"Oh," with conviction, "the Woods and Forests."

I left then. I suppose the honour was too great for me.

Time after time the paedle net fishers have been taken to court, and time after time they have paid their fines and presently rigged up their nets again. As I write, another and, if possible, a final, effort is in preparation to suppress this form of fishing. In 1883 as many as 109 paedle nets were counted.

The netting now practised is net and coble fishing in the tidal part of the river. The tide flows up as far as the weir or "caul" of Dumfries, and it follows, since this weir is, in most conditions of water, a distinct check to ascending fish, that fish congregate below the weir. According to the law south of the Border it would not be lawful to net close up to the foot of the Caul, but in Scotland, unfortunately, as I believe, we have no clause prohibiting this practice. It follows, therefore, that the foot of the Dumfries Caul is the principal netting place. When the stock of fish has run very low, as in the Nith, netting below an obstruction at the mouth of the river is likely to be more than the river can stand. In addition to the tidal netting below the weir, an occasional shot is taken above the weir and at the mouth of, and a short distance up, the tributary of the Cluden. In all, nine shots may be said to be regularly worked and five shots occasionally fished.

At the mouth of the river a certain number of haaf nets are also worked. The haaf net is peculiar to the Solway, as the yair nets and shoulder net of the Dee are, and is fished in the Annan as well as the Nith. It is a net made somewhat in fashion of a shrimp 
net, being a tapering bag of netting having its mouth stretched on a framework of wood, but the handle being shorter. The net is fished by a man who wades into the water near to the edge of the tidal channel, and there stands with the net set upright and the bag floating out with the current. It is only in the much discoloured waters of these muddy Solway estuaries that the haaf net is likely to be successfully fished, since if the water were clear the salmon would avoid the trap. The tide, however, raises so much fine alluvial matter, that the water becomes "drumlie," and the salmon has to adventure into fresh water in a sort of aqueous fog. If he runs into a haaf net, the fisherman immediately raises his frame and wades out with his prize.

Very commonly haaf net men arrange to work in company, and form a string of nets at right angles to the direction of the current, the furthest out man being up to the arm-pits in the water. It is a quaint sight to see a file of submerged men out in the water, each as motionless as any heron watching for a passing smolt. When the rising tide threatens to drown out the ultimate man, he lets his net float up and moves to the shallow end. In time the next man comes in, and so on. When the tide turns, they all turn, and face the other way.

Now, without any doubt, it seems to me, the haaf net is a fixed engine according to the interpretation of that term as regards Scottish salmon fisheries. It is not a net which is caused to move by the hand of the fisherman, or, to use Lord Westbury's accepted expression, which takes a temporary grasp of the water. It is not a net which is set, and left to fish by itself, as an ordinary stake net is, since it is held in position by the fisherman; but it is a stationary engine set and held in position, in as true a sense as is a toot-andhaul net formerly fished in the Tay estuary, and now disallowed by decision of the House of Lords. Moreover, like a drift net which was simultaneously abolished it is, when fished in conjunction with other similar nets, an obstruction to the passage of fish. In ordinary draught netting or net and coble fishing, such, for instance, as is practised below Dumfries Caul, it is not allowable to drift the net along in the water, or to hang it across the river as a species of barrier to ascending fish. The net must be shot, and pulled in through the water to the bank in such a manner as will preclude the possibility of the net being stationary in the sense of not being caused to move through the water by the fisherrnan.

With regard to fixed nets in the Solway, however, in the 33rd 
section of the Salmon Fisheries (Scotland) Act 1862, the provisions of the English Fishing Act ${ }^{1} 1861$ are made to take the place of the Scottish provisions which regulate these matters. The wording is that the Act in question "shall extend and apply to salmon fisheries in the waters and on the shores of the Solway Firth situate in Scotland, as the same may be fixed by authority of this Act, and to the rivers flowing into the same, in so far as such provisions relate to the use of fixed engines for the taking of salmon: Provided that all offences against such provisions shall be prosecuted and punished as directed by this Act." We have therefore to go to the English Act and consult the definition there given of a fixed engine. In Section 4 we find "Fixed Engine" shall include stake nets, bag nets, putts, putchers, and all fixed implements or engines for catching or for facilitating the catching of fish." This is not really very explicit. After mentioning four varieties we are simply told that fixed engines shall include fixed engines. The definition was revised, however, by the Solway Salmon Fisheries Commissioners (Scotland) Act 187T," which says, "In this Act and in the Salmon Fisheries (Scotland) Act 1862, and in any Act therewith incorporated, 'Fixed Engine' shall include any net or other implement for taking fish, fixed to the soil or made stationary in any other way, not being a cruive or mill-dam." This seems to me to be sufficient without any dubiety, to include haaf nets. Many prosecutions have been carried out against haaf netting in the past, but these, I believe, have been mainly on the ground that the fishing was on the ground of proprietors who had not granted permission, the Solway Act of 1804 (Section 9 ${ }^{3}$ expressly providing that permission for any fishing is necessary. Haaf netting as now practised, however, is with permission or by instruction of the proprietor, hence the absence of objection on the broader grounds stated above, is, in my view, in line with the absence of objection to infringement of the Salmon Acts in general, which, as I have already indicated, is a singularly common feature in the district now under review.

This brings us to the third reason for the decline of the Nith fisheries - the obstruction of almost all the tributaries. In 1887, an Inspector of Salmon Fisheries reported that only in three out of sixteen obstructions specified had any attempt, apparently, been made to comply with the Salmon Fishing Regulations. ${ }^{4}$ Things are perhaps not quite so bad now. Fish passes have been constructed at

${ }^{1} 24$ and 25 Vict. C. 109. ${ }^{2} 40$ and 41 Vict. C. CCXI. S. $4 .{ }^{3} 44$ Geo. III. C. 45. 4 Sixteenth Annual Report of the Fishery Board for Scotland, Part II. 
East Cluden and West Cluden Meal Mills, and there is a likelihood that the two Dalgoner dam dykes further up the same main tributary will be removed or else provided with passes. The waterfall usually called the "Cluden Rocks" still remains an obstruction.

The fact remains, however, that the salmon of the Nith are deprived of all the tributaries except the Cluden or Cairn, and that even this, the most important tributary, is obstructed. So long as the stock of the salmon remains low, it is very likely the case that the upper part of the main river can quite easily accommodate all the spawning fish; but it should be recollected that a tributary very commonly offers the most advantageous situation for spawning, having not only suitable gravel but a less volume of water. Fortunately the head waters of the Nith are of fine character, although some pollution does exist, but a salmon river will never reach its greatest perfection, will never maintain the stock of fish it might have, if excellent spawning tributaries are cut off by precipitous dam dykes. The Carron has two total obstructions, the Enterkin has another; the Minnock, the Crawick, the Scaur, and the Shinnell have dykes built across them without any regard to the bye-laws of the Salmon Acts. Complete powers exist for bringing these into the condition they should be, but these powers-which can only be exercised by the District Fishery Board - might be more widely utilised.

An excuse commonly made in the district is that so long as the Dumfries Caul is not right it is not much use dealing with obstructions above, but although advice has been received and plans have even been drawn, the Dumfries Caul remains as before. It is a thousand pities that the Dumfries Caul was ever allowed to be built in its present form. If it was a dyke slanting away up-stream from the right bank, and with a complete gap for an uninterrupted run of water at the left bank after the fashion of all the weirs, say, in the Vale of Leven where an enormous amount of water is taken to the Turkey-red Works, the Nith would not have suffered in its main channel.

Above Dumfries Caul the river is held up for a considerable distance, the gradient being naturally very easy. About a mile out of the town the Cluden joins at the right bank, and here the picturesque ruins of Lincluden Abbey stand.

"Ye holy walls, that, still sublime,

Resist the crumbling touch of time ;"

The Cluden in its upper part is called the Cairn water, but at Moniaive three head streams unite, the Dalwhat, the Craigdarroch, and 
the Castlefern waters. From the source of the first to Lincluden Abbey is about twenty-five miles. It is a fine stream throughout, with good running water, all but about the last mile which is somewhat flat. A footbridge crosses at about the head of this quiet water, and a footpath follows the left bank. The main road crosses about a mile further up. Trout, salmon, and grayling are caught in the Cluden.

The Dumfries and Maxwelltown Angling Association share a deal of this water with the Galloway Angling Promotion and Protection Club. The former rent the Lincluden salmon fishing, and the Jardineton and Ashyholm sections further up, which are chiefly looked upon as trouting and grayling water. The members of the latter do not, so far as I know, specially seek salmon fishing, but have trouting rights on about seven miles of water from Stepford, which is about seven miles up from the mouth; they fish both banks down to near the Irongray bridge, and then the right bank at Terregles and the Grove.

Cluden Mill is situated at a bend of the river where an irregular ridge of rocky ledges occur. From the highest part, situated out in the stream, wooden barriers have been erected to each bank so as to form a mill dam dyke. It is not a serious obstruction, but required a pass.

Next above this comes the so-called Cluden Cruive. This till lately was a quite unique sort of engine. A heck was run right across the river, at an island which occurs, and at the point of main water-flow a gap was formed into which an iron cage with an inverted mouth and no possible exit was lowered by means of a short iron crane. The iron cage has now been done away with, and the cruive conforms to the usual type. In addition to this the cruive is not now fished more than a few times a year. Just above the cruive hecks, a low and smooth weir about two feet in height occurs. This is the West Mill dyke, now provided with a gap.

The next obstruction is the natural waterfall at the Gribton Rocks. In two rocky holes close to the left bank, below the fall, and close to the Gribton Sawmill which stands here, a net stretched between two poles and worked by two men each holding a pole and searching the crannies of the pools, used to be worked After litigation it was discontinued. The falls at all ordinary levels are total obstructions and should certainly be blasted as, I believe was arranged for before the late proprietor of Gribton died. There is a low mill dam for purposes of the sawmill just above the fall, tapering away 


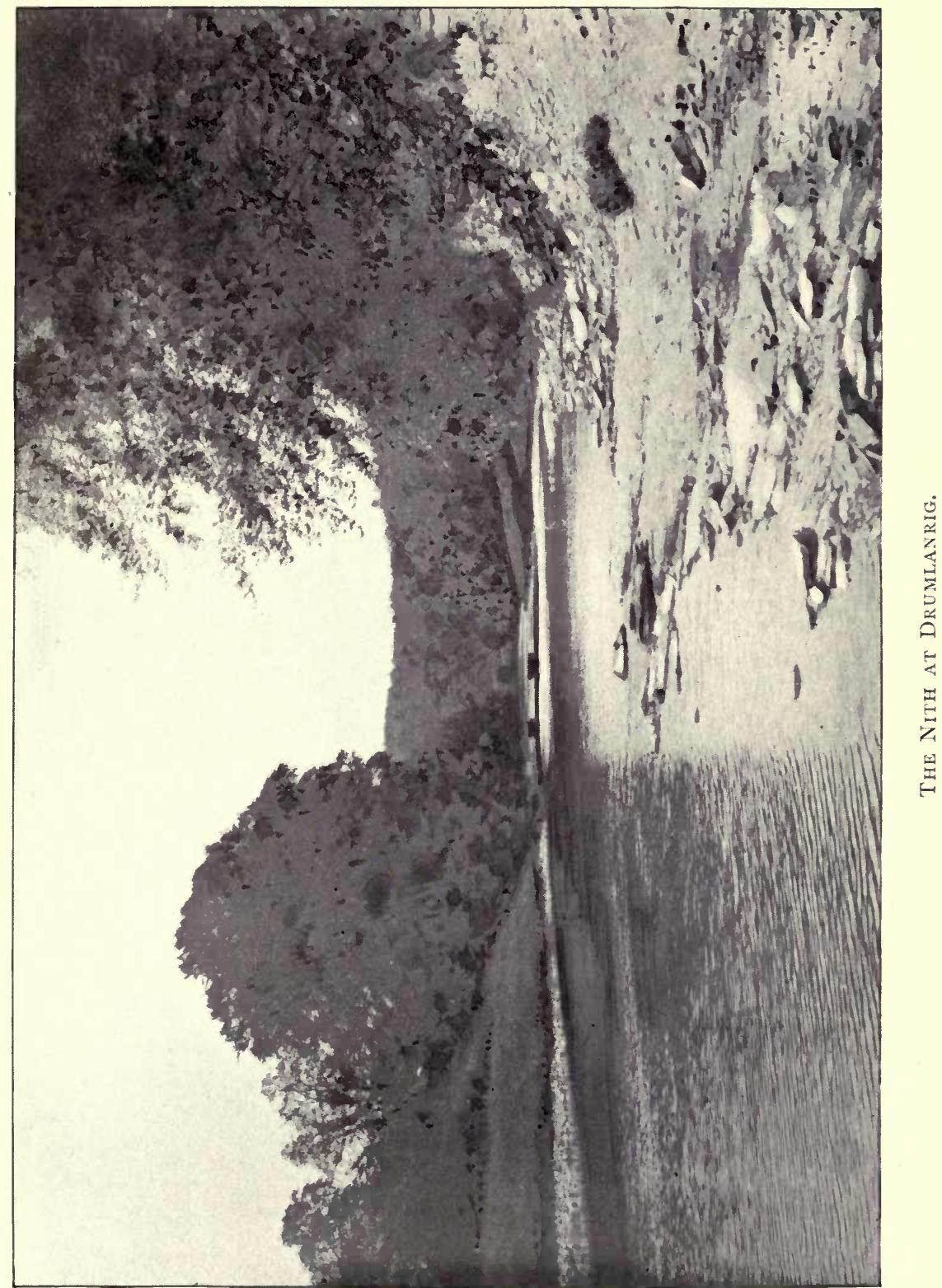



to a vanishing point at the opposite or right bank. The blasting of the fall at the left side would naturally result in a greater concentration of water there, and operations would have to be continued upwards and across the stream towards the low part of the weir at or near the right bank.

About a couple of miles below the mouth of the next tributary, at Barjarg, a famous poacher named Jock Wallace landed a fish of $67 \mathrm{lb}$. in 1812. It was hooked about eight in the morning and landed at six in the evening, by which time, it is reported, only two strands of Jock's hair line held the fish. It was taken to Barjarg Tower and weighed, and a certificate was given signed by witnesses. This fish has been referred to as the heaviest rod-caught fish of Scotland.

The next tributary, as we ascend the main river, is the Scaur. It has a course of about seventeen miles and a direction roughly parallel to the Cairn. The road from Moniaive to Thornhill crosses it near Penpont. The Scaur Water is one of the tributaries possessing most excellent spawning grounds, which can be but little used by salmon. A perpendicular dam of wood is erected on a natural projection of rocks. There is some modification of the rocks in order to facilitate the ascent of fish, but the pass, such as it is, does not, I believe, conform to the regulations and is but a poor one. About a mile further up two waterfalls occur. They are about fifty yards apart and the upper is about six feet high.

It would be wearisome to refer in detail to the dam dykes of other tributaries. The recognised method of forming these structures in this District is apparently by the erection of a perpendicular barrier of wood. With the exception of the Dumfries Caul, the comparatively low structures on the Cluden, and the Crawick wool mill dam now "passed," I think all the weirs are formidable, almost perpendicular affairs, heart-breaking spectacles to the man interested in the welfare of the salmon.

The water from Thornhill for some miles upwards past Drumlanrig Castle is generally regarded as the best part of the Nith. There is fine running water with good and not too deep pools well suited for fly fishing; again, there are steep rocky stretches where the water is rough. The banks are richly wooded in many parts, and the river presents at every bend a prospect so pleasing to the eye of the angler, that he cannot but regret it offers so little reward in the way of sport. The high wooded bluffs are once more the glory of Drumlanrig as one views this huge pile from the river. The hand 
of Time has, however, taken well-nigh a century to heal the scars made by "Old Q," who both here, and at Neidpath on the Tweed, made hideous havoc of the splendid timber. Burns was a frequent visitor to the Duke's Chamberlain, John M'Murdo, and gives speech to the genius of the stream in mourning the wreck, which, a little later, Wordsworth also saw and lamented:

"There was a time, it's nae lang syne,

Ye might hae seen me in my pride, When a' my banks sae bravely saw

Their woody pictures in my tide ;

When hanging beech and spreading elm

Shaded my stream sae clear and cool ;

And stately oaks their twisted arms

Threw broad and dark across the pool ;

"When glinting through the trees appear'd

The wee white cot aboon the mill,

And peacefu' rose its ingle reek,

That slowly curled up the hill ;

But now the cot is bare and cauld,

Its branchy shelter's lost and gane,

And scarce a stinted birk is left

To shiver in the blast its lane."

When mentioning Drumlanrig it is well to recollect that we owe much to Shaw, who was head keeper there 70 years ago, for his valuable experiments in the hatching of salmon eggs and rearing of their fry. It was Shaw who in 1840 first proved that parr are the young of the salmon. The results of his many and carefully guarded experiments were given to the world in the transactions of the Royal Society of Edinburgh. ${ }^{1}$

The Duke of Buccleuch owns something like twenty miles of the river, but in this only a limited stretch is reserved as private water. At Thornhill, and again at Sanquhar, Angling Associations exist which have extensive stretches of the river. In the upper reaches, however, it is chiefly brown trout fishing that is indulged in, and the trout are not in any way famous for their size.

One must go on hoping that a better day is yet to dawn for the Nith salmon angler. The natural conditions of a good second-class river are here. Surely the great value of salmon angling will not be thrown away for ever. 


\section{THE ANNAN.}

Angling Season: 25th February to 15th November. Netting Season: 25th February to 9th September.

District Fishery Board meets at Lockerbie. John F. Cormack, Esq., Solicitor, Lockerbie, is Clerk.

In dealing with the Annan, one comes to the Scottish salmon fishery border, for although, geographically, much of the Esk is in Scotland, it has been decreed that for purposes of salmon fishery supervision and regulation, the whole catchment basin of the Esk shall be regarded as English. Further, in dealing with the Annan we touch more nearly than elsewhere the Solway Question. I do not propose to go into this Solway Question; it affects England as well as Scotland, it is highly contentious, very complicated, and still sub judice.

The river Annan drains some 350 square miles of country, and may be said to have its source in the Devil's Beef Tub about $1 \frac{1}{4}$ miles from Tweed Well. A sharp rise, which attains the elevation of 1566 feet, separates the sources of Tweed and Annan. There is an old rhyme which runs:

\section{"Annan, Tweed, and Clyde, Rise a' out o' ae hill-side."}

As a matter of fact, however, the Clyde proper rises at a considerable distance, for the Daer Water is the head stream of Clyde and rises between the Earncraig Hill and Cairn Hill, nearly ten miles as the crow flies from the Devil's Beef Tub. As if to verify the rhyme, however, there is a side burn called Clyde's Burn which rises on the Hazelbush Hill, an eminence close to Tweed's Well.

The Annan is but a burn as it passes through Moffat, but 2 miles further on it is joined by two streams as big as itself, viz. Moffat Water and Eyan Water. The latter follows the line taken by both the main road south from Lanark and the main Caledonian Railway south. The junction of the 3 streams is practically abreast of Beattock. Thereafter the Annan flows south through the fishings of Poldean, Steurieshill, Wamphray, Hillside of Moffat, Jardine Hall, to the junction with the Water of Ae and Kinnel at Broomhill, within a mile and a half of Lochmaben. The river now commences to wind very much upon itself as it passes through a wide and rather flat agricultural district, and in this stretch of several miles 
justifies its Gaelic title of "quiet river." Halleaths, Dormont, Kirkwood, Castlemilk, Murraythwaite, fish one or other bank to the junction with the Water of Milk on the left. Below this the two best fishings of the District are situated, viz. Hoddam, and Mount Annan, after which the river flows through the old Royal Burgh of Annan, where the Burgh have fishings shared with Newbie, over a weir up to which the tide comes, and so, without any widening out, into a broad and muddy estuary, as is the case with all other Scottish Solway rivers, it enters the upper Solway at Annan Water Foot, about a mile west of the railway viaduct.

The public have most unusual facilities for fishing the Annan. In this respect the Annan and Tweed resemble each other. It is somewhat remarkable, therefore, that these are the two districts in which additional demands have been made for public fishing. Shall I be thought very forward if I recall the fable of the camel which pleaded to be allowed simply to have its head inside the tent, and whose master eventually found himself out in the cold? Complete freedom is allowed in the stretches near Moffat, where, however, the trout fisher is chiefly affected. Other waters may be fished by ticket.

$\left.\begin{array}{l}\text { Castlemilk } \\ \text { Dinwoodie } \\ \text { Wamphray } \\ \text { Girthhead }\end{array}\right\} \begin{aligned} & \text { The property of Sir Robert Buchanan-Jardine, Bart., who issues } \\ & \text { tickets at £2 for the season, through Mr. D. W. Campbell, } \\ & \text { Breckonhill, Lockerbie. }\end{aligned}$

Blacketlees-17s. 6d. for the season, through Mr. D. W. Campbell, Breckonhill, Lockerbie.

Newbie-7s. 6d. for the season, through Mr. J. T. M‘Glasson, Newbie Villa, Annan.

Kinmount-£1. 5s. per season by Mr. C. Brook, proprietor, through Mr. W. H Veitch, Hoddam Estate Office, Ecclefechan.

Hoddam-3s. a day up to 1st Sept., and 3s. 6d. a day after that date; issued at East Lodge, Hoddam.

The proceeds are given to charitable institutions. In most cases tickets may be secured for short periods if desired.

The tidal waters used to be severely fished by net and coble as well as by haaf net. The latter mode of fishing, as well as pokenetting, is still carried on, it being estimated in a return presented to Lord Elgin's Commission that 50 haaf nets and 34 poke nets are fished in the Solway not very far from the river mouth. Net and coble has been discontinued for several years.

From 60 to 160 tons of salmon may be despatched from Annan 
railway station in a season, ${ }^{1}$ so that a very great stock of fish would have to be present to allow of a good run, or a good proportion of every run getting to the upper waters. As a matter of fact, I believe the rods do not get what might very well be expected in a river like the Annan, although it not infrequently happens that towards the close of the season some very heavy fish are taken. In 1903 a 40-pounder was taken at Hoddam, and in 1905 a $36 \mathrm{lb}$. fish was caught. Salmon of about $30 \mathrm{lb}$. are not very uncornmon on the rod. The haaf net has repeatedly taken heavier fish. In 1901 a fish of $46 \frac{1}{2} \mathrm{lb}$. was taken by this means, which is the heaviest fish recorded from this district for some years.

This chance of getting an occasional heavy fish is no doubt some compensation to the angler who finds a blank day on the Annan all too common. It is a great pity, however, that more fish are not present in the river during the netting season. Some 50 or 60 fish may be caught in the lower waters in the autumn, and considerable sport with sea-trout is had in summer, more especially at night, but this is really a poor result for a river such as this. The best angling months may be said to be July, September, and October, but a few of those hundred tons of salmon just referred to would be acceptable in the river.

It has been somewhat emphatically stated before now that the Annan never holds spring fish; that it is essentially a late river, and that the fish locally spoken of as spring fish are in reality silvery kelts. I grant it is often very difficult to tell the difference between a well-minded silvery kelt and a spring fish, but a river the size of the Annan, if unobstructed by swift water or weirs or by serious pollutions, and if properly stocked with salmon, should certainly hold spring fish. In the Annan and Nith districts, the whole Solway question would need to be dragged out if the reasons for a reduced stock of fish were fully gone into. Suffice it to say that the stock is not what it might be. In The New Statistical Account, ${ }^{2}$ under the account of Annan Parish, which was written in December, 1837, I find an interesting foot-note which runs as follows: "A species of the salmon, here named the spring salmon, weighing from five to eight pounds, and in which there is found neither milt or roe, enters the river in the beginning of January, and there remains only a short time. It is remarkably rich, and is sold at from 2s. to 3s. per lb." Now a kelt, no matter how fine in

${ }^{1}$ Minutes of Evidence, Royal Commission on Salmon Fisheries, 1902, p. 426. 
appearance, cannot possibly be described as remarkably rich, and could not possibly be sold for anything like 2s. per lb. Further, reports from the Annan District Board, published annually in Part ii. of the Reports of the Fishery Board for Scotland, repeatedly refer to clean spring fish taken on or about the opening day of the season (25th February). One cannot, therefore, be very readily convinced that spring fish are not to be found in the Annan, although their numbers may be small.

Several weirs exist on the river, but thanks to the supervision of the District Board, fish-passes are provided and the obstructions rendered as harmless as can readily be done. I have already referred to the weir at Annan. The rise of the tide renders it easily passable. The next weir is Brydekirk Cauld, about three miles up-stream. Here a subsidiary dyke has been built, so that a pool about half the breadth of the river is formed half-way up the the original dyke, and from this pool a simple gap and pass is cut through the sill of the weir. It is a good form of pass for a low obstruction of this kind.

A dam dyke at Murraythwaite, about seven miles above Annan, is not a serious obstruction when the river is in running order. A pass is also present. At Dormont there is a more difficult obstacle, a natural reef of rocks having been built upon to form a dyke. A fish-pass has been constructed, but the barrier is naturally greater than the other, and has also a further effect in damming up water for a very considerable distance up-stream, so that during floods the river here not infrequently overflows its banks.

Two of the tributaries are also obstructed by weirs, viz. the Mein and the Milk. On the latter there are two dykes, the upper of which is rather a horrible affair, and the worst structure of its kind in the Annan district. 


\section{APPENDIX A.}

\section{LEGAL ASPECTS. THE RIGHT OF SALMON FISHING AND THE SCOTTISH SALMON ACTS.}

A GOOD deal of ambiguity exists in the minds of many with regard to the nature of the right of Salmon Fishing in Scotland. This ambiguity seems partially caused by the fundamental difference which exists between the right in Scotland and England, but also to some extent owing to a belief that there is, or should be, if one could only understand it properly, a public right to fish for salmon in certain places and under legal conditions.

To get a proper understanding of this matter it is first necessary to grasp the true relations of the Crown to salmon fisheries, and one cannot do better, in this connection, than quote the clear general statement given in the Report of the Commissioners appointed by the Secretary for Scotland to inquire into the Crown Rights in Salmon Fisheries in Scotland. The Commissioners were Sir Herbert Maxwell, Bart., T. G. Murray, now Lord President of the Court of Session, and Donald Crawford, now legal member of the Fishery Board for Scotland. The report was made in 1890.

"In England and Ireland the Crown is vested as trustee for behoof of the whole community in all the Salmon Fishings in rivers and estuaries which are both navigable and tidal, and in the territorial seas, except such fishings as belong to private persons and corporations, and are held under an express grant from the Crown, or by ancient usage presupposing a grant, or by prescription, and also excepting such others as form part of the ancient patrimony of the Crown. The public have a common-law right to fish for salmon in such waters, subject to statutory regulations and limitations, save where several or private fisheries exist. The extent seaward of these rights is assumed to be 3 miles from low water.

In inland waters which are neither tidal nor navigable the Crown 
appears to have no rights, the riparian proprietors being prima facie owners of the fishings opposite or within their lands.

But in Scotland a very different state of matters prevails. The Crown is held to be vested in all Mussel, Oyster, and Salmon Fishings in the sea, estuaries and inland waters as a patrimonial or beneficial right, forming part of its heriditary revenues, but subject to such rights as have been conferred upon private persons and corporations by grant from the Crown."

This right of salmon fishing in Scotland is classed amongst Crown property as regalia minora, and is theoretically regarded as the absolute property of the Sovereign to do with as he likes, the regalia majora on the other hand refer to rights vested in the Crown as custodier for the nation. In practice, one important difference is that the former may be made the subject of grants to subjects while the latter are not capable of alienation. Strictly speaking there is no ownership of salmon, but the right is one of fishing for salmon, the ownership of the fish being incidental, if one may so say, to the legal right of fishing for this particular class of fish.

This right is, in Scotland, a heritable estate like property in land, and it is treated as property in land is treated. It may be conveyed away quite separately from surrounding land, or may be held independently from any possession of land. The fishing may be in the sea or in the fresh water, and in either case the proprietor of the right must have facilities for exercising the same.

This condition often strikes people as anomalous, but it arises, in Scotland, from the original patrimonial rights of the Crown, and for the same reason it follows that all salmon fisheries not alienated to a subject by the Crown, or to which no one can lay legal claim, belong still to the Crown; and also that if by the opening up of some waterfall or obstruction to the ascent of salmon, new fisheries are created, these must necessarily be, at the outset, in the possession of the Crown.

In Scotland, a great stretch of seacoast is still Crown property in so far as salmon fisheries are concerned. but only a very limited amount of fresh water is now so held. The Crown fisheries are under the management of the Office of Woods, etc., London, and the coast fisheries are regularly leased to tenants. The general superintendence of the fisheries, no matter by whom owned, is exercised by the Fishery Board for Scotland, through the instrumentality of the Inspector of Salmon Fisheries.

In the early part of last century it was contended that the Crown's 
exclusive right to salmon fisheries did not include the right of salmon angling, the argument for this view being that salmon angling was not inter regalia, but was a pertinent of the land, like the right of trout fishing, so that any owner of a river bank could fish with rod and line from his own land, and any number of the public could fish in the same way in any public river. Many men believed they could legally angle for salmon within the limits of tide reach at the mouths of rivers. The question was one of great importance and was considered by a full bench of the Justiciary Court. ${ }^{1}$ The decision arrived at was that the Crown's exclusive right to salmon fishing extended to every lawful means of catching salmon.

A quite recent case in which the application of the Crown's right was further tested had reference to fishings in Orkney, and in this case $^{2}$ the Lord Ordinary (Johnston) decided that salmon fishings were not inter regalia in Orkney; that the established doctrine as to the Crown's rights is a part of the feudal law of Scotland, while in Orkney the Crown's rights had arisen through the ancient udal tenure of Norway and passed into the hands of the Crown or to udallers in Orkney without recourse to "feudal fiction." In 1468, King James III. of Scotland married Margaret, daughter of King Charles I. of Norway and received with her a dowry of 60,000 florins, and in security of 50,000 thereof, not paid down, received in pledge, the Orkney Islands. "This hypothecation" adds Lord Johnston, never redeemed, is the source of the Crown rights in Orkney." The Law Officers of the Crown accepted the decision of the Lord Ordinary so that the udallers of Orkney and Shetland are, I suppose for all time, established in their independent position as regards their salmon or rather sea-trout fishings within the bounds of their udal holdings.

What, legally, it may be asked, is a salmon? For answer we may, without reference to common law, quote the definition as given in the most recent statute dealing with the matter." "Salmon shall mean and include salmon, grilse, sea-trout, bull-trout, smolts, parr, and other migratory fish of the salmon kind." In practice this definition has been found not absolutely perfect. Large fish may be poached, cut up, and distributed. If a man is caught with a part of a salmon there is an element of difficulty in declaring he is in possession of a salmon. Great numbers of fish caught in the open season are now

${ }^{1}$ 1867. Anderson $v$. Anderson, 5 Irvine 499, 6 M. 117.

${ }^{2}$ The Lord Advocate $v$. Col. J. W. Balfour, 8th April, 1907.

${ }^{3}$ Salmon Fisheries (Scot.) Act 1862 [25 and 26 Vict. c. 97] Sec. II. 
put into cold stores and sold in the close season. The Fishmongers' Company of London have greatly assisted in preventing the sale of illegally caught fish, which unscrupulous persons might try to pass off as fish from cold stores, by instituting a system of attaching lead seals to fish in stores, so that even if a fish is cut into several pieces each piece will bear the seal of the Fishmongers' Company. The definition also takes no account of the sparling or smelt, a fish of the salmon kind which migrates from the sea to our estuaries at certain seasons. It might well be specially exempt from the definition.

Since in Scotland the right of salmon fishing by whatever method is inter reyalia, the Title to salmon fishing must in every case originate as a Grant from the Crown.

"An express grant of salmon fishings in certain specified waters at once vests the grantee in the right without any need of prescription to complete the right, or any fear of losing the right a non utendo, it being res merae facultatis. But though an express grant does not require possession to complete it, possession is frequently required to explain and define it, as the terms of the grant are often vague, and the change of local names sometimes makes vague a title which was originally clear and precise." 1

"Where there is no express grant of salmon fishings, the right may yet be acquired by possession (i.e. user and enjoyment) for the prescriptive period of forty years, now reduced to twenty years by the Conveyancing (Scotland) Act, 1874 (37 and 38 Vict. C. 94, S. 34), or for time immemorial, proceeding on a habile title. There are two kinds of title habile to found prescription: viz. A Crown grant of the lands with fishings not specified as salmon fishings, and a barony title whether or not such title expressly states cum piscationibus."

"This method of prescribing a title to salmon fishing is also a grant from the Crown, as the prescriptive possession merely interprets the original grant from the Crown on which it proceeds."

An important case in defining the validity of title to salmon fishings was that of The Lord Advocate $v$. Sinclair in $1865 .^{2}$ Lord Deas there laid down the following statement of law respecting the conveyance of a title: "A salmon fishing being inter regalia and seperatum tenementum requires to be conveyed by the dispositive clause of the deed. The proper object of the dispositive clause is to specify and describe the subjects conveyed. The mention of salmon

${ }^{1}$ Tait. The Law of Scotland as applied to the Game Laws, Trout and Salmon Fishing. Edinburgh, William Green \& Sons, 1901.

23 M. 981, per Lord Deas at p. 998. 
fishings in the tenendas or in any other clause of the charter will not operate as a conveyance of salmon fishings. Nor will the word 'fishings' operate as a title for prescription, unless it be in the dispositive clause. The object of each of the other clauses is well understood and is quite different from that of describing the subjects conveyed. One consequence of this has been that the Barons of Exchequer, whose duty it was to revise the signatures of Crown charters when these titles were expede, were not in the practice of revising the clause of tenendas at all. It is quite understood that a specification in the tenendas adds nothing to the dispositive clause."

This case went to the House of Lords, and commenting upon the passage just quoted from Lord Deas, the late Mr. Tait adds: "The House of Lords went hardly so far as this, holding that while the dispositive clause was the only clause in which an effective conveyance of the right of salmon fishing could be made, still an ambiguous word in that clause (e.g. "pertinents") might be construed by a direct reference to fishing in the tenendas." 1 To follow the question of title into nicer points of detail seems to me unnecessary. One or two points of application are, however, of interest to the salmon angler, and these I will endeavour to touch upon.

A Crown fishing on the coast is very frequently ex adverso the estate of a proprietor who has no interest in the salmon fishing. The Crown tenant must, however, have access to his fishery. In the same way, if a river flows through the estate of a proprietor who has no right of salmon fishing, the owner of the right has liberty to be upon the river banks to exercise the right. In net fishing in a river it has in the same way to be decided that if the owner of the right has no property on either bank, he or his tenant may haul his net on either bank.

A proprietor of fishings on one bank may not erect any obstruction, such even as a croy or fishing pier, without the consent of his opposite neighbour. If, however, a proprietor owns both banks he is under no such necessity, but if an obstruction, such for instance as a weir, be erected, it is possible for another proprietor of fishings in the river to raise valid objection provided he can prove damage to his fishings, or show an alteration in the natural flow or conditions of the river so as to induce damage. ${ }^{2}$

Now with regard to Statute Law, it is very interesting to notice

${ }^{1}$ Lord Advocate $v$. Sinclair, 1867, 5 M. (H.L.) 91. Lord Advocate $v$. M'Culloch, 1874, 2 R. 27.

${ }^{2}$ Orr Ewing \& Co. v. Colquhoun's Trustees. 4 R. (H.L.) p. 126. 
that in Scotland from very early times certain well-defined provisions have existed, and that the existing Salmon Acts have, while adding much of value, continued the root principles of the early Scottish Acts. In the twelfth century a weekly close time was in force, and in an Act of 1424 reference is made to the annual close time as we now name it. At this date it was from the Feast of the Assumption of Our Ladie till the Feast of St. Andrew (15th Aug. to 30 th Nov., new style).

In the time of David the First (1124-53) and of William the Lion (1164-1214) it was enacted that in dam dykes there should be a gap or "mid-stream" big enough to allow a three-year-old swine, well fed, to stand in it, "so that neither the grouzie nor the tail may wyn till any side." By the early statutes also there is provision that fixed engines-which may properly be interpreted as cruives-be done away with in the tidal parts of rivers. This stands good to the present day. Unfortunately, the necessity of having a gap or mid-stream in dam dykes and cruive dykes has lapsed or fallen into desuetude, the cruive dyke at Inverawe being the only structure of its kind which does not form a complete barrier across the river. Cruives in fresh waters, although they are held under special charter, have very largely been given up, since this method of fishing is quite inconsistent with the proper ascent and distribution of fish, and materially interferes with the value of neighbouring fisheries. The cruives still fished are on the Conon, the Don, the Earn, the Awe, and the Solway Dee (the Doachs of Tongueland). The fishing of fixed nets on the open coast had in those early days not been thought of. In connection with the removal of fixed engines where the tide ebbs and flows, it became necessary, however, to determine the limits of estuaries. To a limited extent this was done by the Court, but ultimately was completed by the administrative commission under the 1862 Act and the boundaries of the estuaries in Scotland being scheduled in the 1868 Salmon Act.

Those three main provisions of the early statutes were thoroughly sound. By clearing the estuaries of fixed engines fish were enabled to enter fresh waters; by securing a gap in fixed engines in fresh waters fish were further enabled to distribute themselves over the higher reaches, this being also assisted by the operation of the weekly close time-which secured at the same time the proper observance of the Sunday-while the wisdom of protecting fish from all fishing during the breeding season is exemplified by the creation of the annual close time. 
While referring to the subject of fixed engines, I may mention the most recent cases concerning which alterations in previous conditions have been brought about. In 1900 the House of Lords, after a lengthy proof, decided that toot and haul nets and drift or hang nets were fixed engines and must therefore be removed from estuaries. The cases came up from the Tay (Wedderburn $v$. Duke of Atholl, and Duke of Atholl $v$. The Glover Incorporation of Perth, 37 S.L.R. 696). The question of drift net fishing was closely debated since, unlike the toot nets, these were not anchored in any way, but being extended across the tide-way were allowed to drift with the current. It was held, however, that the drift net acted as a barrier to the ascent of fish and was in essence a fixed engine since it was not moved through the water by the fisherman, so as to take a temporary grasp of a particular stretch of water. The result of this decision is that so far as rivers and estuaries are concerned net and coble fishing, i.e. working the sweep or draught net, is now the only legal method of netting in Scotland. An apparent exception exists in one or two rivers entering the Solway, but this apparently is so because the clauses in the Scottish Acts dealing with fixed engines do not apply to rivers entering the Solway, the corresponding clauses of the English Salmon Fishery Act of 1861 being substituted.

With regard to the observance of the weekly close time at seacoast fisheries, a great deal of difficulty has arisen, since the modern development of bag net fishing has come about. Many of the fishing stations are at very inaccessible places on the lonely parts of the Scottish coast, where supervision from the land cannot at all easily be carried out and where patrolling by boat along the coast is too heavy a task for the officers of a District Board. In very many Highland districts, also, no Boards exist and no supervision is attempted. In the past it has not infrequently happened therefore that the "slapping" of nets at six o'clock on Saturday evening has been regarded as altogether unnecessary, as a waste of labour, and a throwing away of profits. In other districts, where supervision was possible, tacksmen very frequently found the sea so rough at six o'clock on Saturday that taking out leaders of bag nets could not be attempted without serious danger. In such localities it is clear the storms come with most surprising regularity. No doubt it is the case that a great amount of destruction is often done to the fishermen's gear by storms, and bag nets are costly engines. This often produces most unfortunate loss of time and money. The custom has been, however, to leave the nets standing if the leaders could not 
be removed at the commencement of the weekly close time, and above all things to avoid breaking the Sabbath by attempting to fulfil the requirements of the law during that day.

The Conon District Board combated the interpretation of this last point, and proceeded against a tacksman, or tackswoman rather, who did not attempt the removal of leaders on Sunday at her fishing station north of the Cromarty Firth. The Sheriff had declined to convict, and as a somewhat similar case ${ }^{1}$ had previously been tried, which the Conon District Board desired to test afresh, the matter was referred to a full bench of judges in the Justiciary Court. $^{2}$ The decision was unanimous that when it was found impossible to slap the nets on Saturday evening, the operation had to be performed on Sunday if the weather then permitted. The grounds for this finding were that Parliament in passing the Salmon Acts made the observance of the weekly close time a necessity; that the plea respecting the reluctance of Scotsmen to perform ordinary duties of this kind on Sunday could not be entertained in view of the special requirements of the case; and that, so far as Sunday observance went, the real breach of observance consisted in the Sunday fishing consequent upon the non-observance of the law. This decision should make a considerable difference to the erstwhile practice in Scotland. I have had occasion to ascertain, from time to time, how far the weekly close time has been observed. On one occasion, on a beautiful quiet Sunday, I found 94 consecutive bag nets fishing. This does not now occur, however, in the district referred to.

I now propose to give a brief review of the main provisions of the existing Salmon Fishery Acts, and subsequently to mention some of the leading suggestions which have been made for future legislation.

The two Acts with which we have mainly to do are the Acts of 1862 and of 1868. The first brought into being a small body of Commissioners whose duties were to fix the limits of fishery districts in Scotland; to fix a point on each river which shall divide upper from lower proprietors; to determine the dates of the annual close time for each district; and to make general regulations as to the observance of the weekly close time, the construction and use of cruives, the construction and alteration of mill-dams or lades or water-wheels, the meshes of nets, and respecting obstructions in rivers or estuaries.

${ }^{1}$ Middleton $v$. Paterson.

${ }^{2}$ Middleton $v$. Tough. 
Fishery districts having been arranged, provision was made for the creation of District Fishery Boards to regulate local matters. These Boards are composed entirely of proprietors, who hold rights of salmon fishing, the maximum number on a Board is seven, and the proprietor who is possessed of the largest rental acts as chairman. Members are elected at meetings of upper and of lower qualified proprietors, so that each group is equally represented independently of the chairman. When proprietors are fewer in number than seven provision is made for an evenly-balanced Board accordingly. The Boards have statutory powers to prosecute against local offences under the Act, and "any other person" is also given this power; to seize nets, rods, etc., by means of their water-bailiffs; and to recover penalties incurred.

By the Act of 1868 the powers and duties of District Boards were defined and extended. By Section IX. they are given power to petition the Secretary for Scotland:

1. To vary the annual close time, which must, however, always be 168 days.

2. To vary the weekly close time, which must, however, always be 36 hours.

3. To alter the regulations with respect to the observance of annual and weekly close times.

4. To alter the regulation with respect to the construction and use of cruives or weirs.

Power is also given to purchase, for purpose of removal, dam dykes, cruives, or other fixed engines; to remove any natural obstruction or water-fall, by agreement, and to attach a fish-pass thereto; and generally to do such acts or execute such works as may appear expedient for the protection and improvement of the fisheries under their charge.

Funds for the execution of such works and for all expenses of District Boards are raised in Scotland by means of an assessment upon the yearly value of the fisheries entered in the Valuation Roll, and this system of assessment is found to answer very well, and to be, as is thought in Scotland, superior to the system of raising money by means of licences as in England, where the granting of over many licences is apt to be prejudicial to the best interests of a district, and where also when, owing to any decline in the fisheries, the licences are not taken out in any number, an absence of funds results. Further, for enabling Boards to meet such 
expenses of a special kind as may not be conveniently covered by the assessment, power is given to borrow money to the extent of two years' assessments.

Penalties for offences are considerably fuller in the 1868 than in the 1862 Act, and cover offences against the close time, in respect of using lights or roe in the capture of salmon, destroying the young of salmon, taking kelts or unclean fish, etc. Being statutory bodies, District Boards have, however, no power to sue an action at common law. ${ }^{1}$

Scheduled at the end of 1868 are seven bye-laws:

A gives the limits of districts and the division between upper and lower proprietors.

$\mathrm{B}$ gives the limits of estuaries.

C gives the annual close times for net-fishing and for rodfishing. These have in several instances been varied by order of the Secretary for Scotland after petition from District Boards. An official list is published each year as an appendix to Part ii. of the Annual Report of the Fishery Board for Scotland.

$D$ gives the general regulations with respect to the due observance of the weekly close time, i.e. the manner in which fixed nets are to be put out of fishing order.

$\mathrm{E}$ gives the regulations as to proper mesh of salmon nets, viz. one and three-quarter inches from knot to knot, measured on each side of the square, or seven inches round each mesh when wet; and against the using of nets in an improper manner.

F gives the regulations with respect to the construction and use of cruives.

$\mathrm{G}$ gives regulations as to dams, sluices, mill-lades, bye-washes, hecks or gratings at mill-lades, and finally fish-passes.

The two first are practically incapable of further operation, having been completed by the original Administrative Commissioners.

A point of importance to notice in connection with any action respecting the enforcing of any of these bye-laws is that action must be at the instance of a clerk to a District Board, and such clerk alone. The Acts of 1862 and 1868 are taken together as one Act, and Section 29 of the former reads: "In the event of any person refusing or neglecting to obey any bye-law made by the Commissioners, or any regulation made by the District Board, the clerk

${ }^{1}$ Tay District Fishery Board v. Robertson, 1887, 15 R. 40. 
may apply to the Sheriff by summary petition in ordinary form, praying to have such person ordained to obey the same, and the Sheriff shall take such proceedings and make such orders thereupon as he shall think just."'

The suggestions which have within recent years been made for the improvement of the existing general Acts have for the most part been based on the recommendations of Lord Elgin's Commission. This Commission made a most exhaustive inquiry into the needs of the country in all matters pertaining to salmon fisheries, and since 1902 legislation based on those recommendations has been waited for. It may not be out of place to mention here the most prominent of the suggestions.

It not infrequently happens in the operations of District Fishery Boards that the carrying out of certain requirements of the Acts is beset with difficulties which a Board hesitates to overcome forcibly. To meet this condition it is proposed that the Fishery Board for Scotland, or a duly selected committee of that Board, should, as a neutral authority, have power to see that the statutory requirements are carried out. In order also that the Central Authority may be provided with fuller information than can at present be obtained, it is proposed that power be given for the compulsory collection of statistics respecting the takes of salmon in every district, such statistics to be regarded as confidential.

In the matter of annual close time it was proposed that the period of 168 days be made uniform in all districts in Great Britain, the argument being that there is no very sufficient evidence to show that the natural reproductive period of the salmon varies very materially in different districts, although many districts have been artificially modified in this respect. The dates suggested are: For nets, August 27 to February 10; for rods, November 1 to February 1. At first this might threaten serious dislocation of local fisheries, and by special bye-laws provision might have to be made for special cases, so that they should only slowly be required to come into line. The benefit in the prevention of poaching would be very great, more especially since the recommendation is also made that no salmon should be sold between September 3 and February 10 inclusive.

The suggestion for weekly close time is that it be for 48 hours instead of 36 as at present, and that it should extend from noon on Saturday till noon on Monday. This, during the early months of the year, gives net fishers on the coast daylight in which to slap

${ }^{\mathrm{I}}$ See Blair $v$. Lumsden and Sandeman, 1869, 7 M. 1126. 
their nets, and at the same time gives water bailiffs daylight to see that the operation is properly carried out.

A very important recommendation also is that a point should be fixed in every river above which netting should cease. This point might conveniently be fixed by authority of the Secretary for Scotland, after petition from a District Fishery Board, and it is suggested that the Central Authority may similarly petition in cases where no District Boards exist. The object of fixing such a point is to secure the just operation of the weekly close time, and of the proposal to remove undue netting, so as to secure that a proportion of every run of fish entering a river may pass through the netted area and contribute to the stock of the river. It is manifestly useless to take off nets at a river mouth, for instance, if netting is carried on in the upper reaches. Removal of nets should in all cases be from above downwards. Such removals should be met by compensation on the part of the District Board, and failing agreement on this matter, by the authority of the Fishery Board for Scotland after inquiry, and the confirmation of the Secretary for Scotland.

These may be said to be the leading suggestions and to embody the features specially set forth by the Elgin Commission. Many minor matters are, of course, also dealt with, such as modifications of bye-laws, erection of salmon passes, and the powers of local boards and proprietors to deal with local methods of fishing, etc., but the points touched upon are preeminently those which would bring about a systematic regulation of Scotland's salmon fisheries in a manner not previously attempted. The alteration from the existing conditions would certainly be very considerable, but it has to be remembered that in the forty years which have elapsed since the passing of the 1868 Act the fisheries themselves have greatly altered, that no Commission has ever dealt so thoroughly with the whole subject as Lord Elgin's Commission, and that we have embodied here the results of most enlightened and matured consideration. In so far as the policy of reducing nets in narrow waters goes, we have already a very considerable amount of experience in Scotland. Within recent years river-netting has been so reduced that it can now be said of comparatively few Scottish rivers that they are over-netted. The netting is referred to in the descriptive accounts of the several rivers. 


\section{APPENDIX B.}

\section{CROYS ON SALMON RIVERS. ${ }^{1}$}

Is all salmon rivers there are some pools which seem to be favourite restingplaces for fish, at certain seasons of the year and in suitable states of water; while there are other parts in which fish are seldom seen or caught, as they apparently run through without a pause. The salmon somewhat resembles the tourist in this respect; both like comfortable quarters when they can get them, and when these are found, both are ready to prolong their stay, if there is no reason to hurry onwards to another place. We may leave the tourist to look after himself, and the ways of attracting him to other people ; our object being to show how more accommodation can be provided for salmon, with a view to their occupying it long enough to give the angler the chance of catching them.

Fishermen of a past generation evidently believed in training the course of the river, as is indicated by the remains of croys in many localities. Their labours would seem to have been chiefly directed to contriving places in which fish would congregate and be easily taken out with a net. We can benefit by their experience to the extent of attracting salmon to various parts of the river, though our means of capture is to be the rod. Some of the ancient croys have been maintained in good order, others have suffered from neglect and been washed away by floods. In the days when it was customary to float timber down the rivers, it was impossible to keep them in repair without annual outlay, a thing obnoxious to some people, especially at a time when salmon were less valuable than at present. The result has been that stretches of water which once produced fish are now barren wastes of shingle, with all the rocky bottom overlaid with several feet of light gravel, on which no respectable spring salmon cares to remain for any time.

Some may enquire what a croy is? It is a stone jetty or structure thrown out into the river, and the name is derived from the Gaelic for "hard," which latter word is applied locally in the South of England to signify a pier or landing stage.

The object of a croy is to divert or alter the character of the flow of water. A sharp current may be required in pools to prevent silting up, or it may be necessary to modify the force of the stream to save the banks, or to afford shelter

II have to thank Messrs. Vinton \& Co., Ltd., for permission to reproduce this article by Mr. H. W. Johnston. It appeared in Bailey's Magazine, May 1908. 
to fish in high water. It is curious to note the varied ways in which anglers make use of croys. One well-known actor, in trying to reach rising trout, stood on the top of the erection, quite ignoring the fact that every fish within range saw him distinctly and fled; while another fisherman with more experience and not so much accustomed to appear before an admiring audience, utilised the shelter to conceal himself. Croys may be convenient for casting from, but this is only a subsidiary reason for erecting them.

If the proprietor of a Scotch salmon fishery owns both banks of the stream, he is in a position to make what erections he likes, provided these do not cause damage to the lands of his neighbours either above or below, and do not impede the free ascent of salmon. In cases where only one side is possessed, he must do nothing to interfere with the natural course of the river without the opposite proprietor's consent. In the latter case it is more satisfactory to have a mutual arrangement, so that work may proceed on both sides, as this generally proves much better than improving one bank only. It does not appear necessary to ask consent to repair an old croy, even if this means almost rebuilding, but there must be some evidence, in the shape of foundations or otherwise, to show that it previously existed, and the former dimensions must be adhered to as nearly as possible.

Any difficulty as to legal rights having been overcome, it now remains to decide where operations are to be commenced, and what the purpose in view is. Great caution must be observed in doing anything to a part of the river that is already good, in case the change may be detrimental instead of beneficial, and work done here should be of a tentative nature, unless it is very clear what the effect will be. Equal care is necessary in changing the course of the stream immediately above a favourite pool, lest gravel be carried down and accumulate in the latter. Until experience is gained it is better to make a beginning with a stretch that is of little use, but which seems capable of improvement, and plans must be made to suit the size of water in which it is likely to fish best. If you can get a pool to fish well in both low and high water, it shows the system has been good, but results nuust not be expected too soon, as it often takes a long time before they are evident.

It is impossible to indicate with any exactness what should be done to improve a stretch of river that has not been thoroughly examined in all states of the water, and for this reason no general rules can be laid down. A water-gauge is a great aid to observations, and one can usefully note the level of the river when each fish is killed. Plans of procedure much depend on whether you are dealing with a large river with a fairly regular flow, or with a smaller one which rises and falls quickly, and after rain resembles a mountain torrent. In it, croys must be of slight elevation and properly sloped, otherwise they will not withstand the force of the water. Also you have to consider the class of salmon you wish to encourage, and the season of the year when they arrive in your water. The salmon requires a certain amount of oxygen to be present in the water he lives in. Too much does not suit his taste, and makes him dull and sluggish, and too little will not sustain his life. The oxygen which he can abstract from the water varies in amount inversely with its temperature, being much greater at $35^{\circ}$ than at $60^{\circ} \mathrm{F}$. This, along with the fact that the heat (and volume) of a 
salmon's blood is regulated by the water, always being $1^{\circ}$ to $3^{\circ}$ above its temperature, accounts partly for their habits differing at certain seasons. In cold weather the salmon prefers deep, slow-running pools, and only moves into the more rapid parts where oxygen is in larger quantity as the water gets warmer. As the heat increases and the oxygen decreases, he likes to lie near a fall where more of it is available.

All these questions have to be considered, but they do not present so many difficulties as they appear to do, and to show that they may be overcome, we may instance the effect of croying a stretch of a river which has yielded good results. By mutual arrangement between the opposite proprietors, who each fish the water three days a week, some $£ 54$ has been spent in repairing ancient erections that had become dilapidated, and in putting up new structures in places where it was thought they might do good. Excluding a few grilse and autumn fish, the catch of one proprietor has averaged 35 salmon over the six years since the greater part of the work was done, against about 15 fish for the four years preceding the improvements. The records for the other side are not available, as it forms part of a larger section, and the captures have not been kept separately; but if we halve the total cost, we find that an expenditure of $£ 27$ has been followed by an annual average increase of 20 fish on the side referred to. This must be looked upon as well-invested money, even if it be conceded that during the latter years there have been more salmon in the river, and that it has been fished with greater perseverance. Interest on expenditure, depreciation, and cost of ordinary repairs, would be amply covered by $£ 5$ or $£ 6$ a year, which is about the food value of three spring salmon, so whether the croys can be credited with the whole of the increased catch or not, there remains a considerable balance in their favour. Fishing is useless unless there are fish to try for, and if they are in the river, and passing through your part of it, it is worth while doing what you can to induce them to wait long enough to inspect your flies, or, it may be, something which they find more attractive.

We may now briefly describe the portion of the river on which most of the above-mentioned $£ 54$ was spent, and try to convey some idea of what was done, with the aid of a plan. The water naturally divides itself into two pools, the uppermost one (A) being some 300 yards long, and in places 80 yards broad, with a good rocky bottom and deepish water towards the left bank, shelving off to gravel on the other side where the current is weaker. In ordinary states the run of the water was slow and smooth, and it was advisable to break it up a little, so that there might be ripples formed on its surface and diverging currents underneath. This is accomplished by four croys at irregular intervals on the left bank, and by three others on the right bank, which serve to guide the stream back towards the middle of the river, and also during spates to ensure a certain amount of slack water for some distance below. Of these seven croys, four were repaired and three are new. The pool fishes well in high to medium water from January till April, but after the temperature rises it is rather sluggish for the requirements of salmon. As is often the case, one of the croys seems to be more effectual than the others, judging by the number of fish caught within the area it influences. The lowest croy on the left bank helps to check the pressure of the stream on the ancient and much longer croy immediately 
below, which runs across the shallow at the head of the next pool, and forms the key to the system adopted in it.

The lower pool (в) is called the Croy Pool, and the name is justified by the number of these erections. It is about 200 yards long, with a breadth of 70 yards at the top, narrowing down slightly at the tail, from which the river flows in a rapid and broken course for several hundred yards. In fact, for another mile down-stream there is not much slow-running water, and the earlier spring fish pass through this stretch without delay, and are ready to rest when they reach the comfortable Croy Pool, for it has an average depth of 10 feet even in low water, a nice rocky bottom, and currents varying in strength at different points. Even the quick-travelling grilse and summer fish find the conditions to their liking, as the stream at the top of the pool runs fairly strong, and is well aerated.

The croy to which we have referred as at the head of this pool extends in a slightly down-stream curve more than half-way across the river. Commencing on the left bank with an elevation of 2 feet, it slopes down to some 6 inches at the extremity; thus it only diverts a portion of the water that strikes it at the different levels of the river, and presents no great resistance to floods, which pass over it without doing damage. In both high and low water the main strean flows round the curved end of the croy, and is thrown towards the right bank, on which four short but higher croys, a few yards apart, slightly check its rapidity and turn it towards the centre again, so that the area of the eddy which forms behind the long croy may be reduced in size. In the middle portion of the pool the stream runs evenly without artificial guidance between even, welldefined banks, but towards the tail where it is inclined to favour one side it is turned outwards by three croys, and compressed by a short one on the opposite bank, which creates a little eddy. This affords a rest to fish that have forced their way up the rapid rush below, and is useful to the angler when fighting with a tired salmon which shows an inclination to leave the pool, for if he can work his fish into its calm water, he may perhaps get it within reach of the gaff or guide it higher up again, and save himself a long run down a quick stream, with, perhaps, a disastrous ending. This pool is best in low water, but will fish fairly in most states, say over a range of more than 5 feet.

Now we come to the method of building croys and the approximate cost. A dry month during summer is the most advantageous time for the work, as a low river and warm water make it easier for the men to handle wet stones, and the foundations may generally be laid down without much wading, though even then some low erections may be profitably kept below water-level. An intelligent labourer will often work and supervise the other men better than a skilled mason, as the latter is apt to aim at greater nicety of construction, which is unnecessary and means time and expense. Three or four men make a convenient squad, and two of them will have plenty of occupation in carrying stones to where the builders are working, and when large rocks are to be moved, all hands may be needed. The only tools required are stone-hammers and crowbars, with a hand-barrow (or wheelbarrow) for transporting material, and the usual line and foot-rule.

The first essential is a good foundation on which the croy shall rest. This 
simply means a rough preparation of the river-bed on all sides of the proposed erection and extending slightly beyond its base. On the centre of the foundation a dry-stone wall from $3 \frac{1}{2}$ to 2 feet wide should be built in fairly regular layers, one or two of which should consist of binding-stones. The wall should be let well into the bank at its starting point, and terminate a few feet short of the extremity of the foundations, leaving space for the addition of the protective apron at the proper slope. Larger stones with a flattish surface will do for "coping," and afford good foothold to the angler. The elevation at each end will depend on the effect the croy is intended to exercise; but as a rule the top of the wall should be highest where it leaves the bank and incline downwards towards the water, and generally the slope of the river-bed contributes to this result. It must be protected on all sides by an apron of stones to give it solidity, and to guide the water over it, or along it, with the least amount of resistance, The slope of the apron must be not less than 1 in 2, and may often with advantage be 1 in 5, especially in low croys that have to withstand a heavy rush of water. The stones forming the surface of the slope need not be of large size, but must be "causewayed" or " cobbled" and well wedged together, beginning at the foundations and working upwards to the top of the copestones, and smaller material can be thrown over them to fill up the interstices. Particular care must be taken to round off the end of the croy, that the water may not find too much to lay hold of.

The cost of stone croys depends principally on the distance the stone has to be carried, but if there is a good supply along the river bank within 50 or 100 yards, the expense should be small; perhaps about 1s. a running foot for a croy about 2 feet high, so that if it extended for 30 feet the cost will be only 30 s.

Where stones are scarce, a very effective croy can be constructed of several layers of old railway sleepers laid on edge, and end to end. A sleeper measures about 9 feet by 10 inches, and costs, say, $1_{s .}$, so that a croy 27 feet long and $2 \frac{1}{2}$ feet high requires three rows, each composed of three sleepers, or nine in all, and in calculating how far it will extend into the river, allowance must be made for the ends being inserted in the bank. The sleepers should be joined together by iron plates and bolted on to stout supports of angle-iron sharpened at one end, and previously driven into the bed of the river at convenient distances, but not too widely apart, as each sleeper should be well secured. Holes should be made in the face of the angle-iron, against which the sleepers will rest, to pass bolts through, and corresponding holes can easily be bored with an augur in the sleepers when placed in position. If there are some stones near, they can be used to strengthen the woodwork by throwing them in on each side, but the erection of a wooden croy generally implies a scarcity of stone. The ironwork adds considerably to the cost of the structure, and makes it more expensive than a stone croy by 50 to 70 per cent. On the other hand, when well built, it should stand for a long time without any repair.

There are other materials that can be used instead of stone and wood, and a mound of gravel or earth covered with turf will resist a good flow of water, provided that the turf has time to catch a firm hold before it is submerged.

Wattling with alder branches, or any other convenient wood, forms a useful protection to the banks above and below a croy, where the action of the water $2 \mathrm{E} 2$ 
is often intensified. If you wish to maintain your river-banks and croys in good order at a small cost, never postpone repairing any damage you may notice, but have it put right as soon as possible. A little care at the time will save much future labour.

The pressure which a croy has to withstand depends on the surface it presents to the stream and the angle at which the water strikes it, therefore it should not be higher at any point than absolutely necessary, and in a strong current it is better to extend it from the bank in a down-stream direction. This is more especially the case with wooden croys which have not the protecting slope of a stone apron, for when they stand at right angles to the stream they have to sustain the weight of a belt of comparatively still water formed above them by the rebound of the current before it takes a new course ; while if their direction be slightly downwards, they guide the water without holding it up.

The eddy that is apt to form behind a croy must be taken into consideration. It is caused by the stream that runs round the point of the structure impinging on the edge of the still water sheltered behind it, with the result that along the line of impact swirls with a reverse motion are set up, and their accumulated action induces an up-stream current near the bank, which may be strong if there is any considerable depth of water at the place. To mitigate this effect, short and low croys, even if you have to build more of them, are better than long and high ones.

We are aware that stones placed in the water to afford resting-places for fish have proved satisfactory in some rivers, but our experience is that, except in rapid streams, they generally collect gravel instead of salmon. Stones of moderate size are better than large rocks, which limit a salmon's range of vision, and interfere with his view of a fly or bait till they have passed. Small stones, however, on a smooth shallow, may help the angler by causing a deceptive ripple. 


\section{INDEX.}

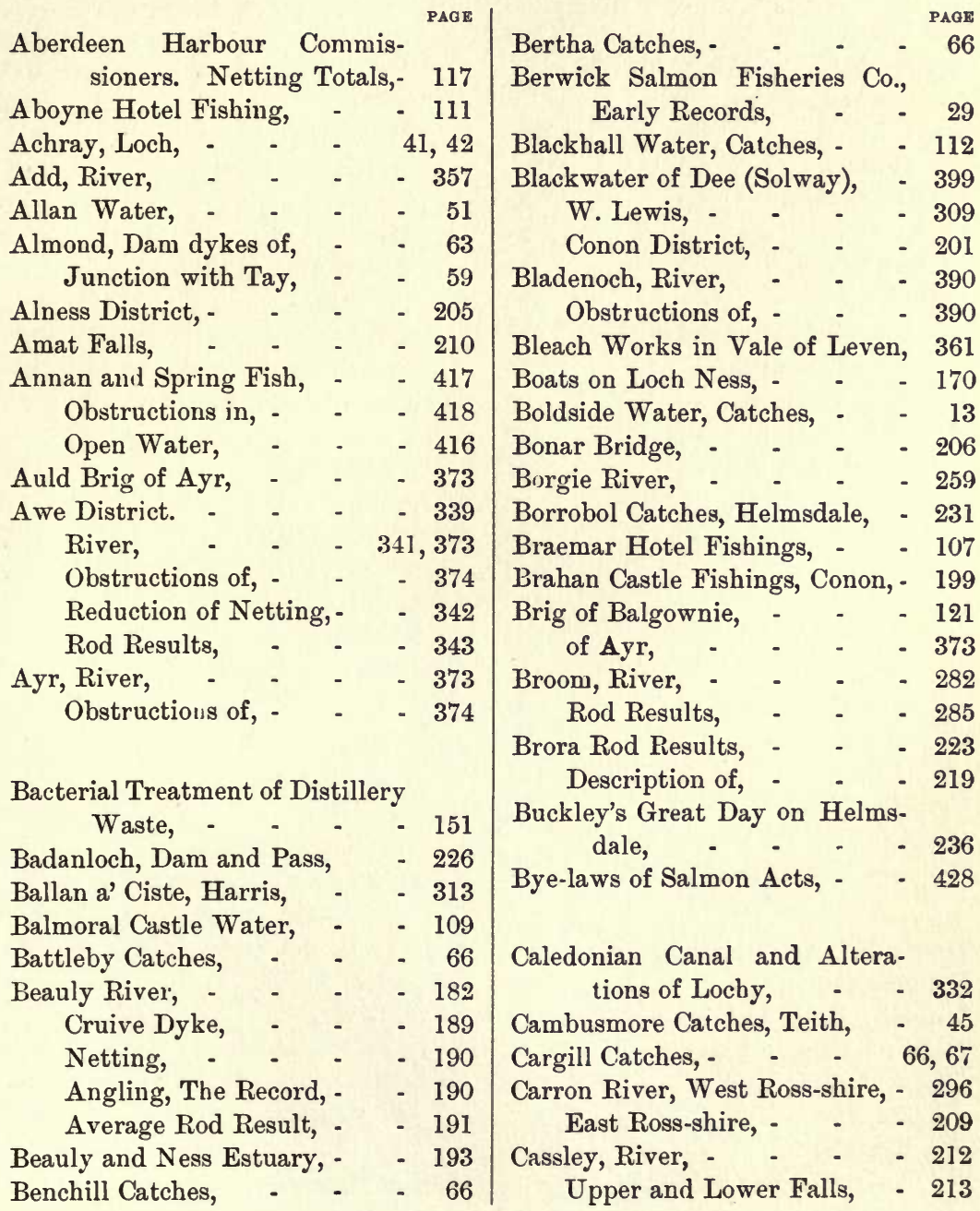


Catchment Basins of Lochs Lubuaig and Vennacher,-

Chesthill, Lyon,-

"Christopher North" at Loch Tulla,

Cluden Cruive, -

Obstructions of

Clyde District and Pollutions, -

Last Salmon in, - - -

Parr in Upper Waters,

Conon, River, - $\quad$ - $\quad$ - 194

Falls, Proposal to open up, - 195

Upper Streams, - - - 196

Rentals, showing period when cruives were not fished, - . .

Cruives, - $\quad$ - $\quad$ - $\quad-200$

Craigforth Cruive Dyke, - $\quad$ - 39

Craigo Dyke, - - $\quad$ - 98

Crathes Water, - $\quad$ - $\quad$ - 112

Cree, River, - - - $\quad$ - $\quad$ - 392

Salmon Angling Association, 395

Crew Chronicle, - $\quad$ - $\quad$ - 395

Cromarty Fishings, - $\quad$ - $\quad-198$

Crown Fishings in Scotland, - 420

Croys in Salmon Rivers, - - 431

Croy-building in Upper Tay, - 70

Cruive Dyke at Craigforth, - 39

of Conon, - $\quad$ - $\quad$ - $\quad-200$

of Awe, - $\quad$ - $\quad$ - $\quad$ - 374

of Beauly, - $\quad$ - $\quad$ - $\quad$ - 189

of Cluden, - - - - $\quad$ - 412

at Tongueland, - - - 400

Dupplin, Earn, - $\quad$ - $\quad$ - 96

of Don, - $\quad$ - $\quad$ - $\quad$ - 122

Culloden Moor, - $\quad$ - $\quad$ - 163

Curphey and Whe:ton. Report

on Pollutions of Tweed, -12, 14

Daenie Fall, Glenstrathfarrar, - 185

Dalguise Catches, - $\quad$ - $\quad 69$

Dalmally Hotel Fishings, - - 353

Deanston Salmon Passes, - - 45

Dee, Aberdeenshire, - - 106

Estuary, - - - $\quad 117$

Rentals, - - . $\quad 117$

Estimated Annual Catch, - 116
Dee Salmon Improvement Assoc. 115

Solway, - - - - 398

Delvine Catches, - $\quad$ - $\quad$ - 69

Deveron, River, _ $\quad$ - $\quad$ - 134

Reduction of Netting, $\quad-136$

Changes in Mouth of River, 136

Riemoval of Cruives, - $\quad 135$

Operations for Improvement of, - - - - - 134

Dionard, River, - $\quad$ - $\quad$ - $\quad-263$

Distilleries, Increase of in Spey,- 150

Treatment of Waste Products, - - - 151

Doaches of Tongueland, - $\quad-400$

Don, River, - $\quad$ - $\quad$ - $\quad$ - 120

Mouth of, - - - $\quad$ - 121

Netting in River, - $\quad$ - 122

Cruives, - $\quad$ - $\quad$ - $\quad$ - 122

Dam Dykes, - $\quad$ - $\quad$ - 122

Abstraction of Water, - 123

Pollutions, - $\quad$ - $\quad$ - $\quad$ - 124

Doon, River, - $\quad$ - $\quad$ - $\quad$ - 376

Mouth and Estuary, - $\quad 380$

Drainage of Land, Result of, - 30

Drift Netting in Estuaries Abolished, - - $\quad 59,425$

Drygrange Water, - - $\quad 17$

Duff House Hotel, - - $\quad 137$

Dundonnell River, or Strathbeg, 288

Dupplin Hatchery, - $\quad$ - $\quad 96$

Catches, - - - $\quad 95$

Durris Water, Dee, Catches, - 114

Earn, River, - $\quad$ - $\quad$ - $\quad$ - 90

Dam Dykes, - $\quad$ - $\quad 94$

Echaig, River, - $\quad$ - $\quad$ - $\quad$ - 366

Ednam Water, Catches, - $\quad 20$

Eilean Aigus Fishing, Beauly, - 186

Erchless Water, Beauly, - $\quad 183$

Esk, North and South, - $\quad-97$

Estuary of Tay, - $\quad$ - $\quad$ - $\quad$ - 55

Etive, River, - $\quad$ - $\quad$ - $\quad-355$

Ettrick Obstructions, - $\quad$ - 13

Ewe, River, - $\quad$ - $\quad$ - $\quad$ - 289

Old Cruives, - $\quad$ - $\quad$ - 290

Falls of Dalness, $\quad$ - $\quad$ - $\quad-\quad 355$ 


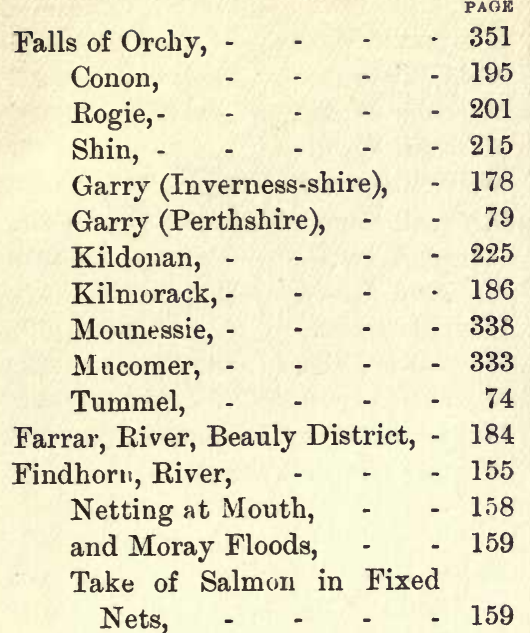

Finnock Fishing in Ugie, - 131, 132

Fintray Water, Catches, - - 126

Fixed Nets in Solway, - $\quad$ - 409

Fleet, River, · - $\quad$ - $\quad$ - 397

Floors Castle Water, Catches, 18, 19

Forsinard Hotel Fishing, - - 254

Forth, River, - $\quad$ - $\quad$ - $\quad$ - 36

Fortingal Hotel Fishing, - $\quad$ - 82

Gala Water and Pollution, - 14 Garry (Inverness-shire), - - 176

Temperature, - - 166, 176

Falls of, - - - $\quad$ - 178

(Perthshire), - - $\quad$ - 78

Falls of, - $\quad$ - $\quad$ - 79

Gartness, Obstructions, - $\quad-364$

Girvan, River, - $\quad$ - $\quad$ - $\quad$ - 381

Pollutions from Coal Pits, - 382

Obstructious, - - $\quad-383$

Glenfinnan and Prince Charlie's Standard, - $\quad$ - 322

Glentana, Catch of, - - $\quad 110$

Grandtully District Catch, - $\quad$-0

Grant of Salmon Fishing Rights, 422

Grilse, Preponderance in Pent-

land Firth, - - $\quad 252$

Grimersta, River, and Lochs, - 301

Record Catch, - $\quad$ - $\quad$ - 307

Gruinard, River, $\quad-\quad$ - $\quad$ - 286
Haaf Nets in Annan, _ - 416

Nith, - - - - $\quad 408$

Haddo House Fishings, - ' - 128

Halladale, - $\quad$ - $\quad$ - $\quad 253$

Harling in the Tay, - $\quad$ - $\quad$ - 62

Harris Streams, - - 311

Hatching of Salmon in Purified -

Distillery Waste, - - 152

Hebridean Streams, - $\quad$ - $\quad$ - 298

Helmsdale, - - - - 225

Netting Stopped, - - 228

Net and Rod Returns, $\quad$ - 229

Rod Results Upper and -

Lower Beats, - _ - 231

Impounding of Head

Waters, - - - - 226

Hendersyde Water, Tweed, - 23

Hope, River, - $\quad$ - $\quad$ - $\quad 261$

Huntly Open Fishings, - $\quad 139$

Inchard, River, - $\quad$ - $\quad$ - $\quad$ - 268

Inver, River, - $\quad$ - $\quad$ - $\quad$ - 273

Rod Results, - - - $\quad 274$

Inverawe Cruive, - $\quad$ - $\quad$ - 345

Invercauld Water, Catch 1892 -

and 1896, - $\quad-\quad-109$

Invermoriston Salmon Passes, - 172

Impounding Head Waters, -

Isla, River, - - $\quad$ - $\quad$ - 70

Islamouth, - - - $\quad$ - 67

Kanaird, River, - $\quad$ - $\quad$ - $\quad$ - 279

Ken, Water of, - $\quad$ - $\quad$ - $\quad-399$

Kildonan Falls, - $\quad$ - $\quad$ - $\quad$ - 225

Kilmorack Falls, - $\quad$ - $\quad$ - 186

Kinloch and Polla, - $\quad$ - $\quad$ - 264

Kirkaig, - - - - - $\quad$ - 276

Kyle of Durness, $\quad$ - $\quad$ - $\quad$ - 264

Sutherland, - - $\quad 206$

Tongue, - - - $\quad$ - 265

Lanrick, Catch, Teith River, $\quad 46$

Laxay, River, Lewis, - $\quad$ - $\quad 310$

Laxdale, River, Harris, - $\quad 313$

Laxford, River, Sutherland, - 270

Rod Results, - - $\quad$ - 272 


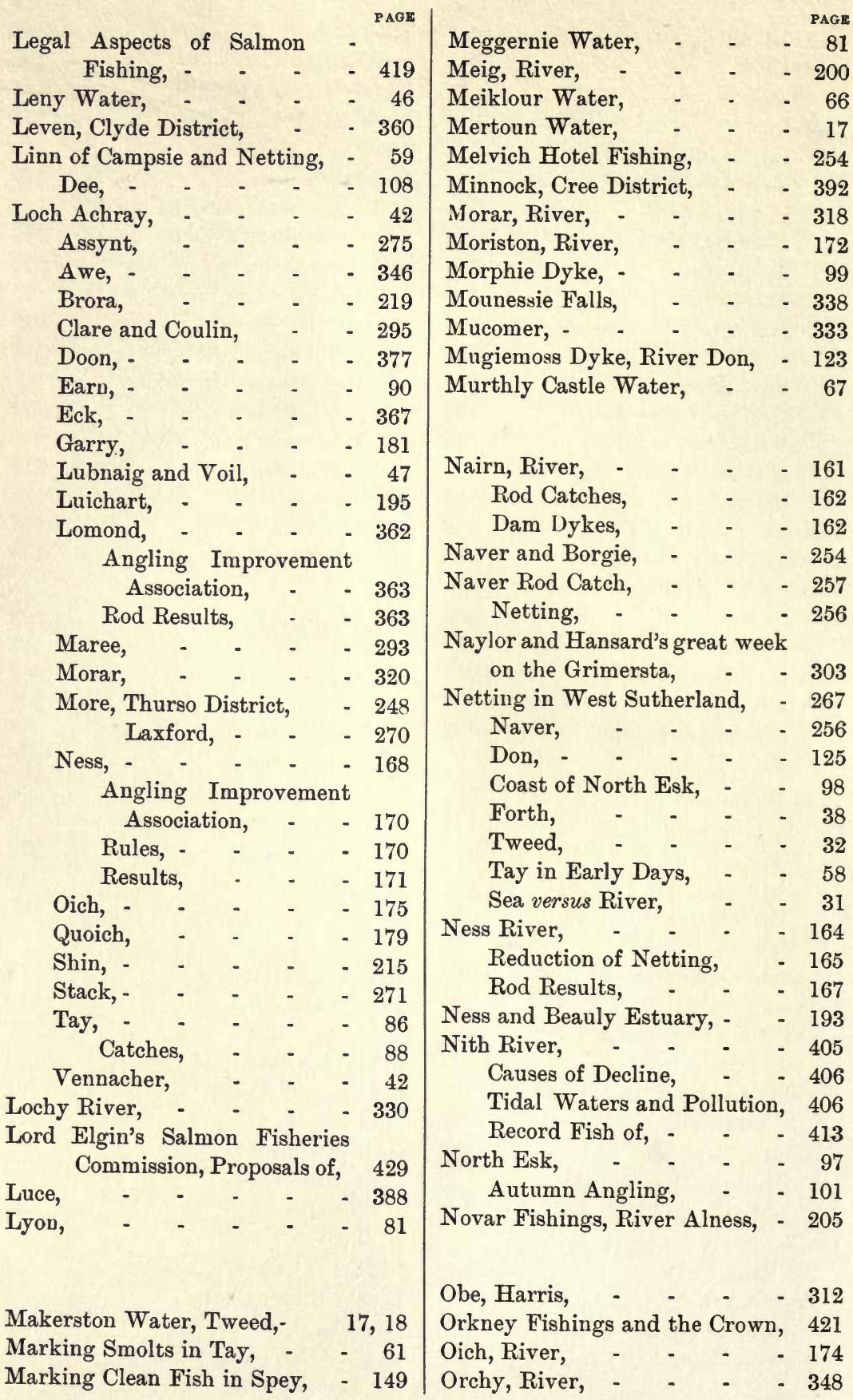


PAGE

Orrin, River, - - - - $\quad$ - 2112

Oykell, River, - $\quad$ - $\quad$ - $\quad$ - 211

Outer Hebrides, Streams of, - 298

Paedle Nets, Nith, - $\quad$ - $\quad$ - 407

Parr in Upper Clyde, - $\quad$ - 10

Pass of Killiecrankie, $\quad$ - $\quad$ - 79

Leny, - - - - 48

Brander, - - - 343

Peebles, Tweed, _ - $\quad$ - 11

Pentland Firth, Nets and Grilse, 252

Pike in Lochs Tulla and Awe, - 349

Polla, River, Sutherland, - $\quad$ - 264

Polly, River, Ross-shire, - $\quad$ - 278

Pollutions at Galashiels, - $\quad$ - 14

of Tweed, Official Report, 12, 14

by Distilleries, - - $\quad$ - 151

of Don, - $\quad$ - $\quad$ - $\quad$ - 124

of South Esk, - - _ $\quad$ - 104

of F'orth, - $\quad$ - $\quad$ - $\quad$ - 38

of Clyde, - $\quad-\quad-\quad-\quad 359$

of Leven, - $\quad$ - $\quad$ - $\quad-360$

of Girvan, - $\quad$ - $\quad$ - $\quad$ - 382

of Nith, - $\quad$ - $\quad-\quad-406$

Pot of Gartness, - $\quad$ - $\quad$ - $\quad$ - 364

Pot Ale, Purification of, - - 151

Poke Nets in Annan, - $\quad$ - $\quad$ - 416

Powans of Loch Lomond, - $\quad$ - 365

Purification, Standard of Purity,

Rannoch, - $\quad$ - $\quad$ - $\quad$ - 73

Redgorton Water, Catch, - - 66

Richmond and Gordon Fishings,

Spey, Early Results, - 147

Royal Commission on Salmon

Fisheries, Proposals of, - 42.9

Ruel, River, - $\quad$ - $\quad$ - $\quad$ - 369

Rod Results, - - $\quad$ - 370

Rutherford Water, Catch, - $\quad$ - 17

Salmon Acts, - $\quad$ - $\quad$ - $\quad$ - 426

Salmon Disease in Tweed, - $\quad$ - 30

Sewage Disposal Commission, Standard of Purity, - $\quad 15$

Sharpitlaw, Tweed, - - $\quad$ - 23

Shiel District, - $\quad$ - $\quad$ - $\quad$ - 322

Shiel, River, - - $\quad$ - $\quad$ - 325
Shin, River, - - - $\quad$ - 214

Recent Alterations of River, 217

Rod Results, - - $\quad 216$

Shoulder Net at Tongueland, - 401

Sir Daniel MacNee at Loch Eck, 368

Skye Rivers, - $\quad$ - $\quad$ - $\quad$ - 314

Sligachan River, _ - - $\quad 315$

Sluie, Great Catch of Findhorn, - 157

Smolt marking in Tay, - $\quad-61$

Snizort, River, - $\quad$ - $\quad$ - $\quad$ - 314

South Esk, River, - $\quad$ - $\quad$ - 102

Pollutions of, - - - 104

Opening up of Weirs, - $\quad-103$

Reduction of Netting, - - 103

Spean, River, - $\quad$ - $\quad$ - $\quad$ - 337

Spey, River, - - - - $\quad$ - 141

Reduction of Netting, - 144,149

Angling Results to 1899, - 148

Increase of Distilleries, $\quad-150$

Sproustoun Water, Tweed,- $\quad$ 20, 24

Dub, - - - - - 22

Stinchar, River, - _ $\quad$ - $\quad$ - $\quad$ - 384

Mouth of, - $\quad$ - $\quad$ - $\quad-385$

Stobhall Water, Tay, - $\quad$ - $\quad$ - 66

Stormontfield Ponds, - - $\quad$ - 60

Struy Fishings, Beauly, - $\quad$ - 185

Stanley Water, Tay, - - - $\quad 66$

Sutherland, Netting on West

Coast of, - - - - $\quad$ - 266

Tarff, Solway Dee District,- $\quad$ - 403

Bladenoch District, - $\quad 391$

Tay District, - $\quad$ - $\quad$ - $\quad$ - 53

Tay, Description of River, - $\quad$ - 61

Heavy Fish of, - - $\quad 63,67$

Autumn Angling Results, - 66

Early Netting Results, - 58

Estuary of, - - - $\quad$ - 55

Drift Net Fishing Case, - 425

Loch, - - - - - 86

Taymount Results, - $\quad$ - $\quad$ - 67

Teaninich Fishing, River Alness, 205

Teith, River, - $\quad$ - $\quad$ - $\quad 41$

Temperatures of Earn, Tay, and

Almond, - - $\quad$ - $\quad$ - 93

In Tay District, - $\quad$ - $\quad$ - 83

Teviot, River, - $\quad$ - $\quad$ - $\quad$ - 21 


\section{INDEX}

Thurso, River, - $\quad$ - $\quad$ - $\quad \begin{array}{r}\text { PAGE } \\ 241\end{array}$

Thurso, Rod Records, _ - $\quad$ - 244

Great Catch in 1792, - - 242

Recent Modifications in - 244

Till, River, - $\quad$ - $\quad$ - $\quad$ - $\quad$ - 24

Toot and Haul Fishing Case,

Tay, - - - 59,425

Tornacoile Hotel Fishing, Dee, - 113

Trossachs, Lochs of, - $\quad$ - $\quad$ - 42

Tulla, Water of, and Loch,- $\quad$ - 348

Tummel, River, - $\quad$ - $\quad$ - $\quad$ - 72

Falls, - - - - - 74

Turkey-red Works in Leven, - 361

Tweed, River, - $\quad$ - $\quad$ - $\quad$ - 9

Spawning Season in, - $\quad 33$

River Netting in, - $\quad-32$

and Spring Fish, _ $\quad-\quad 33$

Decline of Fisheries, - $\quad 31$

Former Catch of Salmon, - $\quad 29$

Mouth of, - - - $\quad 27$

Udny Hotel Fishings, Ytham, - 128

Ugie, River, - $\quad$ - $\quad$ - 130

Annual Catch of, - $\quad$ - 132

Ullapool, River, Rod Results, - 282

Urr, River, - $\quad$ - $\quad$ - $\quad$ - 397

PAGE

Vennacher Loch and Outlet, - 42

Voil, Loch, - $\quad$ - $\quad$ - $\quad$ - 47

Water Storage in Helmsdale, - 226

Water Supply to Glasgow from

Loch Katrine, - $\quad$ - $\quad 38$

Watershed of Scotland, - $\quad 2$

Waterton and Stoney wood Dykes, River Don, - - $\quad 123$

Walkerburn Cauld, Tweed, - 12

Weekly Close Time, Non-

Observance of on Coast, - 425

Necessity of Slapping Nets on Sundays, - $\quad$ - $\quad$ - 426

West Sutherland Rivers, Past Treatment of, - - - 266

Wheaton and Curphey, Report on Pollution of Tweed, 12, 14

Whitadder, River, - - - - 25

"White-Spot," Fish Affected by, in Lewis, - $\quad$ - $\quad$ - 300

Wick, River, - $\quad$ - $\quad$ - $\quad$ - 238

Woodend Water, Dee, _ - 113

Yair Nets of Solway Dee, - - $\quad 403$

Ythan, River, - $\quad$ - $\quad$ - $\quad$ - 127

Annual Catch of, $\quad$ - $\quad$ - 129

THE END 





\section{UNIVERSITY OF CALIFORNIA LIBRARY}

BERKELEY

Return to desk from which borrowed.

This book is DUE on the last date stamped below.

\section{APR 131948}




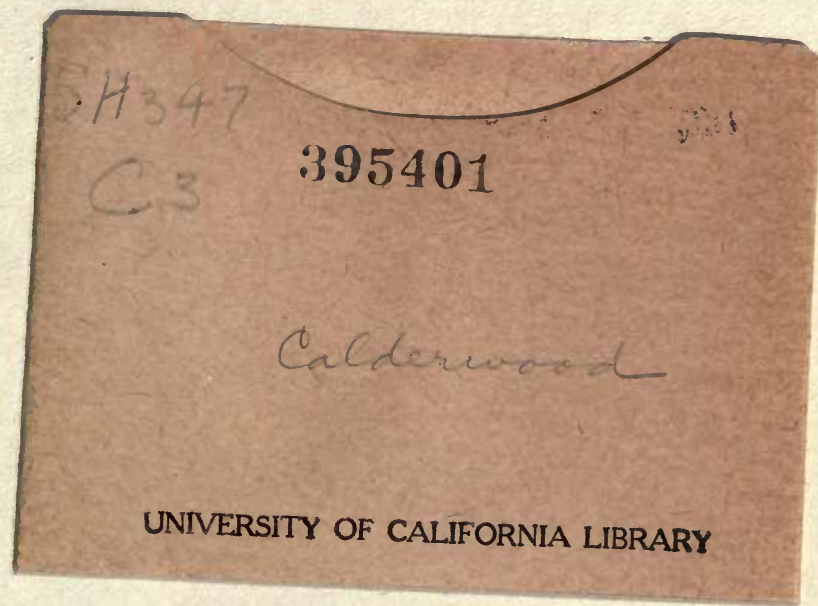


